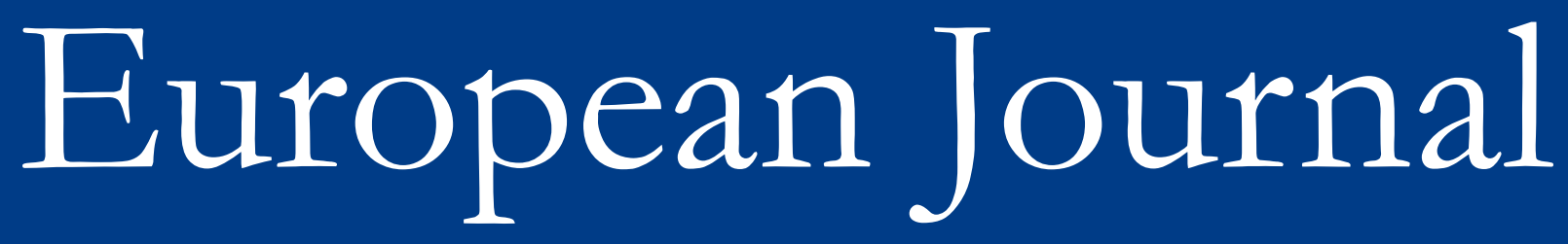

\title{
of Medical Research
}

Official Organ »Deutsche AIDS-Gesellschaft» "German Competence Network for HIV/AIDS «

\section{SÖDAK 2009}

\section{$\pi$ \\ 1. Deutsch-Österreichisch- \\ Schweizerischer AIDS-Kongress (SÖDAK 2009)}

St. Gallen, Schweiz, 24.-27. Juni 2009

Tagungsveranstalter

K.I.T. Swiss AG, unterstützt durch DAIG, ÖAG, SHCS sowie das Kompetenznetz HIV/AIDS 


\section{European Journal \\ of Medical Research}

\section{EDITORS}

$\begin{array}{ll}\text { Adam, D. } & \text { Munich } \\ \text { Arastéh, K. } & \text { Berlin } \\ \text { Arendt, G. } & \text { Düsseldorf } \\ \text { Beinert, Th. } & \text { Munich } \\ \text { Berg, P. A. } & \text { Tübingen } \\ \text { Bogner, J. } & \text { Munich } \\ \text { Brodt, H.-R. } & \text { Frankfurt/Main } \\ \text { Cuevas, P. } & \text { Madrid } \\ \text { Esser, S. } & \text { Essen } \\ \text { Fätkenheuer, G. } & \text { Cologne } \\ \text { Fleckenstein, B. } & \text { Erlangen } \\ \text { Fölsch, U.R. } & \text { Kiel } \\ \text { Forssmann, W.-G. } & \text { Hannover } \\ \text { Gresser, U. } & \text { Munich } \\ \text { Gross, M. } & \text { Munich } \\ \text { Hamouda, O. } & \text { Berlin } \\ \text { Häussinger, D. } & \text { Düsseldorf } \\ \text { Harrer, T. } & \text { Erlangen } \\ \text { Hartung, R. } & \text { Munich } \\ \text { Hehlmann, R. } & \text { Mannheim } \\ \text { Helm, E.B. } & \text { Frankfurt/Main } \\ \text { Holzheimer, R. G. } & \text { Munich } \\ \text { Jablonowski, H. } & \text { Salzgitter } \\ \text { Jäger, H. } & \text { Munich }\end{array}$

Koletzko, B. Munich

Maibach, H. I. San Francisco

Mannucci, P.M. Milano

Marcus, U. Berlin

Meyer, M. Hannover

Mikus, G. Heidelberg

Nüssler, V. Munich

Peiper, M. Düsseldorf

Rasokat, $\mathrm{H}$ Cologne

Reinhardt, D. Munich

Rübsamen-Waigmann, H. Wuppertal

Salzberger, B. Regensburg

Schmidt, R. E. Hannover

Scott, D.L. London

Seemann, M.D. Bochum

Shah, P.M. Frankfurt/Main

Soergel, K. Milwaukee

Staszewski, S. Frankfurt

Stein, G. Jena

Stellbrink, H.-J. Hamburg

Stoll, M. Hannover

Zeitz, M. Berlin

Zierz, S. Halle/Saale

\section{SENIOR EDITOR \\ Zöllner, N. Munich \\ EDITORS IN CHIEF}

Brockmeyer, N.H. Bochum

Rockstroh, J. Bonn 


\section{SÖDAK 2009 \\ $\nabla^{2}$}

\section{Deutsch-Österreichisch- Schweizerischer AIDS-Kongress (SÖDAK 2009)}

St. Gallen, Schweiz, 24.-27. Juni 2009

Veranstalter: DAIG, ÖAG, SHCS sowie das Kompetenznetz HIV/AIDS

\section{Abstracts}

\section{Invited Speakers:}

$I N V / 1-I N V / 11$

VII-X

\section{Oral Sessions:}

OSA - Present and Future HIV Therapy $O S A / 1-O S A / 3 \ldots \ldots \ldots \ldots \ldots \ldots \ldots \ldots \ldots \ldots \ldots$

OSB - HIV under Control ? - not quite $! O S B / 1-O S B / 6 \ldots \ldots \ldots \ldots \ldots \ldots \ldots \ldots$

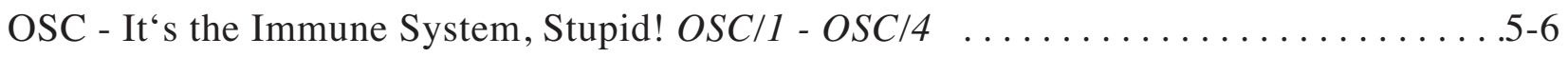

OSD - Disease Management - An Interdisciplinary Approach OSD/1 - OSD/5 . . . . . . . 7-9

OSE - HIV suppressed - which Coinfection to worry about? OSE/1 - OSE/6 . . . . 10-12

OSF - Diagnostics get complex as Therapy gets easier $O S F / 1-O S F / 3 \ldots \ldots \ldots \ldots 13-14$

OSG - New Treatment Options for the Long Run $O S G / 1$ - OSG/4 . . . . . . . . . 14-15

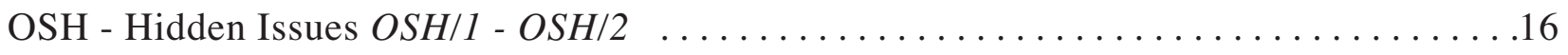

\section{Poster Sessions:}

1 Sozialwissenschaften \& Community Fragen /

Social Sciences \& Community Issues / P100 - P131 . . . . . . . . . . . . 17-32

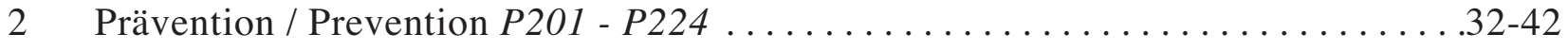

3 Epidemiologie / Epidemiology P300 - P331 ..................43-57

$4 \quad$ Klinik und Therapie / Clinical Therapy

4.1 Neuere Substanzklassen / New substance classes P400- P406 . . . . . . . . . 57-60 
4.2 Non-Nukleotide RT-Inhibitoren / Non-nuclear RT-Inhibitors P407 - P413 _ . .60-63

4.3 Nukleotide RT-Inhibitoren / Nuclear RT-Inhibitors P414 - P417 . . . . . . . . . 64-65

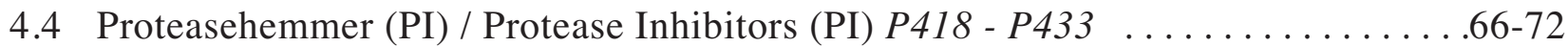

4.5 Anti-retrovirale Behandlung allgemein /

General Anti-Retroviral Therapy P434 - P437 . . . . . . . . . . . . . . . .73-74

4.6 Nebenwirkungen, Resistenzen, Pharmakokinetik /

Adverse Events, Resistance, Pharmacocinetics P438 - P454 . . . . . . . . . . . .75-82

4.7 Koinfektionen, Tumoren, OIs / Coinfections, Tumors, OIs P455 - P480 _ . . . .82-93

4.8 Diagnostik / Diagnostics P481 - P489 . . . . . . . . . . . . . . . . . . . . 94-97

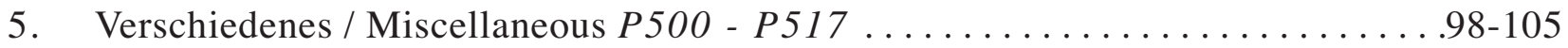

6. Grundlagenwissenschaft / Basic Science P600 - P643 . . . . . . . . . . . 105-122 


\title{
Komitees
}

\section{Kongress präsi dent}

Prof. Dr. med. Pietro L. Vernazza

FB Infektiologie/Spitalhygiene, Kantonsspital St. Gallen, CH-St. Gallen

\section{Kongress -Vizepräsidenti nnen}

Dr. Annette E. Haberl

HIV Schwerpunkt im Klinikum der Johann Wolfgang Goethe-Universität, Zentrum der Inneren Medizin, DE-Frankfurt

Prof. Dr. Elisabeth Puchhammer-Stöckl

Klinisches Institut für Virologie, Medizinische Universität Wien, AT-Wien

\author{
Veranstalter \\ Deutsche AIDS-Gesellschaft e.V. \\ Österreichische AIDS-Gesellschaft e.V. \\ S wiss HIV Cohort Study \\ Kompetenznetz HIV/AIDS
}

\section{Scientific Board Ausschuss}

Prof. Dr. Georg Behrens, DE-Hannover; Prof. Dr. Matthias Egger, CH-Bern;

Prof. Dr. Bernard Hirschel, CH-Genf; Dr. Dirk Sander, DE-Berlin; Prof. Dr. Rebecca Spirig, CH-Basel;

Prof. Dr. Alexandra Trkola, CH-Zürich; Bernd Vielhaber, DE-Edemissen

\section{Scientific Board und Abstract Review Kommitee}

Mag. Phil. Frank Michael Amort, AT-Wien; Prof. Dr. Gabriele Arendt, DE-Düsseldorf; Prof. Dr. Georg Behrens, DE-Hannover; PD Dr. Enos Bernasconi, CH-Lugano;

Prof. Dr. Norbert H. Brockmeyer, DE -Bochum; Prof. Dr. Mag. Eva Brunner, AT-Feldkirchen;

Dr. Bernd Buchholz, DE-Mannheim; Prof. Dr. Matthias Egger, CH-Bern; Dr. Stefan Esser, DE-Essen; Prof. Dr. Gerd Fätkenheuer, DE-Köln; PD Dr. Marek Fischer, CH-Zürich;

Prof. Dr. Hansjakob Furrer, CH-Bern; Prof. Dr. Frank-D. Goebel, DE-München;

Dr. Annette E. Haberl, DE-Frankfurt; David H.-U. Haerry, CH-Bern; Dr. Osamah Hamouda, DE-Berlin;

Prof. Dr. Thomas Harrer, DE-Erlangen; Prof. Dr. Joachim Hauber, DE-Hamburg;

Prof. Dr. Bernard Hirschel, CH-Genf; Dr. Christian Kahlert, CH-St. Gallen;

Dr. rer. nat. Rolf Kaiser, DE-Köln; Rainer Kamber, CH-Zürich;

Prof. Dr. rer. nat. Thomas Klimkait, CH-Basel; Christoph Königs, DE-Frankfurt;

Mag. Birgit Leichsenring, AT-Wien; Dr. Ulrich Marcus, DE-Berlin; Dr. Stefan Mauss, DE-Düsseldorf; MNS Dunja Nicca, CH-St. Gallen; PD Dr. Mark Oette, DE-Köln;

Prof. Dr. Markus Peck-Radosavljevic, AT-Wien; Prof. Dr. Elisabeth Puchhammer-Stöckl, AT-Wien;

Dr. Andri Rauch, CH-Bern; Dr. Martin Rickenbach, CH-Lausanne; Prof. Dr. Armin Rieger, AT-Wien;

Dr. Ansgar Rieke, DE-Koblenz; Prof. Dr. Jürgen Rockstroh, DE-Bonn;

Prof. Dr. Bernd Salzberger, DE-Regensburg; Dr. Dirk Sander, DE-Berlin;

MPH Armin Schafberger, DE-Berlin; Prof. Dr. Reinhold Ernst Schmidt, DE -Hannover;

Dr. Brigitte Schmied, AT-Wien; Prof. Dr. Cornelia Speth, AT-Innsbruck;

Prof. Dr. Rebecca Spirig, CH-Basel; Prof. Dr. Hans-Jürgen Stellbrink, DE -Hamburg;

Dr. Andrea Steuer, AT-Wien; Prof. Dr. Heribert Stoiber, AT-Innsbruck;

Prof. Dr. Matthias Stoll, DE-Hannover; Prof. Dr. Alexandra Trkola, CH-Zürich;

PD Dr. Jan van Lunzen, DE-Hamburg; Prof. Dr. Pietro L. Vernazza, CH-St. Gallen;

Bernd Vielhaber, DE-Edemissen; Prof. Dorothee von Laer, DE-Frankfurt;

Prof. Dr. Robert Zangerle, AT-Innsbruck

Wissenschaftliches Sekretariat

Doris Hoevel; Prof. Dr. Pietro L. Vernazza 


\section{Invited Speakers}

\author{
IN V/1 \\ Pharmacogenetics and personalized care \\ in HIV disease \\ Amalio Telenti \\ Institute of Microbiology - CHUV, Lausanne, Switzerland
}

The HIV field has generated a body of literature on genetic markers of toxicity and on genetic determinants of pharmacokinetics of antiretroviral therapy (ART). Some of the data are solid and comprehensive (the genetics of abacavir hypersensitivity, of efavirenz pharmacokinetics, of atazanavir hyperbilirubinemia), while other data should be considered work underway (the genetic basis of protease inhibitor-associated dyslipidemia), or at the starting block (the genetics of tenofovir nephrotoxicity). The fragmentary nature of the data highlights the need for discovery efforts.

Development in the field of genetics allows a number of focused and general approaches to the identification of new genetic markers. Applying these techniques requires the concerted action of many investigators and sites to identify sufficient numbers of precisely defined study cases and controls. Thereafter, there are important is sues regarding the value of selected genetic markers in the clinics. A recent assessment of currently available markers in a retrospective study of over 577 individuals confirms that the rate of drug discontinuation is higher among individuals carrying the risk alleles for toxicity to first line ART. With an improved understanding of the genetic basis of drug toxicity we can be confident that the pharmacogenetics-driven choice of first line ART will have the potential to- and the cost-effectiveness to improving ART tolerance.

\section{IN V/2}

\section{Use of resistance data to select treatment regimen: guidelines and reality Huldrych Günthard}

Universitätspital Zürich, Klinik für Infektionskrankheiten und Spitalhygiene, Zürich, Switzerland

Remarkable progress has been achieved in the treatment of HIV-1 infected patients. However, the emergence of HIVdrug resistance remains an obstacle, in particular in the light of the current impossibility to eradicate HIV-1. Despite several new very promising drugs available and significant improvements in long-term efficacy over the past years, drug resistance will continue to emerge and spread of resistance by transmission will further occur. Increased role-out of antiretroviral treatment in developing countries has been a success so far, however, limited monitoring frequencies, and lack of second line treatments will increase the burden of resistance on a global level considerably. New resistance testing technologies that are able to detect drug resistant minority quasispecies are becoming available but interpretation of results and clinical utility of this new information remain to be defined. Furthermore, contri- bution to resistance by genetic regions currently not covered by the resistance testing assays used in clinical practise (e.g. protease cleavage sites, connection- / RNase H domain) is currently under intense investigation. Taken together, the field of resistance testing is constantly and rapidly evolving and translation of the generated knowledge into clinical practise remains a challenge. This talk will particularly address this challenge.

\section{IN $V / 3$}

\section{Individualized therapy - therapy for indi vi dual \\ Jürgen Rockstroh}

Universität Bonn, Med. Klinik I, Bonn, Germany

Meanwhile the benefits of highly active antiretroviral therapy (HAART) with regard to both survival and quality of life have been demonstrated beyond any doubts. Nevertheless life-long adherence as well as HAART-associated toxicity remain persistent challenges to the long-term success of antiviral therapy. In order to optimize outcome particularly in an aging population with increasing comorbidities HIV therapy selection needs to carefully take into account other coexisting morbidities. As easy as this may be in patients with HBV coinfection by choosing dual active anti $\mathrm{HBV}$ and HIV drugs the more complicated this can become in the setting of cardiovascular or renal disease, in osteoporosis or metabolic disturbances. In addition with the increasing number of comedications drug-drug interactions are more prone to happen and need to be ruled out carefully. The increased armentarium of HIV drugs in 2009 allows the luxury of choosing the best drug combination possible based on the individual profile of a patient. Recognizing the individual and adapting therapy accordingly further increases virological success rates and ensures lifetime treatment success.

\section{IN $V / 4$}

\section{HIV-therapy tomorrow; HIV-Therapie morgen} Hansjakob Furrer

Universitätsspital Bern, Universitätsklinik für Infektiologie, Bern, Switzerland

- Tomorrows ART will be based on pre-ART resistance testing including minority quasispecies

- Pre-ART toxicogenomics will help to choose individually the ART components with the least probability of severe side effects and pharmacogenomics will allow to choose the optimal dosage

- Better knowledge on long-term toxicity will allow to detect early toxicity signs leading to adaptation in ART regimen

- Antiretrovirals will prevent neurocognitive impairment. - Strategies addressing adherence will remain challenging but better pharmacokinetic properties of ART will increase forgiveness 
- Specific immune enhancing strategies individualised to HLA and the virus will allow broad immune respone and discontinuation of ART

- These advances in the indvidualised treatment in rich countries will be made available to Public Health based treatment settings

\section{INV/5}

Activation of myeloid cells, triggered by viral replication but not microbial trans location, correlates with disease progression in SIV-infected macaques

Christoph Leinert ${ }^{1}$, Ulrike Sauermann ${ }^{1}$, Dietmar Fuchs ${ }^{2}$, Thomas Schneider ${ }^{3}$, Christiane Stahl-Hennig ${ }^{1}$, Sieghart Sopperl

\footnotetext{
${ }^{1}$ Deutsches Primatenzentrum, Göttingen, Germany,

${ }^{2}$ Medizinische Chemie und Biochemie, Medizinische

Universität, Innsbruck, Austria, ${ }^{3}$ Medizinische Klinik I, Charite, Berlin, Germany
}

Chronic immune activation is a hallmark of HIV-infection and has been postulated as major factor in the pathogenesis of AIDS. Recent evidence suggests that activation of immune cells is triggered by microbial translocation through the impaired gastrointestinal barrier, as evidenced by increased LPS levels in blood of HIV-infected patients .

To determine the association between microbial translocation and disease progression, we have retrospectively analyzed the kinetics of microbial products in plasma, viral load and markers of immune activation in a cohort of 37 SIV-infected rhesus monkeys, divided in two groups with distinct disease courses.

As seen in HIV-infected patients we found elevated levels of LPS in infected animals. However, LPS levels did not differ between groups with different disease progression and did not correlate with viral load. Similarly, plasma $\beta$ carotene, a marker for mucosal function, was decreased in both groups to the same extent. The changes in LPS-control mechanisms like endotoxin core antibodies or LPSbinding protein were also not different between the two groups. Flow cytometric analysis revealed lower expression of activation markers on lymphocytes of rapid progressors than of slow progressors. In contrast, urinary neopterin, a metabolic product of activated macrophages, was higher in rapid progressors and correlated with viral replication.

Our data indicate that translocation of microbial products is not the major driving force of immune activation. Rather, the continuous viral replication correlates with immune activation and disease progression. Thus we suggest that chronic activation of macrophages fueled by the persistent viral replication finally leads to AIDS.

\section{IN V/6}

\section{Immunaktivierung und Alterungsprozesse bei HIV}

\section{Georg Behrens}

Medizinische Hochschule Hannover, Klinik für Immunologie und Rheumatologie, Hannover, Germany

Die chronische HIV-Infektion führt über den Verlust der CD4+ Helferzellen zu einem fortschreitenden zellulären Im- mundefekt, der sich klinisch durch opportunistische Erkrankungen (AIDS) manifestiert. Neben der direkten Zerstörung von Helferzellen durch HIV, spielen sekundäre inflammatorische Prozesse für die Störungen des Immunsystems und den progressiven Immundefekt eine wichtige Rolle. Auch diese Entzündungsreaktionen sind durch HIV verusacht oder zumindest ausgelöst und spiegeln die Auseinandersetzung der spezifischen und angeborenen Immunantwort mit der Infektion wieder. Neue Modelle gehen davon aus, dass diese Prozesse schon früh im Verlauf der HIV-Infektion ihren Ursprung haben, sich die schädlichen Auswirkungen systemisch auswirken und nicht allein auf das Immunsystem beschränkt bleiben. Mit dem zunehmenden Alter der HIV-Patienten treten damit durch chronische Entzündung begünstigte Organschädigungen in den Vordergrund, die von körperlichen Einschränkungen bis hin zu schwerwiegenden klinischen Ereignissen wie Myokardinfarkten reichen können. Vorrausschauende Konzepte in der HIV-Medizin versuchen deshalb zu berücksichtigen, dass typische Erkrankungen des höheren Lebensalters, wie Atherosklerose, Niereninsuffizienz, Tumorerkrankungen und Demenz bei HIV-Infizierten Menschan trotz effektiver Therapie früher oder aber häufiger auftreten werden. Dieser Vortrag soll eine anschauliche Darstellung der aktuellen immunologischen Vorstellungen zu dieser Problematik bieten, um die möglichen therapeutischen Interventionen im pathogenetischen Zusammenhang verstehen zu können.

\section{INV/7}

\section{Immunologische Ziele der Therapie und neue Therapieformen}

$$
\text { Jan van Lunzen }{ }^{1,2}
$$

${ }^{1}$ Universitätsklinik Hamburg-Eppendorf, Sektion Infektiologie, Hamburg, Germany, ${ }^{2}$ Heinrich-Pette-Institute for Experimental Virology and Immunology, Dept. for Cell Biology, Hamburg, Germany

Trotz der unbestrittenen Fortschritte in der antiretroviralen Kombinationstherapie und der deutlich gestiegenen Lebenserwartung unter HAART, bleiben einige wesentliche immunologische Fragen bisher unbeantwortet:

1. Wieviel Immunrekonstitution ist nötig? Müssen die CD4-Zellen über Werte von $>200 / \mu 1$ oder $>350 / \mu 1$ ansteigen? Wie ist die Rolle von adjuvantem Il-2 einzuschätzen?

2. Können HIV-spezifische Immunantworten regeneriert werden? Wenn ja, welche Intervention ist die potentiell erfolgreichste?

3. Wieviel Immunaktivierung persistiert trotz erfolgreicher HAART? Sind zusätzliche adjuvante immunsuppressive bzw. immunmodulierende Therapien vielversprechend?

4. Können immunologisch basierte Therapien (IBT) die klassische HAART ergänzen, verzögern oder gar ersetzen?

5. Kommt es zu einer immunologischen "restitutio ad integrum" oder persistieren funktionelle Defizite trotz erfolgreicher antiviraler Therapie?

Dies sind einige der Fragen, die in diesem Übersichtsvortrag diskutiert werden sollen. In diesem Zusammenhang wird auf die Potentiale experimenteller Therapien wie Gentherapie, therapeutische Vakzine, Zytokintherapie (Il-2 \& Il-7) und Stammzelltherapie eingegangen. Auch soll die Frage diskutiert werden in welchen Immunzellen das Virus in welcher Form persistiert und wie potentielle Strategien zur Reduktion dieser 
latenten Reservoire aussehen könnten. Ziel ist es den Zuhörer auf den neuesten Stand der derzeitigen Auffassung zur Immunrekonstitution unter HAART zu bringen, die Probleme derzeitiger Strategien aus immunologischer Sicht aufzuzeigen und mögliche Lösungsansätze kritisch zu diskutieren.

\section{IN $V / 8$}

\section{Global drug policy, the HIV/IDU epidemic in Eastern Europe and Central Asia, and the critical need to scale up opioid substitution therapy \\ Craig McClure}

International AIDS Society, Geneva, Switzerland

Outside of sub-Saharan Africa, $30 \%$ of all people living with HIV were infected through injecting drug use. In the Eastern Europe/Central Asia region, close to $70 \%$ of all HIV infections are related to injecting drug use. Twentyseven years into the HIV epidemic and finally all international normative agencies working on health and HIV have endorsed a comprehensive set of harm reduction interventions to prevent HIV infection and ensure treatment, care and support to injecting drug users, including WHO, UNAIDS and UNODC. However, international drug policy, as outlined in the Political Declaration agreed at the 52nd meeting of the Commission on Narcotic Drugs in March 2009 , does not endorse harm reduction. There is now a greater political chasm than ever before between those focused on the public health and HIV-related implications of drug use, and those focused on drug control through supply and demand reduction. This inconsistency within the UN system raises urgent questions about the lack of coherence in the UN response to HIV/AIDS and drug use. Craig McClure, the outgoing Executive Director of the International AIDS Society, will reflect on the evolving status of the HIV response and injecting drug use, with a focus on the Eastern Europe and Central Asian region, ongoing legislative barriers to methadone in Russia, and the upcoming XVIII International AIDS Conference in Vienna, Austria.

\section{IN V / 9}

\section{Lessons from partnerships Switzerland - Central Asia}

\section{Jak ob Huber}

Contact Netz, Director of the NGO, Bern, Switzerland

A Pilot Model Project of an efficient syringe and condom distribution program in Tashkent and Samarkand, in cooperation with governmental structures and local NGOs. Best practice of HIV-prevention for IDU in Uzbekistan and Central Asia.

Coverage: Snowball system that widely involves drug addicts reaches a 100 times more addicts than the 225 Governmental Trust Points. Differences between the SwissUzbek-Model and the existing health structures. How to become a promoter of change for Trust Points? Or working on the health system not in the system!

Innovative activities: Low educated outreach workers teach new methods of education and training to well educated and high ranked professionals and officials. Capacity building and training for key persons in politics and the medical field. Training of outreach workers and volunteers within the project. New systems of incentives for volunteers and users.

\section{Impact and problems:}

- Risks and limits of the political context for the Pilot Model Project and its staff.

- Political impact of the Pilot Model Project throughout Uzbekistan and Central Asia.

- Organizational impact of the Pilot Model Project within the health and social system

- Promotion and realisation of a Central Asian harm reduction network, difficulties and limits.

- Donor shopping and the competition between NGOs, high turnover of staff.

- International donors and national implementation how much do users get?

- How could monitoring function?

- The self-feeding process of national and international organisations.

A learning process: Sustainability of bilateral projects and national and international prevention, treatment, harm reduction and law enforcement.

\section{INV/ 10}

\section{PrEP and Microbicides - new approaches to HIV-prevention}

\section{Thomas Mertenskoetter}

IPM, International Partnership for Microbicides, Hamburg, Germany

Prevention approaches to the HIV epidemic have shown measureable effects, however large populations, specifically in the developing world are still at immense risk for HIV transmission. For example women urgently need access to self-initiated HIV-prevention options, that are safe, effective and at affordable prices. Two new prevention technologies (NPTs) currently in clinical development seek to utilize the profound potency of antiretrovirals for HIV prevention.

Pre-exposure prophylaxis (PrEP) refers to an experimental HIV prevention strategy that would use anti-retrovirals (ARVs) to protect HIV-negative individuals from infection. Studies of PrEP strategies in non-human primates have shown a reduced risk of infection among animals that received ARVs prior to exposure to a simian form of HIV. Two ARVs, tenofovir disoproxil fumarate (TDF) and emtricitabine (FTC), are currently being tested in various PrEP trials amongst several different populations. Although approved for use in treating HIV infection, more information on the safety profile of daily use of these ARVs among HIV-negative individuals is needed. Microbicides are vaginal products being developed to reduce the transmission of HIV during sexual intercourse. Microbicides could take the form of a gel, film or sponge, or be contained in a vaginal ring that releases the active ingredient gradually. First-generation microbicides include products that work by forming physical barriers to the virus and by changing the chemistry of a woman's vagina to make infection less likely. Until today the early generation products have not shown significant preventive efficacy, although important clinical research results are still awaited. Next-generation microbicides are currently in development such as preparations of the antiretrovirals dapirivine and tenofovir (TFV).

Challenges to the successful development of NPTs and to subsequent access are the risk-benefit balance in HIV-uninfected populations, the acceptability by the potential users and their adherence as well as the product introduction and distribution strategies. 


\section{INV/11}

\section{Progress in AIDS Vaccine Development}

\author{
Frans van den Boom
}

International AIDS Vaccine Initiative (IAVI), Amsterdam, The Netherlands

The goal of an effective HIV vaccine remains unfulfilled, but the need for one remains urgent. Every day 7,500 people become infected with HIV. Antiretroviral drugs can prolong the lives of those who are infected, but they are not cures, and because of their cost and logistical difficulties, they reach only a minority of those who need them.

Despite significant scientific challenges ahead, we are facing an exciting time in AIDS vaccine science. In the past decade, most HIV vaccine development has focused on the T-cell arm, also called cellular immunity. Such a vaccine might keep HIV in check, slowing or preventing progression to AIDS and, perhaps, reducing the chances of transmitting HIV to another person. The only AIDS vaccine candidate of this type to reach efficacy testing failed to show efficacy in the STEP trial in 2007. However, researchers are working on new $\mathrm{T}$-cell vaccine strategies that can control the amount of virus in infected animals better than approaches previously tested in clinical trials .

The greatest scientific challenge impeding AIDS vaccine development is the antibody problem: how to design a vaccine that elicits antibodies that neutralize the many types of HIV in circulation so that the vaccinee is protected from HIV infection. Here too there is progress to report. The concept of a neutralizing antibody being able to protect against infection was demonstrated for the first time with a gene-therapy approach in an animal model. Furthermore, scientists have identified new antibodies capable of neutralizing a wide spectrum of HIV types circulating worldwide. These antibodies may now provide the keys to new vulnerable targets on the surface of HIV, which can be exploited for vaccine design.

Whilst the steps being taken are small, they signify important progress on the road to a safe and effective AIDS vaccine. To ensure progress can be sustained, and that novel AIDS vaccine candidate can be designed and tested, we need sustained investment in translational research, here in Europe as well as in developing countries, where the burden of AIDS and the need for a preventive vaccine remain greatest. 


\section{Oral Sessions}

\section{OSA - Present and Future HIV Therapy}

\author{
25. Juni 2009 \\ 11.00-12.30 Uhr \\ Saal 1
}

OSA $/ 1$

\section{Antiretroviral treatment outcomes and their predictors in a large cohort of HIV-Infected children in Sub-Saharan Africa}

Maria Cristina Marazzi ${ }^{1}$, Andrea De Luca ${ }^{2}$, Massimo Magnano San Lio ${ }^{3}$, Ersilia Buonomo ${ }^{3}$, Paola Scarcella ${ }^{4}$, Paola Germano ${ }^{4}$, Gianni Guidotti ${ }^{4}$, Giovanna Paturzo ${ }^{4}$, Annamaria Doro Altan ${ }^{3}$, Dieter Wenderlein ${ }^{5,6}$, Leonardo Palombi ${ }^{3}$

${ }^{1}$ LUMSA University, Rome, Italy, ${ }^{2}$ Catholic University, Rome, Italy, ${ }^{3}$ Tor Vergata University, Rome, Italy, ${ }^{4}$ DREAM Program, Rome, Italy, ${ }^{5}$ DREAM Program, Würzburg, Germany, ${ }^{6}$ Universitaetsklinikum, Würzburg, Germany

Background: Treatment of HIV-1 infected children in Sub-Saharan Africa is challenging.

Methods: Outcomes of ART-naive children (age $\leq 14 \mathrm{y}$ ) from 17 Dream-supported public sites in Mozambique, Malawi and Guinea starting ART was investigated. Baseline hemoglobin $(\mathrm{Hb})$, baseline and last available CD4 percentage, plasma HIV RNA (VL, bDNA), age-adjusted weight $\mathrm{z}$-score (WAZ), and height z-score (HAZ) were retrieved for analysis. Predictors of time-to-death were analyzed by multivariable Cox regression.

Results: Of 2,215 children $52.3 \%$ were male; baseline median age was 4 years (IQR 2-8), mean CD4 16\%, VL 5.2 $\log 10 \mathrm{cp} / \mathrm{mL}$, median WAZ -2.16 (-3.02, -1.28), HAZ -2.58 $(-3.65,-1.55)$. Most regimens were based on a thymidine analogue+3TC+NVP. After a median follow-up of 67 weeks, mean change of CD4 percentage was +12 , of WAZ +0.48 $(95 \% \mathrm{CI}+0.43 ;+0.53)$ and of $\mathrm{HAZ}+0.46(95 \% \mathrm{CI}+0.41$; $+0.51)$; VL was $<1,000$ copies $/ \mathrm{mL}$ in 878 of 1,357 with available data (64.7\%). Among 1,410 children (63.7\%) developing at least one clinical event, the first was gastrointestinal infection in $673(30.4 \%)$, malaria in $476(21.5 \%)$, tuberculosis in $158(7.1 \%)$, pneumonia in $102(4.6 \%) ; 897$ $(40.5 \%)$ experienced subsequent events. Overall, 238 children died and 63 were lost to follow-up. The 2-year estimated proportion surviving was 0.92 . At univariable analysis, younger age, lower baseline $\mathrm{Hb}, \mathrm{CD} 4$ percentage, WAZ and HAZ and higher baseline VL were associated with higher hazards for death. In a multivariable model only baseline VL (per $\log 10 \mathrm{cp} / \mathrm{mL}$ higher, HR 1.22; 95\%CI $1.04,1.44$ ) and baseline WAZ (per unit higher, HR 0.58;0.52-0.64) were predictive of death.

Conclusions: In this cohort of HIV-infected children treated with ART in the Sub-Saharan African setting, treatment was followed by a high survival and retention rate. Immunological and growth parameters improved significantly. A high incidence of opportunistic or other infections and a significant proportion of suboptimal virological responses were observed.
OSA $/ 2$

\section{Mortality of HIV-infected patients in the HAAR T era}

Mario Sarcletti ${ }^{1}$, Margret Jöchl ${ }^{2}$, Stefanie Gogl ${ }^{3}$, Armin Rieger $^{4}$, Maria Geit ${ }^{5}$, Bernhard Haas ${ }^{6}$, Robert Zang erle ${ }^{1}$

${ }^{1}$ Univ. Klinik für Dermatologie und Venerologie, Innsbruck, Austria, ${ }^{2}$ AGES, Wien, Austria, ${ }^{3}$ Österr. HIV-Kohortenstudie, Innsbruck, Austria, ${ }^{4} \mathrm{AKH}$ Wien, Wien, Austria, ${ }^{5} \mathrm{AKH}$ Linz, Linz, Austria, ${ }^{6}$ LKH Graz, Graz, Austria

Objective: To describe the characteristics of deaths that occur among HIV-positive individuals in the HAART era.

Methods: Observational database. Deaths were reviewed that occurred among HIV-positive individuals seen at 4 Austrian HIV treatment centres. between January 1997 and December 2007. Patients with loss of follow up were checked with death registry data.

Results: Overall 480 deaths occurred during the study period (17676,6 patient-years). During the study period the mortality rate decreased from 3,1 deaths/100 person-years (d/py) in 1997 to $2,4 \mathrm{~d} /$ py in 2002 and 2,5 d/py in 2007 , respectively.

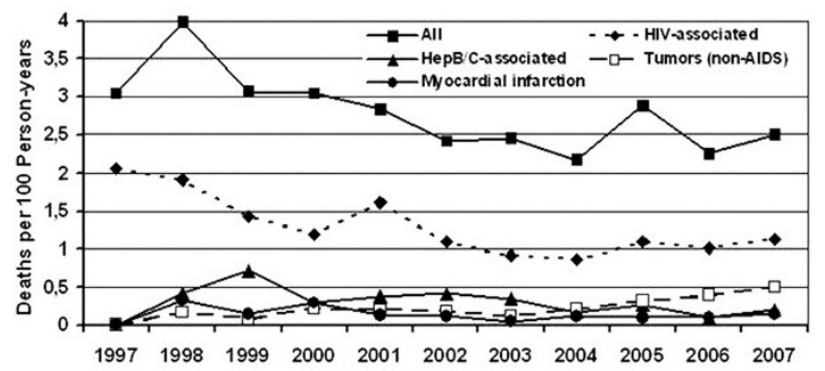

[Causes of death in HAART era]

In parallel, HIV-associated causes of death decreased (1997, 2002 and 2007: 2,1, 1,1 and 1,1 d/py, respective1y). A slight decrease in Hepatitis B/Hepatitis C-associated death rate was observed (1997, 2002 and 2007: 0,4, 0,4 and $0,2 \mathrm{~d} / \mathrm{py}$, respectively), whereas the death rate caused by non-AIDS defining tumours increased during study period (1997, 2002 and 2007: 0,2, 0,2 and 0,5 d/py, respectively). Decreasing death rates were striking in patients of younger age (<34 years: 1997, 2002 and 2007: 10,3, 4,3 and 1,6 d/py, respectively, whereas an increase was observed in older patients ( $>45$ years: 1997, 2002 and 2007: $1,3,1,4$ and $3,0 \mathrm{~d} / \mathrm{py}$, respectively).

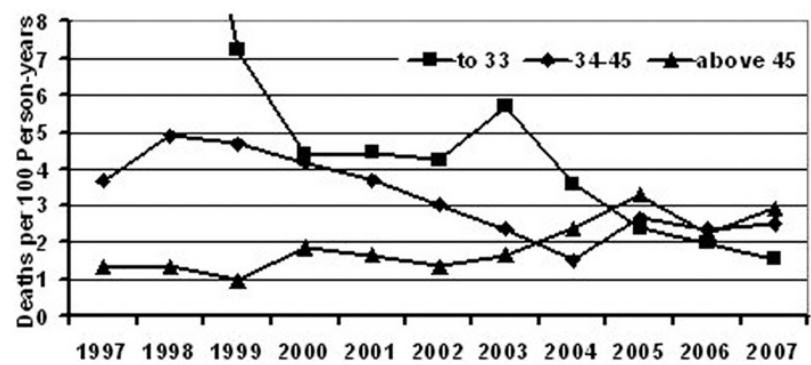

[Mortality among age groups] 
The mortality rate for women was $2,4 \mathrm{~d} /$ py in $1997,1,8$ d/py in 2002 and 2,0 d/py in 2007, for injecting drug user the rate was $8,8 \mathrm{~d} / \mathrm{py}, 8,4 \mathrm{~d} / \mathrm{py}$ and $8,1 \mathrm{~d} / \mathrm{py}$, respectively. The CD4 count increased from 120 cells/ $\mu 1$ in 1997 to 215 cells $/ \mu 1$ in 2007.

Conclusions: HIV-associated mortality has decreased after introduction of HAART. At time of death patients have higher CD4 counts and were of higher age. The spectrum of mortality has changed with HAART, with more deaths due to tumours and myocardial infarction. Women had a lower mortality rate. Exposure to HIV through injection drug use was as sociated with a higher mortality risk.

\section{OSA $/ 3$}

\section{Risk of new AIDS defining events in patients with advanced immunodeficiency during suppressive HAART}

Alex ander Zoufaly ${ }^{1}$, Christina Kreuzberg ${ }^{1}$, Matthias an der Heiden ${ }^{2}$, Christian Kollan ${ }^{2}$, Osamah Hamouda ${ }^{2}$, Jan van Lunzen ${ }^{3}$

${ }^{1}$ Universitätsklinikum Hamburg-Eppendorf, I. Medizinische Klinik, Hamburg, Germany, ${ }^{2}$ Robert Koch-Institut, Berlin, Germany, ${ }^{3}$ Universitätsklinikum Hamburg-Eppendorf, Hamburg, Germany

Backgro und: A large number of HIV patients still present late with advanced immunodeficiency. In these patients the risk of developing AIDS-defining events (ADE) may depend on a solid immune reconstitution with immune-discordant responses being at higher risk.

Methods: Data of 1576 treatment naive patients starting HAART after 1.1 .1996 at a CD4 count $<200$ cells $/ \mu 1$ were followed from the date of full viral suppression until virological failure, the occurrence of a new ADE, loss of follow-up or 31.12.2007. An adjusted Poisson regression model was used to analyze the relative rate (RR) between immune-discordance (all CD4 counts $<200$ cells $/ \mu 1$ ) and immune-response (at least one CD4 count $>200$ cells $/ \mu 1$ ) in the first, second, and third year. In addition, a Cox model was fitted to analyze risk factors for a new ADE encompassing all available follow-up data.

Results: In the first year a total of 42 new ADE occurred with a IRR for immune-discordance of 5.57 (95\%CI 2.96$10.48, \mathrm{p}<0.001)$ in the adjusted Poisson model. In the second ( 9 events) and third year ( 8 events) of viral control a non-significant trend towards a lower influence of immunediscordance was observed (IRR 1.03, 95\%CI 0.13-8.26, $\mathrm{p}=0.98$ and $2.02,95 \%$ CI $0.25-16.41, \mathrm{p}=0.51$, respectively). In the Cox model analyzing 3633 person years of follow up risk factors significantly associated with development of a new ADE included the latest CD4 count below 50 cells $/ \mu 1$ (HR 6.36,95\%CI 2.53-15.95, $\mathrm{p}<0.001)$ and CD4 counts between $50-100$ cells $/ \mu 1$ (HR $3.84,95 \%$ CI 1.70 $8.68, \mathrm{p}=0.001)$.

Conclusions: Immune-discordance is a risk factor for a new ADE while on HAART during the first year of suppressed viremia. After this time the incidence of ADE decreases dramatically even in patients with prolonged immunodeficiency. The risk is highest in patients who fail to increase CD4 counts to $>100$ cells $/ \mu 1$.
OSB - HIV under Control ? - not quite!

\author{
25. Juni 2009 \\ 11.00-12.30 Uhr \\ Saal 2
}

OS B $/ 1$

\section{Erwartungen an den Arzt - optimale HIV/S TD-Prävention aus der Sicht schwuler Männer \\ AngelikaWolf ${ }^{1}$, JulikaLoss ${ }^{1}$, Steffen Taubert ${ }^{2}$}

${ }^{1}$ Universität Bayreuth, Medizinmanagement, Bayreuth, Germany, ${ }^{2}$ Deutsche AIDS-Hilfe e.V., Berlin, Germany

Ziel: Verbesserung der Kommunikation zwischen Ärzten und Männern mit sexuellen Kontakten zu Männern (MSM) hinsichtlich der Prävention von sexuell übertragbaren Krankheiten (STDs) und HIV.

Methodik: Qualitative Studie. Semi-standardisierte Einzelinterviews mit 30 MSM in Berlin und Franken zu vier Themenbereichen. Parallel dazu drei Fokusgruppendiskussionen mit jeweils 6-8 Ärzten, sowie 7 semi-standardisierte Einzelinterviews mit Ärzten zu deren Erfahrungen mit MSM in Beratungen zu HIV/STD-Prävention. Forschungsdesign in Anlehnung an Grounded Theory.

Ergebnis: Der Arzt wird auch im Bereich der Prävention von HIV und anderen STDs (insbesondere Hepatitis C) als kompetenter Ratgeber angesehen. Vom Arzt wird aktuelles Fachwissen und Kenntnisse über in der Szene kursierende Infektionen erwartet. Auf Sexualverhalten und Präventionsmöglichkeiten angesprochen $\mathrm{zu}$ werden, solle aber nicht mit Drohungen oder mit dem ,erhobenen Zeigefinger" geschehen, sondern als „Anpieksen" und als beständiger freundschaftlicher Hinweis praktiziert werden. Bislang scheint die Initiative zum Gespräch über Fragen der Prävention und damit auch über Sexualität eher von Patienten aus zugehen .

Bis auf wenige Ausnahmen besteht große Zufriedenheit mit HIV-Schwerpunktpraxen sowohl in Berlin als auch im fränkischen Raum. Viele MSM wollen aber nicht auf Spezialpraxen angewiesen sein, sondern wünschen sich einen besseren Umgang mit schwulen Themen in den Allgemein- und Fachpraxen.

Vor allem im ländlichen Raum ist die Atmosphäre in der Arztpraxis von Tabuisierung, Kommunikationsschwierigkeiten und einer bemerkenswerten Übereinstimmung zwischen Ärzten und Patienten bezüglich der Nicht-Kommunizierbarkeit des Themas Sexualität geprägt. Ärzte in Franken haben mitunter Schwierigkeit, die Codes, die schwule Männer zu Fragen der Sexualität aus senden, zu verstehen. Schl us s folg erungen: Unter Berücksichtigung der Grenzziehungen ihrer Patienten könnten Ärzte präventive Gespräche mit MSM durchaus offensiver anbieten. Basierend auf den Forschungsergebnissen wird derzeit an der Entwicklung eines modulbasierten Fortbildungscurriculum mit Schwerpunkt auf Kommunikationsstrategien für Ärzte mit Zugang zu MSM gearbeitet. Ein HIV/STD-Präventionszertifikat sollte angestrebt werden.

Das Projekt erfolgt in Kooperation mit dem Kompetenznetz HIV/AIDS sowie mit Unterstützung durch DAGNÄ, DAIG und der $\mathrm{BZgA}$. 
$O S B / 2$

Trends in risk-taking and risk reduction among German MSM. Results of follow-up surveys "Gay Men and AIDS " 1991-2007

\author{
Axel J. Schmidt, Michael Bochow
}

Wissenschaftszentrum Berlin für Sozialforschung, Forschungsgruppe Public Health, Berlin, Germany

Objectives: To calculate esti-mates for group level trends among German men who have sex with men (MSM) regarding parameters related to HIV epidemiology: frequency of anal intercourse, consistency in condom use, risk-taking, numbers of sex partners, incident bacterial STIs, and HIVtesting behaviour.

Methods: Data derived from six large cross-sectional national follow-up surveys among MSM, conduc-ted 19912007. Questionnaires were circulated with German magazines for gay men; in 2003/2007, online recruitment was added. 23,878 anonymously self-administered questionnaires were analyzed in multiple regression models for five subgroups.

Results: With the normalization of AIDS, restriction of anal intercourse to primary partnerships has lost its relevance as a risk avoidance strategy for MSM. Other traditional risk reduction strategies among MSM in Germany showed a high degree of time stability: Between 1991 and 2007, condom use in anal intercourse has been relatively stable; numbers of sex partners have been rather constant. No positive trends in the use of Nitrite inhalants were seen, party drugs were increasingly used by a minority of gay men during the $1990 \mathrm{~s}$. The syphilis epidemic seen after 1999 among German gay men is well reflected in the survey data. No evidence was found for a concurrent rise in urethral gonorrhoea. The proportion of MSM with a recent HIV test has been continuously increasing.

Conclusions: We found no evidence for increasing 'carelessness' or 'prevention fatigue'. However, given the increasing proportions of MSM who frequently engage in anal inter-course with casual partners, a rise in HIV incidence is likely; especially if accompanied by a syphilis epidemic.

Time trend analyses of these large behavioural follow-up surveys suggest that the rise in new HIV diagnoses among MSM in Germany may partially reflect an increased uptake of HIV-testing, rather than new infections due to the erosion of condom use or increased numbers of sex partners.

\section{OS B/3}

HIV serosorting and the risk of sexually transmitted infections in men who have sex with men

Ulrich Marcus, Axel J. Schmidt

Robert Koch-Institut, Infektionsepidemiologie, Berlin, Germany

Objectives: We aimed to quantify the frequency and effectiveness of HIV risk management strategies and tactics other than condom use among men who have sex with men (MSM) in Germany and their impact on the frequency of sexually transmitted infections (STI).

Methods: For a cross-sectional survey a self-administered questionnaire was distributed via German MSM websites and medical practices in 2006 . The majority (87\%) of 6,833 analyzed participants were recruited online. We analyzed risk management of participants who reported HIVserosorting as a strategy (premeditated, planned) or as a tactic (depending on the situation) and explored the impact of HIV serosorting on the incidence of self-reported bacterial STIs by comparing serosorters with participants who reported other forms of risk management.

Results: HIV status has a large impact on the way how HIV serosorting is implemented. While HIV serosorting used strategically and tactically seems to be very similar in HIV positive MSM, there are distinct differences between HIV negative strategic and tactic serosorting. Except for HIV negative strategic serosorters, serosorting is associated with reduced condom use, higher partner numbers and a two to four fold increased risk of being diagnosed with bacterial STIs.

Discussion: HIV serosorting within primary relationships as well as with casual partners has emerged as a common risk management strategy and tactic in MSM. Apart from the problems of unambiguous communication about HIV status and the reliability of an HIV negative serostatus information, HIV serosorting as practiced currently by MSM in Germany is often used as an alternative to condoms, contributes to high incidences of STIs and hence elevated per-contact-risks for HIV transmission. Exclusive emphasis on HIV testing may encourage HIV serosorting, and thus may not solve the problems of HIV prevention, mainly because it lacks a comprehensive sexual risk reduction strategy for ART-naïve MSM diagnosed with HIV.

\section{$O S B / 4$}

\section{"EKAF" avant la lettre? ART-bezogene Risikomanagementstrategien bei MSM in Deutschland \\ Phil C. Langer ${ }^{1}$, Jochen Drewes ${ }^{2}$, Ursula von Rüden ${ }^{3}$, Angela Kühner ${ }^{1,4}$}

${ }^{1}$ Ludwig-Maximilians-Universität München, Department Psychologie, München, Germany, ${ }^{2}$ Freie Universität Berlin, Arbeitsbereich Prävention und psychosoziale

Gesundheitsforschung, Berlin, Germany, ${ }^{3}$ Bundeszentrale für gesundheitliche Aufklärung, Köln, Germany, ${ }^{4}$ Johann Wolfgang Goethe-Universität Frankfurt, Fachbereich für Gesellschaftswissenschaften, Frankfurt, Germany

Hinterg rund: Seit ihrer Publikation im Januar 2008 ist die Stellungnahme der Eidgenössischen Kommission für Aids-Fragen zur Nicht-Infektiösität HIV-Infizierter unter wirksamer ART Gegenstand internationaler Debatten. Der damit verbundenen Hoffnung auf De-Stigmatisierung von HIV-Positiven stehen Befürchtungen hinsichtlich möglicher Auswirkungen auf das Schutzverhalten gegenüber, insofern der Therapiestatus zu einem Entscheidungskriterium für ungeschützten Geschlechtsverkehr werden könnte. Empirische Forschungsergebnisse zu den Auswirkungen der Stellungnahme auf das Sexualverhalten liegen bislang nicht vor.

Methodik: Von November 2006 bis Juli 2007 wurde im Auftrag der Bundeszentrale für gesundheitliche Aufklärung und des Kompetenznetzes HIV/Aids die Studie „Positives Begehren" zur Untersuchung der psychosozialen Dynamiken des HIV-Risikoverhaltens von MSM in Deutschland durchgeführt. Basierend auf der Grounded Theory wur- 
den 58 qualitative Interviews mit kürzlich HIV-diagnostizierten MSM und ungetesteten MSM mit aktuellem Risikoverhalten geführt. Vor dem Hintergrund der Debatte um die EKAF-Stellungnahme wurde eine Sekundäranalyse der Daten mittels diskursanalytischer Auswertungsverfahren vorgenommen, um die bisherigen Implikationen der ART auf sexuelles Risikoverhalten zu bestimmen .

Resul tate: Überzeugungen einer geringeren bis nichtvorhandenen Übertragungswahrscheinlichkeit des HI-Virus bei nicht-nachweisbarer Viruslast lassen sich vielfach in den Interviews identifizieren. Sie korrelieren mit der Bereitschaft zu ungeschütztem Geschlechtsverkehr: Erstens kann vereinzelt eine Risikomanagementstrategie konstatiert werden, die ungeschützten Geschlechtsverkehr in Abhängigkeit vom Therapiestatus des positiven Partners ermöglicht. Zweitens wird auf sie durch die befragten therapierten Positiven rekurriert, um ungeschützten Sex mit anonymen Partnern unbekannten Serostatus zu legitimieren. Zugleich ist ein Bewusstsein des Einflusses anderer STDs auf die Übertragungswahrscheinlichkeit von HIV in den Interviews nur marginal zu finden.

Schlussfolgerung: Bereits seit Jahren kursieren in der schwulen Community verhaltensrelevante Annahmen zur Transmissionswahrscheinlichkeit von HIV unter wirksamer ART. Durch die EKAF-Stellungnahme wird der Therapiestatus vermutlich zu einem weiteren Entscheidungsparameter für Risikoentscheidungen bei MSM. HIV-Prävention hat auf die damit einhergehende Multiplizierung potentieller Risikosituationen durch eine verstärkte Thematisierung der Rolle von STDs in der Übertragung von HIV sowie De-Stigmatisierungsbemühungen zu reagieren, um ein Disclosure des Therapiestatus zu erleichtern.

\section{OS B/5}

\section{Zu den Kontexten von HIV-Neuinfektionen bei schwulen Männern in Berlin zwischen 2003 und 2006: Interviews mit Neuinfizierten}

Michael Bochow

Wissenschaftszentrum Berlin für Sozialforschung, Forschungsgruppe Public Health, Berlin, Germany

Fragestellung: Seit 2003 wurde in Deutschland eine Zunahme von HIV-Infektionen bei Männern, die Sex mit Männern haben (MSM), in einer breiteren Öffentlichkeit diskutiert. Vor diesem Hintergrund wurden unterschiedliche Hypothesen zum tatsächlichen Ausmaß und zu den Gründen des Anstiegs erörtert. Dieses qualitative Projekt hatte zum Ziel, einige Kontexte von HIV-Neuinfektionen bei MSM zu erhellen.

Methodik: Im Auftrag des Bundesministeriums für Gesundheit und in Kooperation mit der Berliner HIV-Schwerpunktpraxis Jessen wurden von Juni 2006 bis Mai 2007 dreißig (halbstrukturierte) Interviews mit schwulen Männern durchgeführt, die sich überwiegend in den Jahren 2003-2006 infiziert haben. Die Durchschnittsdauer des gesamten Interviewgesprächs betrug 95 Minuten (Median). Die Interviewpartner waren 24 bis 46 Jahre alt (Median: 34).

Ergebnisse: Auf der Basis der durchgeführten Interviews wurde eine Typologie gebildet, die fünf Gruppen umfasst. Gruppe 1 besteht aus sieben Interviewpartnern, die über mehrere Jahre vor ihrer Infektion wiederholt ungeschützten
Analverkehr mit Partnern mit unbekanntem Serostatus hatten. Gruppe 2 umfasst fünf Männer, die mehrfach ungeschützten Analverkehr eingingen, die in der Regel jedoch Safer Sex praktizierten. Gruppe 3 umfasst sieben Männer, die meinen, einen singulären ungeschützten analgenitalen Kontakt mit einem Partner mit unbekanntem Serostatus benennen zu können. Gruppe 4 umfasst fünf Männer, die von sich berichten, die Normen des Safer Sex (Kondomgebrauch bei Analverkehr, Vermeidung von oralem Kontakt mit Sperma) konsequent befolgt zu haben . Gruppe 5 besteht aus fünf Männern, die sich in ihrer festen Beziehung infizierten.

Schlussfolgerung: Eine Mehrheit der Interviewpartner mit HIV-Neuinfektionen berichtet über sporadische oder seltene Risikokontakte, einige verweisen auf eine strikte Befolgung der Safer-Sex-Empfehlungen. Es besteht Diskussionsbedarf hinsichtlich der Weitergestaltung der HIV/ AIDS-Prävention unter MSM, inwieweit diesen Untergruppen von Männern in zukünftigen Präventionskampagnen Rechnung getragen werden muss.

\section{OSB $/ 6$}

\section{HIV-exponi erte Schwangers chaften an zwei} deutschen Schwerpunktzentren 2004 - 2008

Andrea Gingelmaier ${ }^{1}$, Ralph Kästner ${ }^{1}$, Milena Sovric ${ }^{1}$, Jan-Peter Siedentopf ${ }^{2}$, Cornelia Feiterna-Sperling ${ }^{3}$, Gundula Notheis ${ }^{4}$, Weizsäcker Katharina ${ }^{2}$

${ }^{1}$ Ludwig-Maximilians-Universität, Campus Innenstadt, Klinik für Gynäkologie und Geburtshilfe, München, Germany, ${ }^{2}$ Charité, Campus Virchow-Klinikum, Klinik für Geburtsmedizin, Berlin, Germany, ${ }^{3}$ Charité, Campus Virchow-Klinikum, Klinik für pädiatrische Pneumologie und Immunologie, Berlin, Germany, ${ }^{4}$ Ludwig-MaximiliansUniversität, Campus Innenstadt, von Haunersche Kinderklinik, Immundefektambulanz, München, Germany

Fragestellung: Welches Outcome kann bei einer leitlinienorientierten Betreuung HIV-exponierter Schwangerschaften an Schwerpunktzentren in Deutschland erreicht werden und welche Komplikationen treten auf?

Methodik: Zwischen Januar 2004 und Dezember 2008 prospektive Dokumentation aller in der Frauenklinik München (LMU, Innenstadt) und an der Klinik für Geburtsmedizin (Charité - CVK, Berlin) betreuten HIV-exponierten Schwangerschaften. Erfaßt wurden u.a.: Infektionsmodus, Herkunftsland, Erstdiagnose, ART in der Schwangerschaft, Viruslast und CD4Status, Geburtsmodus, Gestationsalter, Schwangerschafts- und Geburtskomplikationen, kindl. Infektionsstatus und kindl. Komplikationen.

Ergebnisse: Insgesamt wurden $343 \mathrm{HIV}$-exponierte Schwangerschaften ( $7 \mathrm{x}$ Mehrlinge) bis in ein lebensfähiges Gestationsalter (> $24 \mathrm{SSW}$ ) ausgetragen (2xTotgeburt, 1xTod postpartal). 109 Frauen (32\%) erfuhren ihre Erstdiagnose im Rahmen der Schwangerschaft. $67 \%$ der Schwangeren $(\mathrm{n}=228)$ stammen aus einem Hochprävalenzland. 90\% der werdenden Mütter $(n=308)$ erhielten eine HAART zur Therapie und/oder Transmissionsprophylaxe. Es gab 41 vaginale Geburten (vorwiegend 2008: 30/86 $(35 \%))$ und 302 Kaiserschnitte (42x ungeplant). In 59\% der Schwangerschaften trat mind. eine Komplikation auf, einhergehend mit einer Frühgeburtlichkeit von 16,9\% ( $n=58)$ bei allen Schwangerschaften (mittlere Schwangerschaftsdauer: 38 Wochen). Die meisten Frühgeburten waren zwischen der 34. und 37. SSW $(n=45)$. Die Frühgeburtlichkeit 
unter der 30. SSW betrug $1,2 \%$ des Gesamtkollektivs $(n=4)$. Eine vertikale Transmission von HIV wurde bei zwei Kindern nach gewiesen $(0,6 \%)$.

Schlussfolgerungen: Durch eine leitlinienorientierte Betreuung HIV-exponierter Schwangerschaften kann eine vertikale Transmission erfolgreich in einen sehr niedrigen Bereich reduziert werden. Es zeigten sich jedoch viele Schwangerschaftskomplikationen, die u.a. zu einer erhöhten Frühgeburtlichkeit führten. Allerdings traten nur sehr wenige schwerwiegende Frühgeburten auf. Inwieweit ein Zusammenhang besteht zwischen der erhöhten Frühgeburtlichkeit und dem überwiegenden Einsatz einer HAART, kann anhand der Daten nicht eindeutig geklärt werden.

\section{OSC - It's the Immune System, Stupid!}

$$
\begin{aligned}
& \text { 25. Juni } 2009 \\
& \text { 16.00-17.30 Uhr } \\
& \text { Saal } 1
\end{aligned}
$$

OS C / 1

\section{Association of effective control of HIV-1 with strong CTL selection pressure and a highly mutated nef in a HIV-1-infected patient}

Katja Maurer ${ }^{1}$, Jan Schmökel ${ }^{2}$, Frank Kirchhoff ${ }^{2}$, Jennifer Etschel ${ }^{1}$, Sascha Antoni ${ }^{3}$, Kathrin Eismann ${ }^{1}$, Silke Bergmann ${ }^{1}$, Pia Rauch ${ }^{1}$, Karin Metzner ${ }^{4}$, Angela Hückelhoven ${ }^{1}$, Sandra M. Müller ${ }^{1}$, Ellen G. Harrer ${ }^{1}$, Thomas Harrer ${ }^{1}$, German Competence Network for HIV/AIDS

${ }^{1}$ University Hospital Erlangen, Department for Internal Medicine 3, Erlangen, Germany, ${ }^{2}$ University of Ulm, Institute of Virology, Ulm, Germany, ${ }^{3}$ Georg-Speyer-Haus, Frankfurt,

Germany, ${ }^{4}$ University Hospital Erlangen, Institute of Virology, Erlangen, Germany

Background: Study of diverse courses of HIV-1 infection in infected couples can provide important clues about the role of host genes and immune effector mechanisms for the control of HIV-1. Here, we report on a female individual with excellent control of HIV-1 who had been infected by her partner who had progressed to AIDS.

Methods: We analyzed viral sequences, CTL, antibodies, CCR5, Apobec3G, HLA and viral replication. Analyses of nef functions were performed by cloning nef genes into an HIV-1 NL4-3 based proviral vector expressing eGFP together with nef. After infection of PBMC by these recombinant reporter viruses, we analyzed various nef functions. Results: In comparison to viral genes derived from her partner, nef genes derived from the "controller" were highly mutated $(21.2 \%$ aa divergence and presence of a 5 aa deletion at aa 162-166). Her PBMC could be infected by R5 - and X4-tropic HIV-1 strains and a viral isolate showed normal growth characteristics arguing against the presence of a replication deficient virus. The patient showed a good but not an unusual strong antibody response. Analysis of HIV-1-specific CTL revealed a strong CTL response against a variety of epitopes. The detection of CTL targeting epitopes comprising the deleted amino acids in nef strongly indicates that the controller's CTL response was responsible for the selection of this deletion. Despite strong sequence divergence, functional analyses of nef alleles de- rived from the two subjects showed comparable results except for a lower upregulation of the HLA class II invariant chain (Ii,CD74) by nef alleles derived from the controller.

Conclusion: A strong CTL response presumably contributes to the excellent viral control in this individual. An attenuated upregulation of the HLA II invariant chain (CD74) indicates an important immune evasive role of the nef mediated inhibition of HLA class II presentation.

\section{$\mathrm{OSC} / 2$}

Very rapid response kinetics to HLA-B57/58 gag-restricted CTL epitopes is associated with slow disease progression

Jan van Lunzen ${ }^{1,2}$, Julian Schulze zur Wiesch ${ }^{1,2}$, Philip Hartjen $^{1,2}$, In grid Stahmer ${ }^{1,2}$

${ }^{1}$ Universitätsklinik Hamburg-Eppendorf, Sektion Infektiologie, Hamburg, Germany, ${ }^{2}$ Heinrich-Pette-Institute for Experimental Virology and Immunology, Dept. for Cell Biology, Hamburg, Germany

Background: Slow progression of HIV-1 infection is associated with B27 and B57/58 -restricted CTL responses against gag epitopes. These responses occur before the integration of proviral DNA and may reduce the seeding of latently infected cell pools in a time sensitive manner. We analysed the response kinetics of these CTL in HIV infected subjects with slow disease progression.

Material and methods: Cyropreserved PBL of $21 \mathrm{HIV}-1$ infected subjects (median time of infection: $10 \mathrm{yrs}$, range: 6-22yrs) with different characteristics of disease progression were analysed. Non-progressing patients with good viral control (LTNP, $\mathrm{n}=11$ ) were compared to a control group with progressive disease who received HAART according to current guidelines. Multiple samples were analysed longitudinally (range 1-6 years) by a specialized IFNg-ELISPOT assay using optimal B clade consensus peptides for HLA-A and B haplotypes derived from gag-/pol/nef and/or env-regions. The individual CTL response kinetic was assessed by stopping the ELISPOT reaction after various time intervals (range: $30 \mathrm{~min}$. to 24 hours) and were further characterized by tetramer staining.

Results: HLA-B57/58 and B27 haplotypes were evenly distributed in both groups (8/11 vs. 8/10). The B57-and B58-restricted CTL-responses against gag-epitopes were the immunodominant responses and were detected as early as $30 \mathrm{~min}$ after peptide exposure. This rapid response pattern was conserved in LTNP (2 to 6 yrs of follow up). In contrast most of the HLA-A-restricted responses were only detectable after $24 \mathrm{hrs}$ of in vitro stimulation suggesting a comparatively delayed response kinetic for non-B57/58 restricted epitopes in the control group. Staining with specific B57/B58 tetramers revealed the characteristic phenotype of effector memory CTL.

Conclusion: The dominance of B57/58 haplotypes in slowly progressing HIV-1 infection is not only explained by the breadth and magnitude of CTL-responses but also by preventing establishment of HIV-1 latency via targeting the virus life cycle very early at a pre-integrational level. 


\section{$\mathrm{OSC} / 3$}

HLA-E restringierte Erkennung eines HIV Peptids durch humane CD8(+) T-Zellen

Daniela Schulte, Martin Vogel, Bettina Langhans, Christian Körner, Benjamin Krämer, Hans Dieter Nischalke, Martin Coenen, Tilman Sauerbruch, Ulrich Spengler, Jürgen K. Rockstroh, Jacob Nattermann

Universitaetsklinikum Bonn, Medizinische Klinik und Poliklinik 1, Bonn, Germany

Hintergrund: Die Herunterregulation klassischer MHC Klasse I Moleküle stellt eine wichtige Strategie des HIVirus dar, um der Erkennung durch CD8(+) T-Zellen zu entgehen. Kürzlich zeigten wir jedoch, dass die HIV-Infektion mit einer vermehrten Expression des nicht-klassischen MHC I Moleküls HLA-E assoziiert ist. Hierbei identifizierten wir das HLA-A2-restringierte Epitop HIV p24 aa14-22 als einen Liganden für HLA-E, der die Oberflächenexpression von HLA-E stabilisiert und dadurch die Zytotoxizität von NK-Zellen hemmt.

In der vorliegenden Arbeit beschreiben wir erstmals die HLA-E-restringierte Erkennung des HIV-Peptids (HIV p24 aa14-22) durch humane CD8(+) T-Zellen .

Methoden: 41 HIV-1-infizierte Patienten (17 HIV RNA(-) unter HAART, 24 HIV RNA(+)) und 14 gesunde Individuen wurden in die Studie eingeschlossen. Die Frequenz HIV p24 aa14-22-spezifischer HLA-E-restringierter CD8+ T-Zellen wurde mittels IFN- $\gamma$ und IL-2 ELISpot Assays bestimmt. Hierbei dienten HLA-E-transfizierte K562-Zellen als Antigen-präsentierende Zellen .

Resul tate: IFN- $\gamma$ sezernierende, HLA-E restringierte CD8(+) T-Zellen konnten bei 16/41 HIV(+) Patienten (39\%), jedoch bei keiner der gesunden Kontrollen nachgewiesen werden. Eine IL-2 Antwort fand sich bei 8/33 (24.2\%) Patienten .

Hierbei zeigte sich, dass eine HLA-E restringierte IL-2 Antwort nur bei HAART-Patienten, nicht aber bei den HIV RNA(+) Therapie-naiven Patienten nachweisbar war $(8 / 20$ [40\%] vs. $0 / 13[0 \%] ; p=0.012)$ während der Unterschied bei den IFN- $\gamma$ Antworten weniger deutlich war $(11 / 24 ; 45.5 \%$ vs. $5 / 1729.4 \%$ ).

Zudem war eine HLA-E-restringierte IL-2-Sekretion mit einer hohen CD4-Zellzahl assoziiert (CD4 Zellen/ $\mu$ 1: 588 [457-683] vs . 464 [160-906]; $p=0.013)$.

Im Gegensatz dazu war in der Gruppe der Patienten ohne HAART eine IFN- $\gamma$ Antwort mit hoher Virus last $(56.9 \times 103$ \pm 19.9 × 103 vs. $11.2 \times 103 \pm 2.9 \times 103 ; \mathrm{p}=0.05)$ bei geringer CD4-Zellzahl $(302 \pm 34$ vs. $465 \pm 49 ; p=0.048)$ assoziiert.

Schl uss folgerung en: Unsere Daten zeigen, dass CD8(+) T-Zellen das HIV-Peptid HIV p24 aa14-22a im Kontext des nicht-klassischen MHC Moleküls HLA-E erkennen können. Zudem liefern unsere Daten erste Hinweise auf eine mögliche funktionelle Bedeutung dieser T Zell-Antworten im Rahmen der HIV-spezifischen Immunabwehr.

\section{$\mathrm{OSC} / 4$}

Frequency and phenotype of CD4+FoxP3+ T regulatory cells is associated with disease progression in $\mathrm{HIV}-1$ infected patients

Adriana Thomssen ${ }^{1}$, Philipp Hartjen ${ }^{1}$, Sandra Hertling ${ }^{1}$, Olaf Degen ${ }^{1}$, Stefan Schmiedel ${ }^{1}$, Dirk Meyer-Olsen ${ }^{2}$, Ans gar Lohse ${ }^{1}$, Joachim Hauber ${ }^{3}$, Jan van Lunzen ${ }^{1}$, Julian Schulze zur Wiesch ${ }^{1}$

${ }^{1}$ Universitätsklinikum Eppendorf, Hamburg, Germany, ${ }^{2}$ Medizinische Hochschule Hannover, Hannover, Germany, ${ }^{3}$ Heinrich-Pette-Institute for Experimental Virology and Immunology, Hamburg, Germany

Background: There is increasing evidence that regulatory CD4+ T cells (Tregs) are of clinical relevance for the coordination of HIV-specific cellular immune responses. Until now Tregs have only been sub-optimally defined by their co-expression of CD4+ and CD2 $5^{\text {high }}$. Hence, there are conflicting data about the frequency of $\mathrm{T}_{\text {regs }}$ in HIV. Intracellular FoxP3 expression (as well as surface labeling of CD127 and $\mathrm{CD} 25$ ) was recently described as more definitive markers to identify $\mathrm{T}_{\text {regs }}$, but this has not been tested rigorously.

Methods: A multicolor flow panel was developed to determine the frequency and phenotype of $\mathrm{T}_{\text {regs }}$, defined as $\mathrm{CD} 4+, \mathrm{CD} 25+$, FoxP3+ cells. PBMC of a large cohort of $100 \mathrm{HIV}-1$ infected patients at different stages of immune deficiency were analyzed. The phenotype of these Treg populations using a selection of differentiation markers (CD127, CD39, CCR5, CTLA4 and ICOS). In addition, functional properties of $T_{\text {regs }}$ were tested for selected patients in order to define their inhibitory role.

Results: Overall we saw significantly increased frequencies of $\mathrm{T}_{\text {regs }}$ in the $\mathrm{HIV}+$ cohort in comparison to a healthy control group. Additionally the frequency of $\mathrm{T}_{\text {regs }}$ increased with higher HIV VL $(\mathrm{p}<0.0004)$, while it was inversely proportional to the CD4+ count ( $p<0.0021)$. CD2 $5^{\text {high }}$, CD127-expression alone proved to be sufficient to label the Treg population. Patients with undetectable VL either through spontaneous control or antiviral therapy had a significantly lower frequency of Treg cells $(\mathrm{p}<0.0309)$.

Conclusions: Higher frequencies of $\mathrm{T}_{\text {regs }}$ were detected in patients with progressive HIV disease. These cells might balance cellular activation of CTL driven by viral replication. It remains to be elucidated whether therapeutic depletion of Treg cells at later stages of HIV infection could actually enhance HIV specific cellular immunity. 


\section{OSD - Disease Management - An Interdisciplinary Approach}

\author{
25. Juni 2009 \\ 16.00-17.30 Uhr \\ Saal 2
}

OSD/1

\section{Scheitert eine adäquate ökonomische Abbildung der stationären HIV-Fälle durch die G-DRGs an der niedrigen Prävalenz der HIV-Infektion in Deutschland? \\ Matthias Stoll, Deutsche AIDS Gesellschaft}

Medizinische Hochschule Hannover, Zentrum Innere Medizin, Klinik für Immunologie und Rheumatologie, Hannover, Germany

Hinterg rund: Die Vergütung stationärer Leistungen im deutschen Gesundheitswesen erfolgt für das Krankenhaus auf der Basis von über eintausend Fallpauschalen (German Disease Related Groups: G-DRG). Diese werden jährlich anhand einer Stichprobe von knapp 2 Millionen Behandlungsfällen aus derzeit gut 200 Kalkulationskrankenhäusern bewertet und basieren im Mittel auf 1691 Fällen für jede DRG bzw. 68.223 Fällen für eine übergeordnete MDC. Methodik: Beschreibung und Bewertung der MDC 18A (HIV) anhand der öffentlich zugänglichen Datenbank des InEK im Vergleich zu anderen MDCs und DRGs.

Ergebnisse: Die HIV-MDC 18A unterscheidet sich von den übrigen MDCs: Sie hat die niedrigsten Fallzahlen für MDC ( $\mathrm{n}=752$, das 0,011-fache des Durchschnitts) und deren 8 DRGs (94, Range: 22 - 323, das 0,056-fache des Durchschnitts). Die sehr heterogenen und häufig komplexen Krankheitsbilder im Kontext einer HIV-Infektion erfahren daher nur eine Differenzierung in ebenso wenige DRGs wie die Appendektomie (G07A,-B; G22A,-B,-C; G23A,-B,-C). Als Trenner der ökonomischen Fallschwere eignen sich die bestehenden G-DRGs der MDC18A aber nur bedingt, da mehr als die Hälfte der DRGs (S62Z, S63B, S64Z, S65A, S65B) sehr ähnliche Erlöse erbringen (Abb.). Die Entwicklung seit 2005 deutet zwar eine breitere Spreizung an (S01Z, S63A). Dem steht aber eine leichte Abnahme des Casemix-Index (CMI=durchschnittliche ökonomische Fallschwere/Patient) im Beobachtungszeitraum entgegen. Wenig plausibel ist auch eine Zuordnungslogik, die über $60 \%$ der Fälle aus der fallzahlstarken, aber erlösschwächeren DRG S63B (Infektion bei HIV-Krankheit ohne komplexe Diagnose oder ohne äußerst schwere CC) dennoch in die beiden höchsten PCCL (Patient clinical complexity level) 3 und 4 gruppiert.

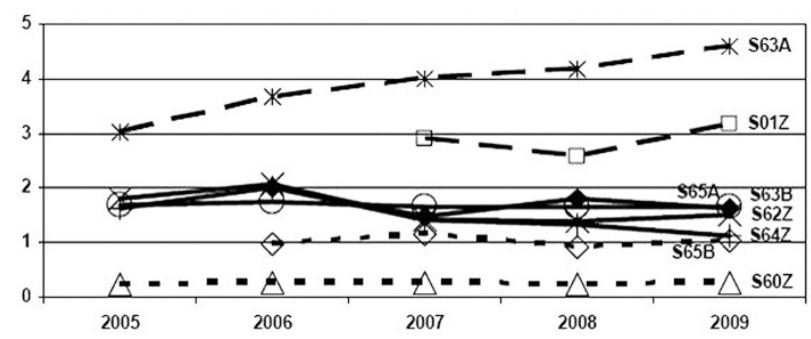

Entwicklung der ökonomischen Relativgewichte der G-DRGs der MDC 18A. [DRGs]
Schlussfolgerung: Die ökonomische Abbildung der HIV-Infektion durch G-DRG ist weiterhin unbefriedigend, insbesondere die Differenzierung komplexer Fälle und solcher, in denen aufwändige Prozeduren erfolgen. Zahlreiche von der DAIG vorgeschlagene Lösungsansätze scheiterten - oft wegen "zu kleiner" Fallzahlen - vorwiegend an den Vorgaben des datengetriebenen DRGSystems sowie an daraus resultierenden datenschutzrechtlichen Bedenken gegen eine weitere Differenzierung.

\section{$O S D / 2$}

Direct costs for highly active antiretroviral treatment (HAART) regimens in the German ClinSurv multicenter cohort $1996-2008 *$

Matthias Stoll ${ }^{1}$, Christian Kollan ${ }^{2}$, Osamah Hamouda ${ }^{2}$, ClinSurv Study Group

\begin{abstract}
${ }^{1}$ Medizinische Hochschule Hannover, Zentrum Innere Medizin, Klinik für Immunologie und Rheumatologie, Hannover, Germany, ${ }^{2}$ Robert Koch-Institut, Infektionsepidemiologie, Berlin, Germany
\end{abstract}

Rational e: HAART has been shown to be cost effective by preventing disease progression and the necessity for concomitant treatment. New antiretrovirals (ARVs) and more complex HAART-combinations are more expensive than in prior periods and thus the economic impact of HAART is rising. This demands increasing efforts for rational data based decisions to allocate resources.

Objective: To evaluate direct costs of HAART in patients treated at specialised clinical centers.

Methods: Analysis of the complete HAART documentation from 23 centers of the German ClinSurv cohort. ARTregimens were calculated individually using documented start and stop dates for each ARV between Jan-1996 and Jun-2008. Direct costs of HAART were calculated as officebased sales prices

Results : Overall 18.4 million treatment-days in 10,499 individuals have been evaluated. Mean observed duration under HAART was 1,765 days. Within the observed 12 year follow-up period overall costs of $€ 703,700,000$ have been accumulated. Average daily costs of an entire regimen are $€ 38.29$. Discounted (4\% p.a.) office based daily drug-regimen (DDD) costs have been doubled since 1996 (+107\%). But this increase is caused predominantly by the introduction of triple-HAART from 1996-98 $(+126 \%)$. Thus since 1998 average DDD-costs remained stable (slight decrease: $8.5 \%)$.

Conclusions: Inflation-adjusted direct costs for HAART regimens remain stable since the introduction of HAART, although more complex and cost intensive treatment options became available. This could be explained by (a) increasing use of NNRTIs as compared to the begin of the HAART-era, (b) moderate pricing of (new) antiretroviral drugs, (c) by health-policy measures, e.g. the $16 \%$ discount by law for drugs in Germany in 2004, and (d) the economically conscientious prescription of ARVs by the specialised physicians. Recent recommendations to start HAART earlier in HIV infection might increase drug costs in the future.

\footnotetext{
* ClinSurv has been founded temporarily within the German CompNet HIV/AIDS by the German BMBF.
} 


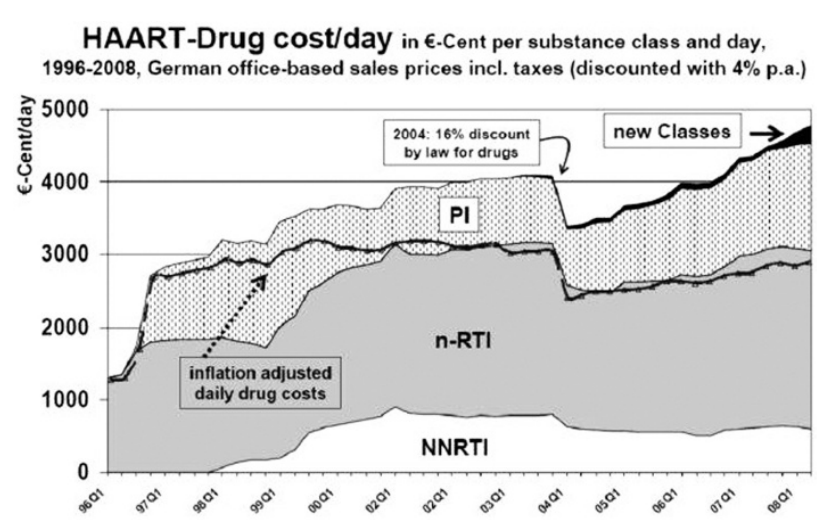

[RKI_SÖDAK]

\section{OS D/3}

\section{Risk factors of "early" and "late" diagnosis of HIV infection in Austria}

Mario Sarcletti ${ }^{1}$, Stefanie Gogl ${ }^{2}$, Margret Jöchl ${ }^{3}$, Armin Rieger ${ }^{4}$, Maria Geit ${ }^{5}$, Bernhard Haas ${ }^{6}$, Ninon Taylor ${ }^{7}$, Manfred Kanatschnig ${ }^{8}$, Robert Zangerle ${ }^{1}$

${ }^{1}$ Univ. Klinik für Dermatologie und Venerologie, Innsbruck, Austria, ${ }^{2}$ Österr. HIV-Kohortenstudie, Innsbruck, Austria,

${ }^{3}$ AGES, Wien, Austria, ${ }^{4} \mathrm{AKH}$ Wien, Wien, Austria, ${ }^{5} \mathrm{AKH}$ Linz, Linz, Austria, ${ }^{6} \mathrm{LKH}$ Graz, Graz, Austria, ${ }^{7} \mathrm{LKH}$ Salzburg, Salzburg, Austria, ${ }^{8}$ LKH Klagenfurt, Klagenfurt, Austria

Background: Frequency and risk factors of patients in Austria with "early" and "late" stage of disease at diagnosis of HIV infection.

Methods: Participants of the Austrian HIV Cohort Study with a diagnosis of HIV infection from 2001 to 2008. "Early diagnosis" was defined by primary infection (western blot pattern or Antigen/HIV RNA combined with the clinical picture) or documented seroconversion within 3 years. "Late diagnosis" was defined by a CD4 cell count $<200$ cells/1 and/or AIDS within 6 and 3 months, respectively, of diagnosis of HIV infection. Risk calculation was done by logistic and Cox regression.

Results: Overall 1666 persons had been diagnosed with HIV infection, 1196 were men $(71,8 \%), 470$ women $(28,2 \%), 546$ patients $(32,8 \%)$ were men who had sex with man (MSM), 232 $(13,9 \%)$ injecting drug users (IDU) and $733(44,0 \%)$ heterosexual contacts,. An "early" diagnosis has been made in 291 patients (17,5\%), more frequently in MSM $(R R=1,82, p<$ $0,001)$ and in patients with residency outside Vienna $(\mathrm{RR}=1,64, \mathrm{p}<0,001)$ and much less frequently in patients originating from high prevalence areas $(\mathrm{RR}=0,28, \mathrm{p}<0,001)$. A "late" diagnosis has been made in 432 patients $(25,9 \%)$. A higher risk for "late" presentation was found in patients with residency outside Vienna $(R R=1,35, p=0,019)$. A lower frequency of "late" presentation was observed in younger patients $(<37$ years; $R R=0,47, p<0,001)$, MSM $(R R=0,41, p<0,001)$ and in IDU $(R R=0,36, p<0,001)$. The frequency of "late diagnosis" did not change essentially from 2001 to 2008 and was associated with a higher risk of mortality $(\mathrm{HR}=3,36, \mathrm{p}<$ $0,001)$.

Conclusions: Late diagnosis of HIV infection is frequent in Austria and an independent risk factor for mortality. Risk factors for early and late presentation have been identified and may provide a basis for a more efficacious testing for HIV infection.

\section{$O S D / 4$}

\section{Prevalence of potential drug-drug interac- tions in the Swiss HIV Cohort Study}

Catia Marzolini ${ }^{1}$, Sara Gibbons ${ }^{2}$, Luigia Elzi ${ }^{1}$, Saye Khoo $^{2}$, Bruno Ledergerber ${ }^{3}$, David Back ${ }^{2}$, Manuel Battegay ${ }^{1}$, Swiss HIV Cohort Study Members

${ }^{1}$ University Hospital of Basel, Basel, Switzerland, ${ }^{2}$ University of Liverpool, Liverpool, United Kingdom, ${ }^{3}$ University Hospital of Zürich, Zürich, Switzerland

Background: Drug-drug interactions (DDIs) related to HIV therapies continue to expand with new drugs, more complex ART regimens, and increasing age-related comorbidities. The identification, resolution and prevention of DDIs are important determinants for clinical management as it may prevent treatment failure and toxicity. This study investigates the prevalence of DDIs (HIV/HIV drugs and HIV/non-HIV drugs) within Swiss HIV Cohort Study (SHCS) patients .

Methods: Detailed SHCS medication forms were screened for potential DDIs during a 3 month period of time using a customised version of the University of Liverpool drug interaction database (www.hiv-druginteractions.org). Physicians were subsequently informed of clinically relevant DDIs.

Results: Medical prescriptions were analyzed for 771 ART-treated patients. ART-regimens were mostly PI-based (41\%) and NNRTI-based (39\%) with tenofovir/emtricitabine as NRTI backbone (38\%). 516 patients had a co-medication, of whom 337 had at least one DDI. Of these, 11 patients (2\%) had red flag DDIs (i.e. contra-indicated) and 333 patients $(65 \%)$ had orange flag DDIs (i.e. potential dose modification or close monitoring). 35 patients $(7 \%$ had HIV/HIV drug interactions, whereas 316 patients $(61 \%)$ had $\mathrm{HIV} /$ non-HIV drug interactions. HIV/non-HIV drug interactions involved mainly ATV/r (21\%), LPV/r (22\%) and EFV $(26 \%)$ with methadone (14\%), cardiovascular drugs (mostly B-blockers and Ca channel inhibitors; 13\%), statins (20\%) and CNS drugs (mostly SSRIs and BZDs; $23 \%$ ). 16 patients (3\%) had a DDI that could have lowered the HIV drug concentration. In the multivariate analysis, older patients $(\mathrm{P}<$ $0.001)$ and IDU patients $(\mathrm{P}=0.001)$ were most likely to have a co-medication. Independent risk factors for DDIs were IDU patients $(\mathrm{P}=0.005)$, PI+NNRTI-based regimens $(\mathrm{P}=0.002)$ and $>2$ co-medications $(\mathrm{P}<0.001)$. No as sociation was found between DDIs and virological failure.

Conclusion: Clinically significant DDIs related to HIV therapy are common. The www.hiv-druginteractions.org database constitutes a valuable tool for the identification of DDIs in clinical practice. 
$O S D / 5$

\section{Clinical outcomes of HIV-positive patients (PLWHA) having different income status: results of an analysis on basis of the KompNet cohort}

Klaus Jansen ${ }^{1}$, Norbert H. Brockmeyer ${ }^{1,2}$, Verena Dlugay ${ }^{3}$, Matthias Stoll ${ }^{4}$, Ramona Pauli ${ }^{5}$, Jörg Gölz $z^{6}$, Thomas Buhk $^{7}$, Andreas Carganico ${ }^{8}$, Peter Kreckel ${ }^{9}$, Mark Müller ${ }^{10}$, Adriane Skaletz-Rorowsk $i^{1}$, Volker Mertens ${ }^{11}$, Claudia Michalik ${ }^{12}$, and the Competence Network for HIV/AIDS

${ }^{1}$ Kompetenznetz HIV/AIDS, Ruhr-Universität Bochum, Bochum, Germany, ${ }^{2}$ Universitätsklinik Bochum, Bochum, Germany, ${ }^{3}$ Institut für Medizinische Statistik, Informatik und Epidemiologie, Köln, Germany, ${ }^{4}$ Medizinische Hochschule Hannover, Hannover, Germany, ${ }^{5}$ Gemeinschaftspraxis Isartorplatz, München, Germany, ${ }^{6}$ Praxiszentrum Kaiserdamm, Berlin, Germany, ${ }^{7}$ Gemeinschaftspraxis Grindelallee, Hamburg, Germany, ${ }^{8}$ Praxis Driesener Straße, Berlin, Germany, ${ }^{9}$ Gemeinschaftspraxis Mehringdamm, Berlin, Germany, ${ }^{10}$ Praxis Schwabstraße, Stuttgart, Germany,

${ }^{11}$ Deutsche AIDS Stiftung, Bonn, Germany, ${ }^{12}$ Zentrum für Klinische Studien, Köln, Germany

Issue of research/question: Income-status is assumed to be a highly influencing factor for health outcomes, generally. Reliable data on income status of PLWHA in Germany are rare, because gathering income-data is challenging, due to privacy of patients. To analyse this aspect for PLWHA in Germany, we evaluated income-data of the nationwide KompNet-cohort with regard to central clinical parameters.
Description: The cohort surveys income-data since $7 / 2007$. By $8 / 2008$, we received data for already $2.045 \mathrm{pa}-$ tients. There were nearly no differences between this subpopulation and the overall-cohort $(\mathrm{N}=6.085)$, comparing age, sex, risk of infection, origin, CDC-stage.

Of the subpopulation, $39.6 \%$ had an income $<=1.000 €$, $48.1 \%=1001 €-2.500 €$ and $12.3 \%>2.500 €$ (Table 1$)$. We observed a lower income structure in women, as well as in migrants. Significantly, we found a distinct poorer health outcome concerning CDC-stage and CD4-cell count, in relation to patient's income status: only $30.0 \%$ of patients having an income $<=1.000 €$ were diagnosed as CDC-stage A (B: $23.8 \%$; C: $43.0 \%), 60.4 \%$ of these patients had an CD4-cell-count $<200$. Differences concerning viral load were slightly and not significantly.

Conclusion: Because the composition of the analysed subpopulation equalled the overall-cohort well, our preliminary data give already a good impression of income status, its sociodemographic impact and its influence on clinical outcomes for the KompNet cohort and therewith an approximation for PLWHA in Germany. The clearly poorer health outcomes for patients with lower income confirm results of studies on incomes status and general health outcomes and show a big need for better treatment and care for this group. Next steps: Data completion has to be carried on. Deutsche AIDS-Stiftung (DAS) and KompNet are planning a study concerning clinical outcomes of PLWHA with low income. Respecting data protection, DAS- and KompNetdatasets will be combined, health parameters of DAS-clientel will be compared to that of KompNet-patients.

Table 1.

Income

\begin{tabular}{|c|c|c|c|c|}
\hline$(\%)$ & $£ 1.000 €$ & $1.001 €-2.500 €$ & $>2.500 €$ & p-value \\
\hline All & 39.6 & 48.1 & 12.3 & \\
\hline Sex & & & & $<0.01$ \\
\hline Men & 38.1 & 48.5 & 13.4 & \\
\hline Women & 48.7 & 45.2 & 6.1 & \\
\hline Migration status & & & & $<0.01$ \\
\hline non migrated 37.6 & 49.1 & 13.3 & & \\
\hline migrated & 52.5 & 41.3 & 6.2 & \\
\hline
\end{tabular}

[Income structure, by sex and migration status]

\begin{tabular}{|c|c|c|c|c|}
\hline & & & Income & \\
\hline$(\%)$ & $£ 1.000 €$ & $1.001 €-2.500 €$ & $>2.500 €$ & p-value \\
\hline All & 39.6 & 48.1 & 12.3 & \\
\hline CD4-cell-count & & & & $<0.01$ \\
\hline$<200$ cells $/ \mathrm{ml}$ & 60.4 & 33.6 & 6.0 & \\
\hline $200-499$ cells $/ \mathrm{ml}$ & 40.4 & 48.4 & 11.2 & \\
\hline$\geq 500 \mathrm{cell} / \mathrm{s} / \mathrm{ml}$ & 35.9 & 49.9 & 14.2 & \\
\hline Viral load $<$ & 67.7 & 70.3 & 71.0 & 0.41 \\
\hline
\end{tabular}

[Income status, by CD4-cell-count and VL]

Income

\begin{tabular}{|c|c|c|c|c|}
\hline$(\%)$ & $£ 1.000 €$ & $1.001 €-2.500 €$ & $>2.500 €$ & p-value \\
\hline All & 39.6 & 48.1 & 12.3 & \\
\hline CDC-stage & & & & $<0.01$ \\
\hline 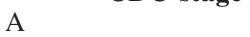 & 30.0 & 55.0 & 15.0 & \\
\hline B & 42.8 & 44.8 & 12.4 & \\
\hline $\mathrm{C}$ & 43.0 & 47.3 & 9.7 & \\
\hline
\end{tabular}

[Income structure, by CDC-stage] 


\section{OSE - HIV suppressed - which Coinfection to worry about?}

\author{
26. Juni 2009 \\ 11.00-12.30 Uhr \\ Saal 1
}

OSE 1

\section{The influence of nucleoside free HAART on the treatment of chronic hepatitis $C$ with pegylated interferon / ribavirin combination treatment}

Martin Vogel ${ }^{1}$, Golo Ahlenstiel ${ }^{1}$, Gerd Klausen ${ }^{2}$ Thomas Lutz ${ }^{3}$, Dirk Schürmann ${ }^{4}$, Christoph Stephan 5 , Christoph Mayr ${ }^{6}$, Axel Baumgarten ${ }^{7}$, Peter Buggisch ${ }^{8}$, Hartwig Klinker ${ }^{9}$, Christine John ${ }^{10}$, Jörg Gölz ${ }^{11}$, Pavel Khayk in ${ }^{5}$, Mark us Bickel ${ }^{5}$, Jürgen Kurt Rockstroh ${ }^{1}$

${ }^{1}$ Bonn University, Department of Internal Medicine I, Bonn, Germany, ${ }^{2}$ Praxis Hintsche / Klausen, Berlin, Germany, ${ }^{3}$ Infektiologikum, Frankfurt / Main, Germany, ${ }^{4}$ Charité Universitätsmedizin, Berlin, Germany, ${ }^{5}$ University of Frankfurt / Main, Frankfurt / Main, Germany, ${ }^{6}$ Ärzteforum Seestraße, Berlin, Germany, ${ }^{7}$ Praxis Dupke / Baumgarten / Carganico, Berlin, Germany, ${ }^{8}$ Institut für Interdisziplinäre Medizin (ifi), Hamburg, Germany, ${ }^{9}$ University of Würzburg, Würzburg, Germany, ${ }^{10}$ Practice John, Berlin, Germany,

${ }^{11}$ Praxiszentrum Kaiserdamm, Berlin, Germany

Introduction: Concomitant use of nucleosides (NUC) as part of HAART and ribavirin may lead to enhanced toxicity during treatment of hepatitis $\mathrm{C}$ in HIV-coinfected patients, possibly compromising treatment outcome of hepatitis $\mathrm{C}$ therapy.

Methods: Prospective, partially randomized controlled trial. HIV-negative (A), HIV-positive without HAART (B), and HIV-positive on HAART (C) were enrolled. Group C was randomized to NUC-free (double PI or PI/NNRTI, C1) or NUC-containing HAART (NRTI at choice of investigator, C2). Patients were treated with pegylated interferon alfa-2a $180 \mu \mathrm{g}$ /week and ribavirin (800 $\mathrm{mg}$ in genotype $2 / 3$, $1000 / 1200 \mathrm{mg}$ in genotype 1/4). Treatment duration was 24 weeks for HCV-genotypes 2 and 3 and 48 weeks for genotypes 1 and 4 . After a protocol amendment all patients were treated for 48 weeks.

Resul ts : 152 patients (group $\mathrm{A}=48, \mathrm{~B}=41, \mathrm{C} 1=19, \mathrm{C} 2$ $=44$ ) received at least one dose of pegylated interferon / ribavirin ribavirin and were evaluated by intent to treat analysis (missing=failure). In HIV+ patients median CD4cellcount was $494 / \mu 1$, and of those off HAART HIV-RNA was $3.9 \log 10$. HCV-genotypes were $1(n=78), 2(n=9), 3$ $(n=52), 4(n=8)$ and double infections $(n=5)$. In HCVmonoinfected patients an end of treatment response (ETR) was reached in $73 \%$ of patients and was sustained (negative HCV-RNA 24 weeks after the end of therapy, SVR) in 55\% of patients. In HIV-coinfected patients, ETR was observed in $72 \%$ of patients and was sustained in $55 \%$ of cases (Group B 59\%, C 52\%). Interestingly, the difference between groups $\mathrm{C} 1$ and $\mathrm{C} 2$ was significant for SVR (C1 74\%, C2 43\%; p=0.031), but not for age, gender, baseline ALT, CD4-cellcount, HIV-RNA, HCV-RNA, or distribution of HCV-genotypes.

Conclusions: High SVR-rates, comparable to HIV-negative patients, were reached in $55 \%$ of HIV-positive patients. NUC-free HAART resulted in higher SVR-rates compared to NUC-containing HAART.
$O S E / 2$

Successful antiretroviral therapy is associated with increasing $\mathrm{HCV}$-specific $\mathrm{T}$ cell responses

Janine Rohrbach ${ }^{1}$, Gillian Harcourt ${ }^{2}$, Silvana Gaudieri ${ }^{3}$, Nicola Robinson ${ }^{2}$, Amalio Telenti ${ }^{4}$, Matthias Egger ${ }^{5}$, Huldrych Günthard ${ }^{6}$, Paul Klenerman ${ }^{2}$, Hansjakob Furrer $^{1}$, Andri Rauch ${ }^{1}$, Meri Gorgievski ${ }^{1}$

${ }^{1}$ University Clinic of Infectious Diseases, Bern, Switzerland, ${ }^{2}$ Nuffield Department of Medicine, Oxford, United Kingdom, ${ }^{3}$ Murdoch University, Perth, Australia, ${ }^{4}$ Institue of

Microbiology, University Lausanne, Lausanne, Switzerland, ${ }^{5}$ Institute of Social and Preventive Medicine, University of Bern, Bern, Switzerland, ${ }^{6}$ Division of Infectious Diseases, University Hospital, Zurich, Switzerland

Background: The impact of long-term antiretroviral therapy (ART) on HCV-specific T cell responses and on HCV viral loads is unclear.

Methods: HCV-specific CD4 $\mathrm{T}$ cell responses were assessed longitudinally in $80 \mathrm{HIV} / \mathrm{HCV}$-coinfected individuals (58 with chronic and 22 with resolved HCV-infection) by ex vivo interferon-gamma ELISpot responses to HCVcore peptides, an as say previously demonstrated to measure CD4 T cell reactivity. HCV-RNA levels were as sessed longitudinally by in-house real-time PCR in 62 individuals. Analyses were performed at the earliest available timepoint after HIV-infection, just before starting ART and at three time-points after starting successful (HIV-viral loads $<1000 \mathrm{cp} / \mathrm{ml}$ during therapy) ART (time-points 1 to 5). All time-points were before starting anti-HCV therapy.

Results: Before starting ART, T-cell responses were detected in $2 / 16$ individuals $(13 \%)$ at time-point 1 and in $12 / 64(19 \%)$ individuals at time-point 2 . At time-point 3 , $12 / 50$ (24\%) individuals had detectable HCV-responses. After a median of 33 and 74 months of successful ART, $29 / 64(45 \%)$ and 18/37 (49\%) individuals had HCV-specific T cell responses ( $\mathrm{p}=0.002$ and 0.003 compared to timepoint 2). In 54 individuals with available PBMCs during both untreated and treated HIV-infection (time-points 2 and 4 ), the emergence of HCV-specific responses during successful ART was considerably more frequent than loss of detectable responses (31\% vs $9 \%$ ). HCV-specific responses on-therapy (time-point 4) were detected more frequently in the 58 individuals with resolved than in the 22 individuals with chronic HCV infection (61\% vs 39\%). Median HCV viral loads were 6.2 and $6.5 \log 10 \mathrm{IU} / \mathrm{ml}$ at time-points 1 and 2 (untreated HIV-infection) and 6.7, 6.3 and $6.2 \log 10$ $\mathrm{IU} / \mathrm{ml}$ at time-points 3,4 and 5 (on-therapy).

Conclusion: A successful ART can increase HCV-specific $\mathrm{T}$ cell responses and is associated with a slight decrease in HCV RNA levels long-term. This finding supports consideration of earlier ART initiation in $\mathrm{HIV} / \mathrm{HCV}$-coinfected individuals. 
$O S E / 3$

\section{Retrospective analysis of orthotopic liver transplantation in human immunodeficiency virus (HIV)-positive patients in German transplant centers}

Evrim Anadol ${ }^{1}$,Christoph Berg ${ }^{2}$, Mark us Bickel ${ }^{3}$, Bernd Salzberger ${ }^{4}$, Matthias Stoll ${ }^{5}$, Alexander Zoufaly 6 , German OLTX-HIV-Group

${ }^{1}$ Bonn University, Department of Internal Medicine I, Bonn, Germany, ${ }^{2}$ University Tübingen, Department of Internal Medicine, Tübingen, Germany, ${ }^{3}$ University Frankfurt, Department of Internal Medicine, Frankfurt, Germany,

${ }^{4}$ University Regensburg, Department of Internal Medicine, Regensburg, Germany, ${ }^{5}$ Hannover Universitiy, Department of Internal Medicine, Hannover, Germany, ${ }^{6}$ Hamburg University, Department of Internal Medicine, Hamburg, Germany

Backgro und: The introduction of HAART has led to a dramatic reduction in $\mathrm{HIV}$-associated morbidity and mortality. As a consequence liver disease associated complications have become an increasing clinical challenge. With one third of European HIV-patients having hepatitis C co-infection and 6-9 \% hepatitis $\mathrm{B}$ co-infection a rising need for liver organ transplantation (OLTX) has emerged. The current study evaluates the outcome of OLTX in HIV-patients throughout Germany.

Methods: Retrospective chart analysis of $18 \mathrm{HIV}$-positive patients who were liver transplanted in 6 German transplant centers (Bonn $n=10$, Hamburg $n=3$, Frankfurt $n=2$, Tübingen $n=1$, Regensburg $n=1$, Hannover $n=1$ ) between 1997-2008.

Results: Reasons for OLTX were end-stage liver disease (ESLD) due to hepatitis $\mathrm{C}$ ( $\mathrm{n}=9$, with 3 having additionally HCC) ESLD due to HBV ( $\mathrm{n}=8$, one with additional alcoholic cirrhosis), one with Budd-Chiari syndrome $(n=1)$. The median CD4 T-cell count before transplantation was 299/ $\mu$ 1 (range 98-595/ $\mu 1$ ). Of all transplanted patients $14 / 18$ are still alive in 2009 with a median survival of 39 months (range 2-138 months). 4/18 patients died, 3 in the early post-transplantation period within 3 months, one due to organ rejection and acute renal failure, the other because of intrathoracal hemorrhage and the last of septicemia. 1 patient died after 8 months respectively, due to anastamotic leak with massive bleeding. In $2 / 18$ patients one or more episodes of acute rejection was observed. Recurrent hepatitis B infection was efficiently prevented in $7 / 8$ patients, whereas hepatits $\mathrm{C}$ reinfection occurred in all patients.

Conclusion: OLTX is a feasible approach in HIV-infected patients with ESLD in Germany with overall acceptable survival rates. Reinfection with HCV remains one of the biggest clinical challenges after OLTX in HIV/HCV coinfection.

\section{OSE $/ 4$}

\section{Outcome of AIDS-related lymphoma depends on CD20 expression}

Christoph Wyen ${ }^{1}$, Gerd Fätkenheuer ${ }^{1}$, Björn-Erik Ole Jensen ${ }^{2}$, Michael Sabranski ${ }^{3}$, Timo Wolf ${ }^{4}$, Jan Siehl ${ }^{5}$, Birgit Ross 6 , Mark us Müller ${ }^{7}$, Jürgen Rockstroh ${ }^{8}$, Jan van Lunzen ${ }^{9}$, Stefan Esser ${ }^{6}$, Marcus Hentrich ${ }^{10}$, Christian Hoffmann 11

${ }^{1}$ Uniklinik Köln, Köln, Germany, ${ }^{2}$ University of Düsseldorf, Düsseldorf, Germany, ${ }^{3}$ ifi institute Hamburg, Hamburg, Germany, ${ }^{4}$ University of Frankfurt, Frankfurt, Germany,

${ }^{5}$ Ärzteforum Seestrasse, Berlin, Berlin, Germany, ${ }^{6}$ University of Essen, Essen, Germany, ${ }^{7}$ Vivantes Krankenhaus Neukölln, Berlin, Germany, ${ }^{8}$ University of Bonn, Bonn, Germany,

${ }^{9}$ University of Hamburg, Hamburg, Germany, ${ }^{10}$ Hospital Harlaching, Munich, Germany, ${ }^{11}$ IPM Study Center Hamburg, Hamburg, Germany

Background: AIDS-related lymphoma remain a significant factor of mortality and morbidity in HIV-infected patients. Optimal treatment remains controversial.

Methods: This ongoing observational study includes all HIV-infected patients with Non-Hodgkin's Lymphoma (NHL) and Hodgkin's Lymphoma (HL) diagnosed since 2005 in 24 participating centres. Characteristics of patients are analyzed, including histology, risk factors such as IPI score, use of specific polychemotherapy, (PCT) and antiretroviral therapy. Pts. are followed prospectively every six months.

Resul ts : As of 06/2008, 202 pts. (172 NHL, 30 HL) have been enrolled. At the time of lymphoma diagnosis, only $34 \%$ of NHL pts. (HL 70\%,p<.001) had prior ART exposure, and only $21 \%$ of the NHL patients (HL $50 \%, \mathrm{p}<.01$ ) had a viral load below 50 copies $/ \mathrm{ml}$. After a median followup of 10.6 months, 58 patients had died. Overall survival (OS) was worse in NHL patients than in HL patients $(\mathrm{p}=.07)$. NHL cases were either treated with a CHOP-based PCT $(76 \%)$ or an intensified protocol adapted from the German study group for adult acute lymphoblastic leukaemia (GMALL protocol,24\%), leading to a complete remission (CR) rate of $66 \%(\mathrm{HL} 88 \%, \mathrm{p}=.048)$. Among NHL cases, CD20positive cases had higher CR rates (71\% vs. $40 \%$, $\mathrm{p}=.04)$ and a significantly better outcome than CD20negative cases (median OS not reached versus 6.3 months, $\mathrm{p}<.0001)$. Age, gender, CD4 cells, previous AIDS, ARThistory, PCT, or IPI score did not differ between CD20positive and CD20negative cases. In CD20positive cases, the use of rituximab was associated with a trend towards higher CR rates (73\%vs.63\%, p>.05) and to better OS $(\mathrm{p}=.06)$. In total, there were $10 \mathrm{PCT}$ associated deaths which were not related to specific PCT regimens, use of rituximab, CD20 expression, or to other factors.

Conclusions: There remains a high mortality rate in AIDS-related lymphoma, especially in patients with CD20negative lymphoma. In CD20 positive cases, outcome was significantly better. 
OSE $/ 5$

HIV-associated Hodgkin's lymphoma (HIV-HL): Interim analysis of a prospective multicenter trial

Marcus Hentrich ${ }^{1}$, Anja Masuhr ${ }^{2}$, Christoph Wyen ${ }^{3}$, Jan Siehl ${ }^{4}$, Timo Wolf ${ }^{5}$, Jan-Christian Wasmuth ${ }^{6}$, Ans gar Rieke $^{7}$, Dagmar Assmann ${ }^{8}$, Anke Meyer ${ }^{9}$, Maike Nickelsen ${ }^{10}$, Dirk Schürmann ${ }^{11}$, Franz Mosthaf ${ }^{12}$, Keikawus Arastéh ${ }^{2}$, Gerd Fätkenheuer ${ }^{3}$, Christian Hoffmann 13

${ }^{1}$ Klinikum Harlaching, München, Germany, ${ }^{2}$ Vivantes Auguste-Viktoria-Klinikum, Berlin, Germany,

${ }^{3}$ Universitätsklinik, Köln, Germany, ${ }^{4}$ Ärzteforum Seestraße, Berlin, Germany, ${ }^{5}$ Universitätsklinik, Frankfurt, Germany, ${ }^{6}$ Universitaetsklinik, Bonn, Germany, ${ }^{7}$ Klinikum Kemperhof, Koblenz, Germany, ${ }^{8}$ Klinikum Stuttgart, Stuttgart, Germany, ${ }^{9}$ Praxis Dr Knechten, Aachen, Germany, ${ }^{10}$ Asklepios Klinik St. Georg, Hamburg, Germany, ${ }^{11}$ Charité Universitätsmedizin, Berlin, Germany, ${ }^{12}$ Schwerpunktpraxis, Karlsruhe, Germany, ${ }^{13}$ Infektionsmedizinisches Centrum Hamburg (ICH), Hamburg, Germany

Background: The outcome of pts with HIV-associated Hodgkin's lymphoma (HIV-HL) has improved since the introduction of HAART. The current trial was initiated to investigate a risk adapted treatment strategy in pts with HIVHL as established in HIV-negative pts with HL.

Methods: Pts are planned to receive $2 x \mathrm{ABVD}+30 \mathrm{~Gy}$ involved field (IF) radiation for early stage (ES) favourable HL, 4x BEACOPP baseline +30 Gy IF for ES unfavourable HL (extranodal involvement, large mediastinal mass, $\geq 3$ lymph node areas involved), and 6-8 x BEACOPP for advanced stage HL. BEACOPP should be replaced by ABVD in pts with far advanced HIV-infection.

Results : 70 pts (68 males) were included in the ongoing trial. 41/63 pts (65\%) had stage III/IV HL. HAART was given prior to HL in $47 / 61$ cases $(77 \%), 21 / 60$ pts (33\%) had a prior AIDS defining illness. The median CD4 counts at HL diagnosis was $210 / \mu 1$ with a median viral load of $<50 / \mathrm{ml}$ (range $0-750.000$ ). Grade $3 / 4$ toxicity occurred in $68 \%$ of pts. After a median follow-up of 12.8 months $10 / 14$ pts (71\%) with ES favourable HL achieved a CR and 4 pts (29\%) an unconfirmed CR. For pts with ES unfavourable HL the CR rate was $100 \%$ (7/7 pts). 19 of 26 pts $(73 \%)$ with advanced HL attained a CR, 5 pts (19\%) a PR and 2 pts experienced stable and progressive disease, respectively. Of 5 pts having relapsed 2 received salvage CT + autologous stem cell transplantation. So far, 5 of 70 pts $(7 \%)$ have died. Causes of death were neutropenic sepsis $(n=2)$, progressive $\mathrm{HL}(\mathrm{n}=2)$ and progressive HIV-infection $(\mathrm{n}=1)$.

Conclusions: In pts with HIV-HL risk-adapted CT and concomitant HAART is feasible and effective. These data suggest that the prognosis of HIV-HD may approach results achieved in the HIV-negative population with HL.

\section{OSE 6}

Low sensitivity of an interferon-gamma releasing assay (Elispot-TB ${ }^{\mathrm{TM}}$ ) for the diagnosis of latent tuberculosis in HIV-infected individuals

Luigia Elzi ${ }^{1}$, Ingrid Steffen ${ }^{2}$, Hansjak ob Furrer ${ }^{3}$, Stefano Bassetti ${ }^{4}$, Manuel Battegay ${ }^{1}$

${ }^{1}$ University Hospital Basel, Infectious Diseases and Hospital Epidemiology, Basel, Switzerland, ${ }^{2}$ University of Basel, Basel, Switzerland, ${ }^{3}$ University Hospital Bern, Bern,

Switzerland, ${ }^{4}$ Regional Hospital Olten, Olten, Switzerland

Background: Interferon-gamma release assays (IGRA) are replacing the tuberculin skin test (TST) for diagnosis of Mycobacterium tuberculosis infection. Data on sensitivity are controversial in the setting of immunosuppression.

Methods: HIV-infected individuals who developed culture-confirmed tuberculosis after inclusion in the Swiss HIV Cohort Study were analyzed. The IGRA (Elispot-TB ${ }^{\mathrm{TM}}$ ) was performed from lymphocytes stored within 6 months before active tuberculosis was diagnosed.

Results: 64 HIV-infected individuals $(68.8 \%$ males, $54.3 \%$ of non-white ethnicity, median age 35 (IQR 31-42) years, $18 \%$ with prior AIDS) were analyzed. The median CD4 T-count was 223 cells/ul (IQR 103-339), HIV-RNA was $4.7 \log 10$ copies/ml (IQR 4.3-5.3). The IGRA was performed using lymphocytes obtained at a median of 91 days (IQR 47-167) before active tuberculosis was diagnosed. Elispot-TB ${ }^{\text {TM }}$ resulted positive in 25 patients $(39.1 \%)$, negative in $18(28.1 \%)$ and indeterminate in 21 (32.8\%), corresponding to a sensitivity of $58 \%$ (95\% CI 43-74\%) if indeterminate results were excluded. Sensitivity of IGRA was independent of CD4 T-count $(\mathrm{p}=0.698)$. Among 44 individuals with available TST results, $22(50 \%)$ had a positive TST, defined as a skin induration of $>5 \mathrm{~mm}$. Agreement between TST and Elispot-TB ${ }^{\mathrm{TM}}$ was noted in only $56.8 \%$ $(\mathrm{kappa}=0.14, \mathrm{p}=0.177)$. In subjects with positive test results by either TST or Elispot-TB ${ }^{\mathrm{TM}}$, only $34.5 \%(10 / 29)$ had positive results with both modalities. TST-positive/IGRA negative discordant results were noted in $27.2 \%$ of subjects and TST-negative/IGRA positive results in $15.9 \%$. If TST and IGRA were combined (at least one test positive) a sensitivity of $66 \%$ (95\% CI $51-80 \%$ ) could be reached. In the multivariate analysis, age was the only risk factor of having both tests negative (OR 3.15, 95\%CI $1.23-8.1, \mathrm{p}=0.017$, per 10 years older).

Conclusions: IGRA (Elispot- $\mathrm{TB}^{\mathrm{TM}}$ ) alone has a low sensitivity to detect latent tuberculosis in HIV-infected individuals. Combination of TST and IGRA may be useful in clinical practice. 


\section{OSF - Diagnostics get complex as Therapy gets easier}

\author{
26. Juni 2009 \\ 11.00-12.30 Uhr \\ Saal 2
}

OSF/1

\section{Specific HIV-1 env traits and association with virologic control in vivo}

Beda Joos ${ }^{1}$, Philip Rieder ${ }^{1}$, Marek Fischer ${ }^{1}$, Herbert Kuster ${ }^{1}$, Peter Rusert ${ }^{2}$, Alexandra Trkola ${ }^{2}$, Satish K Pillai $^{3}$, Joseph K Wong ${ }^{3}$, Rainer Weber ${ }^{1}$, Huldrych F Günthard ${ }^{l}$

${ }^{1}$ University Hospital Zürich, Division of Infectious Diseases and Hospital Epidemiology, Zürich, Switzerland, ${ }^{2}$ University of Zürich, Institute of Medical Virology, Zürich, Switzerland,

${ }^{3}$ University of California, San Francisco, United States

Background: HIV RNA levels are influenced by genetic characteristics of both the host and the virus. Here we studied the relationship between HIV-1 env genotype and viral load in chronically-infected patients undergoing treatment interruptions (SSITT, Swiss-Spanish Intermittent Treatment Trial) and in primary HIV infected (PHI) patients. We applied machine learning techniques to determine if plasma-derived HIV-1 amino acid sequences can be used to predict spontaneous virologic control.

Methods : 20 chronically-infected (SSITT, 1753 clonal sequences) and 104 primary infected (PHI, 1610 clones) patients were studied before antiretroviral therapy and where applicable also after treatment stop. Decision tree learning (Weka, J48-algorithm) was used to classify the amino acid sequences based on virologic response.

Results: Sequences obtained during the first virus rebound from nine SSITT patients with extensive longitudinal sampling during the interruptions were used as training data set and revealed a strong (98.6\% accuracy) genetic signature associated with control of viremia $<5000$ copies $/ \mathrm{mL}$ after treatment stop. The simple sequence pattern at gp 120 positions $268 \mathrm{E} / 358 \mathrm{~T}$ was also predictive of control in the sequences originating from these patients during all subsequent rebounds. Sequences from 11 SSITT patients with less frequent sampling and from the PHI patients were used for external validation. High sensitivities (71-100\%) and negative predictive values $(80-100 \%)$ but low positive predictive values (12-40\%) were achieved in the patient-wise analysis based on presence of the genetic pattern in all clones.

Conclusions: Our results suggest that presence of virus lacking the amino acid pattern $268 \mathrm{E} / 358 \mathrm{~T}$ is associated with viremia $>5000$ at baseline of $\mathrm{PHI}$ and with low probability of spontaneous virologic control after treatment stop. Conversely, however, presence of $268 \mathrm{E} / 358 \mathrm{~T}$ does not predict control of viremia. These residues in HIV gp120 might affect in vivo HIV-1 fitness either at the level of Env function or influence susceptibility to adaptive or innate immune response.

\section{$O S F / 2$}

\section{Genotypic activity of Etravirine in patients failing on Efavirenz or Nevirapine: the Swiss HIV cohort study (SHCS)}

Alexandra U. Scherrer ${ }^{1}$, Barbara Has se ${ }^{1}$, Viktorvon Wyl ${ }^{1}$, Sabine Yerly ${ }^{2}$, Jürg Böni ${ }^{3}$, Philippe Bürgisser ${ }^{4}$, Thomas Klimkait ${ }^{5}$, Heiner C. Bucher 6 , Bruno Ledergerber ${ }^{1}$, Huldrych F. Günthard ${ }^{1}$

${ }^{1}$ Division of Infectious Diseases and Hospital Epidemiology, University Hospital Zürich, Zürich, Switzerland, ${ }^{2}$ Laboratory of Virology and AIDS Center, and Division of Infectious

Diseases, Geneva University Hospital, Geneva, Switzerland, ${ }^{3}$ Swiss National Center for Retroviruses, University of Zürich, Zürich, Switzerland, ${ }^{4}$ Division of Immunology and Infectious Diseases Services, Lausanne University Hospital, Swiss HIV Cohort Study Data Center, Lausanne, Switzerland, ${ }^{5}$ Institute for Medical Microbiology, University of Basel, Division of Infectious Diseases and Hospital Epidemiology, University Hospital Basel, Basel, Switzerland, ${ }^{6}$ Basel Institute for Clinical Epidemiology and Biostatistics, University Hospital Basel, Basel, Switzerland

Background: Etravirine (ETV) is a non-nucleoside reverse transcriptase inhibitor (NNRTI), approved for use in salvage treatment, which includes patients with virological failure on efavirenz (EFV) or nevirapine (NVP). We identified the prevalence of ETV-resistance-associated mutations (RAMs) as defined by IAS-USA and estimated ETVactivity in patients with a NNRTI failure.

Methods: Antiviral activity was predicted with the Stanford algorithm (4.3.6) by calculating a genotypic sensitivity score (GSS). A GSS of 0 indicated full resistance, 0.5 intermediate resistance and 1 full sensitivity. Predicted ETV-susceptibility was compared across GSS levels of a potential optimized background regimen, consisting of two NRTIs and one PI.

Results: The overall prevalence of ETV-RAMs was 51.9\%(95\%CI:45.7-58.2) in patients failing on NNRTI $(n=257)$ and 9.6\%(8.5-10.7) in treatment-naïve patients $(n=3020)$. The prevalence of ETV-RAMs also associated with resistance to EFV/NVP (EFV/NVP-RAMs) was 39.5\% (33.5-45.8) for patients failing on NNRTI, but only $0.9 \%(0.3-1.9)$ for treatment-naïve patients. Estimates were almost identical for an analysis of 51 genotypic tests from treatment-naïve patients with documented recent $(<1$ year $)$ infection, who had acquired HIV before 1998. Prevalence was $9.8 \%(3.3-21.4)$ for ETV-RAMs and 0\%(0.0-7.0) for EFV/NVP RAMs. This suggests that mutations specific for ETV, but not for EFV/NVP, were already present before the wide-spread use of NNRTIs

Full resistance was rare $(5.4 \%, 2.6-8.2)$, but full susceptibility to ETV for patients failing on NNRTI was also only $30.2 \%(24.6-35.9)$. This percentage dropped to $17.3 \%$ (8.2-30.3) for patients with $<2$ fully active drugs in the optimized background regimen, which was significantly lower compared to patients with 2 or more active drugs in the background regimen $(33.2 \%, 27.1-39.9$, Fisher's exact $\mathrm{p}=0.028$ ).

Conclusions: The current IAS-USA list of ETV-mutations includes several polymorphisms already established before NNRTI introduction. Moreover, resistance-profiles of ETV and EFV/NVP may overlap to a higher degree than previously anticipated. Thus, the use of ETV in salvage treatment should be carefully evaluated. 


\section{$O S F / 3$}

\section{Does the addition of rPRT to GRT help in choosing regimens with better virologic response?}

Tracy Glass ${ }^{1}$, Jan Fehr ${ }^{2}$, Severine Louvel ${ }^{3,4}$, Jürg Böni ${ }^{5}$, Sabine Yerly ${ }^{6}$, Philippe Bürgisser ${ }^{7}$, Heiner Bucher ${ }^{1}$, Thomas Klimkait ${ }^{3}$

${ }^{1}$ Universitätsspital Basel, Clinical Epidemiology and Biostatistics, Basel, Switzerland, ${ }^{2}$ Universitätsspital Basel, Infektiologie und Spitalhygiene, Basel, Switzerland, ${ }^{3}$ InPheno AG, Basel, Switzerland, ${ }^{4}$ Universität Basel, Institut für medizin. Mikrobiologie, Basel, Switzerland, ${ }^{5}$ Swiss Reference Center of Retroviruses, Zürich, Switzerland, ${ }^{6}$ University Hospital Geneva, Division of Infectious Diseases Laboratory and Virology, Genf, Switzerland, ${ }^{7}$ Centre Hospitalier Universitaire Vaudois, Division of Immunology and Allergy, Lausanne, Switzerland

Backgro und: Resistance testing (RT) of HIV-1 is important for optimal patient management. Different methodologies of RT are available: genotypic resistance testing (GRT) and phenotypic resistance testing (PRT). The role of replicative PRT (rPRT) is not yet clearly defined. We hypothesize that after repeated treatment changes the information from highly sensitive rPRT provides valuable complementary information to GRT. If so the combination of GRT and rPRT would prove superior and translate into superior virologic response.

Methods: Individuals in the Swiss HIV Cohort Study (SHCS) who had RT performed between 2002 and 2006 were included in the analysis. Patients were followed over time assessing virologic success from the time of switching to a new cART regimen after the RT. Logistic regression models were utilized to test for an association between type of $\mathrm{RT}$ and virologic success (defined as either HIV-1 RNA $<50$ copies/mL or a $1.5 \log$ reduction in HIV-1 RNA).

Results : In total 1158 RT, 937 with GRT and 221 with GRT+rPRT were eligible for analysis. The majority of RT were done in patients with treatment failure (66.5\%). Overall virological success rates did not vary significantly by type of test ( $81.4 \%$ GRT, $85.1 \%$ GRT+rPRT). However, differences were found in success rates in the subset of 533 patients who had RT due to treatment failure and $>2$ previous cART regimens $(69.0 \%$ GRT, $79.6 \%$ GRT+rPRT). Univariable logistic regression models showed that salvage patients with GRT+rPRT were significantly more likely to have success on their follow-up regimen compared to those with GRT alone (Odds ratio (OR): 1.76, 95\% confidence interval (CI): 1.03-2.99). In multivariable analyses this association was no longer significant (OR: $1.61,95 \% \mathrm{CI}$ : 0.90-2.87).

Conclusions: In heavily pre-treated patients, the addition of rPRT to GRT may provide a benefit in choosing a regimen with a higher potential for virologic success.
OSG - New Treatment Options for the Long Run

\author{
26. Juni 2009 \\ 16.00-17.30 Uhr \\ Saal 1
}

$O S G / 1$

Targeting SEVI-mediated enhancement of virus infection to reduce sexual transmission of HIV-1

Ilona Hauber, Heinrich Hohenberg, Joachim Hauber

Heinrich-Pette-Institut, Hamburg, Germany

Background: The global HIV-1 epidemic is primarily driven by heterosexual transmission. Most new infections occur in developing countries, almost half of which are among women. Thus, the development of an efficient microbicide that acts to prevent infection during sexual intercourse would be of major benefit for slowing the global spread of HIV-1. However, current clinical development of such microbicides faces various technical challenges. For example, human semen contains large amounts of peptide fragments, derived from prostatic acidic phosphatase (PAP), that form beta-sheet-rich amyloid fibrils. Importantly, these fibrillar structures, termed semen-derived enhancer of virus infection (SEVI), capture HIV virions and direct them to target cells for subsequent membrane-fusion (Münch et al. 2007 Cell 131:1059-1071). Thus, SEVI is an important infectivity factor of HIV during sexual transmission and its action appears to be detrimental to the successful development of antiretroviral microbicides. Therefore, the inclusion of a SEVI inhibitor into an antiretroviral microbicide-based regimen may improve the potential of such a strategy to prevent sexual transmission of HIV.

Methods: In vitro analysis of a specific inhibitor to block SEVI-formation by photometric detection of fibrillogenesis and by an ultrathin sectioning technique in combination with transmission electron microscopy (TEM). Inhibitor analyses on SEVI-mediated enhancement of HIV1 infection using in vitro generated amyloid fibrils and human semen samples.

Results: We are able to identify a novel small-molecular weight drug that specifically targets SEVI for degradation. Furthermore, it is shown that this compound inhibits SEVI activity and abrogates semen-mediated enhancement of HIV-1 infection in absence of cellular toxicity.

Conclusion: Specific non-toxic SEVI inhibitors appear to be promising supplements of antiretroviral microbicides to reduce sexual transmission of HIV-1. 


\section{$O S G / 2$}

\section{Control of HIV by CCR5D32/D32 stem cell transplantation - an update}

Kristina Allers ${ }^{1}$, Gero Hütter ${ }^{2}$, Jörg Hofmann ${ }^{3}$, Christoph Loddenk emper ${ }^{4}$, Thomas Schneider ${ }^{1}$

${ }^{1}$ Charité, Campus Benjamin Franklin, Internal Medicine I, Department of Gastroenterology, Infectious Diseases and Rheumatology, Berlin, Germany, ${ }^{2}$ Charité, Campus Benjamin Franklin, Internal Medicine III, Department of Hematology, Oncology and Transfusion Medicine, Berlin, Germany,

${ }^{3}$ Charitè, Campus Mitte, Institute of Medical Virology, Berlin, Germany, ${ }^{4}$ Charité, Campus Benjamin Franklin, Research Center ImmunoSciences (RCIS), Berlin, Germany

Allogeneic stem cell transplantation of an HIV-1 infected patient suffering from an acute myeloid leukemia was performed using donor cells homozygous for CCR5D32. HIV1 RNA and proviral DNA remain undetectable since more than two years without ART (Hütter G et al. NEJM 2009 , 360:692-8). Ultra deep sequencing analysis of plasma HIV1 RNA revealed $2.9 \%$ of the total virus population as CXCR4- or dual-tropic HIV-1 variants before transplantation, and the frequency of X4-using viruses in infected cells could be higher (Verhofstede C et al. JAIDS 2009; 50: 126136.). CXCR4-expression levels on peripheral $\mathrm{T}$ cells and plas ma levels of CXCL12, which is known to be a competitive entry inhibitor of CXCR4-using HIV-1, remain comparable to non-infected and HIV-infected controls during the follow-up period. Consequently, long-lived host immune cells depict a potential source for re-seeding HIV-1 using CXCR4 for cell entry in our patient.

We determined the presence of long-lived host cells in different tissues after transplantation by chimerism analysis and by the detection of cellular CCR5-expression in flow cytometric analysis and in situ stainings. CCR5-expressing CD4+ T cells were not observed in peripheral blood and in upper and lower gastrointestinal tract, furthermore, no CCR5+ microglia cells were found in the brain. CCR5-expressing macrophages were absent in the periphery and in the upper gastrointestinal tract, but in rectal tissue we found long-lived macrophages of the host 159 days after transplantation.

The long life-span of monocytes/macrophages in the rectal tissue of our patient might identify intestinal macrophages as a crucial cellular reservoir for HIV-1 variants in patients on HIV-1 suppressive therapy. Our observations further suggest that CCR5-targeted treatment strategies can be successful even in the presence of treatment-unaffected cellular reservoirs like intestinal macrophages.

\section{OS G/3}

\section{Preclinical evaluation of VIR-576, a novel antiretroviral drug candidate blocking the HIV-1 gp41 fusion peptide}

Wolf-Georg Forssmann ${ }^{1}$, Knut Adermann ${ }^{2}$, Ludger Ständker ${ }^{1}$, Matthias Stoll ${ }^{1}, Y$ - -Han The $^{1}$, Frank Kirchhoff ${ }^{3}$, Jan Münch ${ }^{3}$, Reinhold Ernst Schmidt ${ }^{1}$

${ }^{1}$ Hannover Medical School, Clinic of Immunology and Rheumatology, Hannover, Germany, ${ }^{2}$ VIRO Pharmaceuticals GmbH \& Co. KG, Hannover, Germany, ${ }^{3}$ University Clinic Ulm, Institute of Virology, Ulm, Germany

Issue of research: A long-term research programme was initiated to identify peptides which circulate in blood and exhibit antiretroviral effects. Screening of complex peptide libraries derived from human blood filtrate for novel HIV-1 inhibitors in infectivity and replication assays identified several peptides blocking viral spread in vitro. One of them blocked all HIV-1 strains tested by a novel mode of action and without any toxic effects (Münch et al, Cell 129, 263-275, 2007).

Description: The peptide designated VIRIP (Virus Inhibitory Peptide) blocks HIV-1 entry by binding to the gp41 fusion peptide, thereby preventing its insertion into the cell membrane. Comprehensive functional and preclinical analyses of more than 600 VIRIP derivatives revealed VIR-576 to be adequate for clinical studies due to its EC values and stability in plasma. Safety pharmacology showed no side effects and toxicologic studies in mouse, rat, and monkey using high doses of continuous infusion of VIR-576 up to 28 days justified an application in humans.

Conclusions: Because of its unique mechanism, VIR-576 remains effective against viral strains that are resistant to other antiretroviral drugs. We conclude that administration of VIR-576 in humans will prevent viral replication in the same way as in vitro, i.e. HIV-1 will not be capable of entering into $\mathrm{CD} 4+$ target cells and the viral load will be decreased if sufficient plasma concentrations of VIR-576 could be achieved.

Next steps: A clinical phase 1/2 trial has been initiated applying VIR-576 as a continuous infusion of three doses calculated to be effective based on the EC values derived from the in vitro studies and the PK obtained in monkey and rat. The study is carried out with HIV-infected individuals exhibiting viral loads above 10.000 copies per $\mathrm{ml}$ and CD4+ cell counts over 350 per $\mu 1$, thus not yet under antiretroviral therapy.

\section{OS G/4}

\section{A neutralizing monoclonal antibody for HIV gene therapy}

Khalid Al-Shobal, Kimbel Janine ${ }^{1}$, Lisa Egerer ${ }^{1}$, Sebastian Newrzela ${ }^{1}$, Tobias Maetzig ${ }^{2}$, Axel Schambach ${ }^{2}$, Dorothee von Laer ${ }^{1}$

${ }^{1}$ Georg-Speyer-Haus, Applied Virology and Gene Therapy, Frankfurt am Main, Germany, ${ }^{2}$ Hannover Medical School, Hannover, Germany

Background: The neutralizing monoclonal antibody $2 \mathrm{~F} 5$ is directed against the membrane proximal external region of the HIV-1 gp41 and has a longer in vivo half-life than fusion inhibitory peptides. The antibody has been shown to be potent and broadly neutralizing. Genetic modification of cells to produce the antibody in vivo could avoid the need for repeated injections and lead to protection of the transduced as well as untransduced cells (bystander-effect). The bystander effect renders high transduction levels unnecessary, thereby lowering the probability of insertion mutagenesis. Attractive target cells for this approach are cells of the immune system as they migrate to lymph nodes to produce high levels of neutralizing antibody at the major sites of HIV replication.

Methodology: The heavy and the light chain of the 2F5 antibody were cloned into different retroviral vector backbones. Human $\mathrm{T}$ and $\mathrm{B}$ cell lines as well as primary murine $\mathrm{T}$ cells and hematopoietic stem cells were transduced and 
the amount of secreted 2F5 was measured using a T20-binding ELISA. Functionality of the produced antibody was examined in a single round infection as say with HIV pseudotyped lentiviral particles.

Results: After repopulation of Rag-1 deficient mice with the genetically modified primary cells 2 F5 production was detected in therapeutic concentrations in sera of the mice.

We could show that after retroviral gene transfer, 2F5 antibody was secreted by both $\mathrm{B}$ and $\mathrm{T}$ cells in vitro and in vivo. Further experiments are ongoing to compare different $2 \mathrm{~F} 5$ vector constructs for their effectiveness in co-expressing 2F5 heavy and light chain.

\section{OSH - Hidden Issues}

\author{
26. Juni 2009 \\ 16.00-17.30 Uhr \\ Saal 2
}

\section{OS H/ 1}

\section{AIDS und Immigranten aus ehemaliger Sowjetunion (ESU): erste Erkenntnisse über Wissen und Inanspruchnahme von AIDS - Beratungsangeboten in Deutschland}

Laura Kouznetsov ${ }^{1}$, Alexander Vasilevich Kuznetsov ${ }^{2}$, Thomas Ruzicka ${ }^{3}$, Stefan Zippel ${ }^{1}$

${ }^{1}$ Ludwig-Maximilians-Universität München, Psychosoziale AIDS-Beratungsstelle, Klinik und Poliklinik für Dermatologie und Allergologie, München, Germany, ${ }^{2}$ Ruprecht-Karls

Universität Heidelberg, Abteilung Klinische Sozialmedizin,

Berufs- und Umweltdermatologie, Heidelberg, Germany,

${ }^{3}$ Ludwig-Maximilians-Universität München, Klinik und

Poliklinik für Dermatologie und Allergologie, München, Germany

Hi nterg rund: ESU-Immigranten ( $>2$ Mill.) bilden eine der größten Zuwanderergruppen Deutschlands. Seit 2001 wird von hoher HIV-Prävalenz in ESU-Ländern berichtet, somit wird die HIV-Prävention in dieser Immigrantengruppe zur Herausforderung. Hier werden Ergebnisse von 2 Pilotstudien bezüglich Kenntnisstandes und Inanspruchnahme von AIDS-Beratungsangeboten von ESU-Immigranten in Deutschland präsentiert.

Methodik: 1205 ESU-Immigranten (16-65J.) und 448 Befragte der Kontrollgruppe (18-65J.) wurden über HIV/AIDS und AIDS-Beratungsstellen postalisch anonym in Bayern und München befragt. Zusätzlich wurden 344 Gesundheitsämter mit AIDS/STD-Beratungsangeboten sowie 142 AIDS-Hilfen/(-Beratungsstellen) bundesweit über die Versorgung von ESU-Immigranten (darunter auch HIV-Positiven) postalisch anonym befragt.

Resul tate: Rücklaufquote betrug: Immigranten $(38,1 \%)$, Kontrollgruppe $(80,4 \%)$, Gesundheitsämter $(47,4 \%)$, AIDS-Hilfen/(-Beratungsstellen) (46,5\%). Die ESU-Immigranten informierten sich über HIV/AIDS auf Russisch $(75,6 \%)$, Deutsch $(6,2 \%)$ und meist in Herkunftsländern $(70,7 \%)$. Weniger ESU-Immigranten $(17,9 \%)$ als Kontrollgruppe $(27,6 \%)$ haben über AIDS-Hilfen(-Beratungsstellen) gehört $(\mathrm{p}=0,001)$; davon entsprechend $3,9 \%$ und $2,6 \%$ wussten über ihre Aufgaben (\%/\%): Bevölkerungsaufklärung $(80,3 / 63,2)$, psychologische $(75 / 85,1)$ und soziale Hilfe/Beratung $(71,1 / 83,9)$.

114 von $230(49,6 \%)$ an der Befragung teilgenommenen Gesundheitsämtern/AIDS-Hilfen/(-Beratungsstellen) betreuten insgesamt 6410 ESU-Immigranten, darunter 415 HIV-Positiven, die meisten davon wurden in Nordrhein-Westfallen $(47,95 \%)$, Niedersachsen (18.6\%) und Bayern (13.3\%) betreut. Häufigste Gründe für das Aufsuchen dieser Einrichtungen von ESU-Immigranten waren: Testberatung (57,9\%), STD-Beratung $(50,9 \%)$, HIV-Prävention $(46,5 \%)$, alg. gesundheitliche Fragen $(45,6 \%)$. Die meist erwähnten Gründe zur NichtInanspruchnahme von AIDS-Beratungsangeboten waren Sprachbarriere, Unbekanntheit der Angebote, das Ausweichen der Klientel in die Großstädte. Mentalität der ESU-Immigranten erschwere die Arbeit mit dieser Immigrantengruppe.

Schlussfolgerungen: AIDS-Präventionsbotschaften erreichen die ESU-Immigranten kaum, das HIV/AIDS-Wissen stammt meistens aus Herkunftsländern. AIDS-Beratungsangeboten und entsprechende Einrichtungen in Deutschland sind unter ESU-Immigranten kaum bekannt und nur wenige ESU-Immigranten werden von den Einrichtungen betreut bzw. nehmen ihre Angebote in Anspruch. Die Sensibilisierung von ESU-Immigranten zum Thema HIV/AIDS kann zur höheren Inanspruchnahme der AIDS-Präventionsangeboten führen .

\section{$\mathrm{OSH} / 2$}

\section{What do men who have sex with men in Germany know about the most common sexually transmitted infections?

$$
\text { Ulrich Marcus, Axel J. Schmidt }
$$

Robert Koch-Institut, Infektionsepidemiologie, Berlin, Germany

Objectives: A high proportion of sexually transmitted infections (STI) in Germany are diagnosed in men who have sex with men (MSM). A survey on knowledge, attitudes and behaviour as to STI (KABaSTI-study) was conducted to identify potential new approaches to improve STI prevention for MSM.

Methods: A questionnaire including questions on knowledge about common STIs was administered as online $(\mathrm{n}=5,928)$ and print questionnaire $(\mathrm{n}=723)$ to MSM. Knowledge concerning frequency, severity, treatability, symptoms, and mode of transmission was analyzed.

Results: HIV, syphilis, gonorrhoea, the hepatitis viruses $\mathrm{A}, \mathrm{B}$, and $\mathrm{C}$, and genital herpes were known to $>90 \%$ of the respondents. Genital/anal warts $(82 \%)$ and Chlamydia infection $(65 \%)$ were the least known STI. Knowledge was associated with educational status, with the frequency of STI related information seeking, and with a history of previous STI. Severity ranking of STI was in the following order: HIV, HCV, HBV, syphilis, HAV, gonorrhoea, genital herpes, Chlamydia infection and genital warts. Most STI were rated slightly less severe by participants diagnosed with HIV, except hepatitis C. Oral intercourse was not identified as a mode of transmission for bacterial STI by $25-50 \%$ of participants. In terms of the risk for HIV, one in five participants rated insertive anal intercourse without ejaculation as less risky than with ejaculation.

Conclusions: General knowledge about STI is good, however there are knowledge gaps concerning association of HIV transmission with ejaculation and transmission of STI by oral intercourse. Lack of knowledge about oral transmission reflects diagnostic realities, since screening for asymptomatic pharyngeal and rectal STI is rarely offered to MSM in Germany. 


\section{Poster Session}

\section{Sozialwissenschaften \& Community Issues / Community-Fragen / Social Sciences \\ P100 (PW)}

\section{Internetgestützte Sexualkontakte und HIV - Infektions risiko}

\author{
Michael Bochow ${ }^{1}$, Axel J. Schmidt ${ }^{2}$
}

\begin{abstract}
${ }^{1}$ Wissenschaftszentrum Berlin für Sozialforschung, Forschungsgruppe Public Health, Berlin, Germany, ${ }^{2}$ Wissenschaftszentrum Berlin für Sozialforschung, Public Health, Berlin, Germany
\end{abstract}

Fragestell ung: Seit Ende der 1990er Jahre wird die Frage diskutiert, ob online angebahnte Sexualkontakte in weniger geschützter Form erfolgen als offline angebahnte. Das Projekt diente einer Überprüfung dieser Hypothese.

Methodik: Im Auftrag des Bundesministeriums für Gesundheit wurde im April 2006 auf jeweils vier Kontaktseiten für heterosexuelle Frauen und Männer bzw. für homosexuelle Männer Links zu einem anonym auszufüllenden Online-Fragebogen geschaltet. 5050 Fragebögen konnten ausgewertet werden. Vier Gruppen wurden entlang des berichteten Sexualverhaltens gebildet: Homosexuelle ( $\mathrm{n}=$ 3.863), bisexuelle $(n=554)$, heterosexuelle Männer $(n=$ 537), Frauen ( $\mathrm{n}=96$; ohne weitere Differenzierung).

Ergebnisse: Online gesucht aber keine/n Partner/in gefunden haben $18 \%$ der Frauen, $21 \%$ der homosexuellen, $24 \%$ der bisexuellen und $45 \%$ der heterosexuellen Männer. $17 \%$ der Frauen, 32\% der homosexuellen, 16\% der bisexuellen und $11 \%$ der heterosexuellen Männer gaben an, in den zwölf Monaten vor der Befragung mehr als fünf unterschiedliche Sexualpartner/innen gefunden zu haben.

Bezogen auf nicht positiv getestete Teilnehmer/innen bestehen nur geringe Unterschiede im Eingehen von sexuellen HIV-Infektionsrisiken: 27\% der Frauen, 29\% der homo-, $31 \%$ der bi- und 26\% der heterosexuellen Männer berichten über ungeschützten Anal- oder Vaginalverkehr mit Partner/innen mit unbekanntem oder diskordantem HIV-Serostatus. Die explizite Thematisierung des Serostatus vor ungeschütztem Vaginal- oder Antalverkehr wird von einer bedeutsamen Minderheit in allen vier Teilgruppen vernachlässigt.

Bei der großen Mehrheit aller männlichen Befragten (85\%) ist die Häufigkeit HIV-bezogenen Risikoverhaltens unabhängig davon, ob Sexualkontakte online oder offline angebahnt wurden. Homosexuelle Befragte mit vorwiegend oder ausschließlich online angebahnten Sexualkontakten konsumierten in den 12 Monaten vor der Befragung nicht häufiger Drogen und berichteten nicht häufiger hohe Partnerzahlen ( $>10$ pro Jahr), Infektionen mit Syphilis, Gonokokken oder Chlamydien oder eine HIV-Neudiagnose als andere.

Schl uss folgerung en: Internet-Dating ist bei homo-, biund heterosexuellen Männern kein unabhängiger Faktor für das Eingehen von HIV-Risikokontakten. Das Internet bietet allerdings besondere Möglichkeiten für die präventive Ansprache unterschiedlichster Gruppen: kostengünstig, unaufdringlich, aktuell und situationsbezogen.

\section{$P 101(P W)$}

Late and early presenters in the German KompNet Cohort - a comparison of sociodemographic variables

Ulrich Marcus ${ }^{1}$, Claudia Michalik ${ }^{2}$, Norbert Brockmeyer ${ }^{3,4}$, Verena Duglay ${ }^{5}$, Martin Zeitz ${ }^{6}$, Elke Lauenroth-Mai ${ }^{7}$, Martin Hower ${ }^{8}$, Stefan Reuter ${ }^{9}$, Jürgen Stellbrink 10, Ans gar Rieke ${ }^{11}$, Albrecht Ulmer ${ }^{12}$, Klaus Jansen $^{3}$

${ }^{1}$ Robert Koch-Institut, Infektionsepidemiologie, Berlin, Germany, ${ }^{2}$ Zentrum für Klinische Studien, Köln, Germany, ${ }^{3}$ Kompetenznetz HIV/AIDS, Bochum, Germany,

${ }^{4}$ Universitätsklinik Bochum, Bochum, Germany,

55. Institut für Medizinische Statistik, Informatik und Epidemiologie, Köln, Germany, ${ }^{6}$ Universitätsklinikum Benjamin Franklin, Berlin, Germany, ${ }^{7}$ Gemeinschaftspraxis

Turmstraße, Berlin, Germany, ${ }^{8}$ Klinikum Dortmund, Immundefektambulanz, Dortmund, Germany,

${ }^{9}$ Universitätsklinikum Düsseldorf, Düsseldorf, Germany,

${ }^{10}$ Gemeinschaftspraxis Grindelallee, Hamburg, Germany,

${ }^{11}$ Städtisches Krankenhaus Kemperhof, Koblenz, Germany, ${ }^{12}$ Praxis Schwabstrasse, Stuttgart, Germany

Background: Late presentation (CD4-cell-count $<200 / \mu 1$ ) of HIV-infected individuals to medical care is a major risk factor for unfavourable short- and long-term outcomes even with full availability of antiretroviral treatment. We analysed socio-demographic variables collected in the German KompNet Cohort to identify parameters which might help to target efforts to improve timely diagnosis of HIV.

Method: Patients were eligible for analysis if included ART-naïv in the cohort and if e-period between HIV-diagnosis and first documented CD4-cell-count was less than 3 years. We defined patients as early (CD4-count: $>350)$, medium (CD4-count:200-350) and late (CD4-count:<200) presenters.

Result: 990 participants were eligible for analysis. Their sociodemographic distributions regarding sex, age, risk of infection and origin equalled the distribution of the overall-cohort reasonably. The proportion of late, medium, and early presenters was $9 \%, 18 \%$ and $73 \%$ respectively. Comparing late and early presenters we could not observe any significant differences between males and females, individuals living in or outside of larger cities, regarding educational or professional status, partnership status, age $(<$ or $>35 y$ ), income, and region of origin - with exception of individuals coming from Subsahara-Africa, for whom a trend to later presentation could be observed. Concerning HIV transmission risk factor, MSM tended to present earlier, people from high prevalence countries presented later (borderline significant).

Delayed initiation of treatment after HIV diagnosis (treatment initiation>1 year after first CD4-count< 200) was observed in 36 of 126 late presenters $(29 \%)$. It was less frequent in MSM (OR=0.5,95\% CI:0.2-1.0), and more frequent in IDU (OR=25.4,95\%CI:3.0-212.2), more frequent in heavy drinkers ( $>4$ drinks/day) compared with light drinkers $(<2$ drinks/day) (OR=13.9,95\%CI:1.5- 
129.8), and more frequent in unemployed than employed individuals $(\mathrm{OR}=3.6,95 \% \mathrm{CI}: 1.5-8.4)$.

Conclusion: The analysis confirms published observations on late presentation of patients from high prevalence regions. Delayed treatment initiation after HIV diagnosis was associated with current and former substance abuse and unemployment.

\section{$P 102(P W)$}

\section{Support needs and access to services relating to sexual and reproductive health of people living with HIV/AIDS (PLWHA) in Switzerl and}

Sibylle Nideröst ${ }^{1}$, Daniel Gredig ${ }^{1}$, Christophe Roulin ${ }^{1}$, Martin Rickenbach ${ }^{2}$, the Swiss HIV Cohort Study and the Eurosupport Study Group

${ }^{1}$ University of Applied Sciences Northwestern Switzerland, School of Social Work, Institute for Integration and Participation, Olten, Switzerland, ${ }^{2}$ Swiss HIV Cohort Study Data Center, University Hospital, Lausanne, Switzerland

Background: Sexual and reproductive health (SRH) issues of PLWHA gain in attention. Little is known about their SRH-needs and their access to services relating to sexual and reproductive health. Therefore this contribution is going to ask:

1. Do PLWHA utilize services relating to SRH?

2. Do they wish more support in SRH-issues?

Method: For data collection, an anonymous, standardized, self-administered questionnaire was used. Sampling was based on the seven HIV outpatient clinics associated with the Swiss HIV Cohort Study. Data were analyzed by using descriptive statistics stratified by gender and sexual orientation.

Result: Eighty-eight\% ( $\mathrm{n}=295)$ of the 377 respondents have discussed at least once about SRH-issues with health care providers, mostly with HIV-physicians. About 22\% $(n=64)$ reported their general practitioner as the person with whom they have talked about these issues, $13 \%$ $(n=38)$ discussed their problems with the study nurse at the outpatient clinics. During HIV-consultation the HIV-protection behaviour and the prevention of STI issues have been more discussed than sexual problems or questions relating to child wish. Only $18 \%(n=53)$ reported that these discussions have been initiated by the health care providers. Twelve\% $(n=35)$ considered that their HIVphysician has paid insufficient attention to the discussion of SRH-issues. More than half of the respondents wish to have more support in questions concerning SRH, whereas sexual problems and sexual disfunctioning probably due to ART rank first $(62 \%, n=182)$. Also in prevention of STI and HIV, more support is required. Heterosexual men and women need more support in questions concerning child wish and pregnancy. One fifth $(n=59)$ wanted to get support in communication about sexuality with their partners.

Conclusion: SRH-issues should more often be discussed in medical consultation. Thereby it is important that the health-care-providers initiate the discussion and offer their clients a possibility to talk about their SRH-problems and needs.
$P 103(P W)$

\section{Gender differences in social support and mental heal th among HIV positive women and men living in Europe}

Christiana Nöstlinger ${ }^{1}$, Victoria Gordillo ${ }^{2}$, Erin Fekete ${ }^{3}$, Tom Platteau ${ }^{1}$, Eurosupport V Study Group

${ }^{1}$ Prins Leopold Institute of Tropical Medicine, Clinical Sciences, Antwerp, Belgium, ${ }^{2}$ University Complutense of Madrid, Department of Psychology, Madrid, Spain, ${ }^{3}$ University of Miami, Department of Psychology, Miami, United States

Background: Research confirms that social support is strongly associated with physical and psychological adjustment in persons living with HIV/AIDS. The goal of our study was to examine how social support explains psychological well-being in a sample of European PLHA, and how gender modified this association. The study was part of the European research project 'Eurosupport V' (funded by the European Commission) with the overall aim to improve sexual and reproductive health of PLHA.

Methods: In this cross-sectional study carried out in 13 European countries data were collected using an anonymous self-reported questionnaire. Validated scales assessed social support (SSI; Zimmerman, Emanuels-Zuurveen, \& Emmelkamp, 2000) and psychological well-being (DASS-21; Antony, Bieling, Cox, Enns, \& Swinson, 1998). Hierarchical multiple regressions were used to test interactions between social support from partners and family members and psychological well-being.

Results : 409 HIV positive women and men participated. Compared to men, women reported higher levels of stress $\mathrm{t}(407)=4.00, \mathrm{p}<.001$, depression $\mathrm{t}(407)=2.81, \mathrm{p}<.01$, anxiety $\mathrm{t}(407)=2.54, \mathrm{p}<.01($ scale $0-21)$, and lower levels of emotional support from both their families and partners $(t(407)=-2.15, p<.05$ for families and $t(407)=$ $2.27, \mathrm{p}<.05$ for partners; scale $0-5)$. No gender differences were found in the amount of instrumental support received. Results revealed that regardless of the source of support, men's mental well-being was more positively influenced by support than for women.

Discussion: In this clinical convenience sample, the impact of social support on psychological well-being differed between genders, particularly when coming from an intimate source of support, such as partner or family member. These findings illustrate the need to develop more gendersensitive psychosocial models for explaining health behaviour and well-being, as well as for integrating genderspecific approaches into professional psychosocial support and counselling. 


\section{$P 104(P W)$}

Optimierung einer zielgerichteten, subsidiären Einzelhilfe durch die Deutsche AIDS Stiftung (DAS) durch eine Vernetzung mit Daten aus dem Kompetenznetz HIV/AIDS

Matthias Stoll ${ }^{1}$, Volker Mertens ${ }^{2}$, Claudia Michalik ${ }^{3}$, Klaus Jansen ${ }^{4}$, Norbert Brockmeyer ${ }^{5}$, Hans Jäger ${ }^{6}$, Andreas Plettenberg 7 , Arend Moll ${ }^{8}$, Stephan Dupke ${ }^{9}$, Siegfried Köppe ${ }^{10}$, Reinhold E. Schmidt ${ }^{1}$, Kompetenznetz HIV/AIDS

${ }^{1}$ Medizinische Hochschule Hannover, Zentrum Innere Medizin, Klinik für Immunologie und Rheumatologie, Hannover, Germany, ${ }^{2}$ Deutsche AIDS Stiftung, Bonn, Germany, ${ }^{3}$ Universität zu Köln, Zentrum für Klinische Studien (ZKS), Köln, Germany, ${ }^{4}$ Kompetenznetz HIV/AIDS, Bochum, Germany, ${ }^{5}$ Ruhr-Universität Bochum, Klinik für Dermatologie und Allergologie, Bochum, Germany, ${ }^{6}$ Praxiszentrum Karlsplatz, München, Germany, ${ }^{7}$ Ifi-Institut,

AllgemeinesKrankenhaus St. Georg, Hamburg, Germany,

${ }^{8}$ Praxiszentrum Kaiserdamm, Berlin, Germany, ${ }^{9}$ Praxis Driesener Straße, Berlin, Germany, ${ }^{10}$ Gemeinschaftspraxis Mehringdamm, Berlin, Germany

Forschungsthema/Fragestellung: HIV-Infizierte (PLWHA) sind oft in vielfältiger Weise sozial benachteiligt und haben durch die HIV-Infektion ein zusätzliches Risiko in wirtschaftliche Notlagen zu geraten. Ein wesentliches Stiftungsziel der DAS ist die zielgerichtete und unbürokratische Unterstützung betroffener Einzelfälle. Deren Auswertung kann der Politik helfen, die soziale Absicherung von PLWHA zu optimieren, um weiterhin die Stiftungsmittel noch zielgerichteter in subsidiärer Weise rational allozieren zu können. Der Abgleich mit sozialwissenschaftlich ausgerichteten Datenerhebungen des Kompetenznetzes kann dabei helfen, soziale Missstände aufzuspüren. Die vorgestellte Analyse dient einer Konzeptprüfung, ob künftig DAS und Kompetenznetz ihre Daten in einheitlicher Weise darstellen oder - auf freiwilliger Basis - diese verknüpft analysieren sollten.

Beschreibung: Die DAS hat in 2007 Mittel in Höhe von $€ 1.881 .544$ bewilligt, davon etwas über $50 \%$ für 3.742 positiv beschiedene Einzelhilfsanträge, 4269 Personen betreffend. Kompetenznetzdaten $(\mathrm{n}=6.085)$ differenzieren stärker die soziale Situation, Ausbildung, Erwerbsstatus und ausführliche medizinische Befunde. Daten der DAS differenzieren genauer die Einkommensarten und charakterisieren die Notlage durch den Verwendungszweck der beantragten Unterstützung. Die von der DAS im Geschäftsbericht 2007 publizierten Daten wurden den sozialwissenschaftlich relevanten Basidatensätzen des Kompetenznetzwerks gegenübergestellt. Gleichartige Datensätze wurden verglichen und die Ergänzung bzw. Verknüpfung komplementärer Datensätze diskutiert. Unters chiede fanden sich zwischen beiden Kollektiven im Hinblick auf die Verteilung von Altersgruppen, Infektionsrisiken und Geschlechterverteilung. Ergebnisse zeigen die Abbildungen.

Schlussfolgerungen: Die Daten der Anträge der DAS stellen aus sozialwissenschaftlicher Sicht eine besonders wichtige und wertvolle Stichprobe aus der Gesamtheit der PLWHA dar. Die erste vergleichende Analyse mit dem Datenfundus des Kompetenznetzes ist hilfreich und bietet die Option für differenzierte sozialwissenschaftliche Analysen.
Nächste Schritte: DAS und Kompetenznetz arbeiten an einem Konzept, das wissenschaftlichen und datenschutzrechtlichen Gesichtspunkten genügt, um - für jeden Einzelfall individuell konsentiert - künftig ihre Datenbanken teilweise verknüpfen zu können. Auswertungen dieser Datenbank sollen über das Scientific Board Social Sciences des Kompetenznetzwerks koordiniert werden und stehen ausdrücklich auch interessierten externen Wissenschaftlern offen.
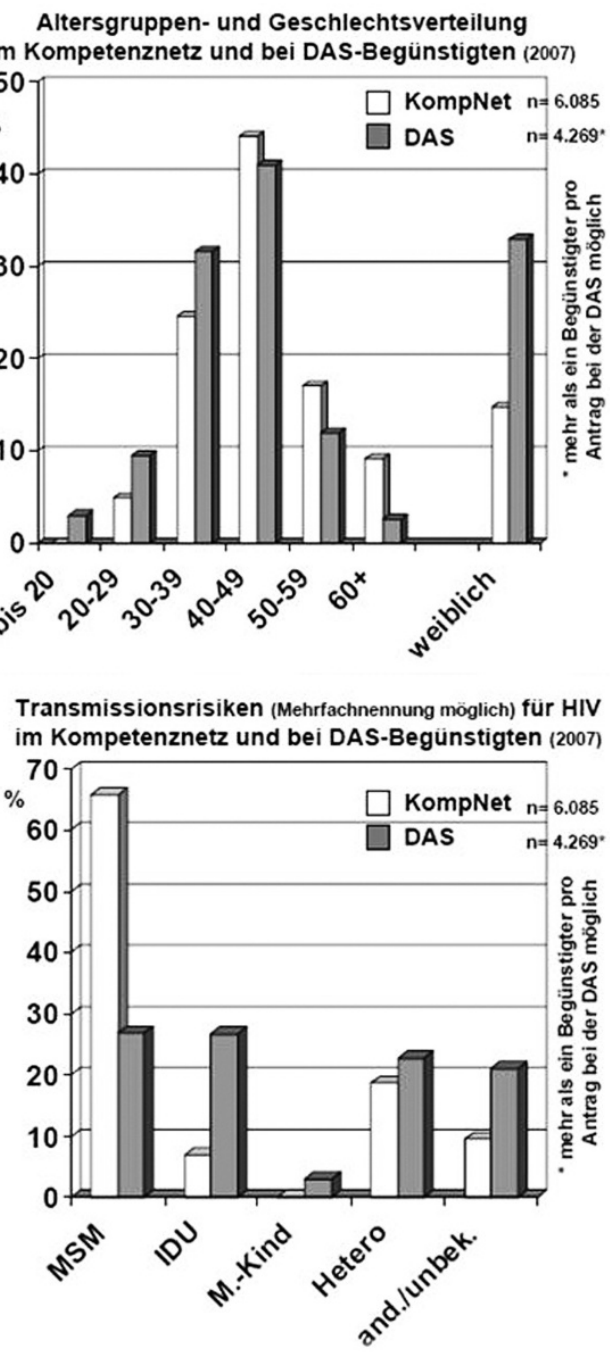

[Age,Gender,Risk]

Nationalitäten im Kompetenznetz und bei DAS-Begünstigten (2007)

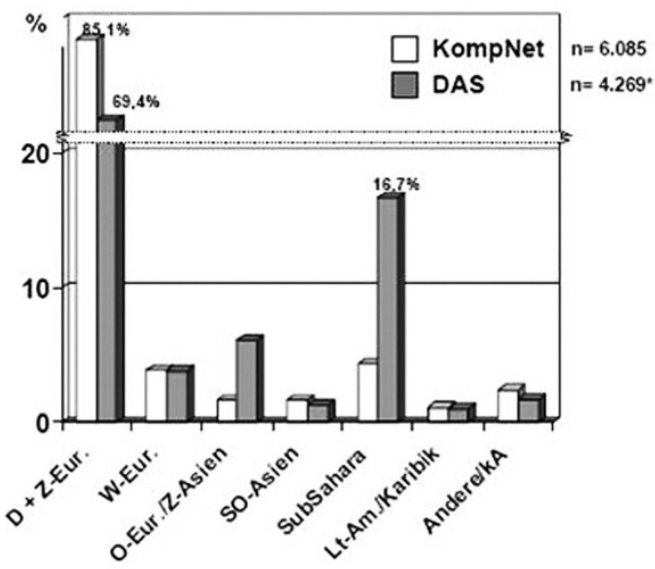


Angaben zum verfügbaren Einkommen (in $€ / M \circ$.) im Kompetenznetz

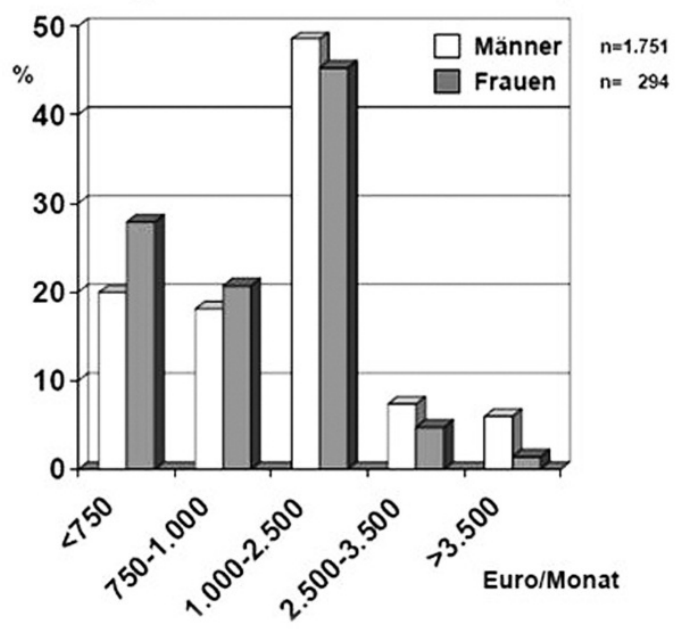

[Region,Income]

\section{P105 (PW)}

Perceived threat of HIV/AIDS and knowledge of highly active antiretroviral therapy (HAART) in heterosexual men and MSM in Germany

Ursula von Rueden

Bundeszentrale für gesundheitliche Aufklärung, Qualitätssicherung und Forschung, Köln, Germany

Background: Men who have sex with men (MSM) are most affected by new HIV infections in Germany. The aim is to investigate the perception of heterosexual men and MSM of HIV/AIDS as a threat, the knowledge of highly active antiretroviral therapy (HAART), as well as possible linkages.

Methods: Since 1987 the Federal Centre for Health Education in Germany (BZgA) is conducting annually nationwide the survey "Public Awareness of AIDS" among the general population over the age of 16 studying knowledge, attitudes towards HIV/AIDS, and protective behaviour. The multi-stage random sample (based on the ADM telephone sample system, random selection of persons in the household) is disproportionately stratified as regards age $(\mathrm{n}=7,000)$. The sample interviewed in 2008 includes 2.651 heterosexual men and 119 MSM between 16 and 65 years old.

Results: According to the higher prevalence and incidence of HIV MSM are more likely to be worried about the possibility to contract HIV (57\%) then heterosexual men (24\%). Whereas $34 \%$ of MSM consider it possible to face the risk of catching HIV when having sex, $11 \%$ of heterosexual men are concerned.

In the group of heterosexual men $30 \%$ know about HAART, in the group of MSM 58\% are informed about this treatment. Regarding the statement that current treatment methods make it possible that a HIV treated positive person is no longer transmitting the virus, 92\% of MSM and $90 \%$ of heterosexual men do not agree or don't know.

Both, heterosexual men and MSM who are better informed about the modern treatment methods are more likely to be worried about HIV infections and vice versa.

Conclusion: Better knowledge of HIV therapy may not lead to less worrying about HIV infection risks in MSM as well as in heterosexual men. Associated factors will be analysed.

\section{$P 106(P W)$}

\section{HIV-related travel restrictions}

DavidHans-U. Haerry ${ }^{1}$, Peter Wiessner ${ }^{1}$, Karl Lemmen ${ }^{2}$

${ }^{1}$ European AIDS Treatment Group, Brussels, Belgium,

${ }^{2}$ Deutsche AIDS-Hilfe e.V., Berlin, Germany

Background: Since the beginning of the HIV epidemic, people living with HIV have been denied entry into or deported from some countries because of their positive HIV status. Such laws restrict the entry or stay of HIV-positive people who seek to engage in tourism, business travel, employment abroad, labour migration, study, and immigration. They can also restrict the entry or stay of those who seek asylum. Governments have cited two reasons for such laws: to protect public health by preventing the spread of HIV, and to avoid potential costs of care, treatment and support associated with the stay of a PLWHA.

Methodology: The Deutsche AIDS-Hilfe (DAH) conducted 2 surveys at German embassies abroad and foreign embassies in Germany. The first survey was performed in 2000. Information was later completed by user feedback and from online resources. In 2007/2008, the DAH commissioned a second survey via embassies. UNAIDS provided additional data. The data is online at www.hivtravel.org. Results : 63 countries, territories and areas still impose restrictions on the entry, stay and residence of people living with HIV based on status. Restrictions take many and varied forms; and impact people who cross borders for short and long stays. 8 countries declare all people living with HIV inadmissible for any reason or length of time; additional 5 countries deny visas for short-term stays. 28 countries deport individuals once their HIV-positive status is discovered. 103 countries have no HIV-s pecific restrictions.

Conclusions: There is no evidence that HIV-related restrictions on entry, stay and residence protect public health. They may in fact impede efforts to protect public health. All mobile populations should benefit from access to evidence-informed HIV programmes as part of efforts to achieve universal access to HIV prevention, treatment, care and support and to implement effective responses to HIV.

$$
P 107 \text { (PW) }
$$

Chancen und Grenzen des Internet für eine erweiterte HIV/AIDS -Prävention, HIV - und STD-Beratung sowie Partizipation der Zi elgruppen

\section{Claudia Corsten}

Bundeszentrale für gesundheitliche Aufklärung, Referat Maßnahmen zur Aidsprävention, Köln, Germany

Die Nutzung des World Wide Web zur HIV/Aids-Prävention hat in den vergangenen Jahren stetig an Bedeutung gewonnen. Neben reinen Informationsangeboten entstanden komplexe Online-Beratungssysteme und interaktive Kommunikationsportale zum vielfältigen Themenfeld der HIV/Aidsprävention. Um durch die User wahr- und auch angenommen $\mathrm{zu}$ werden, müssen Onlineangebote ebenso zielgruppen-orientiert wie web-affin in der Aufbereitung 
ihrer Tools und Inhalte sein. Das Web 2.0 bietet dabei mit user generated content oder social networks gut nutzbare Wege für die Partizipation der Zielgruppen. Die für die nationale Aidspräventionskampagne in Deutschland zuständige Bundeszentrale für gesundheitliche Aufklärung (BZgA) nutzt deshalb heute das Internet umfassend als zentralen Kommunikations weg.

Das Kampagnenportal www.weltaidstag.de arbeitet mit den verschiedenen interaktiven Möglichkeiten: User können in den Austausch mit anderen treten. Veranstalter regionaler Aktionen finden ehrenamtliche Helfer und bewerben ihre Veranstaltungen. Virtuelle Schleifen werden von Usern in social networks hineingetragen und multiplizieren den Effekt der Gemeinschaftsaktion zum WeltAids-Tag in Deutschland. Insbesondere die Kooperation mit anderen hoch frequentierten Portalen wie z.B. studiVZ ermöglicht es der Kampagne, Zielgruppen weit über die altbewährten Medienkanäle hinaus zu erreichen. Das Kampagnenportal dient vorrangig der Aktivierung von Zielgruppen.

Auf Interaktion und Vernetzung setzt ebenfalls das im März 2009 neu veröffentlichte Portal www.machsmit.de. Hier stehen Informationen zu HIV/Aids, anderen STD und Safer Sex sowie die individuelle Auseinandersetzung mit dem eigenen Risikoverhalten im Vordergrund. Hierzu werden niedrigschwellige Tools und Möglichkeiten der Beteiligung angeboten.

Die Erfahrungen, welche die BZgA in der Entwicklung, Umsetzung und Administration dieser beiden Angebote gemacht hat, zeigen deutlich: Eine für Prävention und Aufklärung effektiv genutzte Internetseite ist längst nicht mehr nur ein Zusatzangebot, das man machen „muss", weil es eben dazu gehört. Klug aufgestellte Online-Portale können eine entscheidende Erweiterung und Bereicherung in der Zielgruppenansprache sein. Aufklärung, Beratung und Interaktion haben im Web 2.0 viele Möglichkeiten, die sinnvoll zu nutzen die Herausforderung von heute und der Zukunft sein wird.

\section{$P 108$ (PD)}

Keeping a grip on HIV: collaborative medication and symptom management experiences of persons living with HIV in Switzerland

Dunja Niccal,2, Jan Sven Fehr ${ }^{3}$, Pietro Vernazza ${ }^{4}$, Rebecca Spirig 5,6

${ }^{1}$ Infektiologie \& Spitalhygiene Kantonsspital St. Gallen, St. Gallen, Switzerland, ${ }^{2}$ Instiut für Pflegewissenschaft, Universität Basel, Basel, Switzerland, ${ }^{3}$ Klinik für Infektionskrankheiten \& Spitalhygiene, Zürich, Switzerland, ${ }^{4}$ Infektologie \& Spitalhygiene Kantonsspital St. Gallen, St. Gallen, Switzerland, ${ }^{5}$ Abteilung für klinische Pflegewissenschaft, Universitätsspital Basel, Basel, Switzerland, ${ }^{6}$ Institut für Pflegewissenschaft, Universität Basel, Basel, Switzerland

Background: For optimal health outcomes persons living with HIV (PLWH) need to manage medications and symptoms effectively on a daily bases. The purpose of this qualitative explorative study was to gain understanding on PLWH's symptom and medication management with a focus on their collaboration with close support persons and health care providers.

Methods: The study was rooted in critical hermeneutics. In depth interviews with PLWH from four different centres of the Swiss HIV Cohort study were conducted. Adult participants had to be on antiretroviral therapy and had to have a close support person. Data were analyzed and interpreted using the hermeneutic approach suggested by Diekelmann and Allen (1989).

Results: Findings reveal that already small changes in health and treatment could change participant's impression of having a grip on HIV or loosing it. To keep a grip, they constantly monitored their condition, built up expertise and particularly included health care providers and close support persons with diverse strategies into their management. The collaboration with health care providers revealed to either enable or hinder PLWH's management process.

Conclusions: Health care providers should recognize and support the sometimes hardly visible illness work of PLWH around medication and symptom management. PLWHs' impression of 'having a grip on HIV' appeared to be a phenomenon that could guide support interventions and should be further investigated.

\section{P109}

\section{Motivational patterns of HIV testing among} MS M: Implications for prevention

\section{Phil C. Langer ${ }^{1}$, Jochen Drewes ${ }^{2}$, Ursula von Rüden ${ }^{3}$}

${ }^{1}$ Ludwig-Maximilians-Universität München, Department Psychologie, München, Germany, ${ }^{2}$ Freie Universität Berlin, Arbeitsbereich Prävention und psychosoziale

Gesundheitsforschung, Berlin, Germany, ${ }^{3}$ Bundeszentrale für gesundheitliche Aufklärung, Köln, Germany

Background: Recent studies demonstrate the significant effects of undiagnosed HIV infections on the onward pandemic. HIV testing to reduce undiagnosed infections poses thus a constitutive tool for prevention. To enhance test behavior it is important to know the motivational patterns in the respective target groups. Amongst others the study "Positive Desire" aimed at identifying psychosocial factors that foster or hinder HIV test decision among MSM in Germany.

Methods: Based on Grounded Theory 58 semi-structured qualitative interviews with recently HIV-diagnosed MSM and untested MSM reporting sexual risk behavior were conducted between November 2006 and July 2007 on behalf of the Federal Centre for Health Education and the Competence Network HIV/AIDS. Following computer-based categorical content and discourse analyses, social psychological theories were applied to the data. The research process was escorted by a scientific board and psychologically supervised.

Results: Among those MSM who tested seropositive at a late stage of infection, e.g. with opportunistic infections, three main barriers for earlier testing were identified: lack of risk awareness, fear of the physical consequences of infection due to incorporated social representations of "old Aids", fear of stigmatizing implications of the disease. In contrast three main fostering factors were determined among those tested early for HIV: social support by friends to surge for testing, suggestion for testing by medical practitioners, sense of responsibility for sexual partners. They form motivational patterns to intercept a prevalent dynamic of retarding HIV tests despite of incoherent protective behaviour that is likely to contribute to the pandemic. 
Conclusion: The present study proves the importance of early testing as a tool of HIV prevention. Effective prevention strategies have to aim at promoting a state-of-the-art knowledge of HIV treatment, proactively offering HIV tests as part of regular medical check-ups of MSM, and reducing HIV-Stigma that still poses a major challenge to prevention.

\section{$P 110$}

\section{Gesundheits bezogene Lebens quali tät ( $Q$ oL) HIV-positiver Patienten in einer S chwerpunkt praxis}

Stefan Mauss, Julia Henke, Florian Berger, Petra Hegener, Guenther Schmutz

Center for HIV and Hepatogastroenterology, Duesseldorf, Germany

Hintergrund: Aufgrund verbesserter Therapiemöglichkeiten ist die HIV-Infektion eine mittlerweile gut behandelbare Erkrankung. Dennoch können die chronische Erkrankung und Toxizitäten der Langzeitbehandlung die Lebensqualität (QoL) der Patienten einschränken .

Methodik: Querschnittanalyse $(n=209)$ mit einem für HIV-Patienten validierten Selbstbeurteilungsfragebogen (Erfassung der Lebensqualität über 6 Skalen, SEL), Datenanalyse mit nichtparametrischen Tests .

Verwendete antiretrovirale Substanzen ( $>10$ Patienten) waren Lamivudin/Emtricitabin 152, Tenofovir 121, Abacavir 32, Zidovudin 30; NNRTIs: Efavirenz 50, Nevirapin 28; PIs: Lopinavir 31, Atazanavir 17, Saquinavir 12, Darunavir 11.

Resul tate: Das durchschnittliche Alter war 44 Jahre, 89\% waren männliche Probanden. Das CDC Stadium (1998) war A $44 \%$, B $32 \%$ und C 24\%. $80 \%$ der Probanden bekamen ART.

Es gab keinen Unterschied der Gesamt-QoL zwischen behandelten $(3.62 \pm 0.79)$ und unbehandelten Patienten (3.66 $\pm 0.80)(\mathrm{p}=0.78)$.

Alle Patienten beurteilten ihren köprperlichen Zustand (QoL-P) (3.73 \pm 0.85$)$ besser als den kognitive-emotionalen (QoL-CE) $(3.44 \pm 0.86)(\mathrm{p}<0.001)$, unabhängig davon, ob sie antiretroviral behandelt wurden. Es gab keinen Zusammenhang zwischen der CD4+-Zahl und der Lebensqualität.

Patienten mit CDC A berichteten in allen Bereichen bessere QoLals Patienten mit CDC B or CDC C $(\mathrm{p}<0.05)$.

Patienten mit NNRTIs hatten eine bessere QoL als mit PIs für QoL-P (3.91 \pm 0.79 vs. 3.58 \pm 0.87$)$, QoL-CE (3.65 \pm 0.83 vs. $3.31 \pm 0.89)$ und Gesamt-QoL $(3.80 \pm 0.81$ vs. $3.48 \pm 0.84)($ alle $p<0.05)$. Ein größerer Anteil Patienten mit fortgeschrittener HIV-Infektion wurde jedoch mit PIs behandelt als mit NNRTIs, CDC B 59\%/42\% and CDC C $56 \% / 40 \%(\mathrm{p}<0.05)$.

Die Gesamt-QoL der HIV+Patienten $(3.63 \pm 0.79)$ war schlechter als in der gesunden Normstichprobe (3.81 \pm $0.53)$, aber besser als in der HIV+Normstichprobe (3.51 \pm $0.62)$ aus den Neunzigerjahren. Verglichen mit den HIV+Patienten der Neunzigerjahre hatten behandelte und unbehandelte HIV+Patienten eine bessere Lebensqualität in allen Bereichen.

Schlussfolgerungen: HIV+Patienten beurteilen ihre Lebensqualität schlechter als gesunde Kontrollen, jedoch besser als die HIV+Patienten der Neunzigerjahre. Gegenüber HIV-Negativen ist die kognitiv-emotionale Leben- squalität unabhängig vom Gesundheitszustand beeinträchtigt. Dies legt nahe, dass trotz verbesserten physischen Befindens die HIV-Infektion zu emotionaler Beeinträchtigung führt.

\section{P111}

\section{Die gesellschaftliche Regierung der HIV - Infektion. Eine empi risch-geneal ogische S tudie \\ Katrina Pfundt}

Institut für Soziologie, Hamburg, Germany

Hinterg rund: Der gesellschaftliche Umgang mit der HIVInfektion wird nicht nur durch die Konstruktion der HIV-Infektion als Stigma, sondern gleichsam durch makropolitische Implikationen und Kräfteverhältnisse strukturiert, die das Informationsmanagement Infizierter wie auch die Verhaltensweisen und Reaktionen Nicht-Infizierter konstituieren.

Methodik: Die Zusammenführung empirisch-qualitativer Forschung mit dem von Foucault (2004) entwickelten Konzept der Gouvernementalität ermöglicht es über den Begriff der Regierung, Mikro- und Makroebene unter einer einheitlichen Perspektive zu untersuchen und entsprechend zu zeigen, wie soziale Strukturen subjektiv relevant werden.

Resultate: Der Umgang mit der Diagnose wird für Infizierte durch zwei Implikationen zu einer Aporie: der Angst vor Stigmatisierungen und der Technologie der „Geständnispraxis" (Foucault 1983; 1993), die dazu leitet, anderen die „Wahrheit" der Infektion zu enthüllen.

Das Informationsmanagement infizierter Frauen zeigt, wie sich diese alte christliche Praxis in biopolitische Belange eingeschrieben hat, ohne ihre Wirkungsmacht im Kontext relevanter Anderer einzubüßen. Mobilisiert durch die ,gesellschaftliche Lernstrategie" (Rosenbrock 2000), werden biopolitische Belange selbst- und fremdverantwortlich umgesetzt: Um die eigene Gesundheit präventiv zu sichern und den Schutz des Gegenüber vor einer Transmission aufzurufen, wird die HIV-Infektion - trotz Angst vor Stigmatisierungen - offen gelegt. Verschwiegen wird sie, um sich und die eigenen Kinder vor Stigmatisierungen und signifikante Andere vor emotionalen Belastungen zu schützen. Der Geständnisimperativ bleibt gleichwohl wirkungsmächtig und strukturiert die Suche nach konstruktiven Lösungen, die jedoch kaum gefunden werden.

Legen die Informantinnen die Infektion offen, so werden sie mit Unterstützung einerseits, Stigmatisierungen und Diskreditierungen andererseits konfrontiert. Beide Verhaltensweisen erhalten durch den jeweiligen Kontext (Medizin; Arbeit; signifikante Andere) ihre spezifische Formierung, auch wenn klassische Stigmatisierungspraktiken bereichsübergreifend auftreten .

Stigmatisierungen und Diskreditierungen begegnen die Informantinnen durch den Einsatz von Widerstandspraktiken, Hilflosigkeit und Korrekturverhalten, die gleichsam durch den Kontext strukturiert und konstituiert werden.

Schlussfolgerungen: Die Ergebnisse verdeutlichen, dass makropolitische Implikationen das Handeln strukturieren. Dies eröffnet die Chance, die Suche nach konstruktiven (politischen) Lösungen neu zu beginnen. 


\section{$P 112$}

Niedrigschwellige Beratung von HIVPatienten als interdiszi plinäre Kooperation zwischen Ärzten von Schwerpunktpraxen und psychosozialen Beratern einer Selbsthilfeorganisation

Leo Locher1,2, Gaby Knecht ${ }^{1}$, Imke Klein ${ }^{2}$, Michael Bohl2

${ }^{1}$ Infektiologikum Frankfurt/Main, Frankfurt am Main, Germany, ${ }^{2}$ AIDS-Hilfe Frankfurt e.V., Frankfurt am Main, Germany

Durch den Prozess der "Normalisierung" haben HIV und AIDS im letzten Jahrzehnt ein anderes Gesicht bekommen und dies insbesondere dank der Verfügbarkeit Antiretroviraler Kombinationstherapien. Die HIV-Infektion ist eine behandelbare, wenn auch nicht heilbare Krankheit geworden. Obwohl sich der frühere Zus ammenhang der HIV-Infektion mit dem baldigen und gewissen Tod für die HIV-Patienten entdramatisiert hat, bleibt bei ihnen die alte Bedeutung von AIDS virulent. Sowohl die Diagnose HIV-positiv als auch der Zeitpunkt der notwendigen ART-Initiierung, aber auch befürchtete oder nachweisbare Langzeitnebenwirkungen der ART werden von den meisten Patienten als bedrohlich erlebt; viele reagieren mit Angst, Rückzug, Depression, Perspektivlosigkeit, psychosomatischen Symptomen und nicht selten auch Adhärenzproblemen mit der ART.

Aus der Erfahrung, dass institutionelle und persönliche Barrieren einen zeitnahen Zugang zu psychosozialer Beratung für viele Patienten behindern, wurde von 2001-03 ein vom Institut für Sexualwissenschaft der Universitätsklinik Frankfurt am Main (Prof. Dr. Martin Dannecker) wissenschaftlich begleitetes Modellprojekt "Psychosoziale Begleitung von HIV-Patienten in zwei Frankfurter Schwerpunktpraxen" durchgeführt, dessen Kern die individuelle psychotherapeutische Beratung von HIV-Patienten direkt in den kooperierenden Praxen ist. In den beiden Praxen werden ca. 1800 Patienten mit HIV und AIDS kontinuierlich betreut.

Die positive Resonanz von Patienten und Behandlern führte dazu, dass das Projekt anschließend in Zusammenarbeit mit der AIDS-Hilfe Frankfurt weitergeführt wurde. Die häufigsten Beratungsanlässe waren Anpassungsstörungen (29\%), Depressionen \& Burnout-Syndrome (58\%), Angstsymptome ( $8 \%$ ) sowie Partnerschafts- und Sexualkonflikte (5\%).Im Jahr 2008 wurden insgesamt 116 Patienten (31 Frauen, 85 Männer) an 316 Terminen zu je 50 Min. beraten. Die durchschnittliche Anzahl der Gespräche belief sich auf 2,7.

38 Patienten wurde eine weiterführende Therapie beim Psychotherapeuten od. Psychiater empfohlen. 16 Patienten nahmen im Anschluss an weiteren Angeboten der AIDSHilfe Frankfurt teil.

Das Projekt könnte Modellcharakter haben für eine interdisziplinäre Kooperation zwischen naturwissenschaftlich medizinischer Betreuung einerseits und psychosozialer Begleitung andererseits.

\section{$P 113$}

\section{HIV -related vulnerability dynamics and syndemic productions in homosexual life contexts}

\author{
Phil C. Langerl, Angela Kühner ${ }^{1,2}$
}

${ }^{1}$ Ludwig-Maximilians-Universität München, Department Psychologie, München, Germany, ${ }^{2}$ Johann Wolfgang GoetheUniversität Frankfurt, Fachbereich für

Gesellschaftswissenschaften, Frankfurt, Germany

Background: Gay and bisexual men are exceptionally affected by the disease in all industrialized nations. Focusing on the social conditions of behavior the concept of 'structural prevention' presents an innovative reaction that has yet come under criticism in the context of a significantly rising number of HIV diagnoses. The study "Positive Desire" aimed at identifying the psychosocial dynamics that drive HIV risk behavior among MSM in Germany. Methods: Based on Grounded Theory 58 semi-structured qualitative interviews with recently HIV-diagnosed MSM and untested MSM reporting sexual risk behavior were conducted between November 2006 and July 2007. Following computer-based categorical content and discourse analyses, social psychological theories were applied to the data. The research process was escorted by a scientific board and psychologically supervised.

Results: The analyses reveal the degreee and multiple forms of stigmatization, discrimination, and physical violence MSM still experience today. They reflect severe coming-out problems, a sense of rejected social acceptance, and self-worth deficits and are correlated with high levels of depression, anxiety, and suicide susceptibility as well as high levels of substance/drug use. According to the Minority Stress Model the mental health burdens can be interpreted as result of these biographical experiences and the substance use as problematic strategy to cope with them. Both are interlinked with dispositions for sexual risktaking by spoiling a coherent identity. For sexuality constitutes a decisive part of gay and bisexual men's identities, identity conflicts are acted out through sexual risk behavior.

Conclusion: The present study proves the extensive influence of stigmatizing and discriminating experiences on risk behavior among MSM in Germany. They constitute vulnerability dynamics in which mental health burdens, drug use, and sexual risk taking synergistically fuel each other. HIV prevention thus has to expand its focus to the interconnection of these health-related problems and reemphasize its structural dimension.

\section{$P 114$}

\section{Die hausärztliche Betreuung HIV-Positiver aus Sicht der betroffenen Patienten}

\section{Heike Nestel, Burkhard Schappert, Michael Jansky, Ulrich Seifert}

Johannes Gutenberg-Universität, Allgemeinmedizin, Mainz, Germany

Hinterg rund: Die Fortschritte auf dem Gebiet der HIVTherapie haben dazu geführt, dass man in Deutschland die HIV-Infektion als eine "chronische Erkrankung" bezeichnen kann. Aufgrund dessen fällt dem Hausarzt eine wichtige 
Rolle bei der Betreuung HIV-Infizierter zu. Uns interessierte wie sich der HIV-infizierte Patient von seinem Hausarzt bezüglich seiner Infektion betreut fühlt .

Methodik: Ein selbst entwickelter, standardisierter Fragebogen diente als Erhebungsinstrument. Die Fragebögen wurden durch HIV-Spezialisten bzw. durch deren Personal den Patienten ausgehändigt. Die Teilnahme war freiwillig und anonym.

Resul tate: N=247 HIV-positive Patienten haben den Fragebogen ausgefüllt.

Davon standen $87,7 \%$ unter einer antiretroviralen Therapie.

$55,6 \%$ der Befragten fühlen sich durch ihren Hausarzt bezüglich ihrer HIV-Erkrankung "gut" bis "sehr gut" betreut, 17,9\% hingegen "mangelhaft" bis "ungenügend".

Von den Untersuchungsteilnehmern geben $60,3 \%$ an, dass sie mit dem Hausarzt keine Unterhaltung über den HIVTest und 68,8\% keine über die Übertragungswege des Virus geführt haben. Fast $80 \%$ ( genau 77,7\%) der HIV-Postiven kreuzten an, dass nie ein Gespräch mit ihrem Hausarzt über Safer-Sex-Praktiken stattgefunden hat.

"Wichtig" bis "sehr wichtig" ist für die Befragten, dass der Haus arzt:

- offen und ehrlich ist $(99,1 \%)$,

- vertraulich mit der Diagnose HIV umgeht $(97,9 \%)$,

- durch fachliches Wissen überzeugt $(97,4 \%)$,

- schnell und unkompliziert erreichbar ist (97\%),

- in der Lage ist, alle gesundheitlichen Probleme mit dem Patienten zu besprechen $(95,3 \%)$,

- sympathisch ist $(93,5 \%)$,

- das Umfeld des Patienten kennt $(72,1 \%)$

Über $90 \%$ der Patienten geben an, in der Hausarztpraxis keine Probleme an der Anmeldung, mit den Arzthelferinnen, bei der Blutabnahme und mit der Vertraulichkeit ihrer Daten zu haben.

Schlussfolgerung: Aufgrund des chronischen Charakters der HIV-Erkrankung kommt dem Hausarzt bei der Betreuung infizierter Patienten eine wichtige Rolle zu. Durch gezielte Fortbildung auf dem Gebiet HIV/AIDS sollte versucht werden, hausärztlich tätige Ärzte noch besser auf die Belange ihrer infizierten Patienten vorzubereiten.

\section{P115 (PD)}

\section{Der kleine Unterschied - Symptomerfahrung bei HIV-positiven Personen mit oder ohne Bezugs pers on}

Katharina Fierz ${ }^{1}$, Kimberly Moody ${ }^{2}$, Dunja Nicca ${ }^{3,4}$, Tracy Glass ${ }^{5}$, Manuel Battegay ${ }^{6}$, Rebecca Spirig 1,4

${ }^{1}$ Universitätsspital Basel, Klinische Pflegewissenschaft, Basel, Switzerland, ${ }^{2}$ University of Southern Maine, School of Nursing, Portland / ME, United States, ${ }^{3}$ Kantonsspital St.Gallen, St. Gallen, Switzerland, ${ }^{4}$ Universität Basel, Institut für Pflegewissenschaft, Basel, Switzerland, ${ }^{5}$ Universitätsspital Basel, Klinische Epidemiologie, Basel, Switzerland,

${ }^{6}$ Universitätsspital Basel, Departement Biomedizin, Basel, Switzerland

Hinterg rund: Die individuelle Erfahrung diverser Symptome und das soziale Umfeld spielen eine bedeutende Rolle im Umgang mit der HIV-Erkrankung .

Wir haben untersucht, ob sich Teilnehmende mit oder ohne nahe Bezugsperson in ihrer Symptomerfahrung unterscheiden.
Methoden: Zwischen 2003 und 2005 haben wir HIV-infizierte Personen mit oder ohne eine nahe stehende Person in diese multizenter-Querschnittsstudie eingeschlossen. Wir erfassten die Selbsteinschätzung der Teilnehmenden in Bezug auf 82 Symptome (Vorhandensein, Häufigkeit des Auftretens, Schweregrad, Belastung und Handhabbarkeit). Ergänzend erhoben wir Daten zu Lebensqualität, Sozialer Unterstützung / sozialem Netzwerk, sowie Depressivität und Ängstlichkeit. Personenbezogene Informationen wurden uns von der zentralen SHCS-Datenbank zur Verfügung gestellt.

Resul tate: 150 Personen wurden ohne, 122 Personen mit Bezugsperson in die Studie eingeschlossen. Die beiden Gruppen waren in Bezug auf die meisten demografischen und psychosozialen Parameter vergleichbar, und in beiden Gruppen schien die Krankheit gut behandelt (AIDS: 39\% (Einzelpersonen, E) vs 27\% (mit Bezugsperson Teilnehmende, mBT); RNA< 50: 83\% vs. 78\%. Teilnehmende mit Bezugsperson schätzten ihre soziale Unterstützung höher ein als Einzelpersonen. Der Median der Anzahl wahrgenommener Symptome im Lauf der Woche vor Ausfüllen des Fragebogens lag bei 17 (IQR:19) für Einzelpersonen und bei 16 (IQR:14) für mBT.

Für beide Gruppen waren Sorgen (57\% vs, 67\%) und fatigue (50\% vs. $57 \%$ ) (E vs.mBT) unter den 10 häufigsten Symptomen

Die Auftretenshäufigkeit von Symptomen war für beide Gruppen mit verminderter Lebensqualität und (nur für mBT) mit Depressivität korreliert; der Schweregrad mit verminderter Lebensqualität, erhöhter Ängstlichkeit und mehr sozialer Unterstützung für Einzelpersonen, mit besserer Rollenfunktion, vermehrter Depressivität und erhöhter RNA für mBT korreliert. Distress durch Symptome stand mit erhöhter Depressivität und Ängstlichkeit, weiblichem Geschlecht, und verminderter Lebensqualität für Einzelpersonen und mit Ängstlichkeit / Depressivität für mit Bezug sperson Teilnehmende in Zusammenhang.

Schlussfolgerungen: Symptome sind nach wie vor häufig auftretende und z.T. mit viel Leid verbundene Phänomene. Unsere Ergebnisse belegen die Wichtigkeit optimaler und differenzierter Symptomkontrolle.

\section{P116}

\section{Fortbildungsbedarf von Hausärzten im Bezug auf HIV/AIDS}

\section{Burkhard Schappert, Michael Jansky, Stefan Graafen}

Johannes Gutenberg-Universität, Allgemeinmedizin, Mainz, Germany

Hinterg rund: Statistisch gesehen kam im Jahre 2007 auf jeden Hausarzt in Deutschland durchschnittlich "ein" HIVPatient. Aufgrund dieser geringen Anzahl stellte sich für uns die Frage, ob und wenn ja welchen Fortbildungsbedarf Allgemeinmediziner im Bezug auf HIV sehen .

Methodik: Als Erhebungsinstrument diente ein selbst entwickelter Fragebogen, der an N=475 Hausärzte im näheren Einzugsgebiet der Universität Mainz per Post versandt wurde. Bei einer Rücklaufquote von $44 \%$ konnten $\mathrm{N}=200$ Fragebögen ausgewertet werden.

Resultate: Bei Allgemeinmedizinern besteht ein generelles Interesse an vermehrter Fortbildung im Bereich HIV/AIDS. Dieses steigt parallel mit der Anzahl der zu betreuenden HIV-Patienten an. Den Wunsch nach vermehrten 
Fachartikeln über HIV/AIDS äußern 61,5\% der Studienteilnehmer.

Themenbereiche in denen Allgemeinmediziner einen besonderen Fortbildungsbedarf sehen, sind die Postexpositionsprophylaxe und das Erkennen von Symptomen der Akuten HIV-Infektion.

Schlussfolgerungen: Da fast zwei Drittel der Befragten Artikel über HIV/AIDS in Fachzeitschriften bevorzugen, sollte diesem Fortbildungsinstrument, am besten auch im Rahmen von CME, verstärkt Rechnung getragen werden

Bei der Frage nach Fortbildungsinhalten nannten die Allgemeinmediziner an erster Stelle die „Postexpositionsprophylaxe". Dies könnte seinen Ursprung darin haben, dass dies ein in der hausärztlichen Praxis, wenn vielleicht auch ein seltener, aber durchaus ernstzunehmender Beratungsanlass ist. Möglicherweise steht hinter dem Wunsch nach diesem Fortbildungsinhalt aber auch ein Eigeninteresse des Arztes, zu seinem eigenen Schutze und zu dem seines Personals.

Etwa die Hälfte der HIV-Neu-Infektionen kommt während der „Akuten HIV-Infektion" zustande, daher lässt sich ermessen, welch große epidemiologische Bedeutung das Stellen der Erstdiagnose zu diesem Zeitpunkt hat. Hier kommt dem Hausarzt, der in der Regel für den Patienten die erste Anlaufstelle ist, eine wichtige Funktion zu. Anhand gezielter Fortbildung sollte er in die Lage versetzt werden, aufgrund der Anamnese des Expositionsrisikos und der klinischen Symptomatik die Verdachtsdiagnose zu stellen. Desweiteren sollten ihm Kenntnisse bezüglich der spezifischen Labortests (z.B. HIV-PCR, negativer HIV-AK-Test) und deren Interpretation vermittelt werden.

\section{$P 117$}

\section{Die Bedeutung von HIV in der hausärztlichen Praxis}

Burkhard Schappert, Michael Jansky, Stefan Graafen

Johannes Gutenberg-Universität, Allgemeinmedizin, Mainz, Germany

Hi ntergrund: In den kommenden Jahren wird die Anzahl HIV-positiver Menschen in Deutschland stetig steigen. Deshalb und aufgrund dieser bei uns ,chronischen Erkrankung" wird sich zukünftig der hierzulande tätige Hausarzt vermehrt mit dieser Problematik auseinandersetzen müssen. Wir wollten von den Allgemeinmedizinern wissen, welche Bedeutung HIV für sie selbst in ihrer Praxis hat.

Methodik: Als Erhebungsinstrument diente einer von den Autoren selbst entwickelter Fragebogen. Dieser wurde in einem Pretest-Verfahren evaluiert und anschließend N=475 allgemeinmedizinisch tätigen Ärzten im näheren Einzugsgebiet der Universität Mainz per Post zugesandt. Bei einer Rücklaufquote von $44 \%$ konnten so 200 Fragebögen ausgewertet werden.

Resultate: In der vorliegenden Untersuchung ( $\mathrm{N}=199)$ haben $64 \%$ der Hausärzte in den letzten 5 Jahren im Median „Zwei" HIV-postive Patienten in ihrer Praxis betreut. Wie die Allgemeinmediziner subjektiv ihr Wissen auf dem Gebiet HIV/AIDS einschätzen ist der nachstehenden Abbildung zu entnehmen.

$59,5 \%$ der Hausärzte haben bereits an einer Fortbildung über das Thema HIV / AIDS teilgenommen. Als Gründe für eine Nicht-Teilnahme an Fortbildungsveranstaltungen wer-
Wissen über HIV/AIDS von Hausärzten $(\mathrm{N}=188)$

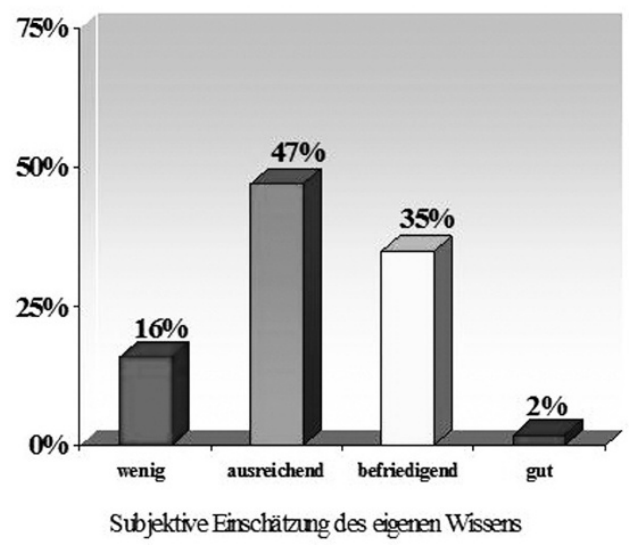

[Wissen von Hausärzten über HIV/AIDS]

den vor allem der nicht vorhandene Bedarf aufgrund geringer HIV-Patientenzahlen, der persönliche Zeitmangel und das geringe Angebot an geeigneten Fortbildungsveranstaltungen genannt.

Eine enge Zusammenarbeit mit einem HIV-Spezialisten pflegen 93,8\% der Studienteilnehmer. Diese Kooperation wurde im Median als befriedigend beurteilt.

Je besser die Zusammenarbeit mit einem HIV-Spezialisten vom Allgemeinmediziner eingeschätzt wird, desto geringer ist sein subjektiver Bedarf an Fortbildung in diesem Bereich.

Schlussfolgerungen: Zukünftig wird die Bedeutung von HIV/AIDS im hausärztlichen Sektor zunehmen. Um den Hausarzt auf diese Herausforderungen vorzubereiten, sollte man ihm ein solides Basis wissen bezüglich HIV/AIDS vermitteln. Entsprechende Fortbildungsangebote müssen konzipiert und dem Hausarzt zugänglich gemacht werden. Gleichzeitig sollte die Kooperation mit dem „HIV-Spezialisten" verbessert werden, da dies die Hausärzte entlastet und dem Patienten zu Gute kommt.

\section{P118}

\section{Ermittlung von Patientenpräferenzen bei der} Therapie von HIV/AIDS

Matthias Nübling ${ }^{1}$, Hans-Joachim Lincke ${ }^{1}$, Verena Donatz ${ }^{2}$, Axel Christian Mühlbacher ${ }^{1}$, Kompetenznetz. HIV

${ }^{1} \mathrm{GEB}$ mbH, Gesellschaft für Empirische Beratung, Freiburg, Germany, ${ }^{2}$ Janssen-Cilag GmbH, Health Economics \& Reimbursement Virology, Neuss, Germany

Forschungs thema/Fragestellung: Mit dem wachsenden Fokus auf das "Shared decision making (SDM)" Konzept wird es zunehmend wichtig, die Präferenzen der Betroffenen selbst zu berücksichtigen. Ziel dieser Studie ist es, die Therapiepräferenzen von Patienten mit HIV / AIDS zu ermitteln. Die zentrale Fragen lauten: „An Hand welcher Qualitätsmerkmale beurteilen HIV-Patienten medikamentöse Therapien?", „Welche Merkmale sind ihnen am wichtigsten?" und: „Gibt es für Subpopulationen unterschiedliche Präferenzstrukturen?".

Beschreibung: Die Studie ist mehrstufig aufgebaut (s. Abbildung). Ein qualitativer erster Teil beinhaltet die Literaturanalyse und die Durchführung von vier Fokusgruppen mit je 6-8 Patienten. Ziel ist die möglichst vollständige 
Sammlung der aus Patientensicht potenziell relevanten Qualitätsmerkmale einer HIV-Therapie (,,content validity").

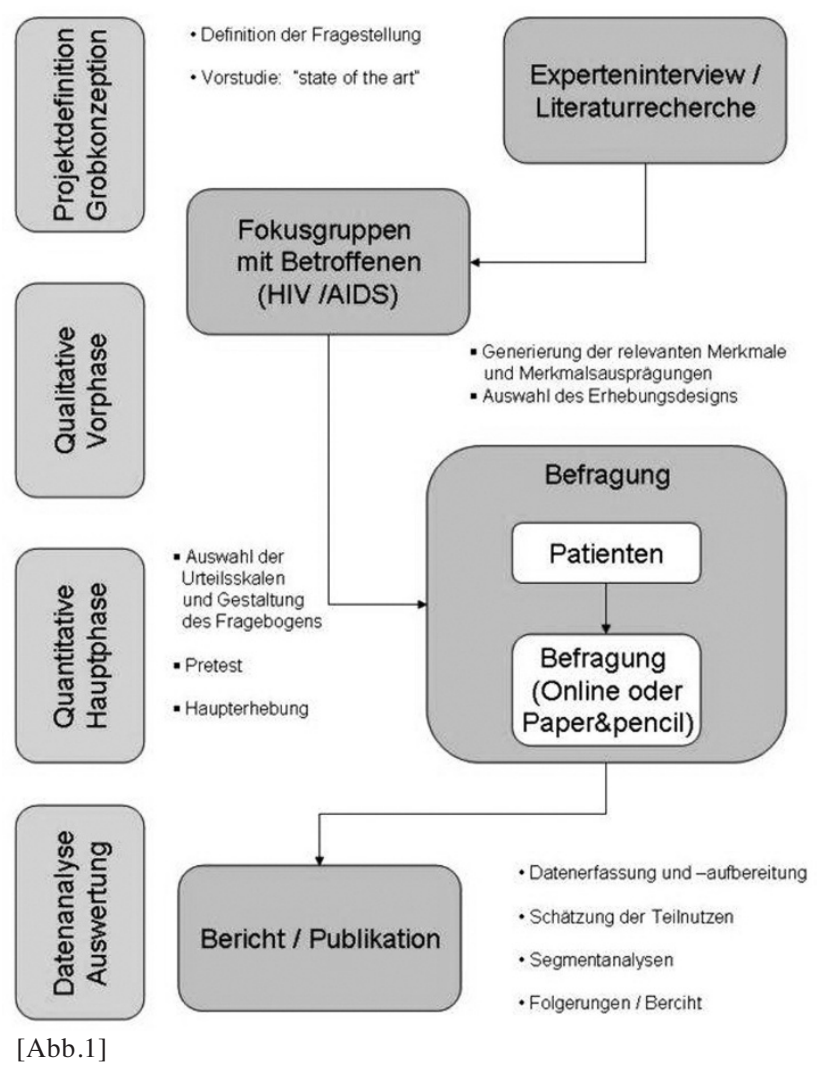

Die Ergebnisse münden in die Erstellung des Fragebogens für den quantitativen Studienteil. Themen sind soziodemographische Merkmale, Gesundheitszustand und als Kernstück die Messung der Patientenpräferenzen. Diese erfolgt zweistufig in direkter Abfrage (ca. 15-20 Items) und in Wahlentscheidungen eines Discrete Choice Experiment (DCE, 6-8 Therapieeigenschaften, 8 Paare).

Die Rekrutierung der Patienten erfolgt über das Kompetenznetz HIV und HIV-Selbsthilfeorganisationen. Zielgröße sind 250-300 Personen.

Schlussfolgerungen - nächste Schritte: Die bisher abgeschlossene Literaturanalyse und erste Eindrücke aus den Fokusgruppen zeigen, dass Patienten in: Wirksamkeit, Art und Intensität der unerwünschten Wirkungen, Handhabbarkeit im Alltag, Darreichungsform sowie emotionaler und sozialer Lebensqualität wichtige Qualitäts merkmale für die Bewertung medikamentöser Therapien sehen .

Eine vollständige Abfrage und Gewichtung dieser Faktoren nach ihrer patientenbezogenen Relevanz wird in der quantitativen Hauptstudie erfolgen.

Zu vermuten steht zudem, dass sich die Präferenzstruktur in Untergruppen unterscheiden wird (z.B. HIV-Infizierte ohne Symptome vs an AIDS Erkrankte), dies wird in Varianzanalysen (direkte Präferenzen) und in der Prüfung von unterschiedlichen Präferenzmodellen für Subgruppen analysiert.
P119

\section{Lebensqualität von HIV/AIDS Patienten und Patientinnen}

Daniela Fuchs

Allgemeines Krankenhaus, Dermatologie, Linz, Austria

Fragestellungen: Gibt es einen Unterschied in der Lebensqualität, der Depressivität, der Ängstlichkeit und der Kontrollüberzeugung in Abhängigkeit vom Geschlecht und dem HIV Status und können soziodemographische, medizinische und psychologische Variablen die Lebensqaualtiät von HIV/Aids PatientInnen vorhersagen?

Methode: Die Lebensqualität wurde mittels WHOQOL-100 (2000), Depressivität mittels Beck-Depressionsinventar II (2006), Ängstlichkeit mittels State-Trait-Angstinventar (1970) und die Kontrollüberzeug ung mittels KKG (Kontrollüberzeugung zu Krankheit und Gesundheit, 1989) gemessen.Die Stichprobe setzt sich aus 106 HIV PatientInnen (56 Männer, 50 Frauen) aus dem AKH Linz und 111 Personen (60 Männer, 51 Frauen) einer gesunden Kontrollgruppe zusammen.

Ergebnisse: Je jünger die Person, desto höher ist die Unabhängigkeit und desto besser sind tendenziell ihre sozialen Beziehungen. HIV positive Personen weisen in allen Bereichen eine niedrigere Lebensqualität auf als die Kontrollgruppe $\left(\mathrm{F}_{7,206}=19.307 ; \mathrm{p}=.000\right)$. Männer zeigen eine höhere Lebensqualität in der Domäne psychisch $\left(\mathrm{F}_{1,215}=6.850 ; \mathrm{p}=.010\right)$. HIV positive Personen zeigen in der Depressivität höhere Werte als die Kontrollgruppe $\left(F_{1,215}=33.512 ; p=.000\right)$. Es wurden keine Unterschiede zwischen Männern und Frauen gefunden. Je jünger die Untersuchungsperson, desto tendenziell ängstlicher ist sie. HIV positive Personen sind ängstlicher als die Kontrollgruppe $\left(\mathrm{F}_{1,215}=22.267 ; \mathrm{p}=.000\right)$. Es konnte kein Unterschied in Abhängigkeit vom Geschlecht festgestellt werden. Im Bereich der Kontrollüberzeugung zeigt sich, je jünger die Personen, desto höher ist die Internalität. Es gibt keinen Unterschied im Haupteffekt Geschlecht. HIV PatientInnen zeigen tendenziell niedrigere Internalität $\left(\mathrm{F}_{1,215}=3.212 ; \mathrm{p}=.075\right)$, höhere soziale Externalität $\left(\mathrm{F}_{1,215}\right.$ $=6.494 ; \mathrm{p}=.012)$, sowie tendenziell höhere fatalistische Externalität $\left(\mathrm{F}_{1,215}=3.195 ; \mathrm{p}=.075\right)$. Die Lebensqualität der PatientInnen kann durch die Prädiktoren Ängstlichkeit, allgemeine medizinische Beschwerden und Depressivität vorhergesagt werden $\left(\mathrm{F}_{3,92}=34.777 ; \mathrm{p}=.000 ; \mathrm{R}=.729\right.$, $\left.\mathrm{R}_{-}=.531\right)$. Je weniger ängstlich HIV PatientInnen sind, je weniger allgemeine medizinische Beschwerden und je niedriger die Depressivität, desto höher die Lebensqualität. Conclusion: HIV positive Personen haben eine niedrigere Lebensqualität, höhere Depressivität und Ängstlichkeit als die Kontrollgruppe. Überraschenderweise zeigte sich, dass je jünger die Person ist, desto ängstlicher ist sie und desto höher ist ihre Internalität. Daraus könnten sich weiterführende Fragestellungen ableiten. 


\section{P120}

\section{HIV und AIDS und Arbeit/Beschäftigung - Situation HIV-positiver Frauen in Deutschland}

Gaby Wirz ${ }^{1}$, Ulrike Sonnenberg-Schwan ${ }^{2}$, Harriet Langanke ${ }^{3}$, Dag mar Klimesch ${ }^{4}$, Netzwerk Frauen und Aids Deutschland

${ }^{1}$ Aids-Hilfe Baden-Württemberg e. V., Geschäftsführung, Stuttgart, Germany, ${ }^{2}$ Sektion AAWS der DAIG, München, Germany, ${ }^{3}$ Gemeinnützige Stiftung Sexualität und Gesundheit, Köln, Germany, ${ }^{4}$ Aids-Hilfe Baden-Württemberg e. V ., Stuttgart, Germany

Fragestellung: Regelmäßige Berichte zur problematischen sozioökonomischen Lage veranlassten das Netzwerk Frauen \& Aids, sich intensiv mit dem Thema „HIV/Aids und Arbeit/Beschäftigung" zu befassen.

Methodik: Ein einfach formulierter zweiseitiger Fragebogen für Frauen mit HIV/Aids zu Schul- und Berufsausbildung, Beschäftigungssituation, Einkommen und möglichen Problembereichen sollte auch Frauen mit fehlender Schulausbildung und Migrantinnen die Teilnahme ermöglichen. Er wurde über das Netzwerk, Beratungsstellen und ÄrztInnen verteilt und war im Internet verfügbar.

Ergebnisse: Von Juli 2007 bis November 2008 wurden 84 gültige Fragebogen eingesendet. Rund $70 \%$ der Befragten hatten Kontakt zu Aids-Hilfen. Alterstruktur: bis 25 Jahre 8\%, 26 - 45 Jahre 36\%, 46-55 Jahre 15,5\%, älter als 55 Jahre $12 \%$. Mittlere bis hohe Bildungsabschlüsse waren häufig: Realschulabschluss 34,5\%, Fach-/Hochschulreife 40,5\%; Hauptschulabschluss $15,5 \%$. Eine abgeschlossene Berufsausbildung hatten 57\%, einen Fach-/Hochschulabschluss $17 \%$. Ohne Schulabschluss waren $6 \%$, ohne Berufsausbildung $12 \%$.

$23 \%$ der Frauen gingen einer Vollzeit- und 13\% einer Teilzeitbeschäftigung nach, $15 \%$ waren geringfügig beschäftigt, je $31 \%$ davon zusätzlich zu einer Erwerbsunfähigkeits- bzw. Erwerbsminderungs-Rente. Insgesamt waren $40 \%$ der Teilnehmerinnen berentet (davon $55 \%$ EURente, 36\% EM-Rente und 9\% Altersrente). 54\% der Frauen bestritten ihren Lebensunterhalt mit weniger als $1.000 €$. Ca. $25 \%$ der Frauen hatte Kinder, $50 \%$ von ihnen war allein erziehend.

Im Vordergrund der Belastungen standen „Verschweigen der HIV-Infektion am Arbeitsplatz" (45\%) und „eingeschränkte Leistungsfähigkeit" (35\%) sowie Probleme mit der sozialen/finanziellen Absicherung (25\%) und Erfahrungen mit Diskriminierung und Ausgrenzung wegen der HIVInfektion (17\%). $11 \%$ der Befragten berichteten von Schwierigkeiten oder diskriminierenden Erfahrungen in der Beratung bei Arbeitsverwaltung, Kranken- und Rentenversicherungen.

Schlussfolgerungen: Trotz überwiegend guter schulischer Ausbildung ist die schlechte Beschäftigungslage und finanzielle Situation der Befragten auffällig. Wenige Frauen können am Arbeitsplatz über die HIV-Infektion sprechen. Reale oder befürchtete Diskriminierungen, bedingt durch fehlendes Wissen, führen zum Verschweigen im Arbeitsumfeld und beeinträchtigen die Beratungsqualität rund um Arbeitsvermittlung, Rehabilitation oder Rente. Intensive Antidiskriminierungs- und Aufklärungsarbeit ist notwendig.
P121

\section{Spiritual and mind-body beliefs as barriers and motivators to HIV-treatment decision- making and medication adherence?}

\author{
Heidemarie Kremer, Gail Ironson, Martina Porr \\ University of Miami, Department of Psychology, Coral \\ Gables, United States
}

Objectives and method: We examined spiritual/mindbody beliefs related to treatment decision-making and adherence in 79 HIV-positive people (35\% female, $41 \%$ African American, 22\% Latino, 24\% White) who had been offered antiretroviral treatment by their physicians. Interviews (performed in 2003) identified spiritual/mind-body beliefs; the ACTG questionnaire assessed adherence and symptoms/side-effects.

Resul ts : Decision-making was influenced by health-related spiritual beliefs (e.g., calling on God/Higher Power for help/protection, God/Higher Power controls health) and mind-body beliefs (e.g., mind controls body, body tells when medication is needed). Participants believing God/Higher Power controls health were 4.75 times more likely to refuse, and participants with mind-body beliefs related to decision-making were 5.31 times more likely to defer antiretrovirals than those without those beliefs. Participants believing spirituality helps coping with side-effects reported significantly better adherence and fewer symptoms/side-effects. Fewer symptoms/side-effects were significantly associated with the beliefs mind controls body, calling on God/Higher Power for help/protection, and spirituality helps adherence.

Conclusions: Spiritual/mind-body beliefs as barriers or motivators to taking or adhering to treatment are important, since they may affect survival and quality of life of HIV-positive people.

\section{$P 122$}

Beyond being not wanting to be a guinea pig: barriers and motivators to participation of minority women in clinical trials

Heidemarie Kremer ${ }^{1}$, Gail Ironson ${ }^{1}$, Martina Porr ${ }^{1,2}$

${ }^{1}$ University of Miami, Department of Psychology, Coral Gables, United States, ${ }^{2}$ University of Tuebingen, Department of Psychology, Tuebingen, Germany

Significance: The HIV epidemic disproportionately affects minority women of lower socio-economic background that are underrepresented in clinical trials. Even antiretroviral licensing agencies require enhanced enrollment of minority women in clinical trials. There is growing need for qualitative research why minority women fail to enroll in clinical trials. Yet, there is a worrying paucity on studies focusing on these hard-to-enroll patients. Barriers to enrollment that need to be identified may be patient-related, protocol-related, and physician-related.

Objectives: This qualitative study will try to fill this gap and will identify the barriers and motivators of minority women living with HIV to enroll in clinical trials. This study will also address the barriers and motivators of HIV-treating physicians to propose clinical trial participation to minority women.

Methods: Qualitative content analysis of interviews with $\mathrm{HIV}+$ minority women who have been offered participation 
in a clinical trial (targeted $\mathrm{N}=100$ ) and their study-physicians/coordinators (targeted $\mathrm{N}=15$ ) will be used to: identify barriers and motivators to participation in clinical trials from the perspective of the ethnic minority woman as it relates to patient, physician, and protocol issues; identify the barriers and motivators from the perspective of HIVtreating physicians to enroll ethnic minority women in clinical trials; and assess the criteria of HIV-treating physicians to offer or not to offer ethnic minority women participation in clinical trials.

Results: The first findings of this study will be presented at the conference.

Discussion: The results should aid researchers in clinical trials to develop strategies to maximize participation of hard-to-enroll populations in HIV clinical trials and enable them to meet the licensing criteria for new antiretroviral agents. We will discuss new aspects how to facilitate participation of those hard-to enroll populations and critically review the current criteria of HIV-treating physicians to exclude certain minority women from participation in clinical trials.

\section{$P 123$}

\section{Coping-Prozesse bei HIV/AIDS-Patienten aus der Perspektive westlicher und buddhis tischer Psychologie}

\section{Carsten Klöpfer}

Universität zu Köln, Psychologisches Institut, Köln, Germany

Hintergrund: Trotz massiver Fortschritte in der medizinischen Wissenschaft verweist das Phänomen HIV/Aids noch immer den Menschen - unabhängig von seinem kulturellen Hintergrund - in seine Schranken und konfrontiert ihn mit sich selbst, mit seiner Ohnmacht und Endlichkeit. Damit ist nicht nur die bisher fehlende Heilungsmöglichkeit gemeint, sondern der individuelle und soziale Verarbeitungsprozess einer Erkrankung, die jeden von uns treffen kann .

Methodik: Im Fokus dieser qualitativ-psychologischen Dissertation steht die Transkulturelle bzw. Ethnopsychologie (z.B. Quekelberghe 1991, Colombo 2000, Thomas 2003). Um aus der subjektiven Sichtweise der Betroffenen und Akteure Aufschlüsse zu erhalten, wurden in den Jahren 2002-2008 56 halbstrukturierte problemzentrierte Experteninterviews (nach Witzel 1985) in asiatischen und europäischen Ländern durchgeführt. Die Auswahl der Interviewpartner erfolgte mit Hilfe des „Theoretical Sampling" (nach Strauss \& Corbin 1995), die Auswertung unter zu Hilfenahme der "Grounded Theory" (nach Glaser \& Strauss 1967, 2005).

Resul tate: Das Trauma HIV-positiv ist bestimmt durch die Bedrohung der körperlichen, sozialen und psychosexuellen Existenz und bringt gravierende Änderungen in fast allen Lebensbereichen mit sich. Coping, was sinngemäß die Summe der Bewältigungsmechanismen zur Verarbeitung traumatischer Lebensereignisse bedeutet, beschreibt einen Prozess von Anpassungsvorgängen, die eine Modifikation der hierarchischen Struktur des Selbst- und Beziehungskonzeptes erfordert.

Schlussfolgerungen: Diese psychische Dynamik lässt sich aus der Sicht westlicher Psychologie durch spezifische Einflussfaktoren der Bewältigung einer HIV-Infektion beschreiben (z.B. Stress, Soziale Unterstützung, Optimis- mus, HIV-Masterstatus). Alternativ hierzu verfolgt die buddhistische Psychologie, die als unabdingbare Voraussetzung der inneren Balance die Auseinandersetzung des Individuums mit sich selbst und den unvermeidlichen Gesetzen des Lebens wie Krankheit und Tod betont, die Auflösung innerpsychischer Abhängigkeiten und damit das Verlöschen des Leidens. Stellt man aber einen interkulturellen Vergleich der Schlussfolgerungen des Umgangs mit einer HIV-Infektion an, so wird deutlich, dass die spezifischen Faktoren, die das Fortschreiten der Krankheit möglichst lange hinauszögern oder gar verhindern sollen, im Wesentlichen identisch sind.

\section{$P 124$}

Preparing for the long run - Ein

Wochenendseminar über HIV Therapie und Prävention für internationale Ärzte der nächsten Generation

Tessa S. Lennemann ${ }^{1}$, Rose Marie Beck ${ }^{2}$, Christoph Königs ${ }^{3}$, Holger Pfister ${ }^{4}$, Gabriele Nisius ${ }^{1}$, Mira Gruber $^{1}$, Lena Kroeker ${ }^{5}$, Reinhard Brodt ${ }^{6}$

${ }^{1}$ Klinikum der Goethe Universität, HIVCENTER, Frankfurt am Main, Germany, ${ }^{2}$ Goethe Universität Frankfurt, Institut für Afrikanische Sprachwissenschaften, Frankfurt am Main, Germany, ${ }^{3}$ Klinikum der Gothe Universität, Mol Hemostasis and Immunodeficiency, Department for Pediatrics, Frankfurt am Main, Germany, ${ }^{4}$ www.hiv-facts.net, Frankfurt, Germany, ${ }^{5}$ Bayreuth International Graduate School of African Studies,

Bayreuth, Germany, ${ }^{6}$ Klinikum der Goethe Universität, Infektiologie, Frankfurt am Main, Germany

Hinterg rund: Die wachsenden Möglichkeiten der HIV Therapie mit einem immer älter werdenden Patientenkollektiv bei fehlender Heilung sowie der zunehmende Zugang zu HIV Therapie in Entwicklungsländern machen HIV/AIDS zu einem wichtigen Thema in der Ausbildung der nächsten Generation von Ärzten weltweit. Unabhängig von ihrer Spezialisierung spielen Ärzte oft eine entscheidende Rolle im stigmafreien and professionellen Umgang mit der Infektion und müs sen hierauf vorbereitet werden.

Methodik: In Zusammenarbeit mit der Universität Frankfurt am Main, der AIDS Hilfe und Betroffenen führt das HIVCENTER seit 2008 ein Wochenendseminar für Medizinstudenten deutscher Universitäten durch, um auf die spezifischen Herausforderungen von HIV Behandlung und Prävention vorzuberieten. Der Schwerpunkt hierbei liegt auf der Ausbildung ausländischer Studierender in Deutschland, welche als spätere Meinungsbildner in Ihren Heimatändern angesehen werden.

Neben einer Einführung in die Pathogenese und HIV Behandlung vermittelt das Seminar Grundlagen der HIV Prävention sowie ein Training zum Umgang mit dem HIV Infektionsrisiko am medizinischen Arbeitsplatz. In Rollenspielen wird praktisch die Aufklärungssituation eines HIV Tests sowie die Ergebnissvermittlung geübt.

Resultate: Aus 99 Bewerbungen von 19 Universitäten Deutschlands wurden 33 Studierende ausgewählt, welche vornemlich aus Afrika, Osteuropa und arabischen Ländern stammten. In der durchgeführten Evaluation des Seminars bewerteten die Teilnehmer das Gesammtseminar auf einer Schulnotenskala von 1-6 mit "gut" (2).

Das Seminar gab einen sehr guten Überblick über das Thema (1) und führte zu einem spürbaren Wissenszuwachs (1). Die Evaluation der Einzelvorträge in Bezug auf Rele- 
vanz $(1,5)$, Präsentation $(1,7)$ und Inhalt $(1,6)$ zeigte eine adequate Auswahl von Referenten und Themen sowie eine Ausgewogenheit zwischen praktischen und theoretischen Aspekten, welche die Teilnehmer zu aktiver Diskussion motivierten(2).

Schlussfolgerungen: Medizinstudenten an deutschen Hochschulen haben einen deutlichen Fortbidlungsbedarf in Bezug auf Prävention und Behandlung von HIV, den Umgang mit von HIV Betroffenen und Sozio-kulturelle Einflüsse auf gesundheitsrelevantes Verhalten. 2009 soll das Seminar daher wiederholt und auch vermehrt für deutsche Studierende geöffnet werden.

\section{$P 125$}

\section{Die Regierung der HIV-Infektion: Eine empirisch-genealogische Studie Katrina Pfundt}

Institut für Soziologie Hamburg, Hamburg, Germany

Hi nterg rund: In meiner Dissertation habe ich anhand einer qualitativen Studie untersucht, in welcher Form und in welchem Ausmaß die HIV-Infektion für infizierte Frauen lebensgeschichtlich relevant wird. Im Mittelpunkt der Studie steht die Frage, wie sich das Subjekt unter den Bedingungen einer schwerwiegenden Infektion konstituiert, die im gesellschaftlichen Kontext Stigmatisierungen und Diskreditierungen hervorruft.

Methodik: Das von Foucault (2004) entwickelte Konzept der Gouvernementalität ermöglicht es über den Begriff der Regierung (respektive Führung) Mikro- und Makroebene unter einer einheitlichen Perspektive zu untersuchen und entsprechend zu zeigen, wie makropolitische Strukturen subjektiv relevant werden.

Resul tate: Die Ergebnisse der Studie folgen den zentralen Problematisierungen der Informantinnen, die um drei Themenschwerpunkte kreisen: die Steuerung von Informationen, die die HIV-Infektion betreffen, medizinische Implikationen der Infektion und biographische Transformationsprozesse. Entsprechend stehen die gesellschaftliche, die medizinische und die biographische Regierung der HIVInfektion mit ihren Effekten im Mittelpunkt.

In allen Bereichen zeigt sich, dass Machtausübung heute nicht mehr vorwiegend über Zwang und Repression, sondern v.a. über Techniken erfolgt, denen es gelingt, die Selbstlenkungsfähigkeit der Subjekte zu mobilisieren.

Der (gesellschaftliche) Appell an Selbst- und Fremdverantwortung entfaltet Wirkungsmacht.

Trotz Angst vor Stigmatisierungen strukturiert diese Regierungsweise den Umgang mit der Diagnose im gesellschaftlichen Kontext. Im Zusammenhang der antiretroviralen Therapie leitet neben der Forderung nach Selbstverantwortung, die "Technologie der Werte" die Informantinnen trotz vielfacher Nebenwirkungen zu selbstregulativem Verhalten in Richtung Compliance, wenn sie auf die Zukunft als den zu gestaltenden Bereich rekurrieren.

Im Bereich der biographischen Regierung entfalten schließlich individuelle Erklärungsmuster, die von strukturellen Rahmenbedingungen abstrahieren Geltungsmacht und nehmen das Subjekt für eine gelingende Lebensführung in die Verantwortung.

Schl uss folgerungen: Im Gegensatz zu Studien, die sich auf der Mikroeben situieren wird anhand meiner Studie deutlich, dass Subjektivierungsprozesse, gesellschaftliche Lö- sungsstrategien (das Paradigma der Eigenverantwortung in der Medizin) und sich manifestierende Problematiken (das Offenlegen der Diagnose) durch makropolitische Kräfteverhältnisse, die zu Individualisierungen leiten, strukturiert und konstituiert werden.

\section{$P 126$}

\section{A regional multi-sectoral HIV prevention and AIDS care programme approach to keep the Western Balkans low-preval ent \\ BettinaSchwethelm ${ }^{1}$, LeeNah Hsu ${ }^{1}$, Olimbi Hoxhaj ${ }^{2}$, Genc Ymerhalili 3}

${ }^{1}$ Fondation PH Suisse - Partnerships in Health, Celigny, Switzerland, ${ }^{2}$ People Living with HIV Association Albania, Tirana, Albania, ${ }^{3}$ Director, Centre for Development of Family Medicine, Pristina, Kosovo

Background: HIV prevalence is $<0.2 \%$ in Western Balkans countries. Yet, this region experiences similar factors that contribute to explosive HIV epidemics elsewhere in European continent: post-conflict instability, transition economies with high unemployment, trafficking of people and drugs, thriving sex work and injecting drug use, extensive migration, low level of information among young, lack of confidentiality, stigma and discrimination against marginalized and ethnic populations. Partnerships in Health, a Swiss NGO, with support from Sida, has been implementing since 2003 a regional programme for HIV prevention, AIDS care and support covering Albania, Bosnia and Herzegovina, Croatia, Kosovo, Macedonia, Montenegro, and Serbia.

Methods: Engaging key stakeholders in government, civil societies, international organizations, including PLHIV and marginalized populations, the Programme has created health human resources training curricula to strengthen AIDS clinical services, provided regional study exchanges for shared learning, and NGO grants to fill gaps in country responses at community level, particularly for marginalized populations .

Results :

- Strengthened capacities of NGOs in supporting PLHIV, Roma, IDUs, MSM, sex workers, prisoners, uniformed service personnel, mobile workers preventing HIV and MTCT.

- Organized annual Balkans HIV conferences on GIPA (2005), Multi-sector engagement (2006), Gender (2008) and Mobility (2009).

- Trained 5,000 primary health care doctors, nurses and allied health providers in basic HIV knowledge, stigma and discrimination reduction and patient rights.

- Trained 50 infectious diseases specialists in advanced clinical ART.

- Strengthened mental health and social work professional support to PLHIV.

- Improved workplace safety capacity.

- Conducted research to enhance evidence-based interventions.

- Create communication channels between PLHIV and NGOs.

Conclusion: A regional approach creates synergy in sharing good practices while reducing costs of developing new curricula and tools. It promotes professional exchange advocating rights-based programming for universal access. 
The added benefit is strengthened collaboration and understanding among countries in the region.

\section{$P 127$}

\section{Public acceptance of harm reduction as a major limitation for HIV prevention in Bashkortostan}

Zulfia Galieva ${ }^{1}$, Dunja Nicca ${ }^{2}$, Johannes Schläpfer ${ }^{3}$, Matthias Schlegel ${ }^{2}$, Pietro Vernazza $a^{2}$ Bettina Mäschli ${ }^{4}$, Infekt Team Schweiz Russland(ITSR)

${ }^{1}$ AIDS Center, Ufa, Bashkortostan, Bashkortostan, Russian Federation, ${ }^{2}$ Kantonsspital St. Gallen, Div Infectious Diseases, Dpt of Medicine, St. Gallen, Switzerland, ${ }^{3}$ AHSGA -

Fachstelle für AIDS und Sozialfragen, St. Gallen, Switzerland, ${ }^{4}$ Kantonsspital St. Gallen, St. Gallen, Switzerland

Is s ue of research: For the past 10years, the HIV epidemic has exploded in the Eastern European Region. We established a collaborative partnership with the Federal Republic of Bashkortostan, aiming at knowledge transfer and informatics support.

Description: For the past 4 years, we have established a strong partnership with the ministry of health of Bashkortostan as well as with the key physicians involved in the managment of HIV, STDs and heroin addiction. Three quarters of the more than $7000 \mathrm{HIV}$-infected individuals in Bashkortostan have been infected by injection needle exchange.

The key effort of our collaborative program was the intensive training of a key physician from the AIDS-Center in Ufa in our unit. In addition, a social worker and a member of a non governemental organization involved in the local prevention efforts have been enrolled in an intensive training course in Switzerland.

An increased awareness for the HIV epidemic by the Russian governement has paralleled our efforts. The training visits abroad have resulted in a substantial improvement of the quality of HIV-care. However, little improvement has been observed in treatment results for HIV infected current drug users. Importantly, key physicians and the Ministry of Health became highly motivated to move towards evidence-based harm reduction programs, however, public awareness and the law enforcement system were strong counterparts that prohibited such efforts. Supposedly, lack of public support for methadone and needle-exchange programs are key obstacles.

Conclusion: In order to have a meaningful impact on the HIV epidemic in the Russian Federation, effort should focus on the establishment of harm reduction and mehtadome programs.

Next steps: We will invite representatives of the ministry of justice and local police officers to collaborate with their Swiss partners from the police to help to motivate the legal system to stimulate new ideas in HIV-prevention.
P128

\section{Krankheit als Schuld: Paradigmenwechsel in der Medizin? \\ Stefan Nagel}

HELIOS Klinikum Schwedenstein, Dresden, Germany

In vielen Bereichen des ärztlichen und therapeutischen Handelns verlagert sich das Verständnis nosologischer Entitäten zunehmend vom Final- hin zum Kausalprinzip. Das gilt unter vermeintlich oder real zunehmendem ökonomischem Druck nicht nur für Entscheidungsprozesse im gesamtgesellschaftlichen Kontext und auf gesetzgeberischer Seite, sondern auch für die teils mehr, teils weniger reflektierten subjektiven wie objektiven Krankheitstheorien von Laien und Fachleuten. So werden (und wurden schon immer) Erkrankungen und ihre Träger in ,schuldige' und ,unschuldige' eingeteilt, was verdeckt oder offen sowohl in kurativer als auch in präventiver Hinsicht zu unterschiedlichen Behandlungsmaßnahmen führen kann. Diese Unterschiede beschränken sich nicht allein auf Fragen der Kostenübernahme, sondern können jeden anderen Aspekt der Arzt-Patienten-Beziehung oder sonstiger zwischenmenschlicher Interaktionen mitbetreffen. Menschen mit HIV und AIDS sind aufgrund der hohen Abhängigkeit des Infektionsrisikos und des Infektionsverlaufs vom individuellen Verhalten in besonderem Maße von entsprechenden Fremd-, aber auch Selbstzuschreibungen betroffen. Erschwerend hinzu kommt, daß es sich (anders als zum Beispiel bei Diabetes oder Adipositas) um eine Infektionskrankheit handelt, durch die weitere Personen in Mitleidenschaft gezogen werden können .

Im Vortrag soll zum einen auf der Basis psychoanalytischer und verhaltensbiologischer Überlegungen ein Überblick über verschiedene psychodynamische Mechanismen gegeben werden, die zu dieser Entwicklung beitragen (Schuld-Strafe-Denken, individuelle und kollektive Infektionsängste, parawissenschaftliche Theorien zur Krankheitsgenese, archaische Ausschlußreflexe in Primatengruppen etc.). Zum anderen sollen mittels medizinethischer Überlegungen die Effekte ärztlichen wie sozialen Handelns erwogen werden - nicht zuletzt im Hinblick auf das Solidaritätsprinzip. Grundlage dieses ärztlichen und sozialen Handelns ist letztlich keine wissenschaftliche Position, sondern die moralische Bewertung dessen, was HIV-negative, HIV-positive und ungetestete Menschen in Sachen safer Sex real tun. Da eben von dieser Bewertung und den ihr zugrundeliegenden bewußten und unbewußten Bewertungskriterien in Zukunft weitreichende Behandlungs- und Präventionsstrategien im Umgang mit der HIV-Infektion und anderen durch Verhalten beeinflußbaren Erkrankungen abhängen werden, verdienen sie ein hohes $\mathrm{Ma} \beta$ an Aufmerksamkeit. 


\section{P129}

\section{Berührungsängste verlieren, Professional ität gewinnen - ein Trainings programm des HIVCENTER für Lernende in Ges undheitsfachberufen}

Kathleen Mantzsch ${ }^{1}$, Patricia Luczkowski ${ }^{2}$, Michaela Bracone ${ }^{1}$, Tessa Lennemann ${ }^{1}$, Claudia Kircher ${ }^{1}$. H. R. Brodt ${ }^{1}$

${ }^{1}$ Med. Klinik II der Johann Wolfgang Goethe Universität, HIVCENTER, Frankfurt am Main, Germany,

${ }^{2}$ Universitätsklinik Frankfurt am Main, ZFG/ZRAD, Frankfurt am Main, Germany

Hinterg rund: Aus Un- oder Halbwissen über HIV und AIDS von medizinischem Personal sowie Unsicherheiten im Umgang mit Betroffenen erwächst seit Beginn der Epidemie häufig eine Stigmatisierung und Unterversorgung HIV infizierter Patienten .

Um einen professionellen, den heutigen Therapiemöglichkeiten angepassten Umgang zu fördern, aber auch Raum für Diskussionen zu geben und offene Fragen zu klären, hat das HIVCENTER ein speziell auf Schulen für Gesundheitsberufe ausgelegtes Trainingsprogramm entwickelt.

Methode: Eine medizinisch ausgebildete Mitarbeiterin mit Erfahrung im klinischen Alltag der HIV Behandlung sowie eine von HIV betroffene Person vermitteln grundlegendes medizinisches Wissen über HIV und AIDS und ermöglichen einen „hautnahen" Erfahrungsaustausch. Gemeinsam werden Übertragungs wege diskutiert und Übertragungsrisiken anhand von Praxisbeispielen überprüft. Im Anschluss daran setzen sich die Teilnehmer in Rollenspielen aktiv mit einer Situation auseinander.Dafür wählen sie in Gruppen (Patient/Personal/Beobachter) eine von 3 vorgegebenen Situationen aus. Die Fälle orientieren sich an Beispielen aus dem Kliniksalltag und stellen damit einen engen Bezug zur Realität dar. In einer Feedbackrunde werden die Beobachtungen ausführlich besprochen. Die im letzten Jahr durchgeführte Veranstaltung wurde durch anonymisierte Fragebögen evaluiert $(n=26)$.

Ergebnis: Die Veranstaltungen wurde durchweg positiv bewertet. Die Teilnehmer hatten grossen Informationsbedarf in Bezug auf HIV und AIDS (92\%). Bei $81 \%$ der Auszubildenden hat sich das Wissen durch die Veranstaltung erweitert und 50\% fühlten sich nach der Veranstaltung sicherer für den Umgang mit einem HIV infiziertem Patienten. In den Feedbackrunden beschrieben die Teilnehmer hauptsächlich Unsicherheiten in der Argumentation bei den jeweiligen Rollenspielen. Der Austausch mit einer von HIV betroffenen Person wurde von $100 \%$ als sehr gut empfunden.

Schl uss folg erung en: Die Evaluation bestätigt die Effektivität des Unterrichtkonzeptes in Bezug auf die Sicherheit im Umgang mit HIV Patienten und den Wissenszuwachs der Auszubildenden. Geplant ist eine Broschüre, die die meist gestellten Fragen der Auszubildenden beantwortet.

\section{$P 130$}

Ergebnisse einer kunsttherapeutischen Studie Regine Merz ${ }^{1}$, Norbert Brockmeyer ${ }^{2}$,David Aldridge ${ }^{1}$, Kompetenznetz HIV/AIDS

${ }^{1}$ Nordorff Robbins Zentrum, Witten, Germany, ${ }^{2}$ Klinik für Dermatologie, Ruhr-Universität Bochum, Bochum, Germany

Die HIV-Infektion hat sich zu einer chronischen Krankheit mit individuellen Verlauf gewandelt. Die Bilder scheinen so individuell zu sein, wie deren Schöpfer und ihre Lebenssituationen.

Eine Vergleichsstudie des Kompetenznetzes HIV/AIDS ging der Frage nach, ob in Patientenbildern HIV- spezifische Parameter sichtbar sind und wie sich diese interpretieren lassen.

In vier Settings gestaltete jeder Teilnehmer ein Bild zu einem vorgegebenen Thema. Die Reliabilität der Auswertung der Untersuchung wurde durch Personen verschiedener Berufsgruppen überprüft.

Verwendete standardisierte Testmethoden zur Studienaus wertung:

- POMS: Zur Überprüfung der Nachhaltigkeit der Kunsttherapie wurde jeweils vor Beginn und Ende der Therapiestunde eine Kontrolle mittels eines Profile of Mood States Fragebogen (POMS) zur Messung der aktuellen Stimmung slage durchgeführt.

- ECQ: Die Krankheits bewältigungsstrategie wurdd mittels eines Fragebogens zur Krankheitsverarbeitung, dem Essener Coping Questionnaire (ECQ) erhoben.

- NBS: Zur Bildanalyse wird die Nürtinger Bewertungsskala (NBS) herangezogen .

Die Ergebnisse zeigen den chronischen Verlauf der Krankheit auf. Ein Zusammenhang von Bild und Leben wird sichtbar und kann mit sinnvollen standardisierten Testmethoden nachgewiesen werden.

- Die einzelnen Stadien der CDC-Klassifikation (A,B,C) drücken sich sowohl in der künstlerischen Bildgestaltung durch charakteristische Merkmale als auch im Krankheitsverarbeitungsverhalten aus.

- Ähnlichkeiten sind im künstlerischen Ausdruck bei HIVInfizierten der Klassifikation A mit der Vergleichsgruppe zu finden. Auch bevorzugen diese beiden Untergruppen die Copingstrategie der aktiven, kognitiv strukturierende Bewältigungsarbeit und der Suche nach Selbstbestätigung und des Selbstaufbaus.

- Beim Fortschreiten der Infektion ins Stadium B wird die aktive Suche nach sozialer Einbindung wichtig.

- Beim Eintritt in das Vollbild Aids steht das Vertrauen in die ärztliche Kunst im Vordergrund des Copingverhaltens. Entsprechend entfernt sich der künstlerische Ausdruck von der technisch perfekten Gestaltung und wird direkter und spontaner. Zu Gunsten des individuellen Ausdrucks werden künstlerische Ansprüche vernachlässigt.

Die positive Resonanz der Studienteilnehmer bestätigt, dass Kunsttherapie eine sinnvolle Ergänzung der medizinischen Behandlung darstellt und das zu jedem Zeitpunkt der Erkrankung. 


\section{$P 131$}

Working toward a world without AIDS: How social marketing inspires long-term cultural change

Ruth E. Massingill

University of Teesside, Business School, Huntsville, United States

From the machismo mindset of Latin America to the Sugar Daddy tradition of African countries to the widespread acceptance of casual sex in the United States, cultural norms are recognized as complicit in the global HIV/AIDS epidemic. Preventing the continued spread of AIDS infections requires permanently altering the social fabric of such societies. Social marketing--using marketing techniques to achieve social goals--is widely used to motivate high-risk groups to adopt healthy behaviors, which often requires altering generationslong cultural traditions relating to sex and gender. For more than two decades, social marketing has been a vital tool in this cultural battle against HIV/AIDS.

This paper addresses the question: Which social marketing approaches have been successfully used to motivate long-term changes in cultural norms that contribute to the spread of HIV/AIDS?

Description: To answer this question, the researcher established criteria and selected 18 recent HIV/AIDS social marketing campaigns for content analysis. Follow-up consisted of semi-structured interviews with key informants connected to the campaigns. Informed by this secondary and primary information, the campaigns were compared using a cross-tabulation matrix.

Conclusions: Findings indicated that successful campaigns are sensitive to the cultural context of the target audience, using multilingual and multimedia methods of communication. Initiatives with the most lasting results were those that involved members of the target audience at every stage, from program design through implementation and evaluation. Additionally, key informants agreed that building long-term partnerships and coalitions was challenging but imperative to achieving significant behavioral changes. The complexity of overcoming social, political and economic barriers required cooperation by policymakers across the globe.

Next steps: The researcher is developing an anonymous quantitative survey to determine perceptions of AIDS treatment and prevention information as presented in recent social marketing campaigns .

\section{Prävention / Prevention}

$P 200$

Abstract zurückgezogen

$P 201(P W)$

Prävention für Menschen mit HIV: Sexualverhalten und beeinflussende Faktoren

Dunja Nicca, Synove Daneel, Pietro Vernazza

Infectious Diseases Unit, Hospital St. Gallen, St. Gallen, Switzerland

Hinterg rund: Präventionsinterventionen sollten auch Menschen die bereits mit einer HIV-Infektion leben einschliessen. Während im amerikanischen Raum solche Programme bereits Erfolge zeigten, gab es in der Schweiz und vielen anderen europäischen Ländern bisher keine systematischen Programme. An einer ambulanten Sprechstunde wurde ein theoriebasiertes Pilotprogramm zur Unterstützung von präventivem Sexualverhalten von Menschen mit HIV entwickelt und umgesetzt. Erste Resultate, zu eingeschlossenen Patienten in Bezug auf deren Sexualverhalten werden präsentiert.

Methodik: Präventionsinterventionen werden alle 6 Monate durch geschulte Fachpersonen (Ärzte/Pflegende) durchgeführt. Von März bis Dezember 2008 wurde bei 332 Personen eine erste Intervention durchgeführt. Demographische und gesundheitsbezogene Variablen wurden mit dem Fragebogen der Schweizerischen HIV Kohortenstudie erfasst. Sexualverhalten und Motivation wurden mit einem für die Evaluation entwickelten Fragebogen nach jeder Intervention durch Fachpersonen erfasst. Für die Analyse wurden 3 Gruppen mit unterschiedlichem Sexualverhalten verglichen.

Resultate: Von 401 in der Sprechstunde registrierten Patienten erhielten $83 \%$ (332) eine erste Präventionsintervention. Der mittlere Alterswert war 46 Jahre (IQR 40-50), 69\% davon waren Männer. 122 (37\%) Patienten gaben an, keinen Sex zu haben; 193 (58\%) gaben sicheres Sexualverhalten und $17(5 \%)$ nicht präventives Sexualverhalten an. Diese drei Gruppen waren vergleichbar bezüglich: Alter, Geschlecht, Ausbildung, Ethnie, Transmissionsgruppe. Signifikante Unterschiede zwischen den Gruppen zeigten sich, in Bezug auf: sexuelle Präferenz, fester Partnerschaft, Einzelhaushalt, Alkoholkonsum, CD4 Zellzahl, und HIVRNA. Die Gruppe mit nicht präventivem Sexualverhalten zeigte signifikant häufiger bisexuelle Präferenz, Alkoholkon sum und HIV RNA $>400$.

Schl us sfolgerungen: In den ersten zehn Monaten konnte ein hoher Anteil der hier erfassten Patienten erreicht werden, was als gute Integration des Programms in den klinischen Alltag interpretiert werden darf. Unterschiede zwischen den Gruppen zeigten sich vor allem im Verhaltensbereich und in Bezug auf Gesundheitsfaktoren, dies sollte in der Entwicklung von Interventionen berücksichtigt werden. 
$P 202$

Abstract zurückgezogen
$P 203$

Mach's mit 2009: Emotionen und

Informationen - ein neues

Kommunikationskonzept zur bevölkerungsweiten und zielgruppens pezifischen HIV/AIDS - Prävention

Claudia Corsten, Wolfgang Müller

Bundeszentrale für gesundheitliche Aufklärung, Referat Maßnahmen zur Aidsprävention, Köln, Germany

Seit 1987 setzt die Bundeszentrale für gesundheitliche Aufklärung die Kampagne GIB AIDS KEINE CHANCE in Deutschland um. Die Kampagne kommuniziert auf drei Ebenen: bevölkerungsweite, zielgruppenspezifische und individuelle Ansprache. Die 1993 eingeführte Teilkampagne mach's mit hat sich in diesem Kontext als Schutzkampagne etabliert und die Motivation zur Kondomnutzung in den Vordergrund gestellt.

Ab April 2009 setzt mach's mit Fotografien ein, welche mögliche Risikosituationen thematisieren, und bietet dem Betrachter die Gelegenheit, sich in diese Risikosituationen einzufinden. Es werden zwei Handlungsoptionen angeboten: die positiv besetzte Option für die Kondomnutzung steht der wert-neutralen Option einer möglichen HIV-Infektion gegenüber. Der Betrachter wird emotional und rational angesprochen und zum Schutz motiviert.

Die Ansprache der Gesamtbevölkerung erfolgt über Großplakate, Spots und das Webportal www.machsmit.de, die zielgruppenspezifische Ansprache über Anzeigen und Online-Werbemittel für Jugendliche, MSM und nicht-monogame Erwachsene. Das flexible Bildkonzept entspricht der Heterogenität dieser Zielgruppen. Die Kampagne informiert zu HIV/Aids und anderen STD und spiegelt Ergebnisse der Repräsentativuntersuchung „Aids im öffentlichen Bewusstsein". Sie bietet Anreize, das eigene Schutzverhalten zu überdenken, es ggf. zu optimieren oder sich darin bestätigt zu fühlen.

Das Konzept als auch die Einzelmotive wurden in einem mehrstufigen Verfahren entwickelt, optimiert und durch standardisierte Pretestverfahren überprüft. Die Ergebnisse zeigen, dass die Hauptbotschaft sehr schnell von den Befragten verstanden wird (zwischen $74 \%$ und $92 \%$ ). Dem Inhalt der Anzeigenmotive wird von über $90 \%$ zugestimmt. $78 \%$ bis $94 \%$ der Befragten fänden es gut, solche Anzeigen häufiger in Zeitschriften zu sehen. Alle getesteten Motive werden als nur in geringem Maße angstmachend oder anstößig erlebt. Die häufigste genannte Eigenschaft ist „glaubwürdig". Ebenso werden die Motive von ihren Zielgruppen als verständlich und überzeugend erlebt.

Das neue Kommunikationskonzept optimiert die Verknüpfung der breitenwirksamen mit der zielgruppen-spezifischen Aidsaufklärung der BZgA. Die visuelle Thematisierung von Risikosituationen erweitert darüber hinaus das Spektrum der bisherigen mach's mit-Teilkampagne und wird damit einem sich wandelndem Präventionsumfeld gerecht. 


\section{$P 204$}

\section{Stufen der Partizipation in der HIV- Prävention}

Michael T. Wright ${ }^{1}$, Martina Block ${ }^{1}$, Hellavon Unger ${ }^{1}$, Karl Lemmen ${ }^{2}$

${ }^{1}$ Wissenschaftszentrum Berlin für Sozialforschung, Forschungsgruppe Public Health, Berlin, Germany, ${ }^{2}$ Deutsche AIDS-Hilfe e.V., Referat Qualitätsentwicklung, Berlin, Germany

Hintergrund: Die Einbindung der Zielgruppe in die Gestaltung und Durchführung der HIV-Prävention ist ein Kennzeichnen der Arbeit von Aidshilfe-Organisationen weltweit. Dieser partizipative (politische) Ansatz, der als Qualitätsmerkmal einer effektiven Präventionsarbeit gilt, wurde jedoch bisher nicht näher definiert. Es existieren keine projektübergreifenden Kriterien, um feststellen zu können, inwieweit die Partizipation einer Zielgruppe konkret realisiert wurde.

Vorgehen: Im Rahmen eines gemeinsamen Forschungsprojekts der Forschungsgruppe Public Health im Wissenschaftszentrum Berlin für Sozialforschung (WZB) und der Deutscher AIDS-Hilfe e.V. zum Thema Qualitätsentwicklung in der HIV-Prävention der Aidshilfen wurde ein Stufenmodell der Partizipation entwickelt. Das Forschungsprojekt wurde von der BZgA im Auftrag des BMG gefördert.

Nach unserem Verständnis ist Partizipation keine Entweder/Oder-Option, sondern ein Entwicklungsprozess, der sich in „Vorstufen der Partizipation", „Partizipation" und „Selbstorganisation" einteilt. In vielen Zusammenhängen müssen zunächst Vorstufen der Partizipation realisiert werden, bevor eine Zielgruppe sich an Entscheidungsprozessen hinsichtlich der Präventionsarbeit direkt beteiligen kann.

Erste Erfahrungen: Das Stufenmodell hat sich als Instrument der Selbstevaluation in der Arbeit der Aidshilfen bewährt. Der Anspruch der Partizipation wird durch Anwendung des Modells fassbar und für die Planung, Durchführung und Evaluation von Angeboten handhabbar. Partizipative Prozesse werden näher beschrieben, um Praktiker/innen zu ermöglichen, den Grad der in ihrer Arbeit erreichten Partizipation einzuschätzen und Möglichkeiten zur Steigerung der Partizipation zu entwickeln.

Nächste Schritte: Das Stufenmodell der Partizipation ist ein Kernkonzept der Partizipativen Qualitätsentwicklung (PQE). Durch die PQE erwerben Aidshilfen neue Kompetenzen, um in Zusammenarbeit mit der Zielgruppe und anderen Kooperationspartner/innen die Präventionsarbeit regelmäßig und systematisch zu überprüfen. Das Stufenmodell und die anderen Konzepte und Instrumente der PQE werden auf der Internet-Plattform www.qualitaet.aidshilfe.de präsentiert. Die Verbreitung der PQE wird in den kommenden Monaten auch über diverse Veranstaltungen und Modellvorhaben der Deutschen AIDS-Hilfe erfolgen.
$P 205(P W)$

\section{Condom use among heterosexual HIV positive men and women: what's in a steady relationship? Results of the Eurosupport V study}

Christiana Nöstlinger ${ }^{1}$, Sibylle Nideröst ${ }^{2}$, Daniel Gredig $^{2}$, Tom Platteau ${ }^{1}$, Matthias Müller ${ }^{3}$, Eurosupport $V$ Study Group \& Swiss HIV Cohort Study

${ }^{1}$ Prins Leopold Institute of Tropical Medicine, Clinical Sciences, Antwerp, Belgium, ${ }^{2}$ Fachhochschule Nordwestschweiz, Hochschule für Soziale Arbeit, Institut Integration und Partizipation, Olten, Switzerland, ${ }^{3}$ Klinikum der Universität München, Infektionsabteilung, Medische Poliklinik, München, Germany

Background: This cross-sectional multi-site study aimed to identify factors determining condom use among heterosexual people living with HIV/AIDS (PLHA). We used an adapted Information-Motivation-Behavioural Skills Model to explain positive prevention behaviour in steady relationships.

Methods: Consecutive patients at HIV outpatient clinics (ESV Study Group and Swiss HIV Cohort Study) received an anonymous, standardized, self-administered questionnaire. Data were analysed using descriptive statistics and backward elimination regression analyses stratified by gender and sexual orientation.

Results: Respondents were 364 women (24\%) and 287 men $(19 \%)$ from a total of 1549 PLHA in 14 European countries. Mean age was 39 and 43 years for women and men respectively. Sixty-three percent $(n=229)$ of women and $59 \%$ of men $(n=169)$ reported at least one sexual encounter with a steady partner six months prior to the survey. Fifty-one percent $(n=116)$ of women and $59 \%$ of men $(n=99)$ did use condoms consistently with that partner.

Regression analyses revealed that condom use was positively associated with subjective norms, self-efficacy and partners' serostatus (either HIV+ or unknown). In men, also higher education and knowledge about safe sex increased condom use, while the use of erectile enhancing medication reduced it. For women, also disclosure to partners was negatively associated with condom use. Self-efficacy was mainly explained by positive attitudes to condom use and subjective norms; in men lower levels of anxiety, lower satisfaction with sexuality, greater perceived vulnerability and feeling depressed decreased self-efficacy. In women, self-efficacy was higher for those with more partner support.

Discussion: Slightly more than half of PLHA in this sample used condoms consistently with their steady partners. Condom use in women seemed to be more influenced by their partners' serostatus and subjective norms, whereas in men, sexual and mental health status had more impact. Prevention interventions for PLHA should pay attention to such gender-specific differences. 


\section{$P 206(P W)$}

Glance over the fence - and back! BORDER NETWork- further development of hands-on HIV/AIDS/STI prevention, diagnostic and treatment in Europe

Elfriede Steffan, Tzvetina Arsova Netzelmann SPI Forschung gGmbH, Berlin, Germany

Background: Financed by the German Ministry of Health as an extension of the EU-project BORDERNET, BORDERNETWork develops sustainable cross-border public health policies with 13 partners in 5 regions (Germany, Poland, Ukraine, Bulgaria, Romania, Moldova, and Estonia). Overarching goal is improvement of HIV/STI prevention, diagnostic, and treatment. It commits to the realisation of the German national HIV/AIDS strategy fostering cooperation with Central and Eastern Europe.

Methods : Highly active HIV prevention is no stand-alone measure. Core method is the interaction of public health policy and communities in many different areas. Interdisciplinarity is benchmark of the networks, including selfhelp groups, clinics and public health policy-makers. Further methods are capacity building, transfer of experience, assessments, awareness raising towards human rights of the affected and vulnerable groups, further education, sentinel surveillance and research projects.

Results :

- Politically agreed regional cross-border health goals (Germany, Poland) ensure access to HIV VCT, adequate HIV/STIs prevention and sexual education, expert's continuous education and support to PLHIV;

- Functioning networks in transboundary areas of special importance considering HIV spread Europe wide (Poland/Ukraine; Estonia/the Russian border, Moldova/the Region of Transnistria, Bulgaria/Romania);

- Transfer of proven models for youth prevention - events, drama education, peer training, multipliers' further education;

- Improved prevention, diagnostic and treatment for mostat-risk populations - sex workers, IDUs, Roma youth, HIV-positive adolescents, inmates;

- Extension of regional surveillance systems, outline of epidemiological events, assessment on quality of counselling, counsellors' further education .

Conclusions: Steps toward harmonisation of HIV/AIDS prevention/diagnostic and STIs offers were done. Various interfaces of the public health context remain unaddressed - linking HIV and drug help systems, access to HAART for IDUs, free STI diagnostic/treatment for uninsured persons. The respect of human rights of the most affected communities should be intensively tackled in order to reach better prevention response.

\section{$P 207$ (PW)}

How do we know what works? Assessment survey on quality assurance in the frame of National HIV/AIDS Prevention Programmes

Tzvetina Arsova Netzelmann ${ }^{1}$, Elfriede Steffan ${ }^{1}$, Helene Reemann ${ }^{2}$

${ }^{1}$ SPI Forschung gGmbH, Berlin, Germany, ${ }^{2}$ Bundeszentrale für gesundheitliche Aufklärung, Köln, Germany

Backgro und: Quality assurance (QA) in HIV prevention is no static concept but a process, taking place in a particular context. No internationally applicable definition exists, various approaches are in use. In assignment of the $\mathrm{BZg} \mathrm{A} / \mathrm{WHO} / \mathrm{EURO}$ expert conference in 2008 a qualitative assessment survey was conducted in 10 European countries (Bulgaria, Croatia, Estonia, Germany, Hungary, Netherlands, Poland, Romania, Sweden, Switzerland) with the goal to compile experts' experience in national HIV prevention measures about how QA is being understood and practically transformed in tools for quality management and the related obstacles.

Methods: A three-step process combined desk review on international and national reports and programmes; assessment questionnaire and structured telephone interviews. 13 experts from 11 countries were questioned, good practice QA examples collected, 10 country reports compiled and future challenges outlined.

Results :

- Distinctly marked QA concepts in AIDS prevention are applied in Bulgaria, Germany, Sweden, Switzerland;

- QA in frame of (or only as) monitoring and evaluation activities is implemented in Netherlands, Estonia, Poland, Bulgaria, Romania, Croatia;

- Differences exist among integrated evaluation in national prevention measures (Germany, Poland) and national strategies to evaluate regional measures (Sweden);

- Nationally implemented QA measures have widest spread, realised in centralised (Estonia) or decentralised (Bulgaria) manner;

- Bottom-up QA models are largely initiated by NGOs in community based (Germany) and national (Netherlands) interventions;

Conclusions: Improved link of the QA concepts with research and epidemiological data on HIV/STI is needed, e.g. second generation surveillance, KAB studies. Regular reporting mechanisms seem appropriate for better interlocking of national and regional/municipal levels of quality management. No quality assurance systems without civil society's participation are thinkable. The further exchange and networking in the European Region on the topic of QA implies the openness and the critical stance of all relevant stakeholders at the national and regional levels.

\section{P208}

\section{Development of an HIV prevention flyer for illiterate persons and individuals with functional illiteracy}

Synove Daneel ${ }^{1}$, Adjara Tina ${ }^{2}$, Johannes Schlaepfer ${ }^{3}$, Patrick Schmid 4 , Pietro Vernazza 4 , Dunja Nicca ${ }^{4}$

${ }^{1}$ Kantonsspital St. Gallen, Infektologie und Spitalhygiene, St. Gallen, Switzerland, ${ }^{2}$ NGO Hope (Éspoire), Bamako, Mali, ${ }^{3}$ Fachstelle für Aids und Sexualfragen, St. Gallen,

Switzerland, ${ }^{4}$ Kantonsspital St. Gallen, Infektiologie und Spitalhygiene, St. Gallen, Switzerland

Background: A high level of illiteracy is a main driving force of the HIV epidemic in many countries, such as Mali where illiteracy has been estimated to $80 \%$. A low level of literacy is also frequently present in asylum seekers and migrant population groups in Europe, like Switzerland. In order to reach those populations with AIDS education, frequently repeated interventions using multiple approaches are recommended. Currently, no flyers specifically designed for illiterates have been used in these settings . 
The aim of this project was to develop HIV prevention flyers, which could be independently understood by illiterate and functional illiterate persons.

Methods: 3 flyers were created: heterosexual-, homosexual-, pregnancy flyer. The flyers were developed by a trained Malian AIDS worker (100\% illiterate until age 20); Swiss HIV researchers and clinicians, representatives of patient organization. Flyers were tested in several phases using the "talking/explaining aloud" method.

1 st phase: Swiss nationals ( $100 \%$ literacy; $n=20)$;

2nd phase: asylum seekers in Switzerland (70\% estimated illiteracy; $\operatorname{men}=28$, women $=3$ );

3rd phase: Bamako (Mali) in $100 \%$ illiterates (men $=5$, women $=15$ ) and persons with functional illiteracy (men $=5$, women $=15$ ).

Results : Functionally illiterate persons were able to correctly and independently understand and explain HIV prevention messages. For illiterates, $80 \%$ were able to correctly do so, even though they needed more time (3-4 $\mathrm{x}$ more). $20 \%$ of illiterates did not understand the content of the flyers and could not provide expected answers. Currently, pregnancy flyers are being tested in Mali. Hetero- homosexual flyers are being distributed in Bamako to high risk groups (sex workers, street vendors, truck-drivers) as part of the Malian HIV prevention campaign.

Conclusions: If appropriately designed, information flyers on HIV prevention can be used to educate illiterate individuals and persons with functional illiteracy. This additional information device could act as an important tool complementing already existing HIV prevention efforts.

\section{$P 209$}

Perspektiven der HIV-Prävention mit vulnerablen Jugendlichen: Erfahrungen aus einem Modellprojekt im Berliner Jugendarrest

Thomas Wilke, Phil C. Langer, Birte Seffert, Stefan Müller, Dorothee Krings, Susann Bollmann, Christina Auffenberg, Nils Groß, Patrick Hand, Rosa Heine, Schoolwork-Team der Berliner Aids-Hilfe e.V.

Berliner Aids Hilfe e.V., Jugendprävention 'Schoolwork', Berlin, Germany

Fragestell ung: Jugendliche mit dem Thema HIV/Aids effektiv und nachhaltig zu erreichen, stellt eine andauernde Herausforderung der Präventionsarbeit dar. Dies gilt insbesondere in Bezug auf vulnerable Jugendliche mit gesellschaftlichen Exklusionserfahrungen aufgrund ihres sozialen Status oder ihrer Migrationshintergründe. Im Rahmen des Berliner Modellprojekt „Schoolwork" der Berliner Aids-Hilfe wurde im Januar 2006 in Zusammenarbeit mit dem Jugendarrest Berlin-Lichtenrade ein Präventionsworkshop institutionalisiert, der inhaftierten Jugendlichen das Thema HIV/Aids als Teil eines umfassenden Programms zur Förderung sozialer Kompetenzen näher bringen soll.

Beschreibung: Die 90-minütigen interaktiven Workshops finden wöchentlich in Kleingruppen von acht, überwiegend männlichen Jugendlichen zwischen 16 und 21 Jahren in den Räumen der Arrestanstalt statt. I.d.R. haben mehr als die Hälfte der vor dem Hintergrund fortgeschrittener krimineller Karrieren (Körperverletzung, Raub, Drogenkonsum oder -handel) mehrwöchig Inhaftierten einen türkischen, arabischen oder russischen Migrationshintergrund. Einem erweiterten Peer-Education-Konzept folgend sind die ehrenamtlichen Mitarbeiter/innen des Schoolworkteams zwischen 21 und 33 Jahre alt, um einen lebensweltlichen Zugang zu den Jugendlichen zu ermöglichen. Eine Evaluation der Workshops findet im Gesamtkontext des Sozialprogramms statt.

Schlussfolgerung: Deutlich treten in den Workshops eklatante Wissensdefizite hinsichtlich von HIV/STIs zu Tage sowie ein hohes Stigmatisierungs- und Diskriminierungspotential, das sich nicht nur auf HIV, sondern alle nicht-heterosexuellen Lebensweisen bezieht. Durch spezifisch für das Setting entwickelte Methoden konnte das Projekt Ansatzpunkte zur Bewusstmachung der Gefährdung durch HIV/STIs und einer differenzierten Auseinandersetzung mit dem Leben von HIV-Infizierten schaffen. Angesichts der sexuell sehr aktiven und risikobereiten Teilnehmer/innen ist es notwendig, eine HIV-Awareness gerade in dieser Gruppe vulnerabler Jugendlicher weiter zu verankern, zumal sie als Peer-Multiplikator/innen in den jeweiligen Szenen zu verstehen sind.

Nächste Schritte: Die Erfahrungen verdeutlichen die Wichtigkeit, das bestehende Angebot im Jugendarrest trotz weiterer finanzieller Kürzungen der Präventionsarbeit in Berlin aufrecht zu erhalten und zeitlich zu erweitern. Eine Nachhaltigkeit der Workshops soll über Einbindung der Jugendlichen in konkrete präventive Aktionen sowie durch Zusammenarbeit mit Streetwork-Projekten erreicht werden.

\section{P210}

\section{Mission possible - doch nicht möglich? Effekte der Aktion 3 Monate Safer Sex ein Jahr danach}

Roger Staub ${ }^{1}$, Steven Derendinger ${ }^{1}$, Martin Gebhardt ${ }^{1}$, Thomas Bucher ${ }^{2}$, Christophe Fraser ${ }^{3}$, Hugues Balthasar ${ }^{4}$

1Bundesamt für Gesundheit (Schweiz), Übertragbare Krankheiten, Sektion Aids, Bern, Switzerland, ${ }^{2}$ Aids-Hilfe Schweiz, Zürich, Switzerland, ${ }^{3}$ Imperial College, London, United Kingdom, ${ }^{4}$ Institut de Medecine Sociale et Preventive, Lausanne, Switzerland

Fragestellung: Der Anteil Frischinfizierter ist bei Schweizer MSM überproportional hoch. Während der Primoinfektion ist die Infektiosität gemäss Literatur 30100 fach erhöht. Es ist plausibel, dass Infektionen während der Primoinfektion den wichtigsten Motor der aktuellen HIV-Epidemie bei schwulen Männern in westlichen Industrieländern bilden. Wenn sich in einer Gruppe während drei Monaten niemand neu infiziert, haben alle Infizierten dieser Gruppe das hochinfektiöse Stadium der Primoinfektion hinter sich. Diese Hypothese liegt der Aktion „Mission Possible (MP) zugrunde. Das Experiment MP sollte bei MSM Bewusstseins- und Verhaltensänderungen bewirken und einen Einfluss auf die Epidemie haben. MP wurde von der Aids-Hilfe Schweiz von Februar bis April 2008 in der Schwulenszene durchgeführt und vom Institut für Sozial- und Präventivmedizin der Universität Lausanne evaluiert.

Beschreibung: Die Evaluation zeigt, dass das Wissen um die Bedeutung der Primoinfektion deutlich zugenommen hat. Befragte, die noch 2007 HIV-Risiken eingingen, waren eher bereit, Safer Sex zu praktizieren, wenn sie von MP erreicht bzw. sonstwie über die Primoinfektion Bescheid wussten. Insgesamt war die Verhaltensänderung aber bescheiden, $11 \%$ der Befragten sind zu einer strikteren 
Einhaltung von Safer Sex übergegangen. Die Daten des obligatorischen HIV-Meldewesens der Schweiz zeigen bis zum 31.12.2008 keine sichtbare Veränderung, die auf MP zurück geführt werden könnte.

Schl ussfolgerungen: Mit dem Experiment vom Frühling 2008 konnte die Hypothese weder falsifiziert noch verifiziert werden. Weil die Evaluation zeigt, dass MP vor allem MSM mit höherem Bildungsgrad erreicht hat und das Informationsniveau zur Bedeutung der Primoinfektion nach wie vor nicht genügend ist, sind weitere Massnahmen nötig. Zurzeit ist ein mathematisches Modell der HIV-Epidemie unter MSM in der Schweiz in Erarbeitung. Damit soll getestet werden, wie gross eine Verhaltensänderung sein müsste, um mind. theoretisch einen Impact im Sinne der Hypothese bewirken zu können.

Nächste Schritte: Je nach Resultat des mathematischen Modellings kann eine kommunikativ verbesserte Wiederholung des Experimentes Sinn machen.

\section{P211}

\section{Recurring patterns in safer sex discussions in forums of sex workers' clients \\ Harriet Langanke}

GSSG - Gemeinnützige Stiftung Sexualität und Gesundheit, Köln, Germany

Background and objectives: In Germany, male clients of female sex workers have set up a number of internet forums to discuss their hobby and where and how to find which services. These forums are being used by several hundred men per diem. We wanted to find out whether these users were interested in learning more about STD, sexual health and safer sex.

Methods: Seven major forums have been visited regularly, at least once a month, between 2003 and 2008. With the approval and technical support from the forums' webmasters the forums have been screened for respective key words (like condom, syphilis, clap etc.). The relevant postings and discussions were analyzed for their cognitive and emotional content e.g. by the words used and by the intention declared.

Results : Although statistical data generated from internet forums should be handled with reasonable care, the outcomes show clearly: Users of forums for sex workers' clients are continuously discussing with their peers the risks of commercial sex without condoms or other protection. $80 \%$ of all discussions about sexual health issues include knowledge building information (e.g. presenting links to informative websites); $65 \%$ focus emotional needs (e.g. "don't worry") whereas $55 \%$ include practical advice (e.g. "go and see your doctor/a counsellor"). HIV/AIDS $(78 \%)$ is the most frequently mentioned disease, followed by clap (72\%), herpes and genital warts (both $40 \%$ ).

Conclusions: While sexual health issues are common concerns within the clients' forums, expertise among their users is too rare. Peer-to-peer counselling does include errors and misconception. Prearranged interventions by sexual health experts should be considered.
P212

Feasibility study for a European internet platform in the field of HIV prevention and sexual health

Christiane Firnges ${ }^{1}$, Elfriede Steffan ${ }^{1}$, Dr. Ursula von Rüden ${ }^{2}$

${ }^{1}$ SPI Forschung gGmbH, Berlin, Germany, ${ }^{2}$ Federal Centre for Health Education (BZgA), Köln, Germany

Background: Survey in charge of the BZgA; commissioned by the EU. The Dublin declaration highlighted the need to expand the use of evidence-based interventions and to reinforce the cooperation between countries concerning HIV/STI prevention in Europe. A European internet platform on HIV prevention / sexual health could serve to assess and transfer effective approaches and models of good practice and strengthen expert exchange between countries.

Method:

- Research on internet platforms of HIV prevention / sexual health.

- Survey addressed at European experts of HIV/Aids prevention, sexual health, including an assessment to obtain the needs for evaluated materials/measures and for expert exchange. Ideas on the design of an internet platform concerning aims, functions and scope and the wish to contribute were explored, using a Delphi technique (2 cycles), based on an e-mail questionnaire method, sample size $1 . / 2$. cycle: 23 / 20 experts.

Results: The outcome indicated that the internet provides a large pool of information on approaches of HIV/Aids prevention and sexual health. However, platforms lack transparency, systematic categorisation and assessment of information.

The majority of experts states a need for evaluated materials/measures of HIV/STI prevention / sexual health and for expert exchange. The Delphi survey measured the level of agreement on a number of aims and functions. Experts agreed on a quality assurance function and on the scope of HIV prevention / sexual health. Specific models of quality assurance are still to be discussed in the advisory board to reach consensus.

Conclusion: The survey indicates a particular need for:

- quality criteria to assess information available on the internet,

- resources to implement quality assurance functions consistently.

Not quantity of unstructured information, but the easy access to assessed information is of vital interest in the field of HIV/Aids prevention and sexual health promotion in Europe.

$P 213$

Safe Environment (SE). Entwicklung von $S$ tandards zur HIV -Prävention in kommerziellen Sex-Betrieben für MSM: Leitfaden zur Standardisierung und bundesweiten Umsetzung

Franz-Josef Ehrle, Herbert Engel

AK AIDS Köln c/o Gesundheitsamt Stadt Köln, Köln, Germany

Im Rahmen einer durch das Bundesgesundheitsministerium für Gesundheit finanzierten EU-/EWR-weiten Recherche wurde ein Leitfaden zur Umsetzung von SE erarbeitet. 
Ziele SE:

- Der steigenden HIV-Infektionsrate bei MSM gegensteuern (gerade auch bei MSM in Hochrisikonetzwerken).

- In allen MSM Sex-Betrieben (Bars mit Darkrooms, Saunen etc) durch Verbesserung/Standardisierung der AIDS-/STD-Prävention, eine Safe Environment zu schaffen.

- Safe Environment bedeutet, durch das kostenlose und am Ort des sexuellen Geschehens zugängliche Präventionsmaterial (Kondome, Gleitgel, Latexhandschuhe) soll der Einzelne in seinem Schutzverhalten unterstützt werden und sich auch in persönlich schwierigen Situationen, leichter für den Schutz entscheiden können. Zu einer SE gehört auch das Vorhandensein bzw. die Auslage von Aufklärungsmaterial.

Ziele Recherche:

- Anhand ausgewählter Orte im In- und Ausland, sich vor Ort einen Überblick verschaffen über die räumlichen Gegebenheiten sowie das Vorhandensein lokaler oder überregionaler Präventionsansätze bzw. Präventionsvereinbarungen im Sinne von SE insbesondere Unterschiede zwischen Theorie und Praxis/Umsetzung beschreiben.

- Recherchieren, in welchen Sex-Betrieben eine Implementierung von SE unter dem Aspekt Prävention für MSM sinnvoll ist.

- Daten sammeln für eine bundesweite Etablierung von Präventionsstandards in Sex-Betrieben, die von MSM genutzt werden.

Methoden: Vergleich von Konzepten/Vorbildern und deren Umsetzung. Formulierung eines Leitfadens aufgrund Kölner Erfahrungen und der Ergebnisse der Recherche.

Ergebnis: Die Umsetzung von SE in der schwulen Szene ist möglich und wird von Gästen gut angenommen.

Schlussfolgerung: Eine flächendeckende Umsetzung der SE-Standards ist möglich und realistisch. Die Wege, die in den einzelnen Ländern beschritten wurden, um SE-Standards zu realisieren sind von Land zu Land unterschiedlich. Die Umsetzung gestaltet sich schwierig bis unmöglich, wenn staatliche Behörden die Prävention für MSM behindern.

Die Probleme in der Umsetzung der SE-Standards liegen nicht so sehrim Bereich der Auslage von Aufklärungs- und Informationsmaterial, sondern bei der kostenlosen Abgabe von Kondomen, Gleitmittel und Latexhandschuhen am Ort des sexuellen Geschehens infolge von Widerständen vornehmlich bei Betreibern.

\section{$P 214(P D)$}

\section{"Hard to reach" oder how to reach - anonymer HIV-Test für Migrantinnen in unterschiedlichen Settings \\ Heidrun Nitschke ${ }^{1}$, Anna Knappik ${ }^{1}$, Jan Leidel ${ }^{2}$}

${ }^{1}$ Gesundheitsamt, STD/Aids-Beratung, Köln, Germany, ${ }^{2}$ Gesundheitsamt, Köln, Germany

Background: Migrantinnen gelten als schwer erreichbare Zielgruppe für Angebote von HIV-Prävention, Beratung und Test. Sie erfahren oft nur Im Rahmen der Mutterschaftsvorsorge oder erst bei fortgeschrittener Aidserkrankung von ihrer HIV-Infektion. Angesichts vielfältiger sozialer und gesundheitlicher Notlagen ist die Frage nach dem HIV-Status für viele Migrantinnen nachrangig. In der STD/Aids-Beratungsstelle im Gesundheitsamt Köln wird der
HIV-Antikörpertest in unterschiedlichen Settings angeboten: einerseits nach Terminvereinbarung und vorwiegend psychosozialer Beratung, andererseits im Rahmen einer offenen gynäkologischen STD-Sprechstunde. Der Vergleich der in den beiden Settings getesteten Migrantinnen zeigt Möglichkeiten zur Verbesserung der Beratungs- und Testangebote für diese Gruppe.

Method: Von allen Migrantinnen, die zwischen dem 1.1.2006 und dem 31.12.2008 im Gesundheitsamt Köln einen HIV-Antikörpertest durchführen ließen, wurden anonymisiert Daten erhoben zu Alter, Versicherungsstatus, Herkunftsland, Sexarbeit, früher durchgeführten HIV-Tests und reproduktiver Anamnese. Die Daten wurden im Querschnitt mittels EpiInfo ausgewertet.

Result: Im Erhebungszeitraum wurden im Sprechstundensetting 572 Tests bei 420 Frauen mit Migrationshintergrund, im Beratungssetting 475 Tests bei 464 Frauen durchgeführt. Das mittlere Alter der Migrantinnen betrug 28,8 Jahre im Beratungssetting und 29,4 Jahre im Sprechstundensetting. Bei 59 Prozent der Frauen aus der Subsahara-Region fand der Test im Sprechstundensetting statt, aber nur bei 21 Prozent der Frauen aus Westeuropa. Insgesamt 59 Prozent der im Sprechstundensetting getesteten Migrantinnen waren nicht krankenversichert. Von allen im Sprechstundensetting getesteten Migrantinnen lagen Informationen zur Anzahl der Geburten und Schwangerschaften vor, jedoch nur von 35 Prozent der im Beratungssetting getesteten.

Conclusion: Die unterschiedlichen Settings spielen eine wesentliche Rolle für den Zugang zu unterschiedlichen Migrantinnengruppen. Die Einbettung des HIV-Testes in ein allgemeines Angebot zu sexueller Gesundheit motiviert auch Frauen zum Test, die sonst als schwer erreichbar gelten. Themen wie Schwangerschaft und Empfängnisverhütung bieten vielfältige Anknüpfungsmöglichkeiten, um besonders Frauen in schwierigen Lebenssituationen die Durchführung eines HIV-Tests nahe zu bringen. Diese sollten sowohl in der Testberatung wie in anderen Angeboten für Migrantinnen genutzt werden .

\section{P215}
Die Rolle der Postexpositions-Prophylaxe in der Prävention mit MSM: Ergebnisse einer Befragung von HIV-Schwerpunktärzten

Jochen Drewes ${ }^{1}$, Phil C. Langer ${ }^{2}$, und das Kompetenznetz HIV/Aids

${ }^{1}$ Freie Universität Berlin, AB Prävention und psychosoziale Gesundheitsforschung, Berlin, Germany,

${ }^{2}$ Ludwig-Maximilians-Universität München, Department Psychologie, München, Germany

Hinterg rund: Mit der Postexpositions-Prophylaxe (PEP) steht seit Einführung antiretroviraler Medikamente ein Präventionsinstrument zur Verfügung, das eine HIV-Transmission nach erfolgter Risikoexposition verhindern soll. DAIG, ÖAIG und SKK der EKAF empfehlen eine PEP auch bei spezifischen sexuellen Risikokontakten. Aufgrund fehlender Meldepflicht lagen für Deutschland hierzu bislang keine verlässlichen Daten vor. Die Studie untersucht aus Perspektive der HIV-Schwerpunktärztinnen/ärzte die Bedeutung der PEP in der Primärprävention mit MSM.

Methodik: Die Studie wurde im Frühjahr 2008 im Rahmen des Kompetenznetzes HIV/Aids als schriftliche Befragung 
durchgeführt. Die Fragebögen erfassten Daten zur Häufigkeit, Verteilung und Verlauf der im Jahr 2007 verschriebenen PEP und beinhalteten Fragen zur Einstellung der Ärztinnen/Ärzte in Bezug auf die PEP als Präventionsinstrument bei MSM.

Resul tate: Aus den 25 angeschriebenen Zentren nahmen bis März 200827 Ärztinnen/Ärzte teil. 69\% der Befragten waren niedergelassen tätig. In 2007 wurden von den teilnehmenden Ärzten 234 PEP durchgeführt, im Durchschnitt 8,7 pro Ärztin/Arzt (SD=8,2, Range=1-35). 55\% entfielen auf die Gruppe der MSM. 64\% der zugrunde liegenden HIVExpositionen bei MSM wurden auf Sexualkontakte außerhalb fester Beziehungen zurückgeführt. Von den berichteten PEP bei MSM war nur eine nicht erfolgreich. Bei $10 \%$ der MSM wurde die PEP aufgrund von Neben wirkungen abgebrochen. 12 Ärztinnen/Ärzte gaben an, dass sie im Jahr 200765 Personen aus der Gruppe der MSM die Bitte nach einer PEP verweigern mussten. Dies wurde in der Regel mit einem zu großem Zeitfenster zwischen Risikokontakt und Vorstellung in der Praxis/Klinik oder dem Fehlen eines ausreichenden Risikos begründet.

Schlussfolgerungen: Die Postexpositions-Prophylaxe spielt als wirksames biomedizinisches Instrument bei erfolgter Risikoexposition bereits eine Rolle in der Prävention mit MSM. Ihre Effektivität wird wahrscheinlich von deutlichen Wissenslücken der Patienten bezüglich des Zeitfensters zur Einleitung der PEP und der Einschätzung von Transmissionsrisiken beeinträchtigt. Eine offensive Aufklärung in der schwulen Community zu den Möglichkeiten der PEP ist daher notwendig.

\section{P216}

\section{Ergebnisse einer Befragung der Aidshilfen zu Partizipation und Kooperation in der HIV - Prävention mit Migrant/innen}

Hella von Unger ${ }^{1}$, Silke Klumb ${ }^{2}$, Michael T Wright ${ }^{1}$

${ }^{1}$ Wissenschaftszentrum Berlin für Sozialforschung (WZB), Forschungsgruppe Public Health, Berlin, Germany,

${ }^{2}$ Deutsche AIDS-Hilfe e.V., Berlin, Germany

Hintergrund: $\mathrm{Zu}$ den gegenwärtigen Herausforderungen der HIV-Prävention in Deutschland gehören verbesserte Angebote für verschiedene Gruppen mit Migrationshintergrund. Um diesen Herausforderungen gerecht zu werden, ist eine partnerschaftliche Zusammenarbeit von Wissenschaft und Praxis und von kommunalen Anbieter/innen gesundheitlicher und sozialer Dienste erforderlich. Unabdingbar ist dabei auch die Einbindung der Zielgruppen und Communities mit Migrationshintergrund selbst. Durch ihre Teilhabe (Partizipation) kann das lebensweltliche und kulturelle Wissen einfließen, das notwendig ist, um angemessene und wirksame Prävention zu entwickeln.

Methodik: Das "PaKoMi-Projekt" zur Partizipation und Kooperation in der HIV-Prävention mit Migrant/innen ist ein Projekt der Deutschen AIDS-Hilfe e.V., das von der Forschungsgruppe Public Health am Wissenschaftszentrum Berlin für Sozialforschung (WZB) wissenschaftlich begleitet wird. Ziel ist es, die partizipative und kooperative Entwicklung von zielgruppenspezifischer HIV-Primärprävention mit Migrant/innen über einen Zeitraum von drei Jahren zu fördern und zu untersuchen. In einem ersten Schritt wurden die 120 Mitgliedsorganisationen der Deutschen AIDS-Hilfe e.V. mithilfe eines Fragebogens und Telefoninterviews befragt.
Resultate: Die bundesweite Befragung der Aidshilfen liefert Ergebnisse zu den bestehenden Angeboten, Kooperationen und Erfahrungen in der kommunalen HIV-Prävention mit Migrant/innen. Die Zielgruppen und Maßnahmen der HIV-Prävention sowie die in unterschiedlichem Ausmaß stattfindende Einbindung von Menschen mit Migrationshintergrund in die Präventionsarbeit werden beschrieben. Außerdem wurde erhoben, welche weiteren Anbieter es in den Kommunen gibt, mit welchen Partnern zusammen gearbeitet wird und welchen Bedarf es z.B. an Vernetzung und Weiterbildung gibt.

Schlussfolgerungen: Die Ergebnisse zeigen auf, welche Handlungsbedarfe es aus Sicht der Aidshilfen in den Kommunen gibt und welche Unterstützung notwendig ist, um HIV-Prävention mit Migrant/innen gemeinsam zu gestalten.

\section{P2 17}

\author{
Anonyme HIV-Testberatung und \\ Migrantinnen - wer findet den Weg? \\ Heidrun Nitschke ${ }^{1}$, Anna Knappik ${ }^{1}$, Jan Leidel ${ }^{2}$ \\ 1Gesundheitsamt, STD/Aids-Beratung, Köln, Germany, \\ 2Gesundheitsamt, Köln, Germany
}

Background: Migrantinnen gelten als schwer zu erreichende Zielgruppe für Angebote von HIV-Prävention, Beratung und Test. Sie erfahren häufig nur bei einer Schwangerschaft oder erst bei weit fortgeschrittener Aidserkrankung von ihrer HIV-Infektion. Das Angebot eines kostenlosen anonymen HIV-Antikörpertestes in der STD/Aids-Beratungsstelle im Gesundheitsamt Köln wird von einer stetig steigenden Anzahl von Menschen mit Migrationshintergrund aufgesucht. Die Analyse von soziodemographischen und biographischen Daten der in den letzten drei Jahren getesteten Migrantinnen zeigt Möglichkeiten zur Verbesserung des Zuganges dieser Gruppe zu Test-Angeboten.

Method: Von allen Migrantinnen, die zwischen dem 1.1.2006 und dem 31.12.2008 im Gesundheitsamt Köln einen HIV-Antikörpertest durchführen ließen, wurden anonymisiert Daten erhoben zu Alter, Versicherungsstatus, Herkunftsland, Sexarbeit, früheren HIV-Tests und reproduktiver Anamnese. Die Daten wurden im Querschnitt mittels EpiInfo aus gewertet.

Result: In den Jahren 2006 bis 2008 wurden 1.047 HIVTests bei 877 Frauen mit Migrationshintergrund durchgeführt. Dies waren 12 Prozent aller in diesem Zeitraum durchgeführten Tests und 10 Prozent aller getesteten Personen. Die Frauen kamen aus insgesamt 93 Ländern mit sehr unterschiedlicher HIV-Prävalenz. Die häufigsten Herkunftsländer waren Polen (128), Russland (57), Türkei (51), Nigeria (42), Bulgarien (40), Kenia (39). 31 Prozent der Frauen waren nicht krankenversichert. Das mittlere Alter betrug 29,4 Jahre. 44 Prozent hatten nie zuvor einen HIV-Test durchführen lassen. 33 Prozent der Frauen arbeiteten in der Prostitution. Von 62 bzw. 59 Prozent lagen Angaben zur Anzahl der Geburten bzw. Abruptiones vor. 64 Prozent hatten nie geboren, 41 Prozent mindestens eine Schwangerschaft abgebrochen.

Conclusion: Durch das Testangebot werden Migranten/ innen aus einer Vielzahl von Ländern und in vielfältigen Lebenssituationen erreicht. Ein Vergleich mit Daten aus früheren Jahren ist wegen der Anonymität nicht möglich. 
Daten zur sexuellen und reproduktiven Anamnese, die in der Beratung erhoben werden können, liefern wertvolle Anhaltspunkte für die Gestaltung von Testangeboten und Präventionsbotschaften.

\section{P218}

\section{Klientenorientierte Erhebung zum HIV-Test- Angebot (Hintergründe und Motivation); Orientierung zur Verbesserung des Angebots \\ Dagmar Charrier}

\section{AIDS-AUFKLÄRUNG e.V., Frankfurt, Germany}

Material und Methode: Die Befragung richtet sich an 400 Menschen, die sich zum HIV-Test bei der AIDS-AUFKLÄRUNG e.V. entschlossen haben. Sie erfolgt anonym, durch einen einseitigen Fragebogen Die Befragung ist integriert in den Ablauf des HIV-Testes. Es sind keine Rückschlüsse zu den (ebenfalls anonymen) Datenerhebungen zu den einzelnen Klienten möglich.

Die Fragenkomplexe schließen die Bereiche Einschätzung des ,Schnell-Test-Angebots', allgemeine Einschätzung $\mathrm{zu}$ den angesprochenen Zielgruppen, persönliche Motivation, und die Einschätzung einer möglichen persönlichen Verhaltensänderung mit ein. Die AntwortMöglichkeiten sind überwiegend frei.

Erste Ergebnisse: Nach einer ersten Auswertung von 100 Befragungen schätzen eine Vielzahl der Klienten die Anonymität, die einfache und schnelle Zugänglichkeit zum Termin und die Ergebnismitteilung nach 15 Minuten, wie die guten Informationsmöglichkeiten im Vorfeld durch den Internetauftritt.

Der Blick in die Zukunft bezüglich des eigenen Verhaltens offenbart bei derzeit $96 \%$ der Befragten die Absicht, das Risiko-Verhalten zu verändern und Safer-Sex-Grundsätze zu beachten .

Schlussfolg erung: Das HIV-Test-Angebot der AIDSAUFKLÄRUNG e.V. erfährt großen Zuspruch aller Zielgruppen (vom frischverliebten Paar bis zum diskordanten Paar; vom einmaligen Seitensprung bis zur Bestätigung eines bereits erfolgten HIV-Tests). Die Befragten schätzen das niedrigschwellige, anonyme Angebot einer unabhängigen Beratungsstelle.

Insbesondere das durch Ärzte erbrachte Beratungsangebot, welches eingebettet ist in das professionelle Beratungskonzept durch Fachkräfte der sozialen Arbeit, sollte in dieser Form fortgesetzt werden .

Die intensive Betreuung im Rahmen des HIV-Tests wie auch die Erörterung des persönlichen Risikoverhaltens im Beratungsgespräch führen zu einer intensiven Auseinandersetzung mit vergangenen und aktuellen Risiken. Die Beratung ist als zukunftsweisend und als ein wichtiger Baustein zum künftigen persönlichen Risikoverhalten zu sehen und somit ein unverzichtbarer Bestandteil der Prävention.

Organisation und Hintergründe zum anonymen HIV-Antikörper-Test

Die AIDS-AUFKLÄRUNG e.V. bietet seit Mitte 2000 den anonymen HIV-Antikörpertest mit ärztlicher Beratung an. Mit über 1.000 durchgeführten Testen im Jahr 2008 (hierunter 7 nach Bestätigungstest positiv) verfügt sie über ein Angebot, dass sich wachsender Nachfrage erfreut.
P219

\section{Die Deutsch-Ukrainische Zusammenarbeit im Bereich HIV/AIDS}

\author{
Jenny Bluhm
}

Deutsche Gesellschaft für Technische Zusammenarbeit (GTZ) GmbH, Berlin, Germany

Neben der effektiven Nutzung internationaler Koordierungs- und Finanzierungsmechanismen ist die bilaterale Zusammenarbeit ein entscheidendes Instrument in der HIV/AIDS-Bekämpfungsstrategie der Bundesregierung. Die bilaterale Zusammenarbeit mit der Ukraine ist dabei ein regionaler Schwerpunkt in Osteuropa. Die Zusammenarbeit setzt auf Kooperationen auf staatlicher Ebene und auf Ebene der Zivilgesellschaft in verschiedenen Sektoren unter den Leitlinien von Nachhaltigkeit und Capacity Development. Die Inhaltlichen Schwerpunkte sind dabei Prävention, Diagnostik, Behandlung, soziale Betreuung, Pflege und Surveillance. Im Auftrag des Bundesministeriums für wirtschaftliche Zusammenarbeit und Entwicklung (BMZ) und des Bundesministeriums für Gesundheit (BMG) implementiert und koordiniert die Deutsche Gesellschaft für Technische Zusammenarbeit (GTZ) die bilaterale Zusammenarbeit mit der Ukraine im Bereich HIV/AIDS. Insgesamt stellt die Bundesregierung 2007-2010 für den Ausbau der bilateralen Beziehungen mit den zentral- und osteuropäischen Nachbarstaaten rund 8,5 Mio EUR zur Verfügung.

1. Im Rahmen der "Deutsch-Ukrainische Partnerschaftsinitiative zur Bekämpfung von HIV/AIDS" wird der Wissenstransfer und Expertenaustausch unterstützt. Neben bilateralen Projekten in den Bereichen Prävention, Diagnostik, Behandlung und Epidemiologie richtet sich die Zusammenarbeit insbesondere auf die Unterstützung der Regierung im Rahmen eines Twinningansatzes bei der Weiterentwicklung der Präventionsstrategie der Ukraine und deren Umsetzung.

2. In vier Regionen der Westukraine werden die regionalen AIDS-Koordinationsräte in der multisektoralen Koordination und Interventionsstrategieentwicklung in den Bereichen Prävention in Bildungseinrichtungen, Harm Reduction, medizinische und soziale Dienste für Menschen mit HIV unterstützt

3. In den 3 osteuropäischen Staaten Ukraine, Belarus, Moldau werden sowohl HIV/AIDS Präventionskonzepte in Berufschulen, Wohnheimen und im weiteren Lebensumfeld von Jugendlichen und jungen Erwachsenen als auch HIV/AIDS Arbeitsplatzrichtlinien entwickelt und implementiert. Parallel werden die Mittlerstrukturen bei der HIV/AIDS Strategie- und Politikentwicklung unters tützt.

Bilaterale Kooperationsprojekte führen zu langfristigen Partnerschaften mit nachhaltigen Ergebnissen und stetigem Wissenstransfer. Die Deutsch-Ukrainische Zusammenarbeit ist ein Beitrag zur Umsetzung der Erklärungen von Dublin, Vilnius und Bremen zur Reduzierung der Neuinfektionszahlen und der Verbesserung der Beratung und Behandlung von Menschen mit HIV und AIDS. 


\section{P220}

\section{Microbicide formulations in development}

Thomas Mertenskoetter, Joseph Romano, Paulina Kaptur

International Partnership for Microbicides, Silver Spring, Maryland, United States

Is sue of research/question: What microbicide formulations are currently in development for prevention of sexual transmission of HIV infection in women?

Description: Current microbicide formulations in development address many of the issues associated with the original microbicide gels such as coital dependency, frequency of usage, acceptability, compliance, cost, and adaptability to large-scale production. ARV-based microbicides in clinical trials include vaginal gels for daily use (dapivirine and UC-781) and for use before and after coitus (tenofovir) and vaginal rings for 28-day use (dapivirine). Non-ARV-based microbicides in clinical trials include PRO2000 gel (polyanionic polymer) and VivaGel ${ }^{\circledR}$ (polylysine dendrimer). Other vaginal dosage forms in earlier stages of development include the film, tablet, and soft-gel capsule. The results of clinical trials to date with vaginal gels and rings show that these dosage forms are safe and acceptable to both women and their male sexual partners. From previous study analyses (Carraguard gel), it has become evident that user compliance is difficult to measure and most probably highly variable.

Conclusion: The primary focus of microbicide formulation development is now on ARV-based drug delivery. Multiple dosage forms are available for single use and sustained release. Measurement and enhancement of adherence to microbicide use continues to be a challenge.

Next steps: Phase IIb trial results with tenofovir gel are expected in April 2010. Phase I/II trials investigating the safety profile and the pharmacokinetics and pharmacodynamics are ongoing with dapivirine vaginal gel and ring, with a Phase III trial currently scheduled for 2011. Phase I clinical trials with UC-781 gel have been completed, and data are being analyzed. Preclinical development with additional dosage forms such as vaginal tablets, films, and soft-gel capsules is in progress.

\section{P221}

\section{Internet-Plattform zur partizipativen Qualitätsentwicklung (PQE) in der HIV - Präv ention}

\section{Hellavon Unger ${ }^{1}$, Corinna Gekeler ${ }^{2}$, Martina Block ${ }^{1}$, Karl Lemmen ${ }^{2}$, Michael T. Wright ${ }^{1}$ \\ ${ }^{1}$ Wissenschaftszentrum Berlin für Sozialforschung (WZB), Forschungsgruppe Public Health, Berlin, Germany, ${ }^{2}$ Deutsche AIDS-Hilfe e.V., Berlin, Germany}

Hinterg rund: Qualitätssicherung und Evaluation haben in der HIV-Prävention der Aidshilfen bislang nur wenig systematisiert stattfinden können. Ziel eines gemeinsamen Forschungsprojekts des Wissenschaftszentrum Berlin (WZB) und der Deutschen AIDS-Hilfe e.V. war es, ein interaktives Online-Handbuch zur Qualitätssicherung und Evaluation zu entwickeln, das dem partizipativen Ansatz der HIV-Prävention in Aidshilfen gerecht wird und eine Ressource zur Verfügung stellt, um die Qualität der HIVPrävention vor Ort (weiter) zu entwickeln.
Vorgehen: Im Rahmen des von der BZgA i.A.d. BMG geförderten, zweijährigen Forschungsprojekts wurden Workshops zu Methoden der Partizipativen Qualitätsentwicklung (PQE) durchgeführt und zwölf Aidshilfen vor Ort bei der Anwendung der Methoden wissenschaftlich begleitet. Partizipativ bedeutet, die „Beteiligten" und „Betroffenen" in die Qualitätsentwicklung einzubinden, d.h. die haupt- und ehrenamtlichen Mitarbeiter/innen und die Zielgruppen der HIV-Prävention konsequent zu beteiligen. Die Ergebnisse der Workshops und der Beratungen sind in die Entwicklung der Internet-Plattform eingeflossen.

\section{Die Plattform:}

Auf der Internet-Plattform www.qualitaet.aidshilfe.de finden Praktiker/innen Konzepte, Methoden und Praxisbeispiele für die Qualitätsentwicklung der HIV-Prävention vor Ort.

Es werden Tools zur Verfügung gestellt, mit denen die Qualität der HIV-Prävention praxisnah und partizipativ entwickelt werden kann, wie z.B. die "Stufen der Partizipation" und Methoden-Steckbriefe für Fokusgruppen, Blitzbefragungen und „Open Space"-Veranstaltungen. Praxisbeispiele veranschaulichen, wie die Anwendung konkret aussehen kann und welche Erfahrungen damit gemacht wurden. In Diskussionsforen können registrierte Nutzer/innen sich austauschen und ihre Fragen und Erfahrungen einbringen.

Ausblick: Die Plattform www.qualitaet.aidshilfe.de wird in Zusammenarbeit mit den Nutzer/innen weiterentwickelt. So bietet die DAH ab 2009 auch erstmals ein dreiteiliges Curriculum zu Methoden der Partizipativen Qualitätsentwicklung $(\mathrm{PQE})$ in der HIV-Prävention an. Diese Seminare und weitere geplante Aufbaukurse zur PQE werden Inhalte zur Erweiterung der Plattform liefern.

\section{$P 222$}

\section{Nachwuchsförderung im HIVCENTER - Medizinstudenten als Zielgruppe für HIV Prävention und praktische medizinische Ausbildung}

Claudia Kircher ${ }^{1}$, Sebastian Kessler ${ }^{1}$, Nathalie Schmitz ${ }^{2}$, Tobias Kisch ${ }^{2}$, Reinhard Brodt ${ }^{3}$, Tessa Lennemann ${ }^{1}$

1Klinikum der Goethe Universität, HIVCENTER, Frankfurt am Main, Germany, 2Klinikum der Goethe Universität, Frankfurt am Main, Germany, 3Klinikum der Goethe Universität, Infektiologie, Frankfurt am Main, Germany

Hinterg rund: HIV/AIDS nimmt nicht nur in Entwicklungsländern eine bedeutende Rolle ein und ist inzwischen zu einer chronischen Erkrankung geworden, auf deren Umgang Medizinstudenten unabhängig von ihrer zukünftigen Spezialisierung vorbereitet werden müssen. Da bei der niedrigen Prävalenz in Deutschland der Umgang und die Behandlung von HIV/AIDS vor anderen Erkrankungen in der medizinischen Ausbildung in den Hintergrund tritt, bietet das HIVCENTER im Rahmen seiner internationalen Projekte Blockpraktika, Famulaturen, PJ Tertiale sowie Promotionen an seinen afrikanischen Partnerzentren in Lesotho und Süd Afrika an, in denen sie praktische Erfahrung mit HIV/AIDS machen und die Relevanz der Infektion für den eigenen medizinischen Alltag zu erkennen lernen.

Methode: Studenten der letzten klinischen Studienabschnitte erhalten die Möglichkeit, Teile der im Curriculum 
vorgesehene Ausbildungsabschnitte (Blockpraktika, Famulaturen, PJ-Tertiale) an den Partnerzentren durchzuführen. Zur Vorbereitung erhalten sie ein Training in Bezug auf HIV Übertragung und Risikomanagement sowohl privat als auch am Arbeitsplatz inklusive Postexpositionsprophylaxe.

Ergebniss : 8 Studierende absolvierten bis zu dreimonatige Praktika. Drei nutzten diese Zeit, um Datenerhebung für Ihre Promotion durchzuführen. Seit 2008 besteht eine finanzielle Unterstützung durch Teilstipendien.

Die Kombination von der Auseinandersetzung mit Symptomatik und Behandlung von HIV und der direkte Kontakt mit HIV Infizierten und deren psychosozialer Situation motivierte die Studierenden stark. Die eigene Verantwortung für einen stigmafreien Umgang und die Relevanz von Schutzmassnahmen nicht nur im klinischen Alltag wurde so erfahrbar. Inzwischen hat sich eine Eigeninitiative der Studierenden entwickelt, welche das Projekt weiterhin unterstützen will, in dem sie die Praxiserfahrung mit theoretischer Ausbildlung über Diagnostik und Therapie der HIV Infektion verbinden und die Auseinandersetzung mit dem Thema HIV durch eigenen Erfahrungs austausch fördern will. Schlussfolgerungen: Medizinstudenten sind sowohl aufgrund ihres Alters und entsprechenden Risikos als auch im Hinblick auf ihre spätere Rolle in Prävention und der Versorgung HIV Infizierter eine wichtige Gruppe, die für das Thema HIV sensibilisiert werden muss.

\section{$P 223$}

\section{„Handbuch Jugendprävention": ein neues Instrument der Qualitätssicherung in der Präventionsarbeit}

Thomas Wilke ${ }^{1}$, Phil C. Langer ${ }^{2}$, Birte Seffert ${ }^{3}$, Stefan Müller $^{3}$, Sarah Arriagada ${ }^{2}$,Robin Möser ${ }^{2}$, Stefan

Richter $^{2}$, Franziska Gutsche ${ }^{2}$, Schoolwork-Team der Berliner Aids-Hilfe e.V.

${ }^{1}$ Berliner Aids Hilfe e.V., Jugendprävention, Berlin, Germany, ${ }^{2}$ Berliner Aids Hilfe e.V., Jugendprävention 'Schoolwork', Berlin, Germany, ${ }^{3}$ Berliner Aids Hilfe e.V., Berlin, Germany

Fragestell ung: Jugendspezifische Präventionsangebote stellen einen wichtigen Teil der meisten Aidshilfen, öffentlichen Gesundheitsämter und anderer im HIV-Bereich arbeitenden NGOs dar. Trotz ihrer Bedeutung für die gesellschaftlich wichtige Aufklärung von Jugendlichen gab es bislang keine gemeinsamen inhaltlichen und methodischen Qualitätsstandards. Das durch kontinuierliche Fortbildungen zunehmend professionalisierte ehrenamtliche „Schoolwork"-Team der Berliner Aids-Hilfe e.V. hat daher in einem fast zweijährigen Diskussions- und Arbeitsprozess das „Handbuch Jugendprävention" erstellt. Über die Qualitätssicherung der Präventionsarbeit des Teams hinaus ist es insbesondere im Sinne einer vernetzenden HIV-Jugendprävention zu verstehen.

Beschreibung: Das Handbuch enthält alle für eine aktuelle und hochwertige Präventionsarbeit notwendigen fachlichen Informationen über HIV/Aids und andere sexuell übertragbare Krankheiten (STDs) und bereitet diese in Bezug auf die Vermittlung in jugendspezifischen Veranstaltungen methodisch auf. Es beinhaltet neben Grundlagenwissen zu HIV/Aids/STDs auch Leitfäden und „Drehbücher" für Präventionsworkshops sowie eine Vielzahl von Methoden und Materialien für die HIV/STD-Prävention, die zum
Großteil vom Team selbstständig für die Zielgruppe der Jugendlichen (weiter-)entwickelt und alle erfolgreich in der Praxis erprobt worden sind. Das „Handbuch Jugendprävention" richtet sich an neue wie alte Mitarbeiter/innen in der Präventionsarbeit sowie an alle potentiellen Multiplikator/innen, insbesondere Lehrer/innen und Mitarbeiter/innen in Jugend- und Freizeiteinrichtungen, Vereinen und Verbänden.

Schlussfolgerung: Das Schoolwork-Team möchte mit der Veröffentlichung des Handbuches einen wichtigen Beitrag zur weiteren Vernetzung der HIV-Jugendpräventionen im deutschsprachigen Raum leisten. Es ist ein wirkungsvolles Instrument zum Austausch von effektiven HIV-Präventionsmethoden und zur Entwicklung gemeinsamer Qualitätsstandards. Durch die Adressierung an Multiplikator/innen trägt es zum Mainstreaming der Präventionsinhalte in andere soziale Kontexte bei.

Nächste Schritte: Durch ständige Aktualisierungen und Ergänzungen des Handbuchs werden neue Erkenntnisse der biomedizinischen und sozialwissenschaftlichen Forschung für die jugendspezifische Präventionsarbeit fruchtbar gemacht. Eine Internetplattform zum Download von Methoden und Materialen wird im Februar frei geschaltet. Ein Forum zum Austausch von Erfahrungen in der Präventionsarbeit ist in Arbeit.

$$
\text { P224 (LB) }
$$

\section{HIV-Infektion im Bewusstsein von Studierenden: Ergebnisse einer Pilotstudie}

Alexander Vasilevich Kuznetsov 1,2, Laura Kouznetsov ${ }^{1}$, Uwe Matterne ${ }^{3}$, Rafael Mikolajczyk2 ${ }^{2}$, Thomas Ruzicka ${ }^{4}$, Stefan Albin Zippel ${ }^{5}$, Alexander Krämer ${ }^{6}$

${ }^{1}$ Ludwig-Maximilians-Universität München, Arbeitsgruppe HIV/STI-Präventionsforschung, Klinik und Poliklinik für Dermatologie und Allergologie, München, Germany,

${ }^{2}$ Universität Bielefeld, Arbeitsgruppe Bevölkerungsmedizin und biomedizinische Grundlagen, Fakultät für Gesundheitswissenschaften, Bielefeld, Germany, ${ }^{3}$ Ruprecht-Karls Universität Heidelberg, Abteilung Klinische Sozialmedizin, Heidelberg, Germany, ${ }^{4}$ Ludwig-MaximiliansUniversität München, Klinik und Poliklinik für Dermatologie und Allergologie, München, Germany, ${ }^{5}$ Ludwig-MaximiliansUniversität München, Arbeitsgruppe HIV/STI-

Präventionsforschung, München, Germany, ${ }^{6}$ Universität Bielefeld, Arbeitsgruppe Bevölkerungsmedizin und biomedizinische Grundlagen, Fakultät für Gesunsheitswissenschaften, Bielefeld, Germany

Hinterg rund: Studierende und Jugendliche gehören aufgrund ihrer hohen sexuellen Aktivität und des jungen Alters weltweit zur gefährdeten Gruppe bezüglich sexuell übertragbarer Krankheiten (STD) einschließlich HIV-Infektion. Wir präsentieren die Ergebnisse einer postalischen anonymen Pilotbefragung zum Thema HIV/AIDS bei deutschen Studierenden an einer der größten Universitäten Deutschlands, der Universität München.

Methodik: Von zufällig ausgewählten und angeschriebenen Studierenden $(\mathrm{N}=1000)$ nahmen 298 an der Befragung teil. Der Fragebogen bestand aus Fragen zur Soziodemografie, zum Verhalten einschließlich Kondomgebrauch sowie zum HIV-Wissen.

Resultate: Die meisten Teilnehmer waren jünger als 24 Jahre alt $(65 \%)$, weiblich $(68,1 \%)$, ledig $(55,4 \%)$ oder in Partnerschaft lebend $(38,3 \%) .93 \%$ berichten schon 
Geschlechtsverkehr (GV) gehabt zu haben (Durchschnittsalter beim ersten GV 17,6 Jahre); $65,1 \%$ in den letzten 12 Monaten mit bis zu zwei verschiedenen Partnern. 44,3\% berichteten mindestens einmal ungeschützten Geschlechtsverkehr und benutzten beim letzten Verkehr kein Kondom. Ein Kondom wurde immer $(15,1 \%)$, oft $(20,8 \%)$, manchmal $(16,8 \%)$, gelegentlich $(24,2 \%)$, oder nie $(14,8 \%)$ benutzt; am meisten beim Vaginalverkehr $(60,4 \%)$, seltener beim Anal- $(12,1 \%)$ oder Oralverkehr $(2,7 \%)$ und vor allem zum Schutz vor Schwangerschaft $(62,8 \%)$ sowie vor HIV/AIDS $(52,7 \%)$. Bei Nichtverwendung eines Kondoms wurden feste Sexualbeziehungen $(62,4 \%)$, andere Schutzmethoden $(40,6 \%)$ sowie kein HIV/STD-Risiko $(16,1 \%)$ angegeben. $38,9 \%$ der Studierenden hatten bereits einen HIV-Test machen lassen. HIV/AIDS wurde in 30,9\% als Geschlechtskrankheit angesehen. Die meisten Studierenden (70-99\% abhängig von Variablen) waren über die üblichen HIVÜbertragungswege und Präventionsmaßnahmen informiert. Es wurden ein HIV-Wissensindex (HWI) und ein HIVRisikowissensindex (HRWI) errechnet. Geistwissenschaftler $(14,81 \mathrm{HWI})$ wussten signifikant $(\mathrm{p}<0,05)$ weniger als Mediziner/Naturwissenschaftler (15,34 HWI).

Schl ussfolgerung en: Obwohl das HIV/AIDS-Wissen bei Studierenden vorhanden ist, wird ein Kondom nicht immer benutzt. Ein eigenes Risiko für eine HIV-Infektion wird unterschätzt. Bei der HIV-Prävention bei Studierenden sollte stärker auf den Kondomgebrauch eingegangen werden.

\section{Epidemiologie / Epidemiology} P300

\section{Molecular epidemiology reveals long-term changes in HIV-1 transmission in S witzerl and}

Roger Kouyos ${ }^{1}$, Viktor von Wyl ${ }^{1}$, Sabine Yerly ${ }^{2}$, Jürg Böni ${ }^{3}$, Patrick Taffé ${ }^{4}$, Cyril Shah ${ }^{3}$, Philippe Bürgisser ${ }^{5}$, Thomas Klimkait ${ }^{6}$, Rainer Weber ${ }^{1}$, Bernard Hirschel ${ }^{7}$, Matthias Cavassini ${ }^{5}$, Hansjakob Furrer ${ }^{8}$, Manuel Battegay ${ }^{9}$, Pietro Vernazza ${ }^{10}$, Enos Bernasconi ${ }^{11}$, Rickenbach Martin ${ }^{4}$, Bruno Ledergerber ${ }^{1}$, Sebastian Bonhoeffer ${ }^{12}$, Huldrych Günthard ${ }^{1}$, The Swiss HIV Cohort Study

${ }^{1}$ Division of Infectious Diseases and Hospital Epidemiology, University Hospital Zurich, Zurich, Switzerland, ${ }^{2}$ University Hospital Geneva, Geneva, Switzerland, ${ }^{3}$ Swiss National Center for Retroviruses, University of Zurich, Zurich, Switzerland, ${ }^{4}$ Swiss HIV Cohort Study Data Center, Lausanne, Switzerland, ${ }^{5}$ Division of Immunology, University Hospital Lausanne, Lausanne, Switzerland, 6 Institute for Medical Microbiology, University of Basel, Basel, Switzerland, ${ }^{7}$ Division of Infectious Diseases, Geneva University Hospital, Geneva, Switzerland, ${ }^{8}$ Division of Infectious Diseases, University Hospital Berne, Berne, Switzerland, ${ }^{9}$ Division of Infectious Diseases and Hospital Epidemiology, University Hospital Basel, Basel, Switzerland, ${ }^{10}$ Division of Infectious Diseases, Cantonal Hospital St. Gallen, St. Gallen,

Switzerland, ${ }^{11}$ Division of Infectious Diseases, Regional Hospital Lugano, Lugano, Switzerland, ${ }^{12}$ Institute of Integrative Biology, ETH Zurich, Zurich, Switzerland

The wealth of sequence data from genotypic resistance testing offers unique opportunities to investigate the structure of the HIV-1 epidemic. We used a representative set of HIV1 sequences from 5710 patients enrolled in the Swiss HIV
Cohort Study to investigate the structure of the Swiss HIV1 epidemic. These sequences were pooled with the same number of sequences from foreign epidemics, a phylogenetic tree was inferred, and Swiss transmission chains were identified as clusters that had a minimal size of 10 and contained at least $80 \%$ Swiss sequences. More than half (56\%) of the Swiss sequences were included within 72 clusters. Most of these were significantly dominated by specific transmission routes, which were either men having sex with men (MSM) [37 clusters, average size 31 patients] or patients who have acquired HIV through heterosexual contacts (HET) or injecting drug use (IDU) [14 clusters, average size 130 patients]. Thus, IDU and HET segregated into fewer, but larger clusters compared with MSMs, suggesting more sub-epidemics and smaller transmission chains for MSM. Mixing between transmission groups was observed frequently for HET patients in MSM clusters (13\%), but rarely for MSM patients in IDU-HET clusters (5\%) and IDUs in MSM clusters (3\%). While $51 \%$ of all HET patients infected between 1983-1986 were clustering with IDUs, this percentage was only 9\% in later years (2003-2006, p-trend $<0.001$ ), suggesting a diminishing role of IDUs on the HET epidemic over time. This decline is also reflected in decreasing absolute numbers of newly infected HETs contained in IDU-HET clusters. Thus, we conclude that prevention measures targeted at IDUs can result in substantial alleviations for other transmission groups as well.

\section{P301 (PW)}

\section{HIV-serosorting among German men who have sex with men: Implications for community prevalence of STIs and HIV-prevention}

Axel J.Schmidt ${ }^{1}$,Ulrich Marcus ${ }^{2}$, Jürgen Töppich $^{3}$,
Michael Bochow ${ }^{1}$

${ }^{1}$ Wissenschaftszentrum Berlin für Sozialforschung, Forschungsgruppe Public Health, Berlin, Germany, ${ }^{2}$ Robert Koch-Institut, Infektionsepidemiologie, Berlin, Germany,

${ }^{3}$ Bundeszentrale für gesundheitliche Aufklärung, Köln, Germany

Background: Serosorting, i.e. seeking to only engage in sexual activities with partners of concordant HIV serostatus, has been described as a risk reduction strategy increasingly used by men who have with men (MSM). If replacing condom use, implications of this practice for the risk of HIV-transmissions are controversial. Few data exist on the effect of serosorting on the incidence of bacterial STIs (bSTIs)

Methods: In 2007, a self-administered questionnaire was distributed via magazines and internet sites for MSM. 8,170 questionnaires were analyzed. Adjusted Odds Ratios were calculated to estimate the impact of serosorting on incident bSTIs and HIV.

Results: A substantial minority of respondents engaging in anal intercourse with casual partners reported their last intercourse was unprotected because of presumed seroconcordancy (self-reported HIV-negative: 16\%; HIV-positive: $20 \%$ ). Pure guessing accounted for $55 \%$ of serostatus estimates among HIV-positive, and $36 \%$ among HIV-negative MSM. However, among MSM not diagnosed HIV-positive, $62 \%$ had a test result older than 18 months or were untested. Contrastingly, $3 \%$ of HIV-negative, but $21 \%$ of HIV- 
positive MSM reported serosorting as a main risk reduction 'strategy'.

Compared with traditional safer sex strategies and adjusted for the number of sexual partners, serosorting was strongly associated with recent bSTIs among HIV-positive MSM (OR=4.3;95\%-CI:2 .2-8.3); and recent HIV-seropositivity among participants with a recent HIV-test $(\mathrm{OR}=$ 5.0;95\%-CI:2.7-9.4)

Recent syphilis was reported by $26 \%$ with recent positive; and by $3 \%$ with recent negative HIV-test, suggesting high rates of co-infections.

Conclusions: Serosorting is common among German MSM, but qualifies as 'strategic' only among HIV-positive MSM. However, serosorting is frequently based on assumptions instead of disclosure. (Effective) serosorting among HIV-positive MSM increases incidence and prevalence of bSTIs, and hence per-contact-risk for HIV-transmission. Serosorting among MSM who assume to be HIV-negative is highly ineffective and may further increase the risk for HIV-transmissions.

\section{$P 302(P W)$}

First preliminary results and operational findings from the German HIV incidence study at Robert Koch-Institute

Ruth Zimmermann ${ }^{1}$, Jörg Bätzing-Feigenbaum ${ }^{1}$, Stephan Loschen ${ }^{2}$, Silvia Gohlke-Micknis ${ }^{1}$, Oscar Kamga Wambo ${ }^{1}$, Claudia Kücherer ${ }^{2}$, Osamah Hamouda ${ }^{1}$

${ }^{1}$ Robert Koch-Institute, Infectious Disease Epidemiology, Berlin, Germany, ${ }^{2}$ Robert Koch-Institute, HIV Variability and Molecular Epidemiology, Berlin, Germany

Background: BED-CEIA has been shown to detect recent (incident) HIV-infections in newly diagnosed patients. After piloting the study in Berlin a nation-wide survey for recent HIV infections and related KABP-data collection ("knowledge, attitudes, behaviour, practices") was initiated in 2008 to identify current risk behaviours and populations at increased risk.

Method: Clinical and laboratory data are collected from a representative sample of all newly HIV-diagnosed patients in Germany in a cross-sectional study; according blood samples are tested for recency of infection $(<140$ days $)$ using BED-CEIA.

An additional case-control study collects blood samples, clinical and KAPB-data from patients with newly diagnosed HIV-infections and matched HIV-neg ative controls .

Result: From 1.580 samples in the cross-section (February-July 2008) 640 were identified as eligible new HIV-diagnoses, among these $80 \%(n=511)$ male and $20 \%(n=127)$ female. Among men $33 \%$ of samples were found recently infected with the highest proportions in men having sex with men (MSM) (37\%) and intravenous drug users (IDU) $(36 \%)$. Female samples were incident in $25 \%$. In patients from HIV-high-prevalence countries (HPC) recent infections contributed $9 \%$. Recent infections in MSM were predominantly found in the age-group 20-29 years (46\%; $\mathrm{n}=46 ; \mathrm{p}=0.01$ ), less frequently in older age-groups. This correlation with age was not found for other transmission risk. The case-control arm included 116 newly diagnosed HIV cases (March-September 2008; 103 male, 13 female) mainly from MSM and heterosexuals, so far detecting a higher recency proportion (56\%) in heterosexuals than expected from the cross-section.
Conclusion: First preliminary data show the highest proportions of recent HIV-infections in MSM and IDU compared with other transmission risk categories. Especially MSM aged $<30$ years revealed a high proportion of recent infections. The case-control arm faces operational challenges: to analyse risk behaviours in all populations at risk additional recruitment of patients, mainly IDU and HPC cas es, is needed.

\section{$P 303(P W)$}

Epidemiology of herpes simplex virus infections (HSV) in a cohort of recently HIV-1 infected patients from the German HIV-1 seroconverter study

Christina Lindemann ${ }^{1}$, Claudia Houareau ${ }^{1}$, Nadine Spielmann ${ }^{1}$, Barbara Bartmeyer ${ }^{1}$, Claudia Kücherer ${ }^{2}$, Osamah Hamouda ${ }^{1}$, German HIV-1 Seroconverter Group

${ }^{1}$ Robert Koch-Institute, Department for Infectious Disease Epidemiology, HIV/AIDS, STI Unit, Berlin, Germany, ${ }^{2}$ Robert Koch-Institute, Project HIV Variability and Molecular Epidemiology, Berlin, Germany

Objective: We investigated the seroprevalence of HSV-1 and HSV-2 in patients with a known date of HIV-infection in the German HIV-1 Seroconverter Study.

Methods: The German HIV-1 Seroconverter Study is a prospective multi-center nationwide open cohort study conducted since 1997. Individuals with a last negative and first positive HIV-antibody test within a maximum 3 year interval and individuals with an acute seroconversion defined by laboratory criteria were classified as HIV-seroconverters. In this sub-analysis we screened ART-naïve, inital blood samples for HSV-1-IgG and HSV-2-IgG and $\operatorname{IgM}$ (EIA, Euroimmun, Germany). We compared initial CD-4 cell counts and plasma viral load measurements among HSV-2 positive and negative patients.

Resul ts : A total of 1,083 (94.4\% male) patients were included. Transmission-group categories included: Men having sex with men (MSM) (82.0\%), followed by heterosexuals (HET) (16.4\%) and persons originating from high prevalence countries (HPC) $(2.1 \%)$ and intravenous drug users (IDU) $(1.6 \%)$. The overall prevalence for HSV-1 was $89.7 \%(\mathrm{~N}=952 / 1,083)$, for HSV-2- $\operatorname{IgG} 38.0 \%(\mathrm{~N}=$ $388 / 1,083)$ and for HSV-2-IgM $11.8 \%(\mathrm{~N}=124 / 1,083)$. Positive for both, HSV-2-IgG/ $-\operatorname{IgM}$, were $16.5 \%(\mathrm{~N}=61)$ of our HSV-2 positive patients. The highest prevalence of HSV-2-IgG was found in HPC $(\mathrm{N}=19 / 23)$, followed by HET $(\mathrm{N}=29 / 66)$, MSM $(\mathrm{N}=326 / 888)$ and IDU $(\mathrm{N}=6 / 17)$. Females had a higher chance to be infected with HSV-2 (OR = $2.04 ; 95 \% \mathrm{CI}=1.17 ; 3.58)$ than males. Initial immunological and virological parameters did not differ significantly between HSV-2 positive and negative patients (CD4 cells $/ \mu 1, \mathrm{p}=0.3 ;$ HIV-RNA copies $/ \mathrm{ml}, \mathrm{p}=0.2$ ).

Discussion: Both HSV types were highly prevalent (89.7\% HSV-1, 38.0\% HSV-2) in our cohort. The high proportion of positive HSV-2-IgM indicates recent HSV-2 infections among HIV-seroconverters. Our results support the fact that HSV-2 infections may contribute to the susceptibility to and transmission of HIV-infection in Germany. Prevention programs should address the role of HSV-2 in HIV-infection. 


\section{P304 (PW)}

Line-immunoassay - based differentiation of recent and older HIV-1 infection among all newly diagnosed patients in Switzerland

Jörg Schüpbach ${ }^{1}$, Christoph Niederhauser ${ }^{2}$, Sabine Yerly ${ }^{3}$, Stephan Regenass ${ }^{4}$, Lukas Matter ${ }^{5}$, Philippe Bürgisser ${ }^{6}$, Meri Gorgievski ${ }^{7}$, Ing rid Steffen ${ }^{8}$, Corinne Andreutti ${ }^{9}$, Detlev Schultze ${ }^{10}$, Gladys Martinetti ${ }^{11}$, Simone Schulze ${ }^{12}$, Martin Gebhardt ${ }^{13}$

${ }^{1}$ Universität Zürich / Institut für Medizinische Virologie, Nationales Zentrum für Retroviren, Zürich, Switzerland,

${ }^{2}$ Blutspendedienst SRK, Bern, Switzerland, ${ }^{3}$ Université de Genève / Laboratoire Central de Virologie, Genève, Switzerland, ${ }^{4}$ Universitätsspital Zürich / Klinik für Immunologie, Zürich, Switzerland, ${ }^{5}$ Viollier AG, Basel, Switzerland, ${ }^{6} \mathrm{CHUV} /$ Service d'Immunologie et d'Allergie, Lausanne, Switzerland, ${ }^{7}$ Universität Bern / Institut für Infektionskrankheiten, Bern, Switzerland, ${ }^{8}$ Institut für Med. Mikrobiologie der Universität Basel, Basel, Switzerland, ${ }^{9}$ Clinique de la Source, Laboratoire, Lausanne, Switzerland, ${ }^{10}$ Institut für klinische Mikrobiologie und Immunologie, St. Gallen, Switzerland, ${ }^{11}$ Istituto Cantonale di Microbiologia, Bellinzona, Switzerland, ${ }^{12}$ FutureLab Dr. Güntert, Luzern, Switzerland, ${ }^{13}$ Bundesamt für Gesundheit, Bern, Switzerland

Background: Knowledge of recent infections is fundamental to HIV surveillance. We recently developed algorithms (Alg) which, based on the reaction intensity of a patient's antibodies to five HIV-1 antigen bands on the InnoLia HIV I/II Score confirmation assay, can distinguish between infections of less or more than 12 months duration in a study population. One of these algorithms, Alg12, exhibited $50.3 \%$ sensitivity and $95 \%$ specificity in a baseline study conducted in July 05-June 06 (PLoS Med 2007;4: e343). In the present, prospective study we applied Alg 12 to all patients newly diagnosed with HIV-1 in Switzerland in Sep07-Aug08 and compared the results to those of the baseline study.

Methods: Inno-Lia band pattern of all newly diagnosed HIV-1 cases was notified under code to the Swiss Federal Office of Public Health where it was linked with likewise coded epidemiologic information received from the patient's treating physician.

Results: There was a total of 639 new HIV-1 notifications. Alg 12-based recency as sessment classified 20.2\% of these as recent, compared to $17.4 \%$ of the 748 cases in the baseline study. Based on Alg12's sensitivity and specificity, the number of recent HIV-1 infections in Sep07-Aug08 was back-calculated as 214 , compared to 204 at baseline. Recent infections/older infections in Sep07-Aug08 versus baseline were $91 / 89$ vs. $125 / 119$ for MSM, 15/8 vs. 14/40 for IDU, $64 / 175$ vs. $40 / 258$ for HET (p=.047), and 44/153 vs. $25 / 127$ for other or unknown risk.

Conclusions: The $15 \%$ decrease in HIV-1 notifications observed in the present study was due to reduced numbers of newly diagnosed older infections among MSM, IDU and HET, and also of recent infections among MSM. Recent infections remained stable among IDU, but increased significantly among HET. Inno-Lia based recency assessment can identify covert changes in HIV-1 transmission patterns. Its regular application on an annual basis should significantly improve HIV surveillance.

\section{$P 305(P W)$}

Stable percentages of CD4+ and CD8+ T-cell in Elite Controllers, but not intermediate Controllers of HIV-1 replication

Clara Lehmann ${ }^{1}$, Pia Flossdorf ${ }^{1}$, Dirk Meyer-Olson ${ }^{2}$, Reinhold E. Schmidt ${ }^{2}$, Pavel Khaykin ${ }^{3}$, Stefan Mauss ${ }^{4}$, Jan van Lunzen ${ }^{5}$, Christoph Stefan ${ }^{3}$, Juergen

Rock stroh ${ }^{6}$, Pia Hartmann ${ }^{1}$, Gerd Fätk enheuer ${ }^{1}$, German NaViC Study group

${ }^{1}$ Klinik I für Innere Medizin, Klinische Infektiologie, Koeln, Germany, ${ }^{2}$ Medizinische Hochschule Hannover, Klinik für Immunologie und Rheumatologie, Hannover, Germany, 3 Johann Wolfgang Goethe-Universität Frankfurt,

Medizinische Klinik II, Frankfurt, Germany, ${ }^{4}$ Zentrum für HIV und Hepatogastroenterologie, Düsseldorf, Germany, ${ }^{5}$ Universitätsklinikum Hamburg- Eppendorf,

Ambulanzzentrum, Hamburg, Germany, ${ }^{6}$ Medizinischen

Universitätsklinik Bonn, Innere-Rheuma-Tropen Ambulanz, Bonn, Germany

Background: The objective was to determine whether there is a non-detrimental level of plasma viremia (pVL) in Long-Term Non-Progression and to determine whether individuals with undetectable $\mathrm{pVL}$ are protected against $\mathrm{CD}^{+}$ T-cell loss.

Methods: 34 patients from a database of more than 6000 patients met the definition of Elite Controller (EC, $n=19$ ) or Intermediate Controller (IC, $\mathrm{n}=15)$. We defined 2 groups. EC: $\mathrm{CD}^{+} \mathrm{T}$-cells $\geq 500 / \mathrm{uL}, \mathrm{pVL}<50$ copies $/ \mathrm{mL}$. IC: CD4+ T-cells $\geq 500 / \mathrm{uL}, \mathrm{pVL} 50-2000$ copies $/ \mathrm{mL}$. The minimum follow-up was 1 year, with at least $3 \mathrm{CD}^{+}{ }^{+} \mathrm{T}$ cell counts and three $\mathrm{pVL}$ available for analysis. Exclusion criteria: any confirmed $\mathrm{pVL}>50$ copies $/ \mathrm{mL}$ for $\mathrm{EC}$ and $>2000$ copies/mL for IC, initiation of ART or interleukin-2 treatment.

Results: Median time since HIV-diagnosis was 11 years [2-17] and 3.5 years [2-10.5] for EC and IC, respectively. At baseline, median $\mathrm{CD}^{+}{ }^{+}$and $\mathrm{CD} 8{ }^{+} \mathrm{T}$-cells did not significantly differ between groups. CD4 ${ }^{+} \mathrm{T}$-cell counts and percentage were $880 / \mu 1$ and $39 \%$ [576-1056, 34-41\%] vs. $762 / \mu 1$ and $37 \%[562-983,31-43 \%]$ in EC and IC, respectively. CD $8+$ T-cell counts and percentage were $826 / \mu 1$ and $39 \%$ [709 to $1230,35-48 \%]$ vs. $1059 / \mu 1,42 \%$ [580-1210, $27-53 \%]$ in EC and IC respectively $(\mathrm{p}>0.05)$. While absolute numbers of $\mathrm{CD}^{+}$and $\mathrm{CD} 8+{ }^{+} \mathrm{T}$-cells did not change over time in either patient group $(\mathrm{p}>0.05)$, we observed a significant decrease of CD4+ T-cell percentage (38\% [29$41]$ vs. $31 \%$ [28-34]; $\mathrm{p}=0.0002)$ and increase of $\mathrm{CD} 8+\mathrm{T}-$ cell percentage ( $38 \%[34-54]$ vs . $47 \%$ [34-60]; $p=0.0016)$ in IC - but not in EC - over time.

Conclusions: In ECs, the percentage of CD4+ T-cell remains stable with long-term follow-up. The small, but significant, decrease in the percentage of $\mathrm{CD}^{+}{ }^{+} \mathrm{T}$-cells in IC seems to be related to HIV replication. We conclude that there is no "safe" level of HIV replication. 


\section{P306}

\section{Risk factors for HIV associated Hodgkin's lymphoma during HAART in a large observational study (ClinSurv)}

Alex an der Zoufaly ${ }^{1}$, Hans-Jürgen Stellbrink ${ }^{2}$, Matthias an der Heiden ${ }^{3}$, Christian Kollan ${ }^{3}$, Christoph Wyen ${ }^{4}$, Christian Hoffmann ${ }^{2}$, Jan van Lunzen ${ }^{5}$, Os am ah Hamouda ${ }^{3}$

${ }^{1}$ Universitätsklinikum Hamburg-Eppendorf, I. Medizinische Klinik, Hamburg, Germany, ${ }^{2}$ IPM Study Center, Hamburg, Germany, ${ }^{3}$ Robert Koch-Institut, Berlin, Germany, ${ }^{4}$ Universität zu Köln, Köln, Germany, ${ }^{5}$ Universitätsklinikum Hamburg-Eppendorf, Hamburg, Germany

Background: Incidence rates for HIV associated Hodgkin's lymphoma (HL) have increased since the introduction of HAART. In this cohort analysis we aimed to analyze risk factors for development of Hodgkin lymphoma during HAART. Methods: Data of all patients receiving HAART within the German ClinSurv cohort were analyzed. Patients were followed from initiation of HAART until HL diagnosis, last visit, or December 2007. Characteristics of incident HL cases were compared with those of NHL cases. Risk factors for the development of $\mathrm{HL}$ in the entire cohort were analyzed using a multivariable Cox model .

Results: A total of $53 \mathrm{HL}$ and $118 \mathrm{NHL}$ were identified. HL occurred at a median of 989 (IQR 534-1602) and NHL at 606 days (IQR 227-1642, $\mathrm{p}=0.04)$. In the HL group a prior AIDSdefining condition was more frequent $(64.3 \%$ vs. $43.1 \%$, $\mathrm{p}=0.04$ ) and more patients had an undetectable viral load at diagnosis $(60.9 \%$ vs. $44.8 \%, \mathrm{p}=0.07)$. No significant differences were observed with respect to age, sex, transmission risk, or CD4 nadir. Analysis of risk factors for HL in a Cox model (based on 42.405 person years of follow-up on HAART) suggested a modest risk at a latest CD4 count of $0-100$ cells $/ \mu 1$ (HR 3.05, 95\% CI 0.96-9.65, p = 0.06), the highest risk at 100 200 CD4 cells $/ \mu 1$ (HR 6.10, 95\%CI 2.72-13.69, $\mathrm{p}<0.001$ ) and a somewhat lower risk at 200-300 CD4 cells (HR 3.25, 95\% CI 1.37- 7.67, $\mathrm{p}=0.007$, reference $>400 \mathrm{CD} 4$ cells $/ \mu 1)$. No impact of age, sex, CD4 nadir, or latest viral load was observed. Conclusion: HL share many features with NHL in HIV infection, but diagnosis occurs later after HAART initiation. In addition, risk for $\mathrm{HL}$ culminates at moderate stages of immune dysfunction as opposed to NHL underlining the different biology of both tumors.

\section{P307}

The connection domain mutation N348I in HIV-1 reverse transcriptase may compensate for $\mathrm{M184} \mathrm{V}$-mediated deficits in viral fitness

Viktor von Wyl' ${ }^{1}$, Maryam Ehteshami ${ }^{2}$, Philippe Bürgisser ${ }^{3}$, Monique Nijhuis ${ }^{4}$, Lisa Demeter ${ }^{5}$, Sabine Yerly ${ }^{6}$, Jürg Böni $^{7}$, Thomas Klimkait ${ }^{8}$, Matthias Götte ${ }^{2}$, Huldrych Günthard $^{9}$, and the Swiss HIV Cohort Study (SHCS)

${ }^{1}$ University Hospital Zurich, Zurich, Switzerland, ${ }^{2}$ McGill University, Montreal, Canada, ${ }^{3}$ Lausanne University Hospital, Lausanne, Switzerland, ${ }^{4}$ University Medical Center, Utrecht, Netherlands, ${ }^{5}$ University of Rochester Medical Center, Rochester, United States, ${ }^{6}$ Geneva University Hospital, Geneva, Switzerland, ${ }^{7}$ University of Zurich, Zurich, Switzerland, ${ }^{8}$ University of Basel, Basel, Switzerland, ${ }^{9}$ University Hospital Zurich, Zürich, Switzerland

Background: The connection domain (CD) mutation N348I in HIV-1 reverse transcriptase (RT) has been associ- ated with resistance to zidovudine (AZT) and nevirapine (NVP). This mutation is often observed together with thymidine analogue mutations (TAMs) and/or M184V, which confers resistance to lamivudine (3TC). Recent studies suggest that N348I can amplify excision of AZT in the presence of TAMs, while its effects in the context of M184V remain elusive.

Methods: Genotypic data from patients receiving their first antiretroviral therapy (ART) with either AZT, 3TC, or AZT/3TC from the SHCS and two clinical trials (ACTG 320; 3 TC mono therapy phase I/II) were pooled. Rates of emergence of N348I were compared between treatment groups using Poisson regression.

Results: The complete pooled data set consisted of 1027 genotypic sequences from 818 ART-experienced patients, of which only 54 (AZT), 11 (3TC), and 10 (AZT/3TC) fulfilled the selection criteria. Median time from ART initiation to genotypic testing was 1.3 years and did not differ between groups (Kruskal-Wallis $\mathrm{p}=0.45$ ). N348I was observed in 3 (5.6\%; AZT), 0 (3TC) and 4 (40\%; AZT/3TC) patients and never occurred in absence of TAMs or M184V. However, of the 7 viral samples with N348I detected, 3 $(42 \%)$ and $7(100 \%)$ would have been classified as sensitive to AZT and NVP, respectively, with the current version of the Stanford algorithm (4.3.6). The rate of N348I emergence was 7-fold higher in patients receiving AZT/3TC (15.9 [95\% Confidence Interval 4.3-40.8] per 100 personyears on ART) compared with patients receiving AZT only (2.3 [0.5-6.7], likelihood ratio $\mathrm{p}=0.01)$.

Conclusion: The selection of N348I appears to be driven by AZT, but strongly facilitated when 3TC is added, which indicates compensatory interaction effects between the N348I and M184V mutations. The clinical relevance of these findings remains to be determined.

\section{$P 308$ (PD)}

Prognostic factors of survival in HIV-infected individuals with progressive multifocal leukoencephal opathy

Nina Khanna ${ }^{1}$, Luigia Elzi ${ }^{1}$, Nicolas Müller ${ }^{2}$, Christian Garzoni ${ }^{3}$, Christoph Fux ${ }^{4}$, Matthias Cavas sini ${ }^{5}$, Pietro Vernazza ${ }^{6}$, Enos Bernasconi ${ }^{7}$, Manuel Battegay ${ }^{1}$, Hans H. Hirsch ${ }^{8}$

${ }^{1}$ University Hospital Basel, Infectious Diseases and Hospital Epidemiology, Basel, Switzerland, ${ }^{2}$ University Hospital Zurich, Infectious Diseases and Hospital Epidemiology, Zurich, Switzerland, ${ }^{3}$ University Hospital Geneva, Geneva, Switzerland, ${ }^{4}$ University Hospital Bern, Bern, Switzerland, ${ }^{5}$ University Hospital Lausanne, Lausanne, Switzerland,

${ }^{6}$ Regional Hospital St. Gallen, St. Gallen, Switzerland, ${ }^{7}$ Regional Hospital Lugano, Lugano, Switzerland, ${ }^{8}$ University of Basel, Basel, Switzerland

Background: Progressive multifocal leukoencephalopathy (PML) is a rare demyelinating disease caused by lytic infection of JC virus (JCV) in the central nervous system and is associated with a poor prognosis. PML has been consistently diagnosed in patients with primary and secondary immunodeficiency particularly in HIV-1 infected patients. Risk factors for mortality in patients with PML were defined.

Methods: All HIV-1 infected persons participating in the Swiss HIV Cohort Study diagnosed with PML with a premortem diagnosis and available CD4 T-cell counts were in- 
cluded. PML diagnosis was checked by chart review. Mortality was classified as PML-attributable when directly associated with PML and all other causes were excluded. According to the introduction of combination antiretroviral therapy (cART), 2 calendar periods were defined: 19881995 and 1996-2007. Cox proportional hazard models were used to estimate the hazard ratios (HR) of PML-attributable death during the first year after diagnosis of PML.

Results: A total of 159 patients were included. Eightynine patients (56\%) were diagnosed before 1996 and 70 patients (44\%) after 1996. Patients diagnosed before 1996, had more prior AIDS-defining conditions $(\mathrm{p}=.009)$, but similar CD4 T-cell counts. PML-attributable 1-year mortality rate was 82.3 (95\% (confidence interval (CI) 58.8115.1 ) in the pre-cART period versus 37.6 (95\% CI 23.$60.5)$ per 100 patient-years in the cART period. In the multivariate analysis, PML-attributable mortality was significantly reduced by cART $(\mathrm{p}<.001$; HR $0.15,95 \%$ CI, 0.05 $0.44)$, whereas all-cause mortality was associated with baseline CD4 T-cell counts ( $\mathrm{p}=.004$; HR 0.35 , 95\% CI, $0.17-0.72$ per $100 \mathrm{CD} 4 \mathrm{~T}$-cells $/ \mu 1$ increase) and cART $(\mathrm{p}=.013$; HR 0.52, 95\% CI, 0.31-0.87).

Conclusions: cART has improved the prognosis of PML. PML-attributable mortality is irrespective of baseline CD4 T-cell counts and HIV RNA.

\section{P309}

\section{Patients in Mafeteng on Antiretroviral Therapy (PIMA) - a cross-sectional study of patients receiving antiretroviral treatment (ART) in Lesotho}

Claudia Kircher ${ }^{1}$, Piet Mc Pherson ${ }^{2}$, Mtate Tsasanyana ${ }^{3}$, Me Rantequa ${ }^{3}$, Jan Bergmann ${ }^{1}$, Reinhard Brodt ${ }^{4}$, Shlomo Staszewski ${ }^{1}$, Tessa Lennemann ${ }^{1}$

${ }^{1}$ Hospital of the Goethe University Frankfurt/Main, HIVCENTER, Frankfurt am Main, Germany, ${ }^{2}$ Ministry of Health and Social Welfare of the Kingdom of Lesotho, Maseru, Lesotho,

${ }^{3}$ Mafeteng Government Hospital, KARABONG Clinic,

Mafeteng, Lesotho, ${ }^{4}$ Hospital of the Goethe University Frankfurt/Main, Department of Infectiology, Frankfurt am Main, Germany

Background: With $23 \%$ HIV prevalence, Lesotho initiated a nation wide ART program in 2004 to provide CD4 guided HIV treatment aligning with the WHO public health approach. The PIMA study presents first virological, clinical and immunological data on therapy outcome on district level.

Methods : PIMA crossectionally assessed 199 adult HIV infected patients after at least 12 months on ART at the Mafeteng Government Hospital in Lesotho. At study visit, clinical and retrospective data were assessed and plasma samples collected for virological analysis.

Results : $148(74 \%)$ female and 51 (26\%) male patients were included. The median age was 38 (range $16-68$ ). Median CD4 count at treatment initiation was 97 cells $/ \mathrm{mm}^{3}$ with women presenting with higher CD4 cell count (103 cells $\left./ \mathrm{mm}^{3}\right)$ than men $\left(67\right.$ cells $\left./ \mathrm{mm}^{3}\right)$. Medical history assessed at study visit identified 2358 clinical events, of which 261 were classified as CDC class B and 273 as CDC class $\mathrm{C}$, of which the most common were tuberculosis $(36 \%)$, followed by wasting syndrome (34\%) respectively. Treatment initiation showed a fast decline of B diagnosis- from $202(77 \%)$ prior ART initiation to 59 (23\%) after treatment initiation- and C diagnosis from 232 (85\%) to 41 $(15 \%)$ after treatment initiation.

$97 \%$ of patients initiated treatment with D4T, 3TC and NVP. 61 patient switched regime, 49 due to toxicity. Peripheral neuropathy was the main indicator for treatment change. When using the WHO definitions of clini$\mathrm{cal} / \mathrm{immunological}$ failure, 11/199 patients could be identified. Nevertheless, they did not correspond to the 17/199 patients who failed virologically.

Discussion: This first assessment of the national ART program in Lesotho indicates efficacy despite restricted resources and severely ill patients at treatment initiation. Nevertheless, it becomes clear that clinical and immunological definitions of failure do not identify virologic failure of therapy and ART associated side effects remain to be addressed.

\section{$P 310(P D)$}

\section{Todesurs achen von HIV-Patienten in der Köln-Bonn Kohorte}

Caroline Hertenstein ${ }^{1}$, Joerg Janne Vehreschild ${ }^{1}$, Jan-Christian Wasmuth ${ }^{2}$, Tim Kümmerle ${ }^{1}$, Jürgen Rockstroh $^{2}$, Gerd Fätkenheuer ${ }^{1}$

${ }^{1}$ Universität zu Köln, Innere Medizin I, Infektiologie, Köln, Germany, ${ }^{2}$ Universitaetsklinikum Bonn, Innere-RheumaTropen Ambulanz, Bonn, Germany

Hinterg rund: Die Sterblichkeit von HIV-Patienten ist seit Einführung der HAART stark zurückgegangen, dennoch bleibt die Mortalität gegenüber der Normalbevölkerung erhöht. Während die Sterblichkeit an AIDS definierenden Erkrankungen zurückgeht, spielen andere Todesursachen eine zunehmende Rolle.

Methoden: In der Köln Bonn Kohorte (CBC) werden alle Patienten mit einer HIV-Infektion der beiden Universitätsambulanzen Köln und Bonn prospektiv verfolgt (seit 1996 3364 Patienten). Klinische Daten und Laborparameter werden in einer gemeinsamen Datenbank dokumentiert. Bei verstorbenen Patienten wird die Todesursache nach dem „CoDe"-System (,causes of death") in standardisierter Weise erfasst und nach ICD10 klassifiziert. Ausgewertet wurden Todesfälle von 2004-2008.

Ergebnis se: Insgesamt wurden 127 Todesfälle (106 Männer,26 Frauen) erfasst. Das Alter (Median) zum Todeszeitpunkt betrug 47Jahre (Bereich: 24-77). Bei 12\% war die HIV-Infektion erst seit einem Jahr, bei 15\% 1-5Jahre, bei $61 \%$ 5-20Jahre und bei $12 \%$ mehr als $20 \mathrm{~J}$ ahre bekannt.

Letzte gemessene CD4-Werte $(/ \mu \mathrm{L})$ waren wie folgt: $<100$ (30,5\%); 100-199 (15,5\%); 200-349 (22\%); >350 (26\%), unbekannt $(6 \%)$. Eine antiretrovirale Therapie (ART) wurde bis zum Tod bei 111 Patienten durchgeführt (87\%). Bei 55 Patienten (43\%) war die HIV-RNA zum Todeszeitpunkt $<50$ Kopien $/ \mathrm{mL}$, während sie bei 35 Patienten (27\%) über 10.000 Kopien/mLlag (unbekannt: $\mathrm{n}=10,8 \%$ ).

An einer HIV-assoziierten Erkrankung starben 36 Patienten $(28 \%)$, während bei 63 Patienten $(50 \%)$ eine andere Todesursache vorlag. Bei 28 Patienten (22\%) war die Todesursache nicht zu ermitteln. In der Gruppe der nicht HIV assoziierten Todesfälle führten Infektionen (15\%), bösartige Neubildungen (12\%) und Herz-Kreislauferkrankungen (12\%).

Diskussion: Nur bei einer Minderheit der Patienten der CBC lag eine HIV-assoziierte Todesursache vor. Bei einem 
erheblichen Teil der Patienten ließ sich trotz intensiver Nachforschungen keine eindeutige Todesursache feststellen. Obwohl die große Mehrheit der Patienten mit einer ART behandelt wurde, hatte die Hälfte aller verstorbenen Patienten einen ausgeprägten Immundefekt (CD4-Zellen< $200 / \mu \mathrm{L})$.

Weitere Studien müssen in Zukunft die Zusammenhänge zwischen Immundefekt, Virusreplikation und nicht AIDS assoziierter Mortalität näher untersuchen .

\section{P311 (PD)}

\section{Ongoing syphilis epidemic among HIV-infected men who have sex with men in Austria}

Stefanie Gogl ${ }^{1}$, Mario Sarcletti ${ }^{2}$, Margret Jöchl $^{3}$, Armin Rieger ${ }^{4}$, Maria Geit ${ }^{5}$, Bernhard Haas ${ }^{6}$, Ninon Taylor ${ }^{7}$, Manfred Kanatschnig ${ }^{8}$, Robert Zangerle ${ }^{2}$

${ }^{1}$ Österr. HIV-Kohortenstudie, Innsbruck, Austria, ${ }^{2}$ Univ Klinik für Dermatologie und Venerologie, Innsbruck, Austria, ${ }^{3}$ AGES, Wien, Austria, ${ }^{4} \mathrm{AKH}$ Wien, Wien, Austria, ${ }^{5} \mathrm{AKH}$ Linz, Linz, Austria, ${ }^{6} \mathrm{LKH}$ Graz, Graz, Austria, ${ }^{7} \mathrm{LKH}$ Salzburg, Salzburg, Austria, 8LKH Klagenfurt, Klagenfurt, Austria

Background: After declining steadily for years, the number of reported cases of syphilis increased in the last five years in Western Europe. The increases have occurred primarily among men who have sex with men (MSM). The objective of our study was to assess the rate of syphilis among HIV-infected patients in Austria.

Methods: Retrospective, cohort analysis. All consecutive HIV infected persons who have been cared for in six Austrian HIV treatment centres have been evaluated. Demographic data and syphilis diagnoses were collected from a digitalized clinical record.

Results: Overall, prevalence of syphilis increased from 3,7 cases per 1000 person-years in 2003 to 44,7 in 2006, 26,0 in 2007 and 33,4 in 2008, respectively. In MSM prevalence of syphilis increased from 9,1 cases per 1000 person-years in 2003 to 121,0 in $2006,74,7$ in 2007 and 110,1 in 2008 , respectively.

If only patients were analyzed who had an initial negative (including successfully treated syphilis) serology status, then the syphilis incidence rate increased from 1,6 cases per 1000 person-years in 2003 to 15,5 in $2006,15,5$ in 2007 and 19,4 in 2008, respectively. In the subgroup of MSM, syphilis incidence rate increased from 5,5 cases per 1000 person-years in 2003 to 44,9 in 2006, 46,2 in 2007 and 68,3 in 2008 , respectively.

Limitations: The findings in this study are subject to at least two limitations. First, information from health records was not collected systematically; variation occurred in data collection and recording. Second, behavioural data were not available.

Conclusions: The increasing rate of syphilis among $\mathrm{HIV}$-infected individuals reflects increased sexual risk-taking behaviour, particularly among MSM.

\section{P312}

Trends of transmitted drug resistance in Germany: an update of the German HIV-1 seroconverter cohort

Claudia Kuecherer ${ }^{1}$, Barbara Bartmeyer ${ }^{2}$, Kathrin Keeren ${ }^{1}$, Claudia Houareau ${ }^{2}$, Christian Kollan ${ }^{2}$, Sybille Somogyi ${ }^{1}$, Bernhard Bienek ${ }^{3}$, Stefan Dupke ${ }^{4}$, Heiko Jessen ${ }^{5}$, Klaus Fischer ${ }^{6}$, Osamah Hamouda ${ }^{2}$, German HIV-1 Seroconverter Study Group

${ }^{1}$ Robert Koch-Institut, HIV Variabilität und Molekulare Epidemiologie, Berlin, Germany, ${ }^{2}$ Robert Koch-Institut, HIV/AIDS und andere STI, Berlin, Germany, ${ }^{3}$ Medizinische Praxis, 10243, Berlin, Germany, ${ }^{4}$ Praxis Dres. S. Dupke / A. Carganico / A. Baumgarten, Berlin, Germany,

${ }^{5}$ Gemeinschaftspraxis Jessen-Jessen-Stein, Berlin, Germany, ${ }^{6}$ Praxis Dres Schranz/Fischer, Berlin, Germany

Objective: Aim of the study was to investigate the prevalence of transmitted drug resistance (TDR) and trends of resistance over time of individual drug classes in patients with a known date of infection in the German HIV-1 Seroconverter Cohort.

Methods: Between 1996 and 20071.564 patients with a known date of HIV-infection were included in a national multicentre observational study. Genotypic resistance was analysed in 1.276/1.312 primary samples from drug-naïve patients. Mutations were identified according to the surveillance drug resistance mutations list (SDRM). Expected phenotypic resistance was predicted with the Stanford algorithm interpretation tool (version 4.3.1).

Resul ts : Prevalence of TDR stabilized at a high level during a decade of observation in the HIV-1 seroconverter cohort (11.3\%; CI 9.63-13.2; $\mathrm{p}=0.5)$. NRTI resistance predominated with $6.3 \%$, followed by $2.4 \%$ NNRTI- and $1.1 \%$ PI-resistance. Dual- and multi-class resistance was observed in $1.3 \%$ and $0.2 \%$ of the study participants. Prevalence of NRTI-resistance decreased over time (p trend $=0.03$ ). Prevalence of NNRTI-resistance showed a potential increase (NNRTI: p trend 0.08). PI-resistance transiently decreased between 2004 and 2006 but remained stable over time (PI: $p$ trend $=0.4$ ). NRTI resistance was mainly caused by TAMs $(81,5 \%)$ and $66 \%$ of TAMs were T215revertant substitutions. Frequently, resistance was limited to single resistance mutations (66\%). $93 \%$ of NNRTI resistance was caused by a singleton resistance mutation.

Conclusion: Prevalence of TDR remained stable during the period of observation. However, trends over time differed among individual drug classes. High prevalence of NRTI resistance is most likely a heritage from treatment concepts based solely on NRTI. Continuously improved HAART regimens since 1996 are likely to have contributed to the decrease of NRTI resistance. Increase of NNRTI resistance could be related to the fact that K103N mutations frequently persist in absence of selective drug pressure and thus might contribute to spread in the infected population. 


\section{P313}

Transmission of drug resistant HIV in Austria

Margret Jöchl ${ }^{1}$, Stefanie Gogl ${ }^{2}$, Armin Rieger ${ }^{3}$, Mario Sarcletti $^{4}$, Maria Geit ${ }^{5}$, Bernhard Haas ${ }^{6}$, Ninon Taylor ${ }^{7}$, Manfred Kanatschnig ${ }^{8}$, Robert Zangerle 4

${ }^{1}$ AGES, Wien, Austria, ${ }^{2}$ Österr. HIV-Kohortenstudie, Innsbruck, Austria, ${ }^{3}$ AKH Wien, Wien, Austria, ${ }^{4}$ Univ. Klinik für Dermatologie und Venerologie, Innsbruck, Austria, ${ }^{5} \mathrm{AKH}$

Linz, Linz, Austria, ${ }^{6}$ LKH Graz, Graz, Austria, ${ }^{7}$ LKH

Salzburg, Salzburg, Austria, ${ }^{8}$ LKH Klagenfurt, Klagenfurt, Austria

Objective: To evaluate the frequency of transmitted drug resistant HIV in patients in Austria.

Method: We analyzed all resistance tests performed from 2001 to January 1 st. 2009 in treatment naïve patients. Mutations were judged as resistant according to Shafer R et al (AIDS 2007).

Two groups were established: patients with „recent infection" (primary HIV infection or a last negative test within 3 years before the positive test) and patients with infection of unknown date. For the patients with recent infection the year of infection was obtained by the date of primary HIV infection or the median point in time between negative and positive HIV test. For the patients with infection of unknown date the rate of resistance was plotted against the year of the HIV test.

Results: Overall 1666 persons had been diagnosed with HIV infection, 738 had a resistance test before antiretroviral therapy (ART) among them 66 patients $(8,9 \%)$ with at least one resistance mutation against NRTI or NNRTI or PI. In the 301 patients with ,recent infection" 174 had a resistance test before ART among them 15 patients $(8,6 \%)$ with at least one resistance mutation, with similar rates in men who have sex with men (MSM), injecting drug users (IDU) and those who acquired HIV by heterosexual contact (Hetero). One patient $(0,6 \%)$ a virus with resistance mutations against 3 drug classes (K70R; K103N; L90M). In the 1354 patients with infection of unknown date 560 had a resistance test before ART among them 51 patients $(9,1 \%)$ with at least one resistance mutation, with a rate of resistance of $15,4 \%$ in MSM, $4,9 \%$ in IDU and 6,5\% in Hetero.

Conclusions: In Austria, transmission of antiretroviral resistance appears to be stable. Only one three-class transmitted resistance and no difficult to treat cases of transmitted resistance has been observed.

\section{P314}

Epidemiology of primary drug resistance in chronically HIV infected patients in Germany

Mark Oette ${ }^{1}$, Rolf Kaiser ${ }^{2}$, Thomas Lengauer ${ }^{3}$, Stefan Reuter $^{4}$, Nadine Sichtig ${ }^{2}$, Gerd Fätk en heuer ${ }^{5}$, Jürgen $K$ Rockstroh ${ }^{6}$, Heribert Knechten ${ }^{7}$, Stefan Scholten ${ }^{8}$ Dieter Häussinger ${ }^{4}$, and the RESINA Study Group

${ }^{1}$ Krankenhaus der Augustinerinnen, Klinik für Allgemeine Innere Medizin, Gastroenterologie und Infektiologie, Köln, Germany, ${ }^{2}$ Institut für Virologie, Universität zu Köln, Köln, Germany, ${ }^{3}$ Computational Biology and Applied Algorithmics, Max-Planck-Institut für Informatik, Saarbrücken, Germany,

${ }^{4}$ Klinik für Gastroenterologie, Hepatologie und Infektiologie, Universitätsklinikum Düsseldorf, Düsseldorf, Germany,

${ }^{5}$ Klinik für Innere Medizin, Universität zu Köln, Köln, Germany, ${ }^{6}$ Klinik für Innere Medizin, Universitätsklinikum Bonn, Bonn, Germany, ${ }^{7}$ Praxiszentrum Blondelstr., Aachen, Germany, ${ }^{8}$ Schwerpunktpraxis, Köln, Germany

Objectives: Primary drug resistance (PDR) in untreated HIV-infected patients is associated with suboptimal virological outcome of first-line HAART. The aim of this study was to evaluate the epidemiology of PDR.

Methods: In a prospective multicenter study in Nordrhein-Westfalen, Germany, genotypic resistance testing was performed in chronically HIV-infected individuals before initiation of first-line HAART. Resistance was classified according to AIDS 2007;21:215. Expert interpretation was provided using the geno 2 pheno ${ }^{\circledR}$ tool.

Resul ts : From 2001 to 2008 , results of resistance testing were available for 1690 individuals. Baseline characteristics were as follows: $79.3 \%$ of the cases were males, mean age was 42.3 years (SD, 10.4), 32.6\% were at clinical stage of AIDS, mean CD4-cell count was $244 / \mu 1$ (SD, 200), mean viral load was $4.7 \mathrm{log} / \mathrm{ml}(\mathrm{SD}, 0.9)$. The overall prevalence of PDR was $9.5 \%$ (95\%-CI, 8.1-10.9). The majority of mutations were seen within the group of nucleoside reverse transcriptase inhibitors (NRTI)(6.4\%; 95\%-CI, 5.2-7.6). In the subgroups of non-NRTI $(3.0 \% ; 95 \%-\mathrm{CI}, 2.2-3.8)$, protease inhibitors $(2.0 \%$; $95 \%$-CI, $1.3-2.7)$, revertants (4.1\%; 95\%-CI, 3.2-5.1), and multi-class-resistance (1.5\%; 95\%-CI, 0.9-2.1), PDR was less common. After a low level of resistance from 2001 to 2003 (8.2\%, 4.9\%, and $8.5 \%$, respectively), the prevalence peaked in the period from 2004 to $2007(11.6 \%, 10.7 \%, 12.7 \%$, and $12.6 \%$, respectively). In 2008, the rate of PDR declined to $8.4 \%$ (95\%-CI, 4.8-12.0).

Conclusions: The prevalence of PDR was almost $10 \%$ in chronically HIV infected patients. Due to the large size of study population and geographic coverage of a complete federal state, the results are representative for a larger region in middle Europe. After a high level of prevalence from 2004 to 2007, we could show a recent decline of PDR in 2008. Thus, continuous surveillance of PDR in this patient group is mandatory. First-line HAART should not be administered without prior genotypic resistance testing. 


\section{P315}

\section{Hepatitis B- (HBV) and hepatitis C- (HCV) co-infection in patients with a known date of HIV-infection in the German HIV-1-seroconverter-cohort}

Nadine Spielmann, Barbara Bartmeyer, Claudia Houareau, Claudia Kücherer, Christina Lindemann, Osamah Hamouda

Robert Koch Institut, Infektionsepidemiologie, Berlin, Germany

Objective: To determine the prevalence of HBV- and $\mathrm{HCV}$-co-infection in patients with a known date of HIV-infection in the German HIV-1-Seroconverter-Cohort.

Methods: The HIV-1-Seroconverter-Study is a national prospective multi-centre observational cohort study conducted since 1997. Individuals with a last negative and first positive HIV-antibody-test within a maximum 3 year interval and individuals with an acute seroconversion as defined by laboratory criteria were defined as HIV-seroconverters. As of 31.12.2007 a total of 1285 treatment naïve blood samples of HIV-1 infected patients (94\%men, 6\% women) were screened for HBV and HCV co-infection. Serological detection of $\mathrm{HBV}$ was performed by anti-HBc, anti-HBs and $\mathrm{HbsAg}$; HCV diagnosis by anti-HCV-ELISA and anti-HCVImmunoblot (Abbott, Microgene, Germany).

Results: Most frequent transmission routes were men having sex with men (MSM) 85\%, followed by $8 \%$ heterosexual intercourse (HET), $2 \%$ intravenous drug use (IDU) and $2 \%$ patients originating from high prevalence countries (HPC). 27\% (347/ 1285) of patients were identified who ever had a HBV-infection but have cleared the virus (positive for anti-HBc and anti$\mathrm{HBs}$ ). Acute or chronic HBV-infection (positive for anti-HBc and HBsAg) was found in 2\% (26/1285) of patients. The criteria for $\mathrm{HBV}$-vaccination (positive for anti-HBs only) was matched only in $0.3 \%$ (3/912) individuals. Patients who have cleared the virus were most prevalent among individuals from HPC (40\%), followed by MSM, IDU and heterosexuals (28\%, $27 \%, 10 \%$ ), respectively. Any acute or chronic HBV-infection was identified mainly in patients from HPC $(11 \%)$, followed by IDU (6\%) and by MSM (2\%). Overall prevalence for HCV-infection was $4.4 \%$ (56/1285). 22/56 patients were simultaneously positive for $\mathrm{HBV} / \mathrm{HCV}$. HCV-infection was highly prevalent in IDU (94\%), followed by HET (8\%) and by MSM (2\%).

Conclusion: HBV co-infection is frequent (27\%) among HIV-1 seroconverters. HBV-co-infections mostly were detected in patients from HPC. Although dealing with a highrisk group ( $85 \% \mathrm{MSM}), \mathrm{HBV}$-vaccination coverage was extremely low.

\section{P316}

Minority quasispecies of drug-resistant viruses in acutely HIV-1 infected patients in Hamburg, Germany: Prevalence patterns and time-trends

Hans-Jürgen Stellbrink ${ }^{1}$, Christian Noah ${ }^{2}$, Karin Metzner ${ }^{3}$

${ }^{1}$ ICH / ICH Study Center Hamburg, Hamburg, Germany, ${ }^{2}$ IPM Biotech / Labor Lademannbogen, Hamburg, Germany, ${ }^{3}$ University Hospital Zurich, Department of Medicine, Division of Infectious Diseases and Hospital Epidemiology, Zürich, Switzerland

Background: The prevalence of transmitted drug resistance in Germany has remained almost stable over the last
10 years. However, minority drug-resistant quasispecies are not detected by population sequencing. More sensitive assays such as allele-specific real-time PCR (AS-PCR) could provide a more accurate picture of transmission of drug-resistant virus.

Methods: Population sequencing and AS-PCR for key resistance mutations L90M in protease, K65R, K103N, and M184Vin RT were performed on plas ma samples of $86 \mathrm{HIV}$ 1 seroconverters diagnosed in Hamburg, Germany, between $8 / 2001$ and 12/2007. All samples were obtained prior to antiretroviral therapy.

Results: Conventional genotyping revealed drug resistance in $7 / 86$ patients ( $8 \%$ ). In 8 additional cases $(9 \%)$, resistant variants were detected only as a minority. The M184V mutation was found at frequencies of $0.3-2.7 \%$ in 7 patients, and only one patient carried it as a major population. The opposite pattern was observed with regard to K103N: 3 Three patients harboured K103N as a majority, while one patient had a K103N minority quasispecies in conjunction with G190A and T69S mutations identified by population sequencing. The K65R mutation was neither detected by population sequencing nor by AS-PCR. The L90M mutation was present in only one patient as a minority quasispecies without genotypic PI resistance. An increase of transmission of drug-resistant virus was not observed during the 8 year observation period with either method.

Conclusions: While the K103N mutation was detected predominantly as a major variant, the $\mathrm{M} 184 \mathrm{~V}$ mutation was observed almost exclusively at low frequencies. This pattern indicates that transmission of mixed populations of drug-sensitive and drug-resistant viruses is possible, followed by rapid selection of more replication-competent variants. A reversion of M184V to M184M appears less likely given the number of patients. Less replication competent, drug-resistant variants are likely to be missed by conventional genotyping.

\section{P317}

Concomitant diseases in HIV-positive persons (PLWHA) in Germany - a comparison between sexes on basis of the KompNet cohort

Klaus Jansen ${ }^{1}$, Norbert H. Brockmeyer ${ }^{1,2}$, Monika Baudewig ${ }^{3}$, Ravi Walli ${ }^{3}$, Burk hard Haastert ${ }^{4}$, Matthias Freiwald $^{5}$, Thomas Harrer ${ }^{6}$, Shlomo Staszewsk $i^{7}$, B. Kuhlmann ${ }^{8}$, Franz Mosthaf ${ }^{9}$, R. E. Schmidt ${ }^{10}$, S. Scholten ${ }^{11}$, Adriane Skaletz-Rorowski ${ }^{1}$, Stefan Esserl2, Claudia Michalik ${ }^{13}$, and the Competence Network for HIV/AIDS

${ }^{1}$ Kompetenznetz HIV/AIDS, Ruhr-Universität, Bochum, Germany, ${ }^{2}$ Universitätsklinik, Bochum, Germany, ${ }^{3}$ GlaxoSmithKline, München, Germany, ${ }^{4}$ mediStatistica, Neuenrade, Germany, ${ }^{5}$ Gemeinschaftspraxis, Fuggerstraße, Berlin, Germany, ${ }^{6}$ Universitätsklinik, Erlangen, Germany,

${ }^{7}$ HIVCENTER, Universitätsklinik, Frankfurt, Germany, ${ }^{8}$ Praxis Georgstraße, Hannover, Germany, ${ }^{9}$ Gemeinschaftspraxis, Kriegsstraße, Karlsruhe, Germany, ${ }^{10}$ Medizinische Hochschule, Hannover, Germany, ${ }^{11}$ Praxis Hohenstaufenring, Köln, Germany, ${ }^{12}$ Universitätsklinik, Essen, Germany, ${ }^{13}$ Zentrum für Klinische Studien, Köln, Germany

Background: With increased life expectancy, concomitant diseases (CD) become more important for treatment of 
PLWHA. Knowledge on prevalences of CD is important to sensitise for possible long-term outcomes of both, ART and HIV-infection, especially regarding constraints of liver and kidney function as well as coronary heart disease (CHD) and risk of cardiovascular events. On basis of the KompNet cohort, we analysed specifics of CD in Germany. Method: Cross-sectionally (1.9.2008), we estimated prevalences (using 95\%-confidence-intervalls) of $\mathrm{CD}$ for PLWHA having regular follow-ups, stratified by sex. Regarding reduction of liver function, nephrological constraints and risk of cardiovascular events, we estimated prevalences by cumulating events specific for these groups of diagnoses, counting identical diagnoses only once per patient.

Result: 6,085 patients were included in analysis, of which $85.2 \%$ were male. Mean age was 45.2 years, $74.9 \%$ had an CD4-count $>350$ cells $/ \mu 1,6.5 \%<200.46 .2 \%$ of PLWHA were classified as CDC-stage B (A:28.2\%,C:25.6\%).

Depression had the highest prevalence in both sexes (men: $19.5 \%$,CI: $18.4 \%-20.6 \%$,women: $16.2 \%$, CI: $13.8 \%$ $18.7 \%$ ), followed by Lipodystrophy (men: $12.2 \%$, CI: $11.3 \%-13.1 \%$, women: $11.7 \%$, CI: $9.7 \%-14.0 \%$ ), myosceletal diseases (men: $10.1 \%$, CI: $9.3 \%-10.9 \%$, women: 8.3\%, CI: $6.5 \%-10.3 \%$ ), and arterial hypertension (men: $9.8 \%$, CI: $9.0 \%-10.7 \%$, women: $7.0 \%$,CI: $5.4 \%-8.9 \%$ ). Prevalence of reduced liver function in men was $6.5 \%$ (CI: $5.8 \%-7.2 \%$ ), in women $5.1 \%$ (CI: $3.8 \%-6.8 \%$ ), prevalence of nephrological constraints in men was $3.6 \%$ (CI: $3.1 \%$ $4.1 \%$ ), in women $1.7 \%$ (CI: $0.9 \%-2.7 \%$ ). Prevalence of diseases resulting in increased cardiovascular risk in men was $25.3 \%$ (CI: $24.2 . \%-26.6 \%$ ), in women $19.6 \%$ (CI: $17.1 \%$ $22.4 \%$ ), prevalence of CHD in men was $25.3 \%$ (CI: $24.2 . \%$ $26.6 \%$ ), in women $19.6 \%$ (CI: $17.1 \%-22.4 \%$ ).

Conclusion: Depression and lipodystrophy had a striking impact with regard to treatment of PLWHA. Prevalence of diagnosed arterial hypertension was high, but equal to estimated prevalences in general population. We found no major differences concerning the most frequent prevalences of $\mathrm{CD}$ between sexes in our cohort. Only regarding nephrological constraints, prevalence in men was double as high as in women.

\section{P318}

\section{Frauenspezifische Risikofaktoren für ,frühe" und ,späte" HIV-Diagnosen in Österreich}

\section{Margret Jöchl, Stefanie Gogl}

Österreichische HIV-Kohortenstudie, Innsbruck, Austria

Ziel : Evaluation der Risikofaktoren von Frauen für „frühe" und "späte" Diagnosen der HIV-Infektion.

Methodik: Analyse von Patientinnen aus 6 österreichischen-Behandlungszentren, bei denen die HIV-Infektion in den Jahren 2001 bis 2008 diagnostiziert wurde. „Frühe" Diagnosen: primäre HIV-Infektion (Westernblotbanden oder Antigen/HIV RNA mit klinischem Bild) oder nachgewiesene Serokonversion innerhalb von 3 Jahren. „Späte" Diagnosen: CD4-Nadir $<200$ Zellen/ml innerhalb von 6 Monaten und/oder AIDS innerhalb von 3 Monaten nach dem HIV-Test. Analyse der Risikofaktoren: logistische Regression.

Resultate: Im Beobachtungszeitraum 2001 bis 2008 wurde bei 438 Frauen die HIV-Infektion diagnostiziert. 144 Patientinnen $(32,9 \%)$ waren unter 30 Jahre alt, 185
$(42,2 \%)$ waren zwischen 30 und 40 und $109(24,9 \%)$ über 40 Jahre alt. $343(78,3 \%)$ hatten sich über heterosexuelle Kontakte mit HIV infiziert, 57 (13,0\%) über intravenösen Drogenkonsum. 134 Patientinnen $(30,6 \%)$ stammen aus high prevalence areas. Eine „frühe" Diagnose wurde bei 12,3\%, eine „späte" Diagnose bei 29,7\% der Patientinnen gestellt. „Frühe" Diagnosen sind bei Männern häufiger $(\mathrm{RR}=1,74, \mathrm{p}<0,001)$ und „späte" Diagnosen seltener $(R R=0,75, p=0,023)$. Risikofaktoren für eine „frühe" Diagnose waren bei Frauen das Alter und die Übertragungsart. Je jünger die Frauen waren, umso eher wurde eine „frühe" Diagnose gestellt (Altersgruppe bis $30: \mathrm{RR}=0,22, \mathrm{p}<0,001$; Altersgruppe 30 bis $40: R R=0,45, p=0,004)$. Weiters haben Frauen mit intravenösem Drogenkonsum häufiger eine „frühe" Diagnose ( $R R=2,48, p=0,020)$. Eine „späte" Diagnose wird signifikant häufiger bei Frauen aus high prevalence areas gestellt $(R R=1,82, p=0,016)$. Das Risiko für eine ,späte" Diagnose ist bei heterosexuellem Infektionsweg um ein Vielfaches größer als bei einer Übertragung durch intravenösen Drogenkonsum ( $R R=0,14$, $\mathrm{p}=0,007)$.

Schlussfolgerung: Der Anteil der Patientinnen mit einem fortgeschrittenen Krankheitsbild bei der HIV-Diagnose ist signifikant höher als bei Männern. "Späte" Diagnosen finden sich häufiger bei Frauen über 40, bei heterosexuellem Übertragungsweg und bei Patientinnen aus high prevalence areas. „Frühe" Diagnosen sind signifikant häufiger bei jungen Frauen und bei einer Infektion durch intravenösen Drogenkonsum.

\section{P319}

\section{Identification of a novel recombinant form of HIV-1 in Switzerland}

Daniel H. Paris ${ }^{1,2}$, Roberto F. Speck ${ }^{1}$, Jürg Böni ${ }^{3}$

${ }^{1}$ University Hospital Zürich, Division of Infectious Diseases and Hospital Hygiene, Zürich, Switzerland, ${ }^{2}$ Wellcome Trust Mahidol University, Oxford Tropical Medicine Research Programme, Faculty of Tropical Medicine, Bangkok, Thailand, ${ }^{3}$ Universität Zürich, Nationales Zentrum für Retroviren, Institut für Medizinische Virologie, Zürich, Switzerland

Background: HIV-1 has attained a remarkable diversity. To date 9 clades and 43 recombinant circulating forms (CRF) have been described in the main group. There is evidence that many more uncharacterized unique recombinants (URF) or CRFs occur. Three closely related virus isolates suggestive of a novel recombinant between subtypes A and $\mathrm{D}$ were noted during routine sequencing. It was the goal of this project to genetically characterize these viruses.

Methods: Clonal near-full length sequences were generated by amplification of proviral DNA from PBMCs under limiting dilution conditions. Recombination sites were mapped by bootscanning analysis using RDP vs. 2. The uniqueness of the recombinant form was assessed by distance-based neighbour-joining trees with bootstrap analysis, and BLAST searches. Epidemiological information was collected by patient interviews. All patients gave their informed consent.

Results: Full-length sequences of the three patient isolates clustered with a bootstrap value of 100 . Bootscanning analysis confirmed the recombinant nature of the isolates. They all exhibited a simple pattern of recombination 
in the background of an A1 genome, characterized by 740 bp derived from subtype $\mathrm{D}$ in the pol gene, and immediately followed by $225 \mathrm{bp}$ derived from A2. The sequence of the third patient contained two additional subtype D-derived sequences of $200 \mathrm{bp}$ and $390 \mathrm{bp}$ in SU and TM of the env gene. No sequences with the same recombination points could be found in the data base. Patient interviews indicated heterosexual transmission, but absence of contacts between the patients. Patient background suggested east africa (Kenya) as origin of the viral recombinant, a region in which A1D recombinants are prevalent.

Conclusion: A novel recombinant HIV-1 was identified, that was repeatedly introduced to Switzerland in independent events. Although the criteria are formally not met, it is very likely that two of the isolates represent a true CRF, not a URF.

\section{P320}

Treatment interruptions (TI) of antiretroviral combination therapy (cART) in the German ClinS urv cohort 2005-2008

Christian Kollan ${ }^{1}$, Claudia Houareau ${ }^{1}$, Barbara Bartmeyer ${ }^{1}$, Andrea Kühne ${ }^{1}$, Osamah Hamouda ${ }^{1}$, for the ClinSurv Study Group

1Robert Koch Institute, Department for Infectious Disease Epidemiology, Berlin, Germany

Objective: Structured treatment interruptions (STI) in chronic HIV infection have recently been associated with increased morbidity. We aimed to investigate the last drugcombination before, reasons for and viral load at TI as well as the proportion of STI among all TI in the German ClinSurv Cohort.

Methods: ClinSurv was established as a national multicentre unselected prospective open observational cohort study in 1999. Data on cART from 11 centres between 01.07.2005 to 30.06.2008 were evaluated. Type of classregimen, reasons for termination and the last viral load of the TI preceding regimen (PR) where analysed. Reasons and regimen with $\mathrm{n}<10$ were pooled as "others". Mono-PI with a preceding mono-NNRTI regimen running $<21$ days were ranked as a strategic-exit-regimen (ER).

Results: Since July 2005 TI were reported in $885 / 8839$ $(10 \%)$ treated patients (TI range 1-4/person). The median duration of TI was 112 days. TI were reduced by more than half in the last 36 month. Data on PR were available from 987 TI. 387/987 TI with unknown reason were excluded. $25 \%(121 / 600)$ of treatment changes were caused by patients wish followed by low adherence in $24 \%(141 / 600)$ and by STI in 20\% (121/600) of cases. Only STI decreased significantly $(\mathrm{c} 2=7.4 ; \mathrm{p}<0.01)$ over time. Mostly backbone optimized PI $(51 \%, 505 / 987)$ and NNRTI (24\%, 233/987) were contained in the PR. Twelve ER were observed. HIV-RNA was documented max. 30 days before TI for $329 \mathrm{PR}$. The ratio of viral-load below and above detection-limit was nearly 1 over time for all backbone optimized PR.

Conclusion: TI were mostly patient initiated. STI significantly declined during the observation period. The low rate of HIV-RNA-measurements and the high proportion of PI containing PR suggest that a large part of ART-interruption were initiated spontaneously and not well-planned and these patients could be lower adherent.

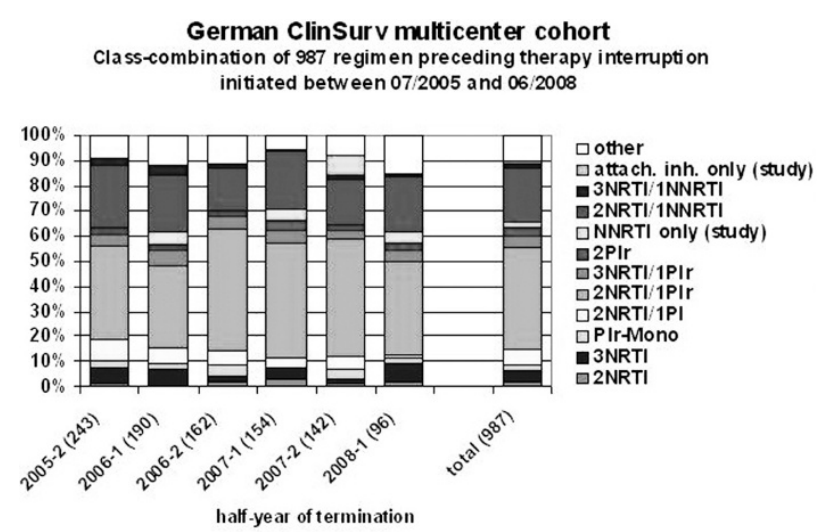

[Regimen]

German ClinSurv multicenter cohort

Reas on of termination of 600 regimen preceding ther apy interruption Reas on of termination of 600 regimen preceding ther apy interruption
between 07/2005and $06 / 2008$ (excl. 387 regimen with unknown reason)

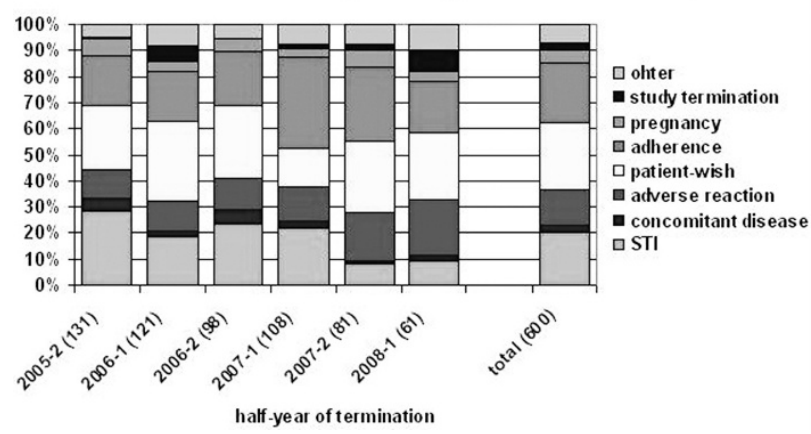

[Reason]

P321

Epidemiological situation of STI in the border region Vienna/Austria: results of the BORDERNET sentinel surveillance

Klaus Jansen ${ }^{1}$, Andreas Gilsdorf ${ }^{1}$, Elfriede Steffan ${ }^{2}$, Osamah Hamoudal, Viviane Bremer ${ }^{1}$

${ }^{1}$ Robert Koch-Institut, Berlin, Germany, ${ }^{2}$ SPI Forschung gGmbH, Berlin, Germany

Background: Austrian surveillance data show the highest numbers of STI in Vienna, but there is a lack regarding more detailed data on STI in Austria Within the project BORDERNET, a sentinel-surveillance system for STI was established in four European border regions, including Vienna, to provide more detailed data on STI, especially on risk behaviour.

Method: All major STI testing points in Vienna participated in the study. Using standardised questionnaires, clinical data regarding chlamydia, gonorrhoea, HIV and syphilis were gathered from physicians, information on risk of infection, sexual behaviour and social background from patients. Physicians also reported number of clients, STI tests and their results monthly.

Result: Between 1.1.2006 and 31.12.2007, 127,940 STI tests in 71,042 clients were reported by ten sentinel sites. Among STI patients, $41.7 \%$ were men, mean age 29.3 years. Most frequent infection was chlamydia ( 1,466 positive tests), followed by gonorrhea (492), syphilis (208) and HIV (100). HIV (73.9\%) and Syphilis (62.1\%) were mainly diagnosed in men, chlamydia in women (64.9\%), gonorrhea equally (51.3\% men). A previous STI was reported for $15.7 \%$ of men and $22.3 \%$ of women $(\mathrm{p}<0.01)$. 
Most important mode of transmission for men were heterosexual contacts (48.2) and sex with men (42.1\%), for women prostitution (79.5\%). $49.2 \%$ of men and $25.2 \%$ of women reported sex with casual partners. Inconsistent condom use with casual sex partners was stated by $55.4 \%$ of all men and $40.3 \%$ of all women. $83.3 \%$ of men and $70.4 \%$ of women stated casual sex as source of infection in this group.

Conclusion: Important epidemiological data were gained which were not available through national reporting systems, covering of potential Viennese sentinel sites was sufficient. This applies especially for epidemiological data on chlamydia and data on risk behaviour.

Migration and prostitution turned out as important influencing factors for STI, especially in women.

\section{P322}

\section{HIV patient care under real life conditions: experiences from the Southwestern German cohort}

Jens Kittner ${ }^{1}$, Ana Paula Barreiros ${ }^{1}$, Bernd Claus ${ }^{2}$, Martin Däumer ${ }^{3}$, Kurt Fischer ${ }^{4}$, Georg Friese ${ }^{5}$, Jürgen Lohmeyer ${ }^{6}$, Thomas Rath ${ }^{7}$, Ans gar Rieke ${ }^{8}$, Burk hard Schappert ${ }^{9}$, Jörg Schubert ${ }^{10}$, Bernhard Thiele ${ }^{3}$, Marcus Schuchmann ${ }^{1}$

${ }^{1}$ Universitätsmedizin, 1. Med. Klinik, Mainz, Germany, ${ }^{2}$ Klinikum Ludwigshafen, Ludwigshafen, Germany, ${ }^{3}$ Inst. für Immunologie und Genetik, Kaiserslautern, Germany,

${ }^{4}$ Z. für Informatik, Hamburg, Germany, ${ }^{5}$ Schwerpunktpraxis, Giessen, Germany, ${ }^{6}$ Universitätsklinik Giessen / Marburg, Giessen, Germany, ${ }^{7}$ Westpfalz Klinikum, Kaiserslautern, Germany, ${ }^{8}$ Kemperhof, Koblenz, Germany,

${ }^{9}$ Schwerpunktpraxis, Mainz, Germany, ${ }^{10}$ Universität des Saarlandes, Homburg / Saar, Germany

Background: Although clinical trials consistently demonstrate high success rates of modern HIV treatment regimens, safety and efficacy have to be verified in larger patient population. In addition, characteristics of patients may differ which may require adaptation of strategies in treatment and prevention.

Methods: To evaluate current situation of HIV patients in southwestern Germany, data of 1,454 patients with a total of 20,591 visits from eight HIV outpatient clinics was analyzed. Median observation time was 2.5ys (range 0-19ys). Data was collected until 31.12.2007. The results are compared to numbers for Germany (2007) from Robert-KochInstitut, Berlin.

Results: $24.7 \%$ of patients were female (RKI:17\%). $45.7 \%(65 \%)$ were diagnosed in stadium CDC A, whereas $25.7 \%(21 \%)$ were classified as B and $28.5 \%(12.4 \%)$ as C. The most common risk factor for HIV infection were heterosexual contacts including origin from high prevalence countries $(32.5 \%$, RKI: $28 \%)$, followed by homosexuality $(30.5 \%)(59 \%)$, and IVDU $(16.3 \%)(12 \%)$. Rare routes of infection were hemophilia ( $1 \%)$ or vertical $(0.4 \%) .11 .6 \%$ of patients did not state any known risk factor $(7.7 \%$ : missing data). Median of $\mathrm{CD}^{+}{ }^{+}$cells/ $\mu 1$ before initiation of HAART was 242 in women and 283 in men. Viral load in patients on therapy was below limit of detection in $68.1 \%$ of women and $72.3 \%$ of men. Prevalence of coinfection with Hepatitis B, C, and Lues were $8.2 \%, 17.1 \%$, and $4.5 \%$, respectively. During observation time, $10.4 \%$ of patients developed AIDS-defining illness, with PCP and CMV-reac- tivation being the most common. No serious unexpected laboratory events were observed.

Conclusion: In our region, infection in females and heterosexual transmission are relatively common. In addition, CDC status at time point of diagnosis already showed a progressed status. However, in most cases time point of HAART initiation was in accordance with current guidelines, and the rate of virological success was comparable to results of clinical trials.

\section{P323}

\section{Recent antiretroviral treatment (ART) prac- tice in Germany - results from the ClinSurv multicenter cohort}

Christian Kollan, Andrea Kühne, Barbara Bartmeyer, Osamah Hamouda, for the ClinSurv Study Group

Robert Koch Institute, Department for Infectious Disease Epidemiology, Berlin, Germany

Objective: To determine and to specify the use of antiretroviral treatment and main ART-class-combination (mcART) in a large cohort of German HIV patients.

Methods: ClinSurv was established as a national, multicentre prospective observational and unselected open cohort study in 1999. Recent ART data from 11 ClinSurv centres from 01.07.2005 to 30.06.2008 were analyzed. Daily ART was generated using documented single-drug start and stop dates. Ongoing ART was censored at the last known clinical event or at the end of the observation time (OT). mcART, $>1 \%$ of the total ART-experienced time (OTe) were calculated.

Results : 10,247 individuals contributed 20,883 personyears of OT (mean: $752 \mathrm{~d} /$ individual). $84 \%$ of OT was ARTexperienced, $14 \%$ treatment naïve. $18 \%(1884 / 10,247)$ of individuals initiated ART and 14\% (1408/10247) remained therapy naïve during OT, ART-status of $2 \%(223 / 10,247)$ was unknown.

$1967 / 2795$ patients newly enrolled in the OT $(70 \%)$ were ART-naiv, but 763 (39\%) started ART within the following 90 days.

Double-NRTI-backbone use time (OTdn) represented 68\% of OTe and $96 \%$ of NRTI-backbone mcART. These mainly contained three combinations, zidovudin/lamivudin which declined from $37 \%$ to $19 \%$ over OTdn, whereas tenofovir/emtricitabine and abacavir/lamivudin rose from $21 \%$ to $53 \%$ and from $9 \%$ to $17 \%$ respectively.

Among protease inhibitors lopinavir was preferred (45\%), followed by atazanavir (28\%), fosamprenavir (14\%) and by invirase (6\%). The use of these PI increased slightly over OTe, exept for atazanavir.

Non-mcART such as salvage and new class regimen were used continually in $9 \%$ of OTe.

Time on any ART-interruption declined from $11 \%$ to $5 \%$ of OTe.

Conclusions: The use of NRTI and NNRTI or PI containing main regimen increased over time.

Once-daily nuke backbone combinations were predominantly prescribed (70\%).

Since structured treatment interruption was recently associated with greater disease progression treatment interruptions declined more than half.

Recent therapy strategies seem to take account of current discourse. 
German ClinSurv multic enter cohort Composition of observation time Analysis of 20.883 person-years from 10.247 individuals from 0712005 to 0612008

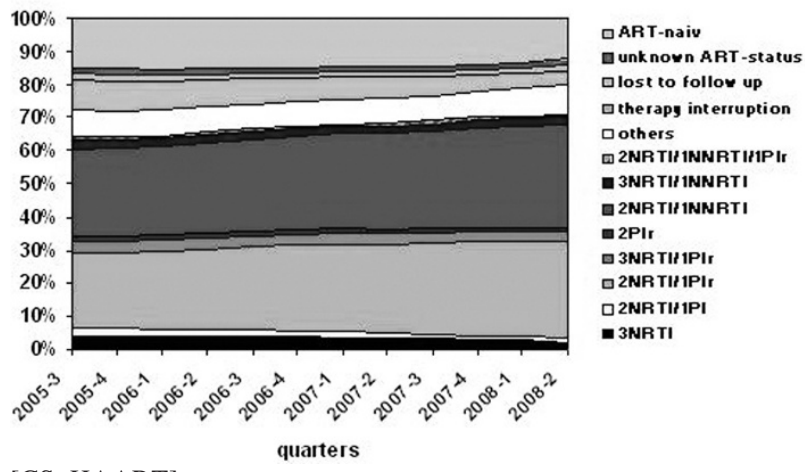

[CS_HAART]

$$
\text { P324 }
$$

High influence of migration and sex-work on the epidemiological situation of STI in

Vienna/Austria: results of the BORDERNET sentinel-s urveillance

Klaus Jansen ${ }^{1}$, Andreas Gilsdorf' ${ }^{1}$ Elfriede Steffan ${ }^{2}$, Osamah Hamoudal, Viviane Bremer ${ }^{1}$

${ }^{1}$ Robert Koch-Institut, Berlin, Germany, ${ }^{2}$ SPI Forschung gGmbH, Berlin, Germany

Background: Due to migration and sex work, STI are assumed to increase in regions along the old EU borders, like Vienna. Within the project BORDERNET, a sentinel surveillance system for STI was set up to gather more detailed epidemiological data with special focus on migration and sex work.

Method: All major STI testing points in Vienna participated in the study. Using standardised questionnaires, clinical data regarding chlamydia, gonorrhoea, HIV and syphilis were gathered from physicians, information on risk of infection, sexual behaviour and social background from patients. Physicians also reported number of clients, STI tests and their results monthly.

Result: Between 1.1.2006 and 31.12.2007, 127,940 STI tests in 71,042 clients were reported by ten sentinel sites. Among STI patients, $41.7 \%$ were men, mean age 29.3 years.

Proportion of migrants (non-Austrian nationality) was $47.2 \%, 30.0 \%$ in men and $59.3 \%$ in women $(\mathrm{p}<0.01)$. $74.9 \%$ of migrants originated from Central Europe, 9.2\% from Subsahara-Africa. Most important mode of transmission in migrated men were heterosexual contacts $(57.1 \%)$, in migrated women prostitution $(91.8 \%) .86 .7 \%$ of prostitutes were migrants.

Most frequent infection in migrants was chlamydia (men: $46.1 \%(\mathrm{~N}=217)$, women: $76.9 \%(\mathrm{~N}=590))$, followed by gonorrhea (men: $28.6 \%$, women: 19.7\%), syphilis (men: $10.1 \%$, women: $6.4 \%$ ) and HIV (men: $8.3 \%$, women: $2.2 \%$ ). With $27.2 \%$, migrants had more frequently a previous STI than non-migrants $(14.2 \%, \mathrm{p}<0.01)$.

Conclusion: We reached a sufficient coverage of sentinel sites to monitor STI in Vienna. Migration and prostitution were highly influencing factors for epidemiology, especially in women. Results should be applied in shaping adequate prevention tasks and treatment facilities, with special regard to intercultural competences. Prevention to avoid chlamydia infections should be strengthened, both for migrated men and women.

\section{P325}

\section{Impact of 44 months cART-dispensing on} HIV-care in rural south-central Tanzania

Erik Mossdorf 1,2,3, Geofrey Mwaigomole ${ }^{1}$, Evarist Chiweka ${ }^{1}$, Patience Kibatal ${ }^{4}$, Christoph Hat $z^{3}$, Manuel Battegay ${ }^{5}$, Marcel Stoeckle $e^{3,5}$

${ }^{1}$ St. Francis Designated District Hospital, Chronic Diseases Clinic, Ifakara, Tanzania, United Republic of,

2Ifakara Health Institute, Ifakara, Tanzania, United Republic of, ${ }^{3}$ Swiss Tropical Institute, Basel, Switzerland,

${ }^{4}$ St. Francis Designated District Hospital, Ifakara, Tanzania, United Republic of, ${ }^{5}$ University Hospital Basel, Division of Infectious Diseases and Hospital Epidemiology, Basel, Switzerland

Is sue of question: Impact of 44 months cART dispensing by the Chronic Diseases Clinic of St. Francis Designated District Hospital on HIV-care in south-central Tanzania.

Des cription: CDCI of SFDDH dispenses cART according the National AIDS control programme (NACP) since April 2005. 3440 patients were enrolled into NACP until December 2008. Among them 2445 (71.1\%) were active in December 2008, $646(18.8 \%)$ were lost to follow-up and 241 (7\%) died. $1491(61 \%)$ of the 2445 active patients were under cART (471 men, 907 women) by December 2008. In the catchment area of the hospital, which covers the districts of Kilombero and Ulanga, $4.2 \%$ of the 520 '000 inhabitants are estimated to be HIV-positive. Therefore the 3440 enrolled patients represent $15.8 \%$ of the $21^{\prime} 840$ persons estimated to be infected. In general $10 \%$ of infected patients are considered to be in need of treatment. Therefore the 1491 patients under treatment equal $68.3 \%$ of the 2184 patients estimated to be in need of treatment. There are two other small cART dispensing site within the catchment area with few patients enrolled into NACP and under cART.

Conclusion: Within 44 months, CDCI reached an estimated $15.8 \%$ of HIV-positive patients but already two third of patients in need for cART. The percentage of lost to follow-up patients is considerable, but within the range seen at other sites.

Next step: Decentralization of VCT services and cART dispensing are necessary to reach patients in very remote areas. Such decentralization has to be accompanied by intense repeated training for health care workers and regularly close supportive supervision. 


$$
\text { P326 }
$$

\section{The influence of genotypic resistance testing on antiretroviral first-line treatment decision in the German HIV-1-seroconverter-study- group}

Claudia Ho uareau ${ }^{1}$, Barbara Bartmeyer ${ }^{1}$, Claudia Kücherer ${ }^{2}$, Nadine Spielmann ${ }^{1}$, Christian Kollan ${ }^{1}$, Christina Lindemann ${ }^{1}$, Osamah Hamouda ${ }^{1}$, German Serokonverter Study Group

${ }^{1}$ Robert Koch-Institute, Department of Infectious Disease, HIV/AIDS, STI and other Blood Born Infections Unit, Berlin, Germany, ${ }^{2}$ Robert Koch-Institute, Project HIV Variability and Molecular Epidemiology, Berlin, Germany

Background: To analyse the impact of genotypic resistance results on antiretroviral firstline treatment (FLT) decision in patients with a known date of HIV-infection.

Methods: As of 31.12.2007, a total of 1,564 patients with a known date of infection were included in a national multi-centre observational study cohort. Genotypic resistance analysis was carried out in 1,276/1,312 treatmentnaïve samples. Mutations were identified according to the surveillance drug resistance mutations list (Shafer RW et al., 2008). Phenotypic resistance was predicted with the Stanford algorithm (version 4.3.1 2007). Patients with resistance mutations were categorized: group-1 $(n=16)$ start of FLT before, group-2 $(n=26)$ start of FLT after resistance results were provided.

Results: In our genotyped cohort, 89\% (1133/1276) susceptible and $11 \%(143 / 1276)$ resistant viruses were identified. Physicians were provided with resistance results form $117 / 143$ patients. NRTI resistance was predominant (4\%) followed by NNRTI and PI resistance $(4 \%, 2 \%)$, respectively. Time between seroconversion and start of FLT was 442 days (median, IQR 134-660). FLT was initiated in 36\% $(42 / 117)$ of patients with resistant HIV. Median duration of FLT varied between both groups (group 1: 124 days versus group 2: 132 days). Initial CD4 cell counts did not differ between both groups (group-1: 405 cells/ $\mu 1$ versus group2: 374 cells $/ \mu 1$ ), whereas higher initial viral loads were reported for group-1 (group-1: 220,713 copies/ml versus group-2: 123,000 copies/ml). $37 \%(6 / 16)$ active and $62 \%$ $(10 / 16)$ inactive drugs were included in group-1 FLT. Mainly active drugs were comprised in the FLT of group-2 (active: $61 \%, 16 / 26$ versus inactive: $38 \% 10 / 26)$.

Conclusion: Our result reinforces the benefit of resistance test guided therapy. More active drugs were given in resistance-guided FLT. However, decision on FL combination and initiation may also depend on other factors such as patient adherence and tolerability and was not solely bound to laboratory criteria.

\section{$P 327$}

Factors associated with adverse pregnancy outcome in HIV positive women: evidence from the Swiss Mother and Child HIV cohort study

Karoline Aebi-Popp ${ }^{1}$, Louise Vilén ${ }^{2}$, Tracy Glass ${ }^{3}$, Olav Lapaire ${ }^{1}$, Irene Hoesli ${ }^{1}$, Mother and Child HIV Cohort Study

${ }^{1}$ University Hospital Basel, Department of Obstetrics and Gynecology, Basel, Switzerland, ${ }^{2}$ University of Bern, Institute of Psychology, Department of Developmental Psychology, Bern, Switzerland, ${ }^{3}$ Institute for clinical Epidemiology, University Hospital Basel, Basel, Switzerland

Background: The question whether and how the course of pregnancy in HIV infected women is influenced by maternal factors has been discussed controversially.

Methods: Using prospective cohort data, HIV positive women, included in the Swiss Mother and Child cohort study, with normal and adverse pregnancy outcome were compared using chi2 test and multivariate logistic regression.

Results: In total 266 seropositive women, of which $25.2 \%(67 / 266)$ were first diagnosed as HIV positive during pregnancy, were included.

80 of 266 women $(30.1 \%)$ were reported to have pregnancy complications after 24 weeks of gestation. The preterm delivery rate in the collective was $27 \%(72 / 266)$. Other complications include preeclampsia $(n=7 ; 2.6 \%)$ and gestational diabetes $(\mathrm{n}=7 ; 2,6 \%)$. Ethnicity, smoking habits, drug use, co-infections and treatment modalities did not significantly differ in women with normal and adverse pregnancy outcomes. However, maternal age was found to be a significant risk factor: For every additional year older the mother was, a $6.5 \%$ higher risk of adverse pregnancy outcome was found (adjusted odds ratio OR: $1.06,95 \% \mathrm{CI}$ 1.01-1.12, $\mathrm{p}=0.02)$.

Conclusions: The high number of HIV diagnoses during pregnancy substantiates the importance of HIV screening in pregnant women.

Even with no additional known risk factors, the risk for adverse pregnancy outcome, especially preterm delivery, remains high in HIV positive women. A close observation in an interdisciplinary setting of a perinatal center is therefore essential. Furthermore, HIV positive women should be advised to consider family planning as early as possible.

\section{P32 8}

Self-reported history of STI and STI-related utilization of the German health care system by MSM

Axel J. Schmidt, Ulrich Marcus

Robert Koch-Institut, Infektionsepidemiologie, Berlin, Germany

Objective: Diagnosis and care of sexually transmitted infections (STI) in Germany are dispersed among different medical disciplines. Common STI like gonorrhoea, Chlamydia infection, and genital herpes are not reportable in Germany. We analyzed the self-reported burden of STI and STI-related health care utilization in men who have sex with men (MSM). 
Methods: A sexual behaviour survey was conducted among MSM in 2006. Participants were recruited online $(n=5,928)$ and offline in medical practices $(n=723)$. Questions on self-reported histories of STIs, reasons and barriers for STI-related health care, STI screening, active and passive partner notification were analyzed.

Results : A lifetime history of an STI other than HIV was reported by $43 \%$ of the survey participants. STI risk perception depended on number/type of sexual partners, frequency of unprotected anal intercourse, and HIV serostatus. Unprotected (anal) sex was the main specific reason for STI concerns (27\%). Symptoms or knowledge of an STI in a partner motivated $76 \%$ of survey participants to consult a health care provider. Embarrassment/shame, and fear of disclosure of same sex contacts were the main barriers for seeking STI care. Among respondents with an STI in the previous 12 months, $74 \%$ had notified their sexual partners, and $46 \%$ had been notified by a partner. Lifetime and recent 12 months history of STI screening differed between infections which are diagnosed serologically and local infections which require swab-testing and/or culture: screening for serologically diagnosed infections was about 3times more frequent.

Conclusions: Awareness of STIs is high among MSM in Germany. Health concerns focus on risks due to unprotected anal sex. STI testing rates tend to be lower than in published samples from other countries. Comprehensive STI checks including screening for asymptomatic pharyngeal and rectal infections are rarely offered. Communication about sexual risks between homosexual clients and health care providers need to be improved.

\section{P329}

\section{The spectrum of malignancies in the era of HAART}

Martin Vogel ${ }^{1}$, Oliver Friedrich ${ }^{1}$, Tobias Höller ${ }^{2}$, Jan-Christian Wasmuth ${ }^{1}$, Evrim Anadol ${ }^{1}$, Carolynne Schwarze-Zander ${ }^{1}$, Bernd Holleczek ${ }^{3}$, Jürgen Kurt Rockstroh ${ }^{1}$, Ulrich Spengler ${ }^{1}$

${ }^{1}$ Bonn University, Department of Internal Medicine I, Bonn, Germany, ${ }^{2}$ Bonn University, Institute for Medical Biometry and Epidemiology, Bonn, Germany, ${ }^{3}$ Saarland Cancer Registry, Saarbrücken, Germany

Backgro und: With the introduction of highly active antiretroviral therapy (HAART) HIV and AIDS related mortality have dramatically declined and the overall life expectancy of HIV-infected patients has improved. Conversely, as HIV-infected individuals grow older, comorbidities and other competing health risks gain more importance in the clinical management of patients. Little is known on the incidence of AIDS and non-AIDS related cancers in the era of HAART.

Methods: Single-center cohort study. Patients who regularly visited our center during the time period 1996 - 2006 were analyzed. Data was retrieved by a standardized questionnaire. Age and sex adjusted standardized incidence rates were compared to incidence rates reported by the Saarland Cancer Registry. Data will be shown for male patients and tumor entities with a crude incidence of 3 or more cancers within the observation period.

Resul ts: During the 11 year observation period 1,338 patients ( $81 \%$ male, $19 \%$ female) presented to our clinic and were followed over a median of 3 years. At the time of first presentation patients were a median of 35 years old. Median CD4-cellcount was 363 cells/ $\mu 1$, HIV-RNA $3.9 \log 10$. At initial presentation $37 \%$ of patients received HAART. Overall 103 malignancies were observed. Cancers observed in male patients and with a crude incidence $\geq 3$ comprised 87 cancers. Comparison of sex and age adjusted standardized incidence rates of these cancers with the population of Saarland showed an excess risk of classic AIDS-related cancers, but also of the non-AIDS related hepatocellular and anal cancer and Hodgkin lymphoma (Table 1).

\begin{tabular}{|c|c|c|c|}
\hline Malignancy & $\begin{array}{l}\text { Aggregated } \\
\text { Incidence } \\
\text { Bonn-Cohort } \\
1996-2006 \\
\mathrm{n}\left(/ 10^{5}\right)\end{array}$ & $\begin{array}{l}\text { Aggregated } \\
\text { Incidence } \\
\text { Saarland Cancer } \\
\text { Registry } \\
1996 \text { - } 2006 \\
/ 10^{5}\end{array}$ & p-Value \\
\hline \multicolumn{4}{|l|}{ KS } \\
\hline total & $35(295.2)$ & 0.1 & $<0.0001$ \\
\hline 20 - 39 years & $21(388.8)$ & - & - \\
\hline $40-59$ years & $14(247.6)$ & - & - \\
\hline \multicolumn{4}{|l|}{ NHL } \\
\hline total & 29 (244.6) & 19.8 & $<0.0001$ \\
\hline 20 - 39 years & $12(222.2)$ & 5.2 & $<0.0001$ \\
\hline $40-59$ years & $14(247.6)$ & 15.7 & $<0.0001$ \\
\hline $60-79$ years & $3(373.6)$ & 47.3 & 0.0134 \\
\hline \multicolumn{4}{|l|}{$\mathrm{HCC}$} \\
\hline total & $7(59.0)$ & 10.6 & 0.0007 \\
\hline 20 - 39 years & $3(55.6)$ & 0.1 & $<0.0001$ \\
\hline $40-59$ years & $3(53.0)$ & 7.1 & 0.0159 \\
\hline $60-79$ years & $1(124.5)$ & 30.6 & 0.4364 \\
\hline \multicolumn{4}{|l|}{ Hodgkin } \\
\hline total & $5(42.2)$ & 3.1 & $<0.0001$ \\
\hline $20-39$ years & $3(55.6)$ & 3.2 & 0.0015 \\
\hline $40-59$ years & $2(35.4)$ & 2.8 & 0.0225 \\
\hline \multicolumn{4}{|l|}{ Anal Ca } \\
\hline total & $5(42.1)$ & 1.2 & $<0.0001$ \\
\hline 20 - 39 years & $2(37.0)$ & 0.1 & $<0.0001$ \\
\hline $40-59$ years & $3(53.1)$ & 1.4 & 0.0002 \\
\hline \multicolumn{4}{|c|}{ Oropharyngeal Ca } \\
\hline total & $3(25.3)$ & 6.0 & 0.0710 \\
\hline 20 - 39 years & $1(18.5)$ & 0.3 & 0.0321 \\
\hline $40-59$ years & $2(35.4)$ & 9.4 & 0.1996 \\
\hline \multicolumn{4}{|l|}{ Bronchial $\mathrm{Ca}$} \\
\hline total & $3(25.3)$ & 131.0 & 0.0003 \\
\hline $40-59$ years & $3(53.1)$ & 81.1 & 0.6539 \\
\hline
\end{tabular}

[Table 1]

Conclusions: Whereas opportunistic infections and related mortality have decreased considerably after the introduction of HAART, HIV-related malignancies and importantly non HIV-related malignancies are remaining therapeutic challenges in the health-management of HIV-infected patients. 


\section{P330}

Increasing prevalence of syphilis in MSM with known date of $\mathrm{HIV}$-infection from the German HIV-1 seroconverter study

Ulrich Marcus ${ }^{1}$, Claudia Kücherer ${ }^{2}$, Axel J. Schmidt ${ }^{1}$, Barbara Gunsenheimer-Bartmeyer ${ }^{1}$, Christina

Lindemann ${ }^{1}$, Nadine Spielmann ${ }^{1}$, Osamah Hamoudal, German HIV-1 Seroconverter Study Group

${ }^{1}$ Robert Koch-Institut, Infektionsepidemiologie, Berlin, Germany, ${ }^{2}$ Robert Koch-Institut, Projektgruppe HIV Variabilität und Molekulare Epidemiologie, Berlin, Germany

Background: The number of newly diagnosed HIV-infections in men who have sex with men (MSM) in Germany has increased after the year 2000. We investigated the seroprevalence of syphilis markers in MSM with a known date of HIVinfection in the German HIV-1 Seroconverter Study (GHSS). Methods: Seroprevalence of syphilis markers in MSM from the GHSS was determined and compared with syphilis seroprevalence in HIV negative MSM. MSM from the GHSS were included in the analysis if HIV seroconversion occurred between 1996 and 2007 and a blood sample taken within two years after seroconversion was available for testing. The samples were tested for antibodies against treponema pallidum. Data on the time point of clinical syphilis diagnosis were not available. HIV negative participants of a MSM behaviour survey served as a control group. Participants had been recruited in Berlin in 2006 and had been tested serologically for HIV and syphilis.

Results: 1,004 MSM from the seroconverter cohort were eligible for analysis. Seroprevalence of syphilis markers was $27 \%$, and increased from $10 \%$ before 2000 , to $29 \%$ between 2000 and 2004 , and to $31 \%$ in the period after 2004. Syphilis seroprevalence in the HIV negative control group $(n=235)$ tested in 2006 was $9 \%$. Compared with HIV negative MSM, the odds ratios to test positive for syphilis in MSM who experienced HIV seroconversion were 1.1 (95\% CI: $0.5-2.3 ; \mathrm{p}=0.44$ ) before 2000 , 3.9 (95\%CI: $2.4-6.3 ; \mathrm{p}<0.001$ ) for the period 2000-2004, and 4.3 (95\%CI: $2.6-7.0 ; \mathrm{p}<0.001$ ) from 2005-2007.

Discussion: Since information on the date of syphilis acquisition is not available we can not directly prove a connection between HIV seroconversion and syphilis. Nevertheless, our results support the hypothesis that the syphilis co-epidemic may have been the primary trigger for an increase of HIV incidence in MSM in Germany due to its HIV transmission cofactor effect.

\section{P331}

HBV genotype diversity in HIV/HBV coinfected patients in the $S$ wiss HIV cohort

Florian Bihl ${ }^{1}$, Gladys Martinetti ${ }^{2}$, Bruno Ledergeber ${ }^{3}$, Sandrine Estoppey Younes ${ }^{4}$, Rainer Weber ${ }^{3}$, Pietro Vernazza $a^{5}$, Manuel Battegay 6 , Hans Jakob Furrer ${ }^{7}$, Matthias Cavassini ${ }^{8}$, Bernhard Hirschel ${ }^{9}$, Enos Bernasconi ${ }^{10}$, Swiss HIV Cohort Study

${ }^{1}$ University Hospital Geneva, Division of Gastroenterology and Hepatology, Geneva, Switzerland, ${ }^{2}$ Istituto Cantonale di Microbiologia, Bellinzona, Switzerland, ${ }^{3}$ Universität Zürich, Zurich, Switzerland, ${ }^{4}$ Swiss HIV Cohort Study Data Center, Lausanne, Switzerland, ${ }^{5}$ Spital St Gallen, St Gallen, Switzerland, ${ }^{6}$ Universitässpital Basel / Klinik für Infektionskrankheiten, Basel, Switzerland, ${ }^{7}$ Inselspital, Bern, Switzerland, ${ }^{8}$ University Hospital Lausanne, Lausanne, Switzerland, ${ }^{9}$ University Hospital Geneva, Geneva, Switzerland, ${ }^{10} \mathrm{Hosptal}$ of Lugano, Lugano, Switzerland

HBV co-infection in patients with HIV is common and the prevalence varies according to the geographic region and risk category. The liver-related mortality in $\mathrm{HIV} / \mathrm{HBV}$ coinfected patients is considerably high compared to patients with $\mathrm{HIV}$ alone and is highest in patients having low $\mathrm{CD}^{+}$ counts. Seven HBV genotypes have been so far described (A-G) with different geographical distribution. The role of $\mathrm{HBV}$ genotypes on the natural history and clinical outcome of the liver disease in HIV/HBV co-infected patients is not yet fully investigated.

To determine HBV genotype distribution in HIV/HBV coinfected participants to the Swiss HIV Cohort Study (SHCS) and to correlate demographic data and clinical outcome, 128 patients with chronic active HBV infection (HBs Ag+, HBV DNA+) were studied. HBV DNA was extracted and amplified by RT-PCR and genotypes assessed by direct sequencing.

The great majority of the identified HBV genotypes were A (64\%) followed by genotype D (30\%) whereas genotype $\mathrm{B}, \mathrm{C}, \mathrm{E}, \mathrm{G}$ were only represented in a minority of cases (1$2 \%$ ). This distribution resembles the HBV mono-infected patients in Europe, where HBV genotype A is the most predominant in Northern Europe and genotype D in the Mediterranean area. Further analyses include the association between genotypes and ethnicity and country of origin from patients.

In conclusion, the preliminary results of our study reveal a HBV genotype distribution pattern in HIV/HBV co-infected patients similar to HBV mono-infected patients.

\section{Klinik und Therapie / Clinical Therapy}

\subsection{Neuere Substanzklassen / New substance classes \\ $P 400(P W)$}

\section{Switching to raltegravir in HIV-infected patients with well controlled viral load - efficacy and safety}

Stefan Mauss ${ }^{1}$, Ana Milincovic ${ }^{2}$, Florian Berger ${ }^{1}$, Julia Henke ${ }^{1}$, Guenther Schmutz ${ }^{1}$, Petra Hegener ${ }^{1}$, Dieter Kuschak ${ }^{3}$, Stephan Schauseil ${ }^{3}$, Jospe Mallolas ${ }^{2}$, Amina Carlebach $^{4}$, Axel Müller ${ }^{4}$, Peter Gute ${ }^{4}$

${ }^{1}$ Center for HIV and Hepatogastroenterology, Duesseldorf, Germany, ${ }^{2}$ Hospital Clinic Barcelona, Barcelona, Spain,

${ }^{3}$ Medical Laboratories Duesseldorf, Duesseldorf, Germany,

${ }^{4}$ Infektiologikum Frankfurt, Frankfurt, Germany

Introduction: Raltegravir has been proven efficacious in salvage therapy. In addition its adverse event and metabolic profile in a study with antiretroviral naïve patients makes it an attractive candidate for patients with clinical intolerance or laboratory toxicities and limited treatment options due to pre-existing antiretroviral resistance.

Methods: Cohort of consecutively enrolled patients without hepatitis co-infection switching to raltegravir as replacement of a third agent due to clinical intolerance or laboratory toxicities in the presence of controlled HIVRNA (all $<500$ copies $/ \mathrm{ml}$ ). Patients were followed and adverse events, laboratory markers and treatment discontinuations were recorded.

Results: In total 74 patients were enrolled. 46/74 (62\%) 
switched from a boosted protease inhibitor due to intolerance or raised lipids in patients with myocardial infarction or high cardiovascular risk. The median follow up is 12 weeks. Baseline HIV-RNA was $<40$ copies/ $\mathrm{ml}$ in $53 / 74$ (72\%). Median $\mathrm{CD}^{+}+$cell count was 543 cells $/ \mu 1.5 / 74$ patients were discontinued due to adverse events (4/5 liver toxicity). No patient experienced viral failure. After 12 weeks HIV-RNA was $<40$ copies $/ \mathrm{ml}$ in $86 \%(\mathrm{p}=0.08)$ and median CD4+ cell count was 481 cells $/ \mu 1(\mathrm{p}=0.201)$.

Median ALT (alanine aminotransferase) increased from 28 to $35 \mathrm{U} / 1(\mathrm{p}<0.01)$ and median AST (aspartate transaminase) from 29 to $31 \mathrm{U} / 1(\mathrm{p}<0.01)$. Proportion of patients with ALT grade 1 or 2 increased from $20 \%$ to $38 \%$ ( $p<$ 0.05 ). Triglycerides decreased from median 206 to 137 $\mathrm{mg} / \mathrm{dl}(\mathrm{p}=0.06)$. In patients switched from PI the decrease in triglycerides was 183 to $109 \mathrm{mg} / \mathrm{dl}(\mathrm{p}=0.001)$. All other lipids were not substantially changed.

Conclusion: After switching to raltegravir antiviral efficacy was maintained over at least 12 weeks. However there was an increase in ALT leading to raltegravir discontinuation in some patients. Concerning lipids switching to raltegravir seem to decrease triglycerides in particular in patients previously treated with a PI.

\section{P401 (PW)}

\section{HIV integrase inhibition - more complex that simply blocking one key viral enzyme function}

\author{
Séverine Louvel ${ }^{1}$, François Hamy ${ }^{2}$, Thomas KIimkait ${ }^{1}$
}

${ }^{1}$ Institute of Medical Microbiology, University of Basel, Switzerland, ${ }^{2}$ InPheno AG, Basel, Switzerland

Background: In Patients, raltegravir treatment is associated with a stunningly steep viral load decline, suggesting that under raltegravir treatment the viral half life in the blood is significantly shorter than with other classes. Nevertheless, from the viral dynamics perspective inhibiting retroviral integration should not differ much from a block of the RT step.

Raltegravir has been qualified as an "Interface Inhibitor" suggesting that beyond inhibiting strand-transfer reaction it may disrupt interactions with host and/or viral factors.

This study investigates therefore potential secondary effects of INT-inhibition and the possible impact of unintegrated proviral DNA on viral life cycle.

Methods: Several HIV mutants coding for disabled or inhibitor-resistant integrase were used to study secondary drug-effects. The replicative reporter system PhenoTect was used to assess viral transactivation, replication, release, or particle infectivity.

Results : In our replicative format assay, INT-inhibition consistently produces an unexplained plateau significantly below $100 \%$ viral inhibition that is not seen with PIs or RTIs. In order to explain this remnant signal, we sought to monitor the expression of early vs late genes with respect to integrase activity ( \pm drug vs mutants).

Lastly, as integrase is part of viral particles, we investigated whether the "Interface Inhibition" will impair steps of viral production.

Conclusion: Our study provides evidence that integrase inhibition may lead to an impaired production of viral progeny. Contrastingly, residual proviral activity from unintegrated HIV might promote aspects of resistance devel- opment with clinical implications when starting therapy at high viral loads.

P402 (PD)

\section{New antiretroviral treatment options with integrase-inhibitors, CCR5-antagonists and second-generation-NNRTI and combination antiretroviral therapy (cART) in the ClinSurv cohort}

Barbara Bartmeyer, Kollan Christian, Kühne Andrea, Osamah Hamouda, Studiengruppe Klinische Surveillance ClinSurv

Robert Koch-Institut, Abteilung für Infektionsepidemiologie, HIV/AIDS und andere sexuell und durch Blut übertragbare Erkrankungen, Berlin, Germany

Objective: Treatment options for patients harbouring resistance to the three initially licensed antiretroviral drug classes are limited. New antiretroviral drugs (NAD) are now available. We aimed to investigate the frequency of raltegravir (RAL), maraviroc (MVC) and etravirine (ETR) containing cART use in heavily pre-treated patients in the ClinSurv Cohort since the start of early access programmes (EAP) in Germany in January, February and September 2007 for ETR, RAL and MVC, respectively .

Methods: The ClinSurv cohort was conducted since 1999 as a national, multi-centre prospective observational open cohort study. As of June 30th 2008, a total of 13,957 patients were included. Biannually, data on demographics, transmission route, CD4 and HIV RNA data, cART and HIV/AIDS related diagnoses were reported. Any substance change in cART was considered a new regimen.

Results: Since January 2007, 347 NAD comprising regimen were used in 279 heavily pre-treated patients (mean number of previous drug changes $=13$ ). NAD therapy started in $71 \%(199 / 279)$ of patients with unsuppressed viraemia (median: 54,630 copies/ml; range: 50-1,070 000 copies $/ \mathrm{ml}$ ). NAD comprising regimen were used in $29 \%$ $(80 / 279)$ of patients although viral load was undetectable ( $\leq 50$ copies $/ \mathrm{ml}$ ). RAL containing cART was preferred $71 \%$ (248/347), followed by ETR $24 \%(85 / 347)$ and by MVC $20 \%(71 / 347)$. NAD were mostly combined with double or triple nucleotide-reverse-transcriptase-inhibitor backbone and boosted second generation protease inhibitors (darunavir, atazanavir, tipranavir). 3 months after switch to NAD therapy viral suppression $(\leq 50$ copies $/ \mathrm{ml})$ was observed in $63 \%$ of patients $(177 / 279)$ while $36 \%(102 / 279)$ showed decreased but still detectable HIV-RNA (median, 9,850 copies/ml, range 50-530,000).

Conclusion: Treatment success was achieved in more than half of the heavily pre-treated patients who switched to NAD. Treatment options for patients with multi drug resistance have increased, but appropriate use of NAD is necessary to secure treatment success in patients on salvage therapy. 


\section{$P 403$}

Final results from the Connect cohort confirm efficacy and safety of enfuvirtide in a "real life setting "

Olaf Degen ${ }^{1}$, Gerd Faetkenheuer ${ }^{2}, J$. Bogner ${ }^{3}, S$ Dupke ${ }^{4}$, S. Koeppe ${ }^{5}, S$ Gute $^{6}$, W Becker ${ }^{7}$, A Tappe ${ }^{8}$, Egbert Wellmann $^{8}$, Hans-Juergen Stellbrink ${ }^{9}$

${ }^{1}$ Universitaetsklinikum Hamburg-Eppendorf, Ambulanzzentrum Infektiologie, Hamburg, Germany, ${ }^{2}$ Universitaetsklinikum, Köln, Germany, ${ }^{3}$ Universitätsklinikum, München, Germany, ${ }^{4}$ Praxis Dres. S. Dupke / A. Carganico / A. Baumgarten, Berlin, Germany, 5 Praxis Dres. S. Koeppe / P.Kreckel, Berlin, Germany, ${ }^{6}$ Infektiologikum, Frankfurt, Germany, ${ }^{7}$ Praxis Dres. Becker,Volker, München, Germany, ${ }^{8}$ Roche Pharma, Grenzach Wyhlen, Germany, ${ }^{9}$ Infektionsmedizinisches Centrum Hamburg (ICH), Hamburg, Germany

Objective: The CONNECT cohort is an observational study that assesses the efficacy and tolerability of treatment with enfuvirtide in a non-selected patient population. 171 patients were enrolled from Jun2005 - Oct 2007. We present the final analysis of 140 patients with at least complete available baseline data.

Methods: Multicenter, prospective, open label, 24 week observational study. Assessments at week 4, 12 and 24 include change in viral load, CD4 count, antiretroviral therapy (ART) and concomitant medication from baseline. Tolerability assessments include safety laboratory parameters, injection site reactions (ISR) and adverse effects. Resistance data and Active Drug Scores (ADS) are also obtained. Results: Final analysis of 140 patients. Baseline characteristics: $86 \%$ male, median age 45 years, median time since first diagnosis 14.0 years (11-17 IQR), Proportion of patients with HIV stage A $11 \%$, B $27 \%$ and C $61 \%$, respectively. Median baseline VL $4.3 \log 10 \mathrm{HIV}$ RNA copies/mL (3.4 -4.9 IQR ), median CD4 count 185 cells/ $\mu 1$ (61-331 IQR ). $23.6 \%$ of patients received TPV, $44.3 \%$ DRV, $11.4 \% \mathrm{ETV}, 8.6 \% \mathrm{RGV}$ as part of their ART regimen. $7.9 \%$ of patients were enfuvirtide-experienced. Week 24 results: $51.9 \%$ of ENF-naïve patients and $36.6 \%$ of ENF-experienced patients had a VL $<50$ copies/mL (ITT). Median decline in VL was $-2.6 \log 10$ and $-2.4 \log 10$, respectively. There were no clinical grade 4 adverse events. ENF was stopped in $17.1 \%$ of the patients. Resistance data were available from 91 patients, ADS scores ranged from 0 to 5 (median 1).

Conclusions: VL-response and safety data confirm the good overall efficacy and safety profile of ENF in a real life setting. The high number of patients using ENF in combination with (at that time) investigative agents show the value of ENF as a backbone in investigative ART-Regimens.

\section{P404}

Treatment of HIV-infected patients with a HAART regimen containing Enfuvirtide and a "second generation" protease inhibitor

Thore Lorenzen ${ }^{1}$, Irene Walther ${ }^{1}$, Johannes R. Bogner ${ }^{2}$, Jan van Lunzen ${ }^{3}$, Christoph Schuler ${ }^{4}$, Gerd Fätkenheuer ${ }^{5}$, Peter Gute 6 , Carl-Knut Schewe ${ }^{7}$, Siegfried Köppe ${ }^{8}$, Dietmar Schranz ${ }^{9}$, Heinz-Aug ust Horst ${ }^{10}$, Albrecht Stoehr ${ }^{1}$, Andreas Plettenberg ${ }^{1}$

${ }^{1}$ Institut für Interdisziplinäre Medizin (ifi), Hamburg, Germany, ${ }^{2}$ Ludwig-Maximilian-Universität, München, Germany, ${ }^{3}$ Universitaetsklinikum Hamburg-Eppendorf, Hamburg, Germany, ${ }^{4}$ Praxisgemeinschaft Turmstraße, Berlin, Germany, ${ }^{5}$ Universität zu Köln, Klinik I für Innere Medizin, Köln, Germany, ${ }^{6}$ Infektiologikum Frankfurt, Frankfurt/M,

Germany, ${ }^{7} \mathrm{ICH}$ (Infektionsmedizinisches Centrum Hamburg), Hamburg, Germany, ${ }^{8}$ Praxis Dr Köppe, Berlin, Germany,

${ }^{9}$ Praxis Dres Schranz/Fischer, Berlin, Germany, ${ }^{10}$ Städt. Krankenhaus Kiel GmbH, Infektionsambulanz, Kiel, Germany

Background: The new protease inhibitors Darunavir (DRV) and Tipranavir (TPV) demonstrate improved efficacy in HAART experienced HIV-infected patients. Additional use of Enfuvirtide in the phase III studies of DRV and TPV showed better outcome.

Methods: Treatment experienced patients initiating HAART containing ENF and DRV or TPV were recruited in a cohort to observe 1. virological/immunological outcome, 2. occurrence of AIDS-defining events and 3. reasons for interruption of ENF and/or DRV/TPV.

Resul ts : 55 patients with a median age of 46 years (19-75 years) were observed. Median baseline viral load was 4.49 $\log (1.59$ to $6.13 \mathrm{log})$ and CD4+ cells were $147 \mathrm{c} / \mu 1(8-751$ $\mathrm{c} / \mu 1)$. Patients had a median of 5 prior ART regimens and of 107 months treatment experience. Resistance analyses showed 8 (0-12) RT- and 8 (0-11) PI-as sociated mutations in median. 35 patients started DRV and 20 used TPV in combination with ENF. Viral load declined by $2.77 \mathrm{log}$ and $2.49 \log$ HIV-RNA after 6 and 12 months. $26(47,3 \%)$ and 23 patients $(41.8 \%)$ achieved undetectable viral load, respectively. CD4-cells increased by $76 \mathrm{c} / \mu 1$ and $96 \mathrm{c} / \mu 1$ at month 6 and 12. None of the patients was affected by AIDSdefining illnesses but 16 other clinical events were observed: $11(65 \%)$ occurred within the first three months after initiating new HAART. 17 patients terminated treatment: 8 patients $(47 \%)$ were unable to tolerate ENF application, 5 (29\%) were lost to follow up. One patient stopped regimen due to nausea, vomiting and diarrhea and one patient died.

Conclusion: Data show good efficacy of HAART containing ENF plus DRV or TPV. Despite long pre-treatment and multiple resistance mutations over $40 \%$ of patients achieved undetectable viral load. Immunological parameters improved substantially. Most adverse events occurred early after initiation of new HAART. Treatment termination was most frequently related to intolerability of ENF. 


\section{P405}

Opportunities to assessan optimized salvage regimen in $\mathrm{HIV}$ infected triple-class experienced patients by the expert advice system RADATA

Thore Lorenzen ${ }^{1}$, Irene Walther ${ }^{1}$, Peter Gute ${ }^{2}$, Johannes R. Bogner ${ }^{3}$, Stefan Mauss ${ }^{4}$, Matthias Stoll ${ }^{5}$, Heribert Knechten ${ }^{6}$, Jürgen Rockstroh ${ }^{7}$, Jan van Lunzen ${ }^{8}$, Bernd Salzberger ${ }^{9}$, Albrecht Stoehr ${ }^{1}$, Andreas Plettenberg ${ }^{1}$, for the Radata Study Group

${ }^{1}$ Institut für Interdisziplinäre Medizin (ifi), Hamburg, Germany, ${ }^{2}$ Infektiologikum Frankfurt, Frankfurt/M, Germany, ${ }^{3}$ Ludwig-Maximilian-Universität, München, Germany, ${ }^{4}$ Praxis Dres Mauss/Schmutz/Hegener/Athmann, Düsseldorf, Germany, ${ }^{5}$ Medizinische Hochschule Hannover, Hannover, Germany, ${ }^{6}$ Praxis Dr Knechten, Aachen, Germany,

${ }^{7}$ Universitätsklinikum Bonn, Medizinische Klinik und Poliklinik I, Bonn, Germany, ${ }^{8}$ Universitaetsklinikum Hamburg-Eppendorf, Hamburg, Germany, ${ }^{9}$ Universität Regensburg, Klinik I für Innere Medizin, Regensburg, Germany

Objective: To evaluate efficacy of expert-advice-guided antiretroviral therapy in patients with triple class failure. Introduction: Clinical studies suggest expert recommendations as a possibility to optimize antiretroviral therapy in patients with triple class failure and/or extensive drug resistant virus strains. An online system to provide expert advice for the drug therapy of HIV-infected patients was established (RADATA).

Design and methods: The virological and immunological outcome of patients with at least 3 prior ART regimens including NRTI, NNRTI and PI use from the RADATA expert advice system were analysed. Changes of HIV-RNA and $\mathrm{CD}^{+}{ }^{+}$cell count were evaluated at month 6,12 and 24 .

Results : 183 patients with a median baseline viral load of $3.90 \log (1.88$ to $6.54 \mathrm{log})$ and baseline $\mathrm{CD}^{+}$cells of 298 $\mathrm{c} / \mu 1(5-910 \mathrm{c} / \mu 1)$ were eligible for analysis. Patients had a median of 7 prior ART regimens and of 83 months treatment experience. A median of 3 (0-8) NRTI-, 2 (0-7) TAMs, 1(0-4) NNRTI- and $3(0-13)$ PI-as sociated mutations were present. Overall $66 \%(n=119)$ of all patients started their new ART regimen without any active drug according to the resistance analysis. A median decline of $0.61 \mathrm{log}$ and 0.92 log HIV-RNA was demonstrated after 12 and 24 months respectively and $\mathrm{CD} 4{ }^{+}$cells increased by a median of $+9 \mathrm{c} / \mu \mathrm{l}$ and $+25 \mathrm{c} / \mu 1$. No significant differences could be found neither related to number of prior regimens nor to number of active substances use.

Conclusion: Despite an extensive pre-treatment and numerous resistances against prescribed HAART patients demonstrated a viral decline and a stable $\mathrm{CD}^{+}{ }^{+}$cell count over an observation period up to 24 months. Thus, activity of antiretroviral regimens is not exclusively explained by current algorithms used for estimation of antiretroviral drug activity. Expert advice may be a valueable tool to create HAART-regimens in deep salvage situations .
P406

\section{Maraviroc in clinical practice - 24 weeks data}

Heribert Knechten ${ }^{1}$, Christian Höhn ${ }^{1}$, Robert Ehret ${ }^{1}$ Frank Wiesmann ${ }^{1}$, Martin Hower ${ }^{2}$, Stefan Scholten ${ }^{3}$, Anton Neuwirth ${ }^{4}$, Wolfgang Köthemann ${ }^{4}$, Patrick Braun ${ }^{1}$

${ }^{1} \mathrm{PZB}$, Aachen, Germany, ${ }^{2}$ Klinikum Dortmund, IDAmbulanz, Dortmund, Germany, ${ }^{3}$ Praxis, Köln, Germany, ${ }^{4}$ Gemeinschaftspraxis, Köln, Germany

Purpose: Maraviroc is the first approved CCR5-Inhibitor in the treatment of HIV. Prior to application a tropism test is mandatory. Clinical Trials showed a good safety and efficacy in study population. Our objective is the prove of value in daily routine.

Methods: Phenotypic tropism test was performed with Trofile $^{\mathrm{TM}}$ (Monogram) and genotype by sequencing the V3-loop region interpreted by geno2pheno (false positive X4-rate 15\%; last update september 19th, 2008). 21 heavily pre-treated patients, 17 male/4 female, with a median HIV RNA of 68.209 copies $/ \mathrm{ml}$ and mean CD 4 counts of $437 \pm 288$ cells $/ \mu 1$ were analysed at week 12 and 24 on a Maraviroc containing regimen. Two patients switched in remission. Therapy-success was defined as a plasma viral load $\leq 50$ copies $/ \mathrm{ml}$.

Results : 16 patients reached week 24 . In one patient only a CXCR4-virus could be detected with both assays. Due to limited therapy options he received Maraviroc and declined under the limit of detection. One patient had a dissenting tropism prediction in both assays, another interrupted his therapy in week 4 . The new ART-regimens showed an active drug score between 1.66 to 6 (HIV-Grade, version 07/2008). 4 patients had drug holidays and therefore no detectable resistance-as sociated mutations before starting the Maraviroc containing regimen. In week 24, 11 patients $(68.75 \%)$ had a viral load $\leq 50$ copies/ml and 3 patients (14.3\%) a drop of $2 \mathrm{log}$; the mean CD4 count increased to $524 \pm 319$ cells $/ \mu 1$.

Conclusions: Although all patients were heavily pretreated a good treatment response could be observed this maybe due to combinations of new drugs, documented by the high active drug score. This score is partially caused by the drug holidays before starting the new regimen. However, the combination of Maraviroc together with further active drugs, within heavily pretreated patients seems to be an effective option in clinical practice.

\subsection{Non-Nukleotide RT-Inhibitoren / Non-nuclear RT-Inhibitors $P 407$ (PW)}

Durable efficacy and safety of etravirine in treatment-experienced, HIV-1-infected patients: pooled Week-96 results from the phaseIII DUET-1 and DUET-2 trials

$J$ Vingerhoets, $B$ Woodfall

Tibotec BVBA, Mechelen, Belgium

Background: The NNRTI etravirine (ETR; TMC125) has shown durable and superior clinical efficacy over placebo, and tolerability similar to placebo, in treatment- 
experienced patients based on the 48 weeks results of the DUET trials. Pooled 96 -week results are now being presented.

Methods: Patients were randomized to receive $200 \mathrm{mg}$ ETR or placebo bid plus a background regimen (BR) of darunavir/ritonavir, investigator-selected NRTI(s) \pm enfuvirtide (ENF). The primary endpoint was the proportion of patients with confirmed viral load $(\mathrm{VL})<50$ copies $/ \mathrm{mL}$ at 24 weeks. Safety/tolerability were also assessed.

Results: 599 patients received ETR and 604 placebo. There was only a $3 \%$ decrease in the proportion of ETR patients achieving $\mathrm{VL}<50$ copies/mL from Week 48 to 96 ( $60 \%$ to $57 \%$ ), and $91 \%$ of ETR patients maintained their response from Week 48 to 96 . SAEs (26\% vs $26 \%$ ), grade $3 / 4$ AEs (41\% vs 37\%) and AEs leading to discontinuation (9\% vs 6\%) with ETR were comparable to placebo. As expected, incidence of rash did not change significantly from Week 48 (19\% for ETR+BR vs. $11 \%$ for placebo+BR) to Week 96 (21\% for ETR+BR vs $12 \%$ for placebo+BR, p< $0.0001)$. The frequency of grade $3 / 4$ neuropsychiatric $(1 \%$ vs $3 \%$ ) and hepatic (4\% vs $3 \%$ ) AEs were comparable between groups.

Conclusions: Durable and statistically superior efficacy was provided by ETR vs placebo through 96 weeks in the DUET trials. In ETR patients, the decrease in $\mathrm{VL}<50$ copies/mL between Weeks 96 and 48 was only $3 \%$, and 91\% maintained undetectable VL to Week 96 . The safety profile of ETR remained comparable to placebo, excluding rash that was slightly higher with ETR but occurred primarily within the first two weeks of treatment.

\section{$P 408$}

\section{Safety and efficacy of tenofovir DF (TDF) in combination with $3 \mathrm{TC}$ and efavirenz (EFV) in antiretroviral-naïve patients through seven years}

Isabel Cassetti ${ }^{1}$, Jose Valdez R. Madruga ${ }^{2}$, Arnaldo Etzel ${ }^{3}$, Jamal Muhamad A.H. Suleiman ${ }^{4}$, Britta Ranneberg ${ }^{5}$, Lijie Zhong ${ }^{6}$, Andrew Cheng ${ }^{6}$, Jeffrey Enejosa ${ }^{6}$, 903E Study Team

${ }^{1}$ Fundacion Centro Estudios Infectologicos, Buenos Aires, Argentina, ${ }^{2}$ Centro de Referência e Treinamento DST/AIDS, São Paulo, Brazil, ${ }^{3}$ Hospital Guilherme Álvaro, Santos, Brazil, ${ }^{4}$ Brasilmed Assistência Médica e Pesquisas, Sao Paulo, Brazil, ${ }^{5}$ Gilead Sciences, Martinsried, Germany, ${ }^{6}$ Gilead Sciences, Foster City, United States

Background: Study 903 is a Phase III trial with a 3 year, double-blind (DB) phase comparing TDF to d4T in combination with $3 \mathrm{TC}$ and EFV. In the study, TDF was associated with durable efficacy, better lipid profiles and less lipodystrophy. Study $903 \mathrm{E}$ is the ongoing open-label (OL) extension evaluating up to 10 year safety and efficacy of a oncedaily $\mathrm{TDF}+3 \mathrm{TC}+\mathrm{EFV}$ regimen .

Methods: All patients in Argentina, Brazil, and the Dominican Republic who completed the double-blind phase were eligible to roll over to Study $903 \mathrm{E}$ and receive a oncedaily regimen of open-label TDF+3TC+EFV.

Results : 86 patients (62\% male, $70 \%$ white, mean age 33 yrs) originally randomized to TDF continued treatment in the OL extension. At DB-baseline (BL), mean HIV-RNA was $4.9 \log 10 \mathrm{c} / \mathrm{mL}$ and mean CD4 count was 299 cells $/ \mathrm{mm}^{3}$. At year $7,81 \%(\mathrm{M}=\mathrm{F})$ had HIV RNA $<400$ $\mathrm{c} / \mathrm{mL}$ and $80 \%(\mathrm{M}=\mathrm{F})$ had HIV RNA $<50 \mathrm{c} / \mathrm{mL}$; mean CD4 cell count increased 459 cells $/ \mathrm{mm}^{3}$ from BL. One patient discontinued study due to adverse event (elevated amylase/lipase) and 4 due to virologic failure. No patient developed K65R. No patient discontinued due to renal adverse events. Mean change from BL in glomerular filtration rate (GFR) by Cockcroft-Gault was $+1 \mathrm{~mL} / \mathrm{min}$. Decreases in spine and hip bone mineral density (BMD) by dual energy $x$-ray absorptiometry were seen in the first year and remained stable (mean \% change from BL at year 7 in BMD was $-1.5 \%$ in spine and $-2.6 \%$ in hip). No patient experienced pathologic fractures. Median limb fat was $6.7 \mathrm{~kg}$ at year 2 and increased to $8.0 \mathrm{~kg}$ at year 7.

Conclusions: Through 7 years of therapy, the once-daily regimen of $\mathrm{TDF}+3 \mathrm{TC}+\mathrm{EFV}$ demonstrated sustained antiretroviral activity with continued immunologic recovery in antiretroviral-naïve patients and was not associated with limb fat loss, progressive bone loss or declines in estimated GFR.

\section{P409}

The 48-week efficacy and safety of switching to fixed dose efavirenz/emtricitabine/tenofovir DF in HIV-1-infected patients receiving HAAR T

Edwin De Jesus ${ }^{1}$, Anton Pozniak ${ }^{2}$, Markus Bickel ${ }^{3}$, Joel Gallant $^{4}$, Jose Arribas ${ }^{5}, Y_{\text {un Zhou }}^{6}$, Andrew Cheng ${ }^{6}$, Jeffrey Enejosa ${ }^{6}$

${ }^{1}$ Orlando Immunology Center, Orlando, United States, ${ }^{2}$ Chelsea \& Westminster Hospital, London, United Kingdom,

3 JW Goethe Universität, HIV Center, Frankfurt, Germany,

${ }^{4}$ Johns Hopkins University, Baltimore, United States,

${ }^{5}$ University Hospital La Paz, Madrid, Spain, 6Gilead Sciences, Foster City, United States

Background: Study 934 is a 144-week randomized openlabel trial comparing safety and efficacy of emtricitabine/tenofovir DF (TVD) with lamivudine/zidovudine (CBV) both in combination with efavirenz (EFV) in treatment-naïve patients (pts).

Methods: After completing 144 weeks, pts in both arms switched antiretroviral regimen to the fixed-dose combination EFV/emtricitabine/tenofovir DF (ATR) once daily without regards to food.

Results: 286 pts (160 switched from TVD; 126 from $\mathrm{CBV}$ ) rolled over into the extension (88\% male, $65 \%$ white, mean age 40 yrs, mean CD4 535 cells $/ \mathrm{mm}^{3}$ ) and received ATR. At time of switch, 94\% in TVD arm and 97\% in $\mathrm{CBV}$ arm had HIV RNA $<50$ copies/mL. One pt died from cardiac arrest assessed as unrelated to study drug; 2 pts discontinued due to AEs (MAI, anal CA). No pt experienced renal AEs (Table Results).

Conclusions: Switching TVD or CBV + EFV to a single tablet once-daily regimen of efavirenz/ emtricitabine/ tenofovir DF was well-tolerated and resulted in maintenance of virologic suppression through 48 wks. In pts on CBV+EFV for 3 years, switching to ATR did not significantly improve limb fat within the first 48 wks. 
TVD+EFV to ATR

\begin{tabular}{lll}
\hline HIV RNA $<50$ at Wk 48 post-switch $(\mathrm{M}=\mathrm{F}, \mathrm{M}=\mathrm{E})$ & $90 \%, 96 \%$ \\
Est. GFR $^{\mathrm{a}}$ by CG $(\mathrm{mL} / \mathrm{min})$ & $94 \%, 96 \%$ & $120,-10$ \\
Est. GFR $^{\mathrm{a}}$ by MDRD $\left(\mathrm{mL} / \mathrm{min} / 1.73 \mathrm{~m}^{2}\right)$ & $115,-2$ & $106,-9$ \\
Fasting Total Cholesterol $^{\mathrm{a}}(\mathrm{mg} / \mathrm{dL})$ & $98,-1$ & $199,-9$ \\
Fasting LDL-C $^{\mathrm{a}}(\mathrm{mg} / \mathrm{dL})$ & $189,+6$ & $118,-6$ \\
Fasting Triglycerides $^{\mathrm{a}}(\mathrm{mg} / \mathrm{dL})$ & 114,0 & $128,-21$ \\
Median Total Limb Fat $(\mathrm{kg})$ at time of switch \& at Wk 48 & $120,-3$ & $5.5,5.7$ \\
\hline
\end{tabular}

a median at time of switch, median change at Wk 48

\section{P410}

Simplification of therapy (ART) with Efavirenz/Emtricitabine/Tenofovir DF single tablet regimen vs. continued ART in suppressed, HIV-infected patients

B. Young ${ }^{1}$, E. de Jesus ${ }^{2}$, J.O. Morales-Ramirez ${ }^{3}$, Tina

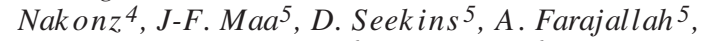
R. Ebrahimi ${ }^{6}$, J. Flaherty ${ }^{6}$

${ }^{1}$ Denver ID Consultants, Denver, United States, ${ }^{2}$ OIC, Orlando, FL, United States, ${ }^{3}$ Clinical Research, San Juan, Puerto Rico, ${ }^{4}$ Bristol-Myers Squibb GmbH \& Co.KGaA, Medizinische Abteilung HIV / Antivirals, München, Germany, ${ }^{5}$ Bristol-Myers Squibb, Princeton, NJ, United States, 6Gilead Sciences, Foster City, CA, United States

Backgro und: AI266073 is a 48 week, randomized, openlabel, multi-center study with the primary objective of evaluating non-inferiority of simplification of ART to efavirenz/emtricitabine/ten ofovir (EFV/FTC/TDF) vs continuation of the same baseline regimen (SBR).

Methods: Patients on stable ART with VL $<200$ copies $/ \mathrm{ml}$ for $\geq 3$ months were stratified by NNRTI/PI-based ART, randomized $(2: 1)$ to switch to EFV/FTC/TDF or continue SBR. Primary endpoint was maintenance of $\mathrm{VL}<200$ copies $/ \mathrm{ml}$ at $48 \mathrm{~W}$ by TLOVR (ITT, $\mathrm{NC}=$ failure, $\mathrm{D}=15 \%$ ); also assessed $\mathrm{VL}<50$ copies/ml, pure virologic response (PVR by Kaplan Meier) and LOCF analysis (early discontinuations for an $\mathrm{AE}$ were considered failures).

Results : 300 patients (EFV/FTC/TDF 203, SBR 97) were evaluated (prior PI/NNRTI 53\%/47\%). Treatment arms were well balanced, median BL CD4 516 cells $/ \mathrm{mm}^{3}, 96 \% \mathrm{VL}<$ 50 copies $/ \mathrm{ml}$.

\begin{tabular}{llll}
$\begin{array}{l}\text { Viralload } \\
\text { copies/ml) }\end{array}$ & EFV/FTC/TDF & SBR & Difference $(95 \%$ CI) \\
\hline$<200($ TLOVR) & $89 \%$ & $88 \%$ & $1.1 \%(-6.7 \%, 8.8 \%)$ \\
$<50($ TLOVR) & $87 \%$ & $85 \%$ & $2.6 \%(-5.9 \%, 11.1 \%)$ \\
$<50($ PVR $)$ & $95 \%$ & $86 \%$ & $8.9 \%(-7.7 \%, 25.6 \%)$ \\
$<50(\mathrm{LOCF})$ & $94 \%$ & $97 \%$ & $-3.3 \%(-8.3 \%, 2.7 \%)$ \\
\hline
\end{tabular}

[efficacy]

At $48 \mathrm{~W}, \mathrm{EFV} / \mathrm{FTC} / \mathrm{TDF}$ was found to be non-inferior to SBR. Similar virologic responses were also observed between arms when analyzed by PI/NNRTI strata and prior or no prior use of TDF. Overall discontinuation rates for EFV/FTC/TDF vs SBR were $11 \%$ vs. $12 \%$ (AE 5\% vs. 1\%; withdrawal of consent $2 \%$ vs. $7 \%$ ). In the EFV/FTC/TDF arm, 1 patient discontinued for virologic failure. Overall, more nervous system symptoms (NSS) were reported for EFV/FTC/TDF vs. SBR, NSS occurred early, were generally transient, mild, and more common with prior PI-based ART. A greater decline in fasting triglycerides was observed with EFV/FTC/TDF vs SBR (median -20 vs. -3 $\mathrm{mg} / \mathrm{dl} ; \mathrm{p}=.035$ ).

Conclusions: High and comparable rates of virologic suppression were maintained with EFV/FTC/TDF vs. SBR, regardless of type of prior ART. The grade/frequency of AEs reported for patients switched to EFV/FTC/TDF was consistent with previous studies.

\section{P411}

Safety and tolerability of etravirine (ETR) in hepatitis $B$ and/or $C$ co-infected patients in DUET-1 and 2: 48 week results

Albrecht Stoehr ${ }^{1}$, Gerd Fätkenheuer ${ }^{2}$, Klaus Göbels ${ }^{3}$, Frank-Detlef Goebel ${ }^{4}$, Hans Jäger ${ }^{5}$, Arend Moll 6 , Jürgen Kurt Rockstroh 7 , Dieter Schuster ${ }^{8}$, Schlomo Staszewski $i^{9}$, T. N. Kakuda ${ }^{10}$, G. De Smedt ${ }^{11}$, BerndSang ${ }^{12}$

1 ifi - Institute for Interdisciplinary Medicine, Hamburg, Germany, ${ }^{2}$ Medical Hospital of the University of Cologne, Department of Internal Medicine I, Cologne, Germany, ${ }^{3}$ Private Practice, Düsseldorf, Germany, ${ }^{4}$ Private Practice, Munich, Germany, ${ }^{5}$ Mucresearch, Munich, Germany, ${ }^{6}$ Praxiszentrum Kaiserdamm, Berlin, Germany, ${ }^{7}$ Medical Hospital of the University of Bonn, Bonn, Germany, ${ }^{8}$ Private Practice, Mannheim, Germany, ${ }^{9}$ Medical Hospital of the University of Frankfurt, Frankfurt, Germany, ${ }^{10}$ Tibotec Inc, Yardley, United States, ${ }^{11}$ Tibotec BVBA, Mechelen, Belgium,

${ }^{12}$ Tibotec / Division of Janssen-Cilag, Neuss, Germany

The pooled 48-week efficacy and safety analysis of the next-generation NNRTI etravirine (ETR) in the DUET studies has been completed. We report safety results from a planned pooled analysis, according to baseline hepatitis co-infection status .

HIV-1-infected patients on stable but virologically failing therapy were randomised to receive either ETR $200 \mathrm{mg}$ twice daily or placebo, both in combination with a background regimen (BR) consisting of darunavir with low-dose ritonavir (DRV/r), investigator-selected NRTIs and optional enfuvirtide (ENF). Hepatitis $\mathrm{B}$ and/or $\mathrm{C}$ virus (HBV and/or HCV) co-infection status was confirmed by hepatitis $\mathrm{B}$ surface antigen or HCV antibody and qualitative HCV ribonucleic acid (RNA). Co-infected patients were eligible if they were clinically stable, with aspartate aminotransferase (AST) and alanine aminotransferase (ALT) levels $<5$ $\mathrm{x}$ the upper limit of normal and did not require anti-hepati- 
tis treatment. Adverse events (AEs) and laboratory parameters were analysed.

At baseline, HBV and/or HCV status was known for 1129 HIV-1-infected patients. Of these, 139 patients $(12.3 \%)$ were co-infected with $\mathrm{HBV}$ and/or HCV; the sample size was too small to compare HBV and HCV groups separately. Median treatment duration for this analysis was 52.3 vs 51.0 weeks in the ETR + BR and placebo + BR groups, respectively. In co-infected patients, grade 3 or $4 \mathrm{AEs}$, serious AEs and deaths were less frequent with ETR than with placebo. Grade 3 or 4 AST/ALT elevations were more frequent in co-infected patients receiving ETR, however the differences between the ETR and placebo groups was small. The incidence of grade 3 or 4 hepatic AEs was similar in both treatment groups.

\section{P412}

\section{Langzeitverträglichkeit und -effizienz von Nevirapin als Bestandteil einer HAART}

\author{
Ivanka Krznaric, Stephan Dupke
}

Gemeinschaftspraxis Dupke, Baumgarten, Carganico, Berlin, Germany

Hinterg rund: 1996 erfolgte die Zulassung von NVP als erster NNRTI.Die Verträglichkeit war in der Regel gut.Rash und Hepatotoxizität erwiesen sich als die häufigsten Nebenwirkungen.Durch die Erhebung retrospektiver Daten wurden die Wirksamkeit und Sicherheit von Nevirapin im Rahmen einer Langzeittherapie untersucht.

Methoden: Die Datenbank einer HIV-Schwerpunktpraxis wurde im Zeitraum von 1997-2007 Patienten durchsucht, die NVP erhielten.Es wurden Patienten ausgewertet,die kontinuierlich über mehr als 5 Jahren mit NVP behandelt wurden.Eingeschlossen wurden sowohl therapienaive als auch Switch-Patienten .

Die Patientendaten wurden hinsichtlich der immunologischen und virologischen Wirksamkeit ausgewertet.Die Daten wurden zu Woche 24,48,nach3 Jahren und danach jährlich erhoben.Zusätzlich wurden bei bekannter potentieller Hepatotoxizität der Verlauf der Transaminasen und Umstellung sgründe dokumentiert.

Ergebnisse: 254 Patienten wurden auf eine NVP-haltige Therapie eingestellt.52 (20.5\%)wurden noch nach 5 Jahren mit Nevirapin behandelt Der Anteil der Männer und Frauen in dieser Gruppe betrug 45 (86.5\%) respektive 7 ( $13.5 \%)$. $33(63 \%)$ der Patienten waren vorbehandelt. Der Zeitraum von der Erstdiagnose bis zum Beginn der Nevirapin-haltigen Therapie betrug im Mittel 52.1 Monate.Die Zahl der CD4-Zellen zur Baseline war $\mathrm{m}=437, \mathrm{w}=318$. Die häufigste vor Umstellung verordnete Kombination bestand aus 2 NRTI+ 1 NNRTI.Bei den 33 Vorbehandelten waren im Median 3 NRTI, 1NNRTI und 1PI benutzt worden .

Der Anstieg der CD 4-Zellen/ $\mu 1$ betrug im Mittelwert 300 und zeigte auch nach 3 Jahren noch steigende Tendenz. Die Viruslast war bei allen zur Wo. 24 unter 50 copies $/ \mathrm{ml}$. Es traten insgesamt wenig Nebenwirkungen auf. Auch bei höherer CD4 Zellzahl kam es zu keiner ausgeprägten Hepatotoxität. Im Langzeitverlauf war ein Anstieg der y-GT bis auf Werte um $100 \mathrm{U} / \mathrm{ml}$ zu verzeichnen bei normaler GOT bzw. GPT.

Zus ammenfass ung: Bei einer retrospektiven Beobachtungszeit von 10 Jahren konnten eine gute Langzeitverträglichkeit sowie ein gutes virologisches und immunolo- gisches Ansprechen von Nevirapin als Bestandteil einer HAART belegt werden. Dieses gilt sowohl für therapienaive als auch mäßig vorbehandelte Patienten. Die häufig beobachtete isolierte Erhöhung der y-GT bleibt in aller Regel kleiner als der doppelte Normalwert.

\section{$P 413$}

Patient reported outcomes after simplification to a single tablet regimen of Efavirenz (EFV)/Emtricitabine (FTC)/Tenofovir DF (TDF)

\author{
S. Hodder ${ }^{1}$, K. Mounzer ${ }^{2}$, E. de Jesus ${ }^{3}$, Tina Nakonz ${ }^{4}$, \\ K. Grimm ${ }^{5}$, A. Farajallah ${ }^{5}$, J. Flaherty ${ }^{6}$
}

${ }^{1}$ University of Medicine and Dentistry of NJ, Newark, United States, ${ }^{2}$ Philadelphia FIGHT, Philadelphia, United States,

${ }^{3} \mathrm{OIC}$, Orlando, United States, ${ }^{4}$ Bristol-Myers Squibb GmbH \& Co.KGaA, Medizinische Abteilung HIV / Antivirals, München, Germany, ${ }^{5}$ Bristol-Myers Squibb, Princeton, NJ, United States, ${ }^{6}$ Gilead Sciences, Foster City, CA, United States

Objective: To assess patient reported outcomes in AI266073, a 48 week, prospective, randomized, open-label, multi-center study.

Methods: Pts on stable ART with HIV-1 RNA $<200 \mathrm{c} / \mathrm{mL}$ for $>3$ months were randomized $(2: 1)$ to EFV/FTC/TDF (single tablet regimen) or to remain on their baseline regimen (SBR) and were stratified by prior PI- /NNRTIbased therapy. In addition to efficacy/safety, the following were collected from both study arms: adherence, QoL by SF-36 survey, HIV Symptoms Index (HSI), and a PERC questionnaire. In the EFV/FTC/TDF arm only, a protocol specific Preference of Medication (POM) questionnaire was collected.

Results : 300 pts (EFV/FTC/TDF 203, SBR 97) were evaluated, $89 \%$ vs $88 \%$ in the EFV/FTC/TDF vs SBR arms maintained HIV-1 RNA $<200 \mathrm{c} / \mathrm{mL}$ by TLOVR (ITT; NC=F). Adherence in both arms at BL and all visits was $>96 \%$. BL SF36 scores were similar to general non-HIV infected pts with no marked changes in adherence and SF-36 scores. HSI results demonstrated improvements in the proportion of pts randomized to EFV/FTC/TDF who experienced diarrhea or loose bowel movements (prior PI stratum: $52 \%$ at BL; $32 \%$ at W48 [p = 0.002]); bloating, pain, or gas in the stomach $(p=0.002)$; changes in the way their body looked $(\mathrm{p}=0.002)$; and problems having sex $(\mathrm{p}=0.032)$. There was a transient worsening of dizziness or lightheadedness symptoms (at W4 only) in pts switched to EFV/FTC/TDF (p $<0.02$ ), primarily in pts who switched from a PI-regimen. By POM, pts randomized to EFV/FTC/TDF preferred this treatment over the previous regimen $(\mathrm{p}<0.001)$ at all post-BL visits.

Conclusion: Simplification to EFV/FTC/TDF from a variety of ART maintained high levels of virol. suppression, adherence and QoL through 48 weeks. Pts switched to EFV/FTC/TDF reported improvements in many HIV-related symptoms, found the new regimen easier to follow and preferred EFV/FTC/TDF over their previous ART regimen. 


\subsection{Nukleotide RT-Inhibitoren / Nuclear RT- Inhibitors \\ P414 (PW)}

\section{Safety and efficacy of tenofovir in pregnant} women

Annette Elisabeth Haberl ${ }^{1}$, Richard Linde ${ }^{2}$, Anke Reitter $^{3}$, Peter Gute ${ }^{4}$, Gaby Knecht ${ }^{4}$, Manfred Mösch ${ }^{5}$, Tessa Lennemann ${ }^{6}$, Gabriele Nisius ${ }^{6}$, Christoph Stephan ${ }^{1}$, Schlomo Staszewski ${ }^{6}$, Reinhard Brodt ${ }^{6}$

${ }^{1}$ HIV Center Treatment and Clinical Research Unit, Hospital of the JW Goethe University, Innere Medizin, Frankfurt,

Germany, ${ }^{2}$ Klinikum der JW Goethe Universität, Kinderklinik, Frankfurt, Germany, ${ }^{3}$ Klinikum der JW Goethe Universität, Frauenklinik, Frankfurt, Germany, ${ }^{4}$ Infektiologikum, Frankfurt, Germany, ${ }^{5}$ Medical Practice, Frankfurt, Germany, ${ }^{6}$ HIV Center Treatment and Clinical Research Unit, Hospital of the JW Goethe University, Frankfurt, Germany

Background: The use of tenofovir (TDF) in pregnant women is discussed controversially. Because of lack of data, EACS recommends not to initiate TDF, but possibly continue during pregnancy. Safety and efficacy of TDF in pregnant women needs to be analysed carefully.

Methods: Women from the Frankfurt HIV Cohort who received TDF during pregnancy were analysed. Main indication for TDF was AZT intolerance or -resistance. When nevirapine could not be used (CD4>250) or the woman was intolerant to PIs, triple NRTI combination of TDF, AZT plus FTC or 3 TC was initiated. Safety and efficacy during pregnancy and fetal outcome were analysed.

Results: 76 pregnant women received TDF. All 78 children were delivered by Caesarean section. There was no HIV transmission. No TDF related toxicity was observed in the children. Two women stopped TDF for exanthema (1) and nausea (1). Data of mothers and children:

Mothers $(n=76)$

Mean age (years): 32

Ethnic origin (\%): African 53, Caucasian 36, Hispanic 7, others 4

AIDS (\%):12

ART-naïv (\%):68

Mean onset of TDF: Pregnancy week 24

ART:

TDF+AZT+FTC or $3 \mathrm{TC}: \mathrm{n}=53(70 \%)$

$\mathrm{TDF}+\mathrm{NRTI}+\mathrm{PI} / \mathrm{r}: \mathrm{n}=13(17 \%)$

TDF+NRTI+NNRTI: $\mathrm{n}=5(6,5 \%)$

other: $\mathrm{n}=5(6,5 \%)$

Mean baseline CD4 (cells/ $\mu 1): 384(10-1390)$

Mean baseline VL (copies/ml): 41,970 $(<40-559,000)$

Mean CD4 at delivery (cells/ $\mu 1): 447(80-1247)$

Mean VL at delivery (copies/ml): $128(<40-1,780)$

AEs (n): Cystitis(12), early contractions(6), gestational diabetes(4), nausea(3), rupture of membranes(3), pyelonephritis(1), Pre-eclampsy(1), exanthema(1)

Children $(n=78)$

Mean time of Caes arean (weeks): 37 (31-40)

Mean birth weight (g): 2880 (1525-4270)

Mean intrauterine TDF exposure (weeks): 12 (1-40)

Malformations (n): Polydactily(3)*, Diaphragm hernia(1)*, Renal cyst(1)*, Cardial malformation in one child with down syndrome

*diagnosed before the onset of TDF
Conclusions: In our study TDF was effective and safe. All 78 exposed children were HIV-negative and had no signs of TDF related toxicity. TDF should be reconsidered for MTCT-prophylaxis

\section{P415}

Kivexa versus Truvada: similar virological outcomes in ART-naïve patients starting a lopinavir/ritonavir-based regimen. 48-weekdata from the STAR and STELLA cohorts

Eva Wolf ${ }^{1}$, Axel Baumgarten ${ }^{2}$, Bernhard Bieniek ${ }^{3}$, Stefanie Holm ${ }^{4}$, Martin Hower ${ }^{5}$, Hans Jaeger ${ }^{6}$, Thomas Lut $^{7}$, Mark us Mueller ${ }^{8}$, Wolfgang Schmidt ${ }^{9}$, Andreas Trein ${ }^{10}$, Ramona Pauli ${ }^{11}$, Christine Koegl ${ }^{1}$, Ralph Petry ${ }^{12}$, Hans-Jürgen Stellbrink ${ }^{13}$

${ }^{1}$ MUC Research, Munich, Germany, ${ }^{2}$ HIV-Practice Dres S. Dupke/A.Carganico/A. Baumgarten, Berlin, Germany, ${ }^{3} \mathrm{MVZ}$ PraxisCityOst Dres C.Cordes/B. Bieniek/ H. Hillenbrand, Berlin, Germany, ${ }^{4}$ Praxis Dres S. Holm/ B. Kuhlmann / H. Heiken, Hannover, Germany, ${ }^{5}$ ID Ambulanz Med. Klinik Nord Klinikum Dortmund, Dortmund, Germany, ${ }^{6}$ MVZ Karlsplatz, HIV Research and Clinical Care Centre, Munich, Germany,

${ }^{7}$ Infektiologikum Frankfurt, Frankfurt, Germany, ${ }^{8}$ Praxis Dres B. Frietsch/ A.Ulmer/ M. Mueller, Stuttgart, Germany,

${ }^{9}$ Aerzteforum Seestraße, Berlin, Germany, ${ }^{10}$ HIV Center, Stuttgart, Germany, ${ }^{11}$ Praxis Dres R.Pauli/ W. Becker,

Munich, Germany, ${ }^{12}$ Abbott GmbH \& Co.KG, Wiesbaden, Germany, ${ }^{13} \mathrm{ICH}$ (Infektionsmedizinisches Centrum Hamburg), Hamburg, Germany

Background: Using abacavir+lamivudine (KVX) as opposed to tenofovir+emtricitabine (TVD), each plus efavirenz or atazanavir/r, resulted in inferior virological outcomes in ACTG 5202. In contrast, the HEAT study using TVD or KVX together with lopinavir/ritonavir (LPV/r) reported similar outcomes. We analysed data from STAR and STELLA, two German prospective, multi-centre, observational studies including HIV-patients initiating a LPV/rbased regimen.

Methods: Virological and immunological treatment outcomes in the groups receiving KVX or TVD were evaluated using intent-to-treat (ITT, NC=F), Kaplan-Meier and Cox$\mathrm{PH}$ regression analyses.

Results : 1047 ART-naive patients (891 men; median age 40 years) were included. N=143 received KVX and 760 TVD. Median baseline CD4-count was significantly higher in the KVX- than in the TVD-group $(247 / \mu 1 \mathrm{vs} .192 / \mu 1 ; \mathrm{p}=0.02)$. Median viral load (VL) was slightly higher in the KVXgroup (5.2 vs. $5.1 \log ; \mathrm{p}=0.02)$. Median follow-up time was 30 weeks ( 36 vs. 28 weeks).

At 48 weeks, $66 \%$ of the KVX-group $(\mathrm{N}=67)$ and $66 \%$ of the TVD-group $(\mathrm{N}=299)$ had a $\mathrm{VL}<50 \mathrm{cop} . / \mathrm{ml}$. Median changes in CD4-count were $+260 / \mu 1$ in KVX- and $+198 / \mu 1$ in TVD-treated patients $(\mathrm{p}=\mathrm{n} . \mathrm{s})$. When analysing patients with $>105$ or $\leq 105 \mathrm{cop} . / \mathrm{ml}$ separately, there was no difference in response between KVX- and TVD-use at 48 weeks ( $58 \%$ vs. $60 \%$ and $85 \%$ vs. $72 \%$; p=n.s.). In the KaplanMeier analysis, median time to reaching a confirmed $\mathrm{VL}<$ $50 \mathrm{cop} . / \mathrm{ml}$ was 26 weeks in the KVX- and 25 weeks in the TVD-group. Results of Cox-PH analysis adjusting for baseline VL and CD4 confirmed that virological outcomes did not differ significantly if KVX or TVD was used. Time to a confirmed CD4-count above $500 / \mu 1$ was 59 weeks in $\mathrm{KVX}$ and 91 weeks in TVD-patients ( $\mathrm{p}=\mathrm{n} . \mathrm{s}$.). 
Conclusions : This prospective non-interventional study did not show a difference in virological response between subjects using KVX or TVD in conjunction with LPV/r adjusted for baseline VL and CD4-count.

\section{P416}

Efficacy and safety of TDF/FTC-containing first line HAART in clinical practice - two year data from the German outpatient cohort

Jan van Lunzen ${ }^{1}$, Gerd Fätkenheuer ${ }^{2}$, Thomas Lutz ${ }^{3}$, Stephan Klauke ${ }^{4}$, Stefan Mauss ${ }^{5}$, Carl Knud Schewe', Heribert Knechten ${ }^{7}$, Patrick Braun ${ }^{7}$, Lothar Gallo $^{8}$, Britta Ranneberg 8

${ }^{1}$ Universitätsklinikum Hamburg-Eppendorf, Hamburg, Germany, ${ }^{2}$ Med. Einrichtungen der Universität Klinik I für Innere Medizin, Köln, Germany, ${ }^{3}$ Infektiologikum, Friedensstrasse, Frankfurt, Germany, ${ }^{4}$ Infektiologikum, Stresemannallee, Frankfurt, Germany, ${ }^{5}$ Center for HIV and Hepatogastroenterology, Düsseldorf, Germany,

${ }^{6}$ Infektionsmedizinisches Centrum Hamburg (ICH), Hamburg, Germany, 7PZB, Aachen, Germany, ${ }^{8}$ Gilead Sciences, Martinsried, Germany

Objectives: First-line HAART with Tenofovir DF (TDF) and FTC in pivotal trials has been associated with high efficacy and good tolerability. However, real-life clinical practice differs from clinical trials due to co-morbidities, co-infections, and less intensive clinical monitoring. To evaluate efficacy and safety of first line HAART in a routine setting, this Gilead-sponsored non-interventional cohort was established.

Methods: Between July 2005 and August 2006, 533 HIV1 infected antiretroviral naïve patients from 50 German centres enrolled in this non-interventional cohort. All patients were followed every three months for three years to monitor efficacy (viral load (VL), CD4), tolerability, renal safety, regimen changes and resistance profile. All patients received TDF+FTC as a single tablet (Truvada, TVD) in combination with either an NNRTI or PI/r as their first regimen.

Results : As of June 2008, two years of therapy have been documented for 330/533 (62\%) patients. At treatment initiation, $81 \%$ were male; median age was 39 years; clinical AIDS diagnosis was documented in 22\%; $47 \%$ started therapy with CD4 $<200$ cells $/ \mathrm{mm}^{3}$. After 24 months, in an AsTreated (AT) analysis, $85 \%$ patients achieved a $\mathrm{VL}<50$ copies/ml (VL< 500 copies/ml: $97 \%$ ), median CD4 count increased from 217 to 450 cells $/ \mathrm{mm}^{3}$ (IQR: 325-608). Truvada showed a good safety profile: 76 adverse events (AEs) of any grade were reported in 66/533 patients (12\%). 12 (2\%) patients discontinued TVD due to AEs; 7 (1.3\%) experienced an SAE considered possibly or probably related to TVD. Virological failure was documented in 9 patients, of which 8 were genotyped; M184V/I was detected in 3, K65R in 2 patients.

Conclusion: During two years of follow-up, overall safety of TVD was good; development of NRTI-resistance was rare. First-line HAART with TVD plus an NNRTI or PI/r in clinical practice showed comparable efficacy to that observed in controlled clinical trials.

\section{$P 417$}

Gutes Ansprechen einer

Kombinationstherapie von Trizivir/Tenofovir bei Vorbehandelten über 96 Wochen. CTPScore vs.1.2 als prädiktives Tool für den Therapi eerfolg

Stephan Dupke ${ }^{1}$, Bettina Hintsche ${ }^{1}$, Christoph Mayr ${ }^{1}$, Frank Schlote ${ }^{1}$, Arend Moll ${ }^{1}$, Felise Krauthausen ${ }^{1}$, Daniel Prziwara ${ }^{1}$, Dorothea Schleehauf ${ }^{1}$, Siegfried Köppe $^{1}$, Andreas Carganico ${ }^{1}$, Axel Baumgarten ${ }^{1}$, Mark us Müller $^{2}$, Thomas Berg ${ }^{3}$, Martin Obermeier ${ }^{3}$

${ }^{1}$ HIV-Praxis, Berlin, Germany, ${ }^{2}$ HIV-Praxis, Stuttgart, Germany, ${ }^{3}$ HIV-Labor, Berlin, Germany

Die gute Wirksamkeit der Quadrupel-Nuke-Therapie AZT+ $3 \mathrm{TC}+\mathrm{ABC}+\mathrm{TDF}$ konnte in mehreren Studien gezeigt werden. Obwohl mit der Mutation L210W bereits eine Mutation, die zu einer deutlichen Einschränkung des Therapieerfolgs führt identifiziert werden konnte, ist die Auswirkung anderer Mutationen oder resensitivierender Effekte deutlich schlechter charakterisiert.

Es wurde das Therapieansprechen in Korrelation zu den Resistenzmutationen bei Baseline untersucht.

Aus den Datenbanken von 9 HIV-Schwerpunktpraxen wurden bei 118 Patienten

Viruslast(VL) und CD4-Zellzahl unter einer TZV/TDFTherapie über 96 Wochen dokumentiert. Die Vorbehandlung umfasste im Median 4 NRTI, 1 NNRTI und 1 PI.

Bei 83 Patienten lagen zu Baseline genotypische Resistenztests vor.

Ergebnisse:

Nach 96 Wochen waren noch 49 Patienten auf der initialen Therapie, 69 hatten die Therapie umgestellt $(9 \mathrm{xVL}-$ Anstieg, 2x ABC-HSR-Verdacht, 8xUAW, 13xTherapiepause, $6 \mathrm{xLTFU}, 7$ sonstige, $24 \mathrm{x}$ unbekannter Umstellungsgrund).

Die Viruslast zu Baseline betrug 4270(Median); nach 96 Wochen hatten $69 \%$ der Pat. eine Viruslast $<50,84 \%<400$ copies/ml(AT-Analyse).

Die CD4-Zellzahl/ $\mu 1$ stieg im Median von 363 auf 567 an.

Zur weiteren Analytik wurden nur Patienten mit einer VL $<50$ nach 3 Monaten als „Responder" definiert. Basierend auf einem Subset der Ergebnisse wurde ein Score entwickelt der jeder Thymidin-Analoga-Mutation(TAM ) und der Mutation M184V einen Punktwert zuordnet. Dieser Score wurde an dem restlichen Datensatz validiert.

Wird bei Baseline der cut-off von 20 Punkten nicht überschritten, ist bei dem individuellen Patienten mit einem Therapieerfolg zu rechnen. Der positive prädiktive Wert für den Score beträgt $78 \%$, der negative prädiktive Wert $95 \%$.

Der Vergleich mit anderen Ansätzen zur Vorhersage des Therapieerfolgs ( REGA, HIV-GRADE, Stanford HIVdb, ANRS, Nach weis der Mutation L210W) zeigt der CTP-Score eine deutliche Überlegenheit für Accuracy, NPW und PPW.

Zusammenfassung: Über 96 Wochen zeigte sich ein gutes virologisches und immunologisches Ansprechen der Kombination von Trizivir + TDF bei mittelgradig Vorbehandelten.

Mit dem CTP-Score vs.1.2 steht ein Tool mit hohem prädiktiven Wert für den Therapieerfolg zur Verfügung. 


\subsection{Proteasehemmer (PI) / Protease Inhibitors} (PI)

\section{P418 (PW)}

\section{8-wk safety and efficacy of daruna- $v i r /$ ritonavir (DRV/r) in treatment-experien- ced children and adolescents in DELPHI}

P. Vis, V. Sekar, B. Van Baelen, S. Spinosa-Guzman

Tibotec BVBA, Mechelen, Belgium

Background: DELPHI (TMC114-C212) is a 48-wk, open-label, 2-part Phase-II study assessing safety and efficacy of $\mathrm{DRV} / \mathrm{r}$ plus OBR in treatment-experienced pediatric patients (pts). DRV/r is approved in the USA for the treatment of HIVinfection in pediatric patients 6 years of age and older.

Methods : Pts received DRV/r by body weight for 48 wks: $20<30 \mathrm{~kg}, 375 / 50 \mathrm{mg}$ bid (20 pts); $30<40 \mathrm{~kg}, 450 / 60 \mathrm{mg}$ bid (24 pts); 40kg, 600/100mg bid (36 pts). Pharmacokinetics (PK), safety and efficacy (HIV-1 RNA, CD4 \%, CD4 counts) were assessed throughout.

Results : 80 pts (71\% male; median 14 yrs [range: 6-17]) received DRV/r. Mean baseline (BL) HIV-1 RNA was 4.64 $\log 10 \mathrm{cp} / \mathrm{mL}$, median BL CD4 was 330 cells $/ \mathrm{mm}^{3}$ and CD4 $\%$ was $17 \%$. At BL, there was a median of 3 IAS-USA primary PI mutations, 11 PI RAMs (65\% had 10 PI RAMs), 2 NNRTI and 4 NRTI RAMs. Target DRV PK exposures for treatment-experienced adults were achieved across all age groups and weight bands, confirming appropriate dose selection. 74 pts (93\%) reported one AE. Most common treatment-emergent AEs (15\%) were pyrexia, cough, upper respiratory tract infection and diarrhea. Most AEs were Gr1/2. Gr3/4 AEs occurred in 21 pts (26\%); most occurred as single events in individual pts and considered unrelated to DRV/r. Serious AEs occurred in 11 pts (14\%); no deaths were reported. One pt permanently discontinued treatment due to $\mathrm{Gr} 3$ anxiety considered unrelated to DRV/r. 6 pts (8\%) had Gr2-4 AEs at least possibly related to DRV/r. At Wk $48,65 \%$ of pts had $1.0 \log 10$ HIV-1 RNA reduction from BL (TLOVR); $59 \%$ and $48 \%$ achieved HIV-1 RNA < 400 and $<50$ copies/mL (TLOVR), respectively. Mean CD4 increase $(\mathrm{NC}=\mathrm{F})$ was $147 \mathrm{cell} / \mathrm{s} / \mathrm{mm}^{3}$.

Conclusion: DRV/r was beneficial in this treatment-experienced, pediatric population based on the favorable tolerability and PK profiles, and virologic response rates at Wk 48 .

\section{P419 (PW)}

Efficient suppression of minority quasispecies of drug-resistant viruses present at primary HIV-1 infection by boosted protease inhibitor containing ART

Karin J. Metzner ${ }^{1}$, Pia Rauch ${ }^{2}$, Viktorvon Wyl ${ }^{1}$, Herbert Kuster ${ }^{1}$, Jürg Böni ${ }^{3}$, Rainer Weber ${ }^{1}$, Huldrych F. Günthard ${ }^{l}$

${ }^{1}$ University Hospital Zurich, Division of Infectious Diseases and Hospital Epidemiology, Zurich, Switzerland, ${ }^{2}$ University of Erlangen-Nuremberg, Institute of Clinical and Molecular Virology, Erlangen, Germany, ${ }^{3}$ University of Zurich, Swiss National Reference Center for Retroviruses, Zurich, Switzerland

It has been shown that a substantial fraction of acutely infected patients harbor minority quasispecies of drug-resis- tant viruses as measured by the very sensitive method of allele-specific real-time PCR (AS-PCR). We have previously demonstrated that rapid selection of those minor populations can lead to virological failure in patients receiving ART regimens with a low genetic barrier. Here, we studied the fate of those minor variants during the first weeks of ART containing a boosted PI, thus, a regimen with a high genetic barrier. Baseline plasma samples from 93 acutely infected patients from the Zurich Primary HIV-1 Infection study were collected between March 2002 and April 2007 and tested by AS-PCR for the K103N and M184V variants (discriminative power: 0.01 and $0.2 \%$, respectively). The $\mathrm{K} 103 \mathrm{~N}$ mutation was detected in $6 / 93$ patients $(6.5 \%)$ and the M184V in $11 / 91$ patients $(12.1 \%)$ at baseline. These variants represented 0.08 to $3.76 \%$ and 0.4 to $8.3 \%$ of plasma viral genomes in a total of $15 / 93$ patients $(16.1 \%)$, respectively. Using conventional population sequencing, none of these mutations were detected in any patient. Follow-up samples of 5 patients harboring minority quasispecies (4 pts: M184V, 1 pt: $\mathrm{K} 103 \mathrm{~N}$ ) of drug-resistant viruses at baseline and 5 control patients were measured by AS-PC during the first 12 wks of ART. The ART regimen contained LPV/r+AZT,+3TC (1 pt: LPV/r+TDF+ddI). All patients showed a rapid decline in viral load and neither K103N nor M184V were detected. 4 patients stopped suppressive ART after 42-87 wks, the other 6 patients show no evidence of treatment failure within the last 80-275 wks. Minority quasispecies, in particular viruses harboring the $\mathrm{M} 184 \mathrm{~V}$ mutation at baseline were efficiently suppressed in acutely infected patients receiving a boosted PI and two NRTIs including 3TC in the majority. Under this high genetic barrier regimen, the M184V was not further selected.

\section{$P 420(P W)$}

Efficacy and safety of 48 weeks maintenance with once-daily ATV vs ATV/r in suppressed patients after induction with $\mathrm{ATV} / \mathrm{r}$

J.-F. Delfraissy ${ }^{1}$, S. Moreno ${ }^{2}$, J. Sanz-Moreno ${ }^{3}$, G. Carosi ${ }^{4}$, V. Pokrovsky ${ }^{5}$, A. Lazzarin 6 , G.Pialoux ${ }^{7}$, A. Balogh ${ }^{8}$, E. Vandeloise ${ }^{8}$, I. Scheirich ${ }^{9}$, U. Meyer-Bunsen ${ }^{9}$, G. Leleu ${ }^{10}$

${ }^{1} \mathrm{CHU}$ Bicetre, Paris, France, ${ }^{2}$ Hospital Ramón y Cajal, Universidad de Alcala, Madrid, Spain, ${ }^{3}$ Hospital Universidad Principe de Asturias, Madrid, Spain, ${ }^{4}$ Spedali Civili, Brescia, Italy, ${ }^{5}$ Central Research Institute of Epidemiology, MoH, Moscow, Russian Federation, ${ }^{6}$ Ospedale San Raffaele, Milan, Italy, ${ }^{7}$ Hopital Tenon, Paris, France, ${ }^{8}$ Bristol-Myers Squibb, Braine L'Alleud, Belgium, ${ }^{9}$ Bristol-Myers Squibb GmbH \& Co. KGaA, München, Germany, ${ }^{10}$ Bristol-Myers Squibb, Paris, France

Background: Once-daily (QD) atazanavir/ritonavir $($ ATV $/ r)+2$ NRTIs has proven efficacy with favourable lipid \& GI profiles in treatment-experienced \& -naive HIV patients. Data are needed on effective simplified treatment strategies.

Methods: AI424136 (INDUMA) is a randomised, open-label, multicentre study to as sess non-inferiority (15\% margin) of 48-wk Maintenance Phase (MP) with ATV $400 \mathrm{mg}$ QD vs ATV/r 300/100 mg QD (1:1), both +2NRTIs (excl. TDF), in patients with confirmed HIV-1-RNA $<50 \mathrm{c} / \mathrm{mL}$ after a 26-30 wk Induction Phase (IP) with ATV/r+2NRTIs in treatment-naive patients. Primary endpoint was proportion 
of patients with HIV-RNA $<50 \mathrm{c} / \mathrm{mL}$ through Wk 48 of MP (End of MP, EoM). Secondary endpoints included percent with HIV-RNA $<400 \mathrm{c} / \mathrm{mL}, \mathrm{CD} 4$ cell count change, and safety of MP.

Results: 252 patients entered IP (median CD4 245 cells $/ \mathrm{mm}^{3}$; median HIV-RNA $4.95 \log 10 \mathrm{c} / \mathrm{mL}$ ), during which 30 patients discontinued ( 9 for AEs). At the End of IP (EoI), 50 were not suppressed and were continued on $\mathrm{ATV} / \mathrm{r}$ regimen (not described here), and 172 were randomised to MP. Demographics and EoI subject characteristics for MP were well-balanced: median CD4 390 cells $/ \mathrm{mm}^{3}$; half of patients were on $3 \mathrm{TC}+\mathrm{ABC}$. Through EoM the ATV arm demonstrated similar (non-inferior) efficacy compared to the ATV/r arm.

\begin{tabular}{llll}
\hline $\begin{array}{l}\text { Proportion of } \\
\text { patients with }\end{array}$ & ATV/r N=85 & ATV N=87 & $\begin{array}{l}\text { Difference Estimate } \\
(95 \% \text { CI) }(\text { ATV }-\end{array}$ \\
$\begin{array}{l}\text { HIV-RNA } \\
<50 / 400 \mathrm{c} / \mathrm{mL}\end{array}$ & & & ATV $/ \mathrm{r})$ \\
$\begin{array}{l}\text { through Week } \\
48 \text { of MP(ITT) }\end{array}$ & & & \\
\hline$\%<50 \mathrm{c} / \mathrm{mL}$ & 75 & 78 & $2.9(-9.8,15.5)$ \\
$\%<400 \mathrm{c} / \mathrm{mL}$ & 81 & 86 & \\
\hline
\end{tabular}

During MP, mean change in CD4 cell count at Wk 48 $\mathrm{ATV} / \mathrm{r}+92(\mathrm{SE}=18.1)$ cell $/ \mathrm{mm}^{3}$ and ATV $+100(\mathrm{SE}=14.7)$ cells $/ \mathrm{mm}^{3}$; discontinuations prior to EoM: ATV/r 14\%, ATV 8\%. Virological rebound: ATV/r 7 patients, ATV 11, none had emergence of PI-resistance. AEs leading to discontinuation: ATV/r 5\%, ATV 1\%. Lab Grade 3-4 total bilirubin: ATV/r 47\%, ATV $14 \%$.

Conclusions: These results are consistent with the proven efficacy of atazanavir in naive patients and suggest that for those patients who have achieved undetectability under ATV/r, switching to unboosted ATV may be an option that results in simplification of treatment regimen.

\section{$P 421(P W)$}

Low nadir CD4 count predicts failure of LPV/r monotherapy (MOST) due to unexpectedly high failure rate in monotherapy arm

Christine Gutmann ${ }^{1}$, Milos Opravil ${ }^{2}$, Christoph Fux ${ }^{3}$, Hansjakob Furrer ${ }^{3}$, Laurent-Arthur Decosterd ${ }^{4}$, Matthias Cavassini ${ }^{4}$, Sabine Yerly ${ }^{5}$, Bernard Hirschel ${ }^{5}$, Pietro Vernazzal, and the Swiss HIV Cohort Study

${ }^{1}$ Kantonsspital St. Gallen, Div Infectious Diseases, Dpt of Medicine, St. Gallen, Switzerland, ${ }^{2}$ Universitässpital Zürich, Zürich, Switzerland, ${ }^{3}$ Inselspital, Bern, Switzerland, ${ }^{4}$ CHUV / Service d'Immunologie et d'Allergie, Lausanne, Switzerland,

${ }^{5}$ University Hospital Geneva, Geneva, Switzerland

Background: Previous PI-monotherapy studies demonstrated full viral load (VL) suppression over more than one year. Concerns remain regarding activity in compartments. The MOST study evaluates antiviral activity of ritonavirboosted lopinavir (LPV/r)-monotherapy in the genital tract and central nervous system as well as predictors of virologic failure. Due to unexpected high failure rate $(>20 \%)$, the study is terminated prematurely as per protocol.

Methods: Patients on full VL suppression have been randomized to either continued standard therapy or LPV/rmonotherapy for $48 \mathrm{wk}$. At baseline and Week 48, VL in
CSF and genital secretions is measured in all patients. Failure was defined as a confirmed VL $>400 \mathrm{cp} / \mathrm{ml}$ in a fully adherent patient.

Results : At Sept 24 2008, the study was prematurely terminated (60 patients randomized) because the predefined stopping criteria (6 failures in monotherapy arm) was reached. $29 / 60$ patients were randomized to monotherapy. The median study duration was 43 weeks. At baseline, all patients had undetectable plasma VL. One patient had a CSF VL of $82 \mathrm{cp} / \mathrm{ml}$ (randomized to continued HAART). Six patients (all in mono-arm) reached the failing criteria. Mean nadir CD4 count was significantly lower (77/ul) in failing patients $(p<0.01)$ than in non failing patients on monotherapy $(166 / \mathrm{ul})$. Lumbar puncture was performed in 5 failing patients. VL in CSF was $0.8 \log 10 \mathrm{cp} / \mathrm{ml}$ higher than in blood in all failing patiengs. Patients confirmed optimal adherence, but drug levels were extremely low in 2 of 5. Three failing patients had neurological symptoms at failure (headache, dizziness, ataxic problems, visual disturbance, concentration problems). All blood and CSF samples were wildtype on genotyping.

Conclusions: Failure rates during LPV/r monotherapy may be associated with low nadir CD4 count and appears to involve the CNS. Use of monotherapy should be restricted to clinical studies.

$$
P 422 \text { (PW) }
$$

Cost effectiveness analysis of atazanavir versus lopinavir in the treatment of naïve HIV patients in Germany

Per-Olof Thuresson ${ }^{1}$, Iris Scheirich ${ }^{2}$, AljoschaS. Neubauer $^{2}$, Bart Heeg ${ }^{1}$

${ }^{1}$ Pharmerit BV, Rotterdam, Netherlands, ${ }^{2}$ Bristol-Myers Squibb, München, Germany

Objectives: To estimate the cost-effectiveness of atazanavir (Reyataz)/r versus lopinavir/r (Kaletra) in treatment-naïve HIV-1 patients in Germany.

Methods: For this purpose a life time Markov model was developed with a cycle length of one year. The model included the following health states; 1 st, 2 nd and 3rd line treatment and within these treatment lines patients could suffer from an MI, stroke or angina. Treatment switch transition probabilities were derived from the $48 / 96$ week data of a randomized controlled trial (CASTLE) and event probabilities were derived from the Framingham risk equations and the trial. Diarrhea was included as a disutility. Variables that differed between the two treatment arms were pharmaceutical treatment costs, lipid profile, probability to switch from 1st line treatment, mortality and incidence of diarrhea. The analysis was conducted from a payer perspective, considering only German direct costs for the healthcare system. Outcomes were reported as cost per (quality adjusted) life year gained. To determine robustness of the model and the impact of uncertainty, uni- and multivariate sensitivity analyses were carried out.

Results: In the base case analysis atazanavir saved 0.14 [0.01;0.31] life years, $0.31[0.18 ; 0.46]$ QALYs and over lifetime -€32,819 [-€91,093;€18,464] costs. The resulting ICER and ICUR were dominant for atazanavir, i.e. cost saving and more effective. Probabilistic sensitivity analyses showed that atazanavir has $0.00 \%, 0.10 \%, 15.20 \%$ and $84.70 \%$ probability to be in NW, SW, NE and SE quadrant 
of cost-effective scatter plot respectively, and $88.7 \%$ probability to be cost-effective at a willingness to pay of $€ 20,000$. Univariate sensitivity analysis showed that the results were especially sensitive to changes in costs of second and third line treatment and switching treatment probabilities.

Conclusions: The present model suggests that atazanavir/ $\mathrm{r}$ has a favourable cost-effective ratio in the treatment of treatment naïve HIV-I patients. Sensitivity analyses showed that these results were stable.

$$
P 423(P W)
$$

\section{Vergleich der Kosten-Nutzen-Relation ver- schiedener Proteaseinhibitoren bei der Erstlinien-Therapie von HIV-Patienten unter Anwendung der vom IQWIG vorgeschlagenen Methode der Effizienzgrenze}

$$
\begin{gathered}
\text { Verena Donatz }{ }^{1} \text {, Erik Smets }{ }^{2}, \text { Andrew Hill }{ }^{3} \text {, } \\
\text { Matthias Stoll }
\end{gathered}
$$

\footnotetext{
${ }^{1}$ Janssen-Cilag GmbH, Health Economics \& Pricing, Neuss, Germany, ${ }^{2}$ Johnson \& Johnson Pharmaceutical Services, LLC, Mechelen, Belgium, ${ }^{3}$ University of Liverpool, Liverpool, United Kingdom, ${ }^{4}$ Medizinische Hochschule Hannover, Zentrum Innere Medizin, Klinik für Immunologie und Rheumatologie, Hannover, Germany
}

Hintergund und Ziel: Im Oktober 2008 hat das IQWIG einen Methodenvorschlag beschrieben, welcher der gesundheitsökonomischen Evaluation von Arzneimitteln dienen soll. Diese Evaluation soll nach Zulassung des Arzneimittels unter Zuhilfenahme des "Modells der Effizienzgrenze" erfolgen. Die Gesundheitseffekte (Nutzen) der Intervention (z.B. Medikament) werden den Kosten graphisch gegenüber gestellt. Hierdurch kann der Entscheidungsträger Therapien, welche die Effizienzgrenze definieren bzw. oberhalb oder unterhalb liegen, rasch identifizieren (Abbildung 1).

\section{Basiskonzept der Effizienzgrenze (Quelle IQWIG)}

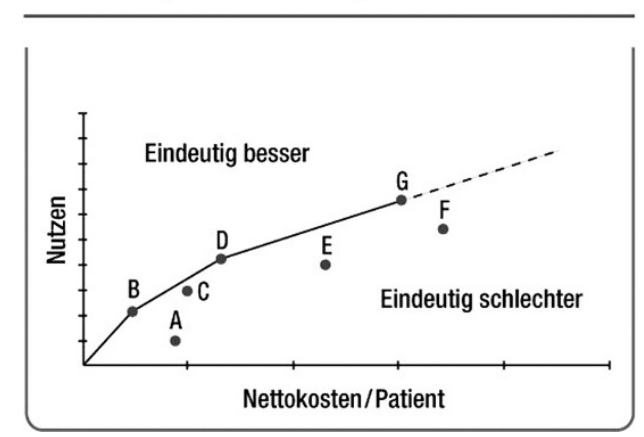

[Abbildung 1]

Ziel dieser Studie war es, die Kosten-Effektivität für das neu in der Erstlinienbehandlung zugelassene antiretrovirale Medikament Darunavir unter Einsatz der Methode der theoretischen Effizienzgrenze mit anderen bereits zugelassenen Erstlinien-Proteaseinhibitoren (PIs) zu vergleichen .

Methodik: Es wurde ein systematischer Review klinischer Studien, die ein PI-basiertes Regime bei therapienaiven HIV-Patienten einsetzten, durchgeführt. Die virologische Wirksamkeit wurde nach 48 Wochen anhand des An- teils der Patienten mit einem HIV-RNA-Plasma-Level $<50$ Kopien/mL bestimmt. In der Basisanalyse wurden die jährlichen antiretroviralen Kosten (Kalkulationsbasis: Lauertaxe 2009) und die Effektivität fünf verschiedener Proteaseinhibitor / Tenofovir basierter Regime gegenüber gestellt und die "inkrementelle Kosten-Effektivitäts-Relation" (ICER) berechnet.

Ergebnisse: Die Basisanalyse zeigte, dass Darunavir/r mit einem ICER von 20.143€pro zusätzlichem Individuum mit einer HIV-RNA $<50 \mathrm{Kopien} / \mathrm{ml}$ der wirksamste $\mathrm{PI} / \mathrm{r}$ ist. Hierbei wurde Darunavir/r mit Fosamprenavir/r verglichen, einer weiteren die Effizienzgrenze definierenden PIbasierten Initialtherapie. Alle anderen PIs, auch Atazanavir und Lopinavir, waren weniger wirksam und teurer als Darunavir oder Fosamprenavir (Vergleiche Abbildung 2).

\section{Konstruktion der theoretischen Effizienzgrenze in der Erstlinien-HIV-Therapie durch Kosten-Nutzen-Evaluation fünf verschiedener PI/TDF-basierter Erstlinien-Regime}

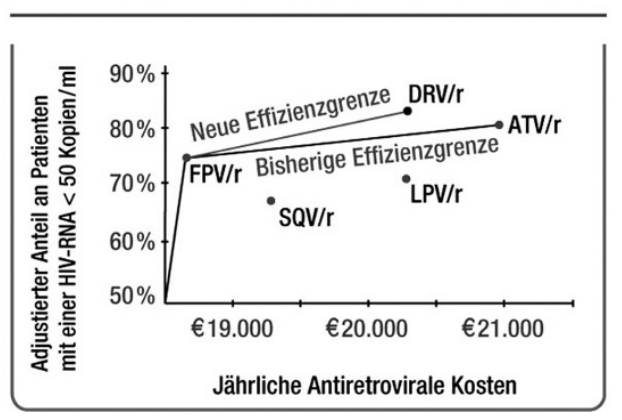

[Abbildung 2]

Schlussfolgerung: Vor der Erstlinien-Zulassung von Darunavir war Atazanvir in einem HAART-Regime der ökonomisch effizienteste PI, mit einem höheren ICER von 41.873 verglichen mit Fosamprenavir. Innerhalb eines festen Budgets von 10 Millionen $€$ könnten mit Darunavir/r 410 Patienten virologisch erfolgreich behandelt werden, mit Atazanavir/r 384, mit Lopinavir/r 353. Diese Evaluation belegt mittels der Methode der Effizienzgrenze anhand einer Cross-Study-Analyse eine ausgewogene Kosten-Nutzen-Relation Darunavir/r-haltiger ErstlinienRegime.

\section{P424}

Efficacy and safety by baseline HIV-RNA and CD4-count in treatment-naive patients treated with Atazanavir/r and Lopinavir/r in the CAS TLE study

J. Uy ${ }^{1}$, R. Yang ${ }^{1}$, A. Thiry ${ }^{1}$, J. Absalon $^{1}$, A. Farajallah ${ }^{1}$, J. Maal , E. Grützner ${ }^{2}$, I. Scheirich ${ }^{2}$, D. McGrath ${ }^{1}$

\footnotetext{
${ }^{1}$ Bristol-Myers Squibb, Research and Development, Plainsboro, NJ \& Wallingford, CT, United States, ${ }^{2}$ BristolMyers Squibb GmbH \& Co. KGaA, München, Germany
}

Background: In the CASTLE study, lower response rates were observed in patients with baseline HIV-RNA $\geq 100,000$ copies $/ \mathrm{mL}$ in both arms and were associated with lower baseline CD4 cell count for LPV/r but not ATV/r.

Methods: Randomized, open-label, prospective study comparing once-daily ATV/r with twice-daily LPV/r, both with fixed-dose TDF/FTC in 883 treatment-naive patients. 


\begin{tabular}{|c|c|c|c|c|c|c|c|c|}
\hline \multicolumn{9}{|c|}{ CVR Treatment Outcomes of HIV RNA $<50 \mathrm{c} / \mathrm{mL}$ at Week 48 by Baseline CD4 Cell Count, $\mathrm{n}(\%)$} \\
\hline \multirow[b]{2}{*}{ As-Randomized } & \multicolumn{4}{|c|}{ ATV $/ r$} & \multicolumn{4}{|c|}{ LPV/r } \\
\hline & $<50$ & $\begin{array}{l}50 \\
<100\end{array}$ & $\begin{array}{l}100- \\
<200\end{array}$ & $\geq 200$ & $<50$ & $\begin{array}{l}50- \\
<100\end{array}$ & $\begin{array}{l}100 \\
<200\end{array}$ & $\geq 200$ \\
\hline ITT & $n=58$ & $n=45$ & $n=106$ & $n=222$ & $n=48$ & $n=29$ & $n=134$ & $n=228$ \\
\hline Responder & $\begin{array}{l}45 \\
(78)\end{array}$ & $\begin{array}{l}34 \\
(76)\end{array}$ & $\begin{array}{l}80 \\
(75)\end{array}$ & $\begin{array}{l}178 \\
(80)\end{array}$ & $\begin{array}{l}30 \\
(63)\end{array}$ & 20 & $\begin{array}{l}104 \\
(78)\end{array}$ & 182 \\
\hline Virologic failure* & $7(12)$ & $7(16)$ & $17(16)$ & $26(12)$ & $6(13)$ & $7(24)$ & $13(10)$ & $24(11)$ \\
\hline Discontinued & $6(10)$ & $4(9)$ & $9(8)$ & $16(7)$ & $12(25)$ & $2(7)$ & $16(12)$ & $20(9)$ \\
\hline $\begin{array}{l}\text { On-treatment, } \mathrm{n} / \mathrm{N} \\
(\%)\end{array}$ & $\begin{array}{l}45 / 52 \\
(87)\end{array}$ & $\begin{array}{l}34 / 40 \\
(85)\end{array}$ & $\begin{array}{l}80 / 95 \\
(84)\end{array}$ & $\begin{array}{l}178 / 202 \\
(88)\end{array}$ & $\begin{array}{l}30 / 35 \\
(86)\end{array}$ & $\begin{array}{l}20 / 25 \\
(80)\end{array}$ & $\begin{array}{l}104 / 114 \\
(91)\end{array}$ & $\begin{array}{l}182 / 201 \\
(91)\end{array}$ \\
\hline
\end{tabular}

[Table 1] response through Week 48 , and rebound without resuppression.

\begin{tabular}{|l|cccccccc|}
\hline \multicolumn{7}{|c|}{ Grade 2-4 Treatment-Related AEs through Week 48 by Baseline CD4 Cell Count (cellsimm3), $\mathrm{n}(\%)$} \\
LPV/r
\end{tabular}

[Table 2]

Treatment outcomes of HIV-RNA $<50 \mathrm{c} / \mathrm{mL}$ at Week 48 using confirmed virologic response (CVR) and grade 2-4 treatment-related AEs through Week 48 are presented by pre-specified baseline HIV-RNA and CD4 cell count strata.

Results: The proportion of responders (CVR HIV-RNA $<50 \mathrm{c} / \mathrm{mL}$, ITT) at week 48 by baseline HIV-RNA strata $(<100,000,100,000-<500,000$, and $\geq 500,000)$ were $83 \%, 76 \%$, and $64 \%$ for ATV/r and $80 \%, 74 \%$, and $61 \%$ for LPV/r (Table 1).

In patients with both baseline CD4 $<100$ and HIV RNA $\geq 100,000,60 / 83(72 \%)$ on $\mathrm{ATV} / \mathrm{r}$ and $40 / 64(63 \%)$ on $\mathrm{LPV} / \mathrm{r}$ achieved HIV-RNA $<50 \mathrm{c} / \mathrm{mL}$ (CVR, ITT).

Incidence of grades 2-4 treatment-related AEs through Week 48 by baseline HIV-RNA strata $(<100,000$, $100,000-<500,000, \geq 500,000)$ were $29 \%, 26 \%$, and $15 \%$ for ATV/r; and $31 \%, 27 \%$, and $30 \%$ for LPV/r (Table 2).

Conclusions: Lower response rates at higher baseline HIV-RNA were seen for both ATV/r and LPV/r. The trend for lower response rates at lower baseline CD4 cell counts for $\mathrm{LPV} / \mathrm{r}$ observed in the ITT analysis did not appear to be present in the on-treatment analysis. ATV/r and LPV/r had consistent AE profiles by baseline HIV-RNA. More AEs, most commonly diarrhea and nausea, were observed with $\mathrm{LPV} / \mathrm{r}$ at low baseline CD4 cell counts .

\section{P425 (PD)}

Susceptibility of diverse HIV-1 patient isolates to the maturation inhibitor, bevirimat, is setermined by clade-specific polymorphisms in Gag CA-SP1

Thomas Klimkait ${ }^{1}$, Karl Salzwedel ${ }^{2}$, Severine Louvel ${ }^{1}$, M. Sakalian ${ }^{2}, M$. Reddick ${ }^{2}, C$. Finnegan ${ }^{2}, D$. Martin $^{2}$, $S$ Mc Callister $^{2}$, Francois Hamy ${ }^{1}$, G. Allaway ${ }^{2}$

${ }^{1}$ University of Basel, Institute of Medical Microbiology, Basel, Switzerland, ${ }^{2}$ Panacos Pharmaceuticals, Gaithersburg, United States

Background: The HIV-1 maturation inhibitor bevirimat (BVM, PA-457) binds to Gag and specifically inhibits CASP1 processing. Recent clinical studies identified key baseline polymorphisms at Gag positions 369/370/371 (QVT) in SP1 that correlated with variable patient responses. Polymorphisms at these 3 positions are found in $~ 30 \%$ of patients with clade $\mathrm{B}$ virus and frequently in other clades. We therefore examined the susceptibility of non-B isolates to BVM.

Methods: A panel of 25 non-clade B viruses was compiled with multiple representatives from each clade with global prevalence $>1 \%$ worldwide (clades A,C,CRF01_AE,CRF02 _AG,D,G), consisting of 10 isolates with known, distinct CA-SP1 genotypes and 15 randomly selected patient samples. The complete Gag-PR regions were amplified and cloned into a pNL4-3 background. InPheno's replicative phenotyping system deCIPhR was used to quantify susceptibility to BVM. Fold-change (FC) in IC50 was compared to FC values for BVM-treated patient isolates and site-directed mutants.

Results: None of the 25 viruses in the test panel contained the wild-type QVT clade B consens us sequence at positions 369-371; nonetheless, 7/25 isolates (28\%) were highly susceptible to BVM $(\mathrm{FC}<2)$. These included 5 viruses containing the clade A and CRF02_AG consensus sequence, QVQ. 9/25 isolates (36\%) had intermediate susceptibility (FC 2-10), and 9/25 isolates (36\%) low susceptibility $(\mathrm{FC}>10)$. Of the less susceptible viruses, 13/18 contained V370A,V370M, or DV370 polymorphisms, all of which are key polymorphisms in clade B.

Conclusions: Our analysis demonstrates that some polymorphisms at Gag 369/370/371 in SP1 reduce the susceptibility of viruses to BVM in vitro. Specifically, the T371Q polymorphism correlating with the clade A and CRF02_AG consensus QVQ appears to have no effect on BVM susceptibility. This suggests that the T371Q polymorphism may not be critical for the susceptibility to BVM. Additional phenotyping and genotyping should help to further refine the genotyping algorithm for non-clade B patients. 


\section{P426}

Once-daily Darunavir used in routine clinical care produces trough Darunavir-drug-concentrations in excess of $30 x$ the protein-corrected (PC)EC50 for wild-type HIV

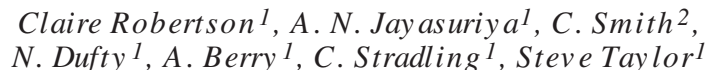

${ }^{1}$ Birmingham Heartlands Hospital, Birmingham, United Kingdom, ${ }^{2}$ University College Medical School, London, Research Department of Infection and Population Health, London, United Kingdom

Background: In clinical practice measured drug concentrations often exhibit significant differences to those published in clinical trials, which can impact on virological efficacy and drug toxicity. We aimed to describe trough darunavir (DRV) concentrations achieved in a cohort of HIV-positive individuals using a non-standard dose of DRV $900 \mathrm{mg}$ once-daily (qd) and RTV $100 \mathrm{mg}$ qd.

Methods: HIV-positive patients (pts) with no darunavirassociated mutations were commenced on antiretroviral therapy regimens with DRV/RTV 900/100mg qd. Trough [DRV] (C24) actual and predicted were measured and compared to published protein-corrected (PC)EC50 values for wild-type (WT) HIV $(55 \mathrm{ng} / \mathrm{ml})$ and (PC)EC50 for resistant HIV $(550 \mathrm{ng} / \mathrm{ml})$. Demographic data, reasons for swap, viral load response and lipid changes were analysed.

Resul ts : 69 pts commenced qd DRV/RTV and have reached a median of 24 weeks of therapy. 15 pts started DRV/RTV as their first PI-based regimen. Others changed for: ARTsimplification (17), GI side-effects (15), low-level viraemia, jaundice (each 6), lipids abnormalities and perceived potency (each 5). 50 trough [DRV] were obtained. Median C24 DRV from actual trough samples $=1593 \mathrm{ng} / \mathrm{ml}$ (range 414-3582), representing 30x the PC EC50 for WT HIV. Median C24 DRV from projected samples using $t 1 / 2$ of $15 \mathrm{hrs}=2026 \mathrm{ng} / \mathrm{ml}$ (range 772-4558), representing $37 \mathrm{x}$ the PCEC50 for WT HIV. 49/50 samples were above the PCEC50 for resistant HIV. No patients have exhibited virological failure to date. All 6 swapping for low level viraemia reached an HIV viral load of $<40$ copies $/ \mathrm{ml}$. There was no incidence of rash and only one grade 1 LFT abnormality. There was no statistically significant association between age, gender or ethnicity with predicted trough DRV concentrations.

Conclusions: DRV/RTV 900/100mg qd used in routine clinical care produces trough [DRV] in excess of $30 \mathrm{x}$ the PCEC50 for WT HIV. This is in keeping with data from randomised controlled trials including ARTEMIS.

$P 427$

Abstract zurückgezogen
P428 (PD)

Lopinavir/ritonavir plus atazanavir in comparison to lopinavir/ritonavir plus nucleoside analogues (zidovudin plus lamivudin) the LORAN-trial, A Phase III-study

Kai Ulbricht ${ }^{1}$, Matthias Stoll ${ }^{1}$, Georg M. Behrens ${ }^{1}$, Bernd Salzberger ${ }^{2}$, Heiko Jessen ${ }^{3}$, Arne Jessen ${ }^{3}$, Birger Kuhlmann ${ }^{4}$, Hans Heiken ${ }^{4}$, Andreas Trein 5 , Reinhold Ernst Schmidt 1

${ }^{1}$ Medizinische Hochschule Hannover, Klinik für Immunologie und Rheumatologie, Hannover, Germany, ${ }^{2}$ Universitätsklinik Regensburg, Regensburg, Germany, ${ }^{3}$ Praxis Dres. Jessen, Berlin, Germany, ${ }^{4}$ Praxis Dres S. Holm/ B. Kuhlmann / H. Heiken, Hannover, Germany, ${ }^{5}$ Praxis Schwabstrasse, Stuttgart, Germany

Background: Double-PI regimens are a therapeutic option in salvage therapy. Regarding side effects, double PI-therapy has to be examined as an option in treatment naïve patients. In the LORAN study, a 72-week, randomized trial among HAART-naïve patients, $\mathrm{LPV} / \mathrm{r}$ is combined with either CBV (ATZ+3TC) or ATV. Primary endpoints are metabolic side effects and QOL, secondary endpoints are virological and immunological response.

Methods: Treatment-naïve HIV-1-infected patients with need for HAART were randomly assigned to either treatment arm. We analysed virological failure in both groups, defined as $\mathrm{VL} \geq 50$ copies/mL at week 48 . Statistical analysis were performed using Fisher's exact test.

Results: We present data of 75 patients focusing on virological and immunological response. $28 / 35$ patients in the CBV-LPV/r arm show virological response vs. 16/40 in the ATV/LPV/r arm. The intent-to-treat analysis revealed inferior virological response in the LPV/r-ATV arm: Chi-Q and Fisher's Exact Test $\mathrm{p}<0.001$. With regard to 75 initially treated subjects, there are 11 failures observed in the $\mathrm{ATV} / \mathrm{LPV} / \mathrm{r}$ arm vs. no failure in the CBV/LPV/r arm ATV/LPV/r failures were on low level (11/12 virological failures $<1,000$ copies $/ \mathrm{mL}$ ). Pharmacokinetic measuring showed reduced LPV concentrations in $1 / 7$ tested subjects in the double-PI failures.

Conclusions: In this setting, ATV/LPV/r is less effective than the conventional RTI-based regimen with mostly low level virological failure. Significant treatment failure of an extended PI-based combination casts a new light on NRTIsparing regimens in naïve patients as previously presented. Further exploration of early RTI-sparing therapy with reg ard to metabolic side effects and QOL is warranted.

P429

Long term outcome of 8 infants, which started treatment with 2 NRTI + Nelfinavir in the first year of life

Bernd Buchholz, Steffen Hien, Matthias Beichert, Matthias Dürken, Horst Schroten

Universitätsklinikum Mannheim, Universitätskinderklinik, Mannheim, Germany

Purpose of the study: According to recommendations for HIV-therapy in children all children younger than 1 year (=infants) should be treated with an antiretroviral therapy. Because only few data about the long term outcome of HIV1-infected infants treated with Nelfinavir (NFV), a pro- 
teaseinhibitor (PI) licensed for this age, exist, a retrospective analysis of antiviral activity in these children was performed.

Methods : 8 naïve (NRTI +PI) children (5boys, 3 girls), who started treatment in infancy with 2 nucleoside reverse transcriptase inhibitors (NRTI) + NFV between Sep.1998 Oct 2006, were analysed. In 6 infants therapy was started below the age of 4 months, in one with ten - and another with 11 months. The last viral load before starting treatment was 100.000-1Mio. HIV1-copies/ml in 2- and $>1$ Mio. HIV1-copies/ml in 6 infants respectively. All children received NFV only as halved, whole or crushed tablets (dissolved in water) in a dosage of $2 \times 60-65 \mathrm{mg} / \mathrm{kg}$.

Results: In one boy triple therapy including NFV failed 5 months after start due to NFV-resistance, which was not detected in the initial genotypic resistance test before therapy. In all other children viral load is still under limit of detection with $2 \mathrm{NRTI}+\mathrm{NFV}$. All 7 children were successful treated (viral load $<400 \mathrm{HIV}$-copies $/ \mathrm{ml}$ ) for a minimum of 2 years, thereof 6 children for 3 years, 5 children for 5 years, 3 children for 6 years and 2 children for 7 years. One child is still on therapy with NFV after 10 years of treatment. Due to stop of European production of NFV all 7 children still on therapy had an unplanned therapy interruption for 2 weeks in summer 2007 .

Conclusions: Antiretroviral therapy with NFV as first line PI in combination with 2 NRTI in infants was well tolerated and the antiviral activity was excellent for more than 5 years.

\section{P430}

Health-related quality of life (HRQoL) improvement in antiretroviral-naive HIVinfected patients on atazanavir/r or lopinavir/r regimens: week 24 results from AI424138

J.Sul ${ }^{1}$ J. Absalon ${ }^{1}$, M.Mancini ${ }^{1}$, U. Iloeje ${ }^{1}$, N. Strobl $^{2}$, I. Scheirich ${ }^{2}$, D. McGrath ${ }^{1}$

${ }^{1}$ Bristol-Myers Squibb, Wallingford, CT, United States,

${ }^{2}$ Bristol-Myers Squibb GmbH \& Co. KGaA, München, Germany

Background: GI tolerability is an important component of HRQoL, and impacts adherence and virologic failure among patients treated with PI-based HAART.

Methods : AI424138 is a randomized, open-label, multicenter, prospective study comparing once-daily ATV/r with twice-daily LPV/r, both in combination with once-daily TDF/FTC. HRQoL endpoints were as sessed using the Irritable-Bowel-Syndrome (IBS)-QoL for treated subjects with evaluable ( $\geq 28 / 34$ items answered) baseline. Principal analyses summarized changes from baseline in IBS-QoL overall score through Week 24. A clinically-relevant score change is not established in HIV. Post-hoc analyses assessed: categories of score change; GI AEs (diarrhea, nausea, vomiting) through Week 24 for subjects with evaluable IBS-QoL at baseline and Week 24 .

Results: Of 692/878 (79\%) treated subjects with evaluable baseline IBS-QoL: median age was 35 years; $71 \%$ were male; $57 \%$ white; median HIV-RNA was $5.02 \log 10 \mathrm{c} / \mathrm{mL}$ and median CD4 210 cells $/ \mathrm{mm}^{3}$. At week 4,12 , and 24 the mean change in overall IBS-QoL score from baseline was 3.2, 4.6, and 4.3 for ATV/r and $-0.7,0.2$, and 1.4 for
$\mathrm{LPV} / \mathrm{r}$, the percentage of patients with a worsening IBSQoL score ( $\geq 2$ points) was $17 \%, 15 \%$, and $16 \%$ for ATV/r and $32 \%, 26 \%$, and $25 \%$ for LPV/r. More subjects had worsening IBS-QoL on LPV/r than ATV/r $(\mathrm{P}<0.01)$. The difference was largest at Week 4 for subjects with baseline CD4 $<50$ cells $/ \mathrm{mm}^{3}$ (ATV/r 14\% vs LPV/r 29\%). Through Week $24,7 \%(20 / 299)$ of ATV/r compared with $15 \%$ (46/300) of $\mathrm{LPV} / \mathrm{r}$ subjects had grade 2-4 treatment-related GI AEs $(\mathrm{P}=0.001)$.

Conclusions : ATV/r resulted in fewer GI AEs than LPV/r. More LPV/r subjects had $\geq 2$-point worsening of overall IBS-QoL scores, however the clinical relevance of this finding is unknown. The difference in IBS-QoL score reductions between $\mathrm{ATV} / \mathrm{r}$ and $\mathrm{LPV} / \mathrm{r}$ are most pronounced early in treatment in subjects with low CD4 counts.

\section{P431}

Gender differences in ART-naive patients initiating a lopinavir/ritonavir-based regimen. 48 week data from the German STAR and STELLA cohorts

Christine Koegl 1, Axel Baumgarten ${ }^{2}$, Bernhard Bieniek ${ }^{3}$, Stefanie Holm ${ }^{4}$, Martin Hower ${ }^{5}$, Hans Jaeger ${ }^{6}$, Thomas Lut $^{7}$, Mark us Mueller ${ }^{8}$, Wolfgang Schmidt ${ }^{9}$, Andreas Trein 10, Ramona Pauli ${ }^{11}$, Eva Wolf ${ }^{1}$, Ralph Petry ${ }^{12}$, Hans-Jürg en Stellbrink 13

${ }^{1}$ MUC Research, Munich, Germany, ${ }^{2}$ HIV-Practice Dres S Dupke/A.Carganico/A. Baumgarten, Berlin, Germany,

${ }^{3}$ MVZ-PraxisCityOst Dres C.Cordes/B. Bieniek/ H.

Hillenbrand, Berlin, Germany, ${ }^{4}$ Praxis Dres S. Holm/ B.

Kuhlmann / H. Heiken, Hannover, Germany, ${ }^{5}$ ID Ambulanz Med. Klinik Nord Klinikum Dortmund, Dortmund, Germany, ${ }^{6}$ MVZ Karlsplatz, HIV Research and Clinical Care Centre, Munich, Germany, ${ }^{7}$ Infektiologikum Frankfurt, Frankfurt, Germany, ${ }^{8}$ Praxis Dres B. Frietsch/ A.Ulmer/ M. Mueller, Stuttgart, Germany, ${ }^{9}$ Aerzteforum Seestraße, Berlin, Germany ${ }^{10}$ HIV Center, Stuttgart, Germany, ${ }^{11}$ Praxis Dres R.Pauli / W Becker, Munich, Germany, ${ }^{12}$ Abbott GmbH \& Co.KG, Wiesbaden, Germany, ${ }^{13} \mathrm{ICH}$ (Infektionsmedizinisches Centrum Hamburg), Hamburg, Germany

Background: We analyzed data from the STAR and STELLA cohorts, two German prospective, multi-centre, observational studies, which includes HIV+ patients (pts) starting a Lopinavir/r-based regimen. Our goal was to compare treatment outcomes and side effects in men and women.

Methods : 48 -week analysis: Comparison of treatment responses to LPV/r-based regimens in men and women using on-treatment (OT), intent-to-treat (ITT) and Kaplan-Meier (KM) analyses.

Results: This analysis is based on 1047 ART-naive HIV+ patients ( 891 men; median age 40 years). Baseline values were available of 849 pts (718 men). At baseline, median CD4 counts did not differ between men and women $(200 / \mu 1$ vs. $215 / \mu 1 ; \mathrm{p}=\mathrm{n} . \mathrm{s}$.), but VL differed significantly $(5.1 \mathrm{log}$ vs. $4.9 \log ; \mathrm{p}<0.001)$. At 48 weeks, $78 \%$ of men $(\mathrm{N}=246 / 317)$ and $82 \%$ of women $(\mathrm{N}=40 / 49)$ had a $\mathrm{VL}<50$ cop./ml (OT; ITT: $65 \%(\mathrm{~N}=246 / 381)$ and $67 \%(\mathrm{~N}=40 / 60)$, respectively, $\mathrm{p}=\mathrm{n} . \mathrm{s}$.). Median changes in $\mathrm{CD} 4$ counts were $+215 / \mu 1$ in men and $+176 / \mu 1$ in women ( $=$ n.s.).

At baseline, symptoms of any grade were documented in $16 \%$ of men and in $10 \%$ of women $(\mathrm{p}=0.05)$. At 48 weeks, $27 \%$ of men and $9 \%$ of women reported side effects $(\mathrm{p}<$ $0.001)$. The probability of remaining on treatment was 
$77 \%$ vs. $80 \%$ in men vs. women (KM-analysis, p=n.s.). 59 men $(6 \%)$ and 8 women $(1 \%)$ discontinued LPV/r due to side effects. 8 men $(1 \%)$ and no women discontinued LPV/r due to virological failure.

The median time to reaching a confirmed VL $<50 \mathrm{cop} . / \mathrm{ml}$ was 26 weeks in men and 24 weeks in women ( $\mathrm{p}=\mathrm{n}$.s.); time to $>500 \mathrm{CD} 4$ cells $/ \mu 1$ was 91 weeks in men and 84 weeks in women ( $\mathrm{p}=\mathrm{n} . \mathrm{s}$.$) .$

Conclusion: Virological and immunological treatment outcomes did not differ between men and women initiating a Lopinavir/r-based regimen. However, women had fewer side effects and discontinued less often due to side effects.

\section{$P 432$}

\section{Starting a Lopinavir/r-based regimen in ART-naive patients improves quality of life. 48-week data from the German STAR and S TELLA cohorts}

Christine Koegl', Axel Baumgarten ${ }^{2}$, Bernhard Bieniek ${ }^{3}$, Stefanie Holm ${ }^{4}$, Martin Hower ${ }^{5}$, Hans Jaeger 6 , Thomas Lutz $^{7}$, Markus Mueller ${ }^{8}$, Wolfgang Schmidt ${ }^{9}$, Andreas Trein ${ }^{10}$, Ramona Pauli ${ }^{11}$, Eva Wolf ${ }^{1}$, Ralph Petry ${ }^{12}$, Hans-Juergen Stellbrink 13

${ }^{1}$ MUC Research, Munich, Germany, ${ }^{2}$ HIV-Practice Dres S. Dupke/A.Carganico/A. Baumgarten, Berlin, Germany, ${ }^{3} \mathrm{MVZ}$ PraxisCityOst Dres C.Cordes/B. Bieniek/ H. Hillenbrand, Berlin, Germany, ${ }^{4}$ Praxis Dres S. Holm/ B. Kuhlmann / H. Heiken, Hannover, Germany, 5 ID Ambulanz Med. Klinik Nord Klinikum Dortmund, Dortmund, Germany, ${ }^{6} \mathrm{MVZ}$ Karlsplatz, HIV Research and Clinical Care Centre, Munich, Germany,

${ }^{7}$ Infektiologikum Frankfurt, Frankfurt, Germany, ${ }^{8}$ Praxis Dres

B. Frietsch/ A.Ulmer/ M. Mueller, Stuttgart, Germany,

${ }^{9}$ Aerzteforum Seestraße, Berlin, Germany, ${ }^{10}$ HIV Center,

Stuttgart, Germany, ${ }^{11}$ Praxis Dres R.Pauli/ W. Becker,

Munich, Germany, ${ }^{12}$ Abbott GmbH \& Co.KG, Wiesbaden, Germany, ${ }^{13} \mathrm{ICH}$ (Infektionsmedizinisches Centrum Hamburg), Hamburg, Germany

Backg ro und: We analyzed data from the STAR and STELLA cohorts, two German prospective, multi-centre, observational studies, which include HIV+ patients (pts) starting a Lopinavir/Ritonavir (LPV/r)-based regimen and evaluated the subjective benefit regarding the ACTG-Symptom-Distress-Module (ASDM) prior to and after treatment start.

Methods: The ASDM, a self-reported questionnaire with 22 items (scale 0-4), quantifies the presence of symptoms related to HIV and/or treatment. Lower scores represent a better Quality of Life (QoL). We analyzed the changes in ASDM scores in ART-naive patients over a treatment period of 48 weeks with respect to viral load (VL) and CD4 count.

Results: This analysis is based on 718 ART-naive patients $(620$ men, median age 40 years, median CD4 counts $207 / \mu 1$, median viral load $5.1 \mathrm{log}$ ) completing all items of the ASDM. The median ASDM score was 11.0 (range 0-86). We compared pts with a high baseline score $(>11.0)$ and pts with a low score $(\leq 11.0)$.

At baseline, median CD4 count was significantly lower in pts with a high ASDM score $(\mathrm{N}=354$; median score 23.5) than in pts with a low score $(\mathrm{N}=364$; median score 4.5$)$ $(185 / \mu 1$ vs. $214 / \mu 1 ;$ p $<0.01)$. Median viral load did not differ between the two groups $(5.1 \log v$ s. $5.0 \log$; p=n.s.).

At 48 weeks, there was no difference in CD4 cells $(425 / \mu 1$ vs. $432 / \mu 1 ; \mathrm{p}=$ n.s.) or $\mathrm{VL}<50 \mathrm{cop} . / \mathrm{ml}$ (85\% vs. $80 \% ; \mathrm{p}=$ n.s. $)$. In pts with a high baseline score $(\mathrm{N}=114)$, the median change was $-10.0(\mathrm{p}<0.01)$, and in pts with a low score $(\mathrm{N}=128)$, median change was $-1.0(\mathrm{p}=\mathrm{n} . \mathrm{s}$. $)$.

Conclusions: ART-naive patients with high symptom stress at the baseline benefit from initiating a Lopinavir/rbased regimen. At baseline high ASDM-Scores were associated with low CD4 cells. The improvement of QoL was not associated with the increase in CD4 cells or the decrease in viral load.

\section{$P 433$}

Safety analysis of darunavir/r (DRV/r): combined data from randomised Phase II and Phase III studies

Gerd Fätkenheuer ${ }^{1}$, Keikawus Arasteh ${ }^{2}$, Johannes Bogner ${ }^{3}$, Frank-Detlef Goebel ${ }^{4}$, Thomas Harrer ${ }^{5}$, Hans Jäger ${ }^{6}$, Jörg-Andres Rump ${ }^{7}$, Dieter Schuster ${ }^{8}$, Albrecht Stöhr ${ }^{9}$, Jan van Lunzen ${ }^{10}$, Eric Lefebvre ${ }^{11}$, Sabrina Spinosa-Guzman ${ }^{12}$, Bernd Sang 13

${ }^{1}$ Medical Hospital of the University of Cologne, Department of Internal Medicine I, Cologne, Germany, ${ }^{2}$ Vivantes AugusteViktoria-Clinical Centre, Berlin, Germany, ${ }^{3}$ Medical Hospital of the University of Munich, Munich, Germany, ${ }^{4}$ Private Practice, Munich, Germany, ${ }^{5}$ Medical Hospital of the University of Erlangen, Erlangen, Germany, ${ }^{6}$ Mucresearch, Munich, Germany, ${ }^{7}$ Private Practice, Freiburg, Germany, ${ }^{8}$ Private Practice, Mannheim, Germany, ${ }^{9}$ ifi - Institute for interdisciplinary medicine, Hamburg, Germany, ${ }^{10}$ University Hospital Eppendorf, Hamburg, Germany, ${ }^{11}$ Tibotec BVBA Mechelen, Belgium, ${ }^{12}$ Janssen-Cilag B.V., Tilburg, Netherlands, ${ }^{13}$ Tibotec / Division of Jassen-Cilag GmbH, Neuss, Germany

$\mathrm{DRV} / \mathrm{r}$ has been evaluated in a large-scale clinical program in a broad range of HIV-1-infected antiretroviral-naïve and experienced patients (pts). This analysis examines the safety profile of $\mathrm{DRV} / \mathrm{r}$ in pts in these studies administered DRV/r $600 / 100 \mathrm{mg}$ bid or $800 / 100 \mathrm{mg}$ qd, as part of combination therapy.

All available safety data at 48 wks were analysed from $1376 \mathrm{pts}$ recruited to the DRV/r 600/100mg bid and $800 / 100 \mathrm{mg}$ qd arms of Phase IIb POWER $1+2$ trials and Phase III ARTEMIS, TITAN and DUET trials. In ARTEMIS, treatment-naïve pts received $800 / 100 \mathrm{mg}$ qd $(n=343)$ or lopinavir/r (LPV/r) 800/200mg (total daily dose; $\mathrm{n}=346$ ); all pts received tenofovir/emtricitabine. In TITAN, treatment-experienced, LPV-naïve pts received DRV/r $600 / 100 \mathrm{mg}$ bid $(\mathrm{n}=298)$ or $\mathrm{LPV} / \mathrm{r} 400 / 100 \mathrm{mg}$ bid $(\mathrm{n}=297)$ + OBR. In POWER $1+2$, highly treatment-experienced pts who only received DRV/r 600/100mg bid + OBR $(n=131)$ were included. Only pts from the control arm of DUET $1+2$ $(\mathrm{n}=604)$ receiving DRV/r 600/100mg + OBR and etravirine (ETR) placebo were analysed.

Most common adverse events (AEs) (regardless of causality or severity) were diarrhoea and nausea. Comparing across all trials, there was a lower incidence of overall AEs, serious AEs, discontinuations due to AEs and lipid AEs in naïve pts receiving $D R V / r 800 / 100 \mathrm{mg}$ qd than in treatment-experienced pts using DRV/r 600/100mg bid. The lower incidence of grade 2-4 at least possibly treatment-related diarrhoea with DRV/r compared to LPV/r was seen in both ARTEMIS and TITAN. No apparent differences were seen with gender, race or age.

In conclusion, DRV/r was consistently well tolerated and caused significantly less grade 2-4 diarrhoea than LPV/r. In 
ARTEMIS, the incidence of grade 2-4 diarrhoea and nausea with DRV/r 800/100mg qd was half that reported with DRV $600 / 100 \mathrm{mg}$ bid in TITAN; this could be related to population, background regimen and/or dosing differences.

\subsection{Anti-retrovirale Behandlung allgemein / General Anti-Retroviral Therapy}

\section{P434 (PW)}

German cost-efficacy analysis to achieve full virological suppression for treatment experienced HIV infected patients in the DUET trials

Matthias Stoll ${ }^{1}$, Verena Donatz ${ }^{2}$, Silas Martin ${ }^{3}$, Andrew M. Hill 4

${ }^{1}$ Medizinische Hochschule Hannover, Zentrum Innere Medizin, Klinik für Immunologie und Rheumatologie, Hannover, Germany, ${ }^{2}$ Janssen-Cilag GmbH, Neuss, Germany,

${ }^{3}$ Johnson \& Johnson Pharmaceutical Services, LLC, Mechelen, Belgium, ${ }^{4}$ University of Liverpool, Liverpool, United Kingdom

Backgro und: The aim of antiretroviral treatment (ART) is long-term suppression of HIV-RNA. The DUET 1 and 2 trials evaluated efficacy of the novel NNRTI etravirine (ETR) versus placebo, given with optimised background regimen (OBR) of NRTIs, darunavir/ritonavir (DRV/r) and optional enfuvirtide (ENF), in treatment experienced patients.

Method: To calculate treatment costs, German pharmacy sales prices including taxes were used (Lauer-Taxe, 2008). At week 48, rates of HIV-RNA suppression $<50$ copies/ml in different treatment groups were analysed in combination with drug costs to calculate the costs per patient with HIVRNA $<50$ copies/ml.

Result: The total drug treatment cost was $€ 42,990$ per person-year in the ETR+OBR arm, versus $€ 35,658$ in the placebo+OBR arm, a $21 \%$ increase. However, more patients reached the viral endpoint $(<50 \mathrm{cp} / \mathrm{ml})$ in the ETR+OBR arm $(61 \%)$ as compared to placebo+OBR $(40 \%)$. Therefore the cost per person with HIV-RNA $<50 \mathrm{cp} / \mathrm{ml}$ at week 48 was $€ 70,476$ in the ETR+OBR arm versus $€ 89,145$ in the placebo+OBR arm, a decrease of $21 \%$. This lower cost per person with HIV-RNA $<50$ copies $/ \mathrm{ml}$ in the ETR+OBR arm compared to the placebo+OBR arm was also seen in the subanalyses of patients using ENF for the first time, those who did not use ENF, and for those with no other sensitive drugs in their background regimen (GSS=0). For a fixed treatment budget of $€ l$ million, this would lead to 14.2 patients showing HIV-RNA suppression if given ETR+OBR, versus 11.2 patients given placebo+OBR.

Conclusions: In the DUET trials, treatment with ETR was associated with significant reductions in the cost per patient with $\mathrm{HIV}-\mathrm{RNA}<50 \mathrm{cp} / \mathrm{ml}$. There was no significant difference in adverse event rates between arms, but a lower rate of disease progression in the ETR arm, which could also favor for an improved cost efficacy of the ETR arm.

\section{P435 (PW)}

HIV RNA levels six months after antiretroviral therapy initiation predict subsequent survival and retention of HIV-1-infected individuals in Sub-Saharan Africa

Maria Cristina Marazzi ${ }^{1}$, Leonardo Palombi ${ }^{2}$, Ersilia Buonomo $^{2}$, Paola Scarcella ${ }^{2}$, Giov anna Paturzo ${ }^{3}$, Anna Maria Doro Altan ${ }^{2}$, Susanna Ceffa ${ }^{3}$, Dieter Wanderlein 4 , Paola Germano ${ }^{3}$, Giovanni Guidotti ${ }^{3}$, Ines Zimba Da Vitoria ${ }^{5}$, Andrea De Luca ${ }^{6}$, Dream Study Group

${ }^{1}$ LUMSA University, Rome, Italy, ${ }^{2}$ Tor Vergata University, Rome, Italy, ${ }^{3}$ Dream Program, Rome, Italy,

${ }^{4}$ Universitätsklinikum and Dream Program, Würzburg, Germany, ${ }^{5}$ Dream Program, Maputo, Mozambique, ${ }^{6}$ Catholic University, Clinical Infectious Diseases, Rome, Italy

Background: Viral load (VL) is not available for treatment monitoring in most ART programs in Sub-Saharan Africa. We investigated the prognostic role of 6-month virological response after ART initiation.

Methods: Naive patients from 5 sites in Mozambique, Malawi and Guinea starting ART, with available VL after 6 months (12-36 weeks) and subsequent follow-up (F/U) were investigated. Baseline and 6-month CD4 and VL, WHO stage, hemoglobin $(\mathrm{Hb})$ and missed pharmacy and clinic appointments( $>7$ days delay) were retrieved for analysis. Predictors of time from the 6-month VL to death and to loss to $\mathrm{F} / \mathrm{U}$ were analyzed by multivariable Cox regression.

Results: Of 1,898 patients $62 \%$ were females, $28 \%$ WHO stage III/IV with median age $35 \mathrm{y}, \mathrm{CD} 4208$ cells $/ \mu \mathrm{L}$, VL $4.6 \log 10 \mathrm{cp} / \mathrm{mL}, \mathrm{Hb} 10.8 \mathrm{~g} / \mathrm{dL}$. Most frequently employed regimens were $\mathrm{d} 4 \mathrm{~T} / \mathrm{ZDV}+3 \mathrm{TC}+\mathrm{NVP}(97 \%) ; 18 \%$ missed $>5 \%$ pharmacy appointments. At 6 months, $84.8 \%$ had $\mathrm{VL}<1,000 \mathrm{cp} / \mathrm{mL}$, median CD4 change was +118 cells $/ \mu \mathrm{L}$. After month 6, during a cumulative $\mathrm{f} / \mathrm{u}$ of 2,356 personyears, 74 patients died, 46 were lost to f/u. Independent predictors of death were male sex, lower baseline $\mathrm{Hb},>5 \%$ missed pharmacy appointments, 6 -month CD4 counts $<50$ cells $/ \mu \mathrm{L}$ versus all strata and 6 -month $\mathrm{VL}>10,000 \mathrm{cp} / \mathrm{mL}$ (HR versus $\mathrm{VL}<502.15,1.14-4.53)$. In the subgroup with 6-month $\mathrm{CD} 4<200$ cells $/ \mu \mathrm{L}(\mathrm{n}=421)$ VL $1,001-10,000$ $\mathrm{cp} / \mathrm{mL}$ (HR versus $\mathrm{VL}<502.94,1.08-7.97$ ) and $\mathrm{VL}>10,000$ $\mathrm{cp} / \mathrm{mL}$ (HR versus $\mathrm{VL}<50 \mathrm{cp} / \mathrm{mL} 2.86,1.18-6.91$ ) predicted death.

Independent predictors of loss to $\mathrm{f} / \mathrm{u}$ were $>95 \%$ attendance to pharmacy appointments (HR 0.05, 0.01-0.16), $>95 \%$ to clinic visits (HR $0.29,0.10-0.86$ ), older age vs 15-24 years (age 35-44y HR 0.25, 0.08-0.76; age $>44$ y HR $0.20,0.05-0.91)$ and 6 -month VL $>10,000 \mathrm{cp} / \mathrm{mL}$ (HR vs < $503.28,1.60-6.74)$.

Conclusions: In a Sub-Saharan African setting, VL $>10,000 \mathrm{cp} / \mathrm{mL} 6$-months (12-36 weeks) after ART initiation independently predicted subsequent mortality and loss to follow-up. 


\section{P436}

\section{Retrospektive Datenerhebung über den Zeitpunkt des Therapiebeginns bei HIV posi- tiven Frauen in zwei Zentren Deutschlands von 1995-2008}

Ivank a Krznaric ${ }^{1}$, Alexander Zoufaly ${ }^{2}$, Sandra Hertling ${ }^{3}$

${ }^{1}$ Gemeinschaftspraxis Dupke, Baumgarten, Carganico, Berlin, Germany, ${ }^{2}$ Medizinische Klinik I, Universitätsklinikum Eppendorf, Hamburg, Germany, ${ }^{3}$ Ambulanzzentrum des Universitätsklinikums Eppendorf $\mathrm{GmbH}$, Bereich Infektiologie, Hamburg, Germany

Hinterg rund: 1996 wurde die hochwirksame antiretrovirale Therapie (HAART) mit mindestens drei kombinierten Substanzen zum Therapiestandard. Anfänglich wurde ein sehr früher Therapiestart befürwortet, während sich im Verlauf zeigte, dass ein verzögerter Therapiebeginn aus reicht. Methode: Die Datenbanken einer Berliner Schwerpunktpraxis sowie des Ambulanzzentrums der Uniklinik Hamburg wurden nach Patientinnen retrospektiv durchsucht, die im Zeitraum von 1995-2008 mit Ihrer HIV Therapie begonnen haben. Ausgewertet wurden die Daten bezüglich der Therapieregime, der immunologischen Ausgangssituation, des Herkunftslandes sowie der Transmissionsweg.

Ergebnisse: Bei 172 Patientinnen konnte die Initialtherapie erfasst werden. Das Durchschnittsalter betrug 41 Jahre. 92 Patientinnen stammen aus Deutschland (53\%) 80 waren Migrantinnen (11 aus Asien, 3 aus Lateinamerika, 53 aus Subsahara Afrika,). Infektionsweg war mit 44\% der heterosexuelle Übertragungsweg, bei $38 \%$ die Herkunft aus einem Hochprävalenz Land und $10 \%$ der iv-Drogenkonsum und bei $8 \%$ war der Infektionsweg unbekannt. Es ergab sich kein Unterschied bezüglich des Therapieregimes 2NRTI in Kombination mit einem PI oder NRTI in Abhängigkeit der Höhe der CD4-Zellzahl $(<200$ oder $>200 / \mu 1)$. Auch ergab sich kein signifikanter Unterschied bezüglich der Therapiewahl im Laufe der Jahre. So wurden in der Gruppe von 1995-2003 PI und NNRTI in Kombination mit 2 NRTI s genau so häufig eingesetzt wie in der Gruppe 2003-2008. Signifikant war jedoch, dass Frauen zum Zeitpunkt des Therapiebeginns in der Gruppe 2003-2008 häufiger CD4Zellen unter $200 / \mu 1$ haben als Frauen in den Jahren 1995$2003(\mathrm{p}=0.01)$.

Zus ammenfass ung: Bezüglich der Therapieregime konnte kein signifikante Tendenz im Laufe der Jahre beobachtet werden. Signifikant ist jedoch, dass in der jüngeren Zeit der Immunstatus zum Zeitpunkt des Therapiestarts schlechter war. Es stellt sich die Frage ob die Zahl der Latepresenter zunimmt oder liegt es am verzögerten Therapiebeginn. Dies bedarf weiter Untersuchungen mit einer größeren Patientenzahl.

\section{$P 437$}

\section{Antiretrovirale Therapie bei einem extremen Frühg eborenen}

David Endress ${ }^{1}$, Richard Linde ${ }^{2}$, Doris Fischer ${ }^{3}$, Elisabeth Förster-Waldl ${ }^{4}$,Wolfhart Kreuz ${ }^{2}$, Andreas
Lischka ${ }^{1}$,Christoph Königs ${ }^{2}$

${ }^{1}$ Wilhelminenspital, Neonatologie, Wien, Austria,

2J.W.Goethe-Universität, Immundefektambulanz, Kinderklinik, Frankfurt am Main, Germany, ${ }^{3}$ J.W.GoetheUniversität, Neonatologie, Kinderklinik, Frankfurt am Main, Germany, ${ }^{4}$ Medizinische Universität Wien, Kinderklinik, Wien, Austria

Aufgrund des hohen Risikos an AIDS zu erkranken oder zu versterben sollen alle HIV-positiven Kinder < 12Monate unabhängig von Viruslast und Immunstatus antiretroviral therapiert werden. Trotz dieser Empfehlung liegen nur wenige Erfahrungen und pharmakokinetische Daten über eine suffiziente Therapie in dieser Altersgruppe vor. Zur Therapie bei Frühgeborenen gibt es keine Daten.

Wir berichten über ein Früh geborenes der 29. Schwangerschaftswoche, das bei unbekanntem Infektionsstatus der Mutter keine präpartale Prophylaxe erhalten hatte und bei unstillbaren Wehen und vorzeitigem Blasensprung per Sectio entbunden wurde. Unter postpartaler Prophylaxe mit AZT, 3TC und NVP wurde am 4. Lebenstag die HIV-Infektion mittels PCR nachgewiesen. Neben eines massiven Immundefekts (CD4: 11\%), einer CMV-Infektion und ausgeprägter Panzytopenie wurden deutlich erhöhte Transaminasen festgestellt. In der Genotypisierung konnten keinen relevanten Resistenzen nachgewiesen werden .

Entsprechend der Erfahrungen bei Reifgeborenen und mangelnder Alternativen wurde trotz der Befundkonstellation neben einer Prophylaxe mit Cotrimoxazol und Diflucan eine Therapie mit NVP, AZT und 3TC eingeleitet. Die CMV Infektion wurde im Verlauf mit Ganciclovir behandelt. AZT und 3TC wurden gewichtsadaptiert dosiert. Nach einer beginnenden NVP Dosierung von $4 \mathrm{mg} / \mathrm{kg}$ KG wurde bei ausreichenden Plasmaspiegeln auf die empfohlene Vervierfachung der Dosis verzichtet. Die Dosierung wurde entsprechend der Plasmaspiegel angepasst. Im Alter von 8 Monaten erreichte das Kind mit der Hälfte der empfohlenen NVP-Dosierung $\mathrm{C}_{\max }$ von bis zu $4846 \mathrm{ng} / \mathrm{ml}$. Der geringere NVP-Bedarf reflektiert die langsame Entwicklung des CYP3A Systems bis zum Alter von 12 Monaten. Unter Therapie sank die Viruslast von initial $122.000 \mathrm{cps} / \mathrm{ml}$ auf $490 \mathrm{cps} / \mathrm{ml}$. Die Helferzellen normalisierten sich (aktuell: 2789/ $\mu 1,40 \%$ ). Sowohl Transaminasen als auch Blutbild normalisierten sich. Das Kind entwickelt sich annähernd altersentsprechend.

Die Therapie von HIV-positiven Frühgeborenen bleibt eine Herausforderung, die trotz dringender Therapieindikation auf wenigen Daten beruht. Durch spiegelgesteuerte Therapieanpassung konnte eine erfolgreiche Senkung der Viruslast und Immunrekonstitution ohne laborchemische Nebenwirkungen erreicht werden, von der das Kind mit extrem schlechter Prognose deutlich klinisch profitierte. 


\subsection{Nebenwirkungen, Resistenzen, Pharmakokinetik / Adverse Events, Resistance, Pharmacocinetics}

\section{$P 438(P W)$}

Atazanavir plasma concentrations substanti ally decreased in HIV-1 infected adults taking concomitantly methadone oral solution in a daily observed therapy

Annette Haberl ${ }^{1}$, Christoph Stephan ${ }^{1}$, Manfred Mösch ${ }^{2}$, Gabi Nisius ${ }^{1}$, TessaLennemann ${ }^{1}$, Pavel Khaykin ${ }^{1}$, Michael Kurowski ${ }^{3}$, Schlomo Staszewski ${ }^{1}$, Reinhard Brodt ${ }^{1}$, Nils Hvon Hentig ${ }^{1}$

${ }^{1}$ J.W.Goethe-University Hospital, HIVCENTER Medizinische Klinik II, Frankfurt am Main, Germany, ${ }^{2}$ Private Practice, Frankfurt am Main, Germany, ${ }^{3}$ HIVLAB, Auguste Viktoria Hospital, Berlin, Germany

Objective: The ritonavir-boosted HIV protease inhibitor atazanavir is approved for a once-daily intake and therefore used in daily observed therapy (DOT) of methadone substituted drug users. As a routine pharmacokinetic databank analysis revealed low atazanavir plasma concentrations in patients taking methadone oral solution, we performed a matched pairs analysis of patients (12 men, 12 women) taking atazanavir/ritonavir 300/100mg QD plus reverse transcriptase inhibitors, with $(n=12)$ or without $(n=12)$ methadone.

Methods: Steady-state 24-hour pharmacokinetic profiles of atazanavir/ritonavir were as sessed and measured by LCMS/MS. Geometric mean (GM, T-test) minimum and maximum plasma drug concentrations $\left(\mathrm{C}_{\min }, \mathrm{C}_{\max }\right)$, area under the concentration-time curve (AUC), and total oral clearance $\left(\mathrm{CL}_{\text {total }}\right)$ were compared between patients, matched for age, gender, ethnicity and weight.

Resul ts: The GM $(90 \% \mathrm{CI})$ atazanavir $\mathrm{C}_{\min }, \mathrm{C}_{\max }$ and AUC of patients taking methadone oral solution at doses of 20 $175 \mathrm{mg} / \mathrm{d}$ were markedly lower than in matched patients not taking methadone: $C_{\min }=315(197-448)$ vs 519 (279-793) $\mathrm{ng} / \mathrm{mL}$ (geometric mean ratio, $\mathrm{GMR}=0.61, \mathrm{p}=.229$ ); $\mathrm{C}_{\max }$ $=1714(1238-2262)$ vs $3190(2412-4076) \mathrm{ng} / \mathrm{mL}(\mathrm{GMR}=$ $0.54, \mathrm{p}=.018) ;$ AUC $=21987(15870-29327)$ vs 35572 (26211-46728) $\quad \mathrm{ng}^{*} \mathrm{~h} / \mathrm{mL} \quad(\mathrm{GMR}=0.62, \mathrm{p}=.074)$. Methadone dose was significantly correlated to atazanavir $\mathrm{C}_{\max }\left(\mathrm{r}_{-}=0.40, \mathrm{p}=.001\right)$ and AUC $\left(\mathrm{r}_{-}=0.32, \mathrm{p}=.006\right)$. Ritonavir pharmacokinetics was similar between the groups $\left(\mathrm{C}_{\min }, \mathrm{C}_{\max }\right.$ and $\mathrm{AUC}$ GMR $=1.01,0.80$ and 0.96, respectively), indicating the patient's therapy adherence in this setting.

Conclusion: A substantial decrease of atazanavir plasma concentrations in patients concomitantly taking methadone oral solution deserves further attention and therapeutic drug monitoring should be considered.

\section{P439 (PW)}

Pharmacokinetics and dose selection of etravirine (ETR) in HIV-infected children between 6 and 17 years, inclusive

Christoph Königs ${ }^{1}$, Cornelia Feiterna-Sperling ${ }^{2}$, Susanna Esposito ${ }^{3}$, Carlo Giaquinto ${ }^{4}$, Thomas Kak uda ${ }^{5}$, RekhaSinha ${ }^{6}$, Rebecca Mack ${ }^{5}$, Katrie Janssen 6 , Richard Hoetelmans 6

${ }^{1}$ J.W.Goethe-Universität, Immundefektambulanz, Kinderklinik, Frankfurt, Germany, ${ }^{2}$ Klinikum der Humboldt Universität, Berlin, Germany, ${ }^{3}$ Università di Milano, Milano, Italy, ${ }^{4}$ Università di Padova, Padova, Italy, ${ }^{5}$ Tibotec Inc.,

Yardley, United States, ${ }^{6}$ Tibotec BVBA, Mechelen, Belgium

ETR is an NNRTI approved for the treatment of HIV-infected adults. Pediatric dosing has not been established. The objective of this trial was to determine the weight-based dose of ETR to achieve exposures in children comparable to those in adults.

HIV-1-infected children between 6 and 17 years with undetectable viral loads on a LPV/r-containing regimen were enrolled; NNRTI use was excluded. In two sequential stages, ETR was added for 7 days followed by a morning dose and 12-hour PK assessment on Day 8. ETR was administered following a meal and dosed $4 \mathrm{mg} / \mathrm{kg}$ bid in stage I and $5.2 \mathrm{mg} / \mathrm{kg}$ bid in stage II. Both $25-$ and $100-\mathrm{mg}$ tablets were used. ETR PK was assessed using non-compartmental analysis. Safety and tolerability were assessed throughout the study up to 30 days post-dosing.

21 children were enrolled into each stage; PK was available in 19 and 20 in stages I and II, respectively. The mean (SD) $\mathrm{C}_{\max }$ in stages I and II respectively was 495 (453) $\mathrm{ng} / \mathrm{mL}$ and 757 (680) $\mathrm{ng} / \mathrm{mL} ; \mathrm{C}_{\min }$ was 184 (151) and 294 (278) ng/mL; AUC12h was 4050 (3602) and 6141 (5586) $\mathrm{ng} \bullet \mathrm{h} / \mathrm{mL}$. PK parameters in stage II were more comparable to adults participating in the Phase III trials DUET-1 and -2. All children remained $<50$ copies $/ \mathrm{mL}$ on Day 8 . No serious adverse events (AEs) occurred during the trial; 14 and 9 children in stage I and II, respectively, reported at least $1 \mathrm{AE}$, mostly Grade 1 or 2. Two children developed a rash (grade 1 and 2).

The selected dose of ETR in children $6-17$ years is $5.2 \mathrm{mg} / \mathrm{kg}$ bid providing comparable exposure to the adult dose and being generally safe and well tolerated. Further PK, safety and tolerability of ETR in children will be investigated in the PIANO trial (Pediatric Intelence as an Alternative NNRTI Option).

\section{P440 (PW)}

Prevalence of virologic failure in HIV-1-infected patients treated with antiretroviral therapy (ART) - results from a German multicenter cohort-study (VIREMIA)

Axel Baumgarten ${ }^{1}$, Stephan Klauke ${ }^{2}$, Knud Schwere ${ }^{3}$, Christoph Mayr ${ }^{4}$, Hans Jäger ${ }^{5}$, Pavel Khaykin 6 , Cam-Tuan Tran 7 , Markus Bickel ${ }^{6}$

${ }^{1}$ Praxis Dupke/Carganico/Baumgarten, Berlin, Germany, ${ }^{2}$ Infektiologikum, Frankfurt, Germany, ${ }^{3} \mathrm{ICH}$, Hamburg, Germany, ${ }^{4}$ Ärzteforum Seestr, Berlin, Germany, ${ }^{5} \mathrm{MUC}$ Research München, München, Germany, ${ }^{6} \mathrm{JW}$ GoetheUniversität, Infektiologie, Frankfurt, Germany, 7Tibotec, Division of Janssen-Cilag GmbH, Neuss, Germany

Background: To assess the prevalence of virologic failure among patients treated with ART and to determine risk factors in HIV-1-infected patients (pts) in Germany . 
Methods: Multicenter, retrospective analysis of HIV-1infected pts older $>18$ years treated with ART for at least 6 months. Follow up data were collected from baseline (July 01 st 2006) until June 30th 2007.

Results: At baseline 19.552 pts receiving medical care in 33 HIV-treatment centers were screened. 14.015 (100\%) of these pts received ART. A viral load (VL) of $>50$ copies $/ \mathrm{ml}$ at baseline was found in 1.408 pts (10\%) on ART, with 718 pts $(51 \%$ of the viremic pts) having a VL $<500$ copies $/ \mathrm{ml}$. Viremic pts were on average $( \pm$ SD) $45 \pm 9$ years old, male (79\%), mean duration of HIV-infection $11.5 \pm 6$ years, $39.9 \%$ had a history of an AIDS defining event and had received ART for a mean of $7.8 \pm 4.2$ years. The median CD4 cell count was 358 (range: $0-1481$ ) cells $/ \mu 1$ with a median VL of 475 (range: $51-3.000 .000$ ) copies $/ \mathrm{ml}$. Only $729 \mathrm{pa}-$ tients $(5.2 \%)$ of treated patients had a VL $>50 \mathrm{c} / \mathrm{ml}$ detected twice during the observational period confirming virologic failure. The rate of patients with high level virologic failure (VL >1000) copies/ml declined only slightly during follow up (39\% baseline, $31 \%$ at last observation). According to the treating physician reasons of virologic failure might have been non-adherence (41\%), drug resistance mutations (37\%), acute disease other than HIV infection (8\%) and non- availability of $(8 \%)$ or intolerance $(6 \%)$ to active antiretroviral drugs .

Conclusion: The overall prevalence of low level viremia and the rate of HIV infected patients with confirmed virologic failure on ART was very low in this retrospective analysis. The major reason for non suppressive ART was non-adherence, whereas unavailability of active antiretroviral treatment options was surprisingly low.

\section{P441 (PW)}

\section{Veränderungen des HIV-1-Mutations profils vor Therapiebeginn in Abhängigkeit von der Zeit}

Stefan Reuter ${ }^{1}$, Rolf Kaiser ${ }^{2}$, Mark Oette ${ }^{3}$, Melanie Balduin $^{2}$, Björn Jensen ${ }^{1}$, Dieter Häussing er ${ }^{1}$, Nadine Sichtig ${ }^{2}$

1Universitätsklinikum Düsseldorf, Klinik für Gastroenterologie, Hepatologie und Infektiologie, Düsseldorf, Germany, 2Universität zu Köln, Institut für Virologie, Köln, Germany, 3Krankenhaus der Augustinerinnen, Köln, Germany

Einleitung: Im Rahmen der RESINA-Studie wird seit mehreren Jahren bei therapienaiven HIV-1 infizierten Patienten die Rate übertragener Resistenzmutationen vor Beginn der antiretroviralen Therapie (ART) untersucht, um bei First-Line-Therapie ein vorzeitiges Therapieversagen aufgrund von Resistenzmutationen zu vermeiden. In der vorliegenden Analyse wurden Veränderungen des Resistenzmusters über die Zeit vor Beginn einer ART untersucht.

Material und Methoden: Bei $54 \mathrm{HIV}-1$ infizierten Patienten wurden jeweils zwei Proben zu unterschiedlichen Zeitpunkten vor ART-Beginn auf resistenz-assoziierte Mutationen untersucht. Die Resistenzanalyse erfolgte über Populationssequenzierung der Protease und Reversen Transkriptase des pol-Gens von HIV-1. Die in der aktuellen IAS-Liste beschriebenen Mutationen wurden als resistenzassoziiert bewertet.

Ergebnisse: Bei 17/54 Patienten mit mehr als 1 Untersuchung vor Therapiebeginn konnten vor Therapiebeginn Resistenzmutationen nachgewiesen werden. Bei den 8 Pa- tienten, deren Proben in einem zeitlichen Abstand von mehrals 180 Tagen (Median 365 Tage) entnommen wurden, konnte eine Veränderung des Mutationsprofils der majoren Viruspopulation nachgewiesen werden. In 6 der insgesamt 8 Fälle kam es über die Zeit zu einer Zunahme von Resistenzmutationen in der majoren Viruspopulation, wohingegen in 2 Fällen primär detektierte Mutationen in der zweiten Resistenzanalyse nicht mehr nachweisbar waren. Bei den 9 der 17 therapienaiven Patienten mit nachweisbaren Resistenzmutationen, deren Proben in einem Abstand von weniger als 180 Tagen analysiert wurden, konnte keine Veränderung des Mutationsprofils der majoren Viruspopulation beobachtet werden. Ein Patient zeigte in der zweiten Resistenzanalyse einen minoren Virusstamm mit einer resistenz-assoziierten Mutation auf.

Diskussion: In Abhängigkeit von der Zeit wurden bei therapienaiven Patienten resistenz-assoziierte Veränderungen des Mutationsprofils beobachtet. Hierbei kam es in den meisten Fällen zu einem vermehrten Nachweis von Resistenzmutationen in der prädominanten Viruspopulation, umgekehrt jedoch auch zur fehlenden Detektion vormals nachweisbarer Resistenzmutationen. Demnach wäre eine primäre Resistenzuntersuchung sowohl zum Zeitpunkt der Erstdiagnose als auch unmittelbar vor Therapiebeginn zu empfehlen, da sich das Resistenzmuster auch ohne medikamentösen Selektionsdruck im Krankheitsverlauf ändern kann.

\section{$P 442(P W)$}

Use of tenofovir disoproxil fumarate (TDF) during pregnancy: an analysis from the Antiretroviral Pregnancy Registry (APR)

Bruce Olmscheid ${ }^{1}$, Sandra Hertling ${ }^{2}$, Sherry Zhang ${ }^{1}$

${ }^{1}$ Gilead Sciences, Foster City, United States,

${ }^{2}$ Universitätsklinikum Hamburg-Eppendorf, Hamburg, Germany

The benefit of antiretrovirals (ARVs) in prevention of mother-to-child transmission (MTCT) of HIV was first demonstrated in ACTG Study 076 using zidovudine (AZT) monotherapy. Studies and case series have shown a benefit of TDF in MTCT in animal models and pregnant women.

The APR is an international prospective registry to detect major teratogenic effects involving ARVs administered to pregnant women through voluntary reporting. Since its introduction in 1989, each year the APR enrolls approximately 1500 pregnant women exposed to ARVs (approximately $87 \%$ from the US, $13 \%$ from other countries). Sufficient numbers of 1 st trimester exposures to 14 ARVs including AZT and TDF have been monitored to detect at least a 1.5 - and 2-fold increase in overall birth defects respectively.

Through July 312008 , no overall increase in congenital anomalies in infants following any first or $2^{\text {nd/ }} 3^{\text {rd }}$ trimester ARV exposure has been seen in 11950 prospective cases documented in the APR compared to the general population. Prevalence of anomalies with any exposure to antiretrovirals in the first trimester was 2.9/100 live births (95\% CI: $2.4-3.5$ ) [126/4329]; with $2^{\text {nd }} / 3^{\text {rd }}$ trimester exposure 2.6/100 live births (2.2-3.0) [145/5618]. Prevalence of anomalies with first trimester exposure to TDF was $2.3 \%$ (1.3-3.9) [14/606]; with $2^{\text {nd } / 3} 3^{\text {rd }}$ trimester exposure $1.5 \%$ $(0.5-3.4)[5 / 336]$. No specific pattern of anomalies was re- 
ported. Prevalence of anomalies with first trimester exposure to AZT was $3.1 \%(2.5-3.7)$ [94/3068]; with 2 nd/3rd trimester exposure $2.7 \%(2.3-3.1)$ [161/6063]. These rates are comparable to those from the CDC population-based birth defects surveillance system $(2.7 / 100$ live births in the US).

To date no increase in prevalence of or any specific pattern of congenital anomalies has been seen with use of TDF in 942 live births through prospective voluntary reporting to the APR. Follow-up of exposed children, additional studies of women receiving TDF during pregnancy and for PMTCT are warranted.

\section{P443 (PW)}

\section{Efficacy of a computerised physician remin- der system to control CHD risk factors in HIV-patients receiving cART (S wiss HIV Cohort Study)}

Heiner C. Bucher ${ }^{1}$, Martin Rickenbach ${ }^{2}$, James Young ${ }^{1}$, Tracy Glass ${ }^{1}$, Yannick Valley ${ }^{2}$, Enos Bernasconi ${ }^{3}$, Matthias Cavassini ${ }^{4}$, Christoph Fux ${ }^{5}$, Véronique Schiffer ${ }^{6}$, Pietro Vernazza ${ }^{7}$, Rainer Weber ${ }^{8}$, Manuel Battegay ${ }^{9}$, and the Swiss HIV Cohort Study

${ }^{1}$ Basel Institute for Clinical Epidemiology and Biostatistics, University Hospital Basel, Basel, Switzerland, ${ }^{2}$ Swiss HIV Cohort Study Data Center, Lausanne, Switzerland, ${ }^{3}$ Division of Infectious Diseases Ospedale Regionale di Lugano, Lugano, Switzerland, ${ }^{4}$ Division of Infectious Diseases, CHUV, Lausanne, Switzerland, ${ }^{5}$ Division of Infectious Diseases, Insel Spital Bern, Bern, Switzerland, ${ }^{6}$ Division of Infectious Diseases, Hôpital Universitaire de Genève, Geneva, Switzerland, ${ }^{7}$ Division of Infectious Diseases, Cantonal Hospital St. Gall, St. Gallen, Switzerland, ${ }^{8}$ Division of Infectious Diseases and Hospital Epidemiology, University Hospital Zurich, Zürich, Switzerland, ${ }^{9}$ Division of Infectious Diseases and Hospital Hygiene, University Hospital Basel, Basel, Switzerland

Background: Exposure to cART may increase the risk of coronary heart disease (CHD). Whether computerized clinical decision support systems improve CHD risk factor management in HIV-infected patients is unknown.

Methods : 165 clinicians at the 7 study SHCS centres, associated hospitals and private practices were randomised in June 2006 to the provision of CHD risk profiles plus guidelines for cART patients versus the provision of evidence-based guidelines for $\mathrm{CHD}$ risk factor management alone. The intervention period was 12 months. CHD risk profiles on a flow chart with $\mathrm{CHD}$ risk factors, 10 years Framingham risk score (FRS), CHD drug prescriptions and CHD events were generated based on regular SHCS as sessments by the SHCS data centre and provided to physicians in the interventon group. Primary outcome was the reduction in total cholesterol (TC); secondary outcomes were systolic and diastolic blood pressure (BP) and FRS. Patients eligible for analysis had to be at baseline on cART for $>90$ days, aged 18 or older, not pregnant and with complete CHD risk factor data.

Results: Of 5782 screened patients, 26 women were pregnant, 1421 patients were not on cART prior to baseline and 377 patients had at missing CHD risk information, leaving an ITT population of 4089 patients. Mean differences in patients cared by physicians with routine provision of CHD risk profiles compared to guidelines alone was for to- tal TC $-0.03 \mathrm{mmol} / \mathrm{L}(95 \% \mathrm{CI}-0.12$ to 0.05$)$, for systolic and diastolic BP $-0.4 \mathrm{mmHg}(-1.7$ to 0.9$)$ and $-0.4 \mathrm{mmHg}$ (1.6 to 0.7$)$ and for the FRS -0.1 (95\% CI -0.3 to 0.1$)$. Overall roughly $15 \%$ of patients with FRS $\geq 10 \%$ for 10 years started either BP or lipid lowering drugs.

Conclusions: Systemic computerized, routine provision of $\mathrm{CHD}$ risk profiles in addition to guidelines did not significantly improve risk factors for $\mathrm{CHD}$ in patients on cART.

$$
\text { P444 (PW) }
$$

\section{Prevalence of minority HIV-1 NNRTI drug resistance mutation $\mathrm{K} 103 \mathrm{~N}$ in antiretroviral treatment-naïve patients}

\author{
Patrick Braun, Robert Ehret, Christian Höhn, Frank \\ Wiesmann, Heribert Knechten
}

PZB, Aachen, Germany

Background: Current genotypic technology used in the clinic is limited to detect resistance mutations that are present at levels of approximately $20 \%$ or greater and may consequently miss low-level resistant HIV variants that can grow rapidly under drug selection pressure and lead to therapy failure. The objective was to determine the prevalence of HIV-1 minority species harbouring the K103N mutation.

Methods : 160 therapy-naïve patients from Germany were included in this evaluation (68\% subtype B; $13 \%$ non-B subtype). There were no major NNRTI resistance mutations detectable by direct sequencing. Minor populations of drug resistant variants were detected by quantitative real-time PCR using allele-discriminating oligonucleotides for the reverse transcriptase mutation K103N according to Metzner et al. 2006. 34 therapy-naïve patients exhibited genotypic differences at NNRTI resistance-associated sites compared to wildtype viruses.

Results: Minority K103N variants, representing $0.5 \%$ to $16 \%$ of the viral population, could be detected in 12 patients $(7.5 \%)$ by sensitive real-time PCR testing (6 with non-B subtype). 2 of these patients showed additional substitutions at NNRTI resistance-associated sites. In addition, there was no evidence for a more frequent occurrence of minority $\mathrm{K} 103 \mathrm{~N}$ variants in patients already showing other resistance-associated mutations as determined by conventional sequencing.

Conclusions: There might be a considerable proportion of transmitted HIV-1 drug resistance undetectable by conventional genotyping. Similar to recent publications where prevalences of minor $\mathrm{K} 103 \mathrm{~N}$ variants are reported in $4.7 \%-20.9 \%$ of patients $(n=211 / n=163)$, we report an occurrence of $\mathrm{K} 103 \mathrm{~N}$ variants in $16.5 \%$ of therapy-naïve patients, indicating a minor impact on treatment efficacy. However, to date there is still no validated clinical cut-off for minor K103N populations regarding their impact on clinical outcome. Nevertheless, an early identification of drug-resistant HIV-1 variants by sensitive baseline drug resistance testing remains a challenge with an important role in future therapy management. 


\section{P445 (PD)}

Tenofovir- and protease inhibitor-use are associated with an Increased prevalence of proximal renal tubular dysfunction in the SHCS

Christoph Andreas Fux ${ }^{1}$, Milos Opravil ${ }^{2}$, Matthias

Cavassini ${ }^{3}$, Alexandra Calmy ${ }^{4}$, Ben Spycher ${ }^{5}$, Barbara

Hass $^{2}$, Patrick Schmid ${ }^{6}$, Marcel Stöckle 7 , Vanina

Gurtner De la Fuente ${ }^{8}$, Hansjakob Furrer ${ }^{1}$, SHCS

${ }^{1}$ Universitätsspital Bern, Universitätsklinik für Infektiologie,

Bern, Switzerland, ${ }^{2}$ Universitätsspital Zürich / Klinik für Infektionskrankheiten, Zürich, Switzerland, ${ }^{3}$ Centre

Hospitalier Universitaire Vaudois and University of Lausanne, Lausanne, Switzerland, ${ }^{4}$ Hôpital Universitaire de Genève, Genève, Switzerland, ${ }^{5}$ Institut für Sozial- und

Präventivmedizin Universität Bern, Bern, Switzerland,

${ }^{6}$ Kantonsspital St. Gallen / Klinik für Infektionskrankheiten, St. Gallen, Switzerland, ${ }^{7}$ Universität Basel, Basel,

Switzerland, 8Ospedale Civico, Lugano, Switzerland

Background: Tenofovir (TDF)-use has been associated with proximal renal tubulopathy (PRT). Excessive renal phosphate losses are of particular concern, as they may stimulate compensatory bone resorption. The prevalence of PRT and as sociated risk factors in HIV-positive patients are unknown.

Methods: We performed a cross-sectional analysis of proximal renal tubular function within a large observational HIV-cohort. We measured 1) the fractional excretion of phosphate (FE_p), 2) the fractional excretion of uric acid, 3 ) the urine protein/creatinine ratio and 4) euglycemic glucosuria in fasting state. PRT was defined as $\geq 3 / 4$ pathological parameters. A FE_p $>20 \%$ ( $>10 \%$ if hypophosphatemic) was considered pathological. Logistic regression analyses were performed to identify associated risk factors.

Results: We included 1.202 consecutive patients. Compared to TDF- and PI-sparing cART, the prevalence of PRT and a pathological FE_p was higher in TDF-treated individuals $(\mathrm{p}=0.06$ and $\mathrm{p}<0.001$, respectively) and highest $(11.5 \%$ and $41.5 \%)$ in patients under combined TDF/PI treatment $(\mathrm{p}<0.001$ each). The calculated glomerular filtration rate was significantly higher in treatment-naïve patients. In multivariable logistic regression the use of TDF (OR 3.3, 95\% CI 1.6-7.0), protease inhibitors $(1.8,1.0$ $3.3)$, age $(1.6,1.2-2.1$ for every 10 years $)$ and BMI $(0.9$, 0.8-0.9) were associated with PRT, while the use of TDF $(2.6,1.9-3.6)$, protease inhibitors $(1.5,1.1-2.0)$, age $(1.3,1.1-1.5)$ and female sex $(0.5,0.3-0.7)$ were associated with a pathological FE_p. IVDU, CDC-stage, CD4 count, viral load, and the duration of HIV-infection or antiretroviral treatment did not show significant associations. Conclusions: Proximal renal tubular dysfunction, and particularly excessive renal phosphate losses, is frequent in cART-treated patients. The prevalence is increased in patients treated with TDF and a PI. A - pathophysiologically plausible - connection between the documented renal dysfunction and the high prevalence of osteopenia in HIVpositive patients should be assessed in further studies.

\section{$P 446$}

\section{$12 \mathrm{~h}$ pharmacokinetics in HIV mono- and HIV/HCV co-infected patients}

Martin Vogel ${ }^{1}$, Norbert Bertram ${ }^{2}$, Jan-Christian Wasm uth $^{1}$, Christoph Wyen ${ }^{3}$, Esther Voigt ${ }^{1}$, Carolynne Schwarze-Zander ${ }^{1}$, Thomas Sudhop ${ }^{4}$, Gerd Fätkenheuer ${ }^{3}$, Jürgen Kurt Rockstroh ${ }^{1}$, Christoph Reichel ${ }^{1}$

${ }^{1}$ Bonn University, Department of Internal Medicine I, Bonn, Germany, ${ }^{2}$ LTA Labor für Toxikologie und Analytik, Königswinter, Germany, ${ }^{3}$ Cologne University, Department of Internal Medicine I, Cologne, Germany, ${ }^{4}$ Bundesinstitut für Arzneimittel und Medizinprodukte (BfArM), Bonn, Germany

Objective: An increased risk of drug related liver injury has been repeatedly reported in hepatitis $\mathrm{C}$ infected individuals receiving the antiretroviral drug nevirapine. This study was undertaken to assess differences in the pharmacokinetics of nevirapine between patients with $\mathrm{HCV} / \mathrm{HIV}$ coinfection and HIV-infection which could explain higher rates of hepatotoxicity.

Methods: HIV-monoinfected or HIV/HCV coinfected patients who were on a stable nevirapine containing HAART for more than 4 weeks were included. Nevirapine was dosed $200 \mathrm{mg}$ twice daily for all subjects. Liver disease other than chronic $\mathrm{HCV}$ or liver cirrhosis had to be ruled out. After a first blood withdrawal in a fasted state and a standardized breakfast together with one tablet of $200 \mathrm{mg}$ nevirapine PK samples were taken at 1,2, 4, 6 and 12 hours thereafter.

Results: 18 patients were recruited into the study, 7 patients with $\mathrm{HCV} / \mathrm{HIV}$ coinfection and 11 with HIV-monoinfection. Comparison of HCV/HIV coinfected patients with HIV-monoinfected patients showed no differences with regard to general demographic parameters. Except for significantly higher liver trans aminases HCV coinfected patients showed comparable parameters of synthetic liver function and HIV surrogate markers as HIV-monoinfected patients .

Comparing pharmacokinetic parameters no differences were observed comparing minimum nevirapine plasma concentrations, as well maximum drug level and AUC of nevirapine between the HIV-monoinfected and HIV/HCV coinfected patients.

Conclusion: Hepatitis C coinfection does not alter the pharmacokinetic of nevirapine in patients with preserved liver function.

\section{P447}

Impact of resistant HIV on first line treatment response in therapy naive patients of the German HIV-1-s eroconverter cohort

Barbara Bartmey er ${ }^{1}$, Claudia Houareau ${ }^{1}$, Claudia Kücherer $^{2}$, Christian Kollan ${ }^{1}$, Johanna Werning ${ }^{1}$, Os amah Hamoudal, Deutsche HIV-1 Seroconverter Studiengruppe

${ }^{1}$ Robert Koch-Institut, Abteilung für Infektionsepidemiologie, HIV/AIDS und andere sexuell und durch Blut übertragbare Erkrankungen, Berlin, Germany, ${ }^{2}$ Robert Koch-Institut, Projekt HIV Variabilität und Molekulare Epidemiologie, Berlin, Germany

Objective: To analyse the impact of transmitted drug resistance on early antiretroviral treatment response in pre- 
viously treatment naïve patients with a known date of HIVinfection.

Methods: As of 31.12. 2007 a total of 1,564 patients with a known date of HIV-infection were included in a national multi-centre observational cohort. Genotypic resistance analysis was performed in 1,276/1,312 treatment naïve samples. Mutations were identified according to the surveillance drug resistance mutations list (SDRM; Shafer RW. et al. 2008). Phenotypic resistance was predicted with the Stanford algorithm (version 4.3.1, 2007). Treatment success was determined as viral suppression $\leq 500$ copies/ml measured by any low level detection system ( $\leq 400 ; \leq 50 ; \leq 40$ copies $/ \mathrm{ml})$.

Results: First line therapy was initiated in 378/1,119 (33.8\%) patients with susceptible wild type and in $65 / 157$ (41.4\%) patients with resistant viruses. Time between seroconversion and cART initiation did not differ significantly between both groups (median, susceptible: $330 \mathrm{~d}$; IQR 65.8-652.5 vs. resistant: 442d; IQR 134-660; p = 0.12). Initial CD4-cell counts were comparable in both groups (median, susceptible: 331 cells/ $\mu 1$ vs. resistant: 345 cells $/ \mu 1 ; \mathrm{p}=0.88)$. Initial viral load was lower in patients with resistant HIV $(129,500$ copies/ml $)$ but did not differ significantly to the susceptible group (median, susceptible: 182,500 copies $/ \mathrm{ml} \quad \mathrm{p}=0.22$ ). Boosted dual NRTI/PI regimen were preferred for first line therapy in both groups (susceptible: 173/378; $45.8 \%$ vs. resistant: $40 / 65,61.5 \%$ ). Treatment success was not achieved in more than half of patients in both groups after 6 months (susceptible: $151 / 266 ; 56.8 \%$ vs. resistant: 30/52; $57.8 \%$ ). 12 months after ART initation constant viral suppression remained low in both groups (susceptible: 57/266, 21.4\% vs. resistant: 14/52, 26.9\%), respectively. Conclusion: The low proportion of treatment success in both groups needs further attention. Poor treatment outcome may indicate that treatment decisions were not only influenced by resistance testing results but were heavily affected by adherence and drug toxicity.

\section{P448}

Quantitative and qualitative mtDNA-lesions with mitochondrial dysfunction in multiple organs after HAART-associated fatal lactacidos is

Jan Thoden ${ }^{1}$, Dirk Lebrecht ${ }^{1}$, Nils Venhoff ${ }^{1}$, Jens $H$. Neumann $^{2}$, Klaus Müller ${ }^{3}$,Ulrich A. Walker ${ }^{1}$

${ }^{1}$ Medizinische Universitätsklinik Freiburg, Rheumatologie und Klin. Immunologie, Freiburg, Germany,

${ }^{2}$ Universitätsklinikum Freiburg, Institut für Pathologie,

Freiburg, Germany, 3Universitätsklinikum Freiburg, Institut für Neuropathologie, Freiburg, Germany

Background: We describe a 62 year-old HIV-infected male, being treated with didanosine (ddI), stavudine (d4T) and efavirenz, who died with lactacidosis. After 16 months of therapy he developed hyperlactatemia $(3.7 \mathrm{mmol} / 1$ [normal <2.2]) without acidosis. Two months later after increasing lactic acidosis ( $\mathrm{pH} 6.9$, lactate $27 \mathrm{mmol} / 1)$ requiring ICU-treatment he died in multiorgan failure without signs of infection.

Methods: Post-mortem, mtDNA copy numbers of liver, skeletal muscle (SM), heart (HM) and kidney were measured by PCR and compared with control autopsies [1].

Results: MtDNA levels were profoundly depleted: liver $7 \%$, kidney $20 \%$, SM $28 \%$, HM $72 \%$. MtDNA of HM and SM showed large scale deletions (8 HM / $3 \mathrm{SM}$ ) [1]. Sequencing confirmed the DNA fragments to be mitochondrial. Western Blotting of SM and HM proteins showed depressed mtDNA-encoded respiratory chain component COXII in relation to nucleus (nDNA) encoded COXIV. Spectrophotometry revealed reduced activities of COX and NADH dehydrogenase which require an intact mitochondrial genome in both tissues. nDNA encoded activities were preserved [Table1]. The ultrastructure of both organs showed mitochondrial damage [Figure 1].

Discussion: This is the first investigation of multiple organs showing severe biochemical and ultrastructural damage secondary to HAART-induced mtDNA lesions. Lactic acidosis is a life-threatening complication of HAART. ddI and $\mathrm{d} 4 \mathrm{~T}$ are strong inhibitors of polymerasegamma which induces mtDNA depletion in adipose tissue and liver [1]. Respiratory chain dysfunction promotes liberation of reactive oxygen species at the respiratory chain, which can at-

\begin{tabular}{|c|c|c|c|c|c|}
\hline & \multicolumn{2}{|c|}{ Heart } & \multicolumn{2}{|c|}{ Skeletal muscle } & \multirow{3}{*}{$\begin{array}{l}\text { [Table 1.] Mitochondrial parameters in pati- } \\
\text { ent tissues in comparison with autopsy mate- } \\
\text { rial from nine controls deemed free of organ } \\
\text { pathology. Control values represent group } \\
\text { means }( \pm \text { SD). }\end{array}$} \\
\hline & Controls & Patient & Controls & Patient & \\
\hline mtDNA copies/ nucleus & $622 \pm 77$ & 451 & $239 \pm 73$ & 66 & \\
\hline Large scale mtDNA deletions & None & +++ & None & ++ & \\
\hline COXII/COXIV-ratio (\% of control mean) & $100 \pm 6$ & 67 & $100 \pm 19$ & 72 & \\
\hline COX activity ( $\mu$ moles $\min ^{-1} \mathrm{~g}$ protein ${ }^{-1}$ ) & $2.7 \pm 0.7$ & 0.8 & $3.1 \pm 1.2$ & 1.1 & \\
\hline COX/SDH-ratio (\% of control mean) & $100 \pm 33$ & 18 & $100 \pm 76$ & 24 & \\
\hline Citrate synthase activity ( $\mu$ moles $\min ^{-1} \mathrm{~g}$ protein ${ }^{-1}$ ) & $147 \pm 26$ & 161 & $152 \pm 19$ & 140 & \\
\hline NADH dehydrogenase activity ( $\mu$ moles $\min ^{-1} g$ protein ${ }^{-1}$ ) & $84 \pm 12$ & 90 & $86 \pm 21$ & 106 & \\
\hline NADH dehydrogenase /SDH-ratio (\% of control mean) & $100 \pm 39$ & 61 & $100 \pm 56$ & 90 & \\
\hline
\end{tabular}



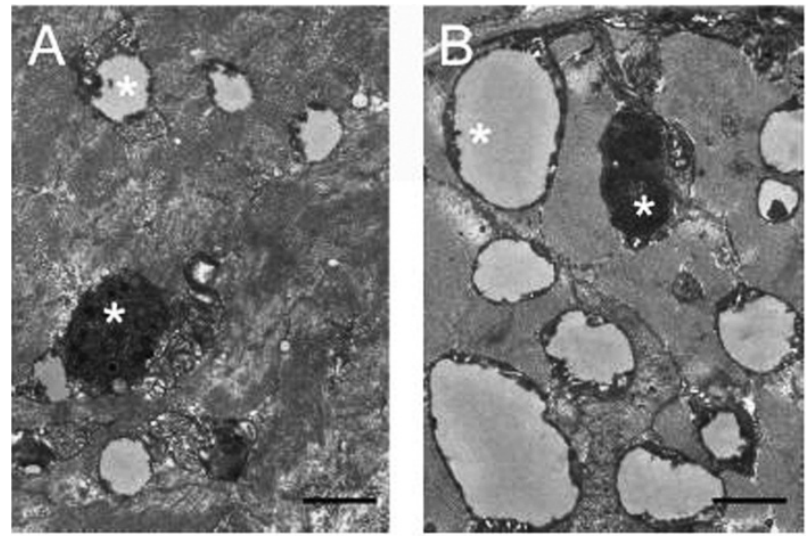

[Fig.1.] Representative electron micrographs from skeletal muscle (A) and heart muscle (B) demonstrating mitochondria with a disturbed crystal achitecture (*) and harbouring electron dense material. Bar $=1 \mu \mathrm{m}$.

tack the respiratory chain itself or induce mitochondrial mutations, leading to mtDNA deletions. A vicious circle of interconnected mtDNA and respiratory chain insults may arise and contribute to organ failure. MtDNA depletion is not confined to single tissues, but is a multisystem complication. Supportive therapy of hyperlactatemia and lactate acidosis may include uridine supplementation which has demonstrated efficacy on mitochondrial toxicity and hyperlactatemia [2].

\section{P449}

\section{Coronary heart disease and risk factors in HIV-1-infected patients in correlation to abacavir treatment}

Thomas Harrer ${ }^{1}$, Almut Taubald ${ }^{1}$, Ellen G. Harrer ${ }^{1}$, Christina Schaub-Koch ${ }^{1}$, Anja Reisch ${ }^{1}$, Sandra M. Müller $^{1}$, Bernd Spriewald ${ }^{2}$, Mohamed Marvan ${ }^{3}$, Frank Flachskampf ${ }^{3}$, Stephan Achenbach ${ }^{3}$, Dieter Ropers ${ }^{3}$, German Competence Network for HIV/AIDS

${ }^{1}$ University Hospital Erlangen, Department for Internal Medicine 3, Erlangen, Germany, ${ }^{2}$ University Hospital Erlangen, Department of Internal Medicine 5, Erlangen, Germany, ${ }^{3}$ University Hospital Erlangen, Department of Internal Medicine 2, Erlangen, Germany

Introduction: In the DAD study and in SMART Abacavir $(\mathrm{ABC})$ has been associated with an increased risk of myocardial infarction and higher levels of inflammatory serum markers, however, this has not been confirmed in other studies.

Methods: To assess the influence of Abacavir on coronary heart disease (CHD) and known risk factors for CHD we analyzed coronary calcification by $\mathrm{CT}$ and serum levels of inflammatory markers such as hs-CRP, TNF-alpha, and IL6 in correlation to the use of ABC (current or ever, respectively). In addition, we tested whether myocardial infarction could represent a HLA B57-as sociated hypersensitivity to $\mathrm{ABC}$.

Results: So far, 101 patients on HAART were analyzed for coronary calcifications. In univariate analyses coronary calcification scores showed no statistical difference between the 64 patients with current or past use of Abacavir in comparison to 37 treated patients not exposed to Abacavir. In ongoing analyses, there were no significant differences between patients on HAART with or without a cur- rent use of $\mathrm{ABC}$ regarding serum levels of hs-CRP, TNF-alpha, IL6 and lipids. HLA typing could be performed in 9 patients with severe coronary heart disease, defined as myocardial infarction or symptomatic CHD treated by stent implantation. 7 of these 9 patients were on treatment with Abacavir, however, none was HLA B57 positive. The only HLA B57 positive patient with severe CHD (frequency $11.1 \%$ ) was on a combination regimen consisting of D4T,3 TC and EFV.

Conclusion: So far, preliminary univariate analyses failed to detect a significant influence of current or past Abacavir treatment on coronary calcifications and the presence of inflammatory markers in serum. Multivariate analyses in larger numbers of patients will be necessary to define a potential influence of $\mathrm{ABC}$ on coronary heart disease. Our data do not support a role of HLA B57-associated hypersensitivity for myocardial infarctions in patients on $\mathrm{ABC}$.

\section{P450}

\section{Detection of abacavir hypersensitivity by ELISpot method}

Stefan Esser ${ }^{1}$, Robert Jablonka ${ }^{1}$, Falko M. Heinemann ${ }^{2}$, Monika Lindemann ${ }^{2}$

${ }^{1}$ HIV/STD-Ambulanz, Klinik für der Dermatologie und Venerologie, Universitätsklinikum, Essen, Germany,

2Institut für Transfusionsmedizin, Universitätsklinikum, Essen, Germany

Abacavir (ABC) causes a potentially fatal hypersensitivity reaction (HSR) in $5-8 \%$ of HIV-infected patients occurring usually within the first 6 weeks after starting treatment. HSR is diagnosed clinically and, actually, the testing for HLA-B*5701 becomes available as a further predictive test. The correlations between the occurrence of HSR, patch test reactions to ABC, and HLA-B*5701 are evaluated in the PREDICT Study. A safe diagnostic tool to confirm ABC-HSR is mandatory. Therefore, we here evaluated an ELISpot method to measure cellular in vitro responses to ABC. ABC-ELISpot was performed in HIV-infected patients with clinically determined HSR to ABC who had stopped the $A B C$ treatment for more than 6 weeks $(n=11)$ and HIVpatients taking $\mathrm{ABC}$ for more than 12 weeks without suspected HSR (control group, $n=13$ ). Twenty of the HIV-patients were male, 4 female, the average CD4 T cell count was $338 / \mathrm{ml}$ (range 26-954). Peripheral blood mononuclear cells from all patients were stimulated by 1,4 , and 10 $\mathrm{mg} / \mathrm{mL}$ of abacavir sulfate in $200 \mathrm{~mL}$ of cell culture medium. Following preincubation for 2 days, the cells were incubated in ELISpot plates for 2 further days and the production of interferon-gamma producing cells was measured. Patients with vs. without HSR displayed a significantly

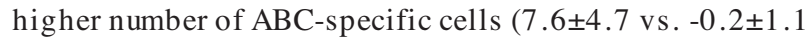
spots increment, $\mathrm{P}=0.03$ ). Using a threshold of 2 spots increment - which was determined by discrimination and receiver operating curve (ROC) analyses - HSR could be predicted with a sensitivity of $64 \%$ and a specificity of $85 \%$. Of note, 2 patients were HLA-B*5701 positive, both suffered from HSR, and both were positive to the ELISpot. Thus, we established the first ABC-specific ELISpot which appears as an additional tool to detect HSR retrospectively. Its application could avoid the risk of life-threatening reactions during rechallenge with $\mathrm{ABC}$ in HIV-patients with vague suspicion of HSR. 


\section{P451}

\section{A German cohort of $54 \mathrm{HIV}$ and LPV/r exposed pregnancies - pharmacokinetics, placental transfer and pregnancy outcome}

Milena Sovric, Andrea Gingelmaier, Ralph Kaestner, Tobias Weissenbacher, Ionnis Mylonas, Klaus Friese

Ludwig-Maximilians-Universität München, Universitätsfrauenklinik, München, Germany

Background: The aims of this study were:

a. to assess pregnancy complications and outcome of HIV infected woman taking a Lopinavir/Ritonavir (LPV/r) containing regimen and

b.to evaluate placental transfer and maternal pharmacokinetics of LPV/r.

Methods: Analysis of 54 pregnant women (20 retrospective, 34 prospective cases) receiving a LPV/r containing ART (2004-2008). LPV/r drug levels in maternal and foetal compartments were measured at the day of delivery. Pregnancy complications, mode of delivery, infant outcome and maternal CD4-count and viral load were evaluated.

Results: The 54 cases resulted in 57 live births including three multiple pregnancies (85\% cesarean section, $15 \%$ vaginal delivery) with 14 cases $(26 \%)$ of preterm birth < $37+0 \mathrm{GA}$, among those 7 cases due to premature rupture of membranes. Maternal viral load at delivery was below detection rate $(<50$ copies $/ \mathrm{ml})$ in $74 \%$ and CD4 count was between 80-969/ $\mu 1$ (mean: 483/ $/ 1$ ). Pharmacokinetic data were obtained in $80 \%$ of the prospective cases, showing in $70 \%$ of the women lower drug levels than recommended for LPV. The placental transfer of LPV was also very low with mean cord-to-mother-ratio of 0,20 and mean amniotic-fluid-to-mother-ratio of 0,09 . There was no vertical HIVtransmission, minor birth defects were identified in 5 cases.

Conclusions: LPV/r during pregnancy was associated with a high risk of preterm birth though being effective regarding prevention of MTCT of HIV. Low concentrations of LPV in the foetal compartments reduce the possible teratogenic effects whilst the risk reduction of vertical HIV transmission seems not to be affected. Despite low maternal drug levels of LPV the virological response was satisfying.

\section{P452}

Frequent pyridoxal phosphate (PLP) inadequacy associated with the use of RTV-boosted protease inhibitors

Hans-Jürgen Stellbrink 1,2, Andreas Lämmel ${ }^{2}$, Christian Noah ${ }^{2}$

${ }^{1}$ ICH Study Center, Hamburg, Germany, ${ }^{2}$ IPM Biotech / Labor Lademannbogen, Hamburg, Germany

Background: Vitamin B6 is essential for a multitude of physiological functions, including immune and neural function. Guided by observations of vitamin B6 deficiency in subjects with peripheral neuropathy, we assessed the frequency of B6 deficiency and possible associations with HAART.

Methods: The B6 vitamers pyridoxal phosphate (PLP), pyridoxal and pyridoxine were measured by HPLC in 73 HIV-positive subjects (61 men, 12 women; RF: MSM 36, heterosexual transmission 15, IVDA 4 , blood products 6 , others 12). 9 were ART-naïve/untreated, 28 received PI/rbased, and 33 NNRTI-based HAART. Vitamin B1, B2, B12, 25-OH- and 1,25-OH-cholecalciferol, and folic acid levels were determined in parallel in a sub-group.

Results: Levels of PLP, but not of the other vitamers, were significantly reduced in patients on $\mathrm{PI} / \mathrm{r}$ in comparison with untreated subjects and those on NNRTI ( $\mathrm{p}=$ 0.0002 , Kruskal-Wallis). Accordingly, subnormal PLP levels were significantly more frequent in the $\mathrm{PI} / \mathrm{r}$ group ( $p=0.0017$, Chi-Square). PLP levels were positively correlated with $\mathrm{HDL}$ and negatively with with $\mathrm{MCV}$, triglycerides, and glucose ( $p<0.05$; Spearman's rank). The MCV correlation lost significance when excluding subjects on thymidine analogues. There was no difference with respect to levels of vitamins B1, B2, B12, 25-OH- and 1,25-OHcholecalciferol, and folic acid. 12 patients with subnormal PLP levels received oral vitamine B6 supplementation (40 mg QD). Levels were significantly higher during substitution ( $\mathrm{p}=0.0051$, Wilcoxon test for paired samples) and achieved normal levels in 11/12 subjects. No correlation was observed between PLP levels and AP.

Conclusions : Patients on PI/r-based HAART have lower levels of PLP and more frequently exhibit inadequately low PLP levels. The correlation with HDL, glucose, and triglycerides could reflect metabolic effects of PLP inadequacy. Oral supplementation normalises PLP levels, indicating increased turnover rather than decreased absorption.

\section{$P 453$}

Transmission of a highly RT-and proteaseinhibitor resistant virus demonstrates the importance of resistance analysis prior to initiation of HAART

Thomas Harrer ${ }^{1}$, Klaus Korn ${ }^{2}$, Hauke Walter ${ }^{2}$, Sandra M. Müller $^{1}$, Werner Matek ${ }^{3}$, Ellen G. Harrer ${ }^{1}$, German Competence Network for HIV/AIDS

${ }^{1}$ University Hospital Erlangen, Department for Internal Medicine 3, Erlangen, Germany, 2University Hospital Erlangen, Institute of Virology, Erlangen, Germany, ${ }^{3}$ Klinikum Coburg, Coburg, Germany

Introduction: Transmission of drug resistant HIV-1 is a major concern for antiretroviral treatment. Here, we describe a patient infected by a multidrug resistant HIV-1 strain displaying resistance to a variety of NRTIs and PIs.

Results: In 2001 the patient had been diagnosed with HIV-1-infection presumably acquired by a heterosexual contact in Germany in 2000 . He showed a low viral load of 1100 copies $/ \mathrm{ml}$ and a normal CD4 count of $672 / \mu 1$. In $9 / 2006$, at a CD4 count of $468 / \mu 1$ and a viral load of $3600 / \mu 1$, genotypic resistance analysis showed a highly resistant virus with presence of following resistance associated mutations: RT: M41L, D67N, S68GS, T69NS, H208Y, T215ST, K219Q. Protease: L10I, L33F, F53L, A71 V, V77I, L90M. According to www.hiv-grade these mutations confer resistance to AZT, D4T, TDF, ATV and NFV, intermediate resistance to DDI, APV, IDV, SQV/r, LPV/r and lowered sensitivity to APV/r, IDV/r, TPV/r. Sensitivity was preserved to $3 \mathrm{TC}$, FTC, $\mathrm{ABC}$, all NNRTIs and darunavir/r. Analysis of genotypic resistance from a plasma sample stored in 4/2005 showed an almost identical sequence (99\% homology) and resistance pattern, except for 
the lack of the S68G mutation in RT. In 10/2006 he developed a diffuse large cell B-NHL that was treated with $8 \mathrm{cy}$ cles $\mathrm{CHOP}$ and rituximab. Based on the resistance analysis an antiretroviral combination therapy consisting of $\mathrm{ABC}$, 3TC, darunavir/ $\mathrm{r}$ and enfuvirtide was started after the first cycle of chemotherapy. After suppression of viral load to < 50 in 4/2007 enfuvirtide could be stopped with ongoing effective viral suppression.

Conclusion: This case demonstrates the importance of resistance analysis prior to initiation of HAART. Treatment by frequently used drug combination regimens such as TDF, FTC and EFV or ATV/r would have surely led to treatment failure and development of further resistance mutations in RT, thereby severely compromising further therapeutic options.

\section{P454 (LB)}

Frequency of lipodystrophy in a large observational cohort using either LPV/r or EFV

Jan van Lunzen ${ }^{1}$, Ramona Pauli ${ }^{2}$, Stefan Hansen ${ }^{3}$, Martin Hower $^{4}$, Clemens Scheidegger ${ }^{5}$, Antonius Mutz ${ }^{6}$, Andreas Trein ${ }^{7}$

${ }^{1}$ Universitaetsklinikum Hamburg-Eppendorf, Hamburg, Germany, ${ }^{2}$ Praxis Dres R.Volkert / W. Becker, München, Germany, ${ }^{3}$ ICH (Infektionsmedizinisches Centrum Hamburg), Hamburg, Germany, ${ }^{4}$ ID Ambulanz Med. Klinik Nord Klinikum Dortmund, Dortmund, Germany, ${ }^{5}$ Praxis Fuderer/Scheidegger, München, Germany, ${ }^{6}$ Klinikum Natruper Holz, Osnabrück, Germany, ${ }^{7}$ HIV Center Stuttgart, Stuttgart, Germany

Background: A higher rate of lipoatrophy (LA) was reported in randomized clinical trials (e.g. ACTG 5142) in association with the use of efavirenz (EFV) compared to boosted lopinavir (LPV/r). However, this effect was preferentially observed in patients receiving these drugs in combination with more toxic nucleoside (NA) backbones (e.g. d4T, ddI, AZT). Clinical observations with more contemporary NA are largely missing.

Objective: Comparison of frequency of lipoatrophy of EFV vs. LPV/r in combination with contemporary NA.

Methods: Patients were enrolled into this cross-sectional analysis after informed consent. LA was assessed by the treating physician and the patient using standardized questionnaires. Medical and treatment history, anthropometric and laboratory data were analysed to detect any differences or associations by descriptive statstics.

Results : A total of 332 patients were enrolled (165 EFV vs. $139 \mathrm{LPV} / \mathrm{r}), 28 \mathrm{pts}$. were not eligible for analysis. Groups were well matched concerning characteristics at baseline and time of observation (VL, CD4, gender, ethnicity, NA backbone). Median duration of therapy was 3.5 years, TDF/FTC or $3 \mathrm{TC}$ was the most frequently used NA backbone (45\%), followed by $\mathrm{ABC} / 3 \mathrm{TC}$ (12\%). TG were higher in the LPV/r group (median 206 vs. $145 \mathrm{mg} / \mathrm{dl}, \mathrm{p}<$ $0.05)$, no differences were detected in LDL and HDL cholesterol; CD4 count increase from baseline was identical $(+303$ cells $/ \mu 1)$. Significant differences were observed in favour of LPV/r in waist to hip ratio, loss of limb fat and lipaccumulation in breasts $(p<0.05)$ with a high concordance of physician and self reported assessments. These changes were most pronounced when using AZT, d4T or ddI as a NA backbone.

Conclusions: EFV and LPV/r containing regimens were equally effective in this observational cohort. Despite higher TG levels in the LPV/r group, more limb fat loss and trunk fat accumulation was reported in the EFV group even in combination with contemporary NA backbone.

\subsection{Koinfektionen, Tumoren, OIs / Coinfections, Tumors, OIs}

\section{P455 (PW) \\ The definition "acute" does not influence SVR in HIV-positive individuals treated with pegylated interferon $+/$ - interferon after acute $\mathrm{HCV}$ infection}

Martin Vogel ${ }^{1}$, Axel Baumgarten ${ }^{2}$, Kevin Ummard ${ }^{3}$, Michael Rausch ${ }^{4}$, Knud Schewe ${ }^{5}$, Christoph Mayr ${ }^{6}$, Dietmar Schranz ${ }^{7}$, Albert Theisen ${ }^{8}$, Heiko Jessen ${ }^{9}$, Stefan Fenske ${ }^{5}$, Thomas Lutz ${ }^{10}$, Bernhard Bieniek ${ }^{11}$, Christoph Schuler ${ }^{12}$, Tim Kümmerle ${ }^{13}$, Stefan Mauss ${ }^{14}$, Bettina Hintsche ${ }^{15}$, Daniela Behrendt ${ }^{2}$, Jörg Gölz ${ }^{3}$, Jürgen Kurt Rock stroh ${ }^{1}$

${ }^{1}$ Bonn University, Department of Internal Medicine I, Bonn, Germany, ${ }^{2}$ Praxis Dupke / Baumgarten / Carganico, Berlin, Germany, ${ }^{3}$ Praxiszentrum Kaiserdamm, Berlin, Germany, ${ }^{4}$ Praxis Freiwald / Rausch, Berlin, Germany,

5 Infektionsmedizinisches Centrum Hamburg (ICH), Hamburg, Germany, ${ }^{6}$ Ärzteforum Seestraße, Berlin, Germany, ${ }^{7}$ Praxis

Schranz und Fischer, Berlin, Germany, ${ }^{8}$ Praxis Wiesel /

Theisen / Voigt, Köln, Germany, ${ }^{9}$ Praxis Jessen, Berlin, Germany, ${ }^{10}$ Infektiologikum, Frankfurt / Main, Germany,

${ }^{11}$ Praxis City Ost, Berlin, Germany, ${ }^{12}$ Praxisgemeinschaft

Turmstrasse, Berlin, Germany, ${ }^{13}$ Cologne University,

Department of Internal Medicine I, Cologne, Germany,

${ }^{14}$ Gemeinschaftspraxis Mauss / Schmutz / Hegener / Athmann, Düsseldorf, Germany, ${ }^{15}$ Praxis Hintsche / Klausen, Berlin, Germany

Introduction: Treatment of acute HCV (AHC) in HIVpositive individuals showed higher sustained virological response rates (SVR) compared to historic data of patients with chronic HCV. In practice the diagnosis of AHC is difficult and the definition used for establishing the diagnosis of AHC may impact treatment outcome.

Methods: Interim analysis of a multicenter, prospective, non-randomized study. Per protocol AHC was present if 2 of the 3 following criteria were met within the past 4 months:

1.exposure to $\mathrm{HCV}$,

2. ALT > $350 \mathrm{IU} / 1$ with normal transaminases the year before,

3. seroconversion of anti-HCV or HCV-RNA.

For epidemiological reasons any case reported with suspected AHC was kept on file, however. Patients who were treated with pegylated interferon +/-ribavirin and with SVR data available were included in the analysis.

Results : 75 male patients with a median age of 38 years were identified. Main HCV transmission risk factor was sexual (84\%), median CD4-cellcount $437 / \mu 1,56 \%$ were on HAART. AHC was defined by seroconversion of anti-HCV or HCV-RNA in the last $4(\mathrm{n}=33$, group $\mathrm{A})$ or in the last 12 months ( $\mathrm{n}=19$, group $\mathrm{B})$, or by expert opinion only $(n=25$, group $C)$. Baseline characteristics did not differ among groups except for maximum ALT and CD4-cellcount (Table 1). 


\begin{tabular}{|c|c|c|c|c|}
\hline & $\begin{array}{l}\text { Group A } \\
\text { Convers. }<4 \text { mo } \\
\text { n=31 }\end{array}$ & $\begin{array}{l}\text { Group B } \\
\text { Convers. }<12 \text { mo } \\
\mathrm{n}=19\end{array}$ & $\begin{array}{l}\text { Group C } \\
\text { Expert Opinion } \\
n=25\end{array}$ & p-value \\
\hline \multicolumn{5}{|l|}{ HCV-Genotype } \\
\hline 1 & $22(71 \%)$ & $10(53 \%)$ & $18(72 \%)$ & \\
\hline 2 & $3(10 \%)$ & $1(5 \%)$ & $1(4 \%)$ & \\
\hline 3 & $1(3 \%)$ & $3(16 \%)$ & $4(16 \%)$ & 0.244 \\
\hline 4 & $2(7 \%)$ & $5(26 \%)$ & $2(8 \%)$ & \\
\hline other & $3(10 \%)$ & - & - & \\
\hline HCV-RNA [log10] & 6.4 & 5.9 & 5.8 & 0.271 \\
\hline Symptomatic Infection & $10(32 \%)$ & $7(37 \%)$ & $10(40 \%)$ & 0.679 \\
\hline Median maximum ALT [IU/I] & 214 & 361 & 593 & 0.014 \\
\hline \multicolumn{5}{|l|}{ CD4-cells } \\
\hline$[/ \mu \mathbf{l}]$ & 375 & 439 & 531 & 0.012 \\
\hline$[\%]$ & 20 & 22 & 25 & 0.098 \\
\hline HAART & $18(58 \%)$ & $11(58 \%)$ & $13(52 \%)$ & 0.914 \\
\hline HIV-RNA [log10] & 4.9 & 4.7 & 4.7 & 0.612 \\
\hline Ribavirin-Usage & $23(74 \%)$ & $11(58 \%)$ & $19(76 \%)$ & 0.424 \\
\hline Treatment Duration [weeks] & 27.3 & 27.4 & 24.3 & 0.345 \\
\hline SVR & $15(48 \%)$ & $14(74 \%)$ & $19(76 \%)$ & 0.065 \\
\hline
\end{tabular}

[Table 1]

SVR was reached in $64 \%$ of patients (48\% group A, $74 \%$ group B, $76 \%$ group C). Noteworthy, SVR rates were not different among groups.

Conclusions: High SVR rates were observed in HIV-positive patients treated with pegylated interferon +/- ribavirin after diagnosis of acute HCV. The definition of acute $\mathrm{HCV}$ infection did not influence treatment outcome. However, experts may have been biased by high ALT and patients diagnosed by experts had higher CD4-cell counts, both factors which have been associated with better treatment outcome.

\section{$P 456(P W)$}

\section{Leberparenchymschaden bei HIV - 1 - Monoinfizierten unter anti retroviraler Therapie (ART) und chronischer Transaminas enerhöhung}

Patrick Ingiliz ${ }^{1}$, Marc-Antoine Valantin ${ }^{2}$, Claudine Duvivier ${ }^{3}$, Fadia Medja ${ }^{4}$, Stephanie Doming uez ${ }^{3}$, Frédéric Charlotte ${ }^{5}$, Roland Tubian ${ }^{3}$, Thierry Poynard ${ }^{2}$, Christine Katlama ${ }^{3}$, Anne Lombès ${ }^{4}$, Yves Benhamou ${ }^{2}$

${ }^{1}$ Vivantes Auguste-Viktoria-Klinikum Berlin, Gastroenterologie und Infektiologie, Berlin, Germany, ${ }^{2}$ Hôpital Pitié-Salpêtrière, Hepatogastroenterologie, Paris, France, ${ }^{3}$ Hôpital Pitié-Salpêtrière, Infektiologie, Paris, France, ${ }^{4}$ Hôpital Pitié-Salpêtrière, Biochemie, Paris, France, ${ }^{5}$ Hôpital Pitié-Salpêtrière, Pathologie, Paris, France

Hinterg rund: $\mathrm{Ob}$ chronisch erhöhte Transaminasen bei HIV-Patienten unter ART tatsächlich zu einem Leberparenchymschaden führen, ist nicht bekannt.

Methodik: Lebergewebe von Patienten, die länger als 6 Monaten erhöhte Transaminasen aufwiesen, wurde histologisch untersucht. Patienten mit Alkoholabusus, Hepatitis C Virus (HCV) oder Hepatitis B Virus (HBV) Infektion, autoimmunen und genetischen Lebererkrankungen wurden ausgeschlossen. In einer Untergruppe, wurde die leberspezifische mitochondriale Aktivität durch Spektrophotometrie und die mitochondriale DNA (mtDNA) durch real-time Polymerasekettenreaktion (PCR) gemessen.

Resul tate: Dreissig Patienten wurden eingeschlossen mit folgenden medianen Werten: Alanine Aminotransferase (ALT): $80 \mathrm{U} / \mathrm{L}$, Alter: 46 Jahre, Body Mass Index: 23 $\mathrm{kg} / \mathrm{m}^{2}$, HIV RNA: 200 copies/mL, CD4 Zellzahl: $365 / \mathrm{mm}^{3}$, Dauer der HIV Infektion: 13 Jahre, Dauer der Behandlungsexposition: 118,41 , und 53 Monate für Nukleosidische Reverse Transkriptaseinhibitorewn, Nicht-nukleosidische Reverse Transkriptaseinhibitoren und Proteaseinhibitoren. Histologische Veränderungen wurden bei 22 von 30 Patienten gefunden. 18 Patienten wiesen eine Steatose auf, davon in neun Fällen schwergradig, in 16 Fällen war diese mit einer Gewebsinflammation verbunden, was mit der Diagnose einer Non-alkoholischen Steatohepatitis (NASH) vereinbar war. 18 Patienten wiesen eine Leberfibrose auf, in sechs Fällen sogar schwergradig und 13 Fällen war diese mit einer Steatose verknüpft. Ein Defekt des Liver respiratory complex I, un im Gegensatz dazu erhöhte Aktivität von Complex IV und ein normaler mitochondrialer DNA Gehalt, wurde in der untersuchten Untergruppe im Vergleich zu gesunden Kontrollen gefunden. Das Auftreten der NASH korrelierte mit erhöhtem Nüchternblutzucker und Nüchterinsulinwerten, nicht jedoch mit der leberspezifischen mitochondrialen Funktion oder mit mitochondrialem DNAGehalt.

Schlus sfolgerungen: HIV-Patienten, die eine antiretrovirale Therapie einnehmen und chronisch erhöhte Transaminasen haben, haben auch häufig Leberparenchymveränderungen. In den meisten Fällen handelt es sich hierbei um eine NASH, verurs acht durch Insulinresistenz. 


\section{P457 (PW)}

Methicillin resistant Staphylococcus aureus and ESBL-producing Escherichia coli, Klebsiella pneumoniae and Klebsiella oxytoca isolated from HIV infected inpatients

Hartmut Stocker ${ }^{1}$, Bettina Eberspaecher ${ }^{2}$, Hubert Schulbin $^{1}$, Christian Traeder ${ }^{1}$, Sonja Swidsinski ${ }^{3}$, Keikawus Arasteh ${ }^{1}$

${ }^{1}$ Vivantes Auguste-Viktoria Klinikum, Gastroenterologie und Infektiologie, Berlin, Germany, ${ }^{2}$ Vivantes Klinikum Neukölln, Institut für Mikrobiologie, Berlin, Germany, ${ }^{3}$ Vivantes Klinikum Neukölln, Berlin, Germany

Background: HIV infected patients frequently require broad spectrum antimicrobial chemotherapy posing them at risk of infection with multiresistant bacteria.

We assessed the frequency of methicillin resistant Staphylococcus aureus and ESBL-producing Escherichia coli, Klebsiella pneumoniae and Klebsiella oxytoca in clinical isolates from HIV (+) and HIV (-) inpatients.

Methods: We retrospectively analysed data from patients hospitalized in the department of infectious diseases of the Vivantes Auguste-Viktoria Klinikum, Berlin from 2005 through 2008. Patients with at least one clinical sample positive for either S. aureus, E. coli, K. pneumoniae and K. oxytoca were included in the analysis. Patients whose MRSA screening test was the only positive sample were ineligible. Patterns of antimicrobial resistance were studied and the frequency of methicillin resistance and expression of ESBL was calculated for each year.

Results: During the study period the median (range) number of HIV infected patients hospitalised at least once in our clinic was 614/year (528 - 698) accounting for a median of 912 hospitalisations/year. 1138 clinical samples from $416 \mathrm{HIV}(+)$ individuals were positive for either S. aureus, E. coli, K. pneumoniae or K. oxytoca. In $20051,3 \%$ of patients with at least one isolate positive for E. coli, K. pneumoniae or K. oxytoca had one or more samples containing an ESBL producing strain. This number rose to $5,9 \%, 5,4 \%$ and $5,6 \%$ in the following years.

Methicillin resistance was found in 8,1\% (2005), 9,9\% (2006) $13,6 \%$ (2007) and 7,8\% (2008) of patients with one or more samples positive for S. aureus. HIV (-) patients had fewer $(1,2 \%)$ ESBL-producing and more (40,8\%) methicillin resistant strains.

Dis cussion: ESBL-producing gram negative rods and methicillin resistant $\mathrm{S}$. aureus are important pathogens, yet their frequency among HIV (+) patients is still low.

\section{P458 (PW)}

Vergleich von TST, QuantiFERON-Gold InTube und T-Spot.TB bei HIV-Patienten

Christoph Stephan ${ }^{1}$, Timo Wolf ${ }^{1}$, Udo Götsch ${ }^{2}$, Oswald Bellinger ${ }^{2}$, Gabriele Nisius ${ }^{1}$, Gerhard Oremek ${ }^{3}$, René Gottschalk ${ }^{2}$, Sonja Stark ${ }^{2}$, Hans-Reinhard Brodt ${ }^{1}$, Schlomo Staszewsk ${ }^{1}$

${ }^{1}$ Universitätsklinik Frankfurt am Main, HIVCENTER, Med

Klinik 2, Frankfurt, Germany, ${ }^{2}$ Stadtgesundheitsamt Frankfurt am Main, Infektiologie, Frankfurt, Germany, ${ }^{3}$ Zentrum der Inneren Medizin, Labormedizin, Frankfurt, Germany

Hinterg rund: Die Interferon- $\gamma$-basierten Bluttests für die Diagnostik der latenten Tuberkuloseinfektion (QuantiFER-
ON-TB Gold [ELISA] und T-SPOT.TB [ELISPOT]) wurden bei HIV-Patienten bisher nicht überprüft

Methodik: In einer prospektiven Querschnittsstudie wurden hinsichtlich einer Tuberkulose asymptomatische, ambulante HIV-Patienten einer großen Universitätsklinikskohorte simultan der serologischen Testung auf Tuberkuloseinfektion mittels ELISA und ELISPOT unterzogen, zusätzlich zur Tuberkulin-Hautprobe (TST). Die statistisch auszuwertende Endpunktgröße war der Anteil der Patienten mit positivem Testergebnis, die Prädiktoren eines positiven Tests sowie die Test-konkordanz (k).

Resul tate: 286 Patienten wurden eingeschlossen. 81\% waren Männer, diese waren im Median 44 Jahre alt, die CD4-Zellen lagen im Median bei 408 Zellen $/ \mathrm{mm}^{3}$ (Schwankungsbereich 7-1510), im medianen Nadir bei 126 (Schwankung sbereich 0-749) und 63.8\% waren virologisch supprimiert (HIV-RNA $<50$ Kopien/mL).

Für 250 Patienten lag ein bestimmtes Resultat für alle drei Tests vor. Sowohl ELISPOT als auch ELISA lieferten mehr positive Testergebnisse als der TST: $25.2 \%$ und $20.0 \%(\mathrm{p}=0.133)$, gegenüber $12.8 \%(\mathrm{p}<0.001$ respektive $\mathrm{p}=0.008)$. Die Übereinstimmung zwischen ELISPOT und TST $(\kappa=0.201)$ sowie zwischen ELISA und TST $(k=0.335)$ war befriedigend, aber schwach zwischen beiden serologischen Tests $(\kappa=0.146)$. ELISPOT lieferte mehr unbestimmbare Resultate als der ELISA (8 gegenüber 1 von 256, p $<0.01)$. Patienten mit einem positiven ELISA Ergebnis wiesen höhere mediane CD4 Zellzahlen auf (457 gegenüber 405 Zellen $/ \mathrm{mm}^{3}$ für Patienten mit negativem Ergebnis, $\mathrm{p}=0.044)$. Die CD4 Zellzahl korrelierte mit der Menge freigesetztem Interferon $-\gamma \quad(\rho=0.199 ; p<0.002)$. Das ELISPOT-Ergebnis war von der CD4-Zellzahl unabhängig.

Schlussfolgerungen: Bei HIV-infizierten Individuen eines Niedrigprävalenzlandes für Tuberkulose zeigten beide Interferon- $\gamma$ basierten Bluttests einen höheren Anteil positiver Ergebnisse als die Tuberkulinprobe. Die schwache Übereinstimmung der Tests untereinander deutet auf eine schwache Sensitivität bei HIV-Patienten hin. Die Tests unterscheiden sich in der Abhängigkeit der vom Patienten zum Testzeitpunkt aufgebrachten CD4-Zellen und in der Anzahl unbestimmbarer Testergebnisse.

\section{P459 (PW)}

\section{Anales Dysplasiescreening bei HIV-infizierten Frauen}

Andrea Gingelmaier ${ }^{1}$, Tobias Weissenbacher ${ }^{1}$, Kästner Ralph $^{1}$, BerndKost ${ }^{1}$, Thomas Grubert ${ }^{2}$, Sovric Milena ${ }^{1}$, Florian Bergauer

${ }^{1}$ Ludwig-Maximilians-Universität München, Campus Innenstadt, Klinik für Gynäkologie und Geburtshilfe, München, Germany, ${ }^{2}$ Praxis, Ravensburg, Germany

Fragestellung: Das Zervixkarzinom sowie dessen Vorstufen ist als AIDS-assoziiertes Malignom seit langem in die CDC-Klassifikation der HIV-Infektion eingegangen. HPV-assoziierte anale Dysplasien treten bei HIV-Infizierten jedoch ebenfalls sehr viel häufiger auf als bei Nicht-Infizierten. Ein entsprechendes standardisiertes Screening existiert bisher jedoch nicht. Ziel dieser Pilotstudie ist, ein Analscreening für Frauen zu evaluieren.

Methodik: Prospektive Untersuchung HIV-infizierter Frauen mittels analer Zytologie, HPV-Abstrich, Anoskopie, ggf.Histologie. Gleichzeitige Dokumentation des Im- 
munstatus, HI-Viruslast, antiretrovirale Therapie (ART), relevante Vorgeschichte.

Ergebnis se: 50 HIV-infizierte Patientinnen aus einer gynäkologischen Sprechstunde wurden von Juli bis Dezember 2008 konsekutiv in die Studie eingeschlossen. Bei 15 von 50 Probandinnen $(30 \%)$ zeigte sich ein anal positiver HPV high-risk Befund. Von diesen 15 Frauen zeigten 6 auch zytologisch eine Dysplasie (5x Pap IIID, 1x Pap IVa). Bei 11/15 Frauen fand sich gleichzeitig zervikal ein HPV highrisk Befund, davon bei 8 zytologisch eine Dysplasie (7x Pap IIID, 1x Pap IVa). Mit Hilfe der Anoskopie wurden bisher bei zwei dieser Patientinnen (1x Pap IIID, 1x Pap IVa) anale Biopsien mit dem Ergebnis AIN II-III vorgenommen und gelasert. Alle 15 Pat. nehmen aktuell eine HAART mit einer gut kontrollierten Viruslast, nur 3 waren mit ihrer CD4Zellzahl $<200 / \mu 1$.

Schl ussfolgerung: Die Kombination aus analer Zytologie, HPV-Abstrich, Anoskopie und ggf Histologie erscheint in diesem Hochrisikokollektiv gerechtfertigt, um eine anale Dysplasie rechtzeitig erkennen und behandeln zu können. Ob dadurch eine wirksame Prophylaxe des Analkarzinoms erreicht werden kann, muß in weiteren Studien unters ucht werden .

\section{P460 (PW) \\ Streptococcal proctitis resembling gonorrhoea in HIV infected men who have sex with men \\ Anja Potthoff, Alexander Kreuter, Norbert H. Brockmeyer, Competence Network for HIV/AIDS}

St. Josef Hospital University of Bochum, Dermatology, Bochum, Germany

Background: The incidence of sexually transmitted diseases is rising world wide. Especially in HIV positive MSM proctitis is very common. Differential diagnoses includes gonorrhoea, chlamydia infection, syphilis, anal intraepithelial neoplasia, mechanical stress and many others.

Case report: Between $7 / 2006$ and $7 / 2008$ proctoscopy was performed in $473 \mathrm{HIV}$ positive patients of the interdisziplinary immunological out patients clinic Bochum. We diagnosed $12(3,5 \%)$ cases of symptomatic anal chlamydia infection (not serovar L1-3) and $17(2,5 \%)$ cases of intraanal gonorrhoea.

We present $7(1,4 \%)$ cases of patients with anal beta-hemolytic streptococcal proctitis. Patients complained about pain and anal discharge. High resolution anoscopy revealed purulent fluid and a highly vulnerable mucosa. Gonorrhoea and chlamydia infection was excluded in all patients by PCR and syphilis by serology. Patients were between 28 and 74 years old. Their HIV infection was either not treated or in an advanced stage. Symptoms resolved after antibiotic treatment with doxycyclin $2 \times 100 \mathrm{mg}$ for 7 days or cefpodoxim 2x200mg for 7 days. Resistant strains were not isolated. One patient had a relaps after 5 months and proctitis resolved after treatment with ciprofloxacin $1 \times 500 \mathrm{mg}$ for 7 days (treatment was initiated before isolation of streptococcus).

Discussion: We diagnosed a significant number of patients with proctitis due to beta-hemolytic streptococcal infection in our cohort. So far one case report of an HIV positive man with anal streptococcus pyogenes infection suffering from local tenderness, erythema of the mucosa and purulent discharge after receptive anal intercourse has been described. An affinitiy to the rectal mucosa is explained by several surface proteins of group B streptococci enhancing bacterial adhesion to host cells in the genital tract. Streptococcal infection is an important differential diagnoses patients presenting with proctitis and should be taken into account in all HIV positive presenting with anal pain and discharge.

\section{P461 (PD)}

\section{Anorectal Chlamydia trachomatis infections in Swiss HIV-infected homosexual men}

Thanh Dang ${ }^{1}$, Katia Jaton ${ }^{2}$, Mark us Flepp ${ }^{3}$, Helen Kovari $^{4}$, Jonh-Marc Evison ${ }^{5}$, Jan Fehr ${ }^{6}$, Patrick Schmid ${ }^{7}$, Emmanuelle Boffi El Amari ${ }^{8}$, Massimo Odorico $^{9}$, Philip E. Tarr ${ }^{10}$, Gilbert Greub ${ }^{1,2}$

${ }^{1}$ Centre Hospitalier Universitaire Vaudois and University of Lausanne, Infectious Diseases Service/Department of Medicine, Lausanne, Switzerland, ${ }^{2}$ Laboratory of Molecular Biology, Institute of Microbiology, University of Lausanne, Lausanne, Switzerland, ${ }^{3}$ Zentrum fur Infektionskrankheiten, Zurich, Switzerland, ${ }^{4}$ Division of Infectious Diseases and Hospital Epidemiology, University Hospital, Zurich, Switzerland, ${ }^{5}$ Infectious Diseases Service, University Hospital, Bern, Switzerland, ${ }^{6}$ Division of Infectious Diseases, University Hospital, Basel, Switzerland, ${ }^{7}$ Infectious Diseases Unit, Hospital St. Gallen, St. Gallen, Switzerland, ${ }^{8}$ HIV-AIDS Unit and Infectious Disease Consultations, University Hospital, Geneva, Switzerland, ${ }^{9}$ Infectious Disease Service, Hospital Lugano, Lugano, Switzerland, ${ }^{10}$ Service of Infections and Hospital Hygiene, University Clinic of Medicine, Bruderholz, Switzerland

Aims: Anorectal lymphogranuloma venereum (LGV) and non-LGV Chlamydia trachomatis infections are re-emerging among homosexual men in developed countries. We prospectively assessed the prevalence and risk factors for these infections in a large cohort, the Swiss HIV Cohort Study (SHCS).

Methods: Male homosexual SHCS participants who reported unprotected receptive anal sex and/or symptoms of proctitis during a SHCS visit from April 2007 to March 2008 were eligible. Those enrolled consented to complete a questionnaire and to have an anal swab screened for $C$. trachomatis DNA by real-time PCR. Positive samples were genotyped by ompA gene amplification and sequencing. Demographic, immunologic and virological data were retrieved from the SHCS database.

Results: 147 anal swabs from 147 men were analyzed. The prevalence of anorectal $C$. trachomatis infection was $10.9 \%$ (95\% confidence interval [CI] 6.2\%-17.6\%). Of the 16 C. trachomatis-positive swabs, only one LGV was identified. The remaining serotypes were $G(n=5), J(4), E(2)$ and $\mathrm{D}(1)$, and undetermined in 3 samples. In both anorectal Chlamydia-positive and negative groups, $19 \%$ of men reported symptoms of proctitis. Having had more than 20 sex partners within the last 2 years was the only identified risk factor for anorectal chlamydial infection (odds ratio $5.6,95 \%$ CI 1.87-17.09). Neither infrequent use of condom with occasional partners, nor other risk factors for sexually transmitted infections (STIs), such as drug use, alcohol misuse, fisting, anal toy use or rimming, were associated with anorectal chlamydial infection. 
Conclusion: In this population at high risk for STIs, the prevalence of anorectal chlamydial infection is high, without evidence of LGV transmission. Since chlamydial infections are commonly asymptomatic and since the risk of transmission of other STIs is high, we recommend screening for anorectal C. trachomatis infection in homosexual men who report unprotected receptive anal sex.

$$
\text { P462 (PD) }
$$

\section{Incidence of bacterial, fungal or viral co-infection in HIV-positive individuals with PCP: a retrospective analysis of the AVK cohort}

Christian Traeder, Susann Kowoll, Hartmut Stocker, Keikawus Arastéh

Vivantes Auguste-Viktoria-Klinikum, Infektiologie, Berlin, Germany

Between 1985 and 200716127 HIV patients were treated in the Vivantes Auguste-Viktoria-Klinikum (AVK) Berlin. PCP remains one of the most threatening opportunistic infections. Super- or co-infection with bacterial, fungal or viral species results in additional morbidity and mortality. Therefore adequate antibiotic coverage is the cornerstone of treatment success.

Methods: We retrospectively analysed the electronic database of our cohort in terms of quantity of bacterial (and other) co-infection of PCP. Diagnose of PCP has been established via bronchoscopy and lavage, followed by immune fluorescence analysis. All additional results were detected out of the lavage.

Results: In total we found 1422 episodes of PCP in 982 different patients (sex m: 907, f: 75 female, risk: MSM: 745, iv: 82 , hetero: 62 , blood: 3 , unkown: 90 ). Co-infections could be detected in 821 PCP- episodes. Bacterial: 566(68.9\%), mycobacterial: 38(4.6\%), fungal: 192 $(23.4 \%)$ and viral infection $25(3 \%)$. The bacteria $(n=$ $566, \%)$ were differentiated for aerobic/anaerobic and gram stain: Gram positive $319(56.4 \%)$, gram negative $195(34.5 \%)$ and anaerobic 52(9.2\%). The leading bacterium was staphylococcus aureus $(n=130,23 \%)$, followed by haemophilus influencae $(n=67,11.8 \%)$ and streptococcus pneumoniae $(n=43,7.6 \%)$. However, there have been other Streptococci (alpha haem. 11, beta haem. 50, not specified $34)$, resulting in $n=138(24.4 \%)$ detections of streptococcal species. The overall incidence of pseudomonas $(\mathrm{n}=11$, $1.9 \%)$, klebsiella $(n=25,4.4 \%)$, e.coli $(n=16,2.8 \%)$ and enterococci $(n=11,1.9 \%)$ was low. Detection of fungi: Candida species (176), aspergillus spec. (17) and cryptococcus neoformans (3). Detection of viruses (not routinely done): CMV (16), HSV (9).

Discussion: Patients presenting with PCP should be treated with antibiotics, which cover staph aureus, streptocci and haemophilus influencae. Fungal infection should be considered. TMP-SMX covers most of the agents, but lack coverage of some isolates of $\mathrm{H}$. influencae. Clindamycin as used as second line treatment provides insufficient coverage of many frequent pathogens.

\section{$P 463$}

\section{Wirksamkeit einer anti-retroviralen Therapie (HAART) bei Patienten mit HBV-HIV Koinfektion}

\author{
Kosi Lana ${ }^{1}$, Thomas Reiberger ${ }^{1}$, Katharina \\ Pfistershammer ${ }^{2}$, A. Rieger ${ }^{2}$, Mark us \\ Peck-Radosavljevic ${ }^{1}$
}

\begin{abstract}
${ }^{1}$ Medizinische Universität Wien, Gastroenterologie und Hepatologie, Wien, Austria, ${ }^{2}$ Abteilung für Dermatologie, Abteilung für Immundermatologie und Infektiöse Hautkrankheiten, Medizinische Universität Wien, Wien, Austria
\end{abstract}

Aufgrund ähnlicher Transmissionwege liegt eine Koinfektion mit dem Hepatitis B Virus (HBV) bei ungefähr 10\% aller HIV Patienten vor. Daten über die Wirksamkeit von HBV-Medikamenten, Lamivudine (3TC), Tenofovir (FTC) oder Emtricitabine (FTC), häufig in einer anti-retroviralen Therapie (HAART) angewandt, sind limitiert. Die Inzidenz einer HAART-assoziierten Hepatotoxizität bei HBV-HIV koinfizierten Patienten wurde bisher nicht systematisch analysiert.

Retrospektiv wurden klinische,virologische und laborchemischen Daten , aller HBV-HIV ko-infizierten behandelt zwischen 1998-2009 an der HIV bzw. hepatologischen Ambulanz der Meduni Wien, analysiert

100 koinfizierte Patienten wurden identifiziert, $82 \%$ unter HAART und mit mittleren CD4 ${ }^{+}$Nadir $184 / \mu$ L. $65 \%$ waren $\mathrm{HBVe}$-Antigen (HBeAg) positiv. 3TC, TDF und FTC wurden bei $46 \%, 64 \%$ und $31 \%$ der Patienten als HAART-bestandteile angewandt. Vor HAART lag die mittlere HBV Viruslast bei $4.47 \pm 2.7 \times 10^{9} \mathrm{IU} / \mathrm{mL}$ und mittlerer HIV-RNA Spiegel bei $4.73 \log$ copies/mL. HBeAg-positive hatten höhere HBV Viruslast $\left(7.47 \pm 5.06 \times 10^{9} \mathrm{IU} / \mathrm{mL}\right)$ als $\mathrm{HbeAg}$ negative Patienten $\left(2.12 \pm 2.10 \times 10^{9} \mathrm{IU} / \mathrm{mL} ; \mathrm{p}<0.001\right)$. Über einen medianen Beobachtungszeitraum von 59 Monaten (Spannweite: 2-204) lag die HIV-RNA bei $78 \%$ unter der Nachweisbarkeitsgrenze (Compliance-Kontrolle). $72 \%$ erreichten eine komplette Suppression der HBV Replikation $(<351 \mathrm{IU} / \mathrm{mL})$.

$43 \%$ der $\mathrm{HBeAg}$-positiven erreichten eine $\mathrm{HBeAg}$ Serokonversion, die kumulative jährliche HBeAg Serokonversionsrate lag bei $9.7 \%$. Die kumulative jährliche Rate an HBV Oberflächen Antigen (Hbs Ag) Verlust betrug bei HBeAg-positiven $6.2 \%$ und bei HbeAg-negativen Patienten $7.5 \%$.

Nachm HAART-Beginn wurde bei $16 \%$ eine transiente Erhöhung der Aminotransferasen festgestellt. Im Gesamtkollektiv kam es zu einem mittleren Anstieg der $\gamma$-GlutarylTransferase $(\gamma \mathrm{GT}+42 \mathrm{U} / \mathrm{L})$ und Abfall der Aspertataminotransferase (AST -21U/L) und Alanin-aminotransferase (ALT -21U/L). Hepatotoxizität Grad III-IV trat nicht auf.

Die Verträglichkeit einer HAART ist bei HBV-HIV koinfizierten Patienten ausgezeichnet und führt bei einem Großteil dieser Patienten mit hoher Ausgangs Virämie rasch zu einer kompletten Suppression der HBV Replikation. Die annuale Rate an $\mathrm{HbeAg}$ Serokonversion und $\mathrm{Hb}-$ sAg Verlusten ist bei HBV-HIV koinfizierten Patienten unter HAART somit vergleichbar oder höher als bei HBV monoinfizierten. 


\section{P464}

\section{Hepatitis C coinfection in HIV-infected patients - evidence for considerable undertreatment}

Axel Baumgarten ${ }^{1}$, Christian Hoffmann ${ }^{2}$, Lutwin Weitner $^{2}$, Arend Moll ${ }^{3}$, Christiane Cordes ${ }^{4}$, Frank Schlote ${ }^{5}$, Heinz-August Horst ${ }^{6}$, Siegfried Köppe 7 , Bettina Hintsche ${ }^{5}$, Christoph Mayr ${ }^{8}$, Stefan Christensen ${ }^{9}$, Martin Obermeier 10

${ }^{1}$ Praxis Dres. S. Dupke / A. Carganico / A. Baumgarten, Berlin, Germany, ${ }^{2} \mathrm{ICH}$ (Infektionsmedizinisches Centrum Hamburg), Hamburg, Germany, ${ }^{3}$ Prazentrum Kaiserdamm, Berlin, Germany, ${ }^{4}$ Praxis City Ost, HIV-Schwerpunktpraxis, Berlin, Germany, ${ }^{5}$ Praxis, Berlin, Germany, ${ }^{6}$ Universitaetsklinikum Kiel, Kiel, Germany, ${ }^{7}$ Praxis Dr Köppe, Berlin, Germany, ${ }^{8}$ Ärzteforum Seestr., Berlin, Germany, ${ }^{9}$ Praxis, Münster, Germany, ${ }^{10}$ Medizinisches Labor Berg, Berlin, Germany

Backgro und: Hepatitis $\mathrm{C}$ virus (HCV) coinfection represents a significant factor of mortality and morbidity in HIV-infected patients. According to current guidelines, $\mathrm{HCV}$ treatment should be considered in the majority of this patient population.

Methods: This multicentric study includes all HIV/HCVcoinfected patients diagnosed since 2001 in 12 participating centres in 2 urban regions in Northern Germany (Berlin, Hamburg). Patient characteristics were analyzed, including demographic factors, HCV and HIV features, as well as the use of antiretroviral therapy and HCV treatment. Results: As of end of 2008, a total of 1.160 coinfected patients ( $81.1 \%$ male, $18.9 \%$ female) have been enrolled. Among patients with an acute HCV infection, there were more patients with male gender $(99,7 \%$ versus $73.8 \%, \mathrm{p}<$ $0.001)$ and with genotype $1+4(89.4 \%$ versus $69.5 \%, \mathrm{p}<$ $0.001)$, compared with chronically coinfected patients. Of the 325 patients with an acute HCV infection, 244 (68.9\%) had received HCV treatment, leading to sustained virological response rates (SVR) of $68.9 \%$. In the-- $81(31.1 \%)$ patients receiving no $\mathrm{HCV}$ treatment during acute $\mathrm{HCV}$ infection, spontaneous clearance of $\mathrm{HCV}$ was observed in $27.2 \%$. Of the 835 patients with chronic HCV infection, only $286(34.3 \%)$ had received HCV treatment with pegylated interferon alpha $2 \mathrm{a}$ or $2 \mathrm{~b}$ and ribavirine. Among treated patients, the SVR was $44.8 \%$. In the remaining 549 $(65.7 \%)$ untreated patients, HCV treatment was withheld or deferred mainly due to assumed lack of adherence (51.6\%) and/or patient's wish $(26.3 \%)$. Other reasons to withhold $\mathrm{HCV}$ treatment were comorbidities $(21.1 \%$, mainly psychiatric disorders), active intravenous drug abuse (16.5\%) and/or profound immune deficiency (14.0\%).

Conclusions: This large cohort study provides evidence for considerable undertreatment of HIV-infected patients with HCV-coinfection. Despite acceptable treatment success in this real-life setting, the vast majority of the patients remains untreated. Strategies to enhance adherence and medical advice for this patient population are urgently needed.

\section{P465}

\section{Antivirale Effektivität von Interferon bei immunkomprimierten HCV Patienten nach Lebertransplantation oder mit HIV Koinfektion}

Thomas Reiberger ${ }^{1}$, Susanne Rasoul-Rockenschaub ${ }^{2}$, Peter Ferenci ${ }^{1}$, Armin Rieger ${ }^{3}$, Mark us Peck-Radosavljevic ${ }^{\text {' }}$

${ }^{1}$ Medizinische Universität Wien, Gastroenterologie \& Hepatologie, Wien, Austria, ${ }^{2}$ Medizinische Universität Wien, Chirurgie, Abt. f. Transplantchirurgie, Wien, Austria,

${ }^{3}$ Medizinische Universität Wien, Dermatologie, Abt. f. Immundermatologie und infektiöse Hautkrankheiten, Wien, Austria

Einleitung: Eine HCV Therapie bestehend aus Interferon (IFN) und Ribavirin wird auch bei immunkompromittierten Patienten nach Lebertransplantation (OLT) oder mit HIV Koinfektion (HIV-HCV) häufig angwandt. Das initiale Ansprechen auf Interferon (Viruskinetik) zwischen immunkompromittierten (OLT / HIV-HCV) und immunkompetenten Hepatitis C (HCV) Patienten wurde bisher nicht systematisch verglichen.

Methodik: 76 Patienten (31 OLT, 20 HIV-HCV, 25 HCV) unterzogen sich einem Interferon-Effektivitätstest mittels HCV Viruslastmessung vor und 24 Stunden nach einer Testdosis mit 9MU IFN. Danach wurde eine antivirale Therapie mit pegyliertem IFN- $\alpha 2$ a $180 \mu \mathrm{g}$ plus Ribavirin $0.8-1.2 \mathrm{~g}$ für 48 Wochen begonnen. Wir verglichen die Patientencharakteristika, das initiale Ansprechen auf Interferon und den Therapieerfolg zwischen den Gruppen. Insbesondere wurde die Art des Calcineurin Inhibitors (CI) bei den OLT Patienten und die Immunfunktion (CD4 ${ }^{+}$Zellzahl) bei HIVHCV Patienten berücksichtigt.

Resul tate: Die mittlere Ausgangsviruslast war in der OLT Gruppe signifikant höher als in der HCV Gruppe, auch in der HIV-HCV Gruppe war der gleiche Trend zu beobachten. Die antivirale Effektivität der IFN Testdosis war in der OLT Gruppe im Vergleich zur HCV Gruppe reduziert, während kein signifikanter Unterschied zwischen HIV-HCV und HCV bestand. Bei den HIV-HCV Patienten korrelierte der Viruslastabfall nach der IFN Testdosis mit der CD4+ Zellzahl. Zwischen den verschiedenen CI bestand kein Unterschied in Bezug auf die Ausgangsviruslast, das initiale Ansprechen auf IFN und den Therapieerfolg zu beobachten. Ein anhaltender virologischer Erfolg (SVR) konnte bei $28 \%$ der OLT, bei $50 \%$ der HIV-HCV und bei $56 \%$ der HCV Patienten erreicht werden.

Schlussfolgerungen: Immunkompromittierte Patienten haben höhere Ausgangsviruslasten. Das initiale Ansprechen auf IFN ist bei OLT reduziert, während zwischen HIV-HCV und HCV Patienten kein signifikanter Unterschied besteht, die antivirale Effektivität von IFN bei HIVHCV Patienten ist aber stark von der CD4+ Zellzahl abhängig. Die SVR Raten sind bei OLT Patienten im Vergleich zu den HIV-HCV Patienten mit höheren $\mathrm{CD}^{+}{ }^{+} \mathrm{Zel}-$ lzahlen nicht zufriendenstellend. 


\section{P466}

Ribavi rin-Plasmakonzentrationen in der anti viralen Therapie der chronischen Hepatitis $\mathbf{C}$

Hartwig Klinker ${ }^{1}$, Werner Heinz ${ }^{1}$, Isabell Trebesch ${ }^{1}$, Christine Guhl ${ }^{1}$, Andreas Trein ${ }^{2}$, Gudrun Tossing ${ }^{3}$, Peter Langmann ${ }^{4}$

${ }^{1}$ Universitätsklinikum Würzburg, Med. Klinik II, Infektiologie, Würzburg, Germany, ${ }^{2}$ Schwerpunktpraxis, Stuttgart, Germany, ${ }^{3}$ Essex Pharma GmbH, München, Germany, ${ }^{4}$ Praxis für Gastroenterologie und Infektiologie, Karlstadt, Germany

Einleitung: In der Therapie der chronischen Hepatitis C kommt der Ribavirin (RBV)-Exposition bereits in den ersten Behandlungswochen eine große Bedeutung im Hinblick auf ein Therapieansprechen zu. Über die sich im Verlauf der Therapie einstellenden RBV-Plasmakonzentrationen (RBV-C) ist wenig bekannt. Ziele: In einer retrospektiven Studie sollten bei Hepatitis C-Patienten unter laufender Interferon (IFN)/RBV-Therapie aus asservierten Serumproben die RBV-C untersucht werden .

Methodik: Mittels HPLC wurden bei 152 konsekutiven HCV-Patienten insges. 613 RBV-C gemessen. Peg-IFN alfa $2 \mathrm{~b}$ erhielten $44.7 \%$, Peg-IFN alfa 2 a $40.1 \%$, ConsensusIFN $15.1 \%$ der Patienten. Analysiert wurden die mittleren RBV-C zu unterschiedlichen Therapiewochen, die RBV-C bei Frauen/Männern, HIV positiven/HIV negativen, sowie bei Patienten mit/ohne EVR (Early Virological Response). Ergebnis: Die mittlere RBV-C stieg langsam von 1321 $\mathrm{ng} / \mathrm{ml}( \pm 764 \mathrm{ng} / \mathrm{ml})$ in Woche $1-2$ auf $1511 \mathrm{ng} / \mathrm{ml}( \pm 608$ $\mathrm{ng} / \mathrm{ml})$ in Woche 3-4 und $1642 \mathrm{ng} / \mathrm{ml}( \pm 592 \mathrm{ng} / \mathrm{ml})$ in Woche 5-6 an. Im steady-state wurde ein mittlerer RBVSpiegel von $1910( \pm 814 \mathrm{ng} / \mathrm{ml})$ erreicht. Hier unterschieden sich die RBV-C in den verschiedenen InterferonGruppen nicht. Frauen $(n=48)$ wiesen in den ersten beiden Wochen annähernd gleiche, im weiteren Verlauf der Behandlung dagegen durchweg höhere RBV-Spiegel auf als männliche Patienten( $n=104)$. Die Unterschiede waren allerdings nicht statistisch signifikant. Bei 8 HIV-Patienten wurden signifikant niedrigere RBV-Spiegel als bei 144 HIV-negativen Patienten gemessen $(\mathrm{p}<0,05$ zu Woche 1-2 und 5-6). Patienten mit einem EVR zeigten in der frühen Behandlungsphase eine signifikant höheren mittleren RBV-C als Patienten ohne EVR (Woche 1-2: $1633 \mathrm{ng} / \mathrm{ml}$ bei Patienten mit EVR vs. $1010 \mathrm{ng} / \mathrm{ml}$ bei Patienten ohne EVR).

Schlussfolgerung: Eine höhere RBV-C in den ersten 2 Wochen ist mit einem besseren frühen Therapieansprechen vergesellschaftet. Aufgrund der RBV-Pharmakokinetik kann ein modifiziertes Dosisregime zu Beginn der Behandlung (RBV-,,loading-dose" oder RBV-Monotherapie-Vorphase) die Behandlungsergebnisse evtl. weiter verbessern. Die höheren RBV-C bei Frauen und die niedrigeren RBV-C bei HIV-Patienten können die unterschiedlichen klinischen Behandlungsergebnisse in diesen Patientengruppen miterklären.
$P 467$

\section{Simultane Radiochemotherapie des Anal karzinoms bei HIV-positiven Patienten unter HAART}

Ingeborg Fraunholz, ${ }^{1}$, Annette Haberl ${ }^{2}$, Claus Rödel ${ }^{1}$

${ }^{1}$ J.W.Goethe-Universität, Klinik für Strahlentherapie und Onkologie, Frankfurt/Main, Germany, ${ }^{2}$ J.W.Goethe-

Universität, Innere Medizin II, HIV-Zentrum, Frankfurt/Main, Germany

Hinterg rund: Aufgrund einer hohen HPV -Prävalenz ist die Inzidenz des Analkarzinoms bei HIV-positiven Patienten in der HAART-Ära gestiegen. Die simultane Radiochemotherapie wird in den wenigen Veröffentlichungen $\mathrm{zu}$ Patienten mit HIV-Infektion in Hinblick auf Lokalkontrolle und therapiebedingte Toxizität kontrovers beurteilt. Vor dem Hinterg rund dieser Literaturdaten werden die Ergebnisse einer Standard-Radiochemotherapie bei HIV-positiven Patienten unter HAART vorgestellt und diskutiert.

Methodik: Zwischen 1997 und 2008 wurde bei $21 \mathrm{HIV}$ positiven Patienten mit Analkarzinom eine simultane Radiochemotherapie durchgeführt $(50,4$ Gy à 1,8 Gy/Tag + 5,4-10,9 Gy Boost; 5-FU: $1000 \mathrm{mg} / \mathrm{m}^{2}$ Tag 1-4 und 29-32; Mitomycin C: $10 \mathrm{mg} / \mathrm{m}^{2}$ Tag 1 und 29). Im Rahmen einer retrospektiven Analyse wurden Tumoransprechen, Lokalkontrolle, tumorspezifisches - und Gesamtüberleben sowie die therapiebedingten Nebenwirkungen evaluiert. Immunologische Parameter wie prä- und posttherapeutische CD4-Zellzahl und Viruslast im Verlauf des follow-up (median 53, range, 10-99 Monate) wurden neben Patienten- und Tumor-bezogenen Charakteristika mit den Therapieergebnissen korreliert.

Resultate: Eine Dosisreduktion der Chemotherapie und/oder Unterbrechung der Strahlentherapie musste in jeweils 5 Fällen vorgenommen werden. Akute Grad 3-Nebenwirkungen traten bei 8/21 Patienten (38\%) auf. Eine komplette Remission wurde bei 17/21 Patienten (81\%) erzielt, Tumor-Persistenz oder ,early progression" wurde bei $4 / 21$ Patienten (19\%) diagnostiziert. Sechs Patienten sind verstorben, fünf aufgrund des progredienten Tumorleidens und ein Patient an den Folgen der Behandlung. Die 5 JahresLokalkontrolle, das tumorspezifische Überleben und das Gesamtüberleben betrugen 59\%, 75\% bzw. 67\%. Der mediane CD4-Wert fiel signifikant von 347,5 Zellen/ $\mu 1$ vor der Radiochemotherapie auf 125 Zellen $/ \mu 13$ bis 7 Wochen nach Ende der Behandlung ( $\mathrm{p}<0.001)$. Bei 6/19 Patienten $(32 \%)$ war im selben Zeitraum ein messbarer Anstieg der Viruslast zu verzeichnen. Beide Parameter erreichten die Ausgangswerte im Verlauf des weiteren follow-up.

Schlussfolgerungen: Unsere Daten bestätigen, dass in der HAART-Ära das HIV-assoziierte Analkarzinom mit dem Standard - Therapieschema einer simultanen Radiochemotherapie ohne übermäßige Toxizitäten behandelt werden kann. Eine engmaschige Überwachung der immunologischen Parameter ist notwendig. 


\section{P468}

Beschleunigte Fibroseprogression und portale Hypertension bei HIV-HCV koinfizierten Patienten mit niedrigem CD4+ Nadir

Thomas Reiberger ${ }^{1}$, Arnulf Ferlitsch ${ }^{1}$, Wolfgang Sieghart ${ }^{1}$, Florian Breitenecker ${ }^{2}$, Armin Rieger ${ }^{2}$, Brigitte Schmied ${ }^{3}$, Mark us Peck-Radosav ljevic ${ }^{1}$

${ }^{1}$ Medizinische Universität Wien, Gastroenterologie \& Hepatologie, Wien, Austria, ${ }^{2}$ Medizinische Universität Wien, Dermatologie, Abt. f. Immundermatologie \& infektiöse Hautkrankheiten, Wien, Austria, ${ }^{3}$ Otto Wagner Spital, Pulmonologie, Wien, Austria

Einleitung: HIV und Hepatitis C Virus (HCV) koinfizierte Patienten habe eine beschleunigte Fibroseprogressionsrate (FPR), wodurch es auch zum Auftreten einer portalen Hypertension (PHT) kommen kann. Wir untersuchten den Einflus s der Immunfunktion (CDC Stadium) auf die FPR und die Inzidenz und Verlauf einer PHT bei HIV-HCV Koinfektion.

Methodik: Daten von 66 interferon-naive HIV-HCV koinfizierte Patienten mit vorhandener Leberbiopsie, Lebervenendruckmessung (HVPG) und diversen Laborwerten (inklusive CD4+ Zellzahl, HIV \& HCV Viruslast) wurden herangezogen. Die FPR, die Zeit bis zum Auftreten einer Leberzirrhose (TTC) und der HVPG wurde in Bezug auf das CDC Stadium analysiert.

Resul tate: Im Mittel zeigten HIV-HCV Patienten eine beschleunigte FPR von 0.204 METAVIR Fibroseeinheiten pro Jahr (FU/y), eine kürzere TTC von 21 Jahren und einen HVPG an der oberen Normgrenze $(5 \mathrm{mmHg})$. Bei moderater oder schwerer Immundefizienz war die FPR wesentlich höher (CDC2: $0.178 \mathrm{FU} / \mathrm{y}$; CDC3: $0.254 \mathrm{FU} / \mathrm{y})$ als bei Patienten im Stadium CDC1: 0.120 FU/y. Es bestand hier eine signifikante indirekte Korrelation zwischen der CD4 ${ }^{+}$ Zellzahl und der FPR. Der HVPG war bei CDC3 Patient oft bereits früh im Krankheitsverlauf erhöht: $4 \mathrm{mmHg}$ nach 10 Jahren, $8 \mathrm{mmHg}$ nach 15 Jahren und $11 \mathrm{mmHg}$ nach 20 Jahren.

Schl ussfolgerungen: Die Progression einer HCV Infektion ist bei HIV-HCV Koinfektion besonders bei niedrigem CD4 ${ }^{+}$Nadir beschleunigt, sodass eine PHT bereits auch früh im Krankheitsverlauf auftreten kann.

\section{P469 (PD)}

\section{The relevance of $\mathrm{CMV}$ viremia, in the HAART era}

Emmanuelle Boffi El Amari, Christophe Combescure, Sabine Yerly, Alexandra Calmy, Laurent Kaiser, Bernard Hirschel, Swiss HIV Cohort Study

Geneva University Hospital, Geneva, Switzerland

Using sensitive quantitative PCR's, CMV DNA is often detectable in the plasma of immunosuppressed patients who do not develop CMV disease. We study the value of a positive CMV DNA in predicting the development of an AIDS defining event or mortality, in patients with $\mathrm{CD} £ 100 / \mu \mathrm{L}$, in the HAART era.

Survival analysis of patients prospectively included in the Swiss HIV cohort Study, from January 1996 to July 2008, CMV seropositive, with a CD4 count $£ 100 / \mu \mathrm{L}$, a plasma sample available for the measurement of CMV DNA, by an automated real-time PCR (Abbot Molecu$\left.\operatorname{lar}{ }^{\circledR}\right)$, threshold of detection of $20 \mathrm{c} / \mathrm{ml}$.
Outcome analyzed: Aids defining event, CMV end organ disease, death. Variables analyzed: demographics, CD4 counts, HIV-1 RNA concentration, use and type of HAART.

Prognostic performance of CMV DNA was assessed using time-dependant ROC curves. HR's determined using a Cox model with a one year time horizon.

Of 1170 patients, 208 presented an Aids defining event and 246 died ( 9.7 and $6.4 \%$ of patients respectively during the first 12 months).

$34.4 \%$ of the total cohort had a positive baseline CMV DNA value, ranging up to $104000 \mathrm{c} / \mathrm{ml}$.

The optimal prognostic performance of the CMV DNA value in predicting an aids defining event was reached between 3 and 5 months (AUC of 0.679; 95\%CI 0.568-0.777 and $0.662 ; 95 \% \mathrm{CI} 0.578-0.736)$, whereas it was reached at 7 months for deaths (AUC of 0.614; 95\%CI 0.520-0.694).

In the multivariate analysis, CMV DNA (cut-off $80 \mathrm{c} / \mathrm{ml}$ ) predicted evolution towards CMV disease (HR 12.5; 95\% CI 4.20-37.25), but also towards other Aids defining events (HR 2.34; 95\%CI 1.43-3.83) and death (HR 1.85; 95\% CI 1.04-3.30).

Low values of CMV DNA detected early in the plasma of HIV patients with CD $4 £ 100 / \mu \mathrm{L}$, significantly predicts the evolution towards CMV end organ disease, other Aids defining events and death.

\section{P470}

\section{High risk of mamma carcinoma in HIV infected men}

Anja Potthoff ${ }^{1}$, Klaus Jansen ${ }^{2}$, Martin Doerler ${ }^{1}$, Claudia Michalik ${ }^{3}$, Norbert H. Brockmeyer ${ }^{1}$, Competence Network for HIV/AIDS

${ }^{1}$ St. Josef Hospital University of Bochum, Dermatology, Bochum, Germany, ${ }^{2}$ Network of Competence HIV/AIDS, University of Bochum, Bochum, Germany, ${ }^{3}$ Centre for Clinical Studies University of Cologne, Cologne, Germany

Background: Breast cancer in men is very rare with an incidence of 1/100.000 inhabitants in Europe. In Germany between 230 and 500 men are diagnosed with breast cancer each year. The mean age of men is 70 years (compared to 62 in women). Ten percent of HIV infected patients develop cancer. Non-AIDS-defining cancers are getting more a more important reasons for death in the HAART era.

Methods: After diagnosing breast cancer in an HIV infected men, the database of the Network of competence was screened for similar cases between 07/2007 and 07/2008.

Resul ts : Case report: In December 2008 a 37-year old man presented with a painless palpable node in his right breast. The man was first diagnosed as having HIV in 1999, current stage B2. The patient's antiretroviral therapy consisted of Kivexa, Viread and Reyataz/r which was administered without interruption since 2006 (CD4 658/ $\mu$ 1, undetectable viral load). His family history revealed multiply malignancies including his mother's breast cancer. Sonography and mammography of the breast could not clarify the dignity of the breast lesion which led to excision in January 2009 . Histology showed an invasive ductal mamma carcinoma of moderate differentiation and a maximum diameter of 1,0 $\mathrm{cm}$. The patient was then referred to a centre specializing in breast cancer for further tumour staging and therapy .

2 more cases of breast cancer in HIV infected men (age 40 and 52) CDC stage B2 and $C 3$ under sufficient antiretroviral 
therapy were identified among 5181 men included and are currently analysed.

Conclusion: The risk of breast cancer in HIV infected men is much higher than in the general population and the tumour occurs at a younger age. Patients should be encouraged to self-examine their breasts and to seek medical care immediately if there is any suspicious finding.

\section{P471}

\section{HBV-markers in HIV-treatment naive patients from the RESINA-cohort}

Frank Wilhelm ${ }^{1}$, Nadine Sichtig ${ }^{1}$, Eugen Schülter ${ }^{1}$, Jens Verheyen ${ }^{1}$, Herbert Pfister ${ }^{1}$, Mark Oette $^{2}$, Rolf

Kaiser $^{1}$, Gerd Fätkenheuer ${ }^{3}$, Thomas Lengauer ${ }^{4}$, Stefan Reuter $^{5}$, Dieter Häussinger ${ }^{5}$, für die RESINAStudiengruppe

${ }^{1}$ Universität zu Köln, Institut für Virologie, Köln, Germany, ${ }^{2}$ Krankenhaus der Augustinerinnen, Köln, Germany,

${ }^{3}$ Universität zu Köln, Klinik für Innere Medizin I, Köln, Germany, ${ }^{4}$ Max Planck Institute for Informatics, Saarbrücken, Germany, ${ }^{5}$ Universitätsklinikum Düsseldorf, Klinik für Gastroenterologie, Hepatologie und Infektiologie, Düsseldorf, Germany

Background: $\mathrm{HBV}$ is a parenterally transmitted disease resulting in a chronification rate of $10 \%$ in adults. Serologic markers like anti-HBc antibodies do not give information about active $\mathrm{HBV}$-infection. Also the HBs Ag-Test may overlook viraemic HBV-infections, so called occult infections. In our RESINA-cohort of treatment-naive HIVpatients we investigated the frequencies of serological and molecul ar HBV markers.

Methods: We investigated samples from 767 patients from a subgroup of the RESINA-cohort for $\mathrm{HBsAg}$, anti-HBc, antiHBs. HBV-DNA was analyzed in 271 patient samples. In case of positive HBV-DNA results, the amplicons were sequenced and typed for resistance mutations, HBV-genotype and possible escape mutants with the help of Geno2pheno[HBV] and HIVGRADE-HBV (www .genafor.org, www.HIV-GRADE.de).

Results: HBsAg was found positive in 32 of 767 patients $(4,2 \%)$. Anti-HBs was detected in $214(27,9 \%)$ and anti$\mathrm{HBc}$ was found in 331 patient samples $(43,2 \%)$, from the latter an isolated anti-HBc without other markers was detected in $75(9,8 \%)$. In 436 patients $(56,8 \%)$ we detected no sign of $\mathrm{HBV}$-infection (anti-HBc negative). In 64 patients, anti-HBs antibodies due to vaccination $(8,3 \%)$ were found. HBV-DNA was detected in 18 of 271 cases $(6,6 \%), 7$ of 18 were also $\mathrm{HBs}$ Ag positive.

So far we could sequence 8 samples, the genotypes were the following: $3 \times \mathrm{A}, 3 \times \mathrm{G}, 2 \mathrm{xD}$. One shows the lamivudinetriple-mutation V173L+L180M+M204Vand was negative for all serological markers

Conclusion: HBV-markers were frequently found in therapy naïve HIV patients, 6,6\% were DNA-positive thereby indicating active $\mathrm{HBV}$-infection. We observed occult infections in 11 of 271 cases (4\%). Thus, the majority of active HBV-infections were occult infections and would would not have been detected by serological markers alone. On the other hand, we found HBsAg in 2 cases without detectable HBV-DNA. We conclude from our data that intensive HBV analysis in treatment-naïve HIV-patients is valuable for the future planning of therapy.

\section{P472}

High dose chemotherapy followed by autologous stem cell transplantation in HIV-related lymphoma or germ cell tumor: the Munich experience

Marcus Hentrich ${ }^{1}$, Tim Röhnisch ${ }^{2}$, Arthur Gerl ${ }^{3}$, Clemens Scheidegger ${ }^{4}$, Eva Jägel-Guedes ${ }^{5}$, Christoph von Schilling 6 , Thomas Sternfeld 7 , Xaver Schiel ${ }^{8}$

${ }^{1}$ Klinikum Harlaching, Klinik für Hämatologie, Onkologie und Palliativmedizin, München, Germany, ${ }^{2}$ Klinikum der Universität München, Standort Innenstadt, München, Germany, ${ }^{3}$ Onkologische Schwerpunktpraxis, München, Germany, ${ }^{4}$ Schwerpunktpraxis, München, Germany,

${ }^{5}$ Kuratorium für Immunschwäche, München, Germany, ${ }^{6}$ Klinikum Freising, Freising, Germany, 7Klinikum rechts der Isar, München, Germany, 8Klinikum Harlaching, München, Germany

Background: In the HIV-negative setting high dose chemotherapy (HDCT) followed by autologous stem cell transplantation (ASCT) is indicated for relapsed NonHodgkin`s lymphoma (NHL), Hodgkin`s lymphoma (HL) and germ cell tumor (GCT)

Methods: We report our experience with mobilizing peripheral blood stem cells in patients (pts) with HIV-associated malignancies who did or did not undergo ASCT.

Res ul ts : From 07/05 to 01/09 peripheral blood stem cells (PBSC) were successfully harvested in $7 \mathrm{HIV}$-infected males with NHL $(n=5)$, HL $(n=1)$ and testicular GCT $(n=1)$. The mean number of collected stem cells was $14.8 \times 10^{6} / \mathrm{kg}$ CD34+ cells (range, 6.3 - 33). PBSC-mobilisation failed in another pt with NHL. All pts were mobilised by chemotherapy (CT) and G-CSF, 3 of 8 while under primary CT for NHL and 5 after salvage CT for NHL $(n=3), H L(n=1)$ or GCT $(\mathrm{n}=1)$. So far, 4 of 7 pts received HDCT + ASCT: Pt 1 (44 yrs, CDC C3; HIV-RNA< $50 \mathrm{cop} / \mathrm{ml}$ ) with $\mathrm{NHL}$ received HDCT as $3^{\text {rd }}$ salvage therapy which resulted in a partial remission lasting for 4 months. He died of progressive lymphoma 6 months after ASCT. Pt 2 (60 yrs, CDC B3; VL< 50) underwent HDCT + ASCT for a 1 st relapse of HL. The pt is well and disease free 8 months after ASCT. Pt 3 (25 yrs, CDC A3, VL< 50) received 3 sequential courses of HDCT in 3 -week intervals for a $3^{\text {rd }}$ relapse of a nonseminomatous GCT. Leukocyte engraftment occurred on time after each transplant. He currently undergoes secondary surgery (11 weeks after the $3^{\text {rd }}$ transplant). Pt 4 (26 yrs, CDC C3, VL< 50), a hepatitis $\mathrm{C}$ co-infected haemophiliac, received HDCT + ASCT for refractory NHL but died of liver cirrhosis and multi-org an failure on day +16 .

Conclusions: Mobilisation of PBSC and ASCT is feasible and effective in selected pts with HIV-infection.

$P 473$

\section{Rupia syphilitica bei HIV-positiver Patientin}

Ahmad Jalili, Martin Mosleh, Katharina Pfistershammer, Armin Rieger

Medizinische Universität Wien, Universitätsklinik für Dermatologie, Abteilung für Immundermatologie und infektiöse Hautkrankheiten, Wien, Austria

Wir berichten über eine 46-jährige HIV-infizierte Patientin mit disseminierten bis zu $5 \mathrm{~cm}$ im Durchmesser haltenden, 
kutanen Ulzera bedeckt mit massiven teils austernschalenartigen Krusten. Die Patientin war auswärts unter der Verdachtsdiagnose „Ecthymata" antibiotisch mit Cefazolin bzw. Kefzol über mehrere Tage anbehandelt und nach Einlangen einer positiven HIV/Syphilisserologie an unsere Station transferiert worden.

Anamnestisch waren die Läsionen etwa 4 Wochen zuvor beginnend an den beiden Armen, dann übergehend auf Stamm und unterer Extremität zusammen mit Fieberschüben aufgetreten. Weiters war im dermatologischen Status eine diffuse Alopezie auffällig. Anogenital bzw. oropharyngeal waren keine Pathologien erkennbar. Die CD4-Zellzahl der Patientin betrug $155 / \mathrm{mm}^{3}$, sie war im wesentlichen hinsichtlich der HIV Infektion bis dato symptomfrei (CDCStadium: A3).

Ein direkter Erregernachweis mittels Dunkelfeldmikroskop aus dem Sekret der Hautläsionen war aufgrund der laufenden antibiotischen Therapie nicht mehr erfolgreich. Laborchemisch zeigte sich neben mäßiggradig erhöhten Entzündungsparametern eine komplett positive Syphilisserologie (VDRL quantitativ 1:32) mit einem reaktiven TPIgM ELISA. Histologisch konnte läsional ein typisches plasmazellreiches Entzündungsmuster dargestellt werden, sodass in Zusammenschau mit den erhobenen klinischen und serologischen Befunden die Diagnose Syphilis maligna (Stadium Syphilis II) gestellt wurde. Nach drei Gaben Retarpen (2,4 Mio. IE Benzathinpenicillin i.m.) im wöchentlichen Intervall kommt es allmählich zur Regression der Hauteffloreszenzen.

Die Syphilis maligna ist eine seltene Form der sekundären Syphilis, die sich dermatologisch mit ulceropapulösen, rasch generalisierenden Läsionen präsentiert. Als Begleiterscheinungen können neben Fieber und Appetitlosigkeit noch Gelenksschmerzen auftreten. Diese Form der Syphilis wurde früher zumeist mit Immundefizienz im Rahmen einer Mangelernährung assoziiert, heutzutage ist vor allem bei HIV-infizierten Personen an diese Form der Frühsyphilis zu denken.

\section{P474}

\section{Untersuchung zur Bedeutung der Syphilis bei} MSM mit HIV Ko-Infektion

Alexander Bubnov ${ }^{1}$, Janine Zweigner ${ }^{2}$, Carmen Zedlack ${ }^{1}$, Heiko Jessen ${ }^{1}$

${ }^{1}$ Gemeinschaftspraxis Jessen-Jessen-Stein, Berlin, Germany, ${ }^{2}$ Charité Universitätsmedizin Berlin, Institut für Mikrobiologie und Hygiene, Berlin, Germany

Fragestellung: Die Inzidenz der Syphilis hat in den letzten Jahren besonders bei MSM zugenommen, wobei eine hohe Rate der Ko-Infektionen von Syphilis mit HIV besteht. Eine Syphilisinfektion begünstigt die Transmission von HIV. Außerdem ist die Anzahl HIV-Infizierter zunehmend, bei denen eine schnellere Progression in die tertiäre Syphilis beobachtet wird. Die serologische Diagnostik der Syphilis ist bei ko-infizierten HIV-Patienten erschwert, mit dem Ergebnis, dass die Anzahl falsch-negativer Befunde steigt und nach erfolgreicher Therapie häufiger der Abfall der Antikörpertiter fehlt. Das Ziel der vorliegenden Studie ist es, zu untersuchen, wie sich bei HIV-Infizierten die Diagnostik, Klinik und der Verlauf der Syphilis im Vergleich zu HIV-negativen Patienten darstellt.

Methode: Retrospektive Datenanalyse von Patienten, die in einer HIV-Schwerpunktpraxis im Zeitraum von 20062008 wegen einer Syphilis behandelt wurden.

Ergebnis: 164 Patienten mit Syphilis wurden in der Studie untersucht, wobei 97 Patienten HIV-positiv und 66 HIV-negativ waren. 6 Patienten (9\%), die zum Zeitpunkt der Syphilisdiagnose HIV-negativ waren, infizierten sich im weiteren Verlauf mit HIV. Zum Zeitpunkt der Syphilisdiagnose waren 69 (71 \%) der HIV-positiven Patienten symptomatisch, dagegen nur $38(57,5 \%)$ der HIV-negativen. Bei $10(10,2 \%)$ der HIV-positiven Patienten zeigte sich klinisch eine Neurosyphilis, die in 5 Fällen durch Liquorserologie bestätigt werden konnte, dagegen konnte bei keinem der HIV-negativen Patienten eine Neurosyphilis festgestellt werden. Bei $24(24,7 \%)$ HIV-positiven konnten neben der Syphilis weitere Ko-Infektionen festgestellt werden, bei HIV-negativen 13 mal, wobei Gonokokken und Hepatitis $\mathrm{C}$ in beiden Gruppen gleichstark vertreten waren, dagegen die Chlamydieninfektion vor allem bei den HIVnegativen, die Hepatitis B überwiegend bei den HIV-positiven Patienten auftrat.

Zusammenfass ung: Patienten mit HIV zeigten im Vergleich zu HIV-negativen bei einer Ko-Infektion mit Syphilis in erhöhtem Maße klinisch und serologisch eine Neurosyphilis. Weitere Analysen sind notwendig, um die Auswirkung von HIV auf den Verlauf der Syphilis, v.a. die Entwicklung der Neurosyphilis besser zu diagnostizieren und behandeln zu können.

\section{$P 475$}

\section{Conservative antibiotic management of infected totally implantable venous access devices (TIVAD). A retrospective analysis of the AVK cohort}

Marlen Wieczorek, Christian Traeder, Dirk Hampf, Keikawus Arastéh

Vivantes Auguste-Viktoria-Klinikum Berlin, Innere 2, Infektiologie, Berlin, Germany

Objectives: In the Vivantes Auguste-Viktoria-Klinikum Berlin 17.043 HIV patients were treated between 1985 and 2008. TIVAD are regularly implanted to secure long-time central venous access in patients receiving chemotherapy, parenteral nutrition or in patients with impaired status of veins. These systems are vulnerable to local or systemic infections. This report focuses on the outcome of conservative antibiotic treatment of infected TIVAD.

Methods: All HIV positive patients presenting in the $\mathrm{AVK}$ are registered in the electronic data base of the department of infectiology. We conducted a retrospective analysis among all patients, who were treated in our in-patientdepartment with infected TIVAD between 06/2005 and 12/2008 (37 infected TIVAD in 27 patients).

Results: Out of 37 infected TIVAD only 2 systems could be ultimately saved by conservative treatment. These two were treated with daptomycin. However, 4 other cases also treated with daptomycin could not be saved. Most patients were in stadium C3 $(18 / 27,66.7 \%)$ or B3 $(4 / 27,14.8 \%)$ and received ART (19/27, 70.4\%). CD4-count at admission was between $3 / \mathrm{ul}$ and $520 / \mathrm{ul}$. The main reason for port-implantation was parenteral nutrition $(22 / 27,81.5 \%)$. From date of implantation, ports lasted between $6 \mathrm{~d}$ and $2.228 \mathrm{~d}$. 3 out of 27 patients died due to port-infection and concomitant diseases. Among the 37 incidences, pathogenic bacte- 
ria could be isolated in 28 cases (gram-positive 15/37, $40.5 \%$, gram-negative $7 / 37,18.9 \%$, multiple $6 / 37$, $16.2 \%)$. A variety of antibiotics was used. Additionally, antimycotic drugs were added in 2 cases with detection of candida sp.

Discussion: As reported previously, TIVAD infection rate in HIV-patients is relatively higher than in other populations. In our cohort, gram-positive bacteria were responsible for most TIVAD infections, followed by gramnegative bacteria. Fungal infections occurred only in multiple infected TIVAD. Contrary to current literature, only a minority of ports could be saved by conservative antibiotic therapy.

\section{P476}

\section{Meningomyelitis complicating primary HIV infection}

Hubert Schulbin ${ }^{1}$, Hartmut Stocker ${ }^{1}$, Siegfried Köppe ${ }^{2}$, Peter Kreckel ${ }^{2}$, Keikawus Arasteh ${ }^{1}$

${ }^{1}$ Vivantes Auguste-Viktoria Klinikum, Gastroenterologie und Infektiologie, Berlin, Germany, ${ }^{2}$ Praxis Köppe \& Kreckel, Berlin, Germany

Introduction: Primary HIV infection occasionally is associated with neurological disease. Peripheral neuropathy, atactic neuropathy, radiculopathy, facial palsy meningoencephalitis and others have been reported. Acute meningomyelitis is an extremely rare complication of primary HIV infection. A case of meningomyelitis occurring five weeks after documented HIV infection is reported here.

Case report: A 44-year-old man presented with acute mononucleosis-like syndrome three weeks after exposure to HIV. In the following week HIV seroconversion was documented. Subsequently he complained of cramping pain in his left thigh followed by a bilateral muscular weakness that finally turned into a painful spastic paraparesis of both legs. CSF analysis showed purely lymphocytic pleocytosis of 122 cells $/ \mu 1$ with total protein and glucose levels of $584 \mathrm{mg} / \mathrm{L}$ and $52 \mathrm{mg} / \mathrm{dL}$ respectively. CSF gram stain and culture were negative. There was no evidence of CNS infection with CMV, HSV and VZV by PCR. Enterovirus PCR was positive, however a retest did not confirm the result. MRI studies revealed signal changes in the thoracic spinal cord corresponding to an acute inflammatory process. Antiretroviral therapy and high dose glucocorticoids were started immediately accompanied by intense physiotherapy which resulted in incomplete recovery.

Discussion: Meningomyelitis is a rare complication of primary HIV infection. The prompt institution of antiretroviral therapy and high dose glucocorticoids may improve the outcome of this debilitating disorder.

\section{$P 477$}

Identical liver fibrosis in a cohort of HIV/HCV-coinfected patients on HAART as compared to HIV-negative HCV-patients assessed by transient elastography

Frank Grünhage ${ }^{1}$, Jan-Christian Wasmuth ${ }^{2}$, Simon Herkenrath $^{2}$, NataschaVidovic ${ }^{3}$, Georg Goldmann ${ }^{3}$, Jürgen Rockstroh ${ }^{2}$, Frank Lammert ${ }^{1}$, Johannes Oldenburg $^{3}$, Tilman Sauerbruch ${ }^{2}$, Ulrich Spengler ${ }^{2}$

${ }^{1}$ Universität des Saarlandes, Medizinische Klinik II, Homburg, Germany, ${ }^{2}$ Universitätsklinikum Bonn, Medizinische Klinik I, Bonn, Germany, ${ }^{3}$ Universitätsklinikum Bonn, Institut für Experimentelle Hämatologie und Transfusionsmedizin, Bonn, Germany

Background: The natural course of HCV-associated liver disease is worse in HIV-infected patients due to immunodeficiency. The latter may be improved by highly active antiretroviral therapy (HAART), resulting in reduced liver-related mortality in HIV/HCV-co-infected patients.

Methods: To analyse the effects of HAART on progression of liver fibrosis we compared hepatic fibrosis by transient elaystography in a cross-sectional comparison between HCV-mono-infected $(n=84)$ and HIV/HCV-co-infected $(n=57)$ patients presenting at our outpatient department in 2007.

Results: There was no significant difference in the distribution of liver stiffness between mono- and double-infected patients $(14.4 \mathrm{kPa}(10.8-18.2)$ versus $12.4 \mathrm{kPa}(9.1-$ $16.1)$, mean $(95 \%-\mathrm{CI}))$. In the $8 \mathrm{HIV}+$ patients with CD4 counts $<200 / \mu 1$ liver stiffness was markedly greater $(18.4$ $\mathrm{kPa}(0.8-36.0))$ than in HIV+ patients with preserved immunity (11.5 kPa (8.4 -15.0)), although not statistically significant $(\mathrm{p}=0.187)$.

Conclusions: These findings confirm an improved prognosis of chronic hepatitis $\mathrm{C}$ in $\mathrm{HIV}+$ patients under effective HAART, and may be a hint that fibrosis progression in well-treated $\mathrm{HIV}+$ patients will no longer be different from that in $\mathrm{HCV}$-mono-infected patients.

\section{P478}

Severe Leucencephalopathy as aseptic form of immune reconstitution inflammatory syndrome in the brain in Caucasian and African patients

Adrian Ringelstein ${ }^{1}$, Christian Oelschlaeger ${ }^{2}$, Ingo W. Husstedt ${ }^{2}$, Christian Mathys ${ }^{1}$, Andreas Saleh ${ }^{1}$, Gabriele Arendt ${ }^{3}$

${ }^{1} \mathrm{HHU}$ Düsseldorf Radiologie, Düsseldorf, Germany, ${ }^{2} \mathrm{WWU}$ Muenster Neurologie, Muenster, Germany, ${ }^{3} \mathrm{HHU}$ Düsseldorf Neurologie, Düsseldorf, Germany

Objective: CNS Immune Reconstitution Inflammatory Syndrome (IRIS) after highly active antiretroviral therapy (HAART) may become manifest in form of aseptic inflammation presenting as severe leucoencephalopathy in HIV1 -positive patients

Design: We describe a case series of immunocompromised HIV-1-positive patients who were started on HAART. All of them had clinical, laboratory follow-up tests and cerebral MRI in order to investigate the course and the underlying pathophysiology of an aseptic form of IRIS. One patient died and we performed a neuropathological examination. 
Methods: HIV-1-positive patients on HAART were treated with corticosteroids after developing IRIS, although Methyl prednisolone has an additional immunosuppressive effect and represents the main therapy in this situation.

Results: No infectious agent was detected in all patients before and during HAART. Three of four immunocompromised patients were successfully treated with corticosteroids while HAART was never interrupted and survived up to now. One African patient died within two days despite intensive care due to cerebral edema.

Conclusions: Starting HAART, HIV-1-positive patients may develop an aseptic type of IRIS of the CNS without any detectable opportunistic infection in form of severe leucoencephalopathy. Treatment with corticosteroids and reduction of HAART are therapeutic options. The severe rapid progressive form may represent as special form linked to the different history of earlier infections in Africa or ethnic reasons.

\section{P479}

\section{Autonomous nervous system activity and glucose metabolism in HIV-patients receiving antiretroviral therapy}

Maximiliane Wiese, Michael Kaspari, Ulrike Möbius, Reinhold E. Schmidt, Georg M. Behrens

Hannover Medical School, Clinic for Immunology and Rheumatology, Hannover, Germany

Background: Lipodystrophy is a side effect of antiretroviral therapy and the autonomous nervous system (ANS) has been proposed to contribute peripheral fat loss and metabolic disturbances.

Methods: Prospective cross-sectional study of 38 HIVpatients with and without lipodystrophy receiving antiretroviral therapy and 15 therapy-naïve HIV-patients . After an overnight fasting patients underwent an oral glucose tolerance test (OGGT), indirect calorimetry, assessment of autonomous nervous system activity (Finometer ${ }^{\circledR}$ ), anthropometric measurements, and DEXA. Constitutive individual differences in ANS activity were assessed by monitoring of the standard deviations of each indicator about its mean value of inter-beat interval and systolic blood pressure during the final 60 s of a verbal serial subtraction task or metronome-paced respiration (six respirations cycles/min-1).

Results: Patients on therapy had dyslipidemia with significantly higher total cholesterol, total triglycerides, higher ApoA2, Abp E, Lp(a), and lower HDL-cholesterol $(p<0.05)$. Therapy was associated with insulin resistance and signs of beta-cell dysfunction as indicated by higher $120 \mathrm{~min}$ glucose during OGTT $(5.1 \pm 0.3$ vs. $6.3 \pm 0.3$ $\mathrm{mmol} / \mathrm{l}, \mathrm{p}=0.007), 120 \mathrm{~min}$ insulin $(30.8 \pm 5.1 \mathrm{vs} .57 .7 \pm$ $7.8 \mu \mathrm{U} / \mathrm{ml}, \mathrm{p}=0.006)$ and $120 \mathrm{~min}$ proinsulin $(2.9 \pm 0.6$ vs. $7.7 \pm 1.2 \mathrm{pmol} / 1, \mathrm{p}=0.001)$. HOMA-IR index was higher in patients on therapy $\left(1.1 \pm 0.1\right.$ vs. $1.7 \pm 0.2 \mathrm{mmol}{ }^{\prime} \mu \mathrm{U}$ $\left.\mathrm{ml}^{2}, \mathrm{p}=0.075\right)$. Patients receiving antiretroviral therapy with low ANS activity had significantly higher $120 \mathrm{~min}$ glucose concentrations as compared to patients with low ANS activity $(6.9 \pm 0.5$ vs $5.5 \pm 0.4 \mathrm{mmol} / 1, \mathrm{p}=0.041)$ and a trend towards a higher area-under the curve for insulin $6195.8 \pm 718.0$ vs $8825.3 \pm 1470.3 \mu \mathrm{U} / \mathrm{ml})$ and C-peptide $(1060.3 \pm 64.2$ vs. $1295.0 \pm 139.3 \mathrm{ng} / \mathrm{ml}, \mathrm{p}<0.09)$. Basal resting energy consumption and during OGTT was signifi- cantly lower in patients with low ANS activity and these patients had a lower central-to-peripheral fat ratio $(1.7 \pm$ 0.2 vs. $2.2 \pm 0.2, p=0.078$ ) but serum lipid were not different.

Conclusion: These data would suggest that low ANS activity may be associated with impaired glucose homeostasis in HIV-patients receiving antiretroviral therapy.

\section{$P 480$}

\section{Do changes of fractional anisotropy predict loss of cognitive functions in HIV patients?}

\begin{abstract}
Bianca Stubbe-Dräger ${ }^{1}$, Michael Deppe ${ }^{1}$, Siawoosh Mohammadi ${ }^{1}$, Harald Kugel ${ }^{2}$, Nora Gregor ${ }^{1}$, Stefan Evers $^{1}$, Erich-B. Ringelstein ${ }^{1}$, Gabriele Arendt ${ }^{3}$, Stefan Knecht ${ }^{1}$, Ingo Husstedt ${ }^{1}$
\end{abstract}

${ }^{1}$ Universitätsklinikum Münster, Klinik und Poliklinik für Neurologie, Münster, Germany, ${ }^{2}$ Universitätsklinikum Münster, Institut für klinische Radiologie, Münster, Germany, ${ }^{3}$ Heinrich-Heine-Universität Düsseldorf, Neurologische Klinik, Düsseldorf, Germany

Background: Diffusion tensor imaging is more sensitive than structural MRI to detect subtle white matter (WM) changes. We investigated HIV 1 infected patients with respect to subtle WM changes and analysed whether these changes were associated with cognitive dysfunction .

Methods: Nineteen male HIV patients were included for analysis. They underwent magnetic resonance imaging (MRI) of the brain with MRI diffusion tensor imaging (DTI) and also routine fluid attenuated inversion recovery and fast spin echo $\mathrm{T} 1$ and $\mathrm{T} 2$ weighted imaging. Regional WM integrity was assessed by whole-brain fractional anisotropy (FA) maps derived from DTI. The FA maps of the HIV patients were statistically compared to a group of 19 age matched healthy control subjects by regions of interest (ROIs). Cognitive functions were measured by neuropsychological testing.

Results: Structural MRI of 12 HIV patients were normal $\left(\mathrm{HIV}_{\text {normal }}\right)$, MRI of $7 \mathrm{HIV}$ patients showed unspecific mild abnormalities (mild atrophy / unspecific focal lesions) $\left(\mathrm{HIV}_{\text {lesions }}\right)$. Compared to healthy controls FA of the corpus callosum, temporal and posterior region was significantly reduced in HIV patients, for the frontal region, there was a mild trend towards reduction. This was the same, comparing the subgroup $\mathrm{HIV}_{\text {lesions }}$ to healthy controls. For $\mathrm{HIV}_{\text {lesions }}$ patients compared to $\mathrm{HIV}_{\text {normal }}$ patients, there was a significant decrease of FA in the corpus callosum.

There were no significant FA differences between patients with and those without neuropsychological evidence of HIV associated neurocognitive disorder.

Conclusion: HIV patients show subtle WM lesions as compared to healthy controls. Even if routine MRI is normal, DTI detects WM alterations in distinct regions. These regions are in concordance with the regions showing mild alterations on structural MRI in more severely affected HIV patients. However, at the present stage, more studies are needed to draw conclusions from DTI changes to therapy indications e.g. for antiretroviral medications. 


\subsection{Diagnostik / Diagnostics}

\section{$P 481(P W)$}

Characterization of revertant HIV from patients in the German seroconverterstudy: viral fitness and in vitro selection of AZT resistance

Kathrin Keeren ${ }^{1}$, Livia Schünadel ${ }^{1}$, Ev a Brandt ${ }^{1}$, Sybille Somogyi ${ }^{1}$, Klaus Fischer ${ }^{2}$, Bettina Hintsche ${ }^{3}$, Gerd Klausen $^{3}$, Heiko Jessen ${ }^{4}$, Barbara Bartmeyer ${ }^{5}$, Osamah Hamouda ${ }^{5}$, Claudia Kücherer ${ }^{1}$, HIV-1 Seroconverter Study Group

${ }^{1}$ Robert Koch Institut, P11, Berlin, Germany, ${ }^{2}$ Gemeinschaftspraxis Schranz/ Fischer, Schwerpunktpraxis HIV und Hepatiden, Berlin, Germany, ${ }^{3}$ Gemeinschaftspraxis Hintsche/ Klausen, Berlin, Germany, ${ }^{4}$ Gemeinschaftspraxis Jessen-Jessen-Stein, Berlin, Germany, ${ }^{5}$ Robert Koch Institut, FG34, Berlin, Germany

Backround: Revertant substitutions T215 ACDEGHILS of the reverse trans criptase (RT) evolve from the AZT selected $\mathrm{T} 215 \mathrm{Y} / \mathrm{F}$ resistance mutation once AZT is withdrawn. Revertant HIV are at higher risk to treatment failure as compared to sensitive wild type (WT). Predicition algorithms vary with respect to revertant substitutions T215AN. The T215A and the WT codons show a 2-nucleotide (nt) change from $\mathrm{T} 215 \mathrm{Y}$ as compared to 1 -nt change of the $\mathrm{T} 215 \mathrm{C}$ codons. Therefore, viral fitness and in vitro selection of AZT-resistance from a T215C and T215A mutant strain was compared to WT.

Methods: HIV pol-RT-PCR fragments carrying T215A (GCC) or T215C (TGC) were cloned into pBSSK. The corresponding WT (ACC) was obtained by site-directed mutagenesis. Recombinant HIV were constructed by cloning the pol-inserts into the HIV deletion vector pNL4.3DPRT. Infected CEMx 174 cells were exposed to increasing AZT concentrations (doubling at each passage performed depending on the number of syncytia observed). RT mutations were identified by sequencing. Replication capacity of recombinant HIV was determined in growth kinetics (p24 measurement).

Results: Evolution to the resistant $\mathrm{T} 215 \mathrm{C} / \mathrm{Y}$ (TRC) became obvious within 7 passages $(1.92 \mu \mathrm{M}$ AZT) of the T215C strain. In contrast, NL4.3 (WT), A215T and T215 A isolates neither showed mutations at position 215 until passage $13(123 \mu \mathrm{M})$. Only other mutations not related to AZT resistance occurred. T215A variants replicated less efficiently than WT $(57 \%)$ whereas $\mathrm{T} 215 \mathrm{C}$ recombinants were similar to WT.

Conclusion: In conclusion, T215A substitution should be considered as an AZT sensitive polymorphism of reverse transcriptase. Its lowered replication capacity is in agreement with its reversion to WT which we observed in vivo during follow-up in the seroconverter cohort.

\section{P482 (PW)}

\section{Delayed detection of HIV seroconversion using $4^{\text {th }}$ generation HIV rapid test \\ Gerrit Mohrmann ${ }^{1}$, Hans-Jürgen Stellbrink ${ }^{2}$, Christian Noahl}

${ }^{1}$ Labor Lademannbogen, Hamburg, Germany, ${ }^{2}$ Infektionsmedizinisches Centrum Hamburg (ICH), Hamburg, Germany

Objective: Early diagnosis of primary HIV infection (PHI) might help to reduce transmission. We as sessed the reliability of a new fourth generation HIV rapid test in this phase.

Methods : 28 sera obtained during PHI were analyzed using the Determine ${ }^{\circledR}$ HIV $1 / 2 \mathrm{Ag} / \mathrm{Ab}$ Combo test (Inverness Medical), an immunoassay-based $4^{\text {th }}$ generation rapid test for detection of p24 antigen and HIV-1 and HIV-2 antibodies. The Architect HIV Ag/Ab Combo test (Abbott Diagnostics) served as a reference method. PHI was defined as a reactive screening test and a negative immunoblot or an evolving immunoblot pattern (positive for p24 and/or gp160/gp120 antibodies), confirmed by positive RT-PCR. Thirty sera of chronically infected subjects (CHI) were analyzed as controls. Furthermore, the HIV seroconversion panel PRB966 (SeraCare) consisting of 10 samples collected over a time period of 55 days after first bleed was tested.

Results : Nine of 28 PHI samples $(32,1 \%)$ tested negative with the rapid test. All reacted positive with the reference test. Of 19 samples reactive in the rapid test, $5(26,3 \%)$ tested positive for p 24 antigen, but not for antibodies. In contrast, all $30 \mathrm{CHI}$ samples were reactive. Samples 8, 9 and 10 of the seroconversion panel (days 44,48 , and 51 after first bleed) reacted in the reference assay, whereas only sample 10 (day 51) was reactive in the rapid test.

Conclusion: This rapid test detects chronic HIV infection with high reliability. During PHI, however, it was falsely negative in $\sim 1 / 3$ of cases. PHI samples reactive to only p24 antigen (26.3\%) most likely would have evaded detection by a $3^{\text {rd }}$ generation assay. Reactivity was delayed by 7 days compared with the Architect test.

Despite improved sensitivity of the $4^{\text {th }}$ generation rapid test, detection of PHI still needs improvement. Conventional testing should be preferred when PHI is suspected.

\section{P483 (PW)}

\section{Predictors for CXCR4-tropism: \\ CD4-nadir and the use of the enhanced sensitivity (ES) trofile assay}

Eva Wolf ${ }^{1}$, Patrick Braun ${ }^{2}$, Lothar Schneider ${ }^{3}$, Anna Balogh ${ }^{1}$, Heribert Knechten ${ }^{2}$, Martin Karwat ${ }^{4}$, Franz Mosthaf ${ }^{5}$, Albrecht Ulmer ${ }^{6}$, Robert Ehret ${ }^{2}$, Hans Jaeger ${ }^{7}$

${ }^{1}$ MUC Research, Munich, Germany, ${ }^{2} \mathrm{PZB}$, Aachen, Germany, ${ }^{3}$ Private Practice, Fuerth, Germany, ${ }^{4}$ Private Practice, Munich, Germany, ${ }^{5}$ Private Practice for Hematology, Oncology and Infectious Diseases, Karlsruhe, Germany, ${ }^{6}$ Private Practice, Stuttgart, Germany, ${ }^{7}$ HIV Research and Clinical Care Centre, Munich, Germany

Background: Cohort studies showed that about $80 \%$ of ART-naïve and $50 \%$ of pre-treated patients harbor CCR5tropic (R5)-virus only. We examined the epidemiology of viral tropism and its clinical correlates in a German HIV- 
cohort using the phenotypic Trofile standard assay or the enhanced sensitivity (ES) Trofile assay with a sensitivity to detect CXCR4-tropic (X4)-virus down to $0.3 \%$.

Methods: Clinical characteristics of patients harboring X4-virus were compared with patients harboring R5-virus only. Multivariate logistic regression analysis was used to evaluate the factors independently as sociated with the presence of $\mathrm{X} 4$-virus. Variables included in the model were CD4-count, CD4-nadir, viral load, history of AIDS, treatment-experience and the tropism assay used (Trofile vs. Trofile ES).

Results: Tropism test results and clinical variables were available for 146 HIV-patients. 33 patients were ARTnaive. Standard Trofile was used in 100 patient samples, Trofile ES in 46 samples. X4-virus was detected in $27 \%$ of patient samples (Trofile: $25 \%$, Trofile ES: $33 \%$, p=n.s.).

The presence of X4-virus in the various clinical categories was as follows:

CD $4 £ 350$ vs. $>350 / \mu 1: 36$ vs. $17 \%, p=0.01 ; C D 4$-nadir $£ 50$ vs. $>50 / \mu 1$ : 56 vs. $21 \%, \mathrm{p}=0.001$; rel. $\mathrm{CD} 4<20$ vs. $\geq 20 \%: 33$ vs. $17 \%, \mathrm{p}=0.04$; AIDS vs. no AIDS: $41 \%$ vs. $23 \%, \mathrm{p}=0.05$; pre-treated vs. ART-naive patients: 30 vs. $18 \%$, p=n.s. Median viral load did not differ significantly in patients with R5 or X4-/dual-mixed-tropic virus (4.1 vs. $4.2 \mathrm{log}$ ).

In multivariate analysis, only CD4-nadir $£ 50 / \mu 1$ (OR 5.2, 95\%-CI 1.5-17.3) and the use Trofile ES (OR 2.4, 95\%-CI 1.0-5.9) were significantly associated with the presence of X4-virus.

Conclusions: In this HIV-cohort, CD4-nadir and the use of Trofile ES were independently associated with the presence of X4-tropic virus. Using a more sensitive assay capturing also minority $\mathrm{X} 4$-tropic virus populations may artificially withhold patients from using a CCR5-antagonist that could benefit from this new compound.

\section{P484 (PD)}

\section{HIV coreceptor tropism in treatment-naive patients newly diagnosed at a late stage of HIV-infection}

Benedikt Simon ${ }^{1}$, Armin Rieger ${ }^{2}$, Mario Sarcletti ${ }^{3}$, Brigitte Schmied ${ }^{4}$, Elisabeth Puchhammer-Stöckl'

${ }^{1}$ Medizinische Universität Wien, Institute for Clinical Virology, Vienna, Austria, ${ }^{2}$ Medizinische Universität Wien, Department of Dermatology, Vienna, Austria, ${ }^{3}$ Medizinische Universität Innsbruck, Department of Dermatology, Innsbruck, Austria, ${ }^{4}$ Sozialmedizinisches Zentrum Baumgartner Höhe Otto-Wagner-Spital, Department of Pulmology, Vienna, Austria

Background: Human Immunodeficiency virus (HIV) cell entry is mediated by interaction of virus protein gp120 with the host cell CD4 receptor and with chemokine coreceptors CCR5 or CXCR4. Coreceptor preference is associated with viral cell tropism and was previously supposed to change over time in an infected host. Since the availability of coreceptor antagonists the coreceptor tropism of the HIV population emerging in a specific host becomes a topic of substantial importance. In Austria, about $26 \%$ of all HIV infections are diagnosed at a late clinical stage. The aim of the present study was to analyse HIV-1 coreceptor tropism in patients with late diagnosis of the HIV-infection and to determine the possibility for use of CCR5 coreceptor antagonists for treatment of these patients.
Material and methods: Late diagnosis was defined by a $\mathrm{CD}^{+}$cell count of $\langle 200 / \mu 1$ at the first diagnosis of HIVinfection. Serum samples of patients with a late diagnosis were retrospectively analysed. The V3 loop sequence of the virus was amplified using a nested PCR protocol and coreceptor tropism was determined genotypically by sequencing and by evaluating the viral tropism using the internet tool Geno2Pheno coreceptor.

Results: Preliminary results indicate that $70 \%$ of the patients investigated so far were infected with CCR5-tropic HIV-1 strains while in 30\%, CXCR4- or dual-tropic HIV-1 strains could be detected during their late stage infection. Average $\mathrm{CD}^{+}{ }^{+}$cell count was $92 / \mu 1$ in patients with CCR5tropic strains and $91 / \mu 1$ in patients where CXCR4-/dualtropic strains were detected. Average viral load at time of diagnosis was $100,000 \mathrm{copies} / \mathrm{ml}$ in both patient populations.

Conclusion: In the majority of the patients, CCR5 coreceptor antagonists could be used. In this small patient group progression markers of late presenters with CCR5tropic HIV-1 strains seem so far to be similar to that of late presenters with CXCR4- or dual-tropic HIV-1 strains.

\section{$P 485$ (PD)}

\section{Selection of peptide ligands for CXCR4-} using HIV-1 by the phage display technology

\section{Ralf Duerr ${ }^{1}$, Kalle Möbius ${ }^{2}$, Oliver Sander ${ }^{3}$, Jutta Eichler $^{2}$, Ursula Dietrich ${ }^{1}$}

${ }^{1}$ Georg-Speyer-Haus, Molecular Virologie, Frankfurt, Germany, ${ }^{2}$ Friedrich-Alexander University, Department of Chemistry and Pharmacy, Erlangen-Nürnberg, Germany, ${ }^{3}$ Max-Planck-Institute for Informatics, Computational Biology and Applied Algorithmics, Saarbrücken, Germany

Background: HIV strains can differ according to their coreceptor usage: those using either the chemokine receptor CCR5 for entry (R5-viruses) or CXCR4 (X4-viruses). Since the approval of the first CCR5 inhibitor Maraviroc, which only inhibits R5-viruses, highly specific tests for the detection of a minority of $\mathrm{X} 4$ viruses are needed to detect their existence before start of therapy or their appearance during therapy. For this purpose, we are screening for peptides that specifically bind to X4-viruses and not to R5viruses, based on the phage display technology.

Methods: Phage display screenings were performed using synthetic V3 peptides as targets. We used two different cyclic X4 peptides for positive selections and an R5 peptide for negative selection. After three rounds of positive and two rounds of negative selection, we analyzed 400 phage clones by ELISA and sequenced the displayed peptides of the phages.

Results: From three different commercially available phage libraries, we selected five promising phage clones. Those phages contained peptides corresponding to two linear 12 mers, two cyclic 7 mers and one linear 7 mer. In ELISAs they showed enhanced binding to either one or both of the synthetic X4 peptides. Furthermore, we identified similarities of the peptides to motifs of the extracellular loops of the CXCR4 receptor, which represent the native binding partners of the V3 loops of HIV. These phages and the corresponding peptides will now be analyzed for their binding specificities to a panel of X4 and R5 pseudoviruses. 
Conclusion: V3 peptides from particular X4 and R5 strains are suited as targets for phage display screenings to select specific peptide ligands.

This project is supported by the BMBF and part of the CorusProject.

\section{$P 486$ (PD)}

Performance of genotypic coreceptor measurement using geno 2 pheno[coreceptor] in B- and non-B HIV subtypes in a large cohort of therapy-experienced patients

Hauke Walter ${ }^{1}$, Eva Wolf ${ }^{2}$, Patrick Braun ${ }^{3}$, Martin Däumer ${ }^{4}$, Alexander Thielen ${ }^{5}$, Christian Noah 6 , Nadine Sichtig ${ }^{7}$, Harm Müller ${ }^{8}$, Martin Stürmer ${ }^{9}$, Thomas Lengauer ${ }^{5}$, Rolf Kaiser ${ }^{7}$, Thomas Berg ${ }^{10}$, Martin Obermeier 10

${ }^{1}$ Institute for Clinical and Molecular Virology, German NRC for Retroviruses, Erlangen, Germany, ${ }^{2}$ MUC Research, Munich, Germany, ${ }^{3}$ PZB Aachen, Aachen, Germany, ${ }^{4}$ Institute of Immunology, Kaiserslautern, Germany, ${ }^{5}$ Max Planck Institute for Informatics, Saarbrücken, Germany, ${ }^{6}$ Laboratory Lademannbogen, Hamburg, Germany, ${ }^{7}$ Institute of Virology, Cologne, Germany, ${ }^{8}$ Laboratory Fenner \& Co, Hamburg, Germany, ${ }^{9}$ Institute of Virology, Frankfurt, Germany, ${ }^{10}$ Laboratory Berg, Berlin, Germany

Coreceptor tropism determination is mandatory for CCR5antagonists. Recently, the validated standard Trofile assay has been replaced by an enhanced version (Trofile-ES) detecting $0.3 \%$ CXCR4-tropic plasma minorities. For Trofile-ES and the faster genotypic approaches which can also be used in cases of undetectable viral load, no prospective clinical validation is available. Here, we compare results of Trofile assays with predictions from geno 2 pheno [coreceptor] (g2p) in treatment-experienced patients and analyze the impact of subtypes.

Coreceptor usage was determined with one of the Trofile assays and by standard bulk-sequencing of gp 120-V3-loop. Tropism and subtype were predicted using $\mathrm{g} 2 \mathrm{p}$ and the REGA-subtyping tool. Fisher's exact test was used to assess statistical significance.

For 738 isolates, results of one Trofile assay (619 standard, 119 Trofile-ES) and g2p were available. The standard (Trofile-ES) assay phenotyped $33.1 \%(39.5 \%)$ of the samples as Dual/Mixed $(\mathrm{D} / \mathrm{M})$-tropic $(\mathrm{p}=0.11)$. Using standard Trofile (Trofile-ES) as reference, sensitivity [proportion of correctly detected $\mathrm{D} / \mathrm{M}$ viruses] and specificity [proportion of correctly classified R5-viruses] of g2p were $63.4 \%$ $(59.6 \%)$ and $89.6 \%(91.7 \%)$. To adjust for the increased sensitivity of the Trofile-ES, the False-Positive-Rate of g2p was increased to $12.5 \%$ (sensitivity $65.9 \%$, specifity $89.6 \%$ ).

The subtype-predictor of geno2pheno classified $35.3 \%$ of $642 \mathrm{~B}$-isolates as $\mathrm{D} / \mathrm{M}$, but only $22.8 \%$ of the 92 non-B isolates $(\mathrm{p}=0.01$, subtyping concordance to REGA was $96 \%$ ). However, the sensitivity of $\mathrm{D} / \mathrm{M}$ predictions was lower for subtype B genotypes than for non-B viruses $(60.3 \%$ vs. $85.7 \%)$.

Although not being significant, this analysis shows that using Trofile-ES more samples were detected to be D/Mtropic, and that $\mathrm{g} 2 \mathrm{p}$ predictions can be adjusted to the higher sensitivity without losing specificity. The clinical impact of these methodological improvements for the suit- ability and the therapy response rates of CCR5 antagonists remains unclear.

Furthermore, the very good agreement between Trofile and $\mathrm{g} 2 \mathrm{p}$ suggests an higher confidence level for tropismpredictions for non-B isolates than for subtype B.

\section{$P 487$}

\section{Development of antigen-based capture ELIS A for serodiagnosis of GB Virus C infection in HIV patients}

Mandy Richter, Susan Jung, Bernhard Fleckenstein, Heide Reil

University Hospital Erlangen, Department of Clinical and Molecular Virology, Erlangen, Germany

Background: The outstanding feature of the non-pathogenic flavivirus GBV-C is its capability to inhibit HIV. Remarkably, not only HIV patients with GBV-C viremia but also those who have cleared their GBV-C viremia by the development of neutralizing $\alpha$-E2 antibodies exhibit a higher survival probability. Due to the lack of commercial detection systems, we developed capture ELISA to investigate the subsets of GBV-C directed antibodies in HIV patients and healthy blood donors.

Methods : cDNA coding for the different GBV-C proteins were cloned into the procaryotic plasmid vector pGEX-6P and expressed in BL2 1 chemically competent E.coli as GST fusion proteins. Recombinant proteins were purified by affinity chromatography and analyzed by SDS-PAGE. 96well MaxiSorp plates were coated with GT-BSA. Fusion proteins were allowed to react for 1 hour. The plates were washed and human sera diluted 1/20 were added and bound antibodies were detected with HRP labeled rabbit a-human $\mathrm{IgG}$. Human sera were obtained from healthy volunteers and HIV positive patients.

Results: Here we present the development of a GBV-C ELISA set, that is able to detect antibodies directed against all regular GBV-C proteins as well as antibodies against putative ORF of the still unknown core. We detected $\alpha$-E2 antibodies in HIV positives and negatives in a comparable manner to the no longer available $\mu$ Plate anti-HGenv ELISA. Interestingly, a small subgroup of $\alpha$-E2 negative individuals was observed, that is not seronegative but positive for other GBV-C antibodies.

Conclusion: The presented ELISA provide a well designed tool for the determination of a more precisely GBV$\mathrm{C}$ seroprevalence based on several $\alpha-G B V-C$ antibodies and not only $\alpha$-E2 antibodies, as it was done in most studies. 


\section{$P 488$}

\section{Underestimation of HIV-1 RNA levels in a commercial real-time PCR assay: reasons and cons equences}

Klaus Korn ${ }^{1}$, Benedikt Weißbrich ${ }^{2}$, Cornelia Henke-Gendo ${ }^{3}$, Albert Heim ${ }^{3}$, Ninon Taylor ${ }^{4}$, Ramona Pauli-Volkert ${ }^{5}$, Josef Eberle 6

${ }^{1}$ Universitätsklinikum Erlangen, Virologisches Institut, Erlangen, Germany, ${ }^{2}$ Universität Würzburg, Institut für Virologie und Immunbiologie, Würzburg, Germany, ${ }^{3}$ Medizinische Hochschule Hannover, Institut für Virologie, Hannover, Germany, ${ }^{4}$ Paracelsus Medical University of Salzburg, 3rd Medical Department, Salzburg, Austria,

5 Ärztezentrum Isartor, München, Germany, ${ }^{6}$ LudwigMaximilians-Universität München, Max von PettenkoferInstitut, München, Germany

Background: Quantification of HIV-1 RNA is crucial for the management of HIV-infected patients. Real-time PCR has substantially improved quantitative nucleic acid detection. For viruses with a high genetic variability, however, it can be difficult to design appropriate real-time PCR primer and probe sets. We identified samples with falsely low or undetectable viral loads by the COBAS TaqMan HIV1 (CTM) assay (Roche Diagnostics) and tried to determine the reasons for these failures.

Methods: Plasma samples were analyzed by the CTM and other assays for quantitative detection of HIV-1 RNA. Patients with discrepant results were identified by systematic screening with different assays or by clinical suspicion. PCR products covering the CTM amplicon were sequenced. Results: Fifteen patients with undetectable or substantially underestimated (20 - >700-fold) viral load in the CTM assay were identified. The most frequent underlying clinical problem was a discrepancy between viral load and clini$\mathrm{cal} /$ immunological status. In one patient, inaccurately low viral load during acute infection was observed. This patient was infected via blood transfusion because the infectious pre-seroconversion donation escaped detection by the CTM assay.

A comparison of gag sequences from patients with underestimation of viral load and control patients without underestimation in the CTM assay showed that in most cases, a single point mutation near the $3^{\prime}$-end of the downstream primer was responsible for the failure of the CTM assay. A database search showed that mutations at this particular site are present in about $2 \%$ of all HIV-1 gag sequences.

Conclusions: The cases described here demonstrate that the CTM assay is highly vulnerable to single point mutations. Thus, for viruses with a high genetic variability, it may be advantageous to base viral load assays on multiple target regions. Recently, a new version of the CTM HIV-1 assay that actually uses a second target region has been released.
P489

Fallbericht: Anhaltend grenzwertiger Westernblot trotz gesicherter HIV-Infektion mit übertragener Multi resistenz

Jens Martin Kittner ${ }^{1}$, Martin Däumer ${ }^{2}$, Bernhard Thiele ${ }^{2}$, Thomas Mertes ${ }^{3}$, Ana-Paula Barreiros ${ }^{1}$, Marcus Schuchmann $^{1}$, Ans gar Rieke 4

${ }^{1}$ Universitätsmedizin, 1. Medizinische Klinik, Mainz, Germany, ${ }^{2}$ Institut für Immunologie und Genetik,

Kaiserslautern, Germany, ${ }^{3}$ Labor Koblenz, Koblenz, Germany, ${ }^{4}$ Klinikum Kemperhof, Koblenz, Germany

Wir berichten über einen 56 jährigen kaukasischen Patienten, bei dem ein HIV-ELISA aus Anlass einer Soor-Oesophagitis und ausgeprägtem Krankheitsgefühl durchgeführt wurde und positiv ausfiel. Zu diesem Zeitpunkt lagen nur noch $20 \mathrm{CD} 4+$ Zellen $/ \mu 1$ vor, die Viruslast betrug mehr als $1 \mathrm{Mio} / \mathrm{ml}$. Mehrere Western-Blots (MP Biomedicals, Chiron, PEI-Eigenproduktion (PD Dr. Schnierle)) konnten zum Zeitpunkt der Erstdiagnose, aber auch noch zwei sowie zehn Monate später (bereits unter stabiler Therapie) als nicht eindeutig positiv interpretiert werden, da nur Antikörper gegen ein bis zwei Banden (gp41 bzw. gp160/120, z.T. p24) nachgewiesen wurden .

Zugleich wies das Virus (Subtyp B) des therapienaiven Patienten in der genotypischen Resistenztestung eine Mehrklassen-Resistenz auf. Unter Verwendung der gängigen Algorithmen war ein fast vollständiger Wirkungsverlust aller zum damaligen Zeitpunkt zugelas senen NRTIs, NNRTIs sowie PIs zu verzeichnen (lediglich Darunavir war noch wirksam). Das Vorliegen eines CXCR4-tropen Virus schloss auch den Gebrauch eines CCR5-Inhibitors aus. Eine Einschränkung in der Wirksamkeit von Enfuvirtide lag hingegen nicht vor.

Erst nach einer testgerechten Eskalation der Therapie auf Tenofovir, Emtricitabin, Zidovudin, Darunavir/r (im EAP) plus Enfuvirtide gelang eine bis heute anhaltende Senkung der Viruslast unter die Nachweisgrenze mit einer klinischen Stabilisierung des Patienten und einem Anstieg der Helferzellzahl auf 249/ $\mu$ l. Nach Verfügbarkeit wurde Enfuvirtide durch Raltegravir ersetzt.

Die Genese der bislang nur schwach und wenig diversifiziert nachweisbaren humoralen Immunantwort gegen HIV ist bislang unklar. Hinweise auf einen zusätzlichen Immundefekt zeigten sich bislang nicht. Wir konnten bei dem Patienten einen HLA B*3501-Genotyp feststellen, der mit raschem Progress assoziiert ist. Weitere Verlaufskontrollen insbesondere des Blots sind geplant.

Wir stellen diesen Fall vor, um auf die Problematik eines anhaltend grenzwertigen Blots hinzuweisen, wodurch unter Einhaltung des üblichen diagnostischen Procederes die Diagnose der HIV-Infektion nicht gestellt worden wäre. Des Weiteren unterstreicht er die Bedeutung einer Resistenztestung vor Initiierung einer antiretroviralen Therapie. 


\section{Verschiedenes / Miscellaneous}

\author{
$P 500(P W)$ \\ Longitudinal modeling of the influence of \\ genetic variants identified through genome- \\ wide analyses and antiretroviral therapy to \\ dyslipidemia in HIV-infected patients \\ Margalida Rotger ${ }^{1}$, Patrick Taffé ${ }^{2}$, Amalio Telenti ${ }^{1}$, \\ Philip Tarr ${ }^{3}$, Swiss HIV Cohort Study
}

${ }^{1}$ Institue of Microbiology, University Lausanne, Lausanne, Switzerland, ${ }^{2}$ Swiss HIV Cohort Study Data Center, Lausanne, Switzerland, ${ }^{3}$ Kantonsspital Bruderholz, Bruderholz, Switzerland

Background: Dyslipidemia is a major cardiovascular concern in HIV-infected individuals. Recent genome-wide association studies (GWAS) have convincingly associated common genetic variants with dyslipidemia in the general population. The prevalent view is that genetic variants explain only a small fraction of interindividual variation in serum lipid levels.

Methods: Fourteen, 20, and 22 GWAS-identified single nucleotide polymorphisms (SNPs) were re-assessed for their contribution to serum lipid levels longitudinally collected in 745 Swiss HIV Cohort Study participants, providing 34565 lipid determinations during a median study duration of 7.6 years. Multivariate regression analysis was used to calculate the proportion of variance of lipid levels explained by SNPs, ART, and by key non-genetic covariables. To evaluate the cumulative effects of the SNPs to dyslipidemia, three genetic scores were evaluated.

Findings: Ten, 7, and 9 SNPs, respectively, were validated as contributing to NHC, HDL-C, and TG in the final, fully adjusted model, including variants of ABCA1, APOA5, APOB, APOE, APOE/C1/C4, CELSR2/PSRC1/SORT, CETP, GCKR, LIPC, LDLR, LPL. The entire model explained $24.6 \%, 22.2 \%$, and $25.2 \%$ of interindividual serum NHC, HDL-C, and TG variation, respectively. The genetic background explained 7.6-5.9\% (NHC), 6.2-5.2\% (HDL-C), and $6.8-5.0 \%$ (TG) of this variation, depending on the genetic score utilized; ART explained $3.9 \%$ (NHC), $1.5 \%$ (HDL-C), and $6.2 \%$ (TG). The performance of the three genotype scores was similar in predicting sustained, abnormal NHC, HDL-C, and TG levels.

Conclusions: Dyslipidemia in HIV-infected individuals has a strong genetic component that can be assessed by considering SNPs previously identified in GWAS in the general population. Genetic variants explain a larger (NHC and HDL-C), or similar (TG) proportion of the lipid variation than that attributable to the dyslipidemic effects of ART.

\section{P501 (PW)}

Integration of structured counseling for smoking cessation in HIV outpatient care

Milo Huber, Rainer Weber, Bruno Lederg erber, and the SHCS

Klinik für Infektionskrankheiten USZ, Zürich, Switzerland

Background: HIV-1 infected persons on antiretroviral treatment are at increased risk of cardiovascular disease.
Smoking (50-60\%) is the most prevalent modifiable risk factor but physicians are often not trained in smoking cessation counseling.

Objectives: To evaluate the uptake of smoking cessation counseling in a single HIV outpatient clinic of the Swiss HIV Cohort Study (SHCS).

Methods: Physicians were subjected to a validated standardized smoking cessation counseling education program. Thereafter they had to complete a short questionnaire on the patients' motivation level to stop smoking and support offered to that respect for every semiannual follow-up visit of participants in the SHCS from 09/2007 until $08 / 2008$. As only few patients contributed multiple visits during this time period, we report results from cross-sectional analyses of individual visits.

Results: Questionnaires were completed for 1448/2001 $(72 \%)$ visits of 1164 patients. While missing questionnaires were equally distributed between current smokers and non-smokers we observed some heterogeneity with respect to individual physicians. In 690/1448 (48\%) visits the patients indicated to currently smoke and 551/690 (80\%) were counseled. Reasons for not counseling were other medical priorities $(54 \%)$, patient's refusal $(20 \%)$ and lack of time (10\%). Motivation levels among counseled smokers were immediate stop of smoking $(5 \%)$, within the next 6 months (14\%), some time later (37\%) and no motivation to stop (44\%). Physicians could choose single or multiple answers among several options to document the provided support: Short counseling (44\%), detailed counseling $(13 \%)$, agreed upon a date for stopping (3\%), agreed upon a next date for discussing stop smoking (7\%), provided a handout $(21 \%)$, referred to specialist $(0.7 \%)$, nicotine substitution $(5 \%)$, prescriptions for bupropion hel (Zyban ${ }^{\circledR}$ ) $(0.7 \%)$ and varenicline $\left(\right.$ Champix $\left.{ }^{\circledR}\right)(4 \%)$.

Conclusions: Structured counseling for smoking cessation is feasible in the HIV outpatient setting. Pharmacotherapy and nicotine substitution were rarely prescribed. Long-term follow-up is needed to evaluate effectiveness.

\section{P502 (PD)}

\section{Reprogramming of $\mathrm{CDB}^{+} \mathrm{T}$ cells with an HIV-1-specificity by TCR-RNA electroporation}

Christian Hofmann ${ }^{1,2}$, Thomas Harrer ${ }^{1}$, Kathrin Eismann ${ }^{1}$, Silke Bergmann ${ }^{1}$, Verena Kubesch ${ }^{2}$, Ellen Harrer $^{1}$, Gerold Schuler ${ }^{2}$, Jan Dörrie ${ }^{2}$, Niels Schaft ${ }^{2}$

${ }^{1}$ University Hospital Erlangen, Department for Internal Medicine III with Institute for Clinical Immunology, Erlangen, Germany, ${ }^{2}$ University Hospital Erlangen, Department of Dermatology, Erlangen, Germany

It has been demonstrated that $\mathrm{HIV}-1$-specific $\mathrm{CD} 8^{+}$cytotoxic T lymphocytes (CTL) with a widespread specificity, especially against conserved epitopes play an important role in the control of HIV-1 replication. A potential immunotherapeutic strategy to eliminate virus-infected cells would be the adoptive transfer of T cells, which are reprogrammed by transfection of an HIV-specific T cell receptor (TCR). Until now, such HIV-1-specific reprogrammed CTL were produced through retroviral transfer of TCR-encoding genes, which has several challenges (i.e. life-long autoimmunity, activation/inactivation of genes). Consequently, we investigated the transfer of TCR-RNA into CD8 ${ }^{+} \mathrm{T}$ cells 
by electroporation and chose TCRs which were able to bind the HLA-A2 restricted HIVpol-peptide IV9 (ILKEPVHGV), and the HIVgag-peptide SL9 (SLYNTVATL). T cells, reprogrammed with these receptors, received the ability to secrete the pro-inflammatory cytokines IL-2, TNF, and IFNg simultaneously, had an up regulation of the activation marker CD25, and kept their ability to proliferate, after stimulation with peptide-loaded target cells or target cells presenting the natural processed epitopes. More importantly, we could prove through killing assays that the TCR-reprogrammed CD8 ${ }^{+} \mathrm{T}$ cells were capable to specifically lyse target cells pulsed with the corresponding peptide (for at least three days), or target cells presenting the natural processed epitopes. Furthermore, we compared the avidity of our reprogrammed T cells with the parental CTL and could demonstrate that the transfected $\mathrm{T}$ cells were only one order of magnitude lower in avidity as the parental CTL. Moreover, we also could reveal, that the recognition pattern of mutant peptides by the TCR-RNA-transfected T cells is preserved from the parental clone. Taken together, $\mathrm{CD}^{+}{ }^{+} \mathrm{T}$ cells which were transfected with TCR RNA may represent a simple and secure alternative to retroviral transduction, and could be used as an alternative method to the retroviral transduction of T cells for therapy.

\section{P503 (PD)}

\section{Kinderwunschberatung bei HIV-infizierten Frauen}

\author{
Andrea Ging elmaier ${ }^{1}$, Katja Wiedenmann $^{1}$, Ralph \\ Kästner ${ }^{1}$, Milena Sovric ${ }^{1}$, Marianne Müller ${ }^{1}$, Ulrike \\ Sonnenberg-Schwan ${ }^{2}$, Katharina Weizsäcker ${ }^{3}$ \\ ${ }^{1}$ Ludwig-Maximilians-Universität, Campus Innenstadt, Klinik \\ für Gynäkologie und Geburtshilfe, München, Germany, \\ ${ }^{2}$ FrauenGesundheitsZentrum e.V., München, Germany, \\ ${ }^{3}$ Charité, Campus Virchow-Klinikum, Klinik für \\ Geburtsmedizin, Berlin, Germany
}

Fragestellung: Die meisten Paare mit HIV-Infektion eines oder beider Partner werden ohne vorherige Beratung oder Aufklärung schwanger. Wie stellt sich das Ergebnis nach erfolgter Kinderwunschberatung bei HIV-infizierten Frauen dar, die sich in einer Schwerpunktsprechstunde vorstellen?

Methodik: Retrospektive Analyse von Kinderwunschberatungen bei HIV-Infektion der Frau an einer Frauenklinik 2000 - 2008. Erfassung relvanter Daten der HIVErkrankung (Zeitpunkt der Erstdiagnose, CDC-Stadium, CD4-Zellzahl, Viruslast, antiretrovirale Therapie, Koinfektionen) sowie Art der Kinderwunschberatung und ggf. Fertilitätsdiagnostik/-therapie, Konzeption und Ausgang der Schwangerschaften.

Ergebnisse: Darstellung der Beratungen bei 57 Paaren mit Kinderwunsch, bei denen eine HIV-Infektion der Frau mit einem diskordanten $(n=39)$ oder konkordanten $(n=18)$ Partner besteht. Bei 16 Paaren (28\%) fand sich eine bestehende Fertilitätseinschränkung in der Diagnostik. Eine oder mehrere Schwangerschaften sind bisher bei insgesamt 23 Paaren (40\%) eingetreten. Die Konzeption erfolgte bei 12 Paaren durch ungeschützten Geschlechtsverkehr, bei 7 durch Selbstinsemination, bei 2 durch Insemination, bei einem Paar durch In-vitro-Fertilisation. Es resultierten 25 Lebendgeburten, eine Totgeburt (Trisomie 18), ein Frühabort, eine zervikale Gravidität und eine Abruptio. $\mathrm{Zu}$ einer horizontalen Transmission bei diskordanten Partnern kam es nicht. Bei 16 Paaren (28\%) besteht noch anhaltender, bisher unerfüllter Kinderwunsch, 11 Paare (19\%) haben ihren Kinderwunsch aus verschiedensten Gründen aufgegeben, 7 Paare (12\%) sind lost to follow-up.

Schlussfolgerungen: Angesichts eines stark vorselektionierten Klientels mit einer hohen Rate von Fertilitätsstörungen konnte nach entsprechender Beratung bzw. ggf erforderlichen Diagnostik und Behandlung bei immerhin $40 \%$ der Paare eine Schwangerschaft erreicht werden ohne daß ein diskordanter Partner infiziert wurde.

\section{$P 504$}

\section{Erste HIV-1/2 Doppelinfektion in Österreich - ein Fallbericht}

Wolfgang Prammer ${ }^{1}$, Josef Eberle ${ }^{2}$, Walter Aichinger ${ }^{1}$

${ }^{1}$ Klinikum Wels-Grieskirchen, Institut für Hygiene und Mikrobiologie, Wels, Austria, ${ }^{2}$ Max von Pettenkofer-Institut der LMU München, Virologie, München, Germany

Einführung: Die Wahrscheinlichkeit für eine HIV-1/2 Doppelinfektion ist vom gleichzeitigen Vorhandensein beider Viren abhängig. Da selbst in Westafrika, wo beide Viren zirkulieren, Doppelinfektionen selten sind, wurden in Europa Doppelinfektionen kaum beobachtet. Wir berichten hier über den ersten Fall einer HIV-1/2 Doppelinfektion in Österreich.

Fallbericht: Bei einem jetzt 46jährigen Patienten aus Westafrika wurde 1998 eine HIV-1 Infektion diagnostiziert (HIV-1/2 Antikörper Enzymimmunoassay, Axsym, Fa. Abbott; HIV-1 Antikörper Western-blot). Die CD4-Zellzahl betrug 100/ $\mu 1$, die HIV-1 Viruslast ergab $3048 \mathrm{cop} / \mathrm{ml}$ (Cobas Amplicor Version 1.5, Fa. Roche).

Die initiale Therapie mit Zidovudin/Didanosin reduzierte die HIV-1 Viruslast auf $450 \mathrm{cop} / \mathrm{ml}$, jedoch ohne Wirkung auf die CD4-Zellzahl $(60 / \mu 1)$, sodass die Therapie auf Stavudin/Lamivudin/Efavirenz umgestellt wurde. Unter dieser Therapie zeigte sich keine Besserung der Messwerte, sodass Efavirenz durch Indinavir ersetzt wurde. Innerhalb von zwei Monaten kam es zu einem bis jetzt bestehenden Absinken der HIV-1 Viruslast unter die Nachweisgrenze $(<50 \mathrm{cop} / \mathrm{ml})$, die CD4-Zellzahl stieg in Folge bis auf 720/ $\mu 1$. Wegen Nebenwirkungen musste im Juni 2003 der Proteasehemmer durch Nevirapin ersetzt werden. Nach anfänglich stabilen Immunwerten kam es jedoch in weiterer Folge zu einem Absinken der CD4-Zellzahl auf 70/ $\mu 1$. Die Therapie wurde erneut auf Lamivudin/Tenofovir/Atazanavir/ $\mathrm{r}$ geändert, worunter die CD4-Zellzahl anfänglich auf 280/ $\mu 1$ stieg, jedoch bis September 2008 wieder auf $90 / \mu 1$ sank.

Zur weiteren Analyse des unerklärlichen CD4-Abfalls wurde Blut des Patienten mit einem weiteren Viruslasttest untersucht (m2000rt HIV-1 RNA, Fa. Abbott). Auch hier war keine HIV-1 RNA nachweisbar $(<40 \mathrm{cop} / \mathrm{ml})$. Letztendlich wurde mittels einer HIV-2 PCR virale RNA nachgewiesen und in einer zweiten Probe HIV-2 Subtyp A durch partielle Sequenzierung identifiziert.

Eine immunologische Verbesserung wird durch die Therapieumstellung auf Tenofovir/Emtricitabin plus Saquinavir/r plus Raltegravir versucht.

Zus ammenfas s ung : Ein nicht erklärbarer CD4-Abfall bei einer erfolgreich behandelten HIV-1 Infektion sollte, vor allem bei Patienten mit Verbindung zu Westafrika, auch an eine HIV-1/2 Doppelinfektion denken lassen. 


\section{$P 505$}

What do HIV-infected patients die of today?

Silja Bühler, Julia Söllner, Ulrich Seybold, Johannes R. Bogner

Med. Poliklinik, University Hospital of Munich, Division of Infectious Diseases, Munich, Germany

Background: The introduction of highly active antiretroviral therapy (HAART) has resulted in a considerable increase of life expectancy in HIV-positive patients and non-HIV-associated causes of death have started to play a major role. Therefore screening and prevention efforts targeting these conditions are of special interest for general practitioners and HIV specialists in treatment of HIV-infected patients.So far the causes of death in HIV infected patients in Germany during the HAART era have been insufficiently defined.

Methods: We conducted a retrospective analysis of causes of death among HIV-positive patients followed in our Infectious Diseases outpatient clinic at the University Hospital of Munich between January 2003 and December 2008. $1193 \mathrm{HIV}$-infected patients attended our clinic at least once in this time period. 54 deaths were documented.

Results : As a main result it can be noted that 13 out of 54 deaths $(24 \%)$ were directly HIV-associated. 8 of $13 \mathrm{HIV}$-associated deaths were caused by Non-Hodgkin-Lymphomas (62\%). Among 38 Non-HIV associated deaths 10 were due to cardiovascular diseases (26\%), 9 were due to Non-HIV-as sociated malignancies (24\%), 6 due to infections (16\%) and 5 due to suicides (13\%). 3 patients died of unknown causes.Comparing Non-HIV-related deaths in our cohort with deaths in the general population in Germany cardiovascular diseases appeared in approximately the same percentage. Non-HIV-associated malignancies occurred $40 \%$ less often in our cohort, but suicides occurred 10 times more often.

Conclusions: Clinicians have to be aware that a majority of HIV-infected patients, in our cohort nearly $75 \%$, die of Non-HIV-related causes. In our cohort the leading cause of deaths were malignancies, followed by cardiovascular diseases. Infections and suicides were disproportionately high represented.These conditions and their risk factors should especially be addressed with prophylaxis and screening.

\section{P506}

Der Beginn der Transmissionsprophylaxe in der 32. Schwangerschaftswoche scheint zu spät zu sein - Daten aus Hamburg

Sandra Hertling ${ }^{1}$, Karen Olah ${ }^{2}$, Irene Walther ${ }^{2}$, Rainer Laux ${ }^{3}$, Rainer Ganschow ${ }^{4}$, Mareike Sornsakrin ${ }^{4}$, Stefan Hansen $^{5}$, Kristin Lauterbach ${ }^{6}$, Sonja Gudowius ${ }^{7}$, Dorette Courtar ${ }^{3}$, Andreas Plettenberg ${ }^{2}$

${ }^{1}$ Ambulanzzentrum des Universitätsklinikums Eppendorf

$\mathrm{GmbH}$, Infektiologie, Hamburg, Germany, ${ }^{2}$ ifi - Institut für Infektiologie und Immunologie, Hamburg, Germany,

${ }^{3}$ Asklepios Klinik Barmbek, Abtlg für Mutter und Kind,

Hamburg, Germany, ${ }^{4}$ Klinik für Kinder- und Jugendmedizin des Universitätsklinikum Hamburg Eppendorf, Hamburg, Germany, ${ }^{5}$ Infektiologisches Centrum Hamburg, Praxis Mitte, Hamburg, Germany, ${ }^{6}$ Klinik für Geburtshilfe und Pränatalmedizin des Universitätsklinikums Hamburg Eppendorf, Hamburg, Germany, ${ }^{7}$ Altonaer Kinderkrankenhaus, Hamburg, Germany

Hi nterg rund: Im Rahmen des Hamburger Qualitätszirkels „HIV und Schwangerschaft" wurde der Verlauf der HIV-in- fizierten Schwangeren und deren Kinder in den Jahren 2005 bis 2008 dokumentiert.

Methode: Die Dokumentation erfolgte interdisziplinär über standardisierte Dokumentationsbögen.

Resul tate: Insgesamt wurden 107 Schwangerschaften erfasst. Davon wurden 89 Frauen entbunden, $4(3,7 \%)$ der Schwangerschaften endeten als Abort und $6(5,6 \%)$ als Abruptio. 8 Patientinnen konnten nicht weiterverfolgt werden. 26 Frauen $(29,2 \%)$ waren deutsche Staatsangehörige, $67,7 \%$ der Frauen kamen aus Hochprävalenzländern (47 Subsahara-Afrika, 8 Osteuropa, 7 Asien ). Bei 26 $(29,2 \%)$ Schwangeren wurde die HIV-Infektion im Rahmen der Schwangerschaftsvorsorge diagnostiziert.

38 Schwangere hatten eine bestehende ART zum Zeitpunkt der Konzeption. Von den Patientinnen ohne ART wurde bei 25 eine Therapie aufgrund einer mütterlichen Indikation begonnen. 43 Frauen erhielten lediglich eine Transmissionsprophylaxe, die im Mittel in der 32. SSW begonnen wurde für die Dauer von im Mittel 5 Wochen.

Zum Zeitpunkt der Geburt lag bei 43 Schwangeren die Viruslast $<50 \mathrm{c} / \mathrm{ml}, 35$ hatten eine Viruslast $<500 \mathrm{c} / \mathrm{ml}$ $>50 \mathrm{c} / \mathrm{ml}$ und $15>500 \mathrm{c} / \mathrm{ml}$. Von den 43 Patientinnen, die lediglich eine Transmissionsprophylaxe erhielten war bei nur 14 die Viruslast $<50 \mathrm{c} / \mathrm{ml}$.

Von den erfassten vollendeten Schwangerschaften erfolgte die Entbindung bei 65 durch primäre Sectio, 5 durch sekundäre Sectio und 1 durch vaginale Entbindung, im Mittel in der 37. SSW (23-40 SSW) (16 lost to follow up).

Von den 91 geborenen Kindern $(2$ x Gemini) konnten 73 nachverfolgt werden. Davon wurde ein Kind HIV-positiv getestet. Die PCR fiel bereits zum Zeitpunkt der Geburt positiv aus, sodass von einer intrauterinen Infektion ausgegangen werden kann.

Schlussfolgerung: Der Beginn der Transmissionsprophylaxe in der 32. SSW entsprechend den Deutsch-Österreischichen Empfehlungen scheint zu spät zu sein, um eine Viruslast von $<50$ zum Zeitpunkt der Geburt zu gewährleisten.

\section{$P 507$}

\section{Virological medical quality management - 9 years follow-up}

Patrick Braun, Christian Höhn, Frank Wiesmann, Robert Ehret, Heribert Knechten

PZB, Aachen, Germany

Purpose: Different antiretroviral treatments and their virological efficacy were analysed in Germany over the past 9 years.

Methods: Up to 23 medical-centres and data sets between 997 (2000) and 2445 (2008) were collected. ART were divided into combinations containing either 3 nucleos(t)ide analogues (NRTI), 2 NRTI +1 protease-inhibitor $(\mathrm{PI}), 2$ NRTI + 1 non-nucleoside-reverse-transcriptase-inhibitor (NNRTI) or "other" regimens. Therapy success was defined as HIV1-RNA < 50 copies/ml. Additionally the proportion and efficacy of firstline regimens were evaluated.

Results: Patients receiving ART remains constant between $77.1 \%$ (2000) and 76.9\% (2008) accompanied by an increase of therapy success from $71.9 \%$ to $83.7 \%$, respectively. Preferred combinations in 2008 were 2 NRTI + 1 PI with $45.3 \%$ followed by NNRTI combinations (36.6\%) and "other" regimens (13\%) and combinations with 3 NRTIs $(4.5 \%)$. 
Therapy success increased as follows: 2 NRTI +1 PI: $68.7 \%$ to $81.6 \%$; 2 NRTI + 1 NNRTI: $72.8 \%$ to $89.7 \%$ and other regimens: $44.5 \%$ to $77.9 \%$. Firstline regimens in 2008 were $32.8 \%$ and showed a therapy success of $78.1 \%$ separated in 3 NRTI with $84.6 \%$; 2 NRTI + 1 PI with $77.5 \%$; 2 NRTI +1 NNRTI with $84.9 \%$ and other regimens with $58.3 \%$. Due to the small amount the regimens containing Integrase-Inhibitors (Raltegravir [16]) and Entry-Inhibitors (Enfuvirtide [5] and Maraviroc [11]) were counted as other regimens.

Conclusions: The increasing rate of the "other" regimens could result from a high rate of heavily pre-treated patients and new treatment strategies. Over the time all regimens achieved a higher therapy success, may be due to a simplified mode of intake, improved drug formulations, new substance classes or treatment strategies. The feedback given to the individual centres leads to an improvement of quality in HIV-treatment as well. The impact of new drugs, approved last year, will be shown in future evaluations.

\section{$P 508$}

\section{Successful HIV1-Post-Expositionprophylax is in 7 extremely premature newborns (birth weight $<1500 \mathrm{~g}$ ) with several risks of HIV1-trans mission}

Steffen Hien ${ }^{1}$, Bernd Buchholz ${ }^{1}$, Matthias Beichert ${ }^{2}$ Thomas Schaible ${ }^{1}$, Horst Schroten ${ }^{1}$

${ }^{1}$ Universitätsklinikum Mannheim, Universitätskinderklinik, Mannheim, Germany, ${ }^{2}$ Universitätsklinikum Mannheim, Universitätsfrauenklinik, Mannheim, Germany

Purpose of the study: In those cases, when maternal HIV1 infection was known during pregnancy, since 1995 the rate of vertical transmission of HIV1 was reduced to < $2 \%$ in developed countries. Because only few data about medical measures and the rate of transmission for pregnancies with complications (including a higher risk of vertical HIV1-transmission) exist, we analysed medical measures and outcome of 7 extremely premature HIV1-exposed newborns ( 2 twins +3 singletons) with birth weight $<1500 \mathrm{~g}$.

Methods: All children were born by caesarian section. According to the German-Austrian Guidelines a treatment regimen with Zidovudine (AZT) $2 \times 1,5 \mathrm{mg} / \mathrm{kg}$ i.v. and Lamivudine $2 \times 2 \mathrm{mg} / \mathrm{kg}$ orally both a total of 6 weeks and two doses of Nevirapine (NVP) on the first and third day of life started directly after birth. If the mothers had a NVPdose 2 hours before birth, the first NVP-dose of the neonate was cancelled. As soon as feeding problems disappeared, AZT was changed to $2 \mathrm{x} 2 \mathrm{mg} / \mathrm{kg}$ orally and after 3 weeks of life increased to $3 \times 2 \mathrm{mg} / \mathrm{kg}$ orally. PCR for HIV1-DNA and -RNA was performed 1, 3 and 6 months after birth.

Results: In 3 newborn mothers had sufficient-, in one a short- ( 2 weeks) and in 3 no antiretroviral therapy before birth. Reasons for prematurity were premature labour in 5(including 2 cases with premature rupture of membranes) and abruption of placenta in 2 neonates. 4 newborn had a birth weight of $650-1000 \mathrm{~g}$ and 3 of $1000-1550 \mathrm{~g}$. Anitretroviral prophylaxis was well tolerated and showed no adverse effects. Two children developed a mild intracerebral hemorrhage with very mild neurological deficits; 2 children a self limiting bronchopulmonary dysplasia. All 7 infants were HIV-negative.

Conclusions : Antiretroviral prophylaxis with AZT $+3 \mathrm{TC}$ for 6 weeks and 2 doses NVP in extremely premature infants, was very effective, well tolerated and showed no serious side effects .

\section{P509}

Single balloon enteroscopy (SBE): findings in the small intestine in HIV infected individuals - a prospective study of the AVK cohort

Julia Brümmer, Christian Träder, Keikawus Arastéh

Vivantes Auguste-Viktoria-Klinikum, II. Innere Abteilung, Berlin, Germany

Objectives: Small bowel evaluation was difficult due to endoscopic limitations. Since January 2007 a novel method for small bowel evaluation was established in the AVK: the single balloon enteroscopy.

Methods: Small intestine can be examined by using a new endoscope $(230 \mathrm{~cm})$ and an overtube with a single balloon at its proximal end. In contrary to double balloon enteroscopy preparation und examination time is reduced. In SBE the distal scope is hook shaped and easier to handle. To examine the upper small bowel an oral, to examine the lower small intestine a rectal access is chosen.

HIV patients with different problems of the small intestine were examined with SBE. Macroscopic and histological findings were monitored.

Resul ts: Between January and December 200819 HIV patients ( $\mathrm{f}=4, \mathrm{~m}=14$, medium CD4 count $302 / \mu 1,20.4 \%$,range 1-1360,3\%-40\%) were examined with SBE. We performed 26 studies: 21 oral and 5 rectal without any complication. Macroscopic findings: 14 patients ( 9 oral and 5 rectal) with no pathological findings. Distortion:2(normal histology), discrete white coating of mucosa:3, discrete mucosal reddening and edema:2, multiple small ulcerations: 1 , heavy white coating of the mucosa suspicious for MAI infection:2.

Histology: 12 (7 oral, 5 rectal) patients with macroscopic normal mucosa also showed a normal histology, whereas histology showed one glutensensitive enteropathy. Other histological findings: abnormal vessels without evidence of HHV-8, non-specific inflammation:1, slight non-specific inflammation:2. erosions and non-specific moderately inflammation:1, lymphangiectasia (endoscopy: heavy white coating, MAI not detected): 2 .

Discussion: In 26 studies of symptomatic HIV patients we found 14 abnormalities either macroscopically or microscopically. Two findings could be related to symptoms and were treated successfully (ulcerating jejunitis treated with cortisone, enterosensitive enteropathy with diet). We conclude that SBE in symptomatic HIV patients is a safe and effective method to examine the small bowel. The need for further evaluation of macros copic und histological findings is evident. 


\section{P510}

10 Jahres-Jubiläum von HIVmobil: Verein für HIV-spezifische medizinische Hauskrankenpflege und Langzeitpflege sowie Sozialbegleitung für Menschen mit HIV. AIDS in Wien

Wolfgang Steflitsch ${ }^{1}$, Elisabeth Maurer ${ }^{2}$, EvaStifter ${ }^{2}$, Beate Dannoritzer ${ }^{2}$, HIVmobil

${ }^{1}$ Otto Wagner Spital, 2. Interne Lungenabteilung, Wien, Austria, ${ }^{2}$ HIVmobil, Wien, Austria

Das HIVmobil-Team, das aus Pflegefachaufsicht (2), freiberuflichem diplomiertem Pflegeteam (6 bis 8), ärztlicher Leitung (1) und Geschäftsführung (1) besteht, betreut und begleitet HIV-positive Menschen unabhängig von Alter, Religion, Herkunft, sozialer Stellung und sexueller Orientierung ohne moralische Bewertung seit einem Jahrzehnt.

Unser Leitbild umfasst "ganzheitliche Pflege" (Berücksichtigung aller menschlichen Ebenen, Recht auf selbstbestimmtes Leben), "gemeinsames Gestalten der Pflege zu Hause" (fachliche Kompetenz, Sensibilität, Einfallsreichtum, Steigerung der Lebensqualität, bedürfnisorientierte Betreuung, interdisziplinäre Zusammenarbeit), "Respekt" (Ausgrenzung entgegenwirken, Wertschätzung zeigen) und "Individualität und Flexibilität" (jahrelange pflegerische Erfahrung mit dem vielseitigen Krankheitsbild, persönliches Engagement, Kreativität). Über all die Jahre erfolgte die größte emotionale und finanzielle Unterstützung durch AIDS LIFE.

Durch seine Infrastruktur kann HIVmobil auf wechselnde Anforderungen flexibel reagieren. Die Anzahl an Klienten, die an einem bestimmten Stichtag betreut wurden, liegt zwischen 2 und 17, die Zahl der Einsatzstunden pro Monat zwischen 40 und 290. Der Bedarf wird in den nächsten Jahren vor allem aus drei Gründen zunehmen: politischer Wille zur extramuralen Betreuung, hohe Überlebensrate durch antiretrovirale Kombinationstherapie, HIV-assoziierte Langzeitkomplikationen vor allem betreffend Leber, Niere, kardiovaskuläres System, Nerven- und Skelettsystem.

Das Betreuungsangebot von HIVmobil umfasst unter anderem Körperpflege mit vorbeugenden Maßnahmen bei geschwächtem Immunsystem, Wundmanagement, Infusions- und Injektionstherapien, Medikamenten-Management, Ernährungs- und Schmerztherapie, Palliative Care, Unterstützung von Angehörigen und Freundeskreis, Koordination mit anderen Diensten und Information über begleitende Möglichkeiten, zum Beispiel psychologische Beratung, Yoga, Meditation, Akupunktur und Aromatherapie.

Als Vorlage für qualitätssichernde Maßnahmen dient das Wiener Modell für ambulante Dienste. Die Durchführung der Pflege wird durch regelmäßige Einsätze der Pflegefachaufsicht und deren Vertretung vor Ort kontrolliert. Wichtige Qualitätsparameter sind Pflegerichtlinien, Hygienestandards, Dokumentation, Supervision, Teamsitzungen und Fortbildungen. Seit Dezember 2007 besitzt HIVmobil als anerkannte Einrichtung der Gemeinde Wien nach umfassender Prüfung einen Leistungsvertrag mit dem Fonds Soziales Wien für medizinische Hauskrankenpflege und Langzeitpflege.

HIVmobil -Büro : c/o Aids Hilfe Wien, Mariahilfer Gürtel 4, A-1060 Wien.

Hotline: +43-(0)-699-19445333; office@hivmobil.org.

\section{P511}

\section{Late HIV presentation at the Chronic Diseases Clinic (CDCI) of the rural St. Francis Designated District Hospital, Ifakara Tanzania}

Nadja Heuer 1,2,3, Marcel Stoeckle 2,4, Boniphace Jullu5, Rehema Mchomvu $u^{1}$, Penelope Vounatsou ${ }^{2}$, Patience Kibatala ${ }^{6}$,Hansjakob Furrer ${ }^{7}$, Manuel Battegay ${ }^{4}$, Christoph $\mathrm{Hatz}^{2}$

${ }^{1}$ St. Francis Designated District Hospital, Chronic Diseases Clinic, Ifakara, Tanzania, United Republic of, ${ }^{2}$ Swiss Tropical Institute, Basel, Switzerland, ${ }^{3}$ Ifakara Health Institute, Ifakara, Switzerland, ${ }^{4}$ University Hospital Basel, Division of Infectious Diseases \& Hospital Epidemiology, Basel, Switzerland, ${ }^{5}$ Ifakara Health Institute, Ifakara, Tanzania, United Republic of, ${ }^{6}$ St. Francis Designated District Hospital, Ifakara, Tanzania, United Republic of, ${ }^{7}$ University Hospital Bern, Division of Infectious Diseases, Bern, Switzerland

Background: Many patients present in a far progressed HIV-stage at CDCI. The aim of this study is quantify the magnitude of the problem and to assess the out-come of late-presenters.

Methods: We stratified adult, treatment-naïve late-presenters (CD4 cell count $<200$ cells/ $\mu 1$ and/or AIDS defining disease) between May 2005 and August 2006 according their first CD4 cell count into the following strata: $<25$, 26-50, 51-100, 101-150, 151-200, and $>200$ cells $/ \mu 1$ but AIDS defining disease. Outcome parameter was death due to any reason.

Results : 418 of 681 patients $(61 \%)$ presented late at CDCI. Data were available for at least 12 months or until death for $282(67 \%)$ late-presenters starting ART.

49 patients $(17 \%)$ presented with a baseline CD4-T-cell count $<25,39(14 \%)$ between 26-50, 46 (16\%) between $51-100,56(20 \%)$ between 101-150, 53 (19\%) between 151-200, and 39 (14\%) with CD4-T-cell count >200 cells/ $\mu 1$ but with an AIDS-defining disease.

Overall 57 patients $(20 \%)$ died, $32(56 \%)$ of them within the first 3 months of treatment.

$20(41 \%)$ patients within the $<25$ cells $/ \mu 1$ stratum died. The mortality rate in this stratum was significantly higher than in the others, based on the log rank test $(\log$ rank= $30.11, \mathrm{p}<0.001)$. In the other strata $18 \%, 15 \%, 14 \%$ and $13 \%$ of patients died respectively. The mortality was $21 \%$ in the AIDS-defining disease group with $>200$ cells $/ \mu 1$.

Conclusions: Late presenting is more frequently observed in this rural Tanzanian district hospital than reported from other African sites. Late presenters with $<25$ cells/ $\mu 1$ have a significantly lower chance of survival, although a considerable number among them survive. There should, however, be no cut-off value for CD4 cells below which treatment will not be offered.

Strategies to detect HIV infection earlier and to assure timely referral for treatment need to be strengthened. 


\section{P512}

\section{Entwicklung einer Hochqualitätsversorgung in der ambulanten Betreuung von HIV infizierten Patienten in Kamerun}

Stefan Schmiedel ${ }^{1}$, Torsten Feldt 2,3,4,5, Nchang Tak $a^{6}$, Jonah Wefuan ${ }^{6}$, Gerd Dieter Burchard ${ }^{1,2}$, Jan van Lunzen ${ }^{1}$

${ }^{1}$ University Medical Center Hamburg Eppendorf, Infectious Diseases\&Tropical Medicine, Hamburg, Germany, ${ }^{2}$ BernhardNocht-Institute for Tropical Medicine, Hamburg, Germany,

${ }^{3}$ School of Medical Sciences, Kwame Nkrumah University of Science and Technology, Kumasi, Ghana, ${ }^{4}$ Komfo Anokye Teaching Hospital, Kumasi, Ghana, ${ }^{5}$ Kumasi Centre for Collaborative Reserch in Tropical Medicine (KCCR), Kumasi, Ghana, ${ }^{6}$ Bamenda Regional Hospital, Bamenda, Cameroon

Hinterg rund: ESTHER ist ein Netzwerk, dass sich zum Ziel gesetzt hat den Aufbau von Kapazitäten und technischer Hilfe im Bereich der HIV/AIDS-Versorgung in afrikanischen Ländern zu fördern. Eine internationale Zusammenarbeit zur Bekämpfung von HIV/AIDS soll durch die Entwicklung und Unterstützung von Partnerschaften zwischen Krankenhäusern und Gesundheitszentren aus der Nord- und der Südhemisphäre den Austauschs von Wissen und „knowhow" befördern. Insbesondere soll durch verbesserte Qualitätssicherung für antiretrovirale Therapien und Pflege in Afrika eine verbesserte medizinische Versorgung von HIV Infizierten erreicht werden. Das Projekt in Bamen$\mathrm{da} /$ Kamerun ist eines dieser Netzwerkprojekte in dem die beteiligten Partner eine Strategie zu Erreichung dieser Ziele vereinbart haben.

Ergebnis: Unser Projekt in Bamenda, in der NordwestProvinz Kameruns, das im Rahmen einer Süd-Süd-Nord Kooperation von HIV-Behandlungszentren und von ESTHER Deutschland koordiniert und gefördert, versucht eine verbesserte HIV-Medizin in Afrika zu etablieren.

Die im Oktober 2008 begonnene Zusammenarbeit der beteiligten Zentren in Bamenda/Kamerun, Kumasi/Ghana und Hamburg/Deutschland soll dargestellt werden. Priorisierte Ziele der Partner sind eine Verbesserung der Patientendokumentation, eine elektronische Krankenakte soll eingeführt werden, eine Verbesserung der medizinischen Ausbildung vor Ort, ein Internet-Lernzentrum für das medizinische Personal wurde errichtet und ein regelmäßiger Erfahrungsaustausch im Sinne einer ,continous medical education" begonnen. Außerdem soll die Verfügbarkeit und Zuverlässigkeit von technischen Equipment, hier ,FACS-cell counting" durch Unterstützung bei Nachbeschaffungen und verbessertem Training, gesichert werden.

Aussichten: Welchen Mehrwert hat diese ESTHER Partnerschaft für die afrikanischen Partner und Patienten? Wo liegen die Probleme unseres Projektes? Welche Verbesserungen konnten bisher tatsächlich erreicht werden? Stehen Einsatz und Ergebnis bei derartigen Partnerschaften in einem vernünftigen Verhältnis? Welche Aussichten ergeben sich aus dem bisher Erreichten, was erhoffen sich die beteiligten Partner von dem Projekt?

\section{P513}

\section{OD - once daily (OD) TDF-containing HAART in HIV-1-infected former IVDU patients receiving opiate substitution: efficacy, tolerability and adherence}

Stefan Esser ${ }^{1}$, Schlomo Staszewski ${ }^{2}$, Annette Haberl ${ }^{2}$, Fiona Mulcahy ${ }^{3}$, Jörg Gölz ${ }^{4}$, Andreas Körber ${ }^{1}$, Britta Ranneberg ${ }^{5}$, Lothar Gallo ${ }^{5}$, Thomas Mertenskötter ${ }^{5}$

${ }^{1}$ Universitätsklinikum Essen, Essen, Germany, ${ }^{2}$ JW Goethe Universität, HIV Center, Frankfurt, Germany, ${ }^{3}$ St. James's Hospital, Dublin, Ireland, ${ }^{4}$ Praxiszentrum Kaiserdamm, Berlin, Germany, ${ }^{5}$ Gilead Sciences, Martinsried, Germany

Objectives: There is a clinical need for antiretroviral therapy (ART) regimens that simplify dosing and make adherence easier for specific patient groups such as former intravenous drug users (IVDU) receiving opiate substitution. The 3OD study was designed to evaluate the use of OD HAART in IVDU patients.

Methods: 3OD was a single-arm, multi-centre 48 weeks trial to assess efficacy, tolerability and adherence to a OD TDF-containing HAART regimen in former IVDU patients receiving opiate substitution. Of 67 patients enrolled, 27 were antiretroviral treatment naïve, 10 were virologically suppressed $(<400$ copies $/ \mathrm{mL})$ and 30 were restarting HAART without prior virological failure. Opiate substitution was adjusted according to subject symptoms of opiate overdosing or withdrawal. Various methods were used to as sess adherence (pill count, MASRI (Medication Adherence Self-Report Inventory) questionnaire and an electronic diary). Calculation of adherence by pill count assumed that unreturned pills had been taken by the subjects.

Resul ts : Overall, $55 \%(n=37$, ITT, M=F) of patients had viral load $<400$ copies $/ \mathrm{mL}$ at Week 48 . Using an ITT, M=E analysis, $90 \%(37 / 41)$ of patients reached undetectable $\mathrm{VL}(<400$ copies $/ \mathrm{mL}), 56 \%$ (23/41 patients) had plasma HIV 1 RNA concentrations $<50$ copies/mL at Week 48.

Only 30 patients (45\%) completed the full study and the follow-up period. In $51 \%$ patients, TDF adherence was $>100 \%$ using pill count. MASRI showed adherence rates of $80-100 \%$ in $83-85 \%$ of patients; however, 15 patients never entered any data. Diary data were entered by 57 patients; diary data were entered for fewer days than patients received treatment (mean difference 113 days).

Conclusion: TDF in combination with other OD antiretrovirals in former IVDU patients showed comparable efficacy to that seen in the average HIV-1 infected population.

However, measurement of adherence to self-administered HAART via pill count, MASRI or diary may be misleading in this population. 


\section{P514}

Experience patients treated by outpatient clinics or by private practitioners differing treatment characteristics and clinical outcomes in Germany?

Klaus Jansen ${ }^{1}$, Norbert H. Brockmeyer ${ }^{1}$, Burkhard Haastert $^{2}$, Axel Baumgarten ${ }^{3}$, A. Stoehr ${ }^{4}$, Georg Behrens ${ }^{5}$, Hans Jaeger ${ }^{6}$, Helmut Hart ${ }^{7}$, A. Mutz ${ }^{8}$, Adriane Skaletz-Rorowski ${ }^{1}$, Stefan Esser ${ }^{9}$, Claudia Michalik ${ }^{10}$, and the Competence Network for HIV/AIDS

${ }^{1}$ Kompetenznetz HIV/AIDS, Ruhr-Universität, Bochum, Germany, ${ }^{2}$ mediStatistica, Neuenrade, Germany, ${ }^{3}$ Praxis Driesener Straße, Berlin, Germany, ${ }^{4}$ ifi - Institut für Interdisziplinäre Medizin, Hamburg, Germany, ${ }^{5}$ Medizinische Hochschule, Hannover, Germany, ${ }^{6}$ Praxiszentrum Stachus, München, Germany, ${ }^{7}$ Praxisgemeinschaft Franz JosephStraße, München, Germany, ${ }^{8}$ Klinikum, Osnabrück, Germany, ${ }^{9}$ Universitätsklinik, Essen, Germany, ${ }^{10}$ Zentrum für Klinische Studien, Köln, Germany

Background: Only about $30 \%$ of persons living with HIV/AIDS in Germany are assumed as treated in outpatient clinics (OC), about $70 \%$ by specialised private practitioners (PP). Partly, PP are assumed to be of lower threshold than OC, resulting in possibly differing patient populations. Treatment outcomes are discussed as being different, due to potentially differing treatment approaches. No reliable data were given regarding that topic so far. KompNet operates a nation wide cohort of PLWHA since 2004.

Method: Semi-annually, we gain sociodemographic and epidemiological data as well as clinical data regarding onset and course of infection, treatment parameters and outcomes, co-infections, and other diseases and their therapy. We analysed cross-sectionally core outcome variables comparing PP and OC.

Result: Of 6,085 patients included in analysis, $68.6 \%$ were treated by $16 \mathrm{PP}, 31.4 \%$ by $10 \mathrm{OC}$. In PP, proportion of women was $30.9 \%$ less compared to OC ( $<<0.01)$, corresponding to a higher proportion of MSM (PP: 70.1\%/ OC: $56.4 \% ; \mathrm{p}<0.01)$. HPL were represented stronger in OC (PP: $4.2 \%$ OC: $7.6 \% ; \mathrm{p}<0.01)$. CDC-stage $\mathrm{C}$ was more frequent in OC (PP: $22.8 \% /$ OC: $31.5 \%$; p < 0.01 ), no differences existed concerning age and therapy status.

Two main regimes covered two third of all treated patients in PP and OC: 2NRTI+1 PI/r (PP: 34.7\%/ OC: $34.9 \%$; $\mathrm{p}<0.01$ ) and 2NRTI+1NNRTI (PP: $33.1 \% /$ OC: $35.6 \%$; $<<$ $0.01)$; also concerning other regimes and treatment interruptions, there were slight differences. CD4-cell-count at start of ART was equal (PP:286/OC:283;p=0.83).

Core outcome parameters were similar concerning mean CD4-cell-count (PP:527/OC:524;p=0.73) and median of viral load above detection limit (PP:3,559/OC:3,087;p< $0.01)$. Proportions of viral loads below detection limit differed (PP:64.7\%/OC: $73.2 \% ; \mathrm{p}<0.01$ ).

Conclusion: Although patient populations differed between PP and OC, treatment standards and outcomes were very similar. This is an important information as to the choice of the type of a treating institution, both for patients and counsellors.

Differences in proportions of viral load below detection limit have to be analysed further.

\section{P515}

HIV - positive Frauen können auch in Deutschland vaginal gebären - Erfahrungen mit 50 vaginal intendierten Geburten 2001 bis 2008

Ralph Kästner ${ }^{1}$, Andrea Gingelmaier ${ }^{2}$, Milena Sovric ${ }^{2}$, Marianne Müller ${ }^{2}$,Ulrike Sonnenberg-Schwan ${ }^{3}$, Weizsäcker Katharina ${ }^{4}$

${ }^{1}$ Frauenklinik LMU München - Innenstadt, Geburtshilfe, München, Germany, ${ }^{2}$ Frauenklinik LMU München Innenstadt, München, Germany, ${ }^{3}$ FrauenGesundheitsZentrum e.V., München, Germany, ${ }^{4}$ Klinik für Geburtsmedizin, Charité, Campus Virchow-Klinikum, Berlin, Berlin, Germany

Einleitung: In den letzten Jahren erhielten nahezu alle HIV-positiven Gebärenden in Deutschland leitlinienkonform eine Sectio zur Tansmission der vertikalen Transmission. 2 Kliniken in Deutschland haben nunmehr ihr Konzept 1. dem internationalen Vorgehen 2. den Bedürfnissen der Schwangeren und 3. neueren Daten angepaßt und ermöglichen bei Vorliegen günstiger Voraussetzungen (Einnahme einer HAART, VL unter der Nach weisgrenze) den HIV-positiven Schwangeren eine normale Geburt.

Ergebnisse: Wir berichten über 50 geplante vag. Geburten, 42 davon endeten auch vaginal, 3 mal davon per Vakuum. Herkunftsland, Parität, CDC-Stadien werden dargestellt, 47 von 50 nahmen eine HAART ein, $38 \%$ bereits vor Eintritt der Schwangerschaft.

Zur Geburt hatten $70 \%$ keine nachweisbare Viruslast, insgesamt $94 \%$ eine Viruslast $<500$ copies $/ \mathrm{ml}$. In seltenen Fällen kam es zur vaginalen Geburt, weil eine Sectio verweigert wurde oder bei $12 \mathrm{~h}$ zurückliegendem Blasensprung kein Benefit mehr davon zu erwarten war.

Keines der Kinder ist HIV-infiziert.

Diskussion und Schlussfolgerung: Eine 100\% Kaiserschnittrate in einigen deutschen Zentren auch noch nach dem Jahre 2008 erschiene angesichts der internationalen Leitlinien und der nunmehr auch guten Erfahrungen in 2 großen deutschen Kliniken unzeitgemäß und ließe auf eine direktive, nicht den Bedürnissen der betreuten Frauen entsprechenden Beratung schließen.

Eine sorgfältige Aufklärung muß selbstverständlich durchgeführt werden, die Nachteile einer Schnittentbindung können in vielen Fällen vermieden werden.

\section{P516}

Training and education programme in the European AIDS Treatment Network NEAT

$$
\begin{gathered}
\text { David Hans-U. Haerry }{ }^{1} \text {, Manuel Battegay }{ }^{1}, \\
\text { Stefano Vella }{ }^{2}
\end{gathered}
$$

\footnotetext{
${ }^{1}$ Universitätsspital Basel, Klinik für Infektiologie und Spitalhygiene, Basel, Switzerland, ${ }^{2}$ Istituto Superiore di Sanità, Dipartimento del Farmaco, Roma, Italy
}

Background: NEAT is a research project funded by the European Commission from 2007 - 2011. It is designed to strengthen Europe's excellence on HIV and co-infections, by integrating the critical mass of expertise needed to provide European leadership and through a joint programme of activities. It is an instrument for strengthening European HIV research. The main deliverable is a durable structuring and shaping of how research is carried out in Europe. 37 
core partners from 16 countries are represented. The main activity is to carry out joint clinical trials. Two trials are in the pipeline and will recruit patients in 2009 .

Methodology/activities: The NEAT training programme is designed to run a reliable, effective T\& E programme on conducting \& implementing clinical trials. The programme is targeting all stakeholders involved in clinical trials - researchers, nurses, lab staff and patients. 47 projects, including a $\mathrm{PhD}$ and master programme, have been submitted or have been carried out already. We started with ad hoc projects and are now concentrating efforts on trainings related to planned trials and trainings held in Central and Eastern Europe. The programme includes workshops, online trainings and resource materials and seminars. Expected outcomes Research will focus on developing innovative and strategic approaches to HIV/AIDS therapy, complementing clinical research conducted by industry. NEAT will promote translational research, from proofof-principle, to phase III-IV strategic effectiveness trials. NEAT will interact with regulatory authorities, will harmonise efficacy and safety data gathering at European level, will implement EU directives on clinical research, will optimise resources and infrastructure throughout Europe, and will disseminate technology and ethical rules. The Network will also spread expertise and resources, provide training and mobility of scientists at all levels, and will foster lasting collaborations between west and centre-east Europe.

\section{P517}

\section{Ein Praxisprogramm zur Unterstützung der Therapiebereitschaft und Adherence bei Menschen mit HIV}

Susanne Stoelzl, Dunja Nicca, Helene Weyermann, Patrick Schmid, Pietro Vernazza

Infectious Diseases Unit, Hospital St. Gallen, St. Gallen, Switzerland

Hintergrund: Beginnende Evidenz zeigt, dass die Therapiebereitschaft (Readiness) von Menschen mit HIV ein Faktor ist, welcher die Therapietreue (Adherence) und damit auch den Behandlungserfolg beeinflusst. Ein Praxisprogramm, welches Betroffene bereits bei der Therapieentscheidung über den Therapiestart bis hin zur langfristigen Einnahme antiretroviralen Kombinationstherapie unters tützt wird vorgestellt.

Beschreibung: In berufsübergreifender Zusammenarbeit wurde an einer HIV spezialisierten ambulanten Sprechstunde schrittweise ein Programm zur Unterstützung der Readiness und der Adherence entwickelt. Gestützt auf eine stufenbasierte Einschätzung der Therapiebereitschaft werden Interventionen basierend auf Information, Motivation und Fähigkeitstraining durch Pflegende, Ärztinnen und Ärzte durchgeführt. Das Fähigkeitstraining mit elektronischen Medikamentenbehältern zeigte eine hohe Akzeptanz bei Patienten. Das Trainingsangebot, vor dem Start der antiretroviralen Therapie, wurde von $90 \%$ der Patienten angenommen. Personen, welche das Training absolviert hatten $(n=50)$, zeigten nach 250 Tagen eine um $21 \%$ bessere Adherence als die Vergleichsgruppe $(n=700)$.

Schlussfolgerung: Programme zur Unterstützung der Readiness und Adherence von Menschen mit HIV scheinen nicht nur im Rahmen von Studien, sondern auch im klinis- chen Alltag umsetzbar zu sein. Im vorgestellten Programm wirkte sich das Fähigkeitstraining, aufbauend auf Informations- und Motivationsinterventionen, positiv auf die Adherence aus. Dies sollte in randomisierten kontrollierten Studien weiter überprüft werden .

\section{Grundlagenwissenschaft / Basic Science \\ P600 (PW)}

\section{Distinct viral interference mechanisms by different GBV-C proteins on HIV replication} Kristin Hänel, Susan Jung, Holger Wend, Bernhard
Fleckenstein, Heide Reil

Universitätsklinikum Erlangen, Virologisches Institut, Erlangen, Germany

Background: GBV-C inhibits HIV-1 in vivo and in vitro but the underlying mechanisms are still undefined. Therefore we screened each single GBV-C protein for HIV-inhibitory ability and tried to localize the impact of the candidates within the HIV life cycle.

Methods: Each GBV-C single protein was expressed in different HIV susceptible cell lines using the bicistronic Tet systems. GBV-C protein expression was induced either in the presence or absence of Doxycycline and HIV replication capacity was compared. Ongoing protein expression was detected by FACS and immunoblotting. Infection assays using wildtype HIV as well as HIV pseudotypes were performed to discriminate between impairment of early and late replication steps. Cell-cell and virus-cell fusion assays were established to prove the influence on HIV binding and fusion in more detail. Potential consequences on HIV transcription were determined with HIV-LTR reporter cell lines. RT-PCR was used to look for any effect on Reverse Transcription.

Results: Our experiments suggest that three GBV-C proteins are involved in the inhibitory mechanism targeting different HIV replication steps. Whereas the E2 glycoprotein mediates inhibition of early HIV replication steps, the non-structural proteins NS3 and NS5A interfere with postentry events. Moreover diverse fusion experiments on $293 \mathrm{~T}$ and HeLa cells revealed that the E2 protein of GBV-C inhibits HIV replication soon after the gp120/CD4 dependent entry mechanis m but prior reverse transcription.

Conclusion: In this study we investigated the involvement of each single GBV-C protein in HIV suppression. Hereby the structural protein E2 and the non-structural serine protease/helicase NS3 and the NS5A protein mediate inhibition of different HIV replication steps. The GBV-C NS3 might lead to a decreased HIV transcription rate due to a reduced NF- $\kappa B$ activation which is described for the $\mathrm{NS} 3 / 4 \mathrm{~A}$ proteases of related flaviviruses GBV-B and HCV. 
P601 (PW)

Uncoupling gag and pol reading frames

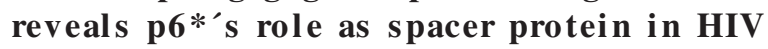

Andreas Leiherer, Christine Ludwig, Ralf Wagner

Universitätsklinikum, Medizinische Mikrobiologie und Hygiene, Regensburg, Germany

Background: Apart from its regulatory role in protease (PR) activation, little is known about the function of the human immunodeficiency virus type 1 (HIV-1) transframe protein $\mathrm{p} 6^{*}$ in the viral life cycle. We have recently reported that the central region of $6^{*}$ can be extensively mutated without abandoning viral infectivity and replication in vitro. However, mutagenesis of the entire $\mathrm{p} 6^{*}$ coding sequence in the proviral context is not feasible without affecting the superimposed frameshift signal or the overlapping 1 1-p6 ${ }^{\text {gag }}$ domains.

Method: To overcome these limitations, we created a novel NL4-3-derived provirus by displacing the original frameshift site to the $3^{\prime}$ end of the gag gene thereby uncoupling the $6^{*}$ sequence from the $\mathrm{p} 1-\mathrm{p} 6^{\mathrm{gag}}$ reading frame.

Result: The resulting provirus AL proved to be infectious and replication competent in different cell lines. Surprisingly extensive mutations in $\mathrm{p} 6 *$, based on this artificial virus, had neutral (substitution) or even positive (deletion) effects on in vitro viral replication. Furthermore, heterologous reporter sequences of different length were expressed from the $\mathrm{p} 6 *$ reading frame and incorporated into virus particles. However, the insertion of a, compared to wt, five times larger reporter gene resulted in a clear reduction of virus release and a loss of infectivity.

Conclusion: These data imply that the length of the p6* spacer protein rather than the sequence context might be limiting for $\mathrm{p} 6 *$ function in vitro. Beyond the obtained insight in $\mathrm{p} 6{ }^{*}$ 's role for viral replication, AL is a new valuable tool for further elucidating HIV mechanisms, as it allows for the first time specific and extensive mutagenesis of naturally superimposed domains (p1, p6 ${ }^{\mathrm{gag}}, \mathrm{p} 6^{*}, \mathrm{PR}$ and the frame shift site) in a replicating virus.

\section{$P 602(P W)$}

Einfluss des CTLA4+49A>G Polymorphismus auf das Ansprechen auf eine HCV spezifische Therapie bei HIV-positiven Patienten mit einer akuten Hepatitis C

Benjamin Krämer, Martin Vogel, Hans Dieter Nischalke, Monika Michalk, Tilman Sauerbruch, Ulrich Spengler, Jürgen Rockstroh, Jacob Nattermann

Universitaetsklinikum Bonn, Medizinische Klinik und Poliklinik I, Bonn, Germany

Hintergrund: Die Ko-Infektion mit dem Hepatitis C Virus $(\mathrm{HCV})$ stellt ein wichtiges Gesundheitsproblem bei HIV-infizierten Patienten dar. Zudem kam es in den letzten Jahren vermehrt zu Ausbrüchen einer akuten Hepatitis $\mathrm{C}$ bei homosexuellen HIV (+) Patienten in Zentren wie London, Paris und Berlin.

Momentan stellt die Kombination von Interferon-a mit Ribavirin das Standard-Therapieschema dar. Momentan ist nur teilweise verstanden, welche Faktoren das Ansprechen auf eine solche Therapie beeinflussen. Verschiedene Arbeiten zeigen jedoch, dass eine robuste T-Zell-Antwort mit einer erfolgreichen Therapie korreliert.
Das CTL Antigen-4 (CTLA4) kann durch Bindung an die ko-stimulatorischen Moleküle CD80 und CD86 T-ZellFunktionen hemmen. Kürzlich wurde nachgewiesen, dass der CTLA4 +49A $>$ G Polymorphismus bei HCV Mono-infizierten mit dem Therapie-Ansprechen assoziiert ist. Wir untersuchten den Einfluss des CTLA-4 Genotyps bei HCV/HIV ko-infizierten Patienten.

Methoden: 72 HIV-Patienten mit akuter Hepatitis C wurden untersucht. Der CTLA4 Genotyp wurde mittels Realtime PCR bestimmt und mit dem Therapieansprechen korreliert.

Ergebnisse: Ein anhaltendes virologisches Therapieansprechen (SVR) wurde bei 45/72 (62.5\%) erzielt. Hierbei unterschied sich die Verteilung der CTLA4 +49A $>$ G Genotypen signifikant zwischen Patienten mit SVR und Therapieversagern $(p=0.022)$. Bei Trägern des $+49 \mathrm{G} / \mathrm{G}$ Genotyps konnte in einem signifikant höheren Prozentsatz ein Therapie-Ansprechen erzielt werden als bei Patienten mit einem anderen Genotyp (12/13 [92.3] vs 33/59 [55.9\%]). In einer logistischen Rregressions-Analyse konnte der +49G/G Genotype als ein unabhängiger Prädiktor für ein Therapieansprechen bestätigt werden .

Schlussfolgerung: Der CTLA4 +49 G/G Polymorphismus ist bei HIV/HCV ko-infizierten Patienten mit einer hohen SVR-Rate assoziiert. Unsere Studie unterstreicht somit die Bedeutung einer effizienten T-Zell-Antwort und genetischer Faktoren für eine erfolgreiche HCV-Therapie.

\section{$P 603(P W)$}

\section{Is the cellular RNA helicase DDX3 a new potential antiviral target for HIV-1?}

\section{Sandra Beermann ${ }^{1}$, Giovanni Maga ${ }^{2}$, Ursula Dietrich ${ }^{1}$}

${ }^{1}$ Georg-Speyer-Haus, Molekulare Virologie, Frankfurt am Main, Germany, ${ }^{2}$ Istituto di Genetica Molecolare IGM-CNR, Pavia, Italy

Background: The HIV-1 life cycle offers many potential targets for antiviral intervention including viral and cellular proteins as well as regulatory RNA structures. These targets can be used to select specific peptide ligands which by binding to the target should interfere with its function in HIV-1 replication. The aim of this study is to select peptide ligands for the DEAD-box RNA helicase DDX3, an essential cofactor for Rev/RRE-mediated HIV RNA-export of unspliced/partially spliced HIV-1 transcripts.

Methods: We have established the conditions to express the recombinant His-tagged form of full-length human DDX3 (661 aa) from human PBMCs as well as diverse mutants in E. coli. Mutants for phage display screenings include a $\mathrm{C}$-and $\mathrm{N}$-terminal deletion, a mutant expressing only an insertion unique for DDX3 as well as a construct lacking this insertion. All constructs were expressed and purified to be used as targets in phage display screenings. We use three phage libraries with peptides of 7 or 12 aa in a linear or cyclic form. Specificity of binding is confirmed by ELISA and peptide inserts are identified by sequencing the the phage genome.

Results: Wild type and mutant DDX3 were cloned into the pET30a+ expression vector and constructs were verified by sequencing. Expression was optimized in Rosetta2(DE3) cells based on Western blot analysis of cell lysates. DDX3 proteins were purified by chromatography using FPLCNiNTA columns and immobilized via His tag for the phage 
display screenings. Additionally, DDX3 nuclear export sequence (NES) and DDX3 insert specific peptides were designed to select peptide ligands, with potential to inhibit NES and DDX3 function specifically. Several specifically binding phages will be tested in functional as says for HIV1 inhibition.

Conclusion: As essential cofactor for HIV-1 infection, the cellular RNA helicase DDX3 represents a new potential antiviral target.

\section{$P 604$}

Mitogenic and adjuvant properties of a
multimeric CD40 ligand variant on the
surface of HIV-1 C-Clade Pr55gag VLP
Simon Bredl, Josef Köstler, Jens Wild, Ralf Wagner

Simon Bredl, Josef Köstler, Jens Wild, Ralf Wagner

Institut für Med. Mikrobiologie und Hygiene, Regensburg, Germany

Background: HIV-1 Pr55gag virus-like particles (VLP) produced in the human 293 T cells have been shown to represent weak activators of human monocyte derived dendritic cells (MDDCs) and induce moderate Th1 based responses in Balb/C mice.

Objective: For efficient activation of dendritic cells (DC) and to modulate the acquired immune responses the CD40 ligand (CD40L; CD154) will be co-administered wether as VLP bound di-trimer or as soluble di-tetramer (MegaCD40L; provided by Apoxis).

Methods : Pr55Gag VLP were produced by transient expression in mammalian 293T cells coexpressing the CD40L derivatives. Immunoglobulin production, induction of proliferation and upregulation of costimulatory molecules (CD69, 80, 83, I-Ad and B220) of B-cells derived from splenic cells of naïve were used as a measure for the activation of innate immunity by VLP antigens and the co-administered CD40L. Further the frequencies and identity of IFN- $\gamma$ producing, Gag-specific T-cells will be determined by FACS and ELISPOT technology. The humoral response will be measured by ELISA.

Results: The cloning of the required vectors have been completed. Expression and purification of the VLP and the CD40L derivatives has been established. The pseudotypisation of the VLP with the CD40L variants was successful and the biological activity of these have been proven. First immunisation studies to examine the adjuvant properties of the CD40L on the VLP derivatives are accomplished.

\section{P605 (PD)}

Sequence and structure information from $\mathrm{V} 3$ as basis for a sensitive genosorting method to determine HIV coreceptor use

Heinz Stucki ${ }^{1}$, Sarah Wagner ${ }^{1}$, Vincent Vidal ${ }^{2}$, François Hamy $^{2}$, Thomas Klimkait ${ }^{1}$

${ }^{1}$ Institute of Medical Microbiology, Department of Biomedicine, University of Basel, Switzerland, ${ }^{2}$ InPheno AG, Basel, Switzerland

Background: The clinical introduction of CCR5-antagonists in HIV-therapy necessitates reliable co-receptor assigning diagnostic tools. Currently the only validated method, "Trofile ${ }^{\circledR "}$, is unacceptably time consuming, and the long delays of treatment decision may lead to omitting the whole drug class from the decision process. Aim of our work was to develop a rapid, reliable diagnostic tool for coreceptor determination. It omits cell culture and, unlike other genotyping systems that rely on amino acid interpretation reads assesses the responsible RNA/DNA utilizing a specific hybridization methodology.

Materials and methods: RT-PCR of HIV-RNA generates a 140 bp DNA fragment. After denaturation defined singlestranded, fluorescently labeled V3-DNA-probes are hybridized to form a double strand, and the degree of matching between sample and known probe suggests the CCR5- or CXCR4-tropism. DNA-duplexes are resolved by semi-denaturing capillary electrophoresis, sorting the sample/probe hybrid populations into distinct migration zones. Those are defined for and corres ponded to discrete co-receptor tropisms.

Results: Large sequence panels with known co-receptor tropism yielded the design of tropism-specific probe sets. With those several distinct but related groups of CCR5- and CXCR4 tropic viruses were discriminated. An algorithm was defined to assign co-receptor usage. The method was first validated in vitro using various lab strains and clinical samples of different subtypes of HIV-1 and HIV-2 from different sources. Tropism assessments are then analyzed further by comparing them to a sensitive replicative phenotyping test. A separate prospective validation on blinded clinical samples compares these results directly in parallel to the Trofile analysis.

Conclusion: Our "geno-sorting" DNA hybridization methodology combines the advantages of genotyping over phenotyping with structural parameters. The establishment of a new specific, cost-effective, and rapid system and appropriate diagnostic method is envisaged that accompanies clinical treatment decisions. The outcome of a comparative study with the Trofile test will establish clinical utility of our system.

\section{P606}

Influence of major protease inhibitor resistance mutations on $\mathrm{CTL}$ recognition

Sandra Michaela Müller ${ }^{\text {, Silke Bergmann }}{ }^{1}$, Pia Rauch ${ }^{1}$, Kathrin Eismann ${ }^{1}$, Angela Hück elhoven ${ }^{1}$, Jennifer Etschel $^{1}$, Bernd Spriewald ${ }^{2}$, Ellen Harrer ${ }^{1}$, Thomas Harrer $^{1}$, German Competence Network on HIV/AIDS

${ }^{1}$ Institut für Klinische Immunologie/Medizinische Klinik 3/ Universität Erlangen-Nürnberg, Erlangen, Germany, ${ }^{2}$ Institut für Hämatologie und Internistische Onkologie/Medizinische Klinik 5/Universität Erlangen-Nürnberg, Erlangen, Germany

Background: Recently, we identified KMIGGIGGF (KF9) as an HLA-B62-restricted CTL epitope in HIV-1 Protease. KF9 comprises several important protease inhibitor (PI) resistance mutations (M46I/L, I47A/V/L, G48V/M and $\mathrm{I} 50 \mathrm{~V}$ ) that have been described as major drug resistance mutations. In this study the influence of these drug resistance mutations on the recognition of the KF9 epitope in B62positive HIV-1-infected individuals was analysed.

Methods: Forty B62-positive HIV-1-infected patients were included in this study. $40 \%$ of these patients were therapy naïve or were treated by PI-sparing drug regimens, whereas $60 \%$ received PI-treatment. PBMC were stimulated with wild-type peptide or variant peptides comprising the 
drug mutations M46I, I47 A, I47V, G48V or I50V. Outgrowing cell lines were evaluated for cross recognition of these peptides by IFN- $\gamma$-ELISPOT analysis .

Results : Assessing the prevalence of KF9 recognition in a B62 positive cohort, we found that the majority of the patients showed a strong recognition of the KF9 epitope. The Saquinavir induced mutation G48V abolished CTL recognition in almost all tested samples. In contrast peptides including the M46I mutation, which confers resistance to Indinavir and several other PIs, were still recognized in 19 from 23 tested samples, although the M46I mutation diminished recognition of M46I-containing peptides. I47V was recognized in $80 \%$ of the samples whereas recognition of I47A was only seen in $29 \%$ of the analysed cells. Peptides comprising the I50V mutation, contributing to Darunavir and Fosamprenavir resistance were recognized in all analysed samples. No differences were found between patients on antiretroviral therapy, patients on PIsparing drug regimens and therapy naïve patients.

Conclusions: KF9 is a frequently targeted CTL epitope in HLA B62-positive patients. The drug mutations 46I, $47 \mathrm{~V}, 47 \mathrm{~A}$ and $48 \mathrm{~V}$ strongly influence recognition of the KF9 epitope by B62-restricted CTL. Our results indicate potential important interactions between the HIV-1-specific immune response and the development of drug resistance.

\section{$P 607$ (PD)}

Relocation and higher apoptosis of plasmacytoid dendritic cells in lymphoid tissues of HIV-1 infected patients

Clara Lehmann ${ }^{1}$, Norma Jung ${ }^{1}$, Jan van Lunzen ${ }^{2}$, Gerd Fätkenheuer ${ }^{1}$, Fabio Romerio ${ }^{3}$, Pia Hartmann ${ }^{1}$

${ }^{1}$ Klinik I für Innere Medizin, Klinische Infektiologie, Koeln, Germany, ${ }^{2}$ Universitätsklinikum Hamburg- Eppendorf, Ambulanzzentrum, Hamburg, Germany, ${ }^{3}$ University of Maryland, Institute of Human Virology, Baltimore, United States

Background: High interferon alpha (IFNa) serum levels are associated with disease progression in HIV-1 infection. However, as a paradox, PDC, which are the main producers of IFNa progressively decrease in peripheral blood at later stages of disease and show impaired IFNa production after in vitro challenge with reference viruses. We hypothesized that peripheral PDC express higher IFNa levels at steady state and migrate to lymphoid tissues (LT) where they undergo apoptosis.

Methods: PDC in peripheral blood of controls $(\mathrm{n}=17)$ and HIV-1+ subjects (viremic: $\mathrm{n}=14$ and aviremic $\mathrm{n}=15$ ) were assessed for expression of the LT homing markers CCR7 and CD62L by flow cytometry. Migration capacity to the CCR7 ligands CCL19 and CCL21 was measured by transmigration assays. The apoptosis rate of PDC in LT from healthy controls and viremic HIV-1+ donors was quantified by Annexin V-staining. To simplify the analysis the expression levels of IFNa were obtained in unstimulated peripheral PBMC by real-time PCR in controls $(n=10)$ and HIV-1+ patients (CDC stage A: $n=10, C: n=10$ ).

Results : PDC from viremic HIV-1+ donors showed higher expression of CCR7 ( $\mathrm{p}=0.004)$ and CD62L $(\mathrm{p}=0.043)$ vs. aviremic HIV-1+ donors and controls. PDC from viremic HIV-1+ patients had higher capacity to migrate to the lig- ands CCL19 and CCL21 ( $\mathrm{p}=0.002)$ vs. controls and aviremic HIV-1+ patients. CCR7 expression correlated positively with PDC frequency $(r=-0.06, p=0.008)$. Higher frequency of apoptotic PDC was found in LT of HIV-1+ patients vs. controls $(p=0.028)$. Elevated total IFNa expres sion in PBMC was observed with disease progression $(\mathrm{p}<$ $0.001)$.

Conclusions: Baseline expression of IFNa in PDCs is increased in HIV+ individuals. Disease progression is associated with an increasing migration of PDC to LT, the sites of high HIV replication, where they finally undergo apoptosis. Thus the mysterious loss of PDC from the periphery may be unraveled as PDC redistribution in different LT.

\section{P608 (PD)}

\section{Interference with the genome of HIV as therapeutic means to block infection}

Verena Oberhauser ${ }^{1}$, Wilfried Posch ${ }^{1}$, Doris Wilflingseder ${ }^{1}$, Brigitte Mïllauer ${ }^{1}$, Stefan Piper ${ }^{2}$, Birgit Werner $^{2}$, Thomas Lindhorst ${ }^{2}$, Holger Bock ${ }^{2}$, Heribert Stoiber ${ }^{1}$

${ }^{1}$ Medizinische Universität Innsbruck, Department für Hygiene und Medizinische Mikrobiologie, Innsbruck, Austria,

${ }^{2}$ Ugichem GmbH, Innsbruck, Austria

Peptide nucleic acids (PNAs) are fully synthetic DNA/RNAanalogues on a peptide-like backbone. Similar to small interfering RNAs (siRNAs), PNAs hybridize to complementary DNA/RNA structures, but in contrast to them the effect of PNAs is rather based on steric blocking of enzymes essential for translation. Unlike conventional siRNAs, PNAs have no charged phosphate groups resulting in increased affinities to complementary DNA/RNA motifs. This special structure also provides the PNAs with a better resistance against cellular nucleases and proteases what would support a prospective in vivo application. Although becoming a valuable tool for gene silencing, regulation or editing in vitro, the transfer of siRNA and PNAs into cells is still an unsolved problem for in vivo applications. Neither electroporation nor microinjection or other conventional means for transfection are feasible in living organisms. We have tested newly-modified PNAs which have the advantage to pass the membrane by diffusion without any further manipulation of the cells. These PNAs are designed to target distinct genomic regions in the HIV-1 gag and are therefore thought to interfere with HIV replication. FACS and fluorescence-microscopical analysis of cells incubated with FITC-labelled PNAs revealed that the compounds are enriched in cells in a dose dependent manner without any further supplement or manipulation. As shown by infection assays, several used PNAs exhibit potent antiviral effect and significantly reduced virus production in cell culture. The inhibition of viral replication was observed at several steps during the intracellular replication cycle of HIV. Thus, self transfecting PNAs may become not only promising candidates as drugs or virucides against HIV-1 but may also be used more generally as microbicides to any given infection.

Supported by the FFG (Bridge Project \#815463). 
$P 609$ (PD)

\section{Expansion of CD56-CD16+ NK cells in HIV infection correlates with differential expression patterns of CCR7 and CD57}

Henoch Hong, Johanna Eberhard, Phillip Keudel, Nupur Bhatnagar, Reinhold E. Schmidt, Dirk Meyer-Olson

Medizinische Hochschule Hannover, Klinik für Immunologie und Rheumatologie, Hannover, Germany

HIV infection has been linked with loss of CD56+ NK cells and expansion of CD56- CD16+ NK cells. Here we demonstrate that occurrence of the CD56-CD16+ NK cells is associated with distinct expression of the lymphnode homing receptor CCR7 and the senescence marker CD57 on this NK cell subset.

We performed a cross-sectional study of NK cells from 34 untreated HIV-infected individuals and 14 healthy subjects. CD57, CCR7, CD38, HLA-DR and killer cell immunoglobulin-like receptor expression patterns on NK cells were assessed by flow cy tometry.

We found a significantly higher fraction of CD57+ cells on CD56- CD16+ NK cells from HIV-infected individuals as compared to healthy controls $(25.8 \% \pm 2.4$ SEM versus $8.2 \% \pm 0.8$ SEM, $\mathrm{p}<0.0001)$. CCR7 is exclusively found on CD57- cells and vice versa. Expansion of CD57+ cells negatively correlated with loss of CCR7 expression on CD56- CD16+ NK cells $(58.4 \% \pm 4.4$ SEM versus $76.9 \% \pm$ 3.1 SEM, $p=0.015 ; \mathrm{r}=-0.66, \mathrm{p}<0.0001)$.

We furthermore show that absolute numbers of CD56CD16+ NK cells correlated with percentages of CD57+ CD56- CD16+ NK cells $(r=0.55, p=0.001)$ and inversely correlated with percentages of CCR7+ CD56- CD16+ NK cells $(\mathrm{r}=-0.6, \mathrm{p}=0.0002)$.

In addition, we sought to phenotypically characterize CD57+ CD56- CD16+ cells and found substantially lower expression of HLA-DR $(\mathrm{p}<0.0001)$ but higher expression of CD38 (p < 0.0001), KIR2DL2/DL3/DS2 ( $<<0.0001)$ and KIR3DS1/DL1 ( $\mathrm{p}=0.0003)$.

In summary, we provide evidence for alterations in senescence marker as well as lymph node homing receptor expression on the CD56- CD16+ NK cell subset, which is associated with HIV-caused disorders of NK cell subset homeostasis. We therefore suggest CD57 and CCR7 are indicators for disrupted homoeostasis of NK cell subpopulations in HIV infection.

\section{P610 (PD) \\ Inhibition of HIV-1 replication by interference with the ESCRT-I subunit Tsg101 \\ Ilona Hauber, Jan Chemnitz, Birgit Schäfer, Joachim Hauber}

Heinrich-Pette-Institut, Hamburg, Germany

Backgro und: The formation of progeny viruses requires multiple intracellular interactions of both viral components and host cell factors. In particular, budding of HIV-1 through the limited membranes of infected cells depends on the interaction of the p6-region of the retroviral Gag polyprotein with a high-molecular-weight cytoplasmic protein complex, referred to as ESCRT-I, which is normally engaged in the formation of late endosomal multivesicu- lar bodies (MVB). MVB mediate the sorting and trafficking of membrane proteins and internalized material along the endocytic degradative pathway. Thus, MVB biogenesis (i.e. vesicle budding at endosomes) and viral budding at the plasma membrane appears to be topologically equivalent. Due to their central role in virus budding, components of the cellular ESCRT machinery may also represent a valuable target for the development of novel antiretroviral therapies.

Methods: Analysis of the mode-of-action of a budding inhibitor by employing HIV-1 infection experiments, toxicity studies, immunofluorescence microscopy, and in vitro protein binding assays.

Results: We are able to demonstrate that a novel peptideinhibitor is internalized by infected cells and accumulates at distinct cytoplasmic foci. Furthermore, this peptide efficiently suppresses virus replication, including the replication of HAART-resistant viruses, by specifically targeting the interaction of the budding late (L)-domain of p6 Gag with the ESCRT-I component Tsg 101.

Conclusion: Our data provide a novel strategy to interfere with HIV-1 replication, and possibly also with the formation of other enveloped viruses, that exploit Tsg 101 for particle budding.

\section{$P 611$ (PD)}

\section{GB Virus C die biologische Alternative zu Maravi roc, T20 \& Co \\ Susan Jung, Heide Reil}

University Hospital Erlangen, Department of Clinical and Molecular Virology, Erlangen, Germany

HIV und AIDS sind eines der größten sozioökonomischen Probleme unserer Zeit. Obwohl Medikamente die Virusreplikation unterdrücken und das Leben Betroffener verlängern, stellt die Infektion auch 25 Jahre nach der Entdeckung des HI Virus eine besondere Herausforderung für Ärzte und Wissenschaftler dar. Umweltkeime und andere Viren können sich nachteilig auf den Verlauf der HIV-Infektion auswirken. Eine Ausnahme ist hierbei aber die Koinfektion mit dem nicht-pathogenen GB Virus C.

Durch die Herstellung von HVS/GBV-C Chimären und die Expression überlappender GBV-C Genkassetten in transformierten, humanen T-Lymphozyten konnten die kausalen GBV-C Gene näher eingegrenzt und mögliche Ziele im HIVReplikationszyklus lokalisiert werden. Während die GBVC Oberflächenproteine ausschließlich die HIV-Infektion der Zielzelle beeinflussen, interferieren die Nicht-Strukturproteine mit späteren HIV-Replikationsschritten. Die gezielte Expression einzelner GBV-C Proteine in T-Zelllinien und Infektionsexperimente mit klinischen HIV-Isolaten und Reporter-HI Viren führte zur Identifikation der anti-retroviral wirksamen GBV-C Proteine E2, NS3 und NS5A. Während die NS3-Protease und das regulatorische NS5A-Protein die späten HIV-Replikationsschritte inhibieren, ähnelt der Wirkmechanismus des E2-Glykoproteins, dem von HIV-Entry-Inhibitoren. Die Inkubation von Lymphozyten mit eukaryotisch exprimiertem, aufgereinigtem E2-Protein induziert die Sekretion eines bisher unbekannten löslichen Faktors, der unabhängig vom Korezeptortropismus, exklusiv den HIV-spezifischen Zelleintritt inhibiert. Der zugrunde liegende Wirkmechanismus beschränkt sich aber nicht nur auf die Stimulation von HIV- 
Zielzellen. Es gibt Hinweise, dass das E2-Protein auch ein Entry-relevantes Oberflächenepitop von HIV wiederspiegelt. Durch HIV-Neutralisierungsversuche wurden zwei monoklonale anti-E2 Antikörper identifiziert, die an Oberflächenstrukturen von HIV-Partikeln binden und dadurch deren Infektiösität reduzieren.

Das GBV-C E2-Protein stellt einen interessanten Ansatzpunkt für die Entwicklung eines innovativen HIV-Inhibitors dar, da es selbst anti-retroviral wirksam ist und zudem HIV-neutralisierende Antikörper zu induzieren vermag. Auch die viralen Proteine NS3 und NS5A können helfen neue Strategien im Kampf gegen HIV zu entwickeln. Die Aufklärung der zugrunde liegenden Mechanismen in vitro kann dabei maßgeblich zum Verständnis der HIV-Inhibition durch das nicht-pathogene GB Virus $\mathrm{C}$ im Menschen beitragen.

\section{P612}

\section{Reduction of HIV infectivity by GB Virus C anti-E2 antibodies}

Susan Jung, Norbert Donhauser, Bernhard Fleckenstein, Heide Reil

University Hospital Erlangen, Department of Clinical and Molecular Virology, Erlangen, Germany

Since the late 1990s, GBV-C was investigated in the context of HIV. Contrary to the experiences with the related $\mathrm{HCV}$, clinical studies demonstrated that a GBV-C co-infection is not correlated with a faster progression to AIDS. Remarkably, not only patients with active GBV-C viremia but also those who have cleared their GBV-C viremia by the development of neutralizing antibodies directed against the GBV-C E2 protein have a higher survival probability. Therefore we like to prove the hypothesis to what extent anti-E2 antibodies reduce the HIV pathogenicity by crossneutralizing activity against HIV antigens or antigens on HIV target cells.

Healthy blood donors were screened for GBV-C RNA as well as GBV-C specific antibodies. IgG subclasses of antiE2 antibodies positive and negative donors were purified by affinity chromatography and their neutralizing capacity was determined in $\mathrm{HIV}_{\mathrm{WT}}$ infection experiments and single round of infection assays. A set of monoclonal anti-E2 antibodies and their respective isotype controls were also tested to corroborate the specificity of the effect.

Indeed, pre-incubation of HIV particles with IgG fractions of anti-E2 positive blood donors as well as two monoclonal anti-E2 antibodies led to reduced HIV infectivity. IC50 could be determined and impairment of reporter-HIV pseudo typed with the VSV glycoprotein suggest a HIVgp 120 independent inhibitory mechanism. Interestingly, the neutralizing MAb detect a linear and a conformational epitope, but compete with each other. Hereby the linear epitope is located in the C-terminal region of the GBV-C E2 protein.

Noteworthy, earlier we could identified the GBV-C E2 protein by itself as a HIV entry inhibitor protein. A combination of both HIV-inhibitory effects (that of E2 and antiE2) presents a real challenge for the future. It might diminish the frequently observed immunologically mediated loss of the efficacy of small molecule or protein inhibitors during the treatment of HIV.

\section{P613}

\section{Identification of PD-1 as a unique marker for discordant immune response in HIV infected patients}

\author{
Katharina Pfistershammer ${ }^{1}$, Armin Rieger $^{1}$, Peter
} Steinberger ${ }^{2}$, Norbert Kohrgruber ${ }^{1,3}$

${ }^{1}$ DIAID, Medizinische Universität Wien, Wien, Austria,

${ }^{2}$ Institut für Immunologie, Wien, Austria, 3Abteilung für Dermatologie, Wilhelminenspital, Wien, Austria

Objectives: PD- 1 expression on T cells correlates with T cell exhaustion and disease progression in HIV infected patients. HAART results in viral suppression and in reduced PD-1 expression and immune restoration in most patients. However, a minority of patients fails to reconstitute their CD4 T cells in spite of successful suppression of HIV replication.

In this study we assessed PD-1 expression on Tlymphocytes in patients with failing immune recovery.

Methods: PD-1 expression was analyzed by FACS on CD4 and CD8 T cells of HIV infected patients showing a defect in immune reconstitution following HAART as defined by less than $300 \mathrm{CD} 4$ cells $/ \mathrm{mm}^{3}$ in spite of viral suppression and compared to PD-1 levels on T cells of patients with good immunological recovery.

Results: We found persistence of high PD-1 expression on CD4 and CD8 T cells in spite of viral suppression in patients with poor immune reconstitution. In contrast failing immune reconstitution was not associated with the expression of other markers associated with immune activation or enhanced endotoxin serum levels. Furthermore we show that these $\mathrm{T}$ cells differ from $\mathrm{T}$ cells of an aged immune system. We find that PD-1 expression negatively correlates with the absolute CD4 cell count and we demonstrate that PD-1 expressing T cells are more responsive to PD-ligand mediated inhibition of $\mathrm{T}$ cell proliferation.

Conclusion: PD-1 is a unique marker for poor immunological recovery. We provide evidence that PD-1 mediated $\mathrm{T}$ cell suppression may have a role in impaired immune reconstitution in HIV patients.

\section{P614}

Mitochondrial DNA depletion, mitochondrial dysfunction and peripheral lipoatrophy

\section{Metodi V. Stankov, Reinhold E. Schmidt, Georg M. Behrens}

Hannover Medical School, Clinic for Immunology and Rheumatology, Hannover, Germany

Objective: Nucleoside-analogue reverse transcriptase inhibitors (NRTI) induced mitochondrial (mt) DNA depletion and $\mathrm{mt}$ dysfunction has been proposed as a pathogenetic mechanism of the ART-associated lipodystrophy syndrome. We wished to assess the impact of NRTI-treatment on subcutaneous adipose tissue (SAT) mtDNA content in C57BL/6 mice and to determine the respiratory chain activity and the development of lipoatrophy.

Methods: Zidovudine (AZT), stavudine (d4T), tenofovir (TDF) or vehicle treatment was applied to groups of C57BL/6 mice for up to 9 months. The drug doses corresponded to the daily human doses adjusted for murine body surface area. MtDNA contend was measured by Real-Time 
PCR in subcutaneous adipose tissue (SAT), kidney, liver and muscle. The activity of cytochrome c oxidase (complex IV) and the cellular ATP/ADP ratio were analyzed. SAT differentiation status was estimated by measuring adipocyte differentiation markers. SAT content was analyzed by magnetic resonance tomography (MRT).

Results : $\mathrm{d} 4 \mathrm{~T}$ treatment was associated with profound $\mathrm{mtD}$ NA depletion in SAT. We were unable to as sociate this depletion with alterations cytochrome c oxidase activity and ATP/ADP ratio. SAT differentiation status was unchanged and MRT revealed no signs of lipoatropy as a result of long term $\mathrm{d} 4 \mathrm{~T}$ treatment alone. AZT treatment reduced the adipogenic marker expression in SAT. However, despite the fact that AZT induced general body wasting, neither mtDNA depletion nor lipoatrophy was detected. Interestingly, TDF treatment decreased the mtDNA content in kidney and altered the cellular energetic status in this organ.

Conclusions: In vivo d4T induced mtDNA depletion in SAT of male C57BL/6 mice was not associated with compromised activity of complex IV and the development of lipoatrophy. Long term $\mathrm{d} 4 \mathrm{~T}$ treatment alone was not sufficient to alter the differentiation status of SAT in mice.

Supported by HW\&J Hector Stiftung.

\section{P615}

HIV-1 Vpr inhibits type I interferon production by plasmacytoid dendritic cells (pDCs) and impairs pDC-NK cell crosstalk in vitro

Henoch Hong ${ }^{1}$, Nupur Bhatnagar ${ }^{1}$, Ulrich Schubert ${ }^{2}$, Matthias Ballmaier ${ }^{3}$, Thorsten Volgmann ${ }^{4}$, ReinholdE. Schmidt ${ }^{1}$, Hans Heiken ${ }^{1}$, Dirk Meyer-Olson ${ }^{1}$

${ }^{1}$ Medizinische Hochschule Hannover, Klinik für Immunologie und Rheumatologie, Hannover, Germany, ${ }^{2}$ FriedrichAlexander-Universität Erlangen-Nürnberg, Institut für

Klinische und Molekulare Virologie, Erlangen, Germany,

${ }^{3}$ Medizinische Hochschule Hannover, Klinik für Pädiatrische Hämatologie und Onkologie, Hannover, Germany, 4Blutspendedienst NSTOB, Springe, Germany

Type I and type II interferons (IFNs) play a pivotal role in innate immunity. Upon activation, pDCs produce large quantities of type I IFNs whereas early type II IFNs are secreted by natural killer (NK) cells. Immune responses of pDCs and NK cells are impaired in HIV infection. Here we show that HIV-1 Vpr can interfere with IFN- $\alpha$ production by pDCs, resulting in a disturbed interplay between NK cells and pDCs.

We analyzed purified human pDCs and/or NK cells in the presence or absence of synthetic HIV-1 Vpr. Secretion of IFNs were measured by ELISA and apoptosis was detected by Annexin V and Viaprobe staining. NK cell phenotype was assessed by flow cytometry and cytolytic activity by standard ${ }^{51} \mathrm{Cr}$ release assay and CD107a degranulation assay.

Vpr treatment of pDCs substantially suppressed IFN- $\alpha$ production by $\mathrm{CpG}$ activated pDCs (\% reduction $49.6 \pm$ 23.0 SD, $\mathrm{p}=0.008$ ) as compared to the control protein HIV p6 where we found a nonsignificant increase of IFN- $\alpha$ production (\% increase $29.36 \pm 23.0 \mathrm{SD}$ ). Vpr did not induce apoptosis. CpG stimulated pDCs were able to activate NK cells in terms of higher CD69 expression, increased cytolytic activity and IFN- $\gamma$ production. Vpr significantly di- minished $\mathrm{pDC}$ induced IFN- $\gamma$ secretion by NK cells $(\mathrm{p}=$ 0.02 ) without directly inhibiting NK activation by PMA/Ionomycin as shown by CD69 and IFN- $\gamma$ expression. Furthermore, Vpr did not interfere with pDC mediated upregulation of CD69 on NK cells and did not impede with increased NK cell killing activity, which we confirmed by CD107a degranulation assay.

Our results suggest the possibility that Vpr-mediated dysregulation of IFN- $\alpha$ production by pDCs and early IFN- $\gamma$ expression by NK cells provides a putative mechanism for evasion of IFN response by HIV. Further clinical studies will address its relevance.

\section{P616 \\ Design of highly efficient fluorescent hydrolysis probes for real-time PCR of HIV-1 nucleic acids with broad cross-clade coverage}

Claudia Althaus, Sara Gianella, Philip Rieder, Viktor Von Wyl, Barbara Niederöst, Beda Joos, Huldrych F. Günthard, Marek Fischer

Universitätsspital Zürich Klinik für Infektionskrankheiten, Zürich, Switzerland

Although widely used in HIV-diagnostics and -research, quantitative PCR using fluorescent hydrolysis probes (FH-probes) remains a challenge due to highly variable viral target sequences and uncertain predictability of probe-performance. Hence rationale algorithms to design FH-probes in regards to performance and target conservation were developed.

Methods: 30 DNA-probes (length 15-32 bases) and 21 modified locked nucleic acid-molecules (LNA; 8-14 bases) with stabilized melting-temperatures (TM) were synthesized mapping to 6 highly conserved regions of the HIV-1 genome (LTR, gag, pol, tat, env nef; $91 \pm 5 \%$ mean conservation). Performance of FH-probes was tested by measuring PCR-signal/noise ratios (SNRs) upon amplification of HXB2-DNA and evaluated by multivariable regression to identify predictors of SNRs. Conservation of FH-probes was determined by comparison with 1137 entries of the Los Alamos HIV database and perfect-match frequencies were computed using R.

Resul ts: TM and probe-length were poor predictors of FHprobe efficacy. GC-content of stem-loops within $\mathrm{FH}-$ probes, the base composition of the 5 ' proximal region, and the overall percentage of strong basepairs $(\mathrm{G} / \mathrm{C}$ and LNA) significantly predicted magnitude of SNRs, resulting in models for DNA- and LNA-probe performance $\left(\mathrm{r}^{2}=0.67\right.$ and 0.55 ) which greatly diverge from currently used rules for FH-probe design.

Conservation of FH-probes exponentially decreased with their length. Thus, match frequencies of DNA probes to viral isolates in the Los Alamos collection were comparably low $(33 \pm 29 \%)$, whereas shorter LNA-probes (8-14 bases) matched better $(71 \pm 23 \%)$. The best probes showed match frequencies of $87 \%$ (LTR and pol). Combination of 2 LNA FH-probes in one reaction resulted in a PCR assay for pol with single copy sensitivity matching $97 \%$ of the globally circulating HIV-1 clades and 99\% B subtypes.

Conclusions: Intelligent design of FH-probes in respect to PCR performance and conservation resulted in PCR assays for comprehensive quantification of both laboratory and patient HIV-1 isolates with single copy sensitivity. 
$P 617$ (PD)

\section{Combating drug resistance - antiretroviral activity and immune function in presence of hypusination inhibitors}

Philip Hartjen ${ }^{1}$, Marcel Krepstakies ${ }^{2}$, Silke Kummer ${ }^{1}$, Ilona Hauber ${ }^{2}$, Joachim Hauber ${ }^{2}$, Jan van Lunzen ${ }^{1}$

${ }^{1}$ Univesity Medical Center Hamburg-Eppendorf, HIV Research Lab, Hamburg, Germany, ${ }^{2}$ Heinrich-Pette-Institute for Experimental Virology and Immunology, Department of Cell Biology and Virology, Hamburg, Germany

Background: A major pitfall of current highly active antiretroviral therapy (HAART) is drug resistance development. As part of an interdisciplinary consortium funded by the BMBF we participate in the project "Combating Drug Resistance" that aims to exploit a unique feature of the cellular protein eIF5 A for a new therapeutic approach in HIV infection. eIF5 A is a critical cofactor of the retroviral Rev regulator and, notably, contains the amino acid hypusine, which is essential for its activity. Compounds that inhibit the posttranslational formation of hypusine in eIF5 A may therefore provide a new strategy to inhibit otherwise multidrug (HAART)-resistant viruses. Here, we characterized inhibitors of the two enzymes that catalyze hypusine formation, deoxyhypusine synthase (DHS) and deoxyhypusine hydroxylase $(\mathrm{DOHH})$, regarding their potential to inhibit HIV-1 replication in vitro. Moreover we studied effects of the DHS inhibitor CNI-1493 on vital T cell functions to assess such drug candidates for further development as antiretroviral therapeutics.

Methods: The effect of DHS and DOHH inhibitors on the replication competence of HIV-1 in vitro was analyzed by monitoring p24 levels as well as cellular viability over 712 days in PM1 cultures infected with the laboratory strains $\mathrm{BaL}$ and NL4/3. Their influence on functional properties of T cells was analyzed with a focus on HIV-specific $\mathrm{CD}^{+}$and $\mathrm{CD}^{+}{ }^{+} \mathrm{T}$ cell immune responses in ELISPOT assays and flow cytometric proliferation assays utilizing CFSE.

Results: Small-molecular weight inhibitors of DHS and DOHH efficiently suppress HIV-1 replication in vitro. Data obtained from ELISPOT and proliferation assays with PBMC from uninfected and HIV-1 infected individuals underpins the principal applicability of the DHS inhibitor CNI-1493 as a therapeutic agent in the context of HIV-1 infection.

Conclusion: The eIF5A modifying enzymes DHS and DOHH represent novel and promising drug targets for the development of advanced antiretroviral therapies, particularly for the inhibition of multidrug-resistant viruses.

\section{P618}

Accumulation of terminally differentiated cells in the $\mathrm{CD4}^{+} \mathrm{T}$-cell population of immunological non-responders

Eva Katharina Meuer, Sandra Winter, Norma Jung, Jan Rybniker, Gerd Fätkenheuer, Pia Hartmann

University of Cologne, 1st Department of Internal Medicine, Cologne, Germany

Background: Some HIV-infected patients do not achieve $\mathrm{CD}^{+}{ }^{+}$cell recovery under antiretroviral therapy even though their HIV-RNA is below detection level. The reasons for the persistent $\mathrm{CD}^{+}{ }^{+}$cell depletion despite of viral control in these so-called Immunological non-Responders (InRs) are not yet clear. We propose that the remaining CD4+ T-cell-population in InRs mainly consists of terminal differentiated CD7- cells lacking the ability to proliferate in an adequate manner to reconstitute the cell loss through HIV infection and to respond sufficiently to infections.

Methods: In this ongoing study we so far analyzed the frequency and immuno-phenotype of certain $\mathrm{CD} 4+\mathrm{T}$ cell subpopulations in 7 INRs, 6 complete responders (CRs) and 6 healthy donors (HDs). Statistical analysis was performed by Students t-test.

Results: Mean of CD4+ T-cells in InRs was $(25,9 \% \pm$ $14,0 \%$ ) containing a higher proportion of terminal differentiated $\mathrm{CD} 4{ }^{+} \mathrm{CD} 7$ - cells compared with age-matched CRs $(8,7 \% \pm 4,6 \% ; \mathrm{p}=0,017)$ and HDs $(8,9 \% \pm 4,6 \%)$. The corresponding $\mathrm{CD} 4+\mathrm{CD} 7+$ subpopulation declined (InRs: $71,5 \% \pm 14,9 \%$; CRs: $90,8 \% \pm 4,6 \% ; \mathrm{p}=0,014$; HDs: $90,6 \% \pm 6,7 \%)$. Characterization of the $\mathrm{CD} 4{ }^{+} \mathrm{CD} 7-\mathrm{sub}-$ population revealed a higher percentage of CD4 ${ }^{+}$CCR7 (InRs: $72,8 \% \pm 15,9 \%$; CRs: $51,3 \% \pm 15,9 \%$; HDs : $41,3 \%$ $\pm 12,1 \% ; \mathrm{p}=0,033)$ and CD4 ${ }^{+}$CCR7-CCR5- cells (InRs: $68,5 \% \pm 16,5 \%$; CRs: $48,2 \% \pm 16,5 \%$; HDs: $38,4 \% \pm$ $14,0 \% ; \mathrm{p}=0,049)$ within InRs compared with CRs and HDs .

Conclusions: The accumulation of terminally differentiated CD4 T-cells exhibiting impaired proliferation capacities provides an explanation for the persistent $\mathrm{CD}^{+}{ }^{+}$depletion in InRs. The CD4 ${ }^{+} \mathrm{CD} 7$ - subpopulation lacks important capacities for a sufficient immune response to opportunistic infections and thus may contribute to a higher susceptibility to infections in InRs. Whether an earlier initiation of ART could prevent this unfavorable distribution of CD4+ ${ }^{+}$-Cell subsets remains to be determinant.

\section{P619}
Parameters of soluble immune activation in vivo correlate negatively with the proliferative capacity of $\mathrm{PBMC}$ in vitro in HIV-infected patients

Katharina Kurz ${ }^{1}$, Christine Winkler ${ }^{2}$, Mario Sarcletti ${ }^{3}$ Nikolaus Romani ${ }^{3}$, Zoltan Banki ${ }^{4}$, Susanne Ebner ${ }^{3}$, Dietmar Fuchs ${ }^{2}$, Robert Zangerle ${ }^{3}$

${ }^{1}$ Univ. Klinik für Innere Medizin, Innsbruck, Austria, ${ }^{2}$ Biozentrum, Division für biologische Chemie, Innsbruck, Austria, ${ }^{3}$ Univ. Klinik für Dermatologie und Venerologie, Innsbruck, Austria, ${ }^{4}$ Biozentrum, Division für Hygiene, Mikrobiologie und Sozialmedizin, Innsbruck, Austria

Objective: In vitro peripheral blood mononuclear cells (PBMCs) of HIV-infected subjects show defective immune responses including impaired proliferative responses after stimulation with antigens and mitogens. The cytokine interferon-gamma, which seems to play an important role in HIV infection, induces neopterin formation and in parallel also tryptophan degradation by the enzyme indoleamine 2,3-dioxygenase.

Design: In this study, interferon-gamma mediated pathways were examined in the plasma of patients and evaluated for associations with the proliferative responses of PBMC to mitogens in vitro. 
Methods: To assess the actual status of immune system activation in patients, plasma concentrations of interferon-gamma, neopterin, tryptophan, and kynurenine were measured by enzyme-linked immunosorbent assay or by high-performance liquid chromatography; the ratio of kynurenine to tryptophan was calculated. Viral load, CD4 counts, and the in vivo immune activation status were compared with the in vitro responses of PBMC isolated from the same patients. PBMCs were stimulated with the mitogens concanavalin A, phytohemagglutinin, and pokeweed mitogen, and their proliferation was assessed by $3 \mathrm{H}-$ thymidine incorporation.

Results: The in vitro proliferative capacity of PBMC was associated with viral load, CD4 counts, and also tryptophan degradation. Particularly, high neopterin concentrations were observed to be the best predictor of impaired proliferative response in logistic regression analysis.

Conclusions: The higher the degree of immune activation in vivo, the lower is the proliferative capacity of PBMC in vitro.

\section{P620}

\section{Mucosal barrier defect and infiltration with $\mathrm{CD4}^{+}, \mathrm{CD8}^{+}$, and perforin+ cytotoxic $\mathrm{T}$ cells in early acute HIV infection}

Hans-Jörg Epple ${ }^{1}$, Christoph Loddenkemper ${ }^{2}$, Kristina Allers ${ }^{1}$, Michael Fromm ${ }^{3}$, Jörg-Dieter Schulzke ${ }^{1,4}$, Martin Zeitz ${ }^{1}$, Thomas Schneider ${ }^{1}$

${ }^{1}$ Charité, Campus Benjamin Franklin, Med. Klin. I, Gastroenterologie, Infektiologie, Rheumatologie, Berlin, Germany, ${ }^{2}$ Charité, Campus Benjamin Franklin, Inst. für Pathologie, Berlin, Germany, ${ }^{3}$ Charité, Campus Benjamin Franklin, Inst. für Klinische Physiologie, Berlin, Germany,

${ }^{4}$ Charité, Campus Benjamin Franklin, Klin. für

Allgemeinmedizin, Naturheilkunde, Psychosomatik und Psychotherapie, Berlin, Germany

Background: The gastrointestinal mucosa plays an important role in acute HIV-infection and HIV-triggered immunological events and functional changes within the gastrointestinal mucosa may have strong impact on the future course of HIV disease.

Aim: To analyze T cell subsets, epithelial apoptosis and barrier function of the duodenal mucosa in acute HIV infection.

Methods: The frequency of mucosal T cell subsets was immunohistochemically quantified in duodenal samples obtained from eight acutely infected patients (absent or incomplete seroconversion; viral load $>10^{6}$ copies $/ \mathrm{ml}$ ) and compared to untreated chronically HIV-infected patients and HIV-negative controls. In addition, mucosal T cells in acutely SIV-infected rhesus macacques were quantified by immunohistochemistry and flowcytometry. Cytotoxic T cells were analyzed by immunohistochemistry (TIA-1, perforin) and immunofluorescence microscopy (perforin/ CD8). Apoptotic epithelial cells were quantified by cleaved caspase-3 staining. Epithelial barrier function was characterized by impedance spectroscopy and ${ }^{3} \mathrm{H}$-mannitol fluxes. Results: As expected, in patients with chronic infection the number of mucosal CD4 ${ }^{+} \mathrm{T}$ cells was decreased while that of $\mathrm{CD} 8+\mathrm{T}$ cells was increased. In patients with acute infection, however, the number of both mucosal CD4 ${ }^{+}$and $\mathrm{CD}^{+} \mathrm{T}$ cells was increased. Similar results were obtained in acutely SIV-infected macacques. Mucosal perforin-ex- pressing cytotoxic $\mathrm{T}$ cells were strongly increased in patients with acute infection, and their frequency correlated with the number of apoptotic epithelial cells. A significant epithelial barrier defect was found not only in chronically but also in acutely HIV-infected patients.

Conclusions: Prior to CD4-T cell-depletion, acute HIV infection triggers mucosal immune activation as illustrated by mucosal CD4 and CD8 ${ }^{+}$T cell infiltration. The HIV-induced barrier defect of the intestinal mucosa is evident already in acute infection and may be due to increased epithelial apoptosis induced by armed mucosal cytotoxic T cells.

\section{P62 1}

\section{The potential of the Equine Herpes Virus - 1 (EHV-1) vector system as HIV-1 vaccine under safety aspects}

Nicole Fiedler ${ }^{1}$, Helga Hofman-Sieber ${ }^{2}$, Jens Wild ${ }^{1}$ Josef Köstler ${ }^{1}$, Karsten Tischer ${ }^{3}$, Jens von Einem ${ }^{4}$, Nikolaus Osterrieder ${ }^{3}$, Ralf Wagner ${ }^{1}$

${ }^{1}$ Universität Regensburg, Regensburg, Germany, ${ }^{2}$ Universität Hamburg, Hamburg, Germany, ${ }^{3}$ Freie Universität Berlin, Berlin, Germany, ${ }^{4}$ Universität Ulm, Ulm, Germany

Objective: Analysis of the capability of gradually attenuated EHV-1 vectors to induce HIV-1 specific immune responses and their biodistribution.

Background: Among other aspects the apathogenicity and the absence of neutralising antibodies in human sera are good premises using EHV-1 as a vector system. Differentially attenuated EHV-1 were generated by passaging and directed deletion of the equine trans-inducing factor (eTIF) blocking replication without loss of infectivity. The ability of such EHV-1 vectors to transduce murine and human antigen presenting cells give reason to investigate the potential of the gradually attenuated EHV-1 vectors as HIV-1 vaccine candidates.

Methods: Gradual attenuated recombinant EHV-1 coding for HIV-1 or luciferase reporter constructs were generated using BAC-Technology and RED-Recombination. Antigen specific antibodies and CTL responses were detected by FACS analysis and ELISA. Biodistribution of EHV-1 was tracked by live imaging of intranasally or intramuscularly immunised Balb/c mice.

Results : EHV-1 induces strongest transgene specific cellular, humoral and mucosal immune responses in Balb/c mice after heterologous DNA-prime:EHV-boost. Live imaging revealed that transgene expression is restricted to the application site. Whereas the eTIF deleted EHV-1 variant results in highly reduced luciferase activity antigen specific immune responses are comparable.

Conclusion: EHV-1 derived viral vectors are a potent tool for induction of broad transgene specific immune responses most suitable for heterologous gene delivery and provide the opportunity of a safe and pointed application. 


\section{P622}

Der Zunahme der Ko-Expression von CD38 und PD-1 auf HIV-spezifischen CD8-T-Zellen folgt ein Anstieg der Viruslast

Thomas Vollbrecht, Heike Brackmann, Nadja Henrich, Jörg Roling, Ulrich Seybold, Frank D. Goebel, Johannes R. Bogner, Rika Draenert

Med. Poliklinik / LMU München, München, Germany

Hinterg rund: T-Zell-Aktivierung - gemessen an der CD38-Expression - ist ein charakteristisches Merkmal der HIV-1-Infektion. In letzter Zeit wurde gezeigt, dass der inhibitorische Rezeptor PD-1 in der fortschreitenden HIV-Infektion signifikant erhöht ist. Wir haben uns die Frage gestellt, ob Marker für Immunaktivierung und Immuninihibition auf verschiedenen CD8-T-Zellen exprimiert sind, was bedeuten würde, dass ein Teil der Zellen aktiviert ist, während der andere Teil der Zellen in das Stadium der Erschöpfung übergeht.

Methodik: Es wurden 12 HIV-Controller, die die Virämie spontan ohne antiretrovirale Therapie (ART) kontrollieren (mediane CD4-Zellzahl 643/ $\mu 1$; mediane Viruslast [VL] $1,174 \mathrm{cp} / \mathrm{ml}$ ), und $12 \mathrm{HIV}$-Progressors, die ohne ART in der Erkrankung fortschreiten (mediane CD4-Zellzahl 259/ $\mu$ 1; mediane VL $180,041 \mathrm{cp} / \mathrm{ml})$ mit intrazellulärer ZytokinFärbung/FACS-Analyse auf die Expression von CD38 und PD-1 der HIV-spezifischen CD8-T-Zellen verglichen. 8 von den 24 Personen wurden longitudinal (median 20 Monate) verfolgt und deren autologes Virus im Bereich der jeweiligen CD8 T-Zellantworten durch Sequenzierung auf EscapeMutationen untersucht.

Ergebnisse: Erstaunlicherweise fanden wir, dass Virusspezifische CD8-T-Zellen von Progressors gleichzeitig CD38 und PD-1 exprimierten, und zwar statistisch hochsignifikant mehr als Controller ( $\mathrm{p}=0.0002)$. Die Ko-Expression dieser Marker korrelierte auch signifikant positiv mit der VL $\left(\mathrm{p}<0.0001 ; \mathrm{r}_{-}=0.61\right)$ sowie invers mit der CD4Zellzahl ( $\left.\mathrm{p}=0.0002 ; \mathrm{r}_{-}=0.69\right)$.

Die longitudinale Analyse zeigte, dass die Zunahme der Ko-Expression von CD38 und PD-1 auf CD8-T-Zellantworten dem Anstieg der VL voranging. Zudem konnten wir hiermit zeigen, dass die Entfernung des Antigens - entweder durch virale Escape-Mutationen oder durch antiretrovirale Therapie - zu einer Herunterregulation der beiden Marker führte.

Schlussfolgerung: Im fortgeschrittenen Krankheitsstadium sind HIV-spezifische CD8-T-Zellen durch gleichzeitige Immunaktivierung und -erschöpfung charakterisiert. Hierbei scheint die Zunahme der Ko-Expression von CD38 und PD-1 dem Anstieg der VL vorauszugehen. Diese Daten tragen entscheidend zum Verständnis der Immunpathogenese der HIV-Infektion bei.

\section{P623}

\section{Frequency and impact of drug resistance mutations in previously naïve patients infected with B and non-B HIV-1}

Markus Bickel ${ }^{1}$, Gundolf Schuettfont ${ }^{1}$, Christoph Stephan ${ }^{1}$, Stephan Klauke ${ }^{2}$, Thomas Lutz ${ }^{2}$, Annette Haberl $^{1}$, Reinhard Brodt ${ }^{1}$, Schlomo Staszewski ${ }^{1}$, Pavel Khayk in ${ }^{1}$, Annemarie Berger ${ }^{3}$, Martin Stürmer ${ }^{3}$

${ }^{1}$ JW Goethe Universität, Infektiologie, Frankfurt, Germany,

${ }^{2}$ Infektiologikum, Frankfurt, Germany, ${ }^{3} \mathrm{JW}$ Goethe Universität, Virologie, Frankfurt, Germany

Background: The prevalence and impact of drug resistance mutations in previously naive patients infected with a HIV-1 clade B on the virologic response of the initial HAART is well studied, but little is known about patients infected with non-B HIV-1 clades .

Methods: Retrospective database analysis and medical chart review including naïve patients with a genotypic resistance analysis from 1996 - 2008 from a large german HIV cohort. Mutations were interpreted according to the Stanford-HIV-Drug-Resistance-Database. Virologic failure was defined as a HIV-RNA-PCR $>400 \mathrm{c} / \mathrm{ml}$ six months after starting initial HAART.

Results : 478 patients were identified of which 395 (83\%) were infected with HIV-1 clade B and $83(17 \%)$ with non-B clades $\left(\mathrm{C}=31, \mathrm{CRF} 02 \_\mathrm{AG}=15, \mathrm{~A}=13, \mathrm{CRF} 01 \_\mathrm{AE}=12\right.$ and various other clades $=12$ ). No major PI mutation was detected. The L10I/V protease mutation was the single most frequent mutation found in $9.8 \%$ of the patients infected with clade B and $9.6 \%$ with non-B $(\mathrm{p}=\mathrm{ns})$. None of 14 clade B infected patients with the L10V/I mutation starting treatment with a boosted PI experienced virologic failure, but 3 of 6 patients with non-B HIV-1 $(\mathrm{p}=0.003)$. NNRTI mutations, mostly the $\mathrm{K} 103 \mathrm{~N}$, were found in $4 \%$ of clade B but none in non-B infected patients $(\mathrm{p}=0.01)$. NRTI mutations were found in $9 \%$ in clade $B$ and $3.6 \%$ in non-B infected patients $(\mathrm{p}=0.07)$. None of non-B patients with a NNRTI or NRTI mutation was started on such regimen.

Conclusions: The frequency of NRTI and NNRTI mutations was higher in clade B vs non-B infected patients. The L10I/V protease mutation was the most common in about $10 \%$ of the patients with no difference between clades, but response to boosted PI containing HAART was significantly less for patients infected with a non-B virus. Algorithms derived from clade $\mathrm{B}$ virus should be translated with caution to patients with non-B.

\section{$P 624$}

\section{Display of HIV-1 envelope epitopes using the mucosal adjuvant Cholera toxin $B$ as a carrier on virus like particles \\ Ruth Kapzan, Alexander Kliche, Ralf Wagner}

Universität Regensburg, Medizinische Mikrobiologie und Hygiene, Regensburg, Germany

Background: Cholera toxin $\mathrm{B}$ (CTB), the non toxic part of cholera toxin, is known to be a mucosal adjuvant and safe for use in humans. The protein forms highly stable pentamers which are resistant to denaturation by chemical or thermal challenge. Used as carrier for short envelope peptides, these epitopes are supposed to take advantage of 
CTB as adjuvant, i.e. direction to mucosal surfaces and stimulation of IgA production.

Methods : Synthetic CTB constructs were designed according to the human codon usage. Following transient transfection of HEK-293T cells, expression, surface presentation and functionality of the fusion proteins was analysed by Western Blot, fluorescence activated cell sorting (FACS) and Electron microscopy .

Results : Following adaptation of the coding sequence to frequently expressed mammalian genes and fused to a transmembrane domain CTB can be presented on the surface of HEK 293-T cells and is incorporated in Human immunodeficiency virus type-1 (HIV-1) virus-like particles (VLP). These VLPs are replication-incompetent and non-infectious. Since they are immunogenic and imitate the native virus situation they are ideal vehicles to present envelope derivatives. FACS analysis showed that envelope epitopes integrated into a surface exposed region or fused to the amino-terminal end of CTB are recognized by specific antibodies.

Conclusion: Such exposed epitopes with strong affinity to broadly neutralizing antibodies (NMabs) on the surface of VLPs or produced in a soluble form might be a powerful tool to promote the development of a potent vaccine against AIDS.

\section{P625}

\section{Role of organic cation transporters in pathogenesis and therapy of HIV-infection}

Norma Jung ${ }^{1}$, Clara Lehmann ${ }^{1}$, Andrea Rubbert ${ }^{1}$, Gerd Fätkenheuer ${ }^{1}$, Pia Hartmann ${ }^{1}$, Dirk Taubert ${ }^{2}$

1Klinik I für Innere Medizin /Uniklinik Köln, Infektiologie, Köln, Germany, 2Institut für Pharmakologie/Uniklinik Köln, Köln, Germany

Background: Membrane transporters regulate both the exchange of endogenous and exogenous substances between cells and intracellular compartments and the absorption, distribution and elimination.

So far the role of the organic cation transporters (OCT) were exclusively shown in pharmacotherapy. We could characterize several drugs used in HIV infection as inhibitors (nelfinavir, ritonavir, saquinavir, indinavir, trimethoprim and pentamidine) and substrates (lamivudine, zalcitabine) of OCT1 and OCT2.

Evidence for a direct role of OCTs in the pathophysiology of HIV is lacking to date.

Therefore, we performed an expression analysis of OCTs focusing on OCTN1 in primary target cells of HIV and studied the intracellular concentrations of ergothioneine, the physiological substrate of OCTN1.

Methods :

Expression analy sis of OCTN1

Expression of OCTN1 mRNA was determined by quantitative real-time PCR relative to GAPDH using TaqMan gene expression assays. Mononuclear cells from lymph nodes (LN) were dissociated mechanically and isolated by density gradient centrifugation over Ficoll. CD4 ${ }^{+}, \mathrm{CD}^{+}$and CD14+ cells were isolated using magnetic Dynabeads .

Quantification of ergothioneine

PBMCs were lysed and ergothioneine was analysed quantitatively by liquid chromatography electrospray-ionization-tandem mass spectrometry (LC-ESI-MS/MS).
Results: Whereas OCTN1 expression in $\mathrm{LN}$ and $\mathrm{CD}^{+}{ }^{+}$and $\mathrm{CD} 14+\left(\right.$ but not $\mathrm{CD}^{+}$) cells of healthy controls were negligible, we determined much higher expression (up to 1000 fold) in HIV-infected therapy-naive persons in correlation with the disease stage together with an increased accumulation of ergothioneine.

Conclusions: We could show that OCTN1 is highly upregulated in the target tissue and cells of HIV primarily in progressive disease accompanied by an increased intracellular accumulation of its physiological substrate ergothioneine. Neither the regulatory mechanisms of OCTN1 nor the the clinical effects of ergothionine in HIV infection have been studied until now. The exploration of the molecular, functional and clinical effects of OCTN1 and ergothioneine could provide new options for a targeted therapy of HIV.

\section{P626}

Uridine supplementation with Mitocnol attenuates mitochondrial cardiomyopathy induced by zidovudine and zalcitabine

Kerstin Balcarek ${ }^{1}$, Dirk Lebrecht ${ }^{1}$, Ana C Venhoff ${ }^{1}$, Catherine Deveaud ${ }^{2}$, Bertrand Beauvoit ${ }^{2}$, Jacques Bonnet ${ }^{2}$, Jan-Bernd Kirschner ${ }^{3}$, Klaus Müller ${ }^{4}$, Nils Venhoff ${ }^{1}$, Ulrich A Walker ${ }^{5}$

${ }^{1}$ Medizinische Universitätsklinik, Department of Rheumatology and Clinical Immunology, Freiburg, Germany, ${ }^{2}$ CNRS-Université Victor Ségalen, Institut de Biochimie et de Génétique Cellulaires, Bordeaux, France, ${ }^{3}$ Medizinische Universitätsklinik, Department of Neuropediatrics and Muscle Disorders, Freiburg, Germany, ${ }^{4}$ Medizinische Universitätsklinik, Department of Neuropathology, Freiburg, Germany, ${ }^{5}$ Basel University, Rheumatologie, Basel, Switzerland

Purpose of the study: Zidovudine is an antiretroviral nucleoside analogue reverse transcriptase inhibitor (NRTI). Long term use of zidovudine is linked to a cardiomyopathy and various other tissue toxicities, which are associated with mitochondrial DNA (mtDNA) depletion. Because zidovudine inhibits thymidine kinases, the mechanism of mtDNA depletion may involve a restriction in the availability of phosphorylated pyrimidine nucleosides which are required as mtDNA and mtRNA building blocks.

We investigated if the cardiomyopathy is a class effect of antiretroviral nucleoside analogues and if the mitochondrial cardiotoxicity can be prevented with uridine as a pyrimidine nucleotide precursor.

Methods: Balb/c mice were fed with zidovudine (100 $\mathrm{mg} / \mathrm{kg} /$ day $)$ or zalcitabine $(13 \mathrm{mg} / \mathrm{kg} /$ day $)$. Mice were cotreated with or without Mitocnol (340mg/kg/day), a dietary supplement with high uridine bioavailability. Cardiac muscle was examined after 9 weeks of treatment.

Summary of results: Zidovudine and zalcitabine both induced mitochondrial cardiotoxicity. Compared to untreated controls the histopathological cardiomyopathy score was increased after treatment with zalcitabine $(312 \%, \mathrm{p}<$ $0.001)$ and zidovudine $(540 \%, \mathrm{p}<0.001)$. Mitochondria were enlarged and their cristal architecture was disrupted. The organelles contained low mtDNA copy numbers (zidovudine $87.1 \%, \mathrm{p}=0.02$, zalzitabine $86.4 \%, \mathrm{p}=0.01$; compared to controls) and reduced cytochrome c-oxidase (COX) activity. The expression of the mtDNA-encoded COX I subunit, but not of nucleus encoded COX IV protein, 
was impaired. Uridine supplementation attenuated or normalized all pathology and had no intrinsic effects.

Conclusion: Both zidovudine and zalcitabine induced a mitochondrial cardiomyopathy, which is antagonized by uridine supplementation. The results provide proof of the importance of pyrimidine pools in the pathogenesis of zidovudine cardiomyopathy. As uridine supplementation is tolerated well by humans, this strategy should be investigated in clinical trials.

\section{P627}

\section{Impact of zidovudine on adipogenesis Metodi Stankov, ReinholdE. Schmidt, Georg M.N. Behrens}

Hannover Medical School, Clinic for Immunology and Rheumatology, Hannover, Germany

Objective: Lipoatrophy is a prevalent side effect of treatment with thymidine analogues. We wished to confine the time point of the anti-adipogenic effect of AZT during adipogenesis and to evaluate the anti-proliferative effect of AZT on adipocytes. Methods: We investigated the effects of AZT on adipogenesis in 3T3-F442A cells and studied their proliferation, differentiation, viability, and adiponectin expression .

Cells were exposed to AZT $(1 \mu \mathrm{M}, 3 \mu \mathrm{M}, 6 \mu \mathrm{M}$ and $180 \mu \mathrm{M})$ for up to 15 days. Differentiation was assessed by RealTime PCR and quantification of triglyceride accumulation. Proliferation and clonal expansion were determined by ${ }^{3} \mathrm{H}$ thymidine incorporation assay.

Results: When induced to differentiate in the presence of AZT at $\mathrm{C}_{\max }$ concentration and below, 3T3-F442A preadipocytes failed to accumulate cytoplasmic triacylglycerol as well as failed to express normal levels of the adipogenic transcription factors C/EBPa and PPARg. AZT exerted an inhibitory effect on early events in preadipocyte differentiation, specifically the completion of the mitotic clonal expansion. This resulted in incomplete 3T3-F442A differentiation and finally in reduction of adiponectin expression. In addition, AZT impaired the constitutive proliferation in murine and primary human subcutaneous preadipocytes.

Conclusion: We conclude that the anti-proliferative and anti-adipogenetic effects of AZT on murine and primary human preadipocytes reveal the drug's impact on fat tissue regeneration. These drug effects are expected to contribute to peripheral fat loss and to be influenced by differential drug concentration and penetration in individual patients.

\section{P628}

Soluble CD40 ligand (sCD40L) reduces type I interferon production in HIV-infected subjects after stimulation with CpG oligodeoxy nucleoti des

Norbert Donhauser ${ }^{1}$, Martin Helm ${ }^{2}$, Kathrin Pritschet ${ }^{1}$, Philipp Schuster ${ }^{1}$, Moritz Ries ${ }^{1}$, Klaus Korn ${ }^{1}$, Sigrun Smola-Hess ${ }^{3}$, Jörg Vollmer ${ }^{4}$, Barbara Schmidt ${ }^{1}$

${ }^{1}$ Institute of Clinical and Molecular Virology, University of Erlangen-Nürnberg, Erlangen, Germany, ${ }^{2}$ Praxis Dr. G. Abelein/ Dr. M. Helm, Nürnberg, Germany, ${ }^{3}$ Institute of Virology, University of Cologne, University of Cologne,

Cologne, Germany, ${ }^{4}$ Coley Pharmaceutical GmbH, A Pfizer Company, Düsseldorf, Germany

Background: Human plasmacytoid dendritic cells (PDC) are the major producers of type I interferons (IFN) after stimulation with $\mathrm{CpG}$ oligodeoxynucleotides (ODN). In HIV-1 infection, PDC innate immune responses are significantly impaired. Since HIV-1 itself increases the IFN-alpha secretion, we investigated the effect of the HIV-1 induced immune stimulation. We specifically focused on CD40L, a member of the tumor necrosis factor family and costimulatory molecule, which can be shedded from the cell surface.

Methods: The levels of soluble CD40L (sCD40L) were measured in the plasma of HIV-1 infected subjects $(n=15)$ and controls $(n=10)$. PBMC of controls were preincubated with SCD40L in the absence and presence of a neutralizing antibody. After subsequent stimulation with $\mathrm{CpG}$ ODN, the IFNalpha production was determined using an IFN-alpha subtype ELISA. The effect of a truncated commercial sCD40L was compared to a naturally occurring full-length variant. Both molecules were further characterized by western blot analysis. The effects on the signaling cascade were evaluated using realtime amplification of the interferon response factor (IRF) 7, an essential transcription factor in the IFN-alpha pathway.

Results: HIV-infected subjects showed significantly higher sCD40L plasma levels compared to controls $(\mathrm{p}=0.006)$. sCD40L significantly reduced the CpG ODN-induced IFN-alpha production $(\mathrm{p}<0.05)$, reversed by a neutralizing sCD40L antibody. The full-length sCD40L was slightly more inhibitory than the truncated form. sCD40L occurred in a monomeric and multimeric form. IRF7 mRNA levels were significantly reduced in PBMC of HIV-1 infected patients compared to controls $(\mathrm{p}=0.008)$, and also when PBMC of controls were exposed to sCD40L ( $\mathrm{p}<0.05)$.

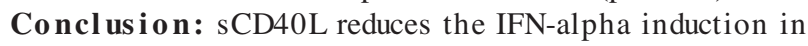
HIV-1 infected subjects by downregulation of IRF7 mRNA levels. Thus, not HIV-1 itself, but the HIV-1 induced immune stimulation silences PDC innate immune responses.

\section{P629}

\section{Instability of HIV-1 antibodies in filter-dried plasma samples stored at room temperature: consequences for its use in incidence tests}

Stephan Loschen ${ }^{1}$, Kristin Strohschein ${ }^{1}$, Christopher Drewell ${ }^{1}$, Jörg Bätzing-Feigenbaum ${ }^{2}$, Ruth

Zimmermann $^{2}$, Osamah Hamouda ${ }^{2}$, Claudia Kücherer ${ }^{1}$

${ }^{1}$ Robert Koch-Institute, HIV Variability and Molecular Epidemiology, Berlin, Germany, ${ }^{2}$ Robert Koch-Institute, Infectiouse Disease Epidemiology, Berlin, Germany

Backg round: Filter-dried plasma samples (DPS) are easier to prepare, to store and to transport than liquid plasma. Therefore, DPS represent a good alternative for serological studies and are used in many HIV-1 studies. To assess the performance of DPS in incidence assays for the German incidence study we performed long-term storage experiments at different temperatures.

Method: A panel of 148 HIV-positive plasma samples which covers a time-period from 0 to 222 weeks (duration of infection) and a commercial HIV-sample panel $(n=15)$ was dropped on filters and stored for two years at roomtemperature. A subset of 24 samples was also stored at $20^{\circ} \mathrm{C}$. The subset-panel was tested after 1,2 and 3 months storage. Eluted samples were measured in the BED-ELISA. This incidence test is used to differentiate recent $(\leq 20$ weeks of infection) and chronic ( $>20$ weeks) infections: Samples with an ODn $\leq 0.8$ are incident; $>0.8$ prevalent.

Result: Mean ELISA reactivity (ODn) after two year stor- 
age at room-temperature showed a decrease of $40 \%$ as compared to the initial value ( $1.38 \mathrm{ODn}$ to $0.83 \mathrm{ODn})$. The result of the subset-panel after 3 months storage showed only a decrease of $6 \%$ (1.23 ODn to $1.16 \mathrm{ODn})$. In contrast, storage at $-20^{\circ} \mathrm{C}$ for 3 months showed no degradation of antibodies.

Conclusion: Handling and transport of filter-dried samples is easier as compared to fresh blood and could facilitate HIV-incidence studies. However, degradation of antibodies at room temperature has to be considered. Sample testing in the BED-ELISA should be performed within maximally 3 months after sample collection. Extended storage will impact the incidence rate by the fact that a high rate of false-incident results will be produced. Elution of samples immediately upon receipt of filters and storage of the eluate at $-20^{\circ} \mathrm{C}$ will overcome the stability problem. Alternative$1 \mathrm{y}$, filters need to be stored at $-20^{\circ} \mathrm{C}$.

\section{P630}

\section{Selective expansion of CD56(-)/CD16(+) NK cells in HIV/HCV-coinfection is associated with increased expression of HLA-DR and CD38}

Phillip Keudel ${ }^{1}$, Henoch Hong ${ }^{1}$, Johanna Eberhard ${ }^{1}$, Nupur Bhatnag ar ${ }^{1}$, Margot Zielinska-Skowronek ${ }^{1}$, Julian Schulze zur Wiesch ${ }^{2}$, Jan van Lunzen ${ }^{2}$, ReinholdE. Schmidt ${ }^{1}$, Dirk Meyer-Olson ${ }^{1}$

${ }^{1}$ Medizinische Hochschule Hannover, Klinik für Immunologie und Rheumatologie, Hannover, Germany,

2Universitätsklinikum Hamburg-Eppendorf, 1. Medizinische Klinik und Ambulanzzentrum UKE, Hamburg, Germany

Both human immunodeficiency virus (HIV) and hepatitis C virus (HCV) are known to be the cause of persistent infections. Hence their share of similar transmission routes, coinfection occurs frequently. NK cells are discussed to play a major role in the pathogenesis of both infections. NK cells are frequently defined as lin(-)/CD3(-) lymphocytes, which can be distinguished in different subsets based on the expression of CD16 and CD56. Here we analyzed the frequency of CD56(+)bright, CD56(+)dim and CD56(-)/CD16(+) NK cells in HIV-mono- and HIV/HCV-co-infected patients as well as the expression of the activation marker HLA-DR and CD38.

Peripheral blood mononuclear cells of HIV-mono-infected $(n=21)$ and HCV-HIV-co-infected subjects $(n=28)$ were isolated, stained and analyzed via flow cytometry. Both cohorts were matched for gender, age, HAART, time infected and CDC-classification. Statistical significance was tested via Student's t-test.

The CD56(-)CD16(+)-NK-cell-subset was significantly higher in co-infected subjects compared to mono-infected ( $7 \%$ vs. $14 \% ; p=0,049)$. Furthermore this subset had a higher expression of HLA-DR ( $8 \%$ vs. $28 \%$; $p=0.003$ ) and a higher mean fluorescence intensity of CD38 (174 vs. 302; $\mathrm{p}=0,044)$. Regarding the CD56(+)bright- and CD56(+)dimNK-cell-subset we found no significant difference in the HLA-DR expression or the MFI of CD38. Moreover, the populations of the B-cells, CD4(+)T-cells, CD8(+)T-cells and the total NK-cell-count did not vary significantly between the two cohorts.

Our data suggest a selective expansion of the CD56()CD16(+)-NK-cell-subset whereas other lymphocyte sub- sets remain stable. In addition we found an isolated increase of HLA-DR and CD38 on this subset, indicating a higher activation state of this subset. Our data suggest a defined role for $\mathrm{CD} 16(+) / \mathrm{CD} 56(-) \mathrm{NK}$ cells in the immune pathogenesis of HIV/HCV co-infection.

\section{P631}

\section{CD4 receptor density on $\mathrm{CD}^{+} \mathrm{T}$ cells is decreased in HIV + patients with faster disea- se progression}

Annette Audigél, Patrick Taffé ${ }^{2}$, Martin Rickenbach ${ }^{2}$, Pietro Vernazza ${ }^{3}$, Manuel Battegay ${ }^{4}$, David Nadal ${ }^{5}$, Roberto F. Speck ${ }^{1}$, Swiss HIV Cohort Study
${ }^{1}$ Universitätsspital Zürich / Klinik für Infektionskrankheiten, Zürich, Switzerland, ${ }^{2}$ Datenzentrum der SHCS, Lausanne, Switzerland, ${ }^{3}$ Kantonsspital St. Gallen / Klinik für Infektionskrankheiten, St. Gallen, Switzerland,
${ }^{4}$ Universitässpital Basel / Klinik für Infektionskrankheiten,
Basel, Switzerland, ${ }^{5}$ Kinderklinik Zürich / Infektiologie, Zürich, Switzerland

Background: In vitro, CD4 expression level is a major determinant of cellular HIV infection efficiency. However, efficient HIV replication in mouse models is associated with CD4 down-regulation. These contrasting findings raise the question if and to what extent CD4 density on HIV target cells is affected in HIV+ patients over time, and if there is any change in CD4 density, does it correlate with HIV disease progression.

Methods: Three groups of HIV+ patients from the SHCS with fast, intermediate, or slow disease progression and a group of HIV- volunteers were included into this study. Disease progression was defined based on the estimated time from seroconversion to decay of $\mathrm{CD}^{+}{ }^{+} \mathrm{T}$ cells to a level of $200 / \mathrm{ml}$. For each patient, 3 cryopreserved PBMC samples before the introduction of highly active anti-retroviral therapy (HAART) and one sample while undetectable under HAART were analysed for CD4 density on $\mathrm{CD}^{+} \mathrm{T}$ cells and monocytes by flow-cytometry using anti-CD4 (unlabeled), CD3 PE and CD14 APC antibodies and the QIFIKIT ${ }^{\circledR}$ (DakoCytomation).

Results : CD4 density was significantly lower on CD4 ${ }^{+} \mathrm{T}$ cells but not on monocytes from HIV+ patients compared to HIV- volunteers. Strikingly, CD4 density, in particular on $\mathrm{CD}_{4}{ }^{+} \mathrm{T}$ cells, tended to remain higher in slow progressors than in intermediate and fast progressors. The CD4 count / CD4 density relationship was significantly different between the three groups of progressors.

Conclusions: HIV infection decreases CD4 density on $\mathrm{CD}^{+} \mathrm{T}$ cells. Since CD4 density in patients with suppressed HIV RNA under HAART was not restored, factors other than viral load appear to contribute to the down-regulation of CD4 observed. Strikingly, slow disease progression appears to be associated with a higher level of CD4 density. These findings warrant further work investigating the molecular mechanism(s) regulating CD4 density on $\mathrm{CD}^{+} \mathrm{T}$ cells and its immunopathogenetic significance in HIV infection. 


\section{P632}

Identification of subdominant $\mathrm{CD8}^{+}$ responses selecting CTL escape mutations in Gag that Impair HIV replication

Arne Schneidewind ${ }^{1,2}$, Christian Boutwell ${ }^{1}$, Zabrina Brumme 1, Mark Brockman ${ }^{1}$, Hendrik Streeck ${ }^{1}$, Chanson Brumme ${ }^{1}$, Katherine Kane ${ }^{1}$, Bruce D Walker ${ }^{1}$, Marcus Altfeld ${ }^{1}$, Todd M Allen ${ }^{1}$

${ }^{1}$ Ragon Institute of Harvard and MIT (formerly Partners AIDS Research Center), Boston, United States,

${ }^{2}$ Universitätsklinikum Regensburg, Klinik für Innere Medizin I, Regensburg, Germany

$\mathrm{CD}^{+} \mathrm{T}$ cell responses, and in particular those targeting the highly conserved Gag protein, play a critical role in the containment of HIV. We have recently demonstrated that CTL escape mutations associated with immunodominant HLA-B57 and -B27 restricted CD8 responses in Gag substantially impair viral replication, supporting an important contribution of CTL escape to immune control. To identify other immune-selected mutations in Gag that impair viral replication, we examined the impact on viral infectivity and replication of 35 HLA class I-associated sequence polymorphisms located in, or immediately adjacent to, Gag CD8 epitopes restricted by their respective HLA alleles. The 35 mutations, associated with 18 HLA alleles and 24 defined CTL epitopes, were engineered into the NL4-3 virus backbone. Half of the mutations exhibited a $>20 \%$ reduction in infectivity, and 9 mutations were highly deleterious causing a $>40 \%$ reduction. In addition, compensatory mutations that restored replication capacity were identified for several deleterious mutations. Importantly, many of the deleterious mutations were associated with epitopes that elicit subdominant p24 CD8 responses. These data demonstrate that numerous immune-selected mutations in Gag impair viral replication and identify subdominant epitopes that represent high-value targets for vaccine-induced responses because of the apparent high viral costs associated with CTL escape. This study was supported by NIAID grant AI054178 and the Bill and Melinda Gates Foundation.

\section{P633}

\section{T-regulatory cells and $\mathbf{T}$-cell activation in chronic HIV infection}

Christian Raphael Kahlert ${ }^{1}$, Reinhard Maier ${ }^{2}$, Burkhard Ludewig ${ }^{2}$, Pietro Vernazzal

${ }^{1}$ Kantonsspital St. Gallen, Infektiologie, St. Gallen, Switzerland, ${ }^{2}$ Kantonsspital St. Gallen,

Laborforschungsabteilung, St. Gallen, Switzerland

Introduction: The definite role of T-regulatory cells in chronic HIV infection is still unclear. Recent data indicate a negative influence on disease progression by suppression of HIV-specific T cell responses. Contrariwise T-regulatory cells might reduce activation of T-cells, resulting in reduced disease progression.

Method: PBMCs from HIV 50 positive patients routinely under control in our HIV clinic in St. Gallen have been stored in liquid nitrogen. We than batch wise analysed these cells by flowcytometry for frequencies of T-regulatory cells $\left(\mathrm{CD} 4{ }^{+} \mathrm{CD} 25+\mathrm{Foxp} 3+\mathrm{CD} 1271 \mathrm{low}\right)$ and activation status of CD4 ${ }^{+}$T-cells (CD38+ and HLA-DR+).
Results : Of all 50 HIV positive patients, 11 were OFF antiretroviral treatment (ART), 39 were treated with combined ART. Median CD4 cell count was 353 cells $/ \mu 1$. Analysis of T-regulatory cell frequencies in patients with CD4 cell count $>350 / \mu 1(\mathrm{~N}=25), 250-350 / \mu 1 \quad(\mathrm{~N}=10)$ and $\mathrm{CD} 4$ cell count $<250 / \mu 1(\mathrm{~N}=15)$ revealed a significant difference $(\mathrm{p}=0.0027)$ between patients with high CD4 cell count (lower T-regulatory cell frequency) and patients with low CD4 cell count (higher T-regulatory cell frequency).

Conclusion: T-regulatory cell frequencies negatively correlates with CD4 cell count in chronic HIV-infection. As Foxp3 is not only part of the phenotypical definition of Tregulatory cells but also an activation marker in humans these results likely reflects increased T-cell activation in progressive HIV infection. Additional information as the integrin alpha subunit CD49d might be helpful to define more precise the pool of T-regulatory cells in chronic HIV infection.

\section{P634}

\section{Event-related potentials and cerebrospinal fluid markers during HIV-associated neurocognitive disorder}

Katrin Biehl ${ }^{1}$, Thorsten Nolting ${ }^{2}$, Eleni Koutsilieri ${ }^{3}$, Peter Young ${ }^{1}$, Doris Reichelt ${ }^{4}$, Gabriele Arendt ${ }^{2}$, Stefan Evers ${ }^{1}$, Ingo W. Husstedt ${ }^{1}$, German Competence Network HIV/AIDS

${ }^{1}$ UKM Münster, Department of Neurology -Division HIVInfektion, Münster, Germany, ${ }^{2}$ Department of Neurology, UK Düsseldorf, Düsseldorf, Germany, ${ }^{3}$ Department of Psychiatry, UK Würzburg, Würzburg, Germany, ${ }^{4}$ Department of Internal Medicine UK Münster, HIV-Outpatient Department, Münster, Germany

Prevalence of HIV-associated neurocognitve disorder (HAN) is increasing and its biochemical pathways remain up to now matter of debate. $50 \mathrm{HIV}-1+$ patients of different stages were included for this analysis. Event-related potentials(ERP), CD4+-cell count, viral load (VL) in blood and cerebrospinal fluid (CSF), routine CSF analysis and special analysis of CSF for dopamine (DOP), dihydroxyphenylacetic acid (DOPAC), homovaniillic aclid (HVA), betaamyloid (BA), total tau (TT) and phosporylated tau (PT) was performed. The mean age (MV) was 44 years, HIV-infection lasted since laboratory diagnosis 7.9 (MV) years. VL was $6977(\mathrm{MV}) \mathrm{c} / \mathrm{ml}$ for CSF and 31500 (MV) for blood. CD4 ${ }^{+}$ cell-count (MV) was 420/mikrol. VL of CSF showed a high correlation to cells in CSF, duration of HIV-infection, CD4+-cell count and BA. ERP showed a significant correlation to cells in CSF, BB and TT. Development of BA was significantly correlated to CDC-classification stages. HAART reduced TT significantly. HAT and BA correlated with CDC-classification stages and were significantly different for patients with and without HAART. HIV-infection of the brain induces profound changes of cognition, which are easily to detect using ERP. Besides correlation to general markes of HIV-infection itself, CSF analysis shows remarkable changes of of neurotransmitters and special markers of dementia. ERP is more correlated to these markers than to changes of the dopaminergic system. HAART reduces pathological markers of dementia and represents an effective therapy of HAN. These results have important implictions for the understanding of HAN and future therapeutic strategies. 


\section{P635}

\section{Glycosylation and processing of inhibitory C-peptides within the secretory pathway}

Andreas Volk, Joerg Kahle, Mina Petkova, Lisa Egerer, Dorothee von Laer

Georg-Speyer-Haus, Applied Virology and Gene Therapy, Frankfurt, Germany

During human immunodeficiency virus (HIV) entry, the viral envelope glycoprotein (gp) 41 undergoes conformational changes. Prior to fusion of viral and target-cell membranes, the $\mathrm{N}$ - and $\mathrm{C}$-peptide regions of gp41 are in an extended conformation called 'prehairpin intermediate'. Rearrangement of this 'prehairpin' into a six-helix bundle composed of a trimeric N-peptide (N-trimer) and three $\mathrm{C}$ peptides mediates fusion of virus and cell membranes and is crucial for viral entry. Hence, the $\mathrm{N}$-trimer region is the primary target of peptide fusion inhibitors derived from the C-peptide region of gp41. We previously developed a gene therapeutic strategy, where membrane-anchored antiviral C-peptides (maC46) and secretable C-peptide precursors are expressed in target cells for HIV from a retroviral vector. We now compared the processing of membrane-anchored relative to secretable C-peptides. Using pulse-chase experiments and FACS analysis we found that the half-life of maC46, in contrast to secretable variants, strongly depends on the cell type. In addition, the role of N-glycosylation on secretion and cleavage efficacy of secretable Cpeptide precursors was analyzed by Western blotting and pulse-labeling. Our results show that C-peptide precursors lacking either of the two N-glycosylation sites were still secreted well but less efficiently than the wild-type form. The mutant lacking both N-glycosylation sites was not processed and hardly secreted. Furthermore, the single Nglycosylation site mutants showed an impaired cleavage of the precursor and a prolonged half-life compared to the wild-type form, which results from a more pronounced aggregation of the peptide in the secretory compartment as additional experiments suggest.

\section{P636}

\section{Novel concepts for HIV-1 therapy: targeting the interaction of the HIV-1 export factor Rev and its cellular cofactor $S$ am 68}

\section{Patricia Skoczylas, Benedikt Asbach, Ralf Wagner}

Institute of Medical Microbiology and Hygiene, Molecular Microbiology and Gene Therapy Unit, Regensburg, Germany

Objective: The search for new strategies and targets suitable for combatting HIV infections has drawn increasing attention to cellular cofactors promoting viral replication which are, unlike the viral proteins not subjected to mutational drift.

Background: One interesting candidate of those HIV-1 cofactors is the nuclear RNA-binding protein Sam68 which has been reported to be a functional homolog and interacting partner of the viral shuttle protein Rev known to mediate the nuclear export of intron containing viral mRNAs.

Methods and results: A prerequisite for the development of a potent transdominant inhibitor targeting the Rev-Sam68 interaction is the detailed knowledge of the protein domains contributing to the proposed interaction. Whereas the Rev binding region has been identified to re- side within the C-terminus of Sam68 harboring the nuclear localization signal, the interaction domain of Rev has not been mapped so far. Thus, a panel of Rev deletion mutants was constructed lacking important functional domains responsible for oligomerization, nuclear localization, nuclear export and binding of viral mRNAs.

Evaluation of the capacity of the various Rev mutants to bind to Sam68 in vitro and in vivo by GST pull down and co-immunoprecipitation assays strongly suggested that Sam68 was mainly bound via the N-terminal oligomerization domain. By further finetuning the deletion mutants we could limit the binding site to a few conserved amino acids within the N-terminus of Rev. Currently, the functionality of these mutants is being evaluated in the light of HIV-1 replication using different viral and subgenomic cellular reporter assays.

Conclusion: In summary these findings will contribute to further unravel the cellular dependencies of HIV RNA metabolism and will help to evolve and construct highly efficient transdominant inhibitors blocking RNA export thereby offering new concepts for HIV therapy.

\section{P637}

\section{Characterization of a chemokine receptor CCR5-negative $T$ cell line to determine the human immunodeficiency virus type 1 phenotype}

Dorothea Binninger-Schinzel ${ }^{1}$, Benjamin Kraus ${ }^{2}$, Daniela Müller ${ }^{1}$, Birgit Krause ${ }^{2}$, Britta Neumann ${ }^{2}$, Gudrun Winskowsky ${ }^{2}$, Timo Wolf ${ }^{3}$, Reinhard Brodt ${ }^{3}$, Albrecht Werner ${ }^{1}$, Barbara Schnierle ${ }^{2}$

${ }^{1}$ Paul-Ehrlich-Institut, Virologie, Langen, Germany, 2Paul-Ehrlich-Institut, Virologie FG2/2, Langen, Germany, ${ }^{3}$ Universität Frankfurt/Main, Klinikum, Frankfurt, Germany

HIV-1 entry is initiated by the interaction of HIV-1 Env with the CD4 receptor molecule and the binding of a coreceptor of the chemokine receptor family. R5-tropic viruses use CCR5 and X4-tropic viruses, which induce syncytia, use CXCR4. R5-tropic strains are found early after infection and replicate efficiently in memory $T$ cells, which express high levels of CCR5 and are particularly abundant in the gut-associated lymphoid tissue, the site of primary HIV replication. However, in half of the infected individuals, HIV strains emerge that use CXCR4, which coincides with a rapid depletion of CD4-positive T-lymphocytes. Recently, a new class of HIV entry inhibitors targeting the CCR5 receptor entered the market and only patients with R5-tropic strains are eligible to this treatment. Therefore we designed an assay system to phenotypically determine the coreceptor usage. We generated a human CD4-positive T cell line from a donor homozygous negative for CCR5. This immortalized cell line, named IsnoR5, is only susceptible to infection by HIV-1 isolates that use CXCR4 or alternative receptors. The later can be identified by addition of AMD 3100, a CXCR4-specific inhibitor. Using primary and well characterized HIV-1 isolates, we demonstrated that this cell line is sufficient to discriminate between coreceptors used. Furthermore, IsnoR5 cell are highly sensitive and allow for the detection of even minor populations of CXCR4 or alternative receptor using viral variants, enabling the diagnosis of emerged changes in coreceptor usage of HIV-infected individuals . 


\section{P638}

Einfluss der HCV-Koinfektion auf die Expression von sog. "Todes-Rezeptoren" und deren korrespondierenden Liganden auf CD4+ T-Zellen bei HIV-positiven Patienten

Christian Körner, Felix Tolksdorf, Benjamin Krämer, Daniela Schulte, Martin Coenen, Hans-Dieter Nischalke, Jacob Nattermann, Jürgen K. Rockstroh, Ulrich Spengler

Universitätsklinikum Bonn, Medizinische Klinik und Poliklinik 1, Bonn, Germany

Hintergund: Apoptose spielt eine zentrale Rolle bei der Pathogenese der HIV-Infektion. Kürzlich konnten wir zeigen, dass eine Koinfektion mit dem Hepatitis C Virus mit einer erhöhten $\mathrm{CD}^{+}{ }^{+} \mathrm{T}$-Zell-Apoptose-Rate bei unbehandelten HIV-positiven Patienten assoziiert ist. Die zugrunde liegenden Mechanismen hierfür sind bislang jedoch nur unzureichend verstanden. Aus diesem Grund untersuchten wir, ob eine veränderte Expression von so genannten "Todes-Rezeptoren" und ihren korrespondierenden Liganden auf $\mathrm{CD}^{+}{ }^{+} \mathrm{T}-Z$-Zllen eine Erklärung für die erhöhte CD4+ T-Zell-Apoptose-Rate bei HIV/HCV-Koinfizierten liefern könnte.

Methodik: 69 Patienten (16 HCV-Monoinfizierte, 31 HIV-Monoinfizierte, $22 \mathrm{HIV/HCV-Koinfizierte)} \mathrm{und} 13$ gesunde Probanden wurden in diese Studien eingeschlossen. Serumspiegel von löslichem TNF $\alpha$, TRAIL und Fas Ligand wurden mittels ELISA bestimmt. Oberflächenexpression von TNF $\alpha$, TRAIL und FasL sowie deren korrespondierenden Liganden Fas, TRAIL-R1/2, und TNF $\alpha-R 1 / 2$ auf $\mathrm{CD}^{+}{ }^{+} \mathrm{T}-Z e l l e n$ wurde mittels Durchflusszytometrie analysiert.

Resultate: In Übereinstimmung mit früheren Arbeiten fanden wir, dass die HIV-Monoinfektion mit erhöhten Serumspiegeln für sTRAIL (HIV vs. Gesund: $2402 \pm 180$ vs. $1716 \pm 134 \mathrm{pg} / \mathrm{ml} ; \mathrm{p}<0,05)$ sowie einer erhöhten Oberflächenexpression von Fas (MFI: $50 \pm 3$ vs . $36 \pm 3,5$ ) assoziiert ist. Interessanterweise führte hier auch die $\mathrm{HCV}$ Monoinfektion zu erhöhten sTRAIL-Serumspiegeln (2132 \pm 97 ; p < 0,05 vs. Gesund) bzw. zu einer erhöhten Fas-Oberflächenexpression $(49 \pm 7 ; \mathrm{p}<0,05$ vs. Gesund) führte. Die höchsten Werte fanden sich bei HIV/HCV-Koinfizierten (Fas: MFI: $78 \pm 20$; sTRAIL $2685 \pm 228$ ), so dass hier ein additiver oder synergistischer Infekt beider Viren vermutet werden kann.

Im Gegensatz dazu war die Expression von FasL (MFI: $86 \pm 6,1$ vs. $66 \pm 3,6 ; p<0,05)$ und löslichem FasL $(145 \pm 14$ vs. $85 \pm 9,7 \mathrm{pg} / \mathrm{mL} ; \mathrm{p}<0.05)$ nur bei HIV-Monoinfizierten signifkant gegenüber Gesunden erhöht.

Schlussfolgerung: Unsere Ergebnisse lassen vermuten, dass die synergistische/additive Erhöhung von Fas und sTRAIL durch HIV und HCV eine wichtige Rolle bei der Induktion der Apoptose von CD4+ T-Zellen bei Patienten mit einer HIV/HCV-Koinfektion spielt. Hierbei könnte insbesondere die HCV-assoziierte Erhöhung der Fas-Expression bei gleichzeitiger HIV-induzierter Erhöhung der Serum-Konzentration von FasL einen wichtigen Mechanismus für die erhöhte Apoptose-Rate bei HIV/HCV-koinfizierten Patienten darstellen.
P639

GBV-C coinfection in the Bonn HIV cohort: impact on cytokine profile

Carolynne Schwarze-Zander, Markus Neibecker, Evrim Anadol, Jan-Christian Wasmuth, Martin Vogel, Ulrich Spengler, Juergen Kurt Rockstroh

Medizinische KLinik I, Universitätsklinik Bonn, Bonn, Germany

Background: Co-infection with the recently discovered flavivirus $\mathrm{GB}$ virus $\mathrm{C}(\mathrm{GBV}-\mathrm{C})$ is frequent in patients suffering from human immunodeficiency virus (HIV) due to shared routes of transmission. GBV-C co-infection has been proposed to exert a beneficial influence on HIV-1 infection, although this has not been confirmed in all studies. In this study we evaluated the frequency and genotype distribution of GBV-C in the Bonn HIV cohort and the differential influence of GBV$\mathrm{C}$ genotypes on serum levels of IP-10 and IFN- $\gamma$.

Methods: The prevalence of GBV-C co-infection and the GBV-C genotype distribution in a cohort of 408 HIV positive patients was analyzed using nested RT-PCR. 87 patients from this cohort were randomly drawn to evaluate serum levels of IP-10 and IFN- $\gamma$ using standard ELISA technique. Statistical analysis was done with SPSS17.0.

Results: Persistent GBV-C replication was detected in 92/408 $(22,5 \%)$ of HIV positive patients. We found 8 patients infected with GBV-C genotype $1(8,7 \%), 76(82,6 \%)$ with genotype 2 , $2(2,2 \%)$ with genotype 3 and $6(6,5 \%)$ with genotype 5 . We found significantly lower IFN- $\gamma$ levels in GBV-C/HIV co-infected patients compared to HIV mono-infected patients $(1,2$ $\mathrm{pg} / \mathrm{ml}$ vs. $26,8 \mathrm{pg} / \mathrm{ml}$, respectively). IP-10 levels were not associated with GBV-C coinfection status, however serum of GBV-C genotype 1 coinfected HIV patients showed significantly higher IP-10 levels compared to GBV-C genotype 2 (129,3 pg/ml vs. $21,7 \mathrm{pg} / \mathrm{ml}$, respectively).

Conclusion: GBV-C coinfection is frequent in the Bonn HIV cohort and GBV-C genotype distribution shows great diversity. We found an association of GBV-C coinfection with serum levels of IFN- $\gamma$, possibly influencing antiviral immunity in HIV coinfection. Interestingly, IP-10 levels showed GBV-C genotype specific differences possibly indicating a GBV-C genotype specific differential influence on the antiviral immunity.

\section{P640}

\section{Uridine supplementation with Mitocnol antagonizes antiretroviral nucleoside analogue-induced mitochondrial peripheral and cerebral neuropathy in vivo}

Dirk Lebrecht ${ }^{1}$, Catherine Deveaud ${ }^{2}$, Jacques Bonnet ${ }^{2}$, Jan-Bernd Kirschner ${ }^{3}$, Klaus Müller ${ }^{4}$, Nils Venhoff ${ }^{1}$, Ulrich A. Walker ${ }^{5}$

${ }^{1}$ Medizinische Universitätsklinik, Department of Rheumatology and Clinical Immunology, Freiburg, Germany, ${ }^{2}$ CNRS-Université Victor Ségalen, Institut de Biochimie et de

Génétique Cellulaires, Bordeaux, France, ${ }^{3}$ Medizinische Universitätsklinik, Department of Neuropediatrics and Muscle Disorders, Freiburg, Germany, ${ }^{4}$ Medizinische

Universitätsklinik, Department of Neuropathology, Freiburg, Germany, ${ }^{5}$ Basel University, Dept. of Rheumatology, Basel, Switzerland

Objective: Peripheral neuropathy and CNS neurodegeneration may be a toxic effect of some antiretroviral nucleo- 


\begin{tabular}{|c|c|c|c|c|c|c|}
\hline & Control & Mitocnol & $\begin{array}{l}\text { Zidovudine } \\
\quad(100 \\
\text { mg/kg/d) }\end{array}$ & $\begin{array}{c}\text { Zidovudine } \\
(100 \\
\text { mg/kg/d })+ \\
\text { Mitocnol }\end{array}$ & $\begin{array}{l}\text { Zalcitabine } \\
(13 \mathrm{mg} / \mathrm{kg} / \mathrm{d})\end{array}$ & $\begin{array}{r}\text { Zalcitabine } \\
(13 \mathrm{mg} / \mathrm{kg} / \mathrm{d}) \\
+ \text { Mitocnol }\end{array}$ \\
\hline $\begin{array}{c}\text { Ischiadic nerve } \\
\text { mtDNA copies }+ \\
\text { Hippocampus }\end{array}$ & $374 \pm 49$ & $372 \pm 38$ & $290 \pm 65 *$ & $346 \pm 35 \dagger$ & $237 \pm 61 * *$ & $335 \pm 48 * \dagger$ \\
\hline mtDNA copies $\ddagger$ & $211 \pm 51$ & $219 \pm 80$ & $104 \pm 32 * *$ & $145 \pm 21 * \dagger$ & $151 \pm 30^{*}$ & $181 \pm 53 *$ \\
\hline COX activity@ & $11 \pm 3$ & $9 \pm 3$ & $4 \pm 2 * *$ & $6 \pm 2 * * \dagger$ & $5 \pm 2 * *$ & $8 \pm 3 * \dagger$ \\
\hline COX/SDH-ratio \% & $100 \pm 9$ & $107 \pm 9$ & $48 \pm 19 * *$ & $90 \pm 18 \dagger \dagger$ & $50 \pm 15 * *$ & $92 \pm 20 \dagger \dagger$ \\
\hline Citrate activity@ & $1152 \pm 201$ & $1086 \pm 179$ & $1124 \pm 275$ & $1265 \pm 314$ & $1791 \pm 33 *$ & $1361 \pm 173 * \dagger$ \\
\hline COXII/COXIV-ratio\% & $100 \pm 5$ & $122 \pm 26$ & $57 \pm 25 * *$ & $89 \pm 22 \dagger$ & $45 \pm 20 * *$ & $94 \pm 20 \dagger \dagger$ \\
\hline
\end{tabular}

[Table] *, P< 0.05 vs. controls; † vs. no Mitocnol. **, $\mathrm{P}<0.001$ vs. control; $\dagger \dagger$ vs. no Mitocnol; \%, of control; $\ddagger$, copies/nucleus; @ $\mu$ moles/ $\mathrm{min} / \mathrm{g}$ protein

side analogues on mitochondria. We investigated if this neuropathology may be antagonized by uridine supplementation in vivo.

Methods: BalbC mice (7 weeks of age) were fed with zalcitabine $(13 \mathrm{mg} / \mathrm{kg} / \mathrm{d})$ or zidovudine $(100 \mathrm{mg} / \mathrm{kg} / \mathrm{d})$ with or without Mitocnol (340 mg/kg/d) a dietary supplement with high uridine bioavailability for 9 weeks. Hippocampus and ischiadic nerve ultrastructure and mitochondrial functions were assessed.

Results: Zalcitabine and to a lower extent zidovudine induced a significant peripheral and cerebral neuropathy with disrupted mitochondrial architecture, depleted mitochondrial DNA (mtDNA), and reduced levels of cytochrome c oxidase activity (COX) and mtDNA-encoded cytochrome c subunit I (COX I). Mitocnol had no side effects but attenuated or fully normalized all pathology of the peripheral and central nervous system (Table).

Conclusion: Zidovudine and zalcitabine induce a mitochondrial peripheral and cerebral neuropathology, both of which are antagonized by Mitocnol.

\section{P641}

\section{Isolation and characterization of $\mathrm{ScFv}$ 's from HIV non-progressors (LTNP/EC)}

Maria Hertje $^{1}$, Zhou Mingkui ${ }^{1}$, Sascha Antoni ${ }^{2}$, Michael Hust $^{3}$, Stefan Dübel ${ }^{3}$, Berta Rodes ${ }^{4}$, Vincent Soriano ${ }^{4}$, Mark us Bickel ${ }^{5}$, Ursula Dietrich ${ }^{1}$

${ }^{1}$ Georg-Speyer-Haus, Molekulare Virologie, Frankfurt/Main, Germany, ${ }^{2}$ Roche Diagnostics GmbH, Penzberg, Germany, ${ }^{3}$ Technische Universität Braunschweig, Institute for

Biochemistry and Biotechnology, Braunschweig, Germany,

${ }^{4}$ Department of Infectious Diseases, Hospital Carlos III,

Madrid, Spain, ${ }^{5}$ Universitätsklinikum Frankfurt am Main, Frankfurt/Main, Germany

The aim of this study is to isolate neutralizing antibodies from HIV-1 infected patients controlling the infection, like LTNP (long-term non-progressors) and EC (elite controllers). The antibody fragments were selected from scFv libraries derived from such patients' sera containing HIV neutralizing antibodies. An LTNP derived scFv library was generated and screened on multimeric gp 140 by phage display. Selected phages were characterized for gp140 binding by ELISA and antibody inserts were sequenced. After expression of recombinant $\mathrm{scFv}$, the neutralizing capacity will be determined in in vitro neutralization assays. Five gp140-specific scFv phages were isolated from an LTNP $\mathrm{scFv}$ phage library after several rounds of biopanning. Genetic analysis of the variable fragments revealed two independent clones. Currently, the scFv are being expressed in recombinant form to test them in HIV-1 neutralization assays. Pannings with the trimeric form of the HIV-1 envelope gp 140 are in progress. Furthermore, we could also detect neutralizing activities in some of our EC patient sera, as we previously described for LTNP sera. ScFv libraries will also be derived from these patients to screen them in biopannings. ScFv phages derived from long-term-nonprogressors or EC with neutralizing antibodies could be a good approach for the identification of neutralizing antibody fragments against HIV-1.

\section{P642}

Interferon- $\gamma$-mediated pathways and proliferation of HIV-infected peripheral blood mono nuclear cells

Katharina Kurz-Schroecksnadel ${ }^{1}$, Christiana Winkler ${ }^{2}$ Ernst R. Werner ${ }^{2}$, Mario Sarcletti ${ }^{3}$, Nikolaus Romani ${ }^{3}$, Susanne Ebner ${ }^{3}$, Dietmar Fuchs ${ }^{2}$, Robert Zangerle ${ }^{4}$

${ }^{1}$ Medizinische Universität Innsbruck, Allgemeine Innere Medizin, Innsbruck, Austria, ${ }^{2}$ Medizinische Universität Innsbruck, Biologische Chemie, Innsbruck, Austria,

${ }^{3}$ Medizinische Universität Innsbruck, Hautklinik, Innsbruck,

Austria, ${ }^{4}$ Medizinische Universität Innsbruck, Innsbruck, Austria

Objective: HIV-infection is characterized by defective immune response, HIV-infected peripheral blood mononuclear cells (PBMC) are not able to react to stimulation with allo-antigens and mitogens properly. Cytokine IFN- $\gamma$ appears to play an important role in the development of HIVinduced immunodeficiency. This study examined Interferon- $\gamma($ IFN- $\gamma)$ mediated pathways and the proliferative response of mitogen-stimulated HIV-infected PBMC in vitro. Material and methods: PBMC of 30 HIV-infected patients and 15 blood donors were isolated and stimulated with mitogens concanavalin A (Con A), phytohemagglutinin (PHA) and pokeweed mitogen (PWM). Concentrations of IFN- $\gamma$ and neopterin were measured by ELISA, tryptophan and kynurenine were determined by HPLC. mRNA expression of IFN- $\gamma$, GCH-I and IDO was quantified by real time PCR. 
Results: Upon mitogen stimulation enhanced mRNA expression of IFN- $\gamma$, GCH-I and IDO was induced in HIV-infected and control PBMC leading to enhanced neopterin formation and tryptophan degradation. IFN- $\gamma$ concentrations were associated with neopterin levels and tryptophan degradation. Proliferative responses to PHA and PWM cytokine were lower in patients than in healthy controls, IFN- $\gamma$ formation predicted proliferative responses. Higher mRNA-expression of IFN- $\gamma$, GCH-I and IDO after 6 hours was related with better proliferative responses.

Conclusion: Induction of IFN- $\gamma$ and subsequent enzymes appears to importantly influence the proliferative response of HIV- infected PBMC in vitro, suggesting a prominent role of the cytokine in the development of immunodeficiency.

\section{P643}

\section{Fungal toxins stimulate HIV infection and replication}

Cornelia Speth ${ }^{1}$, Magdalena Hagleitner ${ }^{1}$, Günter Rambach ${ }^{1}$, Iradj Mohsenipour ${ }^{2}$

${ }^{1}$ Department of Hygiene, Microbiology and Social Medicine, Innsbruck Medical University, Innsbruck, Austria,

${ }^{2}$ Department of Neurosurgery, Innsbruck Medical University, Innsbruck, Austria

Background: HIV-infected patients are prone to invasive aspergillosis, an important factor for morbidity and mortality in these individuals. However, knowledge about a putative cross-effect between fungal and viral infection is very limited. Since a better understanding of these interactions might help to optimise the antiviral therapy in case of invasive aspergillosis, we investigated whether fungal metabolites influence HIV replication and thus contribute to a progression to AIDS.

Metho ds: HeLa cells transfected with a HIV promoter construct, lymphocytes, monocytes and primary microglia, were pre-incubated with fungal metabolites prior to infection with HIV. Viral replication was analysed by quantification of promoter activity and of p24 in the supernatants, cell activation was measured by MTS test.

Results: The fungal toxins gliotoxin and citrinin, known to be produced by pathogenic Aspergillus species, stimulated in subtoxic concentrations the cellular activity. These two substances also strongly enhanced HIV infection of HeLa cells as shown by increase in the number of infected cells and of syncytia. Pre-incubation with gliotoxin or citrinin also amplified the viral load in the culture supernatants in comparison to mock-treated control cells. A similar effect of gliotoxin on cell infection and the production of progenitor virus was visible for T-cells, monocytes and primary microglia. Other fungal metabolites like patulin, fumitremorgin or verruculogen were shown to be ineffective and did not influence viral infection and replication.

Conclusions: Gliotoxin and citrinin can boost and fuel the HIV infection of a spectrum of cell types which represent viral targets in the patient, and consequently stimulate the generation of progenitor virus. Thus an opportunistic fungal infection of HIV-infected individuals should result in adaptation or initiation of antiviral therapy. Further knowledge about the pathogenic mechanisms of gliotoxin and citrinin might help to neutralize to metabolite-induced escalation of virus production and thereby interfere with disease progression in the patients. 


\title{
Autorenverzeichnis / Author index
}

\author{
Beitragsnummern halbfett, Seiten gerade / Abstract numbers bold, pages upright
}

A

Absalon, J: P424, P430 .......688,71

Achenbach, Stephan: P449 ........80

Adermann, Knut: OSG/3 . . . . . . . . . 15

Aebi-Popp, Karoline: P327 . . . . . . . . .55

Ahlenstiel, Golo: OSE/1 . . . . . . . . . . 10

Aichinger, Walter: P504 . . . . . . . . . . 999

Aldridge, David: P130 . . . . . . . . . . . 31

Allaway, G: P425 (PD) . . . . . . . . . . .69

Allen, Todd: P632 . . . . . . . . . . . 118

Allers, Kristina: OSG/2, P620 . . . 15, 113

Al-Shoba, Khalid: OSG/4 . . . . . . . . . 15

Altfeld, Marcus: P632 . . . . . . . . . . . 118

Althaus, Claudia: P616 . . . . . . . . . 111

an der Heiden, Matthias: OSA/3,

P306 .............. 46

Anadol, Evrim: OSE/3, P329,

P639 .............11, 56, 120

Andrea, Kühne: P402 (PD) . . . . . . . . .58

Andreutti, Corinne: P304 (PW) . . . . .45

Antoni, Sascha: OSC/1, P641 . . . .5, 121

Arastéh, Keikawus: OSE/5, P433,

P457 (PW), P462 (PD), P475, P476,

P509 . . . . 12, 72, 84, 86, 91, 92, 101

Arendt, Gabriele: P478, P480,

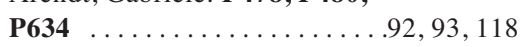

Arriagada, Sarah: P223 . . . . . . . . . .42

Arribas, Jose: P409 . . . . . . . . . . . .61

Arsova Netzelmann, Tzvetina:

P206 (PW), P207 (PW) . . . . . . . . 35

Asbach, Benedikt: P636 ... . . . . . . .119

Assmann, Dagmar: OSE/5 . . . . . . . . 12

Audigé, Annette: P631 . . . . . . . . . 117

Auffenberg, Christina: P209 . . . . . . . 36

\section{B}

Back, David: OSD/4 . . . . . . . . . . .8

Balcarek, Kerstin: P626 . . . . . . . . 115

Balduin, Melanie: P441 (PW) . . . . . .76

Ballmaier, Matthias: P615 . . . . . ..111

Balogh, A: P420 (PW) . . . . . . . . . 66

Balogh, Anna: P483 (PW) . . . . . . .94

Balthasar, Hugues: P210 . . . . . . . . . . . . . . . . . . . . .

Banki, Zoltan: P619 . . . . . . . . . . . . . 112

Barreiros, Ana Paula: P322 . . . . . . . . 97

Barreiros, Ana-Paula: P489 ... . . . . . 53

Bartmeyer, Barbara: P303 (PW),

P312, P315, P320, P323, P326,

P402 (PD), P447, P481 (PW) . . . . . 44,

48, 50, 52, 53, 55, 58, 78, 94

Bassetti, Stefano: OSE/6 . . . . . . . . . 12

Battegay, Manuel: OSD/4, OSE/6,

P115 (PD), P300, P308 (PD), P325,

P331, P443 (PW), P511, P516,

P631 $\ldots \ldots \ldots \ldots \ldots \ldots, 12,24$,

43, 46, 54, 57, 77, 102, 104, 117

Bätzing-Feigenbaum, Jörg: P302 (PW),

P629 ..............44, 116

Baudewig, Monika: P317 .........50

Baumgarten, Axel: OSE/1, P415,

P417, P431, P432, P440 (PW), P455

(PW), P464, P514 . . . . 10, 64, 65, 71,

72, 75, 82, 87, 104

Beauvoit, Bertrand: P626 . . . . . . . 115

Beck, Rose Marie: P124 ... . . . . . 28
Becker, W: P403 .............59

Beermann, Sandra: P603 (PW) . . . . 106

Behrendt, Daniela: P455 (PW) . . . . . . 82

Behrens, Georg: INV/6, P428 (PD),

P479, P514, P614, P627 . . . . VIII, 70, 93,

104, 110, 116

Beichert, Matthias: P429, P508 . . .70, 100

Bellinger, Oswald: P458 (PW) . . . . . . .84

Benhamou, Yves: P456 (PW) . . . . . . .83

Berg, Christoph: OSE/3 . . . . . . . .11

Berg, Thomas: P417, P486 (PD) . . .65, 96

Bergauer, Florian: P459 (PW) . . . . . 84

Berger, Annemarie: P623 . . . . . . . . . 114

Berger, Florian: P110, P400 (PW) .22, 57

Bergmann, Jan: P309 . . . . . . . . . . .47

Bergmann, Silke: OSC/1, P502 (PD),

P606 ................ 5, 98, 107

Bernasconi, Enos: P300, P308 (PD),

P331, P443 (PW) . . . . . . . 43, 46, 57, 77

Berry, A.: P426 ............. . 70

Bertram, Norbert: P446 . . . . . . . . . .78

Bhatnagar, Nupur: P609 (PD), P615,

P630 ..............108, 11, 117

Bickel, Markus: OSE/1, OSE/3, P409,

P440 (PW), P623, P641 . . . . . . . 10, 11,

$61,75,114,121$

Biehl, Katrin: P634 ... . . . . . . . . 118

Bienek, Bernhard: . . . . . . . . .

Bieniek, Bernhard: P312, P415, P431,

P432,P455 (PW) . . . . . . . . . 48, 64

$71,72,82$

Bihl, Florian: P331 . . . . . . . . . .57

Binninger-Schinzel, Dorothea: P637 . .119

Block, Martina: P204, P221 . . . . . .34, 41

Bluhm, Jenny: P219 . . . . . . . . . . . .40

Bochow, Michael: OSB/2, OSB/5,

P100 (PW), P301 (PW) . . . . .3, 4, 17, 43

Bock, Holger: P608 (PD) . . . . . . . .108

Boffi El Amari, Emmanuelle: P461 (PD),

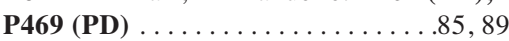

Bogner, Johannes R: P403, P404, P405,

P433, P505, P622 . . . . . . . 59, 60, 72, 100,114

Bohl, Michael: P112 .............23

Bollmann, Susann: P209 ... . . . . . . 36

Bonhoeffer, Sebastian: P300 ... . . . . 44

Böni, Jürg: OSF/2, OSF/3, P300, P307,

P319, P419 (PW) .......13, 14, 43, 46,

51,66

Bonnet, Jacques: P626, P640 . . . .115, 120

Boutwell, Christian: P632 . . . . . . . . 118

Brackmann, Heike: P622 . . . . . . . . 114

Bracone, Michaela: P129 . . . . . . . . . 31

Brandt, Eva: P481 (PW) . . . . . . . . .94

Braun, Patrick: P406, P416, P444 (PW),

P483 (PW), P486 (PD), P507 . . . .60, 65,

77, 94, 96, 100

Bredl, Simon: P604 . . . . . . . . . . . . 107

Breitenecker, Florian: $\mathbf{P 4 6 8}$. . . . . . . .89

Bremer, Viviane: P321, P324 . . . . . 52, 54

Brockman, Mark: P632 . . . . . . . . . 118

Brockmeyer, Norbert H.: OSD/5, P101

(PW), P104 (PW), P130, P317, P460

(PW), P470, P514, ........9, 17, 19,

$31,50,85,89,104$
Brodt, Hans-Reinhard: P124, P129,

P222, P309, P414 (PW), P438 (PW),

P458 (PW), P623, P637 . . . . . 28, 31, 41,

47, 64, 75, 84, 114, 119

Brumme, Chanson: P632 . . . . . . . . . 118

Brumme, Zabrina: P632 . . . . . . . . 118

Brümmer, Julia: P509 . . . . . . . . . . . 101

Bubnov, Alexander: P474 . . . . . . . .91

Bucher, Heiner: OSF/2, OSF/3,

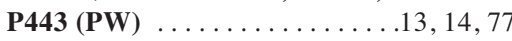

Bucher, Thomas: P210 ... . . . . . . . 36

Buchholz, Bernd: P429, P508 . . . .70, 101

Buggisch, Peter: OSE/1 . . . . . . . . . 10

Buhk, Thomas: OSD/5 . . . . . . . . . 9

Bühler, Silja: P505 . . . . . . . . . . . . . 100

Buonomo, Ersilia: OSA/1,

P435 (PW) . . . . . . . . . 73

Burchard, Gerd Dieter: P512 ... . . . 103

Bürgisser, Philippe: OSF/2, OSF/3,

P300, P304 (PW), P307 . . . . . 13, 14, 43, 45,46

C

Calmy, Alexandra: P445 (PD),

P469 (PD) . . . . . . . . . . . . . . . 78, 89

Carganico, Andreas: OSD/5, P417 . .9, 65

Carlebach, Amina: P400 (PW) . . . . . . .57

Carosi, G: P420 (PW) . . . . . . . . .66

Cassetti, Isabel: P408 . . . . . . . . . . .61

Cavassini, Matthias: P300, P308 (PD),

P331, P421 (PW), P443 (PW),

P445 (PD) . . . . . 43, 46, 57, 67, 77, 78

Ceffa, Susanna: P435 (PW) . . . . . . . .73

Charlotte, Frédéric: P456 (PW) . . . . .83

Charrier, Dagmar: P218 . . . . . . . . . .40

Chemnitz, Jan: P610 (PD) . . . . . . . . .109

Cheng, Andrew: P408, P409 . . . . . . 61

Chiweka, Evarist: P325 . . . . . . . . . . .54

Christensen, Stefan: P464 . . . . . . . .87

Christian, Kollan: P402 (PD) . . . . . . . .58

Claus, Bernd: P322 ...........53

Coenen, Martin: OSC/3, P638 . . . .6, 120

Combescure, Christophe: P469 (PD) . . .89

Cordes, Christiane: P464 ... . . . . . 87

Corsten, Claudia: P107 (PW), P203 20, 33

Courtar, Dorette: P506 . . . . . . . . . . 100

D

Daneel, Synove: P201 (PW),

P208 .................. 32,35

Dang, Thanh: P461 (PD) . . . . . . . . .85

Dannoritzer, Beate: P510 . . . . . . . . 102

Däumer, Martin: P322,

P486 (PD), P489 . . . . . . . . .53, 96, 97

De Jesus, Edwin: P409, P410,

$\mathbf{P 4 1 3} \ldots \ldots \ldots \ldots \ldots \ldots 61,62,63$

De Luca, Andrea: OSA/1,

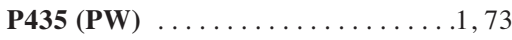

De Smedt, G: P411 . . . . . . . . . .662

Decosterd, Laurent-Arthur: P421 (PW) 67

Degen, Olaf: OSC/4, P403 .......6, 59

Delfraissy, J-F: P420 (PW) . . . . . .66

Demeter, Lisa: P307 . . . . . . . . . . . .46

Deppe, Michael: P480 . . . . . . . . . 993 
Derendinger, Steven: P210 . . . . . . . 36 Deveaud, Catherine: P626,

P640 ..................115, 120

Dietrich, Ursula: P485 (PD),

P603 (PW), P641 . . . . . . . 95, 106, 121

Dlugay, Verena: OSD/5 . . . . . . . . .9

Doerler, Martin: P470 . . . . . . . . . . . .89

Dominguez, Stephanie: P456 (PW) . . .83

Donatz, Verena: P118, P423 (PW),

P434 (PW) . . . . . . . 25, 68, 73

Donhauser, Norbert: P612,

P628 ...............110, 116

Doro Altan, Anna Maria: OSA/1,

P435 (PW) . . . . . . . . . . . 73

Dörrie, Jan: P502 (PD) . . . . . . . . . .98

Draenert, Rika: P622 . . . . . . . . . . . 114

Drewell, Christopher: P629 . . . . . . 116

Drewes, Jochen: OSB/4, P109,

P215 ............. 21, 38

Dübel, Stefan: P641 . . . . . . . . . . . . 121

Duerr, Ralf: P485 (PD) . . . . . . . . . .95

Dufty, N.: P426 . . . . . . . . . . . . .70

Duglay, Verena: P101 (PW) . . . . . . . 17

Dupke, Stefan: P104 (PW), P312,

P403, P412, P417 . . . . . . 19, 48, 59, 63,65

Dürken, Matthias: P429 . . . . . . . . . 70

Duvivier, Claudine: P456 (PW) . . . . . .83

$\mathbf{E}$

Eberhard, Johanna: P609 (PD),

P630 ...................109, 117

Eberle, Josef: P488, P504 . . . . . . .97, 99

Eberspaecher, Bettina: P457 (PW) . . .84

Ebner, Susanne: P619, P642 . . . . 112, 121

Ebrahimi, R.: P410 . . . . . . . . . . . . .62

Egerer, Lisa: OSG/4, P635 . . . . . .15, 119

Egger, Matthias: OSE/2 . . . . . . . . . 10

Ehret, Robert: P406, P444 (PW),

P483 (PW), P507 . . . . . . . 60, 77, 94, 100

Ehrle, Franz-Josef: P213 . . . . . . . . 37

Ehteshami, Maryam: P307 . . . . . . . 46

Eichler, Jutta: P485 (PD) . . . . . . . . 95

Eismann, Kathrin: OSC/1, P502 (PD),

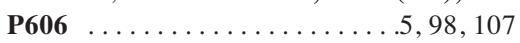

Elzi, Luigia: OSD/4, OSE/6,

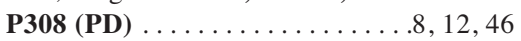

Endress, David: P437 . . . . . . . . . . .74

Enejosa, Jeffrey: P408, P409 . . . . . . .61

Engel, Herbert: P213 . . . . . . . . . . . . 37

Epple, Hans-Jörg: P620 . . . . . . . . . . .113

Esposito, Susanna: P439 (PW) . . . . . . .75

Esser, Stefan: OSE/4, P317, P450,

P513, P514 ..........11, 50, 80,

103, 104

Estoppey Younes, Sandrine: P331 . . . 57

Etschel, Jennifer: OSC/1, P606 _. . .5, 107

Etzel, Arnaldo: P408 . . . . . . . . . . . .61

Evers, Stefan: P480, P634 . . . . 93, 118

Evison, Jon-Marc: P461 (PD) . . . . . . . .85

F

Farajallah, A.: P410, P413,

P424 ...........62, 63, 68

Fätkenheuer, Gerd: OSE/4, OSE/5,

P305 (PW), P310 (PD), P314, P403,

P404, P411, P416, P433, P446, P471,

P607 (PD), P618, P625 . . . .11, 12, 45, 47,

$49,59,62,65,72,78,90,108,112,115$

Fehr, Jan: OSF/3, P108 (PD),

P461 (PD)
Fekete, Erin: P103 (PW) . . . . . . . . 18

Feldt, Torsten: P512 . . . . . . . . . 103

Fenske, Stefan: P455 (PW) . . . . . . . . .82

Ferenci, Peter: P465 . . . . . . . . . . .87

Ferlitsch, Arnulf: P468 . . . . . . . . . . . 89

Fiedler, Nicole: P621 . . . . . . . . . . . 113

Fierz, Katharina: P115 (PD) . . . . . . . .24

Finnegan, C: P425 (PD) . . . . . . . . .69

Firnges, Christiane: P212 . . . . . . . . 37

Fischer, Doris: P437 . . . . . . . . . .74

Fischer, Klaus: P312, P481 (PW) . . . .48, 94

Fischer, Kurt: P322 . . . . . . . . . . 53

Fischer, Marek: OSF/1, P616 . . . .13, 111

Flachskampf, Frank: P449 . . . . . . . 80

Flaherty, J.: P410, P413 . . . . . . .62, 63

Fleckenstein, Bernhard: P487,

P600 (PW), P612 . . . . . . . . 96, 105, 110

Flepp, Markus: P461 (PD) . . . . . . .85

Flossdorf, Pia: P305 (PW) . . . . . . . . 45

Forssmann, Wolf-Georg: OSG/3 . . . . 15

Förster-Waldl, Elisabeth: P437 . . . . .74

Fraser, Christophe: P210 . . . . . . . . . . 36

Fraunholz, Ingeborg: $\mathbf{P 4 6 7} \ldots \ldots . . .88$

Freiterna-Sperling, Cornelia: OSB/6,

P439 (PW) . . . . . . . . . . . . 4, 75

Freiwald, Matthias: P317 . . . . . . . 50

Friedrich, Oliver: P329 . . . . . . . . . . .56

Friese, Georg: P322 . . . . . . . . . . 53

Friese, Klaus: P451 . . . . . . . . . . .81

Fromm, Michael: P620 . . . . . . . . . 113

Fuchs, Daniela: P119 . . . . . . . . . . . . 26

Fuchs, Dietmar: INV/5, P619,

P642 .............VIII, 112, 121

Furrer, Hans Jakob: P331 . . . . . . . . .57

Furrer, Hansjakob: INV/4, OSE/2,

OSE/6, P300, P421 (PW), P445 (PD),

P511 .............VII, 10, 12, 43, 67, 78, 102

Fux, Christoph: P308 (PD), 421 (PW), P443 (PW), P445 (PD) . . . . . .46, 67, 77,78

G

Galieva, Zulfia: P127 . . . . . . . . 30

Gallant, Joel: P409 . . . . . . . . . . . . .61

Gallo, Lothar: P416, P513 . . . . . 65, 103

Ganschow, Rainer: P506 . . . . . . . . . . 100

Garzoni, Christian: P308 (PD) . . . . . .46

Gaudieri, Silvana: OSE/2 . . . . . . . . . 10

Gebhardt, Martin: P210,

P304 (PW) . . . . . . . . . . . 36, 45

Geit, Maria: OSA/2, OSD/3,

P311 (PD), P313 . . . . . . . 1, 8, 48, 49

Gekeler, Corinna: P221 . . . . . . . . 41

Gerl, Arthur: P472 . . . . . . . . . . . . . 90

Germano, Paola: OSA/1,

P435 (PW) . . . . . . . . . . 1, 73

Gianella, Sara: P616 . . . . . . . . . 111

Giaquinto, Carlo: P439 (PW) . . . . . . .75

Gibbons, Sara: OSD/4 . . . . . . . . . . 8

Gilsdorf, Andreas: P321, P324 . . . .52, 54

Gingelmaier, Andrea: OSB/6, P451,

P459 (PW), P503 (PD), P515 . . . . 4, 81, $84,99,104$

Glass, Tracy: OSF/3, P115 (PD),

P327, P443 (PW) . . . . . . . 14, 24, 55, 77

Göbels, Klaus: P411 . . . . . . . . . 62

Goebel, Frank: ..............

Goebel, Frank-Detlef: P411, P433,

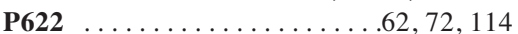

Gog1, Stefanie: OSA/2, OSD/3, P311

(PD), P313, P318 .......1, 8, 48, 49, 51 Gohlke-Micknis, Silvia: P302 (PW) . . .44 Goldmann, Georg: P477 . . . . . . . . . .92 Gölz, Jörg: OSD/5, OSE/1, P455 (PW),

P513 ...........9, 10, 82, 103

Gordillo, Victoria: P103 (PW) . . . . . .18

Gorgievski, Meri: OSE/2,

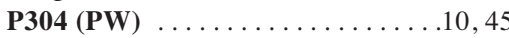

Götsch, Udo: P458 (PW) . . . . . . . .84

Götte, Matthias: P307 . . . . . . . . . 46 46

Gottschalk, René: P458 (PW) . . . . . .84

Graafen, Stefan: P116, P117 . . . . 24, 25

Gredig, Daniel: P102 (PW),

P205 (PW) . . . . . . . . . . 18, 34

Gregor, Nora: P480 . . . . . . . . . . .93

Greub, Gilbert: P461 (PD) . . . . . . . 85

Grimm, K.: P413 . . . . . . . . . . 63

Groß, Nils: P209 ............... 36

Gruber, Mira: P124 . . . . . . . . . . . 28

Grubert, Thomas: P459 (PW) . . . . . . 84

Grünhage, Frank: P477 . . . . . . . . . .92

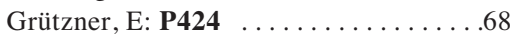

Gudowius, Sonja: P506 . . . . . . . . . . 100

Guhl, Christine: P466 . . . . . . . . .88

Guidotti, Gianni: OSA/1 . . . . . . . . . . 1

Guidotti, Giovanni: P435 (PW) . . . . .73

Gunsenheimer-Bartmeyer, Barbara:

P330 .................57

Günthard, Huldrych: INV/2, OSE/2,

OSF/1, OSF/2, P300, P307, P419 (PW),

P616 .............. VII, 13, 43,

46, 66, 111

Gurtner De la Fuente, Vanina:

P445 (PD) . . . . . . . . . . . . .78

Gute, Peter: P400 (PW), P404, P405,

P414 (PW) .........57, 59, 60, 64

Gute, S: P403 .................59

Gutmann, Christine: P421 (PW) . . . .67

Gutsche, Franziska: P223 . . . . . . . . .42

H

Haas, Bernhard: OSA/2, OSD/3,

P311 (PD), P313 . . . . . . . 1, 8, 48, 49

Haastert, Burkhard: P317, P514 . . .50, 104

Haberl, Annette: P414 (PW), P438 (PW),

P467, P513, P623 . . . . . . . 64, 75, 88,

103, 114

Haerry, David: P106 (PW), P516 .20, 104

Hagleitner, Magdalena: P643 . . . . . . 122

Hamouda, Osamah: OSA/3, OSD/2,

P302 (PW), P303 (PW), P306, P312,

P315, P320, P321, P323, P324, P326,

P330, P402 (PD), P447, P481 (PW),

P629 ........... 2, 7, 44, 46

48, 50, 52, 53, 54, 57, 58, 78, 94, 116

Hampf, Dirk: P475 . . . . . . . . . 91

Hamy, François: P401 (PW),

P425 (PD), P605 (PD) . . . . . 58, 69, 107

Hand, Patrick: P209 . . . . . . . . . . . . . 36

Hänel, Kristin: P600 (PW) . . . . . . . .105

Hansen, Stefan: P454, P506 . . . . . 82, 100

Harcourt, Gillian: OSE/2 . . . . . . . 10

Harrer, Ellen G.: OSC/1, P449, P453,

P502 (PD), P606 . . . . . . . .5, 80, 81,

98, 107

Harrer, Thomas: OSC/1, P317, P433,

P449, P453, P502 (PD), P606 . . . . 5, 50,

72, 80, 81, 98, 107

Hartjen, Philip: OSC/2, P617 (PD) .5, 112

Hartjen, Philipp: OSC/4 ...........6 
Hartl, Helmut: P514 . ..............104

Hartmann, Pia: P305 (PW),

P607 (PD), P618, P625 ....... 45, 108,

112,115

Hasse, Barbara: OSF/2,

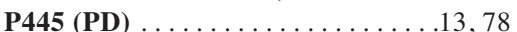

Hatz, Christoph: P325, P511 … 54, 102

Hauber, Ilona: OSG/1, P610 (PD),

P617 (PD) ..............14, 109, 112

Hauber, Joachim: OSC/4, OSG/1,

P610 (PD), P617 (PD) . . . .6, 14, 109, 112

Häussinger, Dieter: P314, P441 (PW),

P471 ...............49, 76, 90

Heeg, Bart: P422 (PW) . . . . . . . . .67

Hegener, Petra: P110, P400 (PW) . .22, 57

Heiken, Hans: P428 (PD), P615 . . .70, 111

Heim, Albert: P488 .............97

Heine, Rosa: P209 . . . . . . . . . . . . . . 36

Heinemann, Falko: P450 . . . . . . . . . 80

Heinz, Werner: P466 . . . . . . . . . . . . .88

Helm, Martin: P628 .............. 116

Henke, Julia: P110, P400 (PW) . . . .22, 57

Henke-Gendo, Cornelia: P488 . . . . . . .97

Henrich, Nadja: P622 ............114

Hentrich, Marcus: OSE/4, OSE/5,

P472 ................11, 12, 90

Herkenrath, Simon: P477 . . . . . . . 92

Hertenstein, Caroline: P310 (PD) . . . . .47

Hertje, Maria: P641 ............121

Hertling, Sandra: OSC/4, P436,

P442 (PW), P506 . . . . . . . .74, 76, 100

Heuer, Nadja: P511 . . ..............102

Hien, Steffen: P429, P508 …. .70, 101

Hill, Andrew: P423 (PW),

P434 (PW) .............68, 73

Hintsche, Bettina: P417, P455 (PW),

P464, P481 (PW) . ...... 65, 82, 87, 94

Hirsch, Hans H: P308 (PD) . . . . . . . .46

Hirschel, Bernard: P300, P421 (PW),

P469 (PD) . . . . . . . . . 43, 67, 89

Hirschel, Bernhard: P331 . . . . . . . . .57

Hodder, S.: P413 . . . . . . . . . . . . . .63

Hoesli, Irene: P327 . . . . . . . . . . . . .55

Hoetelmans, Richard: P439 (PW) . . . .75

Hoffmann, Christian: OSE/4, OSE/5,

P306, P464 ............11, 13, 46, 87

Hofmann, Christian: P502 (PD) . . . . . . 98

Hofmann, Jörg: OSG/2 . . . . . . . . . . 15

Hofman-Sieber, Helga: P621 . . . . . . . 1113

Hohenberg, Heinrich: OSG/1 . . . . . . . 14

Höhn, Christian: P406, P444 (PW),

P507 .................60,77, 100

Holleczek, Bernd: P329 . . . . . . . . . . 56

Höller, Tobias: P329 . . . . . . . . . . . . . 56

Holm, Stefanie: P415, P431,

P432 ...............64, 71,72

Hong, Henoch: P609 (PD), P615,

P630 .................109, 111, 117

Horst, Heinz-August: P404, P464 . .59, 87

Houareau, Claudia: P303 (PW), P312,

P315, P320, P326, P447 ....... .44, 48,

$50,52,55,78$

Hower, Martin: P101 (PW), P406,

P415, P431, P432, P454 .....17, 60, 64, $71,72,82$

Hoxhaj, Olimbi: P126 . . . . . . . . . . 29

Hsu, LeeNah: P126 . . . . . . . . . . . . . . 29

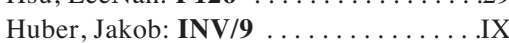

Huber, Milo: P501 (PW) . . . . . . . . . . .98

Hückelhoven, Angela: OSC/1,

P606
Husstedt, Ingo W.: P478, P480,

P634 ................92, 93, 118

Hust, Michael: P641 . . . . . . . . . . . 121

Hütter, Gero: OSG/2 . . . . . . . . . . . . 15

Iloeje, U: P430 ................71

Ingiliz, Patrick: P456 (PW) . . . . . . .83

Ironson, Gail: P121, P122 . . . . . . . . .27

$\mathbf{J}$

Jablonka, Robert: P450 . . . . . . . . . .80

Jaeger, Hans: P415, P431, P432, P483

(PW), P514 ........64, 71, 72, 104

Jägel-Guedes, Eva: P472 . . . . . . . .99

Jäger, Hans: P104 (PW), P411, P433,

P440 (PW) . . . . . . . . . . 19, 62, 72 ,

75,94

Jalili, Ahmad: P473 ...............90

Janine, Kimbel: OSG/4 . . . . . . . . . . 15

Jansen, Klaus: OSD/5, P101 (PW),

P104 (PW), P317, P321, P324, P470,

P514 .............. 17, 19, 50, $52,54,89,104$

Jansky, Michael: P114, P116,

P117 ...................23, 24, 25

Janssen, Katrie: P439 (PW) . . . . . . . .75

Jaton, Katia: P461 (PD) . . . . . . . . . .85

Jayasuriya, A. N.: P426 . . . . . . . . . . .70

Jensen, Björn: P441 (PW) . . . . . . . .76

Jensen, Björn-Erik Ole: OSE/4 ….11

Jessen, Arne: P428 (PD) . . . . . . . . . . .70

Jessen, Heiko: P312, P428 (PD), P455

(PW), P474, P481 (PW) .......48, 70, $82,91,94$

Jöchl, Margret: OSA/2, OSD/3, P311

(PD), P313, P318 ........ 8, 48, 49, 5

John, Christine: OSE $/ 1 \ldots \ldots \ldots \ldots 10$

Joos, Beda: OSF/1, P616 . ......13, 111

Jullu, Boniphace: P511 . . . . . . . . . .102

Jung, Norma: P607 (PD), P618,

P625 ...............108, 112, 115

Jung, Susan: P487, P600 (PW),

P611 (PD), P612 . . . . . . . . . . .96, 105, 109,110

\section{K}

Kahle, Joerg: P635 . . . . . . . . . . . . . .119

Kahlert, Christian: P633 . . . . . . . . . 118

Kaiser, Laurent: P469 (PD) . . . . . . . . .89

Kaiser, Rolf: P314, P441 (PW), P471,

P486 (PD) . . . . . . . . . . 49, 76, 90, 96

Kakuda, Thomas: P411,

P439 (PW) . ...............62,75

Kamga Wambo, Oscar: P302 (PW) . . . 44

Kanatschnig, Manfred: OSD/3, P311 (PD),

P313 ................... 8, 48,49

Kane, Katherine: P632 ….......118

Kaptur, Paulina: P220 . . . . . . . . . . . . 41

Kapzan, Ruth: P624 ................ 114

Karwat, Martin: P483 (PW) . . . . . . . .94

Kaspari, Michael: P479 . . . . . . . . . 93

Kästner, Ralph: OSB/6, P451, P459 (PW),

P503 (PD), P515 . . . . . . . . . 4, 81, $84,99,104$

Katlama, Christine: P456 (PW) . . . . . .83

Keeren, Kathrin: P312,

P481 (PW) . . . . . . . . . . . . 48, 94

Kessler, Sebastian: P222 . . . . . . . . . .41

Keudel, Phillip: P609 (PD), P630 109, 117

Khanna, Nina: P308 (PD) $\ldots \ldots \ldots \ldots .46$
Khaykin, Pavel: OSE/1, P305 (PW),

P438 (PW), P440 (PW),

P623 ................10,45, 75, 114

Khoo, Saye: OSD/4 . . . . . . . . . . . 8

Kibatala, Patience: P325, P511 . . .54, 102

Kircher, Claudia: P129, P222,

P309 .................31, 41, 47

Kirchhoff, Frank: OSC/1, OSG/3 _. .5, 15

Kirschner, Jan-Bernd: P626,

P640 ...................115, 120

Kisch, Tobias: P222 .............41

Kittner, Jens: P322, P489 _......53, 97

Klauke, Stephan: P416, P440 (PW),

$\mathbf{P 6 2 3} \ldots \ldots \ldots \ldots \ldots \ldots 65,75,114$

Klausen, Gerd: OSE/1, P481 (PW) .10, 94

Klein, Imke: P112 . . . . . . . . . . . . 23

Klenerman, Paul: OSE $/ 2 \ldots \ldots \ldots \ldots$

Kliche, Alexander: P624 . . . . . . . . . .114

KIimkait, Thomas: P401,

P605 (PD) . . . . . . . . . . . . . .58, 107

Klimesch, Dagmar: P120 ….......27

Klimkait, Thomas: OSF/2, OSF/3,

P300, P307, P425 (PD), P605 (PD) ...13,

$14,43,46,58,69$

Klinker, Hartwig: OSE/1, P466 . . . .10, 88

Klöpfer, Carsten: P123 . . . . . . . . . . 28

Klumb, Silke: P216 ................39

Knappik, Anna: P214 (PD), P217 . . . 38,39

Knecht, Gaby: P112, P414 (PW) . . .23, 64

Knecht, Stefan: P480 . . . . . . . . . .93

Knechten, Heribert: P314, P405, P406,

P416, P444 (PW), P483 (PW),

P507 ..............49, 60, 65, 77 94,100

Koegl, Christine: P415, P431,

P432 ...............64, 71,72

Kohrgruber, Norbert: P613 . . . . . . . 110

Kollan, Christian: OSA/3, OSD/2,

P306, P312, P320, P323, P326,

P447 ..............2, 7, 46, 48,

$51,53,55,78$

Königs, Christoph: P124, P437, P439

(PW) $\ldots \ldots \ldots \ldots \ldots \ldots .28,74,75$

Köppe, Siegfried: P104 (PW), P403,

P404, P417, P464, P476 .......19, 59, $65,87,92$

Körber, Andreas: P513 . . . . . . . . . . 103,

Korn, Klaus: P453, P488, P628 … . .81,

97,116

Körner, Christian: OSC/3, P638 _. .6, 120

Kost, Bernd: P459 (PW) . . . . . . . . . 84

Köstler, Josef: P604, P621 . . . . . 107, 113

Köthemann, Wolfgang: P406 …....60

Koutsilieri, Eleni: P634 . . . . . . . . . . . 118

Kouyos, Roger: P300 .............43

Kouznetsov, Laura: OSH/1, P224 . .16, 42

Kovari, Helen: P461 (PD) . . . . . . . . . . .85

Kowoll, Susann: P462 (PD) . . .......86

Krämer, Alexander: P224 ..........42

Krämer, Benjamin: OSC/3, P602 (PW),

P638 ...............6, 106, 120

Kraus, Benjamin: P637 . . . . . . . . . 119

Krause, Birgit: P637 .............119

Krauthausen, Felise: P417 . . . . . . .65

Kreckel, Peter: OSD/5, P476 . . . . . 9, 9, 92

Kremer, Heidemarie: P121, P122 …27

Krepstakies, Marcel: P617 (PD) . . . . .112

Kreuter, Alexander: P460 (PW) . . . . . .85

Kreuz, Wolfhart: P437 ............74

Kreuzberg, Christina: OSA/3 . . . . . . . 2

Krings, Dorothee: P209 . . . . . . . . . . . 36 
Kroeker, Lena: P124 . . . . . . . . . . . .28

Krznaric, Ivanka: P412, P436 . . . . .63, 74

Kubesch, Verena: P502 (PD) . . . . . . .98

Kücherer, Claudia: P302 (PW), P303

(PW), P312, P315, P326, P330, P447,

P481 (PW), P629 . . . . . 44, 48, 50, 55,

57, 78, 94, 116

Kugel, Harald: P480 . . . . . . . . . . . 93

Kuhlmann, Birger: P317,

P428 (PD) . . . . . . . . . . . .50, 70

Kühne, Andrea: P320, P323 . . . . . . . 52, 53

Kühner, Angela: OSB/4, P113 . . . . . 3, 23

Kummer, Silke: P617 (PD) . . . . . . . .112

Kümmerle, Tim: P310 (PD)

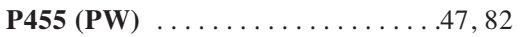

Kurowski, Michael: P438 (PW) . . . . . .75

Kurz, Katharina: P619 . . . . . . . . . . . . 112

Kurz-Schroecksnadel, Katharina:

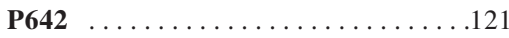

Kuschak, Dieter: P400 (PW) . . . . . . . .57

Kuster, Herbert: OSF/1,

P419 (PW) . . . . . . . . . . .13, 66

Kuznetsov, Alexander: OSH/1,

$\mathbf{P 2 2} 4 \ldots \ldots \ldots \ldots \ldots \ldots \ldots, 42$

$\mathbf{L}$

Lämmel, Andreas: $\mathbf{P 4 5 2} \ldots \ldots \ldots \ldots . . .81$

Lammert, Frank: P477 . . . . . . . . . . . .92

Lana, Kosi: P463 ... . . . . . . . . . . 86

Langanke, Harriet: P120, P211 . . .27, 37

Langer, Phil C.: OSB/4, P109, P113,

P209, P215, P223 . . . . . . .3, 21, 23, 36,

38,42

Langhans, Bettina: OSC/3 . . . . . . . .6

Langmann, Peter: P466 . . . . . . . . . . . . . . . . . . . .

Lapaire, Olav: P327 . . . . . . . . . . . . .55

Lauenroth-Mai, Elke: P101 (PW) . . . .17

Lauterbach, Kristin: P506 . . . . . . . . . 100

Laux, Rainer: P506 . . . . . . . . . . . . 100

Lazzarin, A: P420 (PW) . . . . . . . . .66

Lebrecht, Dirk: P448, P626,

P640 ...............79, 115, 120

Ledergerber, Bruno: OSD/4, OSF/2,

P300, P331, P501 (PW) . . . . . .8, 13, 43, 57, 98

Lefebvre, Eric: P433 . . . . . . . . . . . .72

Lehmann, Clara: P305 (PW), P607 (PD),

P625 ..............45, 108, 115

Leidel, Jan: P214 (PD), P217 . . . . . 38, 39

Leiherer, Andreas: P601 (PW) . . . . . . .106

Leinert, Christoph: INV/5 . . . . . . . VIII

Leleu, G: P420 (PW) . . . . . . . . . . . .66

Lemmen, Karl: P106 (PW), P204,

P221 ................20, 34, 41

Lengauer, Thomas: P314, P471, P486

(PD) . . . . . . . . . . . . 49, 90, 96

Lennemann, Tessa: P124, P129, P222,

P309, P414 (PW), P438 (PW) . . . . .28,

$31,41,47,64,75$

Lincke, Hans-Joachim: P118 . . . . . . . 25

Linde, Richard: P414 (PW), P437 . .64, 74

Lindemann, Christina: P303 (PW),

P315, P326, P330 . . . . . . .44, 50, 57

Lindemann, Monika: P450 . . . . . . . . .80

Lindhorst, Thomas: P608 (PD) . . . . 108

Lischka, Andreas: P437 . . . . . . . . . .74

Locher, Leo: P112 . . . . . . . . . . . . . . .23

Loddenkemper, Christoph: OSG/2,

P620 ..................15, 113

Lohmeyer, Jürgen: P322 . . . . . . . . . . 53

Lohse, Ansgar: OSC/4 .............6
Lombès, Anne: P456 (PW) . . . . . . . . .83 Lorenzen, Thore: P404, P405 . . . . .59, 60 Loschen, Stephan: P302 (PW),

P629 .................44, 116

Loss, Julika: OSB/1 . . . . . . . . . . . . .

Louvel, Severine: OSF/3, P401 (PW),

P425 (PD) . . . . . . . . . . 14, 58, 69 Luczkowski, Patricia: P129 ... . . . . . .31

Ludewig, Burkhard: P633 . . . . . . . . 118

Ludwig, Christine: P601 (PW) . . . . . . .106

Lutz, Thomas: OSE/1, P415, P416,

P431, P432, P455 (PW), P623 . . . . . 10

$64,65,71,72,82,114$

M

Maa, J: P424 . . . . . . . . . . . . .68

Maa, J-F.: P410 . . . . . . . . . . . . 62

Mack, Rebecca: P439 (PW) . . . . . . . .75

Madruga, Jose: P408 . . . . . . . . . .661

Maetzig, Tobias: OSG/4 . . . . . . . . . 15

Maga, Giovanni: P603 (PW) . . . . . 106

Magnano San Lio, Massimo: OSA/1 . . . .1

Maier, Reinhard: P633 . . . . . . . . . 118

Mallolas, Jospe: P400 (PW) . . . . . . . . .57

Mancini, M: P430 . . . . . . . . . . .71

Mantzsch, Kathleen: P129 . . . . . . . . . 31

Marazzi, Maria Cristina: OSA/1,

P435 (PW) . . . . . . . . . . . .1, 73

Marcus, Ulrich: OSB/3, OSH/2, P101

(PW), P301 (PW), P328, P330 . . . .3, 16

$17,43,55,57$

Martin, D: P425 (PD) . . . . . . . . . . . .69

Martin, Silas: P434 (PW) . . . . . . . . .73

Martinetti, Gladys: P304 (PW),

P331 ..............445,57

Marvan, Mohamed: P449 . . . . . . . . . 80

Marzolini, Catia: OSD/4 . . . . . . . . . . . . . .

Mäschli, Bettina: P127 . . . . . . . . . . 30

Massingill, Ruth: P131 . . . . . . . . . 32

Masuhr, Anja: OSE/5 . . . . . . . . . . 12

Matek, Werner: P453 . . . . . . . . . . .81

Mathys, Christian: P478 . . . . . . . . . 92

Matter, Lukas: P304 (PW) . . . . . . . . .45

Matterne, Uwe: P224 . . . . . . . . . . . . . .42

Maurer, Elisabeth: P510 . . . . . . . . . 102

Maurer, Katja: OSC/1 . . . . . . . . . .5

Mauss, Stefan: P110, P305 (PW),

P400 (PW), P405, P416,

P455 (PW) . ........22, 45, 57, 60, 65,82

Mayr, Christoph: OSE/1, P417,

P440 (PW), P455 (PW),

P464

82,87

Mc Callister, S: P425 (PD) . . . . . . . . .69

Mc Pherson, Piet: P309 . . . . . . . . . .47

McClure, Craig: INV/8 . . . . . . . . IX

McGrath, D: P424, P430 . . . . . . . .68, 7

Mchomvu, Rehema: P511 . . . . . . . . . 102

Medja, Fadia: P456 (PW) . . . . . . . . .83

Mertens, Volker: OSD/5,

P104 (PW) . . . . . . . . . . . . 9, 19

Mertenskötter, Thomas: INV/10,

P220, P513 . . . . . . . . . .IX, 41, 103

Mertes, Thomas: P489 . . . . . . . . . . . .97

Merz, Regine: P130 . . . . . . . . . . . . 31

Metzner, Karin: OSC/1, P316,

P419 (PW) ........... 5, 50, 66

Meuer, Eva: P618 . . . . . . . . . . . 112

Meyer, Anke: OSE/5 . . . . . . . . 12

Meyer-Bunsen, U: P420 (PW) . . . . . .66
Meyer-Olson, Dirk: OSC/4, P305 (PW),

P609 (PD), P615, P630 . . . . . .6, 45, 109

111,117

Michalik, Claudia: OSD/5, P101 (PW),

P104 (PW), P317, P470, P514 . . . 9, 17 ,

19, 50, 89, 104

Michalk, Monika: P602 (PW) . . . . . . . . . . .

Mikolajczyk, Rafael: P224 ........42

Milincovic, Ana: P400 (PW) . . . . . . .57

Mingkui, Zhou: P641 . . . . . . . . . .121

Möbius, Kalle: P485 (PD) . . . . . . . .95

Möbius, Ulrike: P479 . . . . . . . . . 99

Mohammadi, Siawoosh: P480 . . . . . .99

Mohrmann, Gerrit: P482 (PW) . . . . . . .94

Mohsenipour, Iradj: P643 . . . . . . . . . 121

Moll, Arend: P104 (PW), P411, P417,

P464 ........... 62, 65, 87

Moody, Kimberly: P115 (PD) . . . . . . .24

Morales-Ramirez, J.O: P410 . . . . . . . 62

Moreno, S: P420 (PW) . . . . . . . . .66

Mösch, Manfred: P414 (PW),

P438 (PW) ..............64, 75

Möser, Robin: P223 . . . . . . . . . . 44 42

Mosleh, Martin: P473 . . . . . . . . . . . 90

Mossdorf, Erik: P325 ... . . . . . . .54

Mosthaf, Franz: OSE/5, P317,

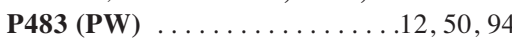

Mounzer, K: P413 . . . . . . . . . . .63

Mühlbacher, Axel: P118 . . . . . . . . 25

Mulcahy, Fiona: P513 . . . . . . . . . . . 103

Müllauer, Brigitte: P608 (PD) . . . . . 108

Müller, Axel: P400 (PW) . . . . . . . . .57

Müller, Daniela: P637 . . . . . . . . . . . . 119

Müller, Harm: P486 (PD) . . . . . . . . . . 96

Müller, Klaus: P448, P626, P640 . . . .79,

115,120

Müller, Marianne: P503 (PD),

P515 ..................... .99, 104

Müller, Mark: OSD/5 . . . . . . . . . . 9

Müller, Markus: OSE/4, P415, P417,

P431, P432 ..........11, 64, 65,

71,72

Müller, Matthias: P205 (PW) . . . . . . . 34

Müller, Nicolas: P308 (PD) . . . . . . . . 46

Müller, Sandra M: OSC/1, P449, P453,

P606 .................5, 80,

81,107

Müller, Stefan: P209, P223 . . . . . .36, 42

Müller, Wolfgang: P203 ... . . . . . . 33

Münch, Jan: OSG/3 . . . . . . . . . . . . . 15

Mutz, Antonius: P454, P514 . . . .82, 104

Mwaigomole, Geofrey: P325 . . . . . . .54

Mylonas, Ionnis: P451 . . . . . . . . . .81

$\mathbf{N}$

Nadal, David: P631 . . . . . . . . . . . . 117

Nagel, Stefan: P128 . . . . . . . . . 30

Nakonz, Tina: P410, P413 . . . . . .62, 63

Nattermann, Jacob: OSC/3, P602 (PW),

P638 ..............6, 106, 120

Neibecker, Markus: P639 . . . . . . . . 120

Nestel, Heike: P114 . . . . . . . . . . . . . 23

Neubauer, Aljoscha: P422 (PW) . . . .67

Neumann, Britta: P637 . . . . . . . . . . 119

Neumann, Jens: P448 . . . . . . . . . . . . .79

Neuwirth, Anton: P406 . . . . . . . . .60

Newrzela, Sebastian: OSG/4 . . . . . . 15

Nicca, Dunja: P108 (PD), P115 (PD),

P127, P201 (PW), P208, P517 . . . 21, 24,

30, 32, 35, 105

Nickelsen, Maike: OSE/5 . . . . . . . . 12 
Nideröst, Sibylle: P102 (PW),

P205 (PW) . . ...............18, 34,

Niederhauser, Christoph: P304 (PW) . .45

Niederöst, Barbara: P616 ..........111

Nijhuis, Monique: P307 ..........46

Nischalke, Hans-Dieter: OSC/3, P602

(PW), P638 ...........6, 106, 120

Nisius, Gabriele: P124, P414 (PW),

P438 (PW), P458 (PW) . . . 28, 64, 75, 84

Nitschke, Heidrun: P214 (PD),

P217 ................... 38, 39

Noah, Christian: P316, P452, P482 (PW),

P486 (PD) ............50, 81, 94, 96

Nolting, Thorsten: P634 ...........108

Nöstlinger, Christiana: P103 (PW),

$\mathbf{P 2 0 5}$ (PW) ............... 18,34

Notheis, Gundula: $\mathbf{O S B} / \mathbf{6} \ldots \ldots \ldots \ldots 4$

Nübling, Matthias: P118 . . . . . . . . . .25

\section{O}

Oberhauser, Verena: P608 (PD) . . . . . 108 Obermeier, Martin: P417, P464,

P486 (PD) . . . . . . . . . . . . 65, 87, 96

Odorico, Massimo: P461 (PD) . . . . . . .85

Oelschlaeger, Christian: P478 _.....92

Oette, Mark: P314, P441 (PW),

P471 ............... 49, 76, 90

Olah, Karen: P506 ................100

Oldenburg, Johannes: P477 . . . . . . 92

Olmscheid, Bruce: P442 (PW) ....... 76

Opravil, Milos: P421 (PW),

P445 (PD) . . . . . . . . . . 67, 78

Oremek, Gerhard: P458 (PW) . . . . . 84

Osterrieder, Nikolaus: P621 . . . . . . . 113

$\mathbf{P}$

Palombi, Leonardo: OSA $\mathbf{1}$,

P435 (PW) ................, 73

Paris, Daniel: P319 .............51

Paturzo, Giovanna: OSA/1,

P435 (PW) .............. 73

Pauli, Ramona: OSD/5,P415, P431,

P432, P454, P488 ........ 9, 64, 71, 72,

82, 97

Peck-Radosavljevic, Markus: P463, P465,

P468 ..................86, 87,89

Petkova, Mina: P635 . . . . . . . . . . 119

Petry, Ralph: P415, P431, P432 .64, 71, 72

Pfister, Herbert: P471 . . . . . . . . . . . 90

Pfister, Holger: P124 . . . . . . . . . . . . 28

Pfistershammer, Katharina: P463, P473,

P613 ................86, 90, 110

Pfundt, Katrina: P111, P125 . . . . . .22, 29

Pialoux, G: P420 (PW) . . . . . . . . . . .66

Pillai, Satish: OSF/1 .............13

Piper, Stefan: P608 (PD) . . . . . . . . . 108

Platteau, Tom: P103 (PW),

P205 (PW) . . . . . . . . . . . 18, 34

Plettenberg, Andreas: P104 (PW), P404,

P405, P506 ..........19, 59, 60, 100

Pokrovsky, V: P420 (PW) .........66

Porr, Martina: P121, P122 ….....27

Posch, Wilfried: P608 (PD) . . . . . . . 108

Potthoff, Anja: P460 (PW), P470 . . .85, 89

Poynard, Thierry: P456 (PW) . . . . . . . .83

Pozniak, Anton: P409 .............61

Prammer, Wolfgang: P504 . . . . . . . . 99

Pritschet, Kathrin: P628 . . . . . . . . 116

Prziwara, Daniel: P417 . . . . . . . . . . .65

Puchhammer-Stöckl, Elisabeth:

P484 (PD)
Rambach, Günter: P643 ...........121

Ranneberg, Britta: P408, P416,

P513 ................61, 65, 103

Rantequa, Me: P309 .............47

Rasoul-Rockenschaub, Susanne: P465 87

Rath, Thomas: P322 .............53

Rauch, Andri: OSE $/ 2$............10

Rauch, Pia: OSC/1, P419 (PW),

P606 .................5, 66, 107

Rausch, Michael: P455 (PW) . . . . . . .82

Reddick, M: P425 (PD) . . . . . . . . . . .69

Reemann, Helene: P207 (PW) . . . . . . 35

Regenass, Stephan: P304 (PW) . . . . . .45

Reiberger, Thomas: P463, P465,

P468 ................ 86, 87, 89

Reichel, Christoph: P446 ..........78

Reichelt, Doris: P634 ............118

Reil, Heide: P487, P600 (PW),

P611 (PD), P612 . . . . . . . . . . 96, 105,

109,110

Reisch, Anja: P449 ..............80

Reitter, Anke: P414 (PW) . . . . . . . . .64

Reuter, Stefan: P101 (PW), P314, P441

(PW), P471 ...........17, 49, 76, 90

Richter, Mandy: P487 . . . . . . . . . . .96

Richter, Stefan: P223 . . . . . . . . . . 44

Rickenbach, Martin: P102 (PW), P300,

P443 (PW), P631 . . . . . . 18, 43, 77, 117

Rieder, Philip: OSF/1, P616 . . ....13, 111

Rieger, A.: P463 .............. 86

Rieger, Armin: OSA/2, OSD/3, P311

(PD), P313, P465, P468, P473, P484

(PD), P613 . . . . . . . . 8, 48, 49, 87, $89,90,95,110$

Rieke, Ansgar: OSE/5, P101 (PW), P322,

P489 ...............12, 17, 53, 97

Ries, Moritz: P628 . . . . . . . . . . . 116

Ringelstein, Adrian: P478 . . . . . . . . .92

Ringelstein, Erich-B .: P480 . . . . . . .99

Robertson, Claire: P426 . . . . . . . . . 70

Robinson, Nicola: OSE/2 . . . . . . . . 10

Rockstroh, Juergen Kurt: INV/3,

OSC/3, OSE/1, OSE/4, P305 (PW),

P310 (PD), P314, P329, P405, P411,

P446, P455 (PW), P477, P602 (PW),

P638, P639 .............VII, 6, 10, 11

$45,47,49,56,60,62,78,82,92,106,120$

Rödel, Claus: P467 . . . . . . . . . . .88

Rodes, Berta: P641 . . . . . . . . . . . . . 121

Röhnisch, Tim: P472 . . . . . . . . . . .90

Rohrbach, Janine: OSE/2 … . . . . . 10

Roling, Jörg: P622 . . . . . . . . . . . . 114

Romani, Nikolaus: P619, P642 ..112, 121

Romano, Joseph: P220 .............41

Romerio, Fabio: P607 (PD) . . . . . . . 108

Ropers, Dieter: P449 … . . . . . . . 80

Ross, Birgit: OSE/4 . . . . . . . . . . . . 11

Rotger, Margalida: P500 (PW) $\ldots \ldots .98$

Roulin, Christophe: P102 (PW) . . . . . . 18

Rubbert, Andrea: P625 . . . . . . . . . . 115

Rump, Jörg-Andres: P433 . . . . . . . . .72

Rusert, Peter: OSF/1 . ...........13

Ruzicka, Thomas: $\mathbf{O S H} / \mathbf{1}$,

P224 ...................16,42

Rybniker, Jan: P618 ….........112

\section{$\mathbf{S}$}

Sabranski, Michael: OSE/4 ..........11

Sakalian, M: P425 (PD) . . . . . . . . .69

Saleh, Andreas: P478 ...........92
Salzberger, Bernd: OSE/3, P405, P428

(PD) ...............11, 60, 70

Salzwedel, Karl: P425 (PD) ….....69

Sander, Oliver: P485 (PD) . . . . . . . .95

Sang, Bernd: P411, P433 …...62, 72

Sanz-Moreno, J: P420 (PW) . . . . . . . .66

Sarcletti, Mario: OSA/2, OSD/3,

P311 (PD), P313, P484 (PD), P619,

P642 $\ldots \ldots \ldots \ldots \ldots \ldots \ldots, 8,48,49$,

$95,112,121$

Sauerbruch, Tilman: OSC/3, P477,

$\mathbf{P 6 0 2}(\mathbf{P W}) \ldots \ldots \ldots \ldots \ldots .6,92,106$

Sauermann, Ulrike: INV/5 . . ......VIII

Scarcella, Paola: OSA/1, P435 (PW) 1, 73

Schäfer, Birgit: P610 (PD) . . ........109

Schaft, Niels: P502 (PD) . . . . . . . . .98

Schaible, Thomas: P508 . . . . . . . . 101

Schambach, Axel: OSG/4 . . . . . . . . 15

Schappert, Burkhard: P114, P116, P117,

$\mathbf{P 3 2 2} \ldots \ldots \ldots \ldots \ldots 23,24,25,53$

Schaub-Koch, Christina: P449 . . . . . .80

Schauseil, Stephan: P400 (PW) . . . . . .57

Scheidegger, Clemens: P454,

P472 .................. 82, 90

Scheirich, Iris: P420 (PW), P422 (PW),

P424, P430 .........66, 67, 68, 71

68,71

Scherrer, Alexandra: $\mathbf{O S F} / \mathbf{2} \ldots \ldots \ldots 13$

Schewe, Carl-Knut: P404, P416,

P455 (PW) .............59, 65, 82

Schiel, Xaver: P472 .............90

Schiffer, Véronique: P443 (PW) . . . . .77

Schlaepfer, Johannes: . . ............35

Schläpfer, Johannes: P127, P208 . . .30, 35

Schleehauf, Dorothea: P417 . . .......65

Schlegel, Matthias: P127 . ...........30

Schlote, Frank: P417, P464 . .....65, 87

Schmid, Patrick: P208, P445 (PD), P461

(PD), P517 .......... 35, 78, 85, 105

Schmidt, Axel J: OSB/2, OSB/3,

OSH/2, P100 (PW), P301 (PW),

P328, P330 ........... 3, 16, 17, 43,

55,57

Schmidt, Barbara: P628 ..........116

Schmidt, Reinhold Ernst: OSG/3,

P104 (PW), P305 (PW), P317,

P428 (PD), P479, P609 (PD), P614,

P615, P627, P630 ........15, 19, 45, 50,

70, 93, 109, $110111,116,117$

Schmidt, Wolfgang: P415, P431,

P432 ................64, 71, 72

Schmied, Brigitte: $\mathbf{P 4 6 8}$,

P484 (PD) . . . . . . . . . . . . . . 89, 95

Schmiedel, Stefan: OSC/4, P512 _. .6, 103

Schmitz, Nathalie: P222 ...........41

Schmökel, Jan: OSC/1 . ...........5

Schmutz, Guenther: P110,

P400 (PW) ..............22, 57

Schneider, Lothar: P483 (PW) ........ 94

Schneider, Thomas: INV/5, OSG/2,

P620 .................VIII, 15, 113

Schneidewind, Arne: P632 . . . . . . . 118

Schnierle, Barbara: P637 .........119

Scholten, Stefan: P314, P317,

P406 ................ 49, 50,60

Schranz, Dietmar: P404,

P455 (PW) . . . . . . . . . . . . . .59,82

Schroten, Horst: P429, P508 …70, 101

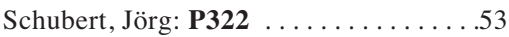

Schubert, Ulrich: P615 ...........111

Schuchmann, Marcus: P322, P489 . .53, 97 
Schuettfont, Gundolf: P623 ........114 Schulbin, Hubert: P457 (PW),

P476 ............ 84, 92

Schuler, Christoph: P404,

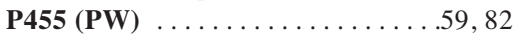

Schuler, Gerold: P502 (PD) . . . . . . .98

Schulte, Daniela: OSC/3, P638 . . .6, 120

Schülter, Eugen: P471 . . . . . . . . . .90

Schultze, Detlev: P304 (PW) . . . . . . 45

Schulze zur Wiesch, Julian: OSC/2,

OSC/4, P630 . . . . . . . . . . 5, 6. 117

Schulze, Simone: P304 (PW) . . . . . . 45

Schulzke, Jörg-Dieter: P620 . . . . . . . 113

Schünadel, Livia: P481 (PW) . . . . . . . .94

Schüpbach, Jörg: P304 (PW) . . . . . .45

Schürmann, Dirk: OSE/1, OSE/5 . .10, 12

Schuster, Dieter: P411, P433 . . . . 62, 72

Schuster, Philipp: P628 . . . . . . . . . . 116

Schwarze-Zander, Carolynne: P329,

P446, P639 .............56. 78, 120

Schwere, Knud: P440 (PW) . . . . . . .75

Schwethelm, Bettina: P126 . . . . . . . . .29

Seekins, D: P410 . . . . . . . . . . . 62

Seffert, Birte: P209, P223 . . . . . . 36, 42

Seifert, Ulrich: P114 ... .........23

Sekar, V: P418 (PW) . . . . . . . . . .66

Seybold, Ulrich: P505, P622 . . . 100, 114

Shah, Cyril: P300 . . . . . . . . . . . . 43

Sichtig, Nadine: P314, P441 (PW),

P471, P486 (PD) . . . . . . 49, 76, 90, 96

Siedentopf, Jan-Peter: OSB/6 . . . . . . .4

Sieghart, Wolfgang: P468 . . . . . . . . .89

Siehl, Jan: OSE/4, OSE/5 . . . . . . 11, 12

Simon, Benedikt: P484 (PD) . . . . . . 95

Sinha, Rekha: P439 (PW) . . . . . . . . .75

Skaletz-Rorowski, Adriane: OSD/5,

P317, P514 ...........9, 50, 104

Skoczylas, Patricia: P636 . . . . . . . . 119

Smets, Erik: P423 (PW) . . . . . . . . 68

Smith, C: P426 . . . . . . . . . . . .70

Smola-Hess, Sigrun: P628 . . . . . . . 116

Söllner, Julia: P505 . . . . . . . . . . . . 100

Somogyi, Sybille: P312,

P481 (PW) . . . . . . . . . . . . . .48, 94

Sonnenberg-Schwan, Ulrike: P120,

P503 (PD), P515 . . . . . . . . 27, 99, 104

Sopper, Sieghart: INV/5 . . . . . . . . VIII

Soriano, Vincent: P641 . . . . . . . . . . 121

Sornsakrin, Mareike: P506 . . . . . . . . 100

Sovric, Milena: OSB/6, P451,

P459 (PW), P503 (PD), P515 ....4, 81,

84, 99, 104

Speck, Roberto F: P319, P631 . . .51, 117

Spengler, Ulrich: OSC/3, P329, P477,

P602 (PW), P638, P639 . . . . . . . 6, 56,

92, 106, 120

Speth, Cornelia: P643 . . . . . . . . 122

Spielmann, Nadine: P303 (PW), P315,

P326, P330 ........44, 50, 55, 57

Spinosa-Guzman, Sabrina: P418 (PW),

P433 ...............66, 72

Spirig, Rebecca: P108 (PD),

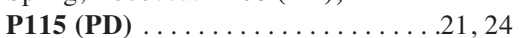

Spriewald, Bernd: P449, P606 . . .80, 107

Spycher, Ben: P445 (PD) . . . . . . . . .78

Stahl-Hennig, Christiane: INV/5 . . . . VIII

Stahmer, Ingrid: $\mathbf{O S C} / 2 \ldots \ldots \ldots$

Ständker, Ludger: OSG/3 . . . . . . . . 15

Stankov, Metodi: P614,

P627 ................110, 116

Stark, Sonja: P458 (PW) . . . . . . . .84
Staszewski, Schlomo: P309, P317,

P411, P438 (PW), P458 (PW),

P513, P623 .......47, 50, 62, 64.

75. 84. 103114

Staub, Roger: P210 ..............36

Stefan, Christoph: P305 (PW) . . . . . 44

Steffan, Elfriede: P206 (PW), P207 (PW),

P212, P321, P324 .......35, 37, 52, 54

Steffen, Ingrid: OSE/6,

P304 (PW) . . . . . . . . . . . . 12.45

Steflitsch, Wolfgang: P510 . . . . . . . 102

Steinberger, Peter: P613 . . . . . . . . 110

Stellbrink, Hans-Jürgen: P101 (PW),

P306, P316, P403, P415, P431, P432,

P452, P482 (PW) .......17, 46, 50, 59,

$64,71,72,81,94$

Stephan, Christoph: OSE/1,

P414 (PW), P438 (PW), P458 (PW),

$\mathbf{P 6 2 3} \ldots \ldots \ldots \ldots \ldots \ldots \ldots, 64,75$, 84,114

Sternfeld, Thomas: P472 . . . . . . . . 990

Stifter, Eva: P510 . . . . . . . . . . . . . . . 102

Stocker, Hartmut: P457 (PW),

P462 (PD), P476 . . . . . . . .84. 86, 92

Stöckle, Marcel: P325, , P445 (PD),

P511 ..............54, 78, 102

Stoelzl, Susanne: P517 . . . . . . . . 105

Stöhr, Albrecht: P404, P405, P411,

P514, P433 ........ 59, 60, 62,

72,104

Stoiber, Heribert: P608 (PD) . . . . . 108

Stoll, Matthias: OSD/1, OSD/2, OSD/5,

OSE/3, OSG/3, P104 (PW), P405,

P423 (PW), P428 (PD), P434 (PW) . . . .7,

$9,11,15,19,60,68,70,73$

Stradling, C: P426 . . . . . . . . . . .70

Streeck, Hendrik: P632 . . . . . . . . 118

Strobl, N: P430 . . . . . . . . . . . .71

Strohschein, Kristin: P629 . . . . . . . 116

Stubbe-Dräger, Bianca: P480 . . . . . . .993

Stucki, Heinz: P605 (PD) . . . . . . . . . 107

Stürmer, Martin: P486 (PD),

P623 ...............96, 114

Su, J: P430 ................71

Sudhop, Thomas: P446 . . . . . . . . . 78

Suleiman, Jamal: P408 . . . . . . . . . 61

Swidsinski, Sonja: P457 (PW) . . . . . .84

T

Taffé, Patrick: P300, P500 (PW),

P631 ...........43, 98, 117

Taka, Nchang: P512 ... . . . . . . . 103

Tappe, A: P403 ...............59

Tarr, Philip: P461 (PD),

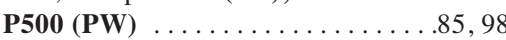

Taubald, Almut: P449 . . . . . . . . . 80

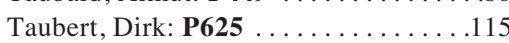

Taubert, Steffen: OSB/1 . . . . . . . .

Taylor, Ninon: OSD/3, P311 (PD), P313,

$\mathbf{P 4 8 8} \ldots \ldots \ldots \ldots \ldots \ldots . \ldots, 48,49,97$

Taylor, Steve: P426 . . . . . . . . . . 70

Telenti, Amalio: INV/1, OSE/2, P500

(PW) $\ldots \ldots \ldots \ldots \ldots \ldots$ VII, 10, 98

The, Yu-Han: OSG/3 . . . . . . . . . . 15

Theisen, Albert: P455 (PW) . . . . . . .82

Thiele, Bernhard: P322, P489 . . . .53, 97

Thielen, Alexander: P486 (PD) . . . . .996

Thiry, A: P424 . . . . . . . . . . .68

Thoden, Jan: P448 . . . . . . . . . . . . .79

Thomssen, Adriana: OSC/4 . . . . . . . .6

Thuresson, Per-Olof: P422 (PW) . . . . 67
Tina, Adjara: P208 . . . . . . . . . . . 35

Tischer, Karsten: P621 . . . . . . . . .113

Tolksdorf, Felix: P638 ...........120

Töppich, Jürgen: P301 (PW) . . . . . . 43

Tossing, Gudrun: P466 . . . . . . . 88

Träder, Christian: P457 (PW),

P462 (PD), P475, P509 ........, 84, 86, $91,101 \ldots \ldots \ldots \ldots \ldots \ldots \ldots \ldots \ldots \ldots \ldots \ldots$

Tran, Cam-Tuan: P440 (PW) . . . . . . .75

Trebesch, Isabell: P466 . . . . . . . . . .88

Trein, Andreas: P415, P428 (PD),

P431, P432, P454, P466 .....64, 70, 71,

72, 82, 88

Trkola, Alexandra: OSF/1 . . . . . . . 13

Tsasanyana, Mtate: P309 . . . . . . . . 47

Tubiana, Roland: P456 (PW) . . . . . . 83

$\mathbf{U}$

Ulbricht, Kai: P428 (PD) . . . . . . . . 70

Ulmer, Albrecht: P101 (PW),

$\mathbf{P 4 8 3}$ (PW) . . . . . . . . . 17, 94

Ummard, Kevin: P455 (PW) . . . . . .82

Uy, J: P424 ...............68

V

Valantin, Marc-Antoine: P456 (PW) . . .83 Valley, Yannick: P443 (PW) . . . . . .77 Van Baelen, B: P418 (PW) . . . . . . . 66 van den Boom, Frans: INV/11 . . . . . X van Lunzen, Jan: INV/7, OSA/3, OSC/2, OSC/4, OSE/4, P305 (PW), P306, P404, P405, P416, P433, P454, P512, P607

(PD), P617 (PD), P630 . . . . . VIII, 2, 5, 6, 11, 45, 46, 59, 60, 65, 72, 82, 103, 108, 112, 117

Vandeloise, E: P420 (PW) . . . . . . . .66 Vehreschild, Joerg: P310 (PD) . . . . . .47 Vella, Stefano: P516 . . . . . . . . . . . . 104 Venhoff, Ana: P626 . . . . . . . . . . 115 Venhoff, Nils: P448, P626,

P640 .............79, 115, 120

Verheyen, Jens: P471 . . . . . . . . . 90

Vernazza, Pietro: P108 (PD), P127,

P201 (PW), P208, P300, P308 (PD),

P331, P421 (PW), P443 (PW), P517,

P631, P633 .........21, 30, 32, 35, 43, 46, 57, 67, 77, 105, 118

Vidal, Vincent: P605 (PD) . . . . . . . . .107

Vidovic, Natascha: P477 . . . . . . . . . 992

Vilén, Louise: P327 . . . . . . . . . . . . . . .55

Vingerhoets, J: P407 (PW) . . . . . . . .60

Vis, P: P418 (PW) . . . . . . . . . . .66

Vogel, Martin: OSC/3, OSE/1, P329,

P446, P455 (PW), P602 (PW),

P639 ...........6, 10, 56, 78, 82, 106, 120

Voigt, Esther: $\mathbf{P 4 4 6} \ldots \ldots \ldots \ldots \ldots \ldots .78$

Volgmann, Thorsten: P615 . . . . . . . 111

Volk, Andreas: P635 . . . . . . . . . . . . 119

Vollbrecht, Thomas: P622 ... . . . . 114

Vollmer, Jörg: P628 . . . . . . . . . .116

von Einem, Jens: P621 ... . . . . . . 113

von Hentig, Nils: P438 (PW) . . . . . . .75

von Laer, Dorothee: OSG/4,

P635 ..................15, 119

von Rüden, Ursula: OSB/4, P105 (PW),

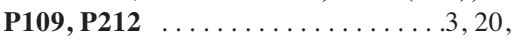

21,37

von Schilling, Christoph: P472

von Unger, Hella: P204, P216,

P221 ...............34,39,41 
von Wyl, Viktor: OSF/2, P300, P307, P419 (PW), P616 . . . . 13, 43, 46, 66, 111

Vounatsou, Penelope: P511 ........102

W

Wagner, Ralf: P601 (PW), P604, P621,

P624, P636 ..........106, 107, 113,

114,119

Wagner, Sarah: P605 (PD) . . . . . . . . . . . . . . . . . .

Walker, Bruce: P632 ... . . . . . . . 118

Walker, Ulrich: P448, P626,

P640 .............79, 115, 120

Walli, Ravi: P317 . . . . . . . . . . . 50

Walter, Hauke: P453, P486 (PD) . . .81, 96

Walther, Irene: P404, P405,

P506 ............59, 60, 100

Wanderlein, Dieter: P435 (PW) . . . . . .73

Wasmuth, Jan-Christian: OSE/5, P310

(PD), P329, P446, P477, P639 . . .12, 47, 56, 78, 92, 120

Weber, Rainer: OSF/1, P300, P331, P419

(PW), P443 (PW), P501 (PW) . . . . . 13,

43, 57, 66, 77, 98

Wefuan, Jonah: P512 . . . . . . . . . . . 103

Weißbrich, Benedikt: P488 . . . . . . . .97

Weissenbacher, Tobias: P451,

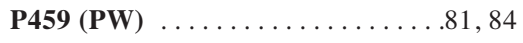

Weitner, Lutwin: P464 . . . . . . . . . .87

Katharina, Weizsäcker: OSB/6, P503

(PD), P515 . . . . . . . . . . . 4, 99, 104

Wellmann, Egbert: P403 ... . . . . . . .59

Wend, Holger: P600 (PW) . . . . . . . . 105
Wenderlein, Dieter: OSA/1 . . . . . . . 1

Werner, Albrecht: P637 ... . . . . . . 119

Werner, Birgit: P608 (PD) . . . . . . . . 108

Werner, Ernst: P642 . . . . . . . . . . 121

Werning, Johanna: P447 . . . . . . . . 78

Weyermann, Helene: P517 . . . . . . . 105

Wieczorek, Marlen: $\mathbf{P 4 7 5}$. . . . . . . . 91

Wiedenmann, Katja: P503 (PD) . . . . . .999

Wiese, Maximiliane: P479 . . . . . . . 93

Wiesmann, Frank: P406, P444 (PW),

P507 ............60, 77, 100

Wiessner, Peter: P106 (PW) . . . . . . . .20

Wild, Jens: P604, P621 . . . . . . 107, 113

Wilflingseder, Doris: P608 (PD) . . . . 108

Wilhelm, Frank: P471 . . . . . . . . . .90

Wilke, Thomas: P209, P223 . . . . . .36, 42

Winkler, Christiana: P642 . . . . . . . . 121

Winkler, Christine: P619 . . . . . . . . 112

Winskowsky, Gudrun: P637 . . . . . . . 119

Winter, Sandra: P618 . . . . . . . . . . 112

Wirz, Gaby: P120 ..............27

Wolf, Angelika: OSB/1 . . . . . . . . . . 2

Wolf, Eva: P415, P431, P432,

P483 (PW), P486 (PD) . . . . . 64, 71, 72,

94, 96

Wolf, Timo: OSE/4, OSE/5, P458 (PW),

P637 ...........11, 12,84, 119

Wong, Joseph: OSF/1 . . . . . . . . 13

Woodfall, B: P407 (PW) . . . . . . . . 60

Wright, Michael: P204, P216,

P221 ............... 34, 39, 41

Wyen, Christoph: OSE/4, OSE/5,
P306, P446

$11,12,46,78$

$\mathbf{Y}$

Yang, R: P424 .................68

Yerly, Sabine: OSF/2, OSF/3, P300,

P304 (PW), P307, P421 (PW),

P469 (PD) $\ldots \ldots \ldots \ldots \ldots 13,14,43,45$ $46,67,89$

Ymerhalili, Genc: P126 . . . . . . . . . 29

Young, B.: P410 ................62

Young, James: P443 (PW) . . . . . . . . 77

Young, Peter: P634 ................118

\section{$\mathbf{Z}$}

Zangerle, Robert: OSA/2, OSD/3,

P311 (PD), P313, P619,

P642 ................ 8, 48, 49, 112, 121

Zedlack, Carmen: P474 ...........91

Zeitz, Martin: P101 (PW), P620 . . 17, 113

Zhang, Sherry: P442 (PW) ..........76

Zhong, Lijie: P408 . . . . . . . . . . . . . . .61

Zhou, Yun: P409 ..............61

Zielinska-Skowronek, Margot: P630 . . 117

Zimba Da Vitoria, Ines: P435 (PW) . . .73

Zimmermann, Ruth: P302 (PW),

P629 ..................44, 116

Zippel, Stefan: OSH/1, P224 ......16, 42

Zoufaly, Alexander: OSA/3, OSE/3,

P306, P436 ...........2, 11, 46, 74

Zweigner, Janine: P474 . . . . . . . . .91 